

\section{DE PORTUGAL A MACAU (A VIAGEM DO PÁTRIA)}

\section{从葡萄牙到澳门 (“祖国号”之旅)}

J. SARMENTO DE BEIRES

J. 萨尔门托 ・ 德贝雷斯 
Título | 书名: De Portugal a Macau (A Viagem do Pátria) | 从葡萄牙到澳门 (“祖国号”之旅)

Autor | 作者: J. Sarmento de Beires | J ・ 萨尔门托・德贝雷斯

Design gráfico | 平面设计: Helena Lobo Design | www.hldesign.pt | 伊莱娜 - 洛布斯设计室| www.hldesign.pt

Imagem da capa | 封面设计: António Six | 奥东尼奥・谢克斯

Fixação do texto em Português e Notas | 葡萄牙语文章撰写及注解: Isabel Morujão| 伊莎贝尔・莫茹让

Paginação do Texto em Mandarim e Coordenação do Projecto de Ilustração: Rita Pina Brito

中文版文本分页及插图项目协调: 丽达・平托・布里托

Ilustradora | 插画: Margarida Ferreira | 玛嘉丽达・费雷拉

Tradutora | 翻译: Yu Yong

Co-edição: CITCEM - Centro de Investigação Transdisciplinar "Cultura, Espaço \& Memória»

Via Panorâmica, s/n | 4150-564 Porto | www.citcem.org | citcem@letras.up.pt

联合出版: CITCEM-—文化、空间与记忆跨学科研究中心

Via Panorâmica, s/n | 4150-564| 帕罗拉米卡公路|4150-564

Porto | www.citcem.org | citcem@letras.up.pt

波尔图| www.citcem.org | citcem@letras.up.pt

Edições Afrontamento, Lda. | Rua Costa Cabral, 859 | 4200-225 Porto

www.edicoesafrontamento.pt | geral@edicoesafrontamento.pt

阿弗龙塔曼托出版有限公司. |葡萄牙波尔图Costa Cabral路 859号 | 4200-225 波尔图

Colecção | 收藏: Fontes, n. ${ }^{\circ} 12$

N. ${ }^{\circ}$ edição| 版本号: 1945

ISBN: 978-972-36-1715-3 (Edições Afrontamento)

ISBN: 978-989-8970-12-1 (CITCEM)

Depósito legal | 法定留存本号码: 450371/18

DOI | 识别码: https://doi.org/10.21747/9789898970121/mac

Impressão e acabamento: Rainho \& Neves Lda. | Santa Maria da Feira

geral@rainhoeneves.pt

印刷装订: Rainho \& Neves有限公司 | 葡萄牙圣玛利亚达费拉市

Distribuição: Companhia das Artes - Livros e Distribuição, Lda.

comercial@companhiadasartes.pt

发行: 艺术团一一图书及发行有限公司

comercial@companhiadasartes.pt

Trabalho cofinanciado pelo Fundo Europeu de Desenvolvimento Regional (FEDER) através do COMPETE 2020

-Programa Operacional Competitividade e Internacionalização (POCI) e por fundos nacionais através da FCT, no âmbito do projecto POCI-01-0145-FEDER-007460

在POCI-01-0145-FEDER-007460框架下, 由欧洲地区发展基金 (FEDER) 通过2020 COMPETE- - POCI竞争力和国际化运营 计划以及国家基金通过FCT共同资助的工作。 


\section{INNDICE GERAL}

总目录

Critérios de edição

编辑标准

Quando os ases escrevem: Memória e história do primeiro raide aéreo Lisboa-Macau (1924)

当机翼也能书写: 第一次里斯本一一澳门空中突袭 (1924年) 的回忆与历史

Isabel Morujão / 伊莎贝尔・莫茹让

De Portugal a Macau em Mandarim: Depois da aterragem do Pátria II chega agora a narrativa de Beires ao Oriente 69 “从葡萄牙到澳门”中文版: 祖国二号降落后, 现在德贝雷斯的叙事传到了东方

Rita Pina Brito / 丽达・皮纳・布里托

A viagem de Lisboa a Macau no eixo do triunfo da aviação

从里斯本到澳门之旅一一一次胜利航程

Mário Correia / 马里奥・科雷亚

Portugal e Macau, viagens e migrações

葡萄牙和澳门, 旅行和移民

Alfredo Gomes Dias / 阿尔弗雷多・戈麦斯・迪亚斯

Ao postigo da História. Lugares, contextos e ambientes em torno da primeira viagem aérea entre Portugal e Macau 115 走向历史之门 葡萄牙——澳门之间第一次空中之旅的地点、背景和周围环境

Henriques-Mateus / 恩里克・马特乌斯

De Portugal a Macau (A viagem do Pátria)

从葡萄牙到澳门 (“祖国号”之旅)

J. Sarmento de Beires / J. 萨尔门托・德贝雷斯

Capítulo I - Antecedentes

第一章、背景

Capítulo II - Vila Nova de Milfontes

第二章千泉新镇

Capítulo III - Sete de Abril

第三章 四月七日

Capítulo IV - O Mediterrâneo e a Argélia

第四章 地中海和阿尔及利亚

第五章 沙漠 
Capítulo VI - Da terra dos faraós à cidade das Mil e Uma Noites

第六章 从法老的故乡到一千零一夜之城

Capítulo VII - A Pérsia

第七章 波斯

Capítulo VIII - Horas trágicas

第八章 悲剧时刻

Capítulo IX - O Pátria II

第九章 “祖国二号”

Capítulo X - A Índia

第十章 印度

Capítulo XI - Da Birmânia ao Tonquim

第十一章 从缅甸到越南东京

Capítulo XII - A última etapa

第十二章 最后一段航程

Capítulo XIII - Conclusão

第十三章 结论

Capítulo XIV - Apêndice - Recapitulação técnica da viagem

第十四章 附录 航程技术回顾

Capítulo XV - Apêndice fotográfico. Fotografias de objectos relativos ao raide Lisboa-Macau 第十五章 照片附录. 里斯本一一澳门空中突袭相关物品照片

编者简历 


\section{ÍNDICE DAS FOTOGRAFIAS DE 1924 E DAS ILUSTRAÇÕES 1924年照片及插图目录}

FOTOGRAFIAS DE 1924 (A PRETO E BRANCO) / 1924年的照片 (黑白)

Preparando o Pátria na Amadora

在阿马多拉准备 “祖国号”飞机

O baptismo do Pátria

“祖国号”的洗礼

Na hora da partida

出发时刻

O avião Pátria

“祖国号”飞机

Ruínas do Templo de Júpiter, Baalbek

朱庇特神庙废墟 巴勒贝克 (叙利亚)

Croquis do itinerário da viagem (I)

行程路线草图 (1)

Jacqueline

“杰奎琳号飞机”

Aterragem do Pátria em Karachi

“祖国号”降落在卡拉奇

O Pátria a ser reparado em Karachi

在卡拉奇修理 “祖国号”

O avião Pátria II

“祖国二号”飞机

萨尔门托 $\cdot$ 德贝雷斯和布里托 $・$ 帕伊斯抵达仰光

飞行路线草稿 (二) 
A bordo da canhoeira Pátria com o comandante Bivar

在 “祖国号” 巡逻舰上与皮瓦尔司令在一起

O Patria II acidentado a ser desmontado no cemitério chinês

荫毁的“祖国二号”在中国墓地被拆解

\section{ILUSTRAÇÕES / 插图}

O avião Pátria

“祖国号”飞机

A tempestade antes da partida

起飞前的风暴

O Pátria descola de Portugal

“祖国号”飞机从葡萄牙起飞

A torre da Mesquita de Túnis

突尼斯的清真寺召唤塔

As Pirâmides e a Esfinge do Cairo

开罗的金字塔和狮身人面像

O Templo de Baalbek

巴勒贝克神庙

O porto de Bushire

布什尔港

A queda do Pátria no deserto

“祖国号”飞机坠落在沙漠

O Forte de Mehrangarth em Jodhpur

贾斯坦邦焦特布尔的梅兰加尔要塞

As pessoas e as ruas de Calcutá

加尔各答的人和道路

A Estátua de Wat Pra Kaew em Bangkok

曼谷的玉佛寺

A Catedral de São Paulo em Macau

澳门的大三巴

O retrato da tripulação (Brito Paes, Sarmento de Beires e Manuel Gouveia)

机组人员肖像 (布里托・德帕伊斯, 萨尔门托・德贝雷斯和曼努埃尔・戈维亚) 


\section{CRITÉRIOS DE EDIÇÃO 编辑标准}


“从葡萄牙到澳门”一书文本的拼写和标点符号是在本版共同发行人之间达成共识并根 据之前的“1990年正字法协议”标准进行更新的。

在书中应用了斜体和大写规则, 同时也尊重作者留下的重点标记。为了使阅读变得顺畅 明白, 在连续的直接引语段落上加了引号。

已纠正明显的印刷错误。

国家、城市和其他外国地点的名称是根据其目前的拼写进行登记的。

鉴于在目前的葡萄牙文化背景下, 法语的使用有限, 在正文脚注中翻译了多个作者使用 的法语句子或是法语习惯用语。

保留了作者在二十世纪历次编辑中写下的所有脚注; 还新增了多条由现任编辑负责的脚 注, 并对它们进行了适当的标注和识别。

效仿本书第三版, 在这版中, 作者本人认定当时给布里托 - 帕艾斯的献词是最终的。这 样, 本书的结构为 14 章, 而不是 15 章, 我们在附录中附上第一版出版后, 萨尔门托 - 德贝雷斯在 其作品文本中附上的技术附录页。 
O texto da obra De Portugal a Macau apresenta-se actualizado na ortografia e na pontuação, de acordo com as normas anteriores ao Acordo Ortográfico de 1990, por consenso entre os promotores desta edição.

Foram aplicados princípios de regularização de itálicos e de maiúsculas, respeitando, todavia, as marcas de ênfase deixadas pelo autor. Com o propósito de facilitar e clarificar a leitura, foram inseridas aspas a assinalar os parágrafos sucessivos de discurso directo.

Os erros tipográficos óbvios foram corrigidos.

Procedeu-se ao registo dos nomes de países, cidades e outras localidades estrangeiras em função da sua grafia actual.

Atendendo ao escasso domínio da língua francesa no actual contexto cultural português, traduziram-se em nota de rodapé várias frases ou expressões francesas utilizadas pelo autor.

Mantiveram-se todas as notas de rodapé que o autor foi criando, ao longo das sucessivas edições do século XX, acrescentando-se várias outras, da responsabilidade dos actuais editores, devidamente assinaladas e identificadas.

Seguiu-se a lição do texto da terceira edição desta obra, considerada a «definitiva» pelo próprio autor, na dedicatória que então fez a Brito Paes. Assim, a obra estrutura-se em catorze capítulos e não em quinze, apresentando em anexo o Apêndice técnico que, após a primeira edição, Sarmento de Beires juntou ao seu texto. 


\section{当机翼也能书写: 第一次里斯本一一澳 门空中突袭 (1924年) 的回忆与历史}

伊莎贝尔・莫茹让 


\section{QUANDO OS ASES ESCREVEM: MEMÓRIA E HISTÓRIA DO PRIMEIRO RAIDE AÉREO LISBOA-MACAU (1924)}

ISABEL MORUJÃO FLUP/CITCEM 


\section{如果回忆是我们所拥有的1: 为什么重印这本书}

值此距1920年4月 7日到6月 20 日第一次实现里斯本——澳门之间的飞行近 100 年之际，我们重印若泽 - 曼努埃尔 - 萨尔门托 - 德贝雷斯的 “从葡萄牙到澳 门”一书, 这不但让我们有提前庆祝之感, 同时让人回忆起那些被遗忘了的时光和 人们。遗忘, 并不是现在才有的趋势。早在 1516 年, 加尔西亚 - 德雷森德在他的 “游吟之歌” 序言中就曾哀叹道: “现在, 所有这些行为和其他本质的影响没有像以 前一样被宣扬, 而其他国家的人们已经做了这件事。”2 抵消这种倾向是任何时代 都有的要求, 具体来说, 这种姿态为研究葡萄牙及世界航空打开了大门, 在国际学 术界受到欢迎并敦促人们给予注意 3 ……实际上，这些二十世纪二十年代的航空 “突袭” 或许是康乃馨革命之前, 葡萄牙人做出的最后一些具有国际影响力的开创 性行为。然而, 今天, 年轻一代的葡萄牙人和外国人对此一无所知。因为与其他那 些也有航空先驱的国家相反, 葡萄牙人把这一切忘记了! 而在其他国家, 航空先驱 成了多样化研究、庆祝活动和各种探讨的主题, 其体裁从技术性很强的文章到电 影都有。

国家记忆的迅速消失引起了法国历史学家皮埃尔・诺拉的反思性关注，他在 1984年组织编纂了重要著作 “记忆的场所”。这表明, 记忆易逝的状况要求并通知 人们要清点那些曾经体现记忆的地方, 以及那些由于人们的意愿, 将记忆永远镌刻 的象征性符号, 纪念物, 字典和博物馆等。

现在, 由萨尔门托 - 德贝雷斯, 布里托 - 帕伊斯和曼努埃尔 - 戈维亚实现的非 凡航空之旅以及当时他们所处的同样非凡的环境, 在葡萄牙留下了许多证据: 千泉 新城有一座纪念碑, 在许多其他城市的地名中留下一些印记 ${ }^{4}$, 在航空博物馆的先 驱厅中保存了与这次飞行有关的一些物件, 他们的名字进入了百科全书和 “伟大的 葡萄牙人名册” 中……此外, 还有飞行员之一的若泽 - 曼努埃尔 - 萨尔门托 - 德贝 雷斯撰写的一本相关旅行叙事书籍。

\footnotetext{
1 费尔南多・佩索阿-・雷伊斯: “颂歌”, “尽你所能, 至高无上。”

2 “加尔西亚・德雷森德的游吟之歌” : 安德烈 - 克拉贝 - 罗沙简介及注解, 第一卷, 里斯本, 巴西图书中心, 1973年版, 第2页。

3 请参阅, 如麦罗德 - 西蒙德-侯顿主编的材料汇编 “新闻和空中征服记: 故事, 图片和诗歌”。“平台: 航空 航天的过去与现在” (在线), 2018年秋季刊第五期。网址: http://revues.univ-tlse2.fr/pum/nacelles/index. php?id=564。“飞行员一作家” “历史见证人” (安东尼奥・蒙特罗, 玛利亚・德法蒂玛 - 奥特里尼奥, 多明戈・ 法利亚及若泽・多明戈斯・德阿尔梅达主编, 2017年。巴黎: 文稿出版社, 207-235页。)

${ }^{4}$ 波尔图, 莱萨。德帕梅拉, 里斯本, 贝雅, 埃武拉等城市的路名。
} 


\section{SE A MEMÓRIA É QUANTO TEMOS ${ }^{1}$ : O INTERESSE DESTA REEDIÇÃO}

Estando-se a poucos anos do centenário do raide aéreo Lisboa-Macau, realizado entre 7 de Abril e 20 de Junho de 1924, a reedição da obra De Portugal a Macau, de José Manuel Sarmento de Beires, adquire antecipadamente um sentido celebrativo, ao mesmo tempo que relembra uma história que o tempo e as pessoas foram deixando cair no esquecimento. Não é esta uma tendência de agora, pois já em 1516 Garcia de Resende, no Prólogo ao seu Cancioneiro Geral, a lamentava: "Todos estes feitos e outros muitos d'outras sustâncias não são divulgados como foram, se gente d’outra nação os fizera $»^{2}$. Contrariar esta propensão é, pois, uma exigência de todos os tempos e, no caso concreto, um gesto que abre portas à investigação sobre a aviação portuguesa e mundial, que tem vindo a encontrar, nos meios académicos internacionais, um acolhimento a que urge ir prestando atenção. ${ }^{3} \mathrm{Na}$ verdade, estes raides aéreos dos anos vinte foram talvez os últimos grandes feitos pioneiros dos portugueses, de repercussão internacional, antes da revolução dos cravos. Contudo, são hoje desconhecidos das gerações mais novas e dos estrangeiros, porque os portugueses se esqueceram deles, contrariamente ao que sucedeu aos pioneiros da aviação de outros países, que são hoje objecto dos mais variados estudos, celebrações e abordagens, desde os artigos mais técnicos até ao cinema.

A constatação do desaparecimento rápido de memórias nacionais suscitou a preocupação reflexiva do historiador francês Pierre Nora, que organizou em 1984 a importante obra Les Lieux de la Mémoire. Aí se demonstra como essa condição perecível das memórias exige e convoca o inventário dos lugares em que elas encarnaram e onde, pela vontade dos homens, elas se fixaram residualmente em símbolos, monumentos, comemorações, dicionários e museus.

Ora, da extraordinária viagem aérea realizada por Sarmento de Beires, Brito Paes e Manuel Gouveia - e das também extraordinárias circunstâncias em que ela se realizou - ficaram diversos testemunhos em Portugal: um monumento em Vila Nova de Milfontes, algumas marcas na toponímia urbana de várias cidades do país ${ }^{4}$, a presença de objetos associados ao raide na sala dos pioneiros do Museu do Ar, entradas em enciclopédias e no Grande Livro dos Portugueses... e um livro, uma narrativa de viagens escrita por um dos aviadores, José Manuel Sarmento de Beires.

Enquanto narrativa da viagem do avião Pátria, no contexto do risco de uma travessia pioneira e sem apoios do Estado, este livro de Sarmento de Beires tem um interesse inegável

\footnotetext{
${ }^{1}$ Fernando Pessoa-Ricardo Reis, Ode «Quanto faças, supremamente faze».

${ }^{2}$ Cancioneiro geral de Garcia de Resende. Introdução e notas de Andrée Crabbé Rocha. Tomo I. Lisboa, Centro do Livro Brasileiro, 1973, p. 2.

${ }^{3}$ Veja-se, por exemplo, o dossier La presse et la conquête de l'air. Histoires, imaginaires, poétiques, sous la direction de Mélodie Simard-Houde. «Nacelles. Passé et présent de l'aéronautique et du spatial / Past and Present of Aeronautics \& Space» [en ligne], n. ${ }^{\circ}$ 5, automne 2018. URL: http://revues.univ-tlse2.fr/pum/nacelles/index.php?id=564 e a obra Aviateurs-écrivains. Témoins de l'histoire, Savoirs / Exotopies (Direcção de António Monteiro, Maria de Fátima Outeirinho, Dominique Faria e José Domingues de Almeida José (2017). Paris: Éditions Le Manuscrit, 207-235.

${ }^{4}$ Em ruas das cidades do Porto, Leça da Palmeira, Lisboa, Beja, Évora...
} 
作为 “祖国号” 飞机的飞行叙事, 叙述在面临开创性飞行的风险且没有国家 支持的背景下的航空之旅，这对于那些对飞行、对葡萄牙第一共和国这个关键时 期发生的历史事件感兴趣的人，萨尔门托 - 德贝雷斯的这本书有着不可否认的兴 趣。这部写在一部见证记录中并经过文学剪裁的优秀作品使得读者群自然而然地 扩展到了不同的公众, 因为这本书讲述了一次真正的冒险, 其中的英雄有血有肉, 他们曾无数次面对极为危险的情况。这本书通过讲述在遥远的二十年代实现的开 拓性飞行, 充分地说明了那次飞行的冒险意义。“冒险” 这个词从词源学的角度来 看, 其字面意思是 “正在到来的”。那时, 正在到来的不仅仅是飞行员接受的飞行逆 境, 还有空中通讯的未来和他们想要在葡萄牙建立的新时代。

实际上, “祖国号”从葡萄牙飞至澳门的空中之旅是国际公认的、航空工程和 航空先驱的非凡壮举。在这次空中航行持续的三个月中, 整个葡萄牙尧首以待, 等 待着飞行员们成功的消息。

在今天我们生活的这个时代, 对于事实和人们的记忆已经不再是一种社会实 践的结果。为纪念那些有关的日期和事件设立了一些假日, 然而从人们的疏离感 中我们得知, 尽管有这种集体表达, 人们对于这些记忆还是不知道, 进而变得无动 于衷。因此, 当记忆越少在人们的内心中存在, 就越有必要通过外部支持恢复它们, 就像历史学家皮埃尔 - 诺拉 ${ }^{6}$ 指出的那样, 只有通过 “存在的有形标记” 才能让记 忆生存下来。

1968年, 即这次飞行之后的四十四年, 萨尔门托 - 德贝雷斯把 “从葡萄牙到 澳门” 这本书的第三版献给布里托 - 帕伊斯, 尽管他始终保留着第一版的 “献 给葡萄牙人民” 的献辞。布里托 - 帕伊斯已于 1934 年去世, 曼努埃尔 - 戈维亚 也已于 1966 年去世。在经历过驾驶飞机前往澳门这个巨大冒险的三位男子中, 当时只有德贝雷斯还活着, 但他已经敏锐地意识到不存在天然的、自发的记忆, 而 “大胆的作品” 不再能够从 “死亡的律法” 7 中解脱出来。这一作者版仿佛意味着 这次出版只是出于他的个人意愿, 出于他自愿、有意记住这次飞行的态度, 还要将 它从历史运动中解脱出来, 在其发展中, 把它从自己身上卸下。萨尔门托 - 德贝雷 斯个人的纪念意识使这本书有了第三版，他自己支付了费用。这本书是一个有形 的、物质的印记, 旨在重塑那段已被湮没的历史时刻, 把它拯救出来成为一个具有 辨识度的地方。

\footnotetext{
5 葡语 “冒险”一词来自拉丁语动词advenire, 意思是 “到来, 随后到来”。这一术语意味着正在到来的动作, 即 将到来的动作 (出乎意料的), 因此还引申出 “运气, 命运, 困难, 财富” 的含义。

6皮埃尔・诺拉, “在记忆和历史之间 地点的争议”。雅拉・安・科里翻译, 载于 “历史计划”, PUC-SP杂志, 圣 保罗, 12月号, 1993年, 12页。https://revistas.pucsp.br/index.php/revph/article/viewFile/12101/8763

7 引自 “卢西塔尼亚之歌”, 第一章, 第二节。
} 
para os entusiastas da aviação e para os que se interessam pelos acontecimentos portugueses nesta época nevrálgica da Primeira República. Mas a relevância da obra, escrita num registo testemunhal e com um recorte literário que não escapa ao leitor, alarga-se, naturalmente, a um público diversificado, pois narra uma aventura real, em que os heróis são de carne e osso e vivem inúmeras situações de alto risco. Pelo facto de narrar um voo pioneiro, realizado nesses já longínquos anos vinte, o livro confere a essa aventura aérea o seu sentido pleno, etimologicamente alicerçado em adventura ${ }^{5}$, que, literalmente, significa «que está a chegar». E o que estava a chegar, naquela altura, era não só a adversidade da viagem que os aviadores aceitaram enfrentar, mas também o futuro das comunicações aéreas e de uma nova era que almejaram construir também em Portugal.

A viagem do Pátria de Portugal até Macau foi, de facto, um extraordinário feito de engenharia aeronáutica e de aviação pioneira, reconhecido internacionalmente. Em Portugal, durante os quase três meses que durou a travessia aérea, o país inteiro viveu suspenso das notícias que chegavam sobre o sucesso dos seus aviadores.

Vive-se hoje numa época em que a memória dos factos e das gentes já não resulta de uma prática social. Sabemo-lo pelo alheamento da população relativamente a feriados que assinalam datas e feitos que, mesmo apesar dessa expressão colectiva, as pessoas ainda desconhecem e a que acabam por se tornar indiferentes. Assim, quanto menos a memória é vivida do interior, maior é a necessidade de a reivindicar através de suportes exteriores, do recurso a «marcas tangíveis de uma existência» que só através delas poderá sobreviver, como constatou o historiador Pierre Nora ${ }^{6}$.

Em 1968, quarenta e quatro anos após a viagem, a terceira edição do livro De Portugal a Macau é dedicada por Sarmento de Beires a Brito Paes, embora mantendo sempre a «dedicatória da primeira edição», dirigida ao povo português. Brito Paes havia já morrido, em 1934, e Manuel Gouveia também, em 1966. Dos três homens que haviam vivido a grande aventura da viagem aérea a Macau, só Beires era ainda vivo, mas já detentor da consciência aguda de que não existia memória espontânea e de que as «obras valerosas» já não libertavam «da lei da morte» ${ }^{7}$. Esta sua edição de autor parece querer significar que a publicação resultou apenas da sua vontade individual de lembrar, do seu gesto tão voluntário quanto intencional de recordar a viagem, arrancando-a assim do movimento da História que, no seu devir, parecia tê-la desgarrado de si. A consciência comemorativa individual de Sarmento de Beires fazia da terceira edição deste livro, que ele próprio custeou, uma marca palpável, materializada, que visava restituir à História esse momento já apagado, resgatando-o como lugar de identidade. A Brito

\footnotetext{
${ }^{5}$ Adventura vem do verbo latino advenire, que significa «chegar, sobrevir». O termo significa, pois, a acção que está a chegar, a acção que sobrevém (sem se estar à espera), de onde resulta ainda o sentido de «sorte, fado, desdita, fortuna».

${ }^{6}$ Pierre Nora, Entre Memória e História. A problemática dos lugares. Tradução de Yara Aun Khoury, in Projeto História, Revista da PUC-SP, São Paulo, (10), Dez. 1993, p. 12. https://revistas.pucsp.br/index.php/revph/article/ viewFile/12101/8763

${ }^{7}$ Cf. Os Lusíadas, Canto I, estrofe segunda.
} 
他满怀深情地把 “这些被湮灭的、我们的航空之旅的残片” 献给布里托 - 帕 伊斯。顺便说一句, 在近20年后的1984年, 皮埃尔 - 诺拉也是通过这个新奇的表达 定义了记忆的场所: “记忆的场所, 首先就是残片”, 意思是被历史活动自身所分解 的历史时刻, 从将它们遗忘的令人眩晕的时间流中解脱出来, 最终又归于历史。确 实, 四十四年后, 随着集体记忆的消退 (还是在康乃馨革命的伟大时刻之前, 那场革 命将创造出各种新的英雄), 萨尔门托 - 德贝雷斯将忠诚的记忆献给他 “缺席” 的同 伴, 这是三位飞行员的私人记忆, 是他们冒险、大胆计划的记忆, 这记忆也同时属 于葡萄牙人集体和葡萄牙历史。

今天，飞往澳门的航空之旅是一个记忆的场所，我们也通过再版这本书恢复 它。在里斯本一一澳门 “空中突袭” 百年纪念之前, 提供这些文字无疑有助于新的 研究、阅读和庆祝活动。

自1999年起, 澳门不再是一个葡萄牙省份。然而, 在其目前的文化全景中, 两 国共同的历史和文化遗产的价值受到重视，这已转化为对葡萄牙语日益增长的兴 趣和中葡之间日益紧密的关系。

2017年, 在若安娜 - 弗雷塔斯的一次报道中 (现在可以在Youtube上观看, 链 接: ps://www. youtube. com/watch?v=yx0Thdy0BuE), 为了给首都航空公司开通北 京一一葡萄牙的航线做宣传, 提及了这次1924年的空中 “突袭”。这不是任何一个 三大传统档案制作人 (即教会, 国家或家庭) 抛出的记忆, 而是由一个航空公司来展 示, 曾早在1924年就能实现的空中连接, 怎样在九十三年之后才能再度以决定性的 方式成为现实。萨尔门托 - 德贝雷斯在 1924 年就预感到可以建立葡萄牙一一澳门 和葡萄牙——中国 8 年度空中连接的机会, 但这从未发生过 9

如果没有一些支持内容将这本书情境化, 将 21 世纪的读者置于那遥远的 1924 年, “从葡萄牙到澳门”这本书是无法重新出现在市场上的。从与航空开拓精神密 不可分的情节、空间的回忆, 到那个时代全世界航空竞争的环境, 还有当时织出葡 萄牙全景的审美-政治思想, 以及作品本身之前的多篇前言, 我们尝试着尽可能广 泛地涵盖这次 “突袭” 的各种情况。所以我们也投入了解移往澳门的葡萄牙移民 潮, 以便更好地理解为什么选择这个遥远的目标作为那次长途飞行的目的地。

\footnotetext{
8 “在无意识的自豪感中, 所有人的眼泪中映射着爱国主义和思念之情一一军官们, 中士们和水手们; 我们瞥 见了每年飞往海外省份的航空旅行将带来的有益后果, 飞机的机翼上载着国旗的色彩, 那曾被遥远的祖国 的太阳照耀的色彩。”他进一步说道: “对于南中国首都的访问尽管很短暂, 但让我们能够再次评估我们的飞 行对于那些居住在国外的葡萄牙人的重要性。”(引自 13 章: 结论)

${ }^{9}$ 1996年, 即这次空中突袭之后七十二年, 葡萄牙航空公司TAP开通了前往澳门的商业航班, 由于无法盈利, 两 年后中止了。
} 
Paes dedica então, emocionadamente, «estes restos apagados da nossa viagem». Será, aliás, através dessa mesma curiosa expressão que, quase duas décadas mais tarde, em 1984, Pierre Nora definirá Les Lieux de la Mémoire: «os lugares da memória são, antes de tudo, restos», isto é, momentos da história que, dissolvidos pelo movimento da própria história, a ela são devolvidos, depois de arrancados a esse fluxo vertiginoso do tempo que os esquece. Efectivamente, ao ser confrontado, quarenta e quatro anos mais tarde, com o esbatimento da memória coletiva (ainda antes do grande momento da revolução dos cravos, que criaria novos heróis de conquistas diversas), Sarmento de Beires dedica ao seu companheiro «ausente» a fidelidade de uma memória que, tendo sido, no plano do risco e da ousadia, privativa de três aviadores, pertencia também à colectividade e à História dos portugueses enquanto traço de uma identidade solidária, audaz e temerária.

A viagem aérea a Macau é hoje, portanto, um lugar de memória, que aqui também se reivindica através desta edição. A disponibilização deste texto antes da comemoração do centenário do raide Lisboa-Macau facilitará certamente novas investigações, leituras, celebrações.

Desde 1999 que Macau já não é província portuguesa. No seu actual panorama cultural sobressai, no entanto, o empenhamento na valorização da história e do património comum aos dois países, que se tem traduzido num crescente interesse pela língua portuguesa e pelo estreitamento dos laços entre Portugal e a China.

Em 2017, numa reportagem de Joana Freitas (disponível hoje no youtube através do link https://www.youtube.com/watch?v=yx0Thdy0BuE), este raide de 1924 foi chamado à colação, para divulgar a abertura da rota Pequim-Portugal pela Capital Airlines. Não foi uma memória accionada por qualquer dos três grandes clássicos produtores de arquivos (Igreja, Estado ou Família), mas por uma companhia aérea, que procurou mostrar como a ligação conseguida em 1924 só noventa e três anos mais tarde se objectivava de forma decisiva. No entanto, Sarmento de Beires já intuíra, em 1924, a oportunidade de uma ligação anual de Portugal a Macau e à China, ${ }^{8}$ que nunca veio a verificar-se ${ }^{9}$.

A obra De Portugal a Macau não poderia reaparecer actualmente no mercado sem alguns conteúdos de apoio que a contextualizassem e que situassem o leitor do século XXI nesse já remoto ano de 1924. Da recordação dos episódios e dos espaços que estiveram indissociavelmente ligados ao pioneirismo aeronáutico, ao ambiente de competição mundial vivido pela aviação da época e aos ideários estético-políticos que cruzavam o panorama português de então, procurou-se, com os vários prefácios que antecedem a obra propriamente dita, cobrir o mais amplamente possível as circunstâncias que envolveram este raide. Por isso se investiu

\footnotetext{
8 «E, inconscientemente, ao sentir o orgulho, o patriotismo e a saudade que se reflete em todos aqueles olhos rasos de água - oficiais, sargentos, marinheiros -, vislumbramos as benéficas consequências que resultariam do empreendimento de uma viagem aérea anual às nossas Províncias Ultramarinas, que ali levasse, nas asas de um avião, as cores da bandeira, ungidas pelo sol da Pátria distante». E ainda, mais adiante: «A nossa visita à capital da República Chinesa do Sul, apesar de breve, permitia-nos avaliar mais uma vez a importância da nossa viagem para os núcleos de portugueses residentes no estrangeiro» (Cf. Cap. XIII - Conclusão).

${ }^{9}$ Em 1996 (setenta e dois anos após este raide aéreo), a TAP inaugurou um voo comercial para Macau, que foi descontinuado dois anos mais tarde, por não ser rentável.
} 
每次再版自己作品时, 萨尔门托 - 德贝雷斯都会引入新的脚注, 以逐步澄清早 在1925年编辑的文本。在这些注解中, 有的解释了一些航空术语 (如, 何为 “木马”); 有的纠正了一些关于某些人民和国家的最初看法, 这些看法后来被证实是不正确 的; 还有的解释了当时 “祖国号” 飞机中途停留之地的政治环境, 以便让人们从最小 的细节以及他们所经历的种种复杂情况中理解整篇 “报告”。这本书在1925年首次 出版后, 于1953年出了第二版, 1968年出了第三版。今天, 每一版都售罄了。

在本版, 即第四版中 (这是自作者1974年6月去世后的第一版, 也是 21 世纪第一 版), 我们保留了原版的所有脚注。同时, 我们注意到无论是事件发生的距离还是 时代都非常遥远, 为使阅读变得较为容易, 增加了一些脚注。我们使用括号标注这 些脚注并标明 “编辑注”, 以便与其他作者的脚注区分。

为了寻求中葡两国间的跨文化对话, 这次我们 (通过与 “WG图书” 的良好合作) 投入出版了葡语一汉语双语版本, 第一次让华人团体能够接触到这个飞行叙事故 事。这个故事的叙述人一—飞行员若泽 - 曼努埃尔 - 萨尔门托 - 德贝雷斯将中国 的地理、文化、烹调和历史也渗透在自己的叙事记录中, 使得早在 20 世纪初, 这种 欧洲人看待中国的眼光就得以传播 ${ }^{10}$ 。

\section{难以预料的八十天不完美的结晶 ${ }^{11}$}

1925年4月7日（根据本版最后的脚注, 这是 “祖国号” 飞机从葡萄牙千泉新城 飞往澳门启程一周年的日子), 从葡萄牙一澳门航空之旅归来之后, 我们正在再版 的这本书立刻得以发表, 当年它取得了巨大的出版成功 ${ }^{12}$ 。

\footnotetext{
10 在连续的再版中, 由作者做出的注解纠正了这些最初的看法, 以寻求更新这些随着时间的流逝已过时的看 法。比如, 飞越北海时, 萨尔门托 - 德贝雷斯承认 “这个重要的中国城市还有一个一年一度的野蛮集市, 在 集市上, 妇女们被以肉类消费市场的价格按体重出售。” (第12章一一最后一段航程)。在第二版中, 这句话 被保留了 (它忠实地反映了1924年的现实), 但是插入了作者的注解, 在注解中, 他澄清 “这种原始的传统在 1930年被废除了。”

11 “从葡萄牙到澳门”萨尔门托・德贝雷斯的表述 (献辞)。

12 本书第一版印数为 2000 册, 此外还有 70 册使用Liorre纸张印刷, 并由作者本人编号、签名的特别发行本。
} 
também na compreensão dos fluxos migratórios portugueses para Macau, no sentido de se perceber melhor a escolha desse destino longínquo como meta para esta viagem de longo curso.

A cada reedição da sua obra, Sarmento de Beires foi introduzindo algumas notas de rodapé, num progressivo processo de clarificação do texto que editara logo em 1925. As notas explicavam termos aeronáuticos (como «cavalo de pau», por exemplo), corrigiam percepções iniciais sobre povos e países que, posteriormente, se revelaram inexactas ou explicitavam circunstâncias políticas dos locais onde o Pátria fez escala, para que todo o relato pudesse ser compreendido nos mínimos detalhes e em toda a complexidade de algumas situações vividas. À primeira edição de 1925 seguiu-se a segunda, em 1953, e ainda a terceira, em 1968. Qualquer delas se encontra hoje esgotada.

Nesta quarta edição da obra (a primeira desde a morte do autor, em Junho de 1974, e também a primeira deste século XXI), todas essas notas ao texto se mantiveram e acrescentaram-se ainda outras, no sentido de facilitar ainda mais a sua leitura, atendendo à distância dos acontecimentos e do tempo. Esta intervenção em nota vai assinalada entre parêntesis com a indicação «nota do editor», para se distinguir das restantes, que foram notas do autor.

A aposta numa edição bilingue Português-Mandarim (que resultou de uma feliz parceria com a WG Books) procura dar resposta ao diálogo intercultural entre os dois países, tornando acessível pela primeira vez, entre a comunidade chinesa, esta narrativa de viagens aéreas, em que o território chinês, a sua geografia, cultura, gastronomia e história perpassam também nos registos do seu narrador, o aviador José Manuel Sarmento de Beires, permitindo esta divulgação do olhar de um europeu sobre a China, nos inícios do século $\mathrm{XX}^{10}$.

\section{UMA CRISTALIZAÇÃO IMPERFEITA DE OITENTA DIAS DE INCERTEZA ${ }^{11}$}

Publicado logo a seguir ao regresso da viagem aérea de Portugal a Macau, aos sete de Abril de 1925 («data do primeiro aniversário da partida do avião Pátria de Vila Nova de Milfontes para Macau», conforme consta da nota final da edição), este livro que agora se reedita conheceu, no ano de 1925, um extraordinário sucesso editorial ${ }^{12}$.

Diversas foram as circunstâncias que explicam o forte impacto deste livro junto dos leitores portugueses da época. Tratava-se da narrativa detalhada de uma viagem aérea pioneira a nível mundial, que devolvera prestígio além-fronteiras a um Portugal que, por força da

\footnotetext{
${ }^{10}$ As notas de rodapé das sucessivas edições controladas pelo autor foram corrigindo esse olhar inicial, procurando actualizar a informação que, com o decorrer dos anos, se tornava ultrapassada. Assim, por exemplo, ao sobrevoar Pakhoi, Sarmento de Beires reconhecera «a importante cidade chinesa onde anualmente se realiza ainda uma bárbara feira, com mulheres vendidas a peso como carne de consumo» (Cap. XII - A Última Etapa). Na segunda edição, manteve a frase (que era fiel à realidade de 1924), mas inseriu uma nota de rodapé, onde esclarece que «esta tradição primitiva foi suprimida em 1930».

${ }^{11}$ Expressão de Sarmento de Beires, em De Portugal a Macau (dedicatória)

${ }^{12}$ A primeira edição da obra teve uma tiragem de dois mil exemplares, acrescida de uma tiragem especial de setenta exemplares em papel Liorne, numerados e rubricados pelo autor.
} 
有多种情况可以解释为什么这本书当时在葡萄牙读者中产生了巨大影响: 这 是一本世界级的、详细讲述一次开拓性航空之旅的叙事故事书, 享誉全世界; 同时, 葡萄牙却处于第一共和国时代的不稳定环境中, 无论是社会、经济还是政治上的 情况都令人沮丧。如加戈 - 科蒂尼奥 ${ }^{13}$ 所说, 从飞行总里程来看, “祖国号” 实际上 飞过了半个世界。这是一个了不起的成就, 特别是与其他国家用于长途飞行的飞 机相比, 无论是飞机型号还是技术条件, 这次飞行使用的飞机不但老旧残破而且技 术落后 ${ }^{14}$ 。

另一方面, 这本书提前在 “新田地” 杂志发布了消息, 引起了人们对于 “即将 出版”15 的 “由作者及布里托 - 帕伊斯以及曼努埃尔 - 戈维亚一年前所做的精彩旅 行的报告” 产生了期望和好奇。书中叙事是建立在有经验的权威讲述故事的基础 上一一讲述者亲身经历了它, 这对于引起人们的兴趣起到了决定性的作用。

最后, 本书的献辞写明 “献给葡萄牙人民”, 使每个葡萄牙人都与这次艰难的飞 行所取得的成功有了联系。这或许可以解释为什么在一个葡萄牙文盲率高达 $65 \%$ 的时代 (根据1920年的人口普查 ${ }^{16}$ ), 这本书被广泛接受。萨尔门托 - 德贝雷斯将通 过这次飞行达到的、意味深长的胜利也归功于葡萄牙人民, 并将这一点载入国家 证明和进步计划中, 使得当时葡萄牙社会最具参与度, 最具思想性的一些领域受到 鼓舞 ${ }^{17}$ : “献给葡萄牙人民, 从他们那儿我们获得了富有吸引力的力量, 让我们走向 胜利; 献给葡萄牙人民, 在飞往澳门的旅程中, 为了让葡萄牙的名字享誉世界, 他们 奉献出惊人的精力和巨大的热情。”

这是一部以第一人称，从自己在这次飞行冒险中获得的直接经历和感觉出发 讲述的故事。葡萄牙人, 所有的葡萄牙人都为这次飞行冒险做出了贡献一一当时 从南到北, 全国都特别为此开设了多个公众募捐手册。这本书是 1924 年 4 月 7 日到 6 月 20 日那 “难以预料” 18 的八十天令人印象深刻的记录。期间, 整个葡萄牙通过后 来在报纸上发表的电报或是信件热切地、紧紧地追随飞行员们从远方传来的消 息。

\footnotetext{
13 科蒂尼奥, 1924:17。

14 请注意, 萨尔门托 - 德贝雷斯怎样介绍曾在巴格达与 “祖国号” 团队相遇的飞行家佩尔蒂埃一窦昔, 在本书 第6章中, 作者觉得那简直就像天外救星, 文字上是这样的: “窦昔那让人羡慕的杰奎琳号飞机也在此降落, 杰 奎琳号优美的线条与祖国号的笨重轮廓形成了鲜明对比。”

15 请参阅, 如, “新田地” 1925年4月, 第44号刊。

16 引自坎迪亚斯, 2007年: 40。

17 萨尔门托 - 德贝雷斯与 “新田地” 杂志 (1921年由卡布拉尔 - 普罗恩萨在里斯本创刊) 的联系是, 1921年 至1926年他是杂志经常性撰稿人, 在接下来的十年里, 尽管不再那样经常, 他还是确认了自己的撰稿才干。 18 萨尔门托・德贝雷斯在作品献辞中的表述。
} 
instabilidade que caracterizou a Primeira República, se encontrava então social, económica e politicamente deprimido. Na totalidade da distância aérea percorrida, o Pátria realizara praticamente metade da volta ao mundo, como afirmou Gago Coutinho ${ }^{13}$, o que configurava um feito de grande notoriedade, sobretudo porque realizado a bordo de um avião frágil e tecnicamente já obsoleto, quando comparado com os modelos e condições técnicas em que os outros países empreendiam os seus voos de longo curso ${ }^{14}$.

Por outro lado, o anúncio do livro fizera-se antecipadamente na Revista «Seara Nova», gerando expectativas e curiosidade em torno do «relato da maravilhosa viagem efectuada há um ano pelo autor, por Brito Paes e Manuel Gouveia», «a sair brevemente» ${ }^{15}$. A narrativa surgia, pois, firmada na autoridade experiencial de quem contava a história, tendo-a vivido, circunstância que terá sido determinante para o interesse que suscitou.

Finalmente, a dedicatória do livro «ao povo de Portugal» implicava cada português no êxito dessa difícil viagem, o que talvez explique a alargada recepção da obra, numa época em que a taxa de analfabetismo em Portugal era de 65\% da população, segundo o censo de $1920^{16}$. Sarmento de Beires atribuía aos portugueses uma co-responsabilidade no tão expressivo triunfo alcançado através da viagem, inscrevendo esta no programa de progresso e afirmação nacional que animava alguns sectores mais interventivos e pensantes da sociedade portuguesa de então ${ }^{17}$ : «Ao Povo de quem recebemos a força magnética que nos fez triunfar; ao Povo que, na afirmação formidável da sua energia e do seu entusiasmo, concorreu para que, na viagem aérea a Macau, o nome de Portugal se aureolasse de um prestígio maior».

Esta era portanto uma narrativa que contava, na primeira pessoa e a partir da experiência directa do vivido e do sentido, o que tinha sido a aventura desse raide aéreo, para cuja realização os portugueses - todos os portugueses - tinham contribuído financeiramente, através das múltiplas subscrições públicas que se abriram para o efeito, de norte a sul do país. O livro era o registo impressivo desses «oitenta dias de incerteza» ${ }^{18}$, vividos entre sete de Abril e vinte de Junho de 1924, durante os quais Portugal inteiro acompanhou ávida e intensamente as notícias longínquas que chegavam dos aviadores, por telegrama ou por carta, e que eram posteriormente divulgadas nos jornais portugueses.

As circunstâncias que envolveram toda a viagem, desde a ideia inicial até à sua consecução, pesaram também na curiosidade e no empolgamento dos portugueses com este raide

\footnotetext{
${ }^{13}$ COUTINHO, 1924:17.

${ }^{14}$ Atente-se na forma como Pelletier-Doisy, que se cruzou com a equipa do Pátria em Bagdad, é apresentado por Sarmento de Beires, no capítulo VI desta obra, quase como um deus ex machina, em sentido literal: «aterra também no seu admirável aparelho - o «Jacqueline» -, cujas linhas elegantes contrastavam violentamente com a pesada silhueta do Pátria.

${ }^{15}$ Veja-se, por exemplo, o n. ${ }^{\circ} 44$ da «Seara Nova», de Abril de 1925.

${ }^{16}$ Cf. CANDEIAS, 2007: 40.

${ }^{17}$ A ligação de Sarmento de Beires à revista «Seara Nova» (fundada em 1921 em Lisboa, por iniciativa de Raul Proença) de que foi um colaborador assíduo entre 1921 e 1926 e, já menos assíduo, na década seguinte, confirma esta vocação actuante.

${ }^{18}$ Expressão de Sarmento de Beires na dedicatória da obra.
} 
从开始的想法到最后完成, 这次空中之旅的种种环境背景也让葡萄牙人对这 次开拓性空中突袭感到好奇和兴奋。实际上, 从葡萄牙航空界第一次投入并开拓 了本国大陆领土之外的新航线之后, 即 1920 年布里托 - 帕伊斯和萨尔门托 - 德贝 雷斯飞越马德拉岛的壮举 (他们飞到了马德拉上空, 但是由于大雾无法降落, 而在 回程中由于事故丧失了飞机 ${ }^{19}$ ), 葡萄牙空军就梦想着能够进行一次长途飞行。飞 行巨子卡洛斯 - 布莱克对这项壮举激动不已, 他通过开设航空武器的募捐册竭尽 全力想要购买一架飞机以实现这个梦想。终于在1921年购入了被布里托 - 帕伊斯 命名为 “祖国号” 的飞机。不过经过了一些事件后, 这架飞机被为购买它而成立的 筹款委员会令人茫然地送给了国家。

而葡萄牙政府则以 “仅使用现有的航空资源, 不得动用国库” 为条件同意实 现这次飞行，但这次飞行直到1923年8月才获得最终授权。这个意外导致了全国 性的认捐运动, 布里托 - 帕伊斯的姐姐玛丽亚 - 多塞乌 - 帕伊斯当年11月在阿兰 特茹开始这项运动。它产生了如此之大的反响: 它不但是一个最富有表现力的时 刻一一其中汇集了所有的努力和资源, 也是葡萄牙人 20 世纪上半叶所经历的最令 人激动、最令人兴奋的时刻。正是有了这种团结、慷慨的资金和情感支持，萨尔 门托 - 德贝雷斯, 布里托 - 帕伊斯和曼努埃尔 - 戈维亚才能实现这次世界航空史 上开拓性的壮举, 将葡萄牙和澳门从空中连接在一起一一因为从国家层面, 没有任 何支持或是表现出任何兴趣——在出发前, 国家元首没有向他们道别, 尽管为此举 行了听证会 ${ }^{20}$ 。

\footnotetext{
19 这次飞行是首次从里斯本到马德拉岛的空中穿越, 执飞的是 “黑骑士号” 飞机。

20 在这次飞行后, 萨尔门托 - 德贝雷斯和布里托 - 帕伊斯被共和国总统授予剑与塔骑士团司令, 机械师曼努 埃尔・戈维亚被同一骑士团奖励为骑士。

当飞行员们于1924年9月9日回到里斯本时, 已经是另外一个政府在主宰国家的命运。许多因素导致了由 奥瓦罗 - 德卡斯特罗领导的葡萄牙第一共和国第39届政府垮台, 但是其与航空有关的政策触发了这届政 府的终结。实际上, 在飞往澳门期间, 对于战争部长或含蓄或明确的指控越来越多, 不仅是对其对于里斯 本一一澳门航空之旅态度的指控, 也是对他无力领导军队, 特别是航空部队的指控。当时这种政府与空军 的紧张状态导致发布了1924年5月 30 日政府令, 根据该令, 空军少校斯弗卡 - 杜阿尔特被免除葡萄牙航空局 主任职务, 并规定, 从那以后, 该职务只能由空军之外的、任何其它军种的上校军官担任。面对既不理解也 不能接受的事实, 空军军官们拒绝服从当时被任命的航空局主任莫莱斯 - 萨尔门托上校的命令, 他们通过 无线电传递消息, 决定在军营中起义并且只服从斯弗卡 - 杜阿尔特少校的命令。接着, 空军军官们飞过里 斯本上空进行政治宣传并表明他们的宗旨不可动摇。因此, 阿马多拉飞机场被政府军队包围 (为此政府动 用了大约 2000 名士兵), 但是空军军官们要求战争部长辞职。五天后, 政府给他们派去了另一位将军 (贝尔纳 多 - 法利亚), 在与其进行对话后, 飞行员们最终投降并被押解至圣儒里昂 - 达巴拉塔的监狱。然而, 政府在 这次镇压中并没有取得完全胜利, 因为公众與论对他们不利, 议会也受到谴责和抨击, 其中包括政府对于里 斯本一一澳门空中突袭不予支持的态度并且与空军站在对立面。1924年6月24日, 政府向议会提交了一份 动议, 然而遭到了议会拒绝, 这样, 奥瓦罗 - 德卡斯特罗政府垮台, 紧接着导致被捕的飞行员们被释放。有关 内容, 可参阅FAVA2016。
} 
pioneiro. De facto, após a primeira investida da aviação portuguesa em desbravar novas rotas aéreas para além do território continental, com o feito aéreo empreendido em 1920 por Brito Paes e Sarmento de Beires até à ilha da Madeira (que sobrevoaram, mas onde não puderam aterrar em virtude do nevoeiro, vindo a perder o avião num acidente de regresso) $)^{19}$, a aviação militar portuguesa sonhava com um voo de longo curso. Entusiasmada pelo prémio com que o magnata Carlos Bleck reconhecera essa primeira proeza, envidou esforços para adquirir um avião que possibilitasse esse feito, através da abertura da subscrição da Arma da Aeronáutica. E assim se adquiriu, em 1921, o avião que Brito Paes baptizou de Pátria e que, após vários incidentes, acabou por ser desconcertantemente oferecido ao Estado, pela mesma comissão que angariara os fundos para a sua aquisição.

Do Governo português passaria, pois, a depender a realização da viagem, que só alcançou a definitiva autorização em Agosto de 1923, na condição de se efectivar «sem dispêndio para a Fazenda Nacional, apenas utilizando os recursos disponíveis da Aviação». Desta contingência resultou o movimento de subscrição nacional que a irmã de Brito Paes, Maria do Céu Paes, iniciou em Novembro desse ano no Alentejo e que teve tal repercussão, que se viria a revelar um dos mais expressivos momentos de congregação de esforços e recursos, empolgamento e entusiasmo vividos pelo povo português na primeira metade do século XX. Foi com este solidário e generoso apoio financeiro e emocional que Sarmento de Beires, Brito Paes e Manuel Gouveia conseguiram realizar esse feito pioneiro da aviação mundial, ligando Portugal a Macau por rota aérea, sem qualquer apoio ou demostração de interesse por parte do Estado português, cujo Chefe supremo nem deles se despediu antes da partida, apesar da audiência solicitada para o efeito. E o mesmo sucedeu com os ministros da Guerra e dos Estrangeiros ${ }^{20}$.

\footnotetext{
${ }^{19}$ Este voo constituiu a primeira travessia aérea de Lisboa à ilha da Madeira e foi realizado a bordo do avião «Cavaleiro Negro».

${ }^{20}$ Depois da viagem, Sarmento de Beires e Brito Paes foram condecorados pelo Presidente da República com a Comenda da Ordem de Torre e Espada, tendo o mecânico Manuel Gouveia sido distinguido como Cavaleiro da mesma Ordem.

No regresso dos aviadores a Lisboa, a 9 de Setembro de 1924, era já outro o Governo que presidia aos destinos do país. Foram vários os factores que precipitaram a queda do $39 .{ }^{\circ}$ Governo da I República Portuguesa, comandado por Álvaro de Castro, mas a sua política relativa à aviação despoletou o seu fim. De facto, enquanto decorria a viagem aérea a Macau, as acusações veladas ou explícitas ao ministro da Guerra cresceram de tom, não se restringindo apenas à sua atitude relativamente ao raide Lisboa - Macau, mas também à sua alegada incompetência para dirigir o Exército, particularmente o ramo da Aeronáutica. Esta tensão que opunha o Governo à Aviação da época extremou-se com a publicação do Decreto Governamental de 30 de Maio de 1924, pelo qual o Major aviador Cifka Duarte era exonerado das suas funções de director da Aeronáutica Portuguesa, determinando que, a partir daquele momento, o cargo só pudesse ser exercido por um coronel de qualquer arma do exército, à excepção da aviação. Postos perante este facto que não entendiam nem aceitavam, os oficiais da aviação militar recusaram-se a acatar as ordens do então nomeado director da Aeronáutica, coronel Morais Sarmento, difundindo por rádio a mensagem de que a aviação se encontrava revoltada nos seus quartéis e que só obedeceria às ordens do Major Cifka Duarte. Seguidamente, os oficiais aviadores sobrevoaram Lisboa, distribuindo propaganda e revelando-se inamovíveis nos seus propósitos. O Campo de Aviação da Amadora foi então cercado por tropas do Governo (foram destacados cerca de dois mil homens para o efeito), mas os oficiais aviadores exigiam a demissão do ministro da Guerra. Cinco dias depois, foi-lhes enviado outro General (Bernardo Faria), a quem os aviadores acabaram por se render, na sequência das conversações então entabuladas, sendo posteriormente conduzidos, sob prisão, para a Torre de S. Julião da Barra. O Governo, no entanto, não saíra totalmente vitorioso desta crispação, pois a opinião pública era-lhe desfavorável, e o Parlamento inflamava-se com censuras e invectivas, pelas quais se acusava o governo de, displicentemente, não ter
} 
这样就可以理解葡萄牙人民看待这次飞行和飞行员们的欣喜之情: 他们用自 己的钱财、祷告和全部的关注和关怀爱护着这几个飞行员。同样的, 我们也可以 理解人们对 “从葡萄牙到澳门 (“祖国号”之旅)”这本书的好奇心, 因为只有通过这 本书, 人们才能真正了解这次空中之旅所经历的许多困难和危险的细节, 而且这项 壮举的参与者之一以第一人称作了见证。作者在致辞中将其称为 “难以预料的八 十天”, 描述了多个在飞行中与死亡擦身而过的瞬间。由于飞行距离 (半个世界) 和 飞行时间 (八十天) 的缘故, 这次空中之旅及其叙事立刻将读者们的想象力召唤了 出来, 他们想起了儒勒 - 凡尔纳著名的小说 “环游世界八十天”。然而, 当冒险是 在真实的飞机上, 由有血有肉的飞行员进行时, 尽管事前知道结果是有利的, 围绕 着这次行动的压力也会带来更大的焦虑和期望。这位叙述者权威的声音从自己亲 历的经验出发, 以第一人称讲述, 使得那个时代的读者们仿佛身临其境一一因为祖 国号搭乘了又一位乘客: 葡萄牙人民, 读者们似乎目睹了那史诗般错综复杂的航程, 并为此激动不已 ${ }^{21}$ 。

\section{施舍之旅}

“众筹” 这个在 21 世纪创造的术语是指: 为了某种共同利益的举动而集体募集 资金的过程 (在葡萄牙, 2015年8月24日发布的102号法律规范了它)。在所有的金 融网络被互联网组织起来之前的大约一个世纪, 正是 “众筹” 这种手段让人们确信, 他们可以购买一架飞机, 这架飞机将实现从里斯本穿越天空, 飞抵澳门的航程。实 际上, 这次空中突袭最有趣、最特别的一面, 特别是对于今天看待这件事的人来说, 是只有通过多个公众认捐筹款运动用来购买需要的飞机以及筹集相关费用，才有 可能实现的这一背景。想象一下, 今天如果要靠国家的参与才能实现这几乎让人 惊呆的航行得怎么做才行。更何况那是差不多一百年前。

\footnotetext{
21 “是葡萄牙人民与我们同在, 是葡萄牙人民指挥一切”。(德贝雷斯, “从葡萄牙到澳门 (第三章)”)。当时新闻界 语言中也弥漫着同样的基调, 比如我们可以在1924年5月5日 “亚速尔日报” 安东尼奥 - 若泽 - 德阿尔梅达的 专栏中读到:

我们记得在这架飞机中, $(\cdots \cdots \cdot)$ 是天才的承载者和种族的希望, 现在去的不仅仅是三个坚定、勇敢、聪明和 充满勇气的男子。一个新的机组已经进入飞机, 带着平静、英勇和自信指挥它。

这个无敌而坚韧的机组成员, 他的名字叫葡萄牙。
} 
Compreende-se assim o enlevo com que o povo português olhava esta viagem e estes aviadores, que acarinharam com o seu dinheiro, as suas preces e toda a sua atenção e desvelo. Entende-se deste modo, também, a curiosidade com que o livro De Portugal a Macau (A viagem do Pátria) foi recebido, pois só através dele todos os detalhes das dificuldades e dos muitos perigos que envolveram esta viagem seriam efectivamente conhecidos, narrados testemunhalmente, na primeira pessoa, por um dos participantes dessa arrojada proeza. A narrativa, que o autor apresenta na dedicatória como sendo a «cristalização imperfeita de oitenta dias de incerteza», presentifica vários momentos da viagem em que os aviadores roçaram de perto a morte. Pela distância percorrida (meia volta ao mundo) e pela duração (oitenta dias), viagem e narrativa convocam de imediato, no imaginário do leitor, a célebre ficção de Júlio Verne, A volta ao mundo em oitenta dias. No entanto, quando a aventura viajeira decorre no plano do real, com aviadores de carne e osso, a tensão gerada em torno da acção assume contornos de maior ansiedade e expectativa, mesmo quando o desfecho se sabe, de antemão, ser favorável. A voz autorizada deste narrador, que fala a partir de uma primeira pessoa legitimada pelo lado vivencial da sua experiência, permitiu ao leitor emocionado da época conhecer, quase na sua própria pele, os meandros dessa épica viagem em que o avião Pátria levou sempre mais um passageiro a bordo: o povo português ${ }^{21}$.

\section{UMA VIAGEM DE ESMOLAS}

O crowdfunding, esse termo que o século XXI forjou para designar os processos de financiamento colectivo para iniciativas de interesse comum (e que em Portugal se encontra regulamentado pela Lei n. ${ }^{\circ}$ 102/2015, de 24 de Agosto), foi o meio que permitiu, quase um século antes de todas estas redes de financiamento organizadas pela internet, a convicta aquisição do avião que realizaria a travessia aérea Lisboa-Macau. De facto, um dos aspectos mais extraordinários e interessantes deste raide, sobretudo para quem o perspectiva hoje, é a circunstância de a sua concretização só ter sido possível pelas várias e sucessivas movimentações de subscrição pública, para aquisição do aeroplano que permitiria a viagem e o suporte das despesas a ela associadas. Imaginar hoje o que seria fazer depender da participação nacional uma viagem desta envergadura quase nos deixa atónitos. E, no entanto, assim foi, há quase cem anos.

Durante o tempo que decorreu entre a subscrição inicial da Arma da Aviação para aqui-

apoiado o raide Lisboa - Macau e de ter afrontado a Aviação Militar. A 26 de Junho de 1924, o Governo apresentou ao Parlamento uma moção de confiança, que foi rejeitada, caindo deste modo o Governo de Álvaro de Castro, de que resultou, seguidamente, a libertação dos aviadores presos. Sobre esta matéria, ver FAVA, 2016.

${ }^{21}$ «É o Povo de Portugal quem vai connosco e quem manda» (Beires, De Portugal a Macau, cap. III). Esta mesma ideia perpassava na linguagem da imprensa da época, como se pode ver pelo excerto da crónica de António José d'Almeida no jornal Diário dos Açores, 5 de Maio de 1924:

Lembremo-nos de que dentro desse avião, (...) portador do Génio e das esperanças da Raça, não vão actualmente apenas três homens de rígida, audaciosa e inteligente coragem. Um novo tripulante saltou já para dentro dele, assumindo-lhe, com calma, heroicidade e confiança, o comando supremo.

Esse tripulante, invencível e indomável, chama-se Portugal. 
在航空武器司为购买飞机开始认捐到飞行 (被战争部了难) 的最后准备期间, 飞行费用由航空部队支持的授权过期了，布里托 - 帕伊斯就从自己的财产里拿出 来 100 康多 (折合今天的 500 欧元, 但当时可是一小笔财富)。萨尔门托 - 德贝雷斯 这边则刚刚编写了一本自己的诗集, 名为 “风的交响曲”, 交由 “新田地” 杂志出售, 所得利润也用于资助这次航空之旅。这本诗集 1924 年 5 月面世, 封面标价 10 埃斯库 多, 当时飞行正在进行中, 许多人以高于标价的价格购买它, 目的就是为了这次使 整个国家受益罒浅的空中突袭做贡献。诗集第一版印刷的 1300 册很快就售罄。后 来增印到3000册, 也很快售罄。

整个葡萄牙从南到北, 还有马德拉群岛, 亚速尔群岛, 在巴西, 还有澳门, 都掀 起了为这次飞行购买飞机募集款项的认捐活动。不久之后，还购买了第二架飞机， 因为在完成飞抵澳门的空中之旅之前, “祖国号” 降落时遭受风暴, 在印度巴塔拉的 一个村庄解体了。正当飞行员们没有钱继续飞行准备回国时，斯弗卡 - 杜阿尔特 少校寄去了葡萄牙政府允许继续这次空中突袭的许可, 于是他们花了 4300英镑购 买新飞机 (“祖国二号”), 这钱也是葡萄牙人辛苦贡献。书中的第八章 “悲剧时刻” 值得一读, 这一章令人激动地叙述了那场迫使 “祖国号” 降落并摧毁了飞机的风 暴。然而, 在航程是否能继续这一令人不安的时刻, 葡萄牙报纸不断发布消息, 在 报纸的页面上、专栏中都是对于葡萄牙航空英雄主义的赞扬。

购买第二架飞机再次点燃了葡萄牙人的激情, 他们展开各种发明和创举来支 持飞行费用, 这次飞行将葡萄牙置于在飞行领域取得不俗成绩的国家之中 22 。安东 尼奥・若泽 - 德阿尔梅达在 “世纪”上撰写了一个长篇专栏, “亚速尔日报” 也转载 了 23 。文中, 他确信这次飞行能够取得成功, “我们一致履行自己的义务, 为你们寄 去我们的钱和我们的灵魂。” 这种无私给予的姿态让布里托 - 帕伊斯在澳门俱乐 部解释自己飞行时的情形时, 将其简明扼要地概括为 “就像各位看到的, 这是架施 舍来的飞机。”24

22 在前往澳门的飞行准备期间, 为纪念巴西独立一百周年, 加戈 - 科蒂尼奥和萨卡杜拉 - 卡布拉尔在国家的 支持下于1922年进行了第一次著名的飞越南大西洋之旅。

23 “亚速尔日报”, 1924年5月5日。

24 “里斯本一一澳门突袭”执行委员会报告”, 1924年: 36页。 
sição do aparelho e os preparativos finais do raide (dificultados pelo Ministério da Guerra), caducou a autorização para que as despesas da viagem fossem suportadas pela Arma da Aeronáutica, pelo que Brito Paes despendeu, do seu próprio património, a quantia de cem contos (o equivalente, hoje, a quinhentos euros, mas que, na época, constituía uma pequena fortuna). Sarmento de Beires, por seu lado, que acabara de aprontar um livro seu de poemas, intitulado Sinfonia do Vento, colocara-o à venda pela «Seara Nova», revertendo o seu lucro para o financiamento da viagem. Com um preço de capa de dez escudos, o livro saiu em Maio de 1924, já a viagem ia a meio, e muitos foram os que o adquiriram por um preço superior, com o objectivo de contribuir para esse raide que galvanizava então o país inteiro. A primeira edição teve uma tiragem inicial de mil e trinta exemplares, reforçada até ao terceiro milhar, tendo esgotado rapidamente.

Por todo o lado, de norte a sul do país, nas ilhas dos Açores e da Madeira, no Brasil e em Macau, emergiram iniciativas de subscrição para aquisição do avião, mais tarde estendidas a um segundo aeroplano, pois o Pátria partiu-se ao aterrar, debaixo de um temporal, na aldeia de Budhana, na Índia, antes de cumprida a travessia até Macau. Sem dinheiro para continuar viagem, os pilotos preparavam-se para regressar, quando o Major Cifka Duarte envia a permissão do governo português para continuarem o raide e adquirirem novo avião (o Pátria II), que foi comprado na Índia por quatro mil e trezentas libras esterlinas, também elas produto do contributo e do empenho esforçado dos portugueses. Vale a pena ler, no capítulo VIII, intitulado «Horas Trágicas», o emocionante relato dessa tempestade que obrigou à aterragem que haveria de destruir o Pátria. Entretanto, acerca do nevrálgico momento de incerteza relativamente à viabilidade de se prosseguir viagem, os jornais portugueses iam dando notícias sucessivas, ao mesmo tempo que, nessas páginas de imprensa, crónicas inflamadas exaltavam a heroicidade da aviação nacional.

A compra do segundo avião fez acender de novo a emoção dos portugueses, que se desdobraram em invenções e iniciativas para suportar as despesas da viagem que colocaria Portugal entre os países com grandes feitos na aviação ${ }^{22}$. António José d'Almeida escreve então uma longa crónica n'O Século, que o Diário dos Açores também reproduz ${ }^{23}$, onde afirma a sua confiança no sucesso da viagem, «se unanimemente cumprirmos o nosso dever, mandando-lhes o nosso dinheiro e a nossa alma». Destes gestos de oferta abnegada resultará a síntese lapidar com que Brito Paes explicaria, no clube de Macau, as circunstâncias em que viajaram: «um avião de esmolas, como V. Exas vêem» ${ }^{24}$.

Por todo o país, nas ilhas, no Brasil e em Macau, se promoveram subscrições e espectáculos diversos, cujos lucros revertiam para a angariação de fundos para a viagem, os aviadores e os aviões, sobretudo após o acidente que inutilizou o primeiro Pátria. A imprensa divulgou

\footnotetext{
${ }^{22}$ Durante os preparativos desta viagem a Macau, realizou-se a primeira e célebre travessia aérea do Atlântico Sul, com Gago Coutinho e Sacadura Cabral, em 1922, com apoio do Estado, no âmbito das comemorações do primeiro centenário da independência do Brasil.

${ }^{23}$ Diário dos Açores, 5 de Maio de 1924.

${ }^{24}$ «Raid» Liboa-Macau. Relatório da Comissão Executiva, 1924: 36.
} 
全国上下, 还有离岛上, 在巴西, 在澳门, 都在推广各多种认捐活动和演出, 得 到的利润归为这次飞行、飞行员和飞机的筹款基金所有, 特别是在 “祖国号” 无法 再使用后。新闻界也为自己的读者开设了认捐册, 比便让读者们能够资助这个艰 巨的国家事业, 许多时候捐款额会出现在报纸首页并且总是在更新, 以此号召大家 一起为此献身。此时, 当飞行已经成功进行了多个阶段, 并首次胜利开辟了从里斯 本到印度的航线之时, 葡萄牙政府考虑要参与其中。然而, 葡萄牙人民拒绝了政府 的帮助, 他们展开各种举措, 骄傲地承担所有费用 ${ }^{25}$ 。足球比赛, 斗牛表演和剧院音 乐演出是最常见的方式, 但是也有其他活动, 比如拍卖会, 出售动物, 甚至还有香皇 和其他产品, 它们包着与此有关的外壳。在这股集体声援、集体努力的浪潮中, 新 闻界发挥了重要作用, 他们不仅报道飞行所取得的进展, 提供飞行员们的信息, 还 促进和推广了所有这些活动 ${ }^{26}$ 。并不只是一些最重要的报纸称自己为推动者, 其他 一些全国性的和地区性的报纸、日报和周刊, 无论是综合性的还是专业性的 (如体 育报刊) 都连续多期为此奋斗。

飞行员们到达澳门后, 在那里居住的葡萄牙人为飞行员们 ${ }^{27}$ 举行宴会, 向他们 赠送礼物 ${ }^{27}$ (其中的一些还可以在位于阿尔维卡的飞行博物馆中看到) : “女士们, 陆 上和海上的军官们, 陆军和海军士官们, 水手和士兵等人, 都向我们赠送贵重的纪 念品” (第十三章)。飞行员们7月 7 日到访香港, 同样的事情也发生在香港。根据总 督罗德里格 - 德梅内斯的命令, 他们乘船回葡萄牙, 并借此经过上海、广东、东京 还有美国等地, 让 “祖国号” 团队与在当地居住的葡萄牙社团共同庆祝这辉煌的胜 利。

\footnotetext{
25 “塞图巴尔人”, 周六, 1924年6月14日, 第一页: “这次航空之旅留下了一笔重要的债务, 它必须由我们所有人 清偿, 因为政府曾完全忽略东方航路, 现在, 在最后阶段却要来支付这史诗般飞行创下的赤字, 这是不可接受 的一一哪怕是用国家的钱。是人民, 他们快速冲向报纸、航空局, 促进在全国各地开设的募捐活动, 他们给 大家好好地上了一节爱国主义的课, 即任何人都不应忽略如此崇高的壮举 $(\cdots \cdots \cdot \cdot$. 只能让人民崇高而充满关怀的价值观黯然失色的协助, 这是可接受的吗? 不! (…… 我们知道我们不应接受 从国家哪怕一分钱。”

${ }^{26}$ 新闻界也自称担任宣传各个认捐册捐款交付截止日的角色。从这点来看, 人们对提供账单有着特别的热 情, 在这些账单上可以看到认捐发起人及其代表, 他们亲自将认捐名单扩展到自己的个人联系人列表中。 人们可以查看多份报告, 这些报告公开发表在在报纸上和单独的小册子上, 列出了每一位捐款人的姓名和 捐赠金额。

27 布里托 - 帕伊斯在澳门俱乐部的演讲。在演讲中, 他讲述了这次航空之旅的各个方面 (各阶段, 准备, 飞 机视福仪式, 在他们暂停的许多地方受到的欢迎, 国际航空界之间友好的氛围, 各个领事馆的态度, 在澳门 受到的接待, 团队勇气等), 列举了澳门人民的善意, 不无讽刺地比较了这个团体的喜悦、信任与某些葡萄牙 人的不信任和苦涩一一这让“祖国号” 的空中之旅变得困难: “晚餐会, 宴会, 芭蕾舞, 音乐演出, 总之, 所有一 系列节庆的表达方式都块让人相信在葡萄牙人们觉得我们只是来了一场充满欢乐和乐趣的旅行。” (帕伊斯, 1924年: 35)
} 
também subscrições para os seus leitores poderem colaborar no financiamento desta exigente causa nacional, e o valor dos donativos aparecia às vezes na primeira página, actualizado sempre, apelando ao empenhamento de todos. Nesse momento em que, já vencidas várias etapas e alcançado o triunfo da primeira ligação aérea de Lisboa até à Índia, o Estado português ponderava envolver-se, o povo recusou a ajuda do Governo e desdobrou-se em iniciativas para arrostar orgulhosamente com todas as despesas ${ }^{25}$. Desafios de futebol, touradas e récitas de teatro foram as mais comuns, mas houve também outras actividades, como leilões, vendas de animais e até a comercialização de sabonetes e de vários outros produtos com invólucro alusivo à efeméride. Nesta onda de solidariedade e de esforço colectivo, a imprensa desempenhou um papel de assinalável relevo, não só noticiando a progressão da viagem e dando informações sobre os aviadores, como também fomentando e divulgando todas estas actividades ${ }^{26}$. E não foram apenas os jornais mais importantes que chamaram a si esse protagonismo: jornais nacionais e regionais, diários e semanários, gerais ou específicos (desportivos, por exemplo) fizeram sua esta causa, em edições sucessivas.

Após a chegada dos aviadores a Macau, a população portuguesa aí residente desdobrou-se em atenções, festas e presentes para os aviadores ${ }^{27}$ (alguns dos quais se podem actualmente ver no Museu do Ar, em Alverca): «As senhoras, os oficiais de terra e mar, sargentos do exército e da marinha, marinheiros e soldados oferecem-nos recordações valiosas» (cap. XIII). O mesmo sucedeu em Hong Kong, que os aviadores visitaram a 7 de Julho, e também nos vários núcleos portugueses de Xangai, Cantão e, ainda, de Tóquio e dos Estados Unidos, através dos quais os aviadores fizeram a sua viagem de regresso a Portugal, em navio, por ordem do Governador Rodrigo de Meneses, de forma a possibilitarem às comunidades aí residentes festejar com a equipa do Pátria o glorioso sucesso. As senhoras portuguesas de Hong Kong quiseram perpetuar a sua gratidão a Sarmento de Beires num álbum encadernado de 11,5 $\mathrm{x}$

\footnotetext{
${ }^{25}$ O Setubalense, Sábado, 14 junho de 1924, p. 1: «Essa viagem deixa ficar em aberto uma importante dívida, que tem de ser saldada por todos nós, visto que não é admissível que o governo, que se alheou por completo da rota ao Oriente, viesse agora no fim cobrir - embora com o dinheiro da nação - o deficit existente por virtude dessa nova epopeia. Foi o povo que, acorrendo pressuroso aos jornais, à Aeronáutica, e concorrendo para as subscrições que foram abertas pelo país fora, deu a grande lição patriótica de que ninguém se devia alhear de tão sublime feito.(...) Era lá admissível que aceitássemos um auxílio que, vindo tarde, só poderia ofuscar o grandioso e solidário valor da grei? Não. (...) Entendemos que do Estado não devemos aceitar nem um ceitil».

${ }^{26}$ Foi também a imprensa que chamou a si o papel de divulgar os prazos para entrega do dinheiro proveniente das múltiplas subscrições. Neste ponto, é de assinalar o extraordinário zelo de prestação de contas que se observa nos promotores de subscrições e nos delegados que por sua vez as alargavam pessoalmente à sua lista pessoal de contactos. Podem consultar-se vários relatórios, que ora aparecem publicados em jornais ora em brochuras avulsas, discriminando cada subscritor, com nome e contributo.

${ }^{27}$ Brito Paes, no discurso que proferiu no Clube de Macau, durante o qual apresentou a viagem nas suas múltiplas vertentes (etapas, preparação, bênção do avião, acolhimento nos vários locais onde fizeram escala, clima de camaradagem entre a aviação internacional, atitudes dos vários consulados, recepção em Macau, coragem da equipa, etc.), enumera muito de passagem as gentilezas do povo de Macau, não sem uma certa ironia, comparando a alegria e confiança desta comunidade com a desconfiança e mordacidade de alguns portugueses que dificultaram a viagem do Pátria: «Jantares, banquetes, bailes, récitas, enfim, toda uma série de manifestações festivas que quási deram razão aos que em Portugal julgavam que só faríamos uma viagem cheia de divertimentos e prazeres.» (Paes (1924: 35).
} 
在香港的葡萄牙女士们希望在一本大小为 11.5 厘米x 15 厘米, 赠给萨尔门托・ 德贝雷斯的相册中永远保存她们对他的感激之情, 相册里有她们所有人的签名 ${ }^{28}$, 她们还在其中绘制了香港的山区风景。
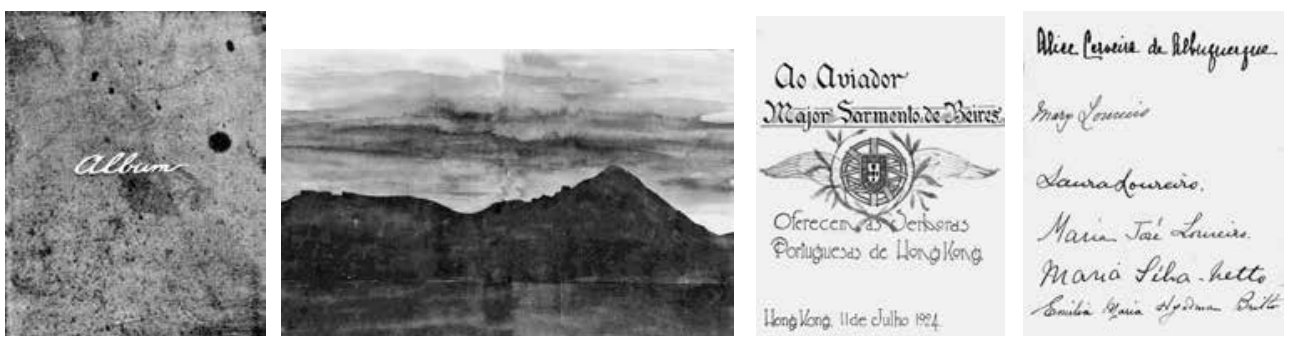

萨尔门托・德贝雷斯提供的相册中的一些图片 (该飞行员的家族档案)

顺便说一句, 那个时代的女性总是被飞行员们所吸引。当然, 这是英雄主义的 魅力所致, 她们可以、也希望用自己的艺术, 在自己能够干涉的 (小但富于创造力 的) 领域参与其中。早在准备阶段, 就是玛丽亚 - 多塞乌斯 - 帕伊斯女士发起了公 众认捐, 并且极受多位女士们的欢迎, 她们追随她的脚步; 还有许多其他女士让露 天游艺会, 茶叙, 音乐演出等活动搞得生气勃勃。女士们 (无论是无名的普通人还 是名人, 例如著名演员阿梅利亚 - 雷伊 - 古拉苏) 的参与、承诺、努力和活力显得 意义特殊, 特别是考虑到当时葡萄牙妇女的情况: 她们被置于安分、谨慎、围绕着 家庭的境地.......

\section{东方的召唤: 或许是萨格雷什海角未知的回忆 ${ }^{29}$}

出于多种原因, 旅行文学一直对读者产生着极大的吸引力: 有时候是为了重新 绘制世界地图时能够获得陌生地区的相关信息; 有时候是为了对新的动植物种类, 或是风俗民情的描述; 还有的时候是为了对于冒险进入蛮荒之地所面临的种种险 境的叙述，这时旅行者的印象和遭受的出乎意料的刺激则为读者们打开了一扇通 往其他人经验和未知世界的大门。

在葡萄牙，所谓的威尼斯人马可・波罗围绕着丝涠之路的经典旅程激起了 国家的战略兴趣——旅程于 13 世纪成书, 以其手稿复制本为基础出现了许多翻译 本。此后, 可能没有一本旅行故事能像费尔南 - 门德斯 - 平托的 “朝圣” 那样产生 了如此巨大的影响。在作者去世后大约 30 年, 这本书于 1617 年出版, 立刻就引发了 关于虚构和现实之间界限的争议。

\footnotetext{
28 签名表中有 74 个名字, 由艾丽斯 - 塞尔韦拉 - 德阿布克尔克领衔, 她很可能是葡萄牙领事塞尔韦拉 - 德阿 布克尔克妻子。当时, 萨尔门托 - 德贝雷斯在飞过澳门, 祖国二号在深圳附近的中国墓地降落后, 在这位领 事家中度过了他踏上中国土地的第一个夜晚。

29 萨尔门托・德贝雷斯 “从葡萄牙到澳门”书中的话。(第二章)
} 
$15 \mathrm{~cm}$ que lhe dedicaram, onde consta a assinatura de cada uma delas ${ }^{28}$ e no qual desenharam também a paisagem montanhosa de Hong Kong.
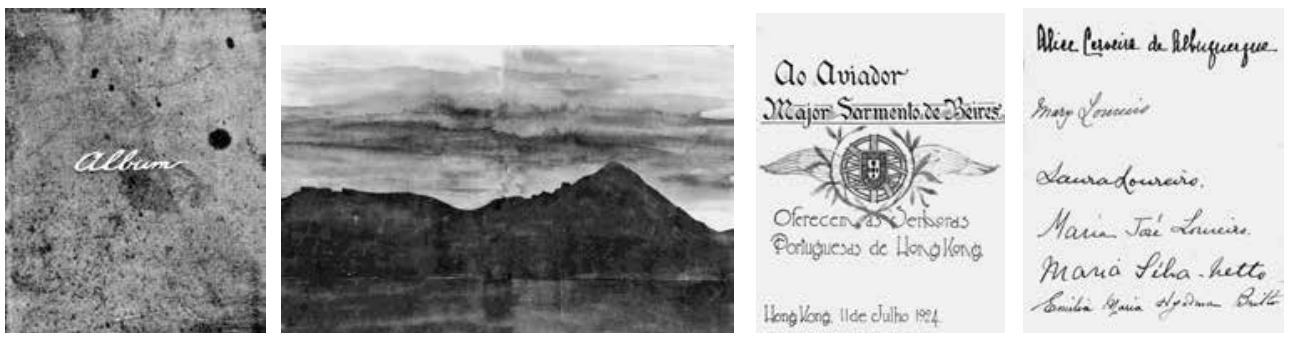

Algumas imagens do álbum oferecido a Sarmento de Beires (arquivo da família do aviador)

Aliás, é curioso ver como a população feminina da época sempre gravitou imenso em torno dos aviadores. Movia-a certamente a atracção pela heroicidade, à qual pôde e quis associar-se com as suas artes e no âmbito da sua esfera (sempre reduzida, mas criativa) de intervenção. Já durante os preparativos para a viagem, a subscrição pública fora iniciada por Maria do Céu Brito Paes, tendo sido muitíssimo bem acolhida por várias senhoras que lhe seguiram o gesto e por muitas outras que dinamizaram quermesses, chás de beneficência, récitas, etc. A elas (às anónimas como às famosas, entre as quais se destacou a actriz Amélia Rey Colaço, por exemplo) se deve envolvimento, liderança, empenhamento, esforço e activismo, tanto mais significativos quanto a situação da mulher, no Portugal de então, pressupunha recato, discrição, circunscrição à esfera do lar...

\section{O APELO DO ORIENTE: TALVEZ REMEMORAÇÕES IGNOTAS DO PROMONTÓRIO DE SAGRES ${ }^{29}$}

A literatura de viagens exerceu desde sempre um grande fascínio sobre os leitores, pelas mais variadas razões: umas vezes pelas informações sobre territórios desconhecidos que iam redesenhando o mapa mundi; outras pela descrição de novas espécies zoológicas e botânicas ou de costumes e de povos; outras ainda pelo relato dos perigos que se abatiam sobre aquele que se aventurava por lugares ignotos, em que a emoção do inesperado e as impressões do viajante abriam ao leitor o mundo da experiência do outro e do desconhecido.

Em Portugal, depois do estratégico interesse pela clássica viagem do supostamente veneziano Marco Polo em torno da Rota da Seda - vertida em livro no séc. XIII e objecto de traduções várias a partir de cópias manuscritas -, talvez nenhuma narrativa viajeira tenha conhecido tanto impacto como a Peregrinação de Fernão Mendes Pinto, salvaguardada a con-

\footnotetext{
${ }^{28}$ A lista de assinaturas contém setenta e quatro nomes e é encabeçada por Alice Cerveira de Albuquerque, provavelmente a esposa do cônsul de Portugal, Cerveira de Albuquerque, em casa de quem Sarmento de Beires passou a primeira noite em território chinês, depois de, tendo sobrevoado Macau, o Pátria II ter aterrado num cemitério chinês, perto da cidade de Shum Chun.

${ }^{29}$ Frase de Sarmento de Beires em De Portugal a Macau (cap. II).
} 
不管怎样, 其中的一些故事也受到国王、宗教修团等人的关注, 比如加斯帕・ 达克鲁斯修士的 “中国-霍尔木兹条约”, 或是安东尼奥 - 特内罗的 “行程路线”。在 那遥远的十六、十七世纪，这些旅行叙事向人们揭示了行程路线、冒险、气候、 地图、地形地势、地理、当地出产、人民秉性、土地财富、风俗、服装等等内 容, 其中的某些作品获得了皇家补贴, 因为它们对国家做出了贡献, 即通过旅行者 的牺牲得以实现了旅行, 这种旅行带来的认知上的进步为国家做出了贡献。这些 作品的一个共同点是充满兴趣、好奇心和倾心于遥远的东方, 特别是那些葡萄牙 人尚未进入的、极为遥远的地区, 比如, 中国, 日本等。

后来, 五个世纪之后, 东方又一次进入葡萄牙人的视野。这次不是为了发现通 往东方的海路或是陆路, 而是开辟新的交通路线: 这次是通过空中连接到达东方, 与已经在那里居住的葡萄牙人团体建立联系。

在二十年代, 为了实现环游世界的目标, 整个航空界都在辛勤工作, 征服新的 航线。萨卡杜拉 - 卡布劳尔 (他在女王新镇是萨尔门托 - 德贝雷斯的教练) 加快了 实现这个梦想的步伐, 不过在梦想实现之前, 1924年11月他死于一场悲惨的飞行事 故。除了其他因素, 前往澳门的飞行漫长而艰苦, 人们需要为这条雄心勃勃的线路 做好准备:

当“祖国号” 即将重生之际, 在我们心中涌现出一个想法, 就是要飞到印度, 让印度成为这次历史性飞行的目的地; 后来在计划中又将它延伸到澳门, 我们希 望同时能为那些开始环游世界的人将这次飞行变为一次准备。30

此外，在 “从葡萄牙到澳门” 第一章之前的很大一部分页面中包含着布里斯 托 - 帕伊斯1924年7月在澳门发表的演讲摘录 ${ }^{31}$ 。在演讲中, 他列出了此次空中之 旅的两个目标: 全世界都在努力实现各种伟大的空中旅程, 要争取将葡萄牙航空的 名字有尊严地列入其中; 而首当其冲的目标是爱国者们需要到达 “澳门, 葡萄牙领 土中最葡萄牙的领土, 在那里, 卡蒙斯获得灵感, 写出了 ‘卢西塔尼亚人之歌””。

\footnotetext{
30 德贝雷斯 (1968年) : 21

31 非常详细地登在澳门报纸上 (在1924年7月19日的 “祖国报”上), 并全文登载在 “里斯本一一澳门 “突袭”: 圣 保罗执行委员会报告”上, 圣保罗, 1924年: 25-38。
} 
trovérsia entre os limites do real e da ficção que logo se gerou desde a primeira hora da sua publicação póstuma, em 1617, cerca de trinta anos depois da morte do seu autor. Em todo o caso, algumas narrativas foram também objeto de interesse por parte de reis, ordens religiosas, etc., de que são exemplo o Tratado das Cousas da China e de Ormuz, de Frei Gaspar da Cruz, ou o Itinerário, de António Tenreiro. Nesses já longínquos séculos XVI e XVII, as narrativas de viagens revelavam roteiros, peripécias, climas, mapas, terrenos, relevos, geografias, produtos locais, natureza dos povos, riquezas das terras, costumes, trajes, tendo algumas obras merecido tenças régias, por elevados contributos à nação, isto é, pelo progresso dos conhecimentos permitido pela viagem e pelo sacrifício dos viajantes que a realizaram. Um traço comum a quase todas elas é o interesse, curiosidade e atracção por esse longínquo Oriente, sobretudo pelas zonas mais distantes e ainda não acedidas pelos portugueses, como a China, o Japão, etc.

Ora, foi novamente o Oriente que, volvidos cinco séculos, voltou a estar na mira dos portugueses, já não para descobrir caminhos marítimos ou por terra, mas ainda para rasgar novas vias de comunicação, desta vez através de ligações aéreas até às comunidades portuguesas que aí se alojaram.

Nos inícios dos anos vinte, a aviação mundial trabalhava arduamente na conquista de novas rotas, com o objetivo de realizar a volta ao mundo, esse sonho acalentado por Sacadura Cabral (instrutor de Sarmento de Beires em Vila Nova da Rainha), que haveria de morrer tragicamente num acidente de aviação, em Novembro de 1924, antes de concretizar essa aspiração. A longa e exigente viagem aérea a Macau apresentava-se, entre outras razões, como uma preparação para esse trajecto mais ambicioso:

Enquanto o Pátria ia renascendo, surgia em nós a ideia de ir à Índia, dada a finalidade histórica de tal viagem, que mais tarde se alongava, em projecto, até Macau, na aspiração de a transformar simultaneamente numa preparação para aqueles que empreendessem a volta ao mundo ${ }^{30}$.

Aliás, a obra De Portugal a Macau contém, significativamente, nas páginas que antecedem o primeiro capítulo, um excerto do discurso de Brito Paes, pronunciado em Macau em Julho de $1924^{31}$, em que enumera as duas finalidades da viagem: a vontade de inscrever condignamente a aviação portuguesa no empenho mundial em realizar grandes viagens aéreas e, antes de mais, a necessidade patriótica de ir «a Macau, terra portuguesa entre as terras portuguesas, onde Camões se inspirou para escrever Os Lusíadas».

No século XXI, o fascínio pela literatura de viagens regressou com uma força insuspeitada e reafirmou-se de um modo consistente, conhecendo configurações singulares: viajar sobre os trilhos e as rotas de anteriores e notáveis viajantes, para depois da viagem - e até durante, dada a era das telecomunicações em que se vive - relatar impressões e arrastar os lei-

\footnotetext{
${ }^{30}$ Beires (1968): 21.

${ }^{31}$ Publicado com grande detalhe na imprensa de Macau (no Jornal A Pátria, em 19 de julho de 1924) e, na íntegra, em «Raid» Lisboa-Macau. Relatório da Comissão Executiva de São Paulo, S. Paulo, 1924: 25-38.
} 
21世纪, 读者对于旅行文学的迷恋毫无疑问地强势回归并不断得到重申, 我们 来认识一些其独特的格局: 即使是生活在电信时代, 也要按照前辈著名旅行家的路 线和道路旅行; 旅行之后报告自己的印象, 将读者吸引进情感、经验、梦想和…… 新的旅行中 ${ }^{32}$ 。因此, 在这种对于旅行文学的兴趣重燃的背景下, 在此离那次航空 之旅100周年纪念还差五年之际, 也是纪念斐迪南 - 麦哲伦 1519 年开始的环球航行 500 周年之际一一上世纪二十年代的那次开拓性空中之旅就是想用长途飞行复制 麦哲伦的旅行, 再版飞行员萨尔门托 - 德贝雷斯的作品 “从葡萄牙到澳门” 变得意 义深远。

今天, 通过与三名飞行员曾中途停留的地方及其居民接触, 可以注意到许多不 同之处。那次, 飞机飞过许多土地, 飞行员们与其他民族、种族、文化、仪式和礼 仪交会。此外, 在这本萨尔门托 - 德贝雷斯的叙事故事第一版中就插入了一张叙 利亚朱庇特神庙废墟和一张空中俯瞰澳门风景的照片, 这表明当时人们的兴趣不 仅落在飞行员们的冒险 (随着空中突袭的进程, 也拍了许多这方面的照片) 之上, 也 落在他们访问的远方文化和地理空间之上。从这个意义上说, 除了文字本身, 这些 照片也构成和加强了本书旅行文学的类型框架。

在葡萄牙新闻界和许多其他出版物中, “祖国号” 机组是新一代航行者和新达 伽马们的代表, 就像当时许多在书店出售的一些海报和传单中证明的那样, 他们能 够加入可以追溯到唐恩里克王子的谱系中。报纸在谈论着新的史诗和荣耀, 将他 们与巴尔托洛梅乌 - 迪亚士, 斐迪南 麦哲伦和佩德罗 - 阿尔瓦雷斯 - 卡布拉尔相 比较。加戈 - 科蒂尼奥明确表示, 把两个历史时期重叠在一起引发了想象, 在 “圣 保罗执行委员会报告” 的简介页中他写道: “ (地理大发现时代) 船队的船长和水手 后代已经成为飞行员” ${ }^{3}$ 。

飞行员们自己也经历了这些由发现、勇敢和英雄主义的想象所构成的现代 航空神话。在起飞前, 布里托 - 帕伊斯的父亲给自己儿子的手指上戴上了一个印 有家族徽章的戒指, 这被儿子记录为 “一个让人忆起我们遥远历史的举动”。“那一 瞬间, 在布里托・帕伊斯上尉身上凝结着整个家族的纯洁传统”。

\footnotetext{
32 想一想旅游记者或是职业旅行者贡萨洛 - 卡迪列的书籍取得的成绩 (比如 “跟随麦哲伦的脚步” 或是 “跟 随费尔南 - 门德斯 - 平托的脚步”) 或是安东尼奥 - 德阿布莱乌 - 弗雷勒沿着安东尼奥 - 维埃拉神父的路 线旅行, 前者在 2008 年为纪念安东尼奥 - 维埃拉神父诞生 400 周年而进行的这次旅行期间, 其博客更新极为 活跃。

1987年由莎力啤酒赞助, 少校飞行员若尔热 - 克鲁斯 - 加莱戈, 阿尔曼多 - 里奥和机械师奥瓦罗 - 门德斯 追随1924年空中突袭的脚步, 使用一架1965年的单引擎飞机 “萨格里什号” 进行了相同的飞行。他们用了 27 天的时间于从里斯本飞抵澳门一一在1987年1月10日起飞后于 2 月 6 日降落。这次飞行的目的是向萨尔门 托 - 德贝雷斯, 布里托 - 帕伊斯和曼努埃尔 - 戈维亚致敬。飞行之后的叙述并不仅仅是一篇纯粹的报告, 而是展示飞行中面对印象最为深刻的时刻的反应和看法, 但并不能构成一篇文学剪裁的文本, 因为缺少情 感的悸动。“萨格里什号” 的飞行并没有改变人们对 “祖国号” 飞行一无所知的情况, 甚至在当时的媒体中 都鲜有反响。

33 科蒂尼奥, 1924年: 17 , 于 “里斯本一澳门 “突袭”: 圣保罗执行委员会报告”。
} 
tores a emoções, experiências, sonhos e... novas viagens ${ }^{32}$. Assim, neste contexto de renovado interesse pela literatura de viagens, torna-se amplamente significativa esta reedição da obra $D e$ Portugal a Macau, do aviador Sarmento de Beires, cinco anos antes do centenário da viagem que está na origem desta efeméride e na abertura do ano que celebrará os quinhentos anos da viagem de circum-navegação iniciada por Fernão de Magalhães em 1519, que a aviação pioneira dos anos vinte tentava replicar, nos seus voos de longo curso.

Muitas e muito diferenciadas anotações resultariam hoje em dia dos contactos com as populações e os locais em que estes três aviadores fizeram escala. A viagem aérea atravessou muitas terras, e os aviadores cruzaram-se com outros povos, raças, culturas, rituais e protocolos. Aliás, a inserção, logo na primeira edição desta narrativa de Sarmento de Beires, de uma fotografia das ruínas do Templo de Júpiter, na Síria, e de uma fotografia aérea paisagística de Macau demonstra que o interesse da época recaía não só na aventura destes aviadores (de que há também várias fotografias, tiradas ao longo do raide), mas também nos espaços culturais e geográficos de terras distantes por eles visitadas. Nesse sentido, além do texto em si, as fotografias configuram e reforçam, na obra, a moldura tipológica da literatura de viagens.

É como renovados navegadores e novos Gamas que a tripulação do Pátria é representada na imprensa portuguesa e em várias publicações, inserida numa genealogia que remonta ao Infante D. Henrique, como se constata de alguns cartazes e desdobráveis vendidos então nas livrarias. Os jornais falavam em nova epopeia e glória, recuperando metáforas e comparações com Bartolomeu Dias, Fernão de Magalhães e Pedro Álvares Cabral. Gago Coutinho expressa claramente o imaginário resultante desta sobreposição dos dois tempos históricos, ao escrever, na página de introdução ao Relatório da Comissão Executiva de S. Paulo, «que os descendentes dos Capitães e Marinheiros das naus se tinham tornado em aviadores ${ }^{33} »$.

Os próprios aviadores viviam também a experiência desses imaginários de descobertas, ousadias e heroicidade que configuravam o mito moderno da aviação. $\mathrm{O}$ momento em que o pai de Brito Paes, antes da descolagem, coloca no dedo do filho o anel com o brasão de família é registado pelo narrador como um «gesto que recorda páginas longínquas da nossa História». «No capitão Brito Paes concentrava-se, naquele instante, a tradição impoluta de uma família inteira». De facto, no imaginário da aviação que a imprensa nacional e internacional difundia,

\footnotetext{
${ }^{32}$ Pense-se no êxito dos livros do jornalista de viagens ou viajante profissional Gonçalo Cadilhe (Nos passos de Magalhães ou Nos passos de Fernão Mendes Pinto, por exemplo) ou na viagem sobre os trilhos do Padre António Vieira, realizada por António de Abreu Freire, que manteve um blog vigorosíssimo durante toda a viagem que realizou em 2008, no âmbito da comemoração dos quatrocentos anos do nascimento do Padre António Vieira.

Em 1987, patrocinados pela Sagres, os pilotos Majores Jorge Cruz Galego e Armando Leal e o mecânico Álvaro Mendes realizaram a mesma viagem a bordo do Sagres, um avião monomotor de 1965, num raide que seguiu as pisadas do de 1924, demorando vinte e sete dias na ligação Lisboa-Macau, onde aterraram a seis de Fevereiro, depois de terem partido a dez de Janeiro de 1987. O objectivo era homenagearem Sarmento de Beires, Brito Paes e Manuel Gouveia. A narrativa que se lhe seguiu procurou não ser um mero relatório, exibindo pontos de vista e reacções face aos momentos mais marcantes da travessia, mas não constitui um texto de recorte literário, sendo também escassa a emoção que aí palpita. A viagem do «Sagres» em nada alterou o estado de desconhecimento em que a viagem do Pátria já então permanecia, até pela escassa repercussão que teve entre os meios de comunicação social da época.

${ }^{33}$ COUTINHO, 1924: 17.
} 
实际上, 在葡萄牙及国际新闻界的假象中, 飞行员们是 “空中骑士”, 在他们身 上建立了一个理想化的形象, 重新唤起了骑士传说, 这或许这是对毅力、忠诚和如 有必要, 投身航空事业直至死亡的想法所至。

在去往东方的途中，萨尔门托 - 德贝雷斯从葡萄牙人曾经出现的土地上空飞 过, 他似乎觉得自己在重走发现者们曾走过的路: “在途中某个时刻, 创造了历史的 阿方索・德 - 阿尔布克尔克时代的葡萄牙纪念碑泛白了。” (第七章) “飞机划过炽 热的天空, 继续向前飞行, 它的背后是寂静忧伤的波斯湾, 葡萄牙人曾经在此秉承 着葡萄牙的伟大辉煌乘风破浪一一此刻, 还是同样的葡萄牙, 她慷慨豪迈的人民推 动着我们向印度前进。” (第七章) 这种将涉及某个过去的事物与地理大发现结合在 一起的想法在整个旅程中层出不穷。在印度, “祖国号” 的螺旋桨损坏了, 飞行无法 继续飞行。在此, 飞行员们偶遇一位年轻人纳努 - 拉姆 (他可以帮助飞行员们与巴 塔拉本地居民交流), 这使得作者想要认识这位当地对话者, 他强调这位年轻人 “对 于达伽马的名字并不陌生; 要知道, 在印度, 到处都能碰到葡萄牙名字。” (第八章)

但是, 在千泉新城这个选定起飞的地方, 就让他的心头仿佛“飘过也许是对萨 格里什角莫名的回忆。” 因为就像后来作者向纳努 - 拉姆解释的那样, “葡萄牙位于 欧洲的角落, 俯瞰着大西洋, 是一个梦想和冒险之乡。”(第八章)

\section{几乎完全情绪化的纪录片 ${ }^{34}$}

从葡萄牙到澳门的航空之旅报告呈现给读者一种危险与征服共存、摇摆不 定的平衡。当时的这次 “空中突袭” 旨在让葡萄牙获得国际承认, 增强自信, 与远离 都市的殖民地加强联系, 让葡萄牙参与进三大洲 (欧洲, 亚洲和美洲) 多个国家进行 的跨洲际飞行之中。这些目标和理想几乎是三位飞行员唯一的目标和目的: “我们 需要加快进度, 而最重要的是要到达澳门” (第六章); “我们是多么渴望着能够到达 终点!”; (第七章) “在我们的思想中, 就像一个无法摆脱的念头, 一个理想, 一种焦虑: 到达澳门”(第七章)。

所以, 在记录这次几乎是极端的航行的 “账本” 中, 任何阻碍执行或是威胁飞 行成功的事情都被仔细报告。具体的困难被精准地提出, 但是技术眼光和经验丰 富的飞行员的需求被精神中、身体中和情感中反射出来的同样的事实所阻断。

34 萨尔门托 - 德贝雷斯 “从葡萄牙到澳门”书中的句子。(第一版献辞) 
os aviadores eram «cavaleiros do céu» e sobre eles se construiu uma figura idealizada, reactivando o mito da cavalaria, resultante talvez da ideia de perseverança, lealdade e entrega à causa da aeronáutica, se necessário fosse até à morte.

A caminho do Oriente, sobrevoando espaços onde os portugueses tinham marcado presença, Sarmento de Beires parece sentir-se a refazer caminhos outrora percorridos pelos descobridores: "A certa altura do percurso, fazendo História, branqueja um padrão português do tempo de Afonso de Albuquerque» (cap. VII). E «o avião prossegue, cruzando o céu candente, sobre o fundo soturno do golfo pérsico, onde outrora portugueses se bateram pela grandeza de Portugal - o mesmo Portugal que naquela hora, pela voz do seu Povo generoso, nos impele para a Índia». (cap. VII). Esses referentes de um passado associado às Descobertas são constantes, ao longo da viagem. Na Índia, onde o avião partira a hélice que o impedia de prosseguir, o encontro ocasional com o jovem Nanu Ram (que se disponibilizara para ajudar os aviadores na comunicação com os habitantes de Budhana) leva o narrador a querer conhecer o seu interlocutor local, de quem afirma que «não ignora o nome de Vasco da Gama e sabe que, na Índia, por toda a parte, se encontram nomes portugueses» (cap. VIII).

Mas já na partida de Vila Nova de Milfontes lhe parecera que desse local escolhido para descolar «esvoaçavam talvez rememorações ignotas do promontório de Sagres», pois, tal como descreveria mais tarde a Nanu Ram, Portugal era um «cantinho da Europa, onde, debruçada sobre o Atlântico, a nossa terra é uma ânsia de sonho e de aventura» (cap. VIII).

\section{DOCUMENTÁRIO QUASE EXCLUSIVAMENTE EMOCIONAL ${ }^{34}$}

$O$ relato desta viagem aérea de Portugal a Macau apresenta-se ao leitor num balanço pendular de perigos e conquistas. A realização deste raide visava o reconhecimento internacional do país e o reforço da sua auto-estima, a ligação à colónia mais longínqua da metrópole, a participação portuguesa nos grandes voos transcontinentais que se levavam a cabo nos vários países de três continentes (Europa, Ásia e América). Eram estas as metas e os ideais, era este o único fito e o intuito quase exclusivo dos três aviadores: «é preciso acelerar a marcha, se bem que, acima de tudo, o que mais importe seja chegar a Macau» (cap. VI); "Que sede imensa, a nossa, de chegar ao fim!» (cap. XII); «no nosso pensamento, como obsessão, só uma ideia, só uma ansiedade: chegar a Macau.» (cap. XII).

Por isso, tudo o que dificultasse a execução ou ameaçasse comprometer o êxito da viagem foi minuciosamente relatado, numa quase conta-corrente desta missão extrema. As dificuldades concretas são referidas com exactidão, mas o olhar técnico e preciso do aviador experiente é interceptado pelas reverberações dos mesmos factos na sua mente, no seu corpo e nas suas emoções. Talvez por isso, ao apresentar o livro que editava, Sarmento de Beires lhe tenha chamado «documentário quase exclusivamente emocional», pois entre os factos e a sua narração se interpôs sempre o estado emotivo do narrador, com variações do êxtase à

\footnotetext{
${ }^{34}$ Frase de Sarmento de Beires, em De Portugal a Macau (dedicatória da primeira edição).
} 
也许是这个原因, 萨尔门托 - 德贝雷斯把它称为 “几乎完全情绪化的记录”, 因 为在事实和他的叙述之间总是夹杂着叙述者的情感状态: 从狂喜到痛苦的变化, 从 严格的自我控制到放松，从责任到情感，从思念葡萄牙到实现目标的意志。一次， 描写关于阿尔赫西拉斯湾, “是一片平静的大湖, 大湖与先前狂怒的大海形成了鲜 明对比。但忽然我们经历了惊心的一幕” (第三章)。后来, 叙述者承认:

飞越到了艾尔 - 达巴上空, 我们感受到那难以形容的美丽。阳光反射在如镜面一 般的海面, 海底的沙石散发出玻璃的色彩, 将 “祖国号” 环绕在一片光亮之中。铝 制机身闪亮得犹如透明的蓝宝石。机翼犹如一道月光……我们忘乎所以, 沉浸在 美不可言的美妙时刻。(第五章)

开放的机舱让飞行员们暴露于大气和天气中，也让他们离飞过的风景很近。 这条线路同时突破了飞机和飞行员的身体，它给飞行中所有的状况带了一种额外 的情感, 无论是在平静的时刻还是在无法控制的事情发生时, 它来自直接的、身体 的感知。“有时, 下面的景象仿佛变得不真实了。像是根据一部无人写过的悲剧所 要求的, 布置出来的一个巨大的舞台布景”。(第七章)

实际上, 对于在高海拔和低海拔旅行的人来说, 风景和身体的感觉构成了一种 感官和情感的刺激。

焦特布尔城就这样坚立在血红的沙漠中, 风景中透出一种神秘鬼力, 让整个 城市有一种我所不知道的、不真实的奇迹的面貌。它将在记忆深处永存, 尽管此 刻野蛮的风鞭笞着我们, 就像熔铅朝我们飞溅而来。(第七章)

在巴格达, 一次轻微的机械故障让飞行员们又耽搁了一夜, 这使得他们精神紧 张, 倍感焦虑: “又是一夜, 我们再度受挫, 又是一个需要战胜的障碍。” (第六章) “又” 这个副词的重复表达了某种心理疲劳, 这种疲劳开始在飞行员们的精神中蔓延, 这 说明人类的脆弱也存在于英雄的性格之中。在波斯, 获得签证的困难转化为一种 混合情绪。

我们在布什尔所度过的几个小时当中, 精神上的压力, 因为不确定而产生的 煎謷折磨, 意外中断旅途的可能性, 这一切都让我们倍感痛苦。我们的言语和思 绪都受到了这种情况的不利影响。

加德纳先生, 戈弗雷先生和苏德诺先生的友爱都无法抹去我们的悲伤。(第 七章) 
angústia, do auto-controlo exigente à descontracção, da responsabilidade à emoção, da saudade de Portugal à vontade de chegar à meta. Assim, sobre a baía de Algeciras, «que é um lago de serenidade a contrastar com o desespero enfurecido do mar, há um momento de angústia ulcerante» (cap. III). Mais adiante, o narrador confessa que

sobre El Daba, vivemos minutos de encanto indescritivel. A luz do sol, reflectida pela superfície espelhada de um mar ao qual o fundo baixo de areia dá tonalidades de vidro, envolve o Pátria num clarão de jade. O alumínio dos mastros e dos depósitos atinge transparências de safira. As asas parecem de luar... A gente esquece tudo, na fascinação desses instantes de beleza inconcebível (cap. V).

A carlinga descoberta do avião deixava os aviadores expostos à atmosfera e ao clima, colocando-os também em proximidade com a paisagem que sobrevoavam. A rota desbravava-se simultaneamente no corpo do avião e no dos aviadores, o que concedeu a todos as situações de voo uma emoção acrescida, resultante desta percepção directa e física quer dos momentos amenos, quer dos acontecimentos incontroláveis. «Por vezes o panorama torna-se irreal. Parece que se trata simplesmente da decoração de um palco imenso, segundo as exigências cénicas de qualquer tragédia que ninguém escreveu. É tudo glabro, inanimado e lúgubre» (cap. VII).

As paisagens e as sensações físicas constituem, de facto, um estímulo sensorial e emocional, para quem viaja a alta ou a baixa altitude.

A cidade de Jodhpur emerge do deserto com a violência de um grito cor de sangue, arrancada à paisagem por misterioso encantamento, que lhe imprime não sei que aspecto de maravilha irreal. É um espectáculo que se grava para sempre na memória, não obstante o vento bárbaro que nos fustiga e parece dardejar sobre nós jactos de chumbo derretido (cap. VII).

Em Bagdad, uma ligeira avaria mecânica retém os aviadores por mais uma noite, criando um estado de espírito de grande nervosismo e ansiedade: «Era mais uma noite, mais uma contrariedade, mais um obstáculo a vencer» (cap. VI). A repetição do advérbio é expressiva de alguma fadiga psicológica que começava a instalar-se no ânimo dos aviadores, traduzindo a fragilidade humana que também habita na índole dos heróis. Na Pérsia, as dificuldades em conseguir um visto traduzem-se numa mescla de emoções.

A depressão moral das horas que passamos em Bushire, o suplício torturante da incerteza, as possibilidades da interrupção inesperada da viagem ferem-nos dolorosamente. As nossas palavras, os nossos pensamentos ressentem-se da situação.

O carinho de Gardner, Godfrey e Sudreau não bastam para destruir a nossa tristeza (cap. VII). 
在卡拉奇, 承担实现飞行任务的飞机出了事故之后, “飞机的悲剧让我们精神 抑郁，谈话也受到了影响。布里托 - 帕伊斯的目光中透露出无法言说的抗拒。戈 维亚的目光中在满是悲伤和痛心。”

$(\cdots \cdots \cdot)$ 午餐在沉默中结束, 我们无法战胜痛苦的压迫。(第九章)

已经是在离开卡拉奇时, 他们以为这次空中突袭的结局已经确定, 萨尔门托・ 德贝雷斯很激动: “我带走了思念。我已经习惯生活在他们中间, 现在我满怀感激 离开了这些朋友, 或许是永远告别了他们” (第九章)。同一时期, 当他们即将驾驶 新的飞机祖国二号继续从印度飞往澳门, 在准备旅程时, 叙述者的反思表达出在葡 萄牙不曾经历过的精神状态: “我无限思念我们的布雷盖飞机, 思念之情让我的心 脏都抽痛了。当我想到曾在我手中的四千七百英镑时, 一股深切的恐惧之情忽然 涌上心头” (第九章)。实际上，如果在最危险的时刻，英雄的性情决定了这几位飞 行员的反应的话, 似乎 “没有把握” 比 “风险” 更有利于他们在中途停留期间产生的 情绪状态。哪怕是在飞过奥尔马拉半岛, 几乎丧生时, 这几位飞行员也从未想到过 这等同于死亡: “当发动机恢复正常时, 我们已经在精神上面对各种可能, 但是死亡 的想法并没有拂过我们的心灵。死亡是唯一把我们遗忘了的。”(第八章)

直到到达印度, 几位飞行员的情绪通常是通过手势而不是言语来表达的。在 “祖国号” 飞机发生事故后, 由于态度的缺乏, 具体来说, 是缺乏胃口体现了他们的 悲伤:

“我们朝树荫下走去, 那些印度村民马上把我们围住了。怀着友爱、关怀之 情, 他们拿来了简婳的活动床铺以便我们休息, 还带来了水、牛奶、黄油、一个 巨大的面饼似的印式面包, 而我们只是咬了两口, 因为悲伤盖过了饥渴, 也感受不 到正在忍受的四十六度高温。”(第九章)

所以说萨尔门托的伤感情绪揭示了英雄们具有人类复杂感情的一面, 在充满 勇气和实现非凡成就的时刻, 除了无私, 他们的不安也隐约可见。

不过, 情绪化的报告不能让这次飞行的纯技术层面陷入沉默, 这是萨尔门托・ 德贝雷斯和布里托 - 帕伊斯之前精心准备的, 并且在航程中几位飞行员不断对其 进行了调整。因此, 在作品的最后, 即第十四章, 全章仅由一篇较长的 “附录” 构 成。作者附上了一个有六栏的表格, 里面是在飞行途中作为飞行员所详尽地记录 的信息, 包括每一段航程, 上午或是下午的航程分配, 降落次数, 每次飞行持续的时 间, 飞过的里程, 平均速度, 最高高度和天气状况等。 
Em Karachi, após o acidente com o avião que comprometia a concretização da viagem, «a conversação ressente-se da depressão moral em que nos deixou a tragédia. Há revoltas mudas no olhar de Brito Paes. Há tristeza e desgosto no olhar de Gouveia.

[...] O lunch termina em silêncio, na opressão torturante que não conseguimos vencer» (cap. IX).

Já à saída de Karachi, onde se jogara definitivamente o destino do raide, Sarmento de Beires emociona-se: «E eu levava saudades. Habituara-me a viver entre eles, e partia cheio de gratidão por aqueles amigos de quem me afastava provavelmente para sempre» (cap. IX). Pela mesma altura, quando viajava a bordo do novo avião Pátria II onde continuariam a viagem da Índia a Macau, as reflexões do narrador traduzem um estado de alma que não experimentara em Portugal, enquanto preparava a viagem: «Uma saudade imensa do nosso Breguet confrangia-me o coração. E, ao pensar que a sorte de quatro mil e setecentas libras esterlinas estava nas minhas mãos, assaltou-me traiçoeiramente um íntimo receio» (cap. IX). De facto, se, durante os momentos de maior perigo, a têmpera de heróis sempre pautava a reacção destes aviadores, a incerteza, mais do que o risco, parecia favorecer os estados emotivos resultantes dos compassos de espera. Mesmo quando sobrevoavam a Península de Ormara, onde quase perderam a vida, nunca os aviadores chegaram sequer a equacionar a morte: «Quando o motor retoma o seu giro normal, mentalmente tem-se encarado as hipóteses prováveis, mas a ideia de morrer não aflorou a nossa mente. Foi a única que nos esqueceu» (cap. VIII).

Até à chegada à Índia, as emoções dos aviadores traduziam-se normalmente por gestos, mais do que por palavras. Mas, após o acidente do avião Pátria, é pela ausência de atitudes, mais concretamente pela falta de apetite, que se avalia a tristeza dos aviadores:

E logo os indianos nos cercam, com demonstrações de carinho e de solicitude, leitos rudimentares trazidos numa lufa-lufa para descansarmos, e água, leite, manteiga, queijo, o pão indígena, espécie de hóstia enorme que mordiscamos apenas, porque a nossa tristeza estancou a fome e estancaria a sede, sem os quarenta e seis graus que suportamos (cap. IX).

Por isso, estas expansões sentimentais de Sarmento de Beires são reveladoras da espessura humana dos heróis, nos momentos em que, para além do altruísmo, da coragem e da realização de feitos extraordinários, se vislumbram as suas inquietações.

O relato emocional não poderia silenciar, entretanto, toda a vertente exclusivamente técnica da viagem, que tão meticulosamente fora preparada por Sarmento de Beires e por Brito Paes e que, no decurso do voo, haveria de ser continuadamente reajustada pelos aviadores. Por isso, no final da obra, o cap. XIV é constituído exclusivamente por um longo «Apêndice». Nele, o autor anexou um quadro de seis colunas, onde consta a informação que, durante o percurso e enquanto aviador, registara minuciosamente, com a data de cada etapa, a distribuição do percurso realizado por manhãs ou tardes, o número de aterragens, a duração de cada voo, os 
总之, 读者们可以了解到在这次惊人的空中之旅中, 两架飞机 (“祖国号” 和 “祖国二号”) 共飞行了118小时21分钟, 飞行里程16760公里, 实际平均飞行速度152 公里/小时。这张表格并没有出现在这本书的第一版中, 这可能是由于要在1925年 4月7日, 纪念 “祖国号” 离开葡萄牙飞往澳门一周年之际赶印此书的原因。但是后 来作者将其加入到附录中, 这对了解细节来说很关键, 在了解了这些纯技术细节之 后, 人们可以更好地理解这个从本质上来说是 “情绪化” 的故事。

\section{铝和丝绸制成的的神鹰 35}

这部作品很大一部分的独特之处来自一个事实，那就是只有这次开拓性的飞 行才能带来对地理和空间的空中透视。萨尔门托 - 德贝雷斯和布里托 - 帕伊斯 (有时还有高素质的机械师曼努埃尔 - 戈维亚的陪伴 ${ }^{36}$ ) 驾驶的飞机, 其结构是带 有敞开式机舱, 这将飞行员们的身体直接置于各种因素之中。在这种环境下, 允许 飞机长途飞行的技术进步, 与驾机人的脆弱危险之间的对比就极为突出。英雄气 概和冲动同时令人神经痛楚地存在于这种压力之中, 在不得不面对的狂风和风暴 中, 这架小飞机仿佛有了自己的生命, 变得难以驾驭。飞行员、作家萨尔门托 - 德 贝雷斯把在不利环境中驾驶一架飞机的壮举戏剧化地呈现了出来, 这让当时的读 者, 还有现在的读者能够直接进入故事场景, 评估在一场不平等的近战中, 那些飞 行员和飞机面对的不可预测的、悲剧性时刻。

飞行员从空中裸眼、不受保护地观察这个世界一一实际上，叙述者的聚焦 创造了令人惊奇的启示。从天空中观看地球、河流和山脉, 实际的比例发生了变 化, 从远处和上空 (从10米到4500米不等的高度) 投下的视线让实物变形, 把它们 缩小了: “在这个城市的天然港口中, 微小的船儿随着河水温柔的波浪起伏着” (第 十二章), “德纳”是一种小型气泡状植被, 反射出大海的平静” (第五章), “塔乌尔吉 亚 (……) 在沼泽地的阴影下退缩。” (第五章), “灯塔像一把七首似的直插云天。 $(\cdots \cdot \cdots)$ 海湾内, 在平静的海水中, 布满牡蚛的岩石像是大泥点” (第九章)。在飞行中 的头几个小时, “塔里发灯塔在上面显得格外泪小, 若隐若现, 仿佛烛台上燃烧的蜡 烛” (第三章)。

\footnotetext{
35 萨尔门托・德贝雷斯在 “从葡萄牙到澳门”书中的表述, 第三章。

36 为了节省燃料, 在一些较长的飞行阶段中需要减轻飞机重量, 这使得机械师曼努埃尔 - 戈维亚不能总是陪 伴在两位飞行员的身边, 他乘火车或是轮船到中途停留地与他们会合。当飞机离开千泉新城时和到达澳门 时都是如此。但 “祖国号” 在巴塔拉的风甚风中紧急迫降时, 这位极其忠诚的机械师在机上, 飞机被抛向地面 而且断裂了。
} 
quilómetros percorridos, a velocidade média, a altitude máxima e o estado atmosférico. No total, fica o leitor a saber que esta prodigiosa viagem, no percurso total dos dois aviões (Pátria e Pátria II), demorou $118 \mathrm{~h} 21 \mathrm{~m}$ de voo, num percurso de $16.760 \mathrm{Km}$, realizado a uma velocidade média de $152 \mathrm{Km} /$ hora. A tabela não figurou logo na primeira edição da obra, o que provavelmente se explica pela urgência em dar à estampa o livro com a data de 7 de abril de 1925, no momento em que se assinalava o primeiro aniversário da partida do Pátria a caminho de Macau. Mas a sua posterior incorporação, em apêndice, foi essencial para se aceder aos pormenores que, sendo estritamente técnicos, permitem, no entanto, depois de conhecidos, apreender melhor esta narrativa tão medularmente «emocional».

\section{DESSE CONDOR GIGANTE DE ALUMÍNIO E SEDA ${ }^{35}$}

Grande parte da singularidade desta obra decorre do facto de trazer perspectivas aéreas sobre espaços e geografias só possíveis com o pioneirismo da aviação. $\mathrm{O}$ aparelho em que viajavam Sarmento de Beires e Brito Paes (algumas vezes acompanhados pelo qualificadíssimo mecânico Manuel Gouveia ${ }^{36}$ ), na sua estrutura de carlinga descoberta, deixava os aviadores directa e fisicamente expostos aos factores meteorológicos. Neste contexto, ressalta sobremaneira o contraste entre o avanço tecnológico que permitira a execução de um voo de longo curso e a fragilidade e exposição humanas de quem conduzia o avião. A heroicidade e o arrebatamento situam-se nevralgicamente nessa tensão em que, face aos ventos e tempestades que houve que enfrentar, a aeronave parecia ganhar vida própria, tornando-se ingovernável. E é a façanha de conduzir um avião nestas circunstâncias adversas que é apresentada em todo o seu dramatismo pelo aviador-escritor Sarmento de Beires, permitindo ao leitor de então - como ao de agora - entrar directamente na cena narrada e avaliar os momentos em que, num corpo a corpo desigual, aviador e avião defrontavam uma natureza imprevisivelmente hostil e trágica.

Do ar, a partir de uma observação do mundo a olho nu e desprotegido, a focalização do narrador cria, de facto, revelações surpreendentes. A partir do céu, de onde se perspectivam a terra, os rios e as montanhas numa captação até então inviável, a escala do real transforma-se, e o olhar de longe e de cima (numa altitude que variou entre os $4500 \mathrm{~m}$ e os $10 \mathrm{~m}$ ) reconfigura a realidade, reduzindo-a: «No seu porto natural, os navios microscópicos deixavam-se embalar pela mareta suave do rio» (cap. XII); «Derna, é um pequenino alvéolo de vegetação» (cap. V), «Taurgha [...] encolhia-se [...] junto à mancha sombria de um paul» (cap. V); «o farol parece a lâmina de um punhal apontado ao céu» [...] . E "as Rochas Ostreiras, dentro da baía, são quatro nódoas de barro, no quadro das águas baças e tranquilas» (cap. IX). Logo nas primeiras horas de voo, «o farol de Tarifa, na sua ilha circular e minúscula, parece uma

\footnotetext{
${ }^{35}$ Expressão de Sarmento de Beires, De Portugal a Macau, cap. III.

${ }^{36}$ A necessidade de aligeirar o peso a bordo, para poupar combustível nas etapas mais longas, levou a que o mecânico Manuel Gouveia nem sempre acompanhasse os aviadores, aos quais se juntava nos locais das escalas, viajando de comboio ou de barco. Assim foi à partida de Vila Nova de Milfontes e, também, à chegada a Macau. Mas o fidelíssimo mecânico estava a bordo quando o Pátria, aterrando de urgência em Budhana, no meio de um furacão, é projectado contra o solo e se quebra.
} 
特别是在埃及, 金字塔群像是 “三座盐丘, 似火的骄阳多烤着它们” (第五章)。 “时不时, 我们还远远看到大小犹如模型般的大篷车一辆又一辆, 缓慢驶过” (第五 章)。“在一条铁路线上, 时不时的有玩具似的火车开过。我们在两千二百米的高 度飞行” (第十章)。“在一个小小的、风景如画的港口, 布什尔城出现在河边, 仿佛 是一条晾晒在阳光下的微微发白的花边织物” (第七章)。

从上面看下去, 捕捉到的景致几乎都是几何形状的, 这对于那些只从地面观 察的人来说是不可能的。因此, “德亚斯科仅仅是个孤立的四边形砌石建筑” (第七 章); 在巴塔拉, 由于沙尘暴和狂风, “祖国号” 断裂了, 德贝雷斯找个 “临近一个当地 的村庄, 有一块比较平坦但倾斜度很大的三角地带, $(\cdots \cdots)$ 悬崖似的” 的地方来降 落 (第八章); “廊曼机场的露台像个白色的四边形似的在地平线上显现出来。” (第 十一章); 在风暴中, “沙子卷起的三角形朱红色旋风也在上升” (第八章); “在卡拉奇 的东边就开始有沙漠了。此时, 沙漠在我们的面前向远方延伸开去, 里面点缀着一 个本地村落形成的黑圈, 那是一个绿洲” (第八章)。关于突尼斯, “当我们飞过一片 开采中的铁矿时, 指南针失灵了。”

实际上, 从又远又高的地方看到的陆地和海洋, 其形状不同寻常的分明, 旅行 者萨尔门托 - 德贝雷斯的文化和敏感对此做出了独特的表述。“山坡上的大马士 革就像是一只高贵的天鹅, 静静地浮在绿树组成的翡翠湖面上。景色突然为之一 变, 沙漠仿佛开始在我们的脚下展开了一卷单调的古铜色毛巾。(……北部, 在灰 暗荒凉的沙漠中, 幼发拉底河像是亮闪闪的金色带子。”

作者通常是在飞机中途停留时描写已飞过的地方 ${ }^{37}$ 。而对于重构的风景记忆 则取决于作者的焦虑程度和飞行时紧张或不紧张或是那些地方让他印象深刻与 否: 比如在马拉加, “焦急地等待着离开, 无心欣赏我们所在的这座古老而美丽的西 班牙城市” (第三章)。在飞往缅甸途中, “我们飞过宽阔的海上通道, 绕过多山的岛 屿, 有时岛上有些小村庄, 如画的风景消失在我们的惶恐不安中” (第十章)。…… 在印度, “焦特布尔城就这样坚立在血红的沙漠中, 风景中透出一种神秘鬼力, 让整 个城市有一种我所不知道的不真实的奇迹的面貌。它将在记忆深处永存, 尽管此 刻野蛮的风鞭笞着我们, 就像熔铅朝我们飞浌而来” (第八章)。

\footnotetext{
37 这个证据源自叙述者在第七章中的话: “招待我们的英国领事给了我完全的独立自由。(……在那幢小屋 中陪伴我度过孤独的时间是他的两条狗: 一条狐狸犬和一条爱尔兰梗, 它们分别叫做斯罗什和杰夫, 在我写 作时它们在我的脚旁打盹”。在第九章中, 萨尔门托 - 德贝雷斯这样描述了自己写作时刻的背景: “我们在卡 拉奇逗留期间, 发生了一件令人好奇的事, 我在旅行日志中记载了它。”
} 
vela de estearina num castiçal» (cap.III). E, sobrevoando o Egipto, as Pirâmides surgem como «três montículos de sal, que o sol bate em chapadas de fogo» (cap. V). «De quando em quando, avistamos caravanas que passam, miniaturais, vagarosas» (cap. V). «Numa linha férrea, alguns comboios se avistam, de tempos a tempos, rodando como brinquedos. Voamos a dois mil e duzentos metros» (cap. X). «Num portozinho minúsculo e pitoresco, a cidade de Bushire surgiu à beira de água, como renda alvadia a secar ao sol» (cap. VII).

Vistas de cima, as paisagens são captadas em formas quase geométricas, numa apreensão impossível para quem só as visualiza a partir de terra. Assim, «Djask é, simplesmente, um quadrilátero de alvenaria isolado» (cap. VII); Em Budhana, onde, devido à tempestade de areia e aos ventos descontrolados, o Pátria se parte, Beires entende que «junto a uma aldeia nativa, um rectângulo mais plano, bem delineado, parece [...] propício» à aterragem (cap. VIII); «a esplanada do aeródromo de Dawn Muang recorta-se como quadrilátero alvacento» (cap. XI); No meio da tempestade, «turbilhões de areia erguem no espaço triângulos de cinábrio» (cap. VIII); «o deserto que começa para Nascente de Karachi, prolonga-se na nossa frente, salpicado de onde a onde pelo círculo de uma aldeia nativa» (cap. VIII). E, sobre a Tunísia, «a bússola endoidece, ao voarmos sobre o polígono sombrio de uma mina de ferro em exploração» (cap. IV).

De facto, a vista de longe e do alto vai revelando formas e contrastes invulgares da terra e do mar, que a cultura e a sensibilidade do viajante Sarmento de Beires apreendem numa expressão singular. "Damasco, nas faldas da montanha, é como um cisne imóvel no lago de jade do arvoredo. Bruscamente, o tom da paisagem modifica-se, e o deserto começa desenrolando sob nós a toalha brônzea da sua monotonia hostil. (...) Ao Norte, o Eufrates surge, fita de oiro a cintilar, incrustada na chapa escura do deserto».

A descrição dos espaços sobrevoados é normalmente feita durante os tempos de escala ${ }^{37}$. A memória da paisagem então reconstituída pelo narrador depende da ansiedade e dos momentos de maior ou menor tensão com que a sobrevoou ou da sensação forte que os espaços lhe imprimiram: Em Málaga, por exemplo, «o enervamento e a ânsia de partir não nos deixaram apreciar a beleza da velha e interessante cidade espanhola» (cap. III). A caminho da Birmânia, «passamos sobre largos canais marítimos, contornamos ilhas montanhosas, por vezes tatuadas de aldeolas, cujo pitoresco se perde na incerteza dos momentos que vivemos» (cap. X). E, na Índia, «a cidade de Jodhpur emerge do deserto com a violência de um grito cor de sangue, arrancada à paisagem por misterioso encantamento, que lhe imprime não sei que aspecto de maravilha irreal. É um espectáculo que se grava para sempre na memória, não obstante o vento bárbaro que nos fustiga e parece dardejar sobre nós jactos de chumbo derretido» (cap. VII).

A viagem do Pátria exigira uma preparação meticulosa, ponderada ao ínfimo pormenor, com muito estudo, cálculo, rigor e dedicação. Voar foi sempre um sonho dos humanos,

\footnotetext{
${ }^{37}$ Uma constatação que decorre das palavras do narrador, no cap. VII: «O cônsul inglês de quem sou hóspede, dá-me absoluta independência. [...]. Nas horas de solidão que passo no seu bungalow, enquanto as suas ocupações o retêm no escritório, fazem-me companhia dois cães, - um fox e um irish terrier, - Slosh e Jaff, que dormitam a meus pés de passo que escrevo». Também no capítulo IX Sarmento de Beires contextualiza os seus momentos de escrita: «Durante a nossa permanência em Karachi, verificou-se um caso curioso, que assinalei nos meus apontamentos de viagem».
} 
驾驶 “祖国号” 飞行之前必须要做精心的准备, 最小的细节都要考虑到, 要进 行大量的研究和计算, 要具备严谨和努力的态度。飞行, 有史以来一直是人类的一 个梦想, 其中不但包含了神话和奥秘, 也包含着征服和成就。在当年资源匮乏的情 况下, 澳门之旅需要极大的勇气和勇敢精神。实际上, 德贝雷斯和帕伊斯决定长途 飞行使用的是一架1919年制造的布雷盖16BN2型飞机, 上面装备的是300马力的雷 诺发动机。这是一种一战期间用于夜间轰炸的战机, 所以必须根据飞行员们的目 的进行改装。在阿马多拉的机库中, 通过减轻军事装备的重量以便在机翼下加装 更多的油箱而让飞机适应了预期的目标。这样, 飞机的航程加长了, 它具备了更大 的自主权, 能够承受更长的阶段飞行, 特别是在面对广衰无垠的沙漠时。驾驶这样 一架并非特地为长途飞行而设计的飞机, 进行里斯本一澳门空中突袭, 这无疑是一 项极为冒险、需要巨大勇气的壮举。

\section{目光可以探测、重建、比 ${ }^{38}$}

在所有的旅行报告中, 旅行者的看法总是由一种不可避免的比较态度主导, 通 过自我体验和其他人的体验之异同做出比较。“祖国号” 飞机从葡萄牙飞到澳门 的旅行报告主要集中在由三位飞行员组成的乘务团队所经历的体验上，但是它并 没有忽略中途停留时, 旅行者, 即飞行员们与其他陌生的现实、新的文化、不同的 人、其他生活方式相遇留下的印迹。实际上, 在萨尔门托 - 德贝雷斯的讲述中, 很 好地反映了在飞往澳门途中, 对自己从空中模模糊糊看见的风景, 还有在中途停留 期间遇到的习俗、地方和人物，这位飞行员的着迷或失望。他受到的葡萄牙、欧 洲和西方教育自然是他欣赏和判断的基础。他在自己的旅行笔记中收集了那些最 令他惊讶、震惊或感动的记录, 还有那些出乎意料的情况和事件。在泰国, 他看到:

“实际上，暹罗政府的标准和葡萄牙大多数政府的标准之间的区别很大…… 在这个坐落在遥远亚洲的国家, 我们习惯于把它想象成一个民智落后的国家。航 空业被视为是在战争与和平中不可或缺的武器。确实, 它不能跟大国空军相比, 这是一个跟我们一样的小国, 然而, 它的航空业已经值得一提。”

38 1924年, 葡萄牙象征主义诗人卡米洛 - 佩塞尼亚居住在澳门, 并在这次空中突袭后出版了题为 “向 1924 年 首次完成里斯本——澳门空中突袭的飞行员们致敬” 的文章。文章发表在 “在向光荣的飞行员们——安东 尼奥 - 亚辛托 - 达席尔瓦 - 布里托 - 帕伊斯上尉, 若泽 - 曼努埃尔 - 萨尔门托 - 德贝雷斯上尉, 曼努埃尔 戈维亚中尉致敬的演出节目单” 前面。该演出于1924年7月4日在澳门唐佩德罗五世剧院举行, 由 “戏剧及音 乐爱好者集团主办”。节目单1924年由费尔南德斯及子女公司Mercanti1 de N. T出版社编辑印刷。 
envolto em mitos e mistérios, mas também em conquistas e superações. Esta viagem a Macau implicou uma dose imensa de ousadia e arrojo, nas condições de escassez de recursos disponíveis à época. De facto, o avião em que Beires e Paes decidiram realizar uma viagem de longo curso era um modelo Breguet 16 BN 2, com motor Renault de trezentos cavalos, datado de 1919. Tratava-se de um modelo concebido durante a Primeira Grande Guerra, para bombardeamento nocturno, que havia que reajustar à finalidade pretendida pelos aviadores. Nos hangares da Amadora, procedeu-se à adaptação do aparelho aos fins em vista, através do aligeiramento da carga militar, para instalação de reservatórios suplementares de combustível sob as asas. Aumentava-se deste modo o raio de acção do avião, dotando-o de maior autonomia para aguentar etapas mais longas e, sobretudo, enfrentar as grandes extensões sobre o deserto. Levar um avião destes, que não fora concebido para percorrer grandes distâncias, a fazer um raide entre Lisboa e Macau foi, indiscutivelmente, um feito de grande rasgo e ousadia.

\section{E A VISTA SONDA, RECONSTRUI, COMPARA ${ }^{38}$}

Em todos os relatos de viagem, o olhar dos viajantes é invariavelmente orientado por uma incontornável atitude comparatista, através da qual o eu faz a experiência do outro, na sua semelhança e na sua diferença. O relato da viagem realizada a bordo do avião Pátria desde Portugal até Macau centra-se dominantemente nas experiências aéreas vividas pela equipa dos três tripulantes do aeroplano, mas não deixa de lado as marcas do encontro dos aviadores viajantes com realidades desconhecidas, novas culturas, gentes diversas, outros modos de ser, aquando das suas escalas. De facto, a narrativa de Sarmento de Beires espelha bem o modo como, ao longo da viagem até Macau, o aviador se foi encantando ou decepcionando com as paisagens que vislumbrava do ar, mas também com os costumes, os espaços e as gentes que conhecia durante as escalas. A sua formação de português, europeu e ocidental estava, naturalmente, subjacente às suas apreciações e juízos, sendo as notações que recolhe nos seus apontamentos de viagem ditadas pelo que mais o surpreendeu, chocou ou sensibilizou e, ainda, pelo inesperado de circunstâncias e acontecimentos. Na Tailândia, constatou:

Como é grande, na realidade, a diferença entre o critério dos governos siameses e o da maioria dos governos portugueses... Ali, naquela nação longínqua dos confins da Ásia, onde nos habituamos a imaginar um povo atrasado, a aviação é olhada como arma indispensável na paz e na guerra. Por certo se não pode comparar com os exércitos aéreos das grandes potências. Pequena potência como nós, no entanto a sua aviação pode ser considerada já modelar.

\footnotetext{
${ }^{38}$ Verso de Camilo Pessanha, poeta simbolista português que vivia em Macau em 1924 e que publicou, na sequência deste raide, o texto intitulado Homenagem aos aviadores que completaram o $1 .^{\circ}$ raid aéreo Lisboa-Macau, 1924, que antecedia o Programa da récita em homenagem dos gloriosos aviadores, Majores António Jacinto da Silva Brito Paes e José Manuel Sarmento de Beires e Tenente Manuel Gouveia, Heróis do raid Lisboa-Macau, realizada na noite de 4 de Julho de 1924 no Teatro D. Pedro V de Macau, organizada pelo Grupo de Amadores de Teatro e Música, Edição da Tip. Mercantil de N.T., Fernandes e Filhos, 1924.
} 
“而在我们的国家……国会1921通过的年度预算，今天已经被不相称地、荒 谬地削减了, 由于飞行员们的善意和他们作出的牺牲, 这预算才能让葡萄牙空军 依然保持活力” (第十一章)。

特别是在耽搁时间比较长的中途逗留期间，飞行员们试着控制自己焦急、不 耐烦的情绪时, 对于文化差异的注视加强了。在叙述者的凝视下, 对于当地的记载 肯定了这种差异:

为了打发时间, 我们参观了卡拉奇。这个城市没有什么令人好奇的建筑, 没 有美感, 没有花园。我们满怀厌倦。

棱形的、细长的寂静之塔零零星星地分布在城里。帕西人把死者的遗体摆 在上面, 在安葬骨架前, 让秃鹰吃掉尸体的肉。

$(\cdots \cdot . \cdot)$ 我们去参观了克里夫登, 开放的露台像是面朝海湾露天剧场, 大海呈 现出不纯净的绿色, 疲劳缓慢地起伏着。

在乳白色的阳光下，印度人和帕西人穿着独特的民族服饰在乘凉。黄昏时 分, 出现了一群群祈祷的人, 他们的礼拜仪式要崇拜太阳。

$(\cdots \cdot \cdots)$ 一些果阿人围着我们, 想要给我们被延长了的旅途助兴。他们把我 们带到了马诺拉岛, 这个岛是卡拉奇港的天然屏障。

广阔的印度洋啊, 被风吹拂, 防波堤上绽开的泡沫, 唤醒我们对大西洋的思 念一一那看着我们出发的海洋。

$(… \cdot)$ 每到一处一一就像后来我们在全印度看到的那样一一无论是办公室, 房间, 酒店客房, 政府机关还是寺庙, 天花板上都装着吊扇。这些吊扇边转边发出 低低的噪声, 像是一首单调冚长的歌。在每天最热的时候, 它们就像是作用温和 的生物碱, 让人昏昏欲睡。

在另一些时候, 这位飞行员的目光捕捉到了周围现实中与葡萄牙的相似之 处。传统上, 旅行文章中描写外国土地时惯用的对照法也出现在萨尔门托 - 德贝 雷斯的叙述中。在埃及, 为了参观金字塔, 他们随着 “安静的驴队前行, 我们想起了 卡西拉斯” (第五章)。但是当作者比较了心理表征和观察到的现实后, 他承认自己 对此感到失望:

不过回程却带着失望, 因为我们之前期待的庄严、壮丽和伟大的形象, 像幻 觉一样破灭了。一百五十米高的大金字塔并没有让我们感到不同, 就想一堆巨石 胡乱堆砌而成一样 (第五章)。 
No nosso país... as verbas que, em 1921, o Parlamento aprovou são hoje, reduzidas por incongruentes e absurdos cortes, aquelas que, mercê da boa vontade e do espírito de sacrifício dos aviadores, conseguem ainda manter activa a Aeronáutica Portuguesa (cap. XI)

As notações de diferença cultural adensam-se sobretudo nas escalas mais demoradas, durante as quais os aviadores tentavam dominar a ansiedade e controlar a impaciência. É então que o registo local se afirma na sua diferença, perante a atenção do narrador:

No intuito de combater a inactividade forçada, visitamos Karachi, que sem curiosidades arquitectónicas, sem beleza, sem jardins, nos enche de tédio.

Aqui e além, uma torre do silêncio, prismática e esguia, a erguer-se acima do casario. É ali que os pársis depõem os cadáveres dos seus mortos, para os abutres lhes virem devorar a carne, antes de dar sepultura aos esqueletos.

[...] Visitamos Clifden, esplanada aberta como um anfiteatro sobre a baía, onde o mar verde-sujo se cava em ondulações lentas de fadiga.

Hindus e pársis vem tomar o fresco, pondo na luz opalina da tarde o folclore dos seus trajos característicos. Ao cair da tarde, há grupos em oração, nos ritos litúrgicos dos que adoram o Sol.

[...] Alguns goaneses, que nos cercam de atenções e procuram amenizar o nosso estágio que se prolonga, levam-nos a Manora Island, defesa natural do porto de Karachi.

O mar largo - o Oceano Índico - batido pelo vento, florindo de espuma o quebra-mar, desperta em nós saudades do Atlântico - desse Atlântico que nos viu partir.

[...] Por toda a parte - o que, de resto, observaremos em toda a Índia -, escritórios, salas e quartos de hotel, repartições públicas e templos têm o tecto eriçado de ventiladores que giram com um murmúrio que é quase melopeia e que, às horas de maior calor, narcotizam como alcalóide de efeito suave.

Noutros momentos, o olhar do aviador capta a realidade envolvente nas suas semelhanças com Portugal. A comparatio que tradicionalmente se impõe nas descrições de terras estrangeiras dos textos sobre viagens emerge também nesta narrativa de Sarmento de Beires. No Egipto, a visita às pirâmides realiza-se «numa pacata burricada que nos recorda Cacilhas» (cap. V). Mas comparando representações mentais com a realidade que observava, o narrador confessa-se decepcionado pelo contraste:

Mas voltamos tristes, porque a impressão de grandeza, de imponência, de majestade que nos habituáramos a esperar, se desfez numa derrocada de ilusões. A Grande Pirâmide, com seus cento e cinquenta metros de altura, deixa-nos indiferentes, como se fosse um simples amontoado de pedregulhos (cap. V). 
从天空往下看, 就像上面看到的那样, 世界被视线以一种新的形式捕捉到, 风 景也以一种新的形象出现。但是, 旅行者的观察不仅被自己的目光左右, 也被内 心世界的个人体验和解读所影响, 它们以一种独特的、个性化方式引领读者看待 那些被发现的事实。很多时候, 萨尔门托 - 德贝雷斯阐释了这些关于认识世界的 内心活动, 这展示出观察者的敏锐和文学修养, 特别是他的思想精神。比如萨尔门 托 - 德贝雷斯在面对风暴时的反应一一当时他驾驶着 “祖国号” 穿过仿佛是雨水 和气流组成的深井, 飞过缅甸上空, 埃德加 - 爱伦坡是他的内心调停者: “渐渐的, 就 像爱伦坡的 “陷阱与钟摆” 中描写的那样, 云雾开始下降到了水田上方, 抓住了我 们, 包围了我们, 迫使我们后退。”(第十章)。

在第五章, 飞越突尼斯的沙漠, 萨尔门托 - 德贝雷斯的思绪忆起了亚特兰蒂斯 和迦太基古国时代, 这是被福楼拜 (肯定是 “萨朗波”) 和戴克波拉 (作家、记者莫里 斯 - 泰西耶的异名) 所引导。几天后, 在一次中途停留中, 他们去参观波斯时, 安东 尼奥 - 帕特里西奥 (诗人, 剧作家, “雄鹰” 杂志撰稿人) 的声音将被德贝雷斯记起, 那时他很失望, 因为 “建立在 “一千零一夜” 基础上的想象和现实之间相距甚远: 当 汽车驶过城中道路, 安东尼奥 - 帕特里西奥的某些定义掠过我们的记忆深处: 旅行 就是品尝失望的艺术……(…… 在返回营地时, 幻想破灭让我们心碎。我们曾经 多少次梦见巴格达: 到处都是宫殿, 清真寺, 美丽的妇女……” (第六章)。

有时, 观察到的现实和作者思想精神之间的对比让作者倍感痛苦的。作者思 想精神中的内容曾经在他脑海中形成了图像、感觉和文化表征: “在这种贫困悲惨 的环境中, 地毯之都、梦幻般的宫殿, 东方式性感的波斯, “鲁拜集” 作者欧玛尔 海亚姆笔下的波斯, 此时向我们展现的却是一个原始、酷热的贫穷市镇, 一幅令人 失望的样貌” (第七章)。有时音乐也会化为一种识别的手势和文化, 比如当他认出 “一个穆斯林神职人员在大声呼喊提醒人们做礼拜, 就像是作曲家科特尔贝的 “波 斯市场” 那样” (第六章)。这位英国作曲家为听众塑造了他想象中的异国情调。

其实, 文学、音乐和喜剧的各种形式的召唤在叙述者的脑海里形成了世界的 精神形象, 它们在叙述者的精神里运作, 作为一种他处理学习和调整的方式。和大 部分旅行书籍相反, 它们没有出现在这本书中, 让萨尔门托的印象与其他作者曾描 写过的、他将飞过或将参观的同一地点的印象进行对话; 而是把理念和他即将经 历的经验融合在一起而生根发芽。因此, 在飞越圣城时, 是在他脑海中出现的基督 教历史与印迹让他印象深刻, 而不是眼中的风景: 
Perspectivado do céu, o mundo adquiriu novas formas de captação e a paisagem apreendeu-se em renovadas imagens, como se viu já no ponto anterior. Mas a observação do viajante não é apenas conduzida pelo olhar, senão também pelo seu mundo interior de experiências pessoais e de leituras que determinam o modo não usual e personalizado com que guia o leitor através das realidades que descobre. Esses mediadores interiores de conhecimento do mundo são frequentemente explicitados por Sarmento de Beires, que assim vai revelando a sua sensibilidade de observador, a sua cultura literária e, sobretudo, a sua biblioteca mental. Edgar Allan Poe foi o mediador de Sarmento de Beires na sua forma de reagir à tempestade que parecia conduzir o avião Pátria através de um poço de ar e chuva, ao sobrevoarem a Birmânia: «A pouco e pouco, como em O poço e o pêndulo, de Edgar Poe, a chapa da névoa desce sobre a chapa quadriculada da inundação, aperta-nos, faz-nos cerco, e força-nos a recuar» (cap. X).

Ao sobrevoar o deserto da Tunísia, no cap. V, o pensamento de Sarmento de Beires evoca os tempos da Atlântida e de Cartago, guiado desta vez por Flaubert (seguramente pela Salamnbô) e Dekobra (pseudónimo do escritor e jornalista Maurice Tessier). Dias mais tarde, será de António Patrício (o poeta-dramaturgo colaborador n’A Águia) a voz que Beires recorda quando, ao visitar a Pérsia numa das escalas da viagem, se decepciona com a realidade que se distanciava da imagem que dela construíra a partir d'As Mil e Uma Noites: «Enquanto o automóvel desliza através das ruas, aflora-nos à memória certa definição de António Patrício: Viajar é a arte de saborear desilusões... [...] Ao voltar ao acantonamento, pungia-nos o desgosto de uma ilusão perdida. Tantas vezes sonháramos Bagdad cheia de palácios bizantinos, mesquitas, lindas mulheres...» (cap. VI).

Às vezes, é doloroso o contraste entre a realidade observada e a biblioteca mental do narrador, que lhe formatara imagens, sensações e representações culturais: «E naquele ambiente de miséria, a Pérsia dos tapetes, dos palácios de sonho, do orientalismo sensual e embalador - a Pérsia de Omar Khayyam e do Rubaiyat - revelava-nos o aspecto decepcionante de um pobre burgo primitivo e canicular.» (cap. VII). Também a música se insinua algumas vezes como forma de identificação de gestos e de cultura, como quando reconhece que «um sacerdote muçulmano clama, convidando à oração, como no Mercado Persa de Ketelbey» (cap. VI), esse compositor inglês que moldou a imaginação dos ouvintes relativamente a cenas exóticas.

Como se vê, a convocação dos modelos literários, musicais e teatrais que lhe haviam imprimido imagens mentais do mundo opera-se no espírito do narrador como modo de processamento de aprendizagens e de reajustes. Diferentemente do que sucede na maior parte dos livros de viagens, eles não surgem na obra para fazer dialogar as impressões de Sarmento de Beires com as de outros autores que tivessem escrito sobre os mesmos locais que ele atravessa ou visita, mas brotam por associação de ideias com a experiência que ele vai vivendo. Por isso, ao sobrevoar a Terra Santa, é a história e o marco do Cristianismo que lhe vêm à mente, mais do que aos olhos, impressionando a sua visão da paisagem: 
“不知不觉中, 拿撒勒生活的一页页仿佛又一次在我们的脑海中翻过。一阵 良善的气息拂面而来……主耶稣, 他所说的比喻, 他对人类无限的爱, 他曾如此强 烈提倡的世界大同、至圣的平等主义心愿等等，悬浮在那极为平静的气息中，悸 动着, 这气息笼罩着魔幻般的花园, 在园中, 雪松林仿佛是山丘上的片片阴影, 粉 刷过的村庄有一种回忆与沉思的集中态度……

在海边, 加沙, 雅法, 海法和阿卡, 静静地辐射开去。

而悲伤也降临到了我们的心间, 那是一种无法言说的乡愁, 在山的那边是我 们无法看见的耶路撒冷 (第六章)。”

只有在拉康塞普西翁花园, 飞行员才参观了一下马拉加, 埃杜阿尔多 - 弗拉波 利的看法代替了他自己的看法, 他大段摘录了一篇1923年7月21日发表在 “艾斯菲 拉” 杂志上的文章, 作为向读者介绍的中介: “下面摘录一段埃杜阿尔多 - 弗拉波利 对那个迷人植物园的描述, 这段描述远胜于我所写” (第三章)。

出于距离和提高民族士气的原因, 澳门被选做这次空中突袭的终点。布里 托 - 帕伊斯在澳门的演讲中解释道: “我们需要来到澳门, 葡萄牙领土中最葡萄牙 的领土, 在那里, 卡蒙斯获得灵感, 写出了 “卢西塔尼亚人之歌” ”。这种航空壮举与 诗歌不可分割的结合极大地荣耀了葡萄牙人民, 在布里托 - 帕伊斯让人印在 “祖国 号” 机身篷布上的话已经体现了这一点, 那上面转载的是这首史诗第三章第 21 节: “这是我富饶的祖国, 我心爱的祖国”。因此, 在抵达澳门时, “祖国号”飞机将代表派 出它的国家。

所以, 比起了解澳门本身及其地理和风俗, 飞行员们的兴趣更多的是在于与 居住在澳门的葡萄牙人取得联系, 从而让他们觉得与祖国的距离不那么遥远, 还 有大都市对于自己移民的关注也能加强彼此间的联系和存在感。因此，与一个去 澳门的旅行者能期待的相反, 萨尔门托 - 德贝雷斯没有去参观白鸽巢公园（卡蒙 斯洞), 至少他在自己书里关于澳门的篇幅中没有提到。不过, 他是一个与澳门有 关的, 与文学紧密相连的一个主题, 但很奇怪, 德贝雷斯没有让步 39 。但是, 从布里 托 - 帕伊斯关于飞行目的地选择的演讲稿摘录中（萨尔门托 - 德贝雷斯将其放在 其叙事编辑之前) 可以看到, 布里托 - 帕伊斯的敏感让他在澳门迸发出了与卡蒙 斯一样的爱国共鸣, 这也是他选择飞机名称和让人在机身上刻下卡蒙斯诗句的来 源 (第一章)。

39 与卡蒙斯诗意的眼光有关的澳门话题, 参见卡特琳娜 - 努内斯 - 德阿尔梅达, 网址: https://www.academia. edu/38535755/2019._DO_OLHAR_PORTUGUÊS_SOBRE_MACAU_algumas_representações_poéticas_ contemporâneas 
Inconscientemente, rememoramos páginas da vida do Nazareno. Um sopro de bondade passa... E a figura de Jesus, as suas parábolas, o seu infinito Amor pela Humanidade, a Fraternidade Universal que tão veementemente pregou, numa aspiração de igualitarismo sacrossanto, pairam invisíveis, latejantes, na atmosfera tranquilíssima que envolve aquele jardim encantado, onde as matas de cedros são flocos de sombra a prender-se nas colinas, e onde as aldeias caiadas têm uma atitude concentrada de recolhimento e de meditação...

Gaza, Jaffa, Haiffa e Acre, junto ao mar, irradiam não sei que vibração silenciosa, de claustro. E no nosso coração desce uma tristeza, uma nostalgia invencível e funda dessa Jerusalém que, para além das montanhas, fica escondida ao nosso olhar (cap. VI).

Só em Hacienda la Concepción, que o aviador visitou em Málaga, a opinião de D. Eduardo Frapoli substitui a sua própria, dando lugar a uma vasta transcrição de um artigo publicado na revista La Esfera, de 21 de Julho de 1923, como mediador da apresentação do espaço ao leitor: «E o trecho que transcrevo de D. Eduardo Frapoli poderá, melhor do que a minha descrição, deixar entrever a maravilha da formosíssima Hacienda» (cap. III).

Macau fora o destino escolhido para este raide, por razões de distância e de exaltação nacional. Brito Paes explicou-o, no seu discurso em Macau: "precisávamos de vir a Macau, terra portuguesa entre as terras portuguesas, onde Camões se inspirou para escrever Os Lusíadas». Esta ligação umbilical do feito aéreo ao poema que, por excelência, glorifica o povo português já se traduzira na frase que o mesmo Brito Paes mandara gravar na tela de fuselagem do Pátria, que reproduzia o primeiro verso do Canto III, estrofe 21 da epopeia: «Esta é a ditosa Pátria minha amada». O avião representaria assim, ao chegar a Macau, o próprio país que o enviava.

Por isso, mais do que conhecer Macau mesmo, na sua geografia e nos seus costumes, o interesse dos aviadores era contactar com os portugueses aí residentes, para que a distância se tornasse por eles menos sentida, e a atenção da metrópole aos seus migrantes potenciasse laços e marcasse presença. Assim, contrariamente ao que seria de esperar de um viajante em Macau, Sarmento de Beires não visita a Gruta de Camões ou, pelo menos, não se lhe refere nas páginas que escreve sobre Macau. E, no entanto, é esse um tópico aglutinador do olhar literário sobre Macau, ao qual Beires estranhamente não cedeu ${ }^{39}$. Mas já a sensibilidade de Brito Paes projectava em Macau essa ressonância de Camões, conforme se pode ver no excerto do seu discurso de justificação do destino (que Sarmento de Beires colocou a anteceder a edição da sua narrativa) e que deflui também do nome que escolheu para o avião e do verso camoniano que nele mandou gravar (cap. I).

A toponímia de Macau, nesta narrativa em que o narrador se acerca da cidade por via aérea, começa pela Ilha da Lapa, continuando de imediato para a Ilha Verde e as Portas do

${ }^{39}$ Sobre os tópicos macaenses associados ao olhar poético de Camões, veja-se Catarina Nunes de Almeida, disponível em https://www.academia.edu/38535755/2019._DO_OLHAR_PORTUGUÊS_SOBRE_MACAU_algumas_ representações_poéticas_contemporâneas 
在作者的叙述中, 他从空中接近澳门城, 首先出现的是路环岛, 紧接着是青州 岛和关闸。“在很低的高度, 若干米开外, 路环岛圆圆的脊背隆起在飞机的右舷, 沉 浸在浓雾之中。暴雨愤怒地抽打着飞机, 我们冲进了澳门地峡, 飞过青州岛和关 闸” (第十二章)。这是片地图绘制了地理状况的领土, 可以被辨认出来。然而, 这 几位飞行员在广东附近降落了, 他们乘坐和自己驾驶的飞机同名的 “祖国号” 巡逻 舰由海路进入澳门。萨尔门托 - 德贝雷斯以并不刻板的眼光从远处看着澳门:

在这小小的半岛上，古老的葡萄牙城市真立在这亚洲的尽头。不规则的街 区排列在关闸和大海之间, 就像中国大陆伸向太平洋的一只手掌, 向自己发向富 庶、阴凉的岛屿乞讨。在南湾, 那条几乎是圆形的大道是手腱和拇指间的弧线, 这里, 圣母雪地殿小教堂静静地真立在一座山丘的顶部 (第十三章)。

在作者的叙述中，对于中国及澳门的人民、习俗、文化、历史和文明的观察 在两种目光中摇摆不定, 一种是夹杂着某种优越感的西方目光, 而另一种是更能触 及到空间和人群独特之处的目光。……作者在船上进入澳门, 此时他所记录的异 国元素以一种象征着葡萄牙过去征服历史的姿态出现，因为那时他的心中充满了 民族主义，感觉自己仿佛是四百年前航海者的化身: “舢舨、三桅快速帆船和漂泊 者的无龙骨小船让人仿佛朦朦胧胧地忆起曾经的快帆船, 这些船的船头低低的, 上 面长方形的船帆被风吹得鼓了起来, 英姿飒爽地在海中摇动” (第十三章)。

实际上, 一直到独立之前, 对于葡萄牙人来说, 澳门都承担着作为帝国和葡萄 牙化强烈象征的任务。因此, 许多旅行者和诗人都将澳门, 这个地理和气候都与葡 萄牙颇为相似的地方, 当做是葡萄牙在远方的另一张面孔。德贝雷斯并没有特地 展现这种态度, 但是, 历史感情影响他的感知, 这种历史感情过滤了他的目光, 以至 在他列举舢板、三桅快速帆船和无龙骨小船, 还有提到一些地点的名称和奇异的 形状时, 他表现出一种观点, 就是没有将目光集中在这些船只的特别之处, 而是集 中在它们身上可能具有的民族性。因为知道自己在葡萄牙领土上, 这种象征性加 强了, 尽管这片领土远离本土。因此, 当萨尔门托 - 德贝雷斯乘坐澳门巡逻舰进入 时, 一种舒适感和民族认同感立刻侵入了他的脑海: “在巡逻舰上, 我们自离开千泉 新城后第一次有踏上了一小片葡萄牙领土。” 不过, 在地理上, 似乎只有中国的沙面 岛对他来说是 “一个被遗忘的欧洲角落。”

在萨尔门托 - 德贝雷斯的语境里, 对于澳门的印象不仅是历史记忆和异国风 情体验。 
Cerco: «A poucos metros de altitude e de distância, a ilha da Lapa soergue-se por estibordo, dorso arredondado a mergulhar na névoa. Sob o açoite furioso dos aguaceiros densos, rompemos para o istmo de Macau, e passamos sobre a Ilha Verde e as Portas do Cerco» (cap. XII). Trata-se de uma geografia de território que os mapas também desenham, permitindo o reconhecimento. No entanto, tendo aterrado perto de Cantão, os aviadores entram em Macau por mar, a bordo da canhoeira homónima do avião em que viajaram: Pátria. E de longe, Macau é singularmente vista por Sarmento de Beires através de um olhar não estereotipado:

A península minúscula em que a secular cidade portuguesa dos confins da Ásia se comprime, na desordem dos seus bairros, entre as Portas de Cerco e o mar, parece a palma da mão que a China estende ao Pacífico, como a mendigar-lhe a esmola das suas ilhas aveludadas e sombrias. A Praia Grande, avenida quase circular, faz a curva entre a chave da mão e o polegar, onde a capelinha da Guia se alcandora no topo de uma colina (cap. XIII).

As notações de pessoas, hábitos, cultura, história e civilização da China e de Macau oscilam, nesta narrativa, entre o lugar-comum do olhar ocidental, pontualmente perpassado por alguma superioridade, e uma visão mais permeável à singularidade dos espaços e das gentes. Os elementos exóticos que o narrador regista na sua entrada em Macau, onde sobressaem os barcos, surgem como remissões a um passado português de conquistas, pois estava então imbuído de espírito nacionalista e sentia encarnar em si o remoto navegador de quatro séculos atrás: «[O]s sampans, as lorchas e os tancares de linha extravagantes, a revelar reminiscências de caravelas, balouçam bizarramente, proas baixas, velas rectangulares enfunadas pelo vento» (cap. XIII).

De facto, até à sua independência, Macau representava, para os portugueses, uma forte carga simbólica de império e de portugalidade, levando a que muitos viajantes e poetas tivessem evocado esse espaço como rosto distante de Portugal, que se lhe assemelhava na geografia e no clima. Beires não revela propriamente essa atitude, mas a sua percepção é mediada por emoções históricas que lhe filtram o olhar, a ponto de a sua enumeração de sampans, lorchas e tancares, ainda que referindo os seus nomes locais e as suas formas bizarras, traduzir uma visão que não se detém nas embarcações pelo que elas têm de específico, mas pelo que podem sugerir de nacional. A simbologia reforça-se pelo facto de se saber em território português, embora distante de Portugal. Por isso, quando Sarmento de Beires entrou a bordo da canhoneira macaense, invadiu-o de imediato um sentimento de reconforto e identidade nacional: «aquela tolda é a primeira parcela de território português que pisamos, depois da largada de Vila Nova de Milfontes». Geograficamente, no entanto, só a ilha de Shameen, na China, lhe parece um «recanto da Europa perdido naquelas paragens».

Em Sarmento de Beires, as impressões de Macau são mais do que memória histórica ou experiências de exotismo. Elas evidenciam sobretudo os traços de união e cumplicidade entre 
在萨尔门托 - 德贝雷斯的语境里, 对于澳门的印象不仅是历史记忆和异国风 情体验。这些印象是这几位飞行员和生活在东方的葡萄牙团体之间团结、理解的 纽带。对于澳门的感情, 是在驾驶 “祖国号” 飞到亚洲尽头, 人们举行欢迎仪式时, 作者表现出来的相遇、分享和震撼之情。因此, 最初作者关于中国的目光被烦恼 不适所左右。这种烦恼不适是面对强烈风暴引发的天气状况的感受, 这场风暴导 致降落时他们驾驶的飞机坠毁; 也是因为没有能够准确地在澳门一一葡萄牙领土 降落, 而是降落在了中国广东附近的一个地方而感到失望。此时, 疲劳, 长时间没 有进食和事故造成的擦伤盖过了他们对周围环境的耐心和好奇, 当地居民被贬低 地看成 “一帮中国人”, “肮脏的孩子”, “呢喃不清”, 作者记道: “第一眼看上去, 中国人 长得全像双胞胎似的” (第十二章)。飞行员疲崽程度升级, 与之相称的是面对中国 人时的不耐烦。当作者第一次与 “像是脚上长了翅膀” 的苦力旅行之后, 他提到, 这 是些除了自己的货币不认识任何其它货币的人，哪怕你付给他们的钱比应收取的 费用高得多都不行。“到了之后我才想起来自己没有中国货币。用一种高高在上 的姿态, 我给了他们在河内用剩的银子。可是在吵闹中他们抗议不要” (第十二章)。

这几位飞行员第一次与中国接触, 就马上就指出这是个分裂的、印刻着军阀 之间分歧的国家, 这些军阀们推翻了中国最后一个帝国王朝, 制造了一种战争和不 信任的氛围。

在我们降落之后一小会儿, 倾盆大雨继续浇下来, 一个中国士兵向我们这边 跑过来。他手中拿着武器, 赤着脚, 穿了一件让我们想起睡衣的浅色衣服, 头上扣 着一顶篮子似的宽边帽。我们试着跟他将葡萄牙语、法语、英语。他怀疑地望 着我们, 好像一个词都没懂。我们只好使用尽可能想象出来的身体语言, 请求他 在我们回来之前, 看管一下飞机。像安南人一样, 这个小男人也摆动他的头部表 示肯定, 但我觉得他什么都没理解 (第十二章)。

访问广东时, 那个时代中国的政治军事现实情况没有逃过作者的观察和评论:

在一些罕见的大道上, 美国的影响力将穿过这古老的城市。大道上, 时不时 地有运兵的汽车通过, 车上的士兵整装待发, 手枪做好了射击准备, 一副好战的样 子一一一个重要角色走在路上。

时不时的嗡嗡声, 吵嚷声, 子弹……

就这样, 孙中山的中国将为了一个重生的未来而苏醒 (第十三章)。 
os aviadores e as comunidades portuguesas que vivem no Oriente. A emoção de Macau é o encontro, a partilha, a comoção que o narrador pressente na recepção à viagem que conduziu o aeroplano Pátria até aos confins da Ásia. Daí que, inicialmente, o olhar do narrador sobre os chineses tenha sido determinado pela contrariedade e indisposição que sentia face às circunstâncias meteorológicas de forte temporal, que originaram/ocasionaram a acidentada aterragem que partira o avião em que viajavam e também face à decepção de não terem pousado exactamente em Macau, terra portuguesa, mas numa localidade chinesa contígua, perto de Cantão. Nesses momentos em que o cansaço, o jejum de longas horas e algumas escoriações resultantes do acidente se sobrepunham à paciência ou à curiosidade pelo que os rodeava, os habitantes locais são depreciativamente vistos como «bando de chineses» «garotada imunda», "palrando», registando o narrador que «à primeira vista, os chineses parecem todos gémeos» (cap. XII). À escalada de exaustão do aviador corresponde um olhar proporcionalmente impaciente face aos chineses. Assim, após a sua primeira viagem com os coolies, de quem se nota que «deslizam como se tivessem asas nos pés», o narrador assinala a atitude de quem não reconhece outra moeda além da sua, ainda que o que se lhes estava a pagar fosse muito superior ao valor em causa: «Só ao chegar me lembro que não temos dinheiro chinês. Num gesto superior, entrego-lhes a prata que nos sobrou de Hanói. Mas os demónios protestam, numa algazarra» (cap. XII).

O primeiro contacto dos aviadores com a China deu logo sinais de um país dividido e marcado por divergências entre os líderes militares que haviam derrubado a última dinastia imperial da China, criando um clima de guerra e desconfiança.

Poucos instantes depois de aterrarmos - a chuva torrencial continuava caindo a cântaros -, um soldado chinês aproximou-se correndo. Trazia a arma na mão, vinha descalço, vestia uma roupa clara que lembrava um pijama e poisava-lhe no alto da cabeça um largo chapéu que mais parecia um cesto. Tentámos falar-lhe em português, francês, inglês. Ele olhava-nos desconfiado, sem dar sinal de entender palavra. Usando então da mímica mais expressiva que nos foi possivel imaginar, pedimos-lhe para guardar o aparelho até voltarmos. E, como os anamitas, o homenzinho oscilou a cabeça num movimento afirmativo, mas julgo que não percebeu nada (cap. XII).

De visita a Cantão, a realidade política e militar que envolvia a China naquela época não escapou à observação do narrador nem ao seu comentário:

Nas raras avenidas que a influência norte-americana vai cortando através da antiquíssima cidade, vêem-se passar, de quando em quando, automóveis com soldados nos estribos, pistolas aperradas, atitude bélica: - um importante personagem que se desloca.

Por vezes um burburinho, uma algazarra, alguns tiros...

É assim que a China de Sun Yat-sen vai acordando para um futuro renascimento (cap. XIII). 
随着时间的流逝，几位飞行员得到了休息, 他们熟悉了当地的人和风俗, 对于 中国人的看法也发生了变化。如果说一开始, 萨尔门托 - 德贝雷斯与中国人接触 时, 强调中国人的 “肮脏”、“贫穷” 40 和难以沟通 ${ }^{41}$, 时间却让他变得可以安静地欣 赏东方文化和文明。司空见惯 (“一眼看上去, 所有中国人长得都像双胞胎”) 让位 于一种较少受到心理构调节的视角的出现, 比如, 他提到 “展示了中国人无限耐心 的象牙项链和牙雕一一它们是一种高尚的艺术” ${ }^{42}$ 。他的眼光变得平静而欣赏。 离开香港时，作者为我们留下了中国美食记录，描写了他们在宴会上享用的美食， “我们品尝了许多珍贵的中国美食: 燕窝, 木耳汤, 烤乳猪, 松花蛋, 蛇肉, 海鲜沙拉, 海 参, 还有许多我不认识的东西”。对于风景的欣赏让他发出了极高的赞叹声: “香港 湾应该是世界上最美的海湾之一。”(第十三章)。

\section{螺旋桨在蓝天中旋转 43}

在这本讲述 “祖国号” 澳门空中之旅的 “情绪化纪录片” 的书里, 每一页中都交 织着来自飞行的、固有的危险和责任之感。不过, 除了危险、惊奇和威胁之外, 很 可能其他因素导致了叙述者几乎以一种准人性来表现现实。当时是二十年代，那 是个特谢拉 - 帕库埃斯的怀旧主义赢得了国内和国际评判范围的时代, 不过一套 明确而有足够根据的法则/理论还没有形成。但是, 在共和国出现后的新政治典范 框架下, 对葡萄牙社会进行文化干预的方针鼓舞了在广阔的 “葡萄牙复兴” 运动中 兴起的、由库埃斯勾勒的怀旧主义思潮。被怀旧主义吸引的知识分子群体及其最 具代表性的文学机关杂志 “雄鹰——葡萄牙复兴的组织” (1910-1932), 若干年后将 分裂, 在 1921 年让位于另一个群体, 这个群体以 “田地人”而为人所知, 它是以“新田 地” 杂志和编辑为中心而组织起来的群体。在这个群体中, 我们将遇到萨尔门托 德贝雷斯, 他为该杂志撰写了多篇有关葡萄牙及国际航空的文章, 杂志社还为他编 辑了诗集 “风的交响曲”, 并且出版了“从葡萄牙到澳门”第一版。

\footnotetext{
40 “两公里外一个古老肮脏而贫穷的城郊村镇是深圳城。(…..) 我们坚决地走向房屋群, 走进迷宫般的狭 窄街道, 这些街道弯弯曲曲, 令人作呕, 有些刺眼的店招在风中摆动, 一群脏脏的小孩在门口牙牙学语。” (第 十二章)

41 参阅在一顶中国帐篷中那令人好的幕, 在第十二章结尾处。

42 第十三章

43 萨尔门托・德贝雷斯在 “从葡萄牙到澳门”书中的句子 (第四章)。
} 
À medida que os dias iam passando e que os aviadores, já mais descansados, se iam familiarizando com as gentes e os costumes, o olhar sobre os chineses foi mudando. Se, nos primeiros momentos de contacto com a China, Sarmento de Beires realçava a sujidade, a pobreza $^{40}$ e as dificuldades de comunicação com os chineses ${ }^{41}$, o tempo haveria de torná-lo receptivo a uma serena apreciação da cultura e da civilização orientais. Os lugares-comuns («à primeira vista, os chineses parecem todos gémeos») cedem lugar à emergência de uma visão menos mediatizada por construções mentais, quando refere, por exemplo, «esculturas de marfim em que se revela a minuciosa paciência chinesa, ao serviço de uma arte superior $»^{42}$. $\mathrm{O}$ olhar torna-se calmo e apreciador. À saída de Hong Kong, o narrador deixa-nos apontamentos da gastronomia chinesa, ao descrever o banquete onde saborearam «as iguarias mais raras da culinária chinesa: sopa de ninhos de andorinha e de alga preta, leitão lacado, ovos podres, cobra, marisco em salada, holotúrias, e não sei que mais». E a admiração pela paisagem leva-o a uma genuína exclamação superlativa: «a baía de Hong Kong deve ser uma das mais belas do mundo» (cap. XIII).

\section{GIRAM HÉLICES NO AZUL ${ }^{43}$}

A emoção decorrente da responsabilidade e do perigo inerentes a esta viagem enlaça cada página deste «documentário emocional» que é a narrativa da viagem do Pátria a Macau, mas muito provavelmente outros factores - além do perigo, da surpresa e da ameaça - terão conduzido à representação da realidade como que investida de uma quase humanidade. Estava-se na década de vinte, numa época em que o Saudosismo de Teixeira de Pascoaes ganhara foros de dinamismo nacional e internacional, ainda que constituindo um conjunto de preceitos/doutrinas pouco claras e insuficientemente fundamentadas. No entanto, a vocação de intervenção cultural sobre a sociedade portuguesa, no âmbito do novo paradigma político saído da implantação da República, animava o pensamento Saudosista delineado por Pascoaes, na esfera do mais amplo movimento da «Renascença Portuguesa». O grupo de intelectuais que gravitou em torno do Saudosismo e do seu órgão literário mais representativo, «A Águia - órgão da Renascença Portuguesa» (1910-1932), viria a cindir-se uns anos mais tarde, dando lugar, em 1921, ao grupo que ficaria conhecido como «os seareiros», organizado em torno da editora e da revista «Seara Nova», onde vamos encontrar Sarmento de Beires como colaborador com vários artigos em torno da aviação portuguesa e internacional, onde editou o seu livro de versos Sinfonia do Vento e por onde sairia ainda a primeira edição do De Portugal a Macau.

Não surpreende, por isso, que algumas modulações literárias desta obra contenham ecos desse movimento que agregou a si o conceito filosófico de Saudade, associando-o à definição

\footnotetext{
${ }^{40}$ «Um velho burgo sujo e miserável era a cidade de Shum Chun (...) Avançamos resolutamente para a aglomeração do casario, dédalo de ruas estreitas, tortuosas, nauseabundas, com letreiros berrantes balouçando ao vento e uma garotada imunda palrando às portas» (cap. XII).

${ }^{41}$ Veja-se o curioso episódio numa tenda chinesa, no final do capítulo XII.

${ }^{42}$ Cap. XIII.

${ }^{43}$ Frase de Sarmento de Beires, em De Portugal a Macau (cap. IV).
} 
因此，这本作品中的一些文学性调节包含着这场运动的回响就不足为奇了。 这场运动增添了思念的哲学概念, 并将这个概念与帕斯库埃斯称为 “卢西塔尼亚 魂” 的定义相关联, 且允许通过人类的灵魂与某些事物与类别的精神部分接触而获 得某种形式的知识。这样, 诞生了一种对世界的思念的目光, 在一种想象哲学的范 围内, 它能够在看不到、听不到的情况下重构各种声音和物品, 它允许 “没有耳朵 听”, “没有眼睛看”。1911年萨尔门托 - 德贝雷斯住在波尔图, 他是刚成立的波尔图 大学科学院第一个课程的注册学生。很自然的, 在这种诞生了第一共和国的学术 环境里, 他与自1910年起就在波尔图编辑出版的“雄鹰” 杂志有了接触。

实际上, 在作者整个叙述中, 都穿插着并非来自某个真实身体附近的声音。在 困难和难以预料的时刻, 这声音帮助了他们一一葡萄牙人民让他们听到了人民的 声音，尽管在那个高度和距离这是不可能真实发生的。在最后一段直接飞往澳门 的航程中, 他们飞越一片海盗猖獗、降落很危险的地区时, 萨尔门托 - 德贝雷斯确 认: “我们预感到了英勇的葡萄牙人的热情, 率性真诚的人民在大冒险的时刻所迸 发出的热情; 我们仿佛还听到了充满力量和勇气地大喊, 就像出发时最重要的那一 瞬间: “前进!” (第十二章)。

这是一种来自作者内心情感, “不用耳朵” 就能听到的呼喊, 它表达了一种爱国 之情。在整个空中突袭中, 这种呼喊至少重复了五次: “远处传来一阵爵士乐的旋 律 $(\cdots \cdots \cdot)$ 葡萄牙的声音回响在夜空, 那是自信, 向上, 如闪电般的嗓音, 呼喊出奇妙 的声音: 前进!” (第五章)。“祖国号继续向东飞行, 在机翼上刻上了耶稣的十字架, 还是那个声音回响在耳边, 像一种超自然的力量推动我们前进。” (第三章)。“而在 我们当中已经没有了当初出发时的那种情感震动, 我们用一种隐蔽的声音下意识 地嘟囔着一些不安和焦虑的话。”(第十二章)。

在某种怀旧密码的背景中, 不但凸显出了风景的灵魂, 还在自然与人类情感之 间建立了某种平行关系。在最初的飞行时刻, 当他们的视线捕捉到米拉河时, 葡萄 牙人的思念之情留下了印记: “哦, 蜷曲在岸间蓝绿色的米拉河, 它在那里哭泣, 在奔 流。” (第三章)。风景灵魂化是一个重点, 它贯穿了所有叙述者经过的空间视角。 因此, 在萨尔门托 - 德贝雷斯的这份报告中, 风景和天气中令人惊奇的一面常常化 身为奇妙的幽灵、其他时代的妖怪和化身其中的魔鬼之类，用来象征宇宙中超然 的一面; 在这种情况下, 就是危险, 就是命运, 就是人类为完成某种任务而进行的斗 争、机遇、运气或死亡。从陌生的天空飞往澳门途中, 萨尔门托 - 德贝雷斯记道: “奥尔马拉半岛那些悬崖峭壁像是超自然的恐怖幽灵一样出现了。”(第八章)。 
do que Pascoaes designou por «alma lusitana» e que permitia uma forma de conhecimento a que se acedia mediante o contacto das almas humanas com a parte espiritual das coisas e dos seres. Desse modo, nasceria um olhar saudoso sobre o mundo, capaz de reconstituir sons e objetos sem os ver e sem os ouvir, no âmbito de uma espécie de filosofia da imaginação, que permitia «ouvir sem ouvidos» e "ver sem olhos», isto é, sem sentidos. Sarmento de Beires residia no Porto no ano de 1911, quando se inscreveu como aluno do primeiro curso da Faculdade de Ciências da recém-formada Universidade do Porto, e é natural que, nesse ambiente académico resultante da Primeira República, tenha contactado com essa revista "A Águia», editada no Porto a partir de 1910.

De facto, ao longo de toda esta narrativa, ressoam vozes que não provêm de um corpo físico próximo. Ajudando nos momentos de dificuldades ou incertezas, o povo de Portugal fazia-se ouvir, ainda que isso fosse impossível de acontecer, àquela altitude e a tal distância. Na última etapa, que conduziria directamente a Macau, Sarmento de Beires afirma, ao sobrevoar uma zona de piratas em que seria perigoso aterrar: «Pressentíamos o entusiasmo da brava gente portuguesa, do povo rude e sincero que sente as horas grandes da aventura, e ouvíamos, como no instante supremo da partida, o mesmo grito de força e de coragem: - Avante!» (cap. XII).

Este grito da partida é ouvido «sem ouvidos», do interior emocional do narrador, expressando um sentimento patriótico que o transcende. E foi-o reiteradamente ao longo do raide, pelo menos por cinco vezes: «Enquanto, de longe, os acordes de um jazz nos chegam aos ouvidos, [...] a voz de Portugal ecoa no espaço, confiante, animadora, relâmpago de som a gritar-nos a palavra mágica: Avante!» (cap. V). «O Pátria retomava a sua marcha para Oriente, cruzes de Cristo sangrando nas asas brancas, e a mesma voz soando na amplidão, a impelir-nos como força sobrenatural» (cap. III). «E em nós, se não vibrava já aquela emoção das horas da partida, falava, porém, inconscientemente, uma voz oculta, a murmurar palavras de inquietação e ânsia» (cap. XII).

No contexto de um código saudosista que realçava a alma da paisagem e que estabelecia paralelos entre a natureza e as emoções humanas, a captação do rio Mira, nos primeiros momentos do voo, vem marcada pela saudade dos portugueses: «O Mira, muito enrodilhado entre as margens, lá fica a chorar, a correr, azul-ferrete» (cap. III). A animização da paisagem é uma tónica transversal à perspectivação de todos os espaços que o narrador atravessa. $\mathrm{E}$ assim, neste relato de Sarmento de Beires, as surpresas da paisagem e da atmosfera são encaradas frequentemente como aparições fantásticas, monstros de outras eras, seres diabólicos que ali encarnam, para significarem o lado transcendente do universo, neste caso o perigo, o destino, o combate humano pelo êxito de uma missão, o acaso, a sorte ou a morte. A caminho de Macau, por entre céus estranhos, Sarmento de Beires regista que «os morros abruptos da Península de Ormara surgem, como aparição medonha de monstro sobrenatural» (cap. VIII). Nas descrições das intempéries que ameaçaram o êxito do raide, a natureza quase ganha autonomia e animização, fugindo ao controlo dos aviadores: «A tempestade, que o vento impele para Nordeste, caminha ao nosso encontro, como teoria de monstros alados que uma inau- 
在描写威胁飞行获得成功的坏天气时, 大自然几乎获得了自主意识灵魂, 却逃 脱了飞行员们的掌控: “东北风推动着风暴, 与我们迎面相撞, 就像被一种听不见的 声音控制的、长着翅膀的妖魔似的。” (第八章。) “我试着往前飞, 但是雨水把我们 包围得越来越紧, 狂风似乎就想要毁掉飞机 $(\cdots \cdots \cdot)$ 然而暴雨继续残酷地惩罚着我 们。” (第十二章)。

在风暴引起的坏天气后, 似乎已经有人胜出。此时, 这几个葡萄牙人再次被一 种不让他们喘息的大自然包围，这被作者称为仿佛是意图谋杀：“在四百米的高度 “祖国号”恢复了正常, 天气也仿佛在谋杀后的疲倦中, 出现了暂时的温和, 但在我们 到了马尔贝拉后, 又重新发起疯来。”(第三章)。“我们行进在惊险刺激的疯狂气氛 中。” (第八章)。而在最后的飞行阶段, 敌对的大自然再次与想要获得胜利的英雄 们抗衡，在与大自然的贴身搏斗中出现了困难：“但强风把祖国二号推远了一点。 我们试图再次俯冲, 却遇到了一道黑色的、不透明的移动水墙, 不得不中止了。” (第十二章。) 在最后一段航程中, 飞机与飞行员联合在一起, “我们的飞机勇敢地顶 住了大风的袭击”, (第十二章); 在旅途中的某些时刻, 飞机似乎也有了生命, 它向敌 对的风景投降, 变成了某种意义上的对手: “我们握控制杆的手在颤抖, 我们的飞机 在坠落, 有失重的感觉, 我们的身体与座椅不再紧靠, 仿佛整个飞机要解体了。我 的椅垫已经从身下飘到了空中, 机身底部残留的葡萄牙尘土掉在我们头上”, 在暴风 雨袭击了阿尔赫西拉斯湾, 迫使他们在马拉加降落时, 萨尔门托 - 德贝雷斯在第三 章这样讲述。

大部分在作品中体现出来的爱国主义情绪一一通过我们已经提到的、聆听 鼓励的呐喊而产生的爱国主义情绪, 让位于一种模糊然而令人信服的情感表达, 一 种不那么精确、贯穿了自然、人群和物品的表达。作者口头表达的思念并不是对 特定的人的思念, 而是一种不确定的思念, 总是与国家或是某种集体的、人道的利 益联系在一起的思念: “呼吸甜美而宁静。怀旧的思绪散发在乳白色的月光下, 大 家缓缓地交流着思乡, 疑问和渴望。”(第五章)。

这几位飞行员在中途暂停突尼斯时与其他飞行员相遇, 德贝雷斯证实: “螺旋 桨在蓝天中旋转。每个人的胸中都鼓动着对露天、对广阔的天空的热切期待。而 在我们的心中则升腾起一阵骄傲, 因为葡萄牙也参与到了这飞行员们组成的世界 性的兄弟会中, 同他们一同完成这至高的壮举。“ “这几分钟我们感到周围的灵魂都 在渴望机翼的胜利。”正是在这些时刻, 他诗意地表达了人类恢复和平的使命, 在最 初, 这鼓舞了国际航空界。但是, 这也与上世纪初葡萄牙思想领域要求国家复兴的 方针和推定进步的轨迹相符。 
dível voz comande (cap. XI) E «o avião singra, seguindo a costa, castigado sempre pelo furor epiléptico da bruma e das rajadas» (cap. VIII). A natureza anima-se de uma vontade destruidora a que os aviadores tentam escapar: «o círculo de água aperta-nos cada vez mais, e a fúria do vento parece apostada em esfacelar o avião. [...] Os aguaceiros continuavam a castigar-nos sem piedade» (cap. XII).

Após intermitências da tempestade de que parecem sair vencedores, os portugueses são de novo apanhados por uma natureza que não lhes quer dar tréguas e em que o narrador coloca uma intenção assassina: «A quatrocentos metros, o Pátria retoma a linha de voo normal, e a atmosfera, como fatigada pelo esforço homicida, abranda por instantes a epilepsia da sua raiva, para começar de novo a sacudir-nos em frente de Marbella» (cap.VIII). «Andam no ar frémitos de loucura» (cap. VIII). Já na etapa final, de novo a natureza hostil se afirma contra os heróis que pretendem vencer, e as dificuldades surgem representadas como luta corpo a corpo: «o Pátria afasta-se um pouco, e ao tentar de novo romper, encontra a muralha líquida que avança, negra e opaca, barrando terminantemente a passagem» (cap. XII). O próprio avião, na última etapa aliado dos aviadores, «resist[indo] galhardamente aos golpes da ventania» (cap. XII), pareceu algumas vezes, durante a viagem, ganhar vida própria, rendendo-se à paisagem inimiga e tornando-se numa espécie de adversário: «Mãos crispadas nas alavancas de comando, sentimos o aparelho que se despenha, que se furta debaixo de nós, que nos abandona no espaço, que parece ir despedaçar-se em pleno voo. A almofada da minha cadeira escapa-se no ar: cai-nos sobre as cabeças a terra de Portugal que restava ainda no fundo da fuselagem», narra Sarmento de Beires no capítulo III, a propósito da tempestade que os surpreendeu sobre a baía de Algeciras, obrigando-os a aterrar em Málaga.

O sentimento patriótico que se traduz maioritariamente na obra pela audição do grito de incentivo que já referimos dá também lugar à expressão de um sentimento vago - mas eloquente -, impreciso, transversal à natureza, às pessoas e às coisas. A saudade que o narrador verbaliza não é de ninguém em especial, é uma saudade indefinida, associada sempre ao país ou a uma causa coletiva e humanitária: «Respira-se doçura, serenidade. Há eflúvios de nostalgia dispersos na claridade láctea do luar, e nas palavras lentas que trocamos rondam saudades, interrogações, anseios» (cap. V).

Na escala realizada em Túnis, onde se cruzam com outros aviadores, Beires constata que «Giram hélices no azul. Há uma aspiração de ar livre, de céu profundo, vibrando intensamente em cada peito. E nos nossos corações, uma rajada de orgulho passa, ao sentir que Portugal trabalha também na obra sublime de fraternização universal, que é a obra dos aviadores». «São minutos em que sentimos à nossa volta almas ansiando o triunfo das asas». E é nesses momentos que expressa poeticamente a missão pacificadora da humanidade que animara a aviação internacional nos seus primórdios, mas que era também coincidente com a vocação de renascimento nacional e com a trajectória propulsora de progresso que se reivindicava então, na esfera do pensamento português do início do século. 


\section{令人眩晕的清单 ${ }^{4}$}

在上面我们已谈到的广泛筹款用来资助购买飞机和飞行的运动中，全国各地 到处都有一些宣传、分发和发布捐款人名单的活动，这些募捐由个人或集体单位 负责, 在他们认识的人中募集资金。在葡萄牙航空局开始募捐后, 布里托 - 帕伊斯 贡献出自己的100康多, 而他的姐姐玛丽亚 - 多塞乌女士则于1923年11月领导了一 份阿兰特茹的捐款名单。就这样, 如这部作品第一章45 所述: “为全国募捐奠定了 第一块基石, 然后全国都表现出葡国魂的狂热”。在许多个月中一一超过了一年的 时间里, 全国各地举行了大量五花八门的活动, 比如音乐演出, 出售书籍, 斗牛, 足 球赛, 出售香皇和火柴等等, 以便筹集资金, 进行资助, 让这次飞行变得有可能实 现。甚至在飞行结束后，有些报纸还在刊登消息，要求尚未提交其负责募捐册名 单的人提交清单, 以便关闭账户, 提供资金。有些地方和机构在这场宣传中对此表 示尊重, 以证实尽管距离遥远, 人们却感到并做到亲密无间（像马德拉或亚速尔群 岛), 也是认同将散落在世界各地的葡萄牙人团体团结在一起的姿态 (比如巴西, 澳 门等地)。在提交了 $\$ 59244$ 埃斯库多的款项后 (折合现在的二百九十七欧元零十一 欧分), “里斯本一澳门 “空中突袭”, 圣保罗执行委员会报告 (1924年)” 的出版引人注 目, 报告最后肯定 “就像本报告证实的那样, 在巴西, 圣保罗的葡萄牙侨民为实现里 斯本一一澳门空中突袭提供了最大协助。” 46 像这份报告一样, 当时还出版了许多 清单。毫无疑问, 这都是些实用清单, 但以今天查阅它们的人的眼光来看, 对它们 的解读超出了纯粹的会计和实用维度。这充斥着许多数字的圥长清单似乎是为了 让人们能够暂时逃避参与现实世界, 而融入到环绕着这次空中之旅的诗意环境中 去: 三位飞行员代表人民, 整整一个国家的人民, 几乎是面对面地识别的人民, 他们 赞助并支持了三位飞行员。这张清单并没有像洪贝尔托 - 艾科 ${ }^{47}$ 说的那样, 由于 这个事实变得参考价值不高, 而是赢得了另一个维度的价值, 它没有贬低第一个维 度而是将其升华了。由于多重性、人类自身的易错性, 还有地理的多样性和无休 止的发展, 一些逃过列举本身的东西被列举了出来。从名词化中脱颖而出的是集 体和群众。萨尔门托 - 德贝雷斯将那场已然遥远的里斯本一一澳门空中突袭的叙 事献给了葡萄牙, 因此, 我们认为通过再次编辑发行本书, 让记忆和历史回归, 这符 合我们的最大利益。

\footnotetext{
44 洪贝尔托・埃科著作书名, 里斯本: 迪菲尔出版社, 2009年。

${ }^{45}$ 萨尔门托 - 德贝雷斯做出的贡献是出版了自己的诗集 “风的交响曲”, 其销售收入全部用于这次飞行。该 书由 “新田地” 编辑出版, 并且在自己的杂志上为此书宣传销售, 并请葡萄牙文学和文化名人在杂志上做出 欣赏性的评论 (莫茹让, 2017)。当时几乎所有受过良好教育的葡萄牙人都购买了该诗集, 比如, 尽管封面上 的标价为 25 埃斯库多, 时任共和国总统曼努埃尔 - 特谢拉 - 戈麦斯先生却支付了 100 埃斯库多购买它。诗 集第一版售出了 3000 册。

46 同上: 91

47 艾科, 2009年: 113
} 


\section{A VERTIGEM DAS LISTAS ${ }^{44}$}

No âmbito do amplo movimento de angariação de recursos para financiar aviões e viagem que já se referiu atrás, um pouco por toda a parte se divulgaram, distribuíram e publicaram inúmeras listas de subscritores, sob a responsabilidade de entidades individuais ou colectivas, que recrutavam fundos entre os seus conhecimentos. Após a incial subscrição da Aeronáutica, Brito Paes contribuiu com cem contos seus, e a sua irmã, Maria do Céu, encabeçou por sua vez, em novembro de 1923, uma lista no Alentejo, lançando «assim a primeira pedra na subscrição nacional, que depois traduziria o fervor da Alma Portuguesa», conforme se relata no capítulo I desta obra ${ }^{45}$. Durante vários meses - mais de um ano -, por todo o país se desenvolveram inúmeras e diversificadas actividades, como récitas, venda de livros, touradas, jogos de futebol, vendas de sabonetes e fósforos, etc, no intuito de angariar fundos para financiar e viabilizar esta viagem. Mesmo após o termo da viagem, alguns jornais publicavam ainda o pedido de que os subscritores que ainda não tivessem entregado a lista por que estavam responsáveis o fizessem então, para se proceder ao encerramento das contas e à efectivação dos financiamentos. Algumas localidades ou instituições fizeram ponto de honra nessa divulgação, para dar prova da adesão dos que, mesmo estando longe, se sentiram e se fizeram perto (caso da Madeira ou dos Açores) e se identificaram com o gesto fraterno de unir as comunidades portuguesas espalhadas pelo mundo (caso do Brasil, de Macau, etc.). Saliente-se a edição do «Raid» Lisboa-Macau. Relatório da Comissão Executiva de S. Paulo, de 1924, que, após apresentar a receita de 59.422\$00 (actuais duzentos e noventa e sete euros e onze cêntimos), termina afirmando que «a Colónia Portuguesa de São Paulo foi, como se verifica do presente Relatório, a que, no Brasil, maior auxílio prestou à realização do "raid" Lisboa-Macau» ${ }^{46}$. Como esta, muitas outras se publicaram. Trata-se de listas práticas, sem dúvida, mas, no olhar de quem hoje as consulta, a sua explicitação extravasa uma dimensão unicamente contabilística e imediatamente prática. A imensa lista de nomes e de números parece, por momentos, subtrair-se à sua inserção no mundo real, para integrar e significar o ambiente épico que envolveu esta viagem: três aviadores que representam um povo; um povo inteiro, quase discriminado pessoa a pessoa, que apoia e patrocina três aviadores. A lista não se torna, por esse facto, menos referencial, como diria Umberto $\mathrm{Eco}^{47}$, mas ganha uma outra dimensão que, não anulando a primeira, a sublima. Enumera-se algo que escapa à própria enumeração, pela multiplicidade, pela falibilidade própria do humano, pela diversidade geográfica e pelos desdobramentos infindáveis. É o colectivo e a multidão que emergem desta nominalização. Portugal, portanto, a quem Sarmento de

\footnotetext{
${ }^{44}$ Título da obra de Umberto Eco, Lisboa: Difel, 2009.

${ }^{45}$ A contribuição de Sarmento de Beires foi a publicação de um livro de versos seu, intitulado Sinfonia do Vento, cujo produto de venda reverteu inteiramente para a viagem. Editado pela Seara Nova, em cuja revista se publicitou a venda e se apresentaram apreciações críticas feitas por figuras de referência da literatura e da cultura portuguesas (MORUJÃO, 2017), o livro foi comprado por quase todos os portugueses mais cultos, tendo o Presidente da República, Manuel Teixeira Gomes, contribuído com cem escudos, face a um preço de capa de vinte e cinco escudos. A primeira edição teve três mil exemplares vendidos.

${ }^{46}$ Op. cit.: 91.

${ }^{47}$ ECO, 2009: 113.
} 


\section{引用参考书目}

阿尔梅达，卡特琳娜 - 努内斯 - 德阿尔梅达 $* 2018$ 年)。“以葡萄牙眼光看澳门: 一些当代诗歌的代 表”, “马特拉加” 杂志, 里约热内卢, 25卷45号, 566-578页, 9月/10月。网页: https://www.academia. edu/38535755/2019._DO_OLHAR_PORTUGUÊS_SOBRE_MACAU_algumas_representações_poéticas_ contemporâneas

德贝雷斯, 若泽・曼努埃尔・萨尔门托, (1968 [1925]年), “从葡萄牙到澳门”。新田地, 里斯本。

坎迪亚斯, 安东尼奥, 等人, (2007年)。“19世纪和 20 世纪葡萄牙的扫盲与学校”, “人口普查与统计”。里 斯本, 古本江基金会。

科蒂尼奥, 加戈 (1924年)：“荣耀睿智的加戈・科蒂尼奥上将专门用于本报告页面的话”。载于 “里斯 本一澳门突袭, 圣保罗执行委员会报告”1924年, 17-18页。

“亚速尔日报”, 1924年5月5日。

艾科, 洪贝尔托 (2009年) : “令人眩晕的列表”。里斯本, 迪菲尔出版社。

法瓦, 费尔南多 - 门多萨 (2016年) : “写给里斯本-澳门空中突袭的历史”, “文化杂志”, 52期, 澳门, 74-87 页。

马特乌斯, 洛伦索・恩里克 - 恩里克斯 (1999年) : “祖国号” 揭幕75周年后”, 里斯本: 乌尼克出版社。

莫茹让，伊莎贝尔 (2018年) : “当葡萄牙新闻界面对萨尔门托 - 德贝雷斯和布里托 - 帕伊斯的开拓 性飞行: 葡萄牙一澳门空中突袭 (1924年)”。材料汇编 “新闻和空中征服记: 故事, 图片和诗歌”, Mélodie Simard-Houde主编。“航空航天的过去与现在” (在线) 秋季第5期。链接: http://revues. univ-tlse2.fr/pum/nacelles/index.php?id=687\#tocto2n6

莫茹让，伊莎贝尔 (2017年)：“在消息和叙事之间: 在葡萄牙至澳门空中之旅中的代表线路”。蒙特罗， 安东尼奥; 奥特里尼奥, 玛丽亚・德法蒂玛; 法利亚, 多米尼克; 阿尔梅达, 若泽・多米尼克・德等 人: “飞行员与作家, 历史的见证, 知识与异想天开”, 巴黎, 手稿出版社, 207-235页。

莫茹让, 伊莎贝尔 (2012年) : “在从前的葡萄牙人的路上: 萨尔门托 - 德贝雷斯的葡萄牙一澳门航空之 旅 (1924年)”。塞楚奇, 皮耶罗, “葡萄牙语文学中的澳门和东方一一恐惧与诱惑”。罗马: 但丁・ 阿利吉耶里出版社, 47-67页。

莫茹让, 伊莎贝尔 (2011年) : “萨尔门托 - 德贝雷斯-——个生物参考书目的试验” 和 “萨尔门托 - 德 贝雷斯及可能的参考书目”。德贝雷斯, 若泽 - 曼努埃尔 - 萨尔门托, “太阳之城”, 若尔热 -巴 斯托斯 - 达席尔瓦和伊莎贝尔 - 莫茹让编辑。波尔图, 阿弗龙塔曼托出版社, 17-35页, 163-168 页。

莫茹让，伊莎贝尔 (2018年)：“坠落的翅膀：萨尔门托 - 德贝雷斯作品中航空之旅的叙事”。“葡萄牙 和巴西文化及流行文学”。波尔图: 文化、空间与记忆跨学科研究中心暨阿弗龙塔曼托出版社, 392-411页。

塞图巴尔人, 1924 年 6 月 4 日, 星期六

莫拉, 皮埃尔 (1993年) - “记忆和历史之间: 关于地点的争议”。雅拉 - 奥恩 - 库里翻译, “历史项目: PUC-SP杂志”, 圣保罗，(10)，12月号，7-28。网址: https://revistas.pucsp.br/index.php/revph/article/ viewFile/12101/8763

佩塞尼亚, 卡米洛 (1924年) - “向完成首次里斯本一澳门空中突袭的飞行员们致敬”, 1924年, “向里斯 本一澳门空中突袭的英雄、光荣的飞行员们——安东尼奥 - 亚辛托 - 达席尔瓦 - 布里托 - 帕伊 斯上尉, 若泽 - 曼努埃尔 - 萨尔门托 - 德贝雷斯上尉, 曼努埃尔 - 戈维亚中尉致敬的演出节目 单。演出与 1924 年7月4日在澳门唐佩德罗五世剧院举行, 由戏剧及音乐爱好者集团主办”。费 尔南德斯及子女公司Mercantil de N.T印刷出版社, 1924年。

雷森德, 加尔西亚・德, (1973年) [1517年]- “加尔西亚・德雷森德的游吟之歌”。安德烈・卡拉贝・罗 沙介绍并做注解。第一卷。里斯本: 巴西图书中心, 第2页。

萨, 路易士・安德拉德・德, (1990年), “澳门航空: 一个世纪的冒险”。澳门: 东方图书出版社。 
Beires dedicou a narrativa desse já distante raide aéreo Lisboa-Macau, que julgamos de todo o interesse fazer regressar à memória e à História, através da presente reedição.

\section{BIBLIOGRAFIA CITADA}

ALMEIDA, Catarina Nunes de Almeida (2018) - Do olhar português sobre Macau: algumas representações poéticas contemporâneas. «Rev. Matraga», Rio de Janeiro, v.25, n.45, 566-578,set./dez.https://www.academia.edu/38535755/2019._DO_ OLHAR_PORTUGUÊS_SOBRE_MACAU_algumas_representações_poéticas_contemporâneas

BEIRES, José Manuel Sarmento de (1968 [1925]) - De Portugal a Macau (A viagem do Pátria). Porto: Imprensa Social da Cooperativa do Povo Portuense.

CANDEIAS, António et al. (2007) - Alfabetização e escola em Portugal nos séculos XIX e XX. Os censos e as estatísticas. Lisboa: Fundação. C. Gulbenkian.

COUTINHO, Gago (1924) - «Palavras de Gago Coutinho especialmente destinadas pelo sábio e glorioso almirante às páginas deste Relatório». In «Raid» Lisboa-Macau. Relatório da Comissão Executiva de S. Paulo, S. Paulo, pp. 17-18.

DIÁRIO DOS AÇORES, 5 de Maio de 1924.

ECO, Umberto (2009) - A vertigem das listas. Lisboa: Difel.

FAVA, Fernando Mendonça (2016) - Para a história do raide aéreo Lisboa - Macau. «Revista de Cultura», n. 52, Macau, pp. 74 a 87. MATEUS, Lourenço Henrique Henriques (1999) - Na esteira do Pátria 75 anos depois. Lisboa: Única.

MORUJÃO, Isabel (2018) - «La presse portugaise devant l'aviation pionnière de Sarmento de Beires et Brito Paes: Le raid Portugal-Macao (1924)». Dossier La presse et la conquête de l'air. Histoires, imaginaires, poétiques, sous la direction de Mélodie Simard-Houde. «Nacelles. Passé et présent de l'aéronautique et du spatial / Past and Present of Aeronautics \& Space» [en ligne], n. ${ }^{\circ}$ 5, automne. URL: http://revues.univ-tlse2.fr/pum/nacelles/index.php?id=687\#tocto2n6

MORUJÃO, Isabel (2017) - «Entre a notícia e a narrativa: um itinerário de representações na viagem aérea de Portugal a Macau» in MONTEIRO, António, OUTEIRINHO, Maria de Fátima,FARIA, Dominique, ALMEIDA, José Domingues de (dirs.) - Aviateurs-écrivains. Témoins de l'histoire, Savoirs / Exotopies. Paris: Éditions Le Manuscrit, pp. 207-235.

MORUJÃO, Isabel (2012) - «Na rota de antigos portugueses: a viagem aérea de Portugal a Macau, de Sarmento de Beires (1924)». In CECCUCCI Piero (dir.), Macau e o oriente nas literaturas de língua portuguesa - Receios e seduções. Roma: Società Editrice Dante Alighieri, pp. 47-67.

MORUJÃO, Isabel (2011a) - «Sarmento de Beires - Ensaio de uma biobibliografia» e «Sarmento de Beires: a bibliografia possível». In BEIRES José Manuel Sarmento de, A cidade do sol, edição de Jorge Bastos da Silva e Isabel Morujão. Porto: Edições Afrontamento, pp. 17-35 e 163-168.

MORUJÃO, Isabel (2011b) - «Asas que naufragam: narrativas de viagens aéreas na obra de Sarmento de Beires». In Literatura culta e popular, em Portugal e no Brasil (...). Porto: CITCEM / Edições Afrontamento, pp. 392-411.

O SETUBALENSE, Sábado, 14 de junho de 1924.

NORA, Pierre (1993) - Entre memória e história. A problemática dos lugares. Tradução de Yara Aun Khoury, «Projeto História, Revista da PUC-SP», São Paulo, (10), Dez., 7-28. https://revistas.pucsp.br/index.php/revph/article/viewFile/12101/8763

PESSANHA, Camilo (1924) - Homenagem aos aviadores que completaram o 1. ${ }^{\circ}$ raid aéreo Lisboa - Macau, 1924, in Programa da récita em homenagem dos gloriosos aviadores, Majores António Jacinto da Silva Brito Paes e José Manuel Sarmento de Beires e Tenente Manuel Gouveia, heróis do raid Lisboa-Macau, realizada na noite de 4 de Julho de 1924 no Teatro D. Pedro V de Macau, organizada pelo Grupo de Amadores de Teatro e Música. Edição da Tip. Mercantil de N.T., Fernandes e Filhos.

RESENDE, Garcia de (1973) [1516] - Cancioneiro geral de Garcia de Resende. Introdução e notas de Andrée Crabbé Rocha. Tomo I. Lisboa: Centro do Livro Brasileiro, p. 2.

SÁ, Luís Andrade de (1990) - Aviação em Macau. Um século de aventuras. Macau: Livros do Oriente. 


\section{“从葡萄牙到澳门”中文版: 祖国二号降落后, 现在德贝雷斯的 叙事传到了东方}

丽达・皮纳・布里托 


\section{DE PORTUGAL A MACAU EM MANDARIM: DEPOIS DA ATERRAGEM DO PÁTRIA II CHEGA AGORA A NARRATIVA DE BEIRES AO ORIENTE}


“生活中的事情在应发生的时候就会发生。我们得认命接 受事情的发生, 尽管不能停止为要实现的目标而奋斗, 因为那 些被战胜的、无法预见的一切和障碍恰如其分地代表了我们 奋斗的价值。”

若泽・萨尔门托・ 德贝雷斯写给路易・德布里托的信 (1961年)

在一封1961年3月14日萨尔门托 - 德贝雷斯写给我的祖父一一作家路易 - 德 布里托的信中, 我发现了上面分享给大家的这段话。这段话以某种方式体现了葡 萄牙至澳门航空之旅的内在精神, 那是一次在极为不利条件下实现的、一次开拓 性空中突袭。

1924年4月7日的清晨, 两位男子登上了一架装备雷诺300CC引擎的布雷盖 $16 \mathrm{BN} 2 飞$ 机, 将自己的身心毫无保留地交给了前人从未尝试过的葡萄牙一一澳门穿 越之旅。这两位男子一位是机长安东尼奥 - 雅辛托 - 达席尔瓦 - 布里托 - 帕伊 斯, 另一位是飞行员若泽 - 曼努埃尔 - 萨尔门托 - 德贝雷斯, 后者就是 “从葡萄牙 到澳门”一书的作者。这本书在穿越之旅实现一年后的1925年初版, 而我们现在正 在编辑中葡双语新版。

将近九十五年过去了, 我们有幸参与这次以葡语再版以及首次以简体中文出 版本书的任务。这部文学作品讲述了一次发生在 20 世纪的旅程, 它包含了一部新 时代史诗的成分一一从最初布里托 - 帕伊斯和萨尔门托 - 德贝雷斯计划空中穿越 之旅到最终 “祖国二号” 降落在深圳的中国墓地。

实际上，这部史诗始于这两位热爱飞行的男子。他们早在1920年10月18日 就一起驾驶一架一战轰炸机一一一架装备了雷诺-比扬古300CC发动机的布雷盖 14-A2飞机一— “黑骑士号”, 第一次试图从空中连接里斯本和马德拉岛。那是架老 旧的飞机, 布里托 - 帕伊斯和萨尔门托 - 德贝雷斯将它 “从机库深处拖出来, 机身 上盖了厚厚一层灰” (佩索托, 1980年: 38), 他们耐心地修复了它。尽管由于 “黑骑 士号” 坠入大西洋底, 没有能够完全实现那次飞行的目标, 但是, 这次首航却揭露了 政府面对 “工业化国家通常系统性、有条理、有计划地向自己的飞行员提供技术 的能力和经济力量” (佩索托, 1980年: 37) 时, 缺乏适当的投资和资源, 以及种种官 僚主义造成的困难。在这次飞行中, 向布里托 - 帕伊斯和萨尔门托 - 德贝雷斯提 供的飞机实在是太老旧了。出发日期被高层一再推迟, 所有能够募集到的资金全 部来自私人。然而, 这两位男子在没有部长授权的情况下秘密起飞, 但是他们拥有 玛亚司令宝贵的帮助和之后舆论的支持, 这使得部长方面 “感觉到一种有利于飞行 员们的压力, 让他们免受纪律处分” (佩索托, 1980年: 47). 
As coisas, na vida, acontecem quando devem acontecer. Temos de resignar-nos a aceitar que as coisas acontecem, embora sem deixar de lutar por aquilo que pretendemos alcançar, porque os imprevistos e os obstáculos a vencer representam justamente a valorização da nossa luta.

J. Sarmento de Beires (1961), Carta a Rui de Brito

Numa carta escrita por Sarmento de Beires a meu avô, o escritor Rui de Brito, com data de 14 de Março de 1961, encontrei esta passagem que acima partilho e que de algum modo caracteriza o espírito que envolveu a viagem aérea de Portugal a Macau, o raide aéreo pioneiro e concretizado nas condições mais adversas.

Dois homens entregam as suas mãos e os seus corações, na manhã de 7 de Abril de 1924, à travessia nunca antes tentada entre Portugal e Macau, a bordo do avião baptizado de Pátria, um Bréguet 16 BN2 com motor Renault 300 cv. Os dois homens naquele avião eram o comandante António Jacinto da Silva Brito Paes e o piloto José Manuel Sarmento de Beires, este último autor da obra De Portugal a Macau, o livro que agora editamos, na sua versão bilingue em Português e Mandarim, e que foi publicado pela primeira vez um ano após a travessia, em 1925.

Volvidos quase noventa e cinco anos, envolvemo-nos nesta missão de publicar novamente em Português, e pela primeira vez em Mandarim simplificado, esta obra literária que narra uma viagem que, ocorrida no século XX, contém em si os ingredientes de uma nova epopeia, desde o planeamento inicial da travessia projectada por Brito Paes e Sarmento de Beires até à aterragem final do Pátria II no cemitério chinês em Shum Chun.

A epopeia começa, na verdade, com este dois homens apaixonados pela aviação, que já tinham voado juntos naquela que foi a primeira tentativa de ligação de Lisboa à Ilha da Madeira, em 18 de Outubro de 1920, com o Cavaleiro Negro, "um velho e anguloso avião de bombardeamento, do tempo da guerra, um Bréguet XIV-A2, com um motor RenaultBillancourt de 300 cv» (Peixoto, 1980: 43), que Brito Paes e Sarmento de Beires pacientemente recuperaram, «retirando-o do fundo de um hangar, onde jazia sob uma boa camada de pó» (Peixoto, 1980: 38). Apesar de o objectivo não ter sido totalmente alcançado, uma vez que o Cavaleiro Negro viu o seu fim no fundo do Atlântico, esta primeira tentativa destapou as dificuldades burocráticas e a ausência de recursos e investimento apropriado por parte do Governo face à «capacidade técnica e o poder económico que os países industrializados punham à disposição dos seus aviadores, fazendo-o habitualmente por forma sistemática, metódica, planeada» (Peixoto, 1980: 37). Nesta travessia, o avião cedido a Brito Paes e Sarmento de Beires era demasiado velho, a partida estava constantemente a ser adiada pelas altas chefias, e todos os fundos conseguidos foram de origem privada. Porém, os dois homens partiram clandestinamente sem autorização do ministro, mas com a preciosa ajuda do comandante Maya e o posterior apoio da opinião pública, que «fez, no entanto, sentir a pressão em favor 
这次飞行除了让我们瞥见在20年代初, 面对葡萄牙飞行现状, 这两位飞行员的 勇敢和坚韧不拔之外 (他们从一开始就展示出使命感和投身其中的精神), 这次从 空中将里斯本一马德拉连接起来的尝试尽管没有完全成功, 但是它对于未来的葡 萄牙一一澳门空中之旅计划至关重要, 因为它获得了公众意见的极大赞赏与支持; 同样, 它还动员了公众认捐和捐赠。

正是由于这些认捐, 布里托 - 帕伊斯和萨尔门托 - 德贝雷斯能够有机会选择 了一架布雷盖16BN2飞机。这架飞机1921年进入阿马多拉的机库, 并为新的长途飞 行做准备。准备就绪后, 在当年的 8 月, 布里托 - 帕伊斯将它命名为 “祖国号”, 并在 上面写下了一行诗句: “这就是我热爱的、富饶的祖国”, 这唤起了卡蒙斯的史诗和 地理大发现时代早期的精神, 这种精神转移到了葡萄牙航空界, 通过飞行员们的坚 㓞、好奇和勇气, 葡萄牙航空界终于一步步崛起。

和之前飞马德拉一样, 启动这次空中穿越也耽搁了很长时间一一在把机库刮 倒压在飞机上的风暴和等待新零件到手修复飞机之间, 时光飞逝。而这期间, 萨卡 杜拉 - 卡布拉尔和加戈・科蒂尼奥启程飞往巴西，这让帕伊斯和德贝雷斯改变了 他们最初飞越南大西洋的计划, 开始考虑飞往印度, “后来又有了一直飞到澳门的 愿望” (佩索托, 1980nian :52)。因此他们提交了第一份申请, 申请使用 “祖国号”进 行长途飞行。申请被批准了。然而, 一些有许多限制的报告出现了, 直到最后, 三 年过去, 战争部批准了飞行, 但是国库却没有任何资助 (帕谢科, 1980年: 52)、

最后, 1924年4月7日, 布里托 - 帕伊斯和萨尔门托 - 德贝雷斯终于开始了这次 伟大的、前人从未尝试过的空中之旅, 就像布里托 - 帕伊斯在澳门的演讲中提到 的那样, 这次飞行要达到两个目的:

第一: 作为部队军官和爱国者, 我们需要来到澳门, 葡萄牙领土中最葡萄牙的 土地, 卡蒙斯曾经在这里获得灵感, 写出了“卢西塔尼亚人之歌”。

我们在这里了。

第二: 众所周知, 所有的国家都在努力实现伟大的飞行之旅, 葡萄牙航空界不 能冷漠无感, 而要不断地参与重大的飞行竞争。

这个目的也到到了。(德贝雷斯, 1968年: 13)。

这一小段摘录让人回想起地理大发现时代的遗产在这次空中穿越之旅中的 分量, 尽管时间已经到了 20 世纪, 而且这次空中穿越之旅再次指向东方, 同时也肯 定了葡萄牙文化的传播规模。 
dos aviadores, para que se não concretizasse a esperada sanção disciplinar» (Peixoto, 1980: 47) por parte do ministro.

Além de nos dar uma amostra da bravura e da resiliência destes homens face à realidade da aviação portuguesa no princípio dos anos vinte (confirmando desde logo o espírito de missão e entrega dos mesmos), esta tentativa de ligação aérea Lisboa - Madeira, apesar de não ter sido totalmente bem-sucedida, foi vital para o futuro projecto da travessia Portugal Macau, uma vez que concitou imensa admiração e apoio por parte da opinião pública, assim como a mobilização de subscrições públicas e donativos.

Fruto dessas subscrições, Brito Paes e Sarmento de Beires têm a oportunidade de escolher o avião Bréguet 16 BN2, que entra nos hangares da Amadora, em 1921, e que se apronta para uma nova viagem de longo curso. Depois de pronto, já em Agosto do mesmo ano, Brito Paes baptiza o avião de Pátria e inscreve nele o verso "esta é a ditosa Pátria, minha amada», evocando a epopeia de Camões e o espírito dos primórdios dos Descobrimentos, que se transpunha, então, para a aviação portuguesa, que finalmente despontava, travessia a travessia, através do ânimo, curiosidade e resiliência dos seus pilotos.

Contudo, tal como sucedera com a anterior viagem de ligação à Madeira, o arranque desta travessia também demorou bastante tempo, entre um temporal que fez abater o hangar sobre o avião e a espera das peças novas para a reparação do mesmo. Por esta altura, já Sacadura Cabral e Gago Coutinho voavam para o Brasil, levando Paes e Beires a alterarem o seu plano inicial de atravessarem o Atlântico Sul. Começam então a pensar na Índia, «mais tarde alimentando já o desejo de chegarem a Macau» (Peixoto, 1980: 52), submetendo o primeiro requerimento para o Pátria ser utilizado numa viagem de longo curso, sendo o mesmo deferido. Contudo, alguns relatórios foram chegando com várias condicionantes, até que finalmente, volvidos três anos, o Ministro da Guerra autoriza a viagem, mas sem qualquer tipo de verba por parte da Fazenda Nacional (Pacheco, 1980: 52).

Finalmente, na manhã de 7 de Abril de 1924, Brito Paes e Sarmento de Beires iniciam a grande travessia aérea nunca antes tentada e que tinha dois fins, como relembra Brito Paes no seu discurso em Macau, aquando da chegada:

Primeiro: sendo nós oficiais do Exército e patriotas, precisávamos de vir a Macau, terra portuguesa entre as terras portuguesas, onde Camões se inspirou para escrever Os Lusíadas.

Aqui estamos.

Segundo: sabendo-se que todas as nações se empenhavam na realização de grandes viagens aéreas, a Aviação Portuguesa não podia permanecer apática e indiferente e cumpria-lhe não deixar de participar condignamente na grande competição.

Atingimo-lo também. (Beires, 1968: 13).

Este pequeno excerto evoca, assim, o peso da herança dos descobrimentos nesta travessia que, já no século XX, voltava a apontar para o Oriente, confirmando a dimensão de 
“在第一次飞越南大西洋之后, “祖国号”的飞行是最能引起人民共鸣、在人民 心中回响最深的” (佩索托，1980年：66)。葡萄牙和澳门之间长达几百年的久远联 系可以解释这种共鸣, 加强和恢复这种联系从未像在今天, 在这 21 世纪那样有意义, 这就是我们要出版中葡双语版的意义。

自十六世纪以来, 从1517年费尔南・佩雷斯・德安德拉德到达广州 (广东) 开 始, 葡萄牙和澳门之间保持了友好的关系。后来, 随着 1554 年 “第一份中葡贸易协 定” (奥利维拉, 1998年: 40) 的消息, 三年后, 即 1557 年成了葡萄牙人在澳门正式建 立据点的开端。从那以后, 对于澳门葡萄牙人建立据点的起源的解释既不一致也 没有共识。这片土地可能是中国为感谢葡萄牙人赶走侵略澳门的海盗而让给葡萄 牙人的, 同样也可能是当地中国官员租给葡萄牙人的 (张海鹏, 1996年)。事实就是, 自那时起, 葡萄牙和澳门保持紧密团结直到今天; 在它们共同的历史中, 经历了许 多令人印象深刻的非凡时刻, 比如1979年中葡两国恢复建立外交关系 (2019年纪念 两国建立外交关系四十周年), 和1999年向中国移交澳门主权 (2019年将迎来20周 年纪念)。当中国国家主席习近平2018年访问葡萄牙, 声明: “中葡两国关系进入历 史最佳时期” (里贝罗, 2018年) 时, 这些日期被铭记。最佳时期很容易地体现在了 两国政府和两国企业间签署的十七份有关电力连接和输送一一 “新丝绸之路” 的 协定, 有关服贸合作、举办文化节和有关科技的协议, 以及与语言和教育有关的计 划 (布里托和维拉洛布斯, 2018年) 上。

尽管中葡关系 “目前主要是经济层面上的” (里贝罗, 2018年), 但中葡关系的未 来充满希望。此外, 语言和教育位于两国合作意愿的顶部: “签署了两个协议, 一个 是在波尔图大学设立一个孔子学院, 另一个是跟中国社科院签署的, 将在科因布拉 大学设立一个中国研究中心” (布里托和维拉洛布斯, 2018年)。

文化, 是两国共同追求的目标。两国曾经并将继续在2019年纪念它。为此, 在 庆祝中葡建交四十周年的框架下, 6 月 20 日在中国北京举办葡萄牙文化节, 届时, 葡 萄牙女高音演唱家伊莉莎贝特 -马托斯和指挥家若安娜 - 卡尔内罗将与中国交响 乐团在北京音乐厅共同演唱。 
diáspora da cultura portuguesa. «O voo do Pátria foi, depois da 1. a Travessia do Atlântico Sul, o que mais retumbância teve e mais fundo ecoou no coração do Povo» (Peixoto, 1980: 66). Uma retumbância que pode ser explicada pela ligação secular que Portugal tem a Macau e que nunca fez tanto sentido retomar e reforçar como neste actual século XXI, justificando assim a relevância desta edição bilingue.

Portugal e Macau mantêm uma relação de amizade desde o século XVI, com a chegada de Fernão Peres de Andrade a Guangzhou (Cantão) em 1517 e, mais tarde, com a notícia do "primeiro acordo luso-chinês de comércio» (Oliveira, 1998: 40), em 1554, que dá o ponto de partida para o estabelecimento definitivo dos portugueses em Macau três anos depois, em 1557. A partir daí, não são unânimes nem consensuais as versões que explicam a origem do estabelecimento dos portugueses em Macau. O território tanto pode ter sido cedido pela China como forma de agradecimento pelo facto de os portugueses terem expulsado os piratas que invadiram Macau, como pode ter sido alugado pelos portugueses aos mandarins locais (Haipeng, 1996). A verdade é que, desde essa altura, Portugal e Macau permaneceram unidos até aos dias de hoje, vivendo vários momentos marcantes na sua história em comum, como o Restabelecimento das Relações Diplomáticas Sino-Portuguesas, em 1979 (que comemora em 2019 o seu quadragésimo aniversário) e a Transferência da Administração de Macau para a China, em 1999 (que assinala o seu vigésimo aniversário também em 2019). Estas datas foram recordadas aquando da visita do presidente chinês Xi Jiping a Portugal, em Dezembro de 2018, quando declarou que «a relação entre Portugal e a China está a entrar no seu melhor período da história» (Ribeiro, 2018). O melhor período é facilmente traduzido na assinatura de dezassete acordos entre os dois Estados e empresas dos dois países relativos à conectividade e à mobilidade eléctrica - «nova rota da seda» -, à cooperação no comércio de serviços, à programação de festivais culturais e à ciência e tecnologia, assim como a projectos relacionados também com a língua e a educação (Brito e Villalobos, 2018).

O futuro avizinha-se entusiasticamente preenchido para as relações sino-portuguesas, apesar de os laços entre a China e Portugal serem «neste momento, essencialmente económicos» (Ribeiro, 2018). Porém, a língua e a educação encontram-se no topo da vontade de cooperação entre os dois países: «Houve dois acordos, um para o estabelecimento de um instituto Confúcio, na Universidade do Porto, e outro com a Academia Chinesa de Ciências Sociais, para o estabelecimento de um Centro de Estudos Chineses na Universidade de Coimbra» (Brito e Villalobos, 2018).

A cultura - objectivo igualmente visado entre os dois países - foi e continuará a ser assinalada ainda em 2019, no âmbito da celebração do quadragésimo aniversário do Restabelecimento das Relações Diplomáticas entre China e Portugal, através da programação de festivais culturais, como o Festival de Cultura Portuguesa na China, assinalado no dia 10 de Junho, em Pequim, com a actuação da soprano Elisabete Matos e da maestrina Joana Carneiro, com a Orquestra Sinfónica da China, no Beijing Concert Hall. Dentro do mesmo festival, também serão inauguradas as exposições «Histórias da Torre do Tombo/Chapas Sínicas na Biblioteca 
同一文化节上，还将在故宫博物院开幕两个展览，“东波塔历史暨北京国家图 书馆中澳门历史记录” 展览和 “十六世纪至二十世纪葡萄牙瓷砖的发展” 展览。此 外, 还会举行第二届葡萄牙一中国文学论坛; 还向中国大学中成绩最佳的葡萄牙语 专业学生颁发徐日升奖。在葡萄牙也同样举行中国文化节, “海上丝绸之路”展览 2018年12月在阿茹达宫开幕, 中国国家歌剧院上演了“杨家将”; 2019年3月和7月中 国国家芭蕾舞团和广东现代舞团的著名舞者分别表演了“黄河” 和 “须弥芥子”。 在2019年9月和10月，澳门民乐团还在里斯本、埃斯托里尔和辛特拉进行巡回表 演。

上述两个文化节的计划编排显示了无论是在中国还是在葡萄牙，文化、语言 和教育之间联系紧密; 还有在两国之间的交流中, 文化从未有如此牢固的接受度, 尽管语言障碍还是个现实状况。

语言障碍实际上是值得两国关注的一个方面, 两方都应秉持冷静和智慧的态 度面对它。在葡萄牙方面, 近年来, 无论是学习汉语普通话的葡萄牙学生人数还是 课程种类都有着明显的增长。在这个中国经济实力日益增长的时代, 汉语被视为 一种能够在世界商业中增加竞争优势的工具。正是由于中国显示出来的强大力 量, 已经有许多葡萄牙机构和企业将自己的信息翻译成汉语普通话, 以便无论是在 葡萄牙的会议、峰会或是智囊团中, 还是在中国的许多国际化任务中, 都能将自己 的信息尽快地传递出去。因此, 在把葡萄牙语翻译成汉语普通话中一一我不但是 其中一员, 也是坚定的支持者, 存在着一种日益现实的倾向。除了可以让我们的信 息以一种高效的方式到达接受者那里之外, 翻译还揭示了在试着与对话者接触时 投入的时间和拥有的细心, 这是中国文化非常重视的。

在中国方面, 同样的令人好奇的是要理解 “对于中国人, 能够讲外国对话者的 语言代表了尊严本身” (王琐英, 2001年:2), 因为 “从一方面来说, 为了能够达到最 大限度地互相理解的目的并尊重别人, 自己要努力地用对方的语言试着沟通; 从另 一方面来说, 他们也意识到了使用中文的困难性和局限性” (王琐英, 2001年:2)。这 就解释了中国 “在与外国人的接触中, 始终拥有自己的口译和笔译人员” 的战略, 这 样就刺激了学习新的语言, 比如葡萄牙语。早在1960年, 在当时的背景下, 北京广 播学院 (现在的中国传媒大学) 就出现了有18个学生攻读的中国第一个四年制葡萄 牙语本科课程。 
Nacional de Pequim» e "A Evolução do Azulejo em Portugal dos séculos XVI ao XX», no Museu do Palácio Imperial. Realiza-se o II Fórum Literário Portugal-China, assim como a entrega dos Prémios Tomás Pereira, galardão que distingue os melhores alunos de Língua Portuguesa, em universidades chinesas. Em Portugal, também se realizou o Festival da Cultura Chinesa em Portugal, com a inauguração da exposição "A Rota Marítima da Seda», no Palácio da Ajuda, em Dezembro de 2018, com a apresentação da performance «As Generais da Família Yang», pela Companhia Nacional da Ópera de Pequim. Também se apresentarão bailados famosos, como «O Rio Amarelo» e a dança «Sumeru», a realizar em Março e Julho de 2019, pela Companhia Nacional de Balé da China e pela Companhia de Dança Moderna de Guangdong. Ainda entre Setembro e Outubro de 2019, a Orquestra Chinesa de Macau actua em digressão por Lisboa, Estoril e Sintra.

A programação em ambos os festivais revela a ligação umbilical entre a cultura, a língua e a educação, quer na China, quer em Portugal e a receptividade que existe na comunicação entre ambos os países, que nunca esteve tão sólida, mesmo tendo em consideração a barreira linguística que ainda é uma realidade.

A barreira linguística é, de facto, um aspecto que tem merecido a atenção de ambos os países e que tem sido encarado pelas duas frentes, a portuguesa e a chinesa, com calma e inteligência. No lado português, é evidente o aumento e a proliferação de cursos e de estudantes portugueses de Mandarim em Portugal nos últimos anos, língua que é vista como uma ferramenta que confere uma vantagem competitiva no mundo empresarial, numa época em que a China consolida diariamente o seu poderio económico. Precisamente pela forte noção de poder emanada pela China, já muitas instituições e empresas portuguesas traduzem a sua informação para Mandarim, de forma a passar mais rapidamente a sua mensagem, seja em solo luso através de cimeiras, reuniões ou think tanks, seja em solo chinês, nas várias missões de internacionalização. Logo, existe uma tendência cada vez mais real - da qual faço parte e de que sou apologista - para a tradução de Português para Mandarim. Além de ser uma forma eficiente de se chegar ao nosso receptor com a nossa mensagem, a tradução revela, acima de tudo, o cuidado que se tem e o tempo que se investiu em tentar ir ao encontro deste interlocutor, algo bastante valorizado pela cultura chinesa.

No lado chinês, é igualmente curioso perceber que "para os chineses, saber falar a língua dos interlocutores estrangeiros representa a dignidade de si próprios» (Suoying, 2001: 2), uma vez que «o respeito aos outros consiste, por um lado, nos próprios esforços de tentar comunicar-se com os outros na sua língua, a fim de alcançar a maior compreensão mútua, e por outro, na própria consciência sobre a dificuldade e os limites do uso da língua chinesa» (Suoying, 2001: 2). Isto explica a estratégia chinesa «de ter sempre os seus próprios intérpretes e tradutores nos contactos com os estrangeiros», dinamizando, deste modo, a aprendizagem de novas línguas, como foi o caso da Língua Portuguesa, que viu o seu primeiro curso ser fundado em 1960 com a Licenciatura de Língua Portuguesa, que funcionou com dezoito alunos, no Instituto de Radiodifusão de Pequim (hoje Universidade de Comunicação da China), com a 
中国的葡萄牙语教学有两种途径: 一是由中国大学教授葡萄牙语, 一是将学 生派往澳门和葡语国家。如果说从1971年 (高等教育恢复的那一年) 到1978年, “高 考考生无论是在大学的选择还是在课程的选择上, 都没有太大余地” (王琐英, 2001 年: 7), 最终都要服从共产党, 那么到了1978年, 自愿选择制度重又运行, 尽管考生要 在一张 “服从所申请大学的调剂表格”上签字 (王琐英, 20211年: 7)。中国学生选择 葡萄牙语本科课程源于对于葡萄牙语, 一门罕见语言 (相对英语和法语来说, 它被 认为是一门较少人说的语言) 的好奇和兴趣; 还有就是中国和葡萄牙在空间上的遥 远距离 (通过澳门拉近了)。总之, 正如人们预料的那样, “与会说英语或其他通用语 言的人相比, 会说葡语的人很少; 而面对向葡语国家那样广阔的市场, 其需求一直 在增长” (王琐英, 2001年: 8)。这种需求使得人们越来越多地寻找中国葡语教师、 翻译和研究人员。

当我们具体地着眼于翻译艺术, 重要的是要注意 “在当代中国, 许多时候外国 文学翻译的概念是与介绍的概念结合在一起的”, 因为 “在中文语境中, 文学具有有 益于社会、服务于社会的任务” (周, 2016年: 270)。因此, 为了得出作品有用性的结 论, “翻译必须向中国的现实介绍外国作者” (周, 2016年: 270)。这种介绍是通过 介绍要翻译的外国作者生平和相关作品在文学史上的重要性来进行的。这种 “至 少在19世纪末期就开始并且延续至今的, 在中国翻译一介绍欧洲文学” 的艺术, 特别 是 “在中国翻译一介绍葡萄牙文学还是非常新鲜和特别的” (周, 2016年: 270), 尽管许 多葡萄牙作家的一些作品已经被翻译了, 比如卡米洛 - 卡斯特洛 - 布兰科, 艾萨 德・克罗兹, 路易士 - 德卡蒙斯, 费尔南多 - 佩索阿, 米格尔・托尔加和若泽 - 萨 拉马戈等等。这里, 澳门再次成为与中国大陆交流的重要据点, 无论是在葡萄牙语 教学方面, 还是在翻译一介绍葡萄牙文学作品方面, “直到今天在一些中国大学图书 馆还仍在使用它们” (周, 2016年: 271)。

与1960年代, 仅有三所中国大学 (过去的北京广播学院, 北京外国语大学和上 海外国语大学) 教授葡语相比, 到2016年, 在中国大陆已经有二十多所大学和高等 教育机构教授葡语 (周, 2016年: 271)。韩少功翻译的佩索阿以异名贝尔纳多 - 苏 亚雷斯写作的 “惶然录” 摘录 (有简体中文和繁体中文两本版本) 经常被中国平台 新浪微博的使用者引用。最近, 这本文学作品在豆瓣上的评分高达 9 分。 
duração de quatro anos. O ensino da Língua Portuguesa na China foi implementado por duas vias: pelo ensino de Português nas Universidades Chinesas e pelo envio de estudantes para Macau e para os países de Língua Portuguesa. Se de 1971 (ano em que recomeçou o ensino superior) até 1978 «os candidatos não tinham o luxo de escolher nem a universidade, muito menos os cursos» (Suoying, 2001: 7), obedecendo em última instância ao Partido Comunista Chinês, em 1978, o sistema das candidaturas voluntárias volta a funcionar, apesar dos candidatos assinarem «na ficha de opções uma declaração sobre a obediência à decisão da Universidade a que concorriam» (Suoying, 2011: 7). A escolha da Licenciatura de Língua Portuguesa pelos estudantes chineses devia-se à curiosidade e ao interesse que a raridade da nossa língua (considerada pouco falada face ao Inglês ou Francês) suscitava, assim como à distância física de Portugal (ainda que próximo, através de Macau). Contudo, e como seria de esperar, «como os que falam Português são poucos, em comparação com os que falam Inglês ou outras línguas mais comuns, além de enfrentar um mercado tão grande como a comunidade dos países de língua portuguesa, a procura tem sido maior que a oferta» (Suoying, 2001: 8). E nesta procura encontram-se cada vez mais professores, tradutores e investigadores chineses de Língua Portuguesa.

Debruçando-nos concretamente sobre a arte da tradução, é importante referir que, «na China contemporânea, o conceito de tradução de literatura estrangeira combina-se, muitas vezes, com o de introdução», uma vez que "a literatura no contexto chinês tem necessariamente a missão de ser útil e de servir a sociedade» (Zhou, 2016: 270). Ora, para se chegar à conclusão da utilidade da obra, «os tradutores têm que introduzir os autores estrangeiros à realidade chinesa» (Zhou, 2016: 270). Esta introdução é feita através da apresentação da biografia dos autores a serem traduzidos e da importância da obra em questão na história da literatura. A arte da «tradução-introdução de literatura europeia na China existe, pelo menos, desde os finais do séc. XIX até hoje», contudo «a tradução-introdução de literatura portuguesa na China é muito mais recente e bastante particular» (Zhou, 2016: 270), apesar de vários autores portugueses já contarem com algumas das suas obras traduzidas, como é o caso de Camilo Castelo Branco, Eça de Queiroz, Luís de Camões, Fernando Pessoa, Miguel Torga e José Saramago, entre outros. Aqui, Macau volta a surgir como um ponto de intercâmbio bastante importante com a China continental, quer no ensino da língua portuguesa, quer na tradução-introdução de várias obras literárias portuguesas, que «ainda hoje se encontram disponíveis, nas bibliotecas de algumas universidades chinesas» (Zhou, 2016: 271).

Comparando com o seu início, nos anos 60, o ensino de Língua Portuguesa passou de três universidades apenas (antigo Instituto de Radiodifusão de Beijing, Beijing Foreign Studies University e Shangai International Studies University) para mais de 20 universidades e institutos de ensino superior a ensinar português (Zhou, 2016: 271), no ano de 2016, na China continental. Excertos da tradução de Han Shaogong (nas suas duas versões de Chinês simplificado e de Chinês tradicional) d'O Livro do Desassossego do heterónimo de Pessoa, Bernardo Soares, são frequentemente citados pelos utilizadores da plataforma chinesa, a Sina 
豆瓣是一个文学艺术批评门户网站, 在上面自2006年起就组建了一个讨论佩 索阿的小组。这最后两个例子值得一提, 它显示了面对如此备受推崇的文学作品, 中国新一代年轻人怎样使用数字平台以令人好奇的方式消费卓越文化。

上面所列的都助长并肯定了通过萨尔门托 - 德贝雷斯的话语, 将第一次葡萄 牙一一澳门航空之旅的回忆带到东方的重要性。这些回忆现在被翻译成汉语普 通话, 用中文简体字与葡萄牙语并列写在纸上, 从视觉上代表了自十六世纪开始的 悠长历史联系; 我们WG图书在与为这个特别版本做出贡献的各方合作中也感受到 了。我们会继续努力, 让不同的文化靠近, 把将遥远的东方作为一次开拓性飞行目 的地的航空报告带到东方。

因此, 除了将整部作品翻译为简体字书写的汉语普通话之外, 这一版我们还 汇集了伊莎贝尔 - 莫茹让, 马里奥 - 科雷亚, 阿尔弗雷德 - 戈麦斯 - 迪亚斯和恩里 克斯 -马特乌斯等人撰写的前言, 他们从不同的角度完成了对萨尔门托 - 德贝雷 斯作品的解读和阅读。在这次再版版本中, 除了文本, 我们还印上了玛嘉丽达 - 费 雷拉为庆祝这次双语出版而专门创作、绘制的插画, 它们描绘了每一章具有象征 意义的时刻或地点。插画流畅的线条, 加上本版中随附的照片, 与德贝雷斯的叙事 对比鲜明，它们共同构成了不同力量间的平衡。这些照片有的来自我们跟随的第 三版, 有两张来自第一版, 有一张是第一次发表。它们和画家及飞机事务长安东尼 奥 - 谢克斯描绘的封面图案保持一致, 最近他过早地离开了。他始终不渝地热爱 航空, 为我们这一版的封面绘制了 “祖国号” 飞机的图案。在这里, 我们向您致敬。

最后, 从第一天我与伊莎贝尔・莫茹让拥抱这个葡汉双语版本开始, 我就认 为这是一个重要而极具意义的项目。我为布里托 - 帕伊斯和萨尔门托 - 德贝雷斯 在孤立无援的情况下, 面对的种种困难而激动不已; 我欣赏每一章所具有的电影风 格一一惊吓, “祖国一号” 坠落, 简单的气温变化, 每个领事馆的外交官; 我羡慕两个 男子之间沉默的兄弟情, 还有他们永远的朋友: 曼努埃尔 - 戈维亚的忠诚; 当然, 还 不能忘记到达东方的最终目标, 这是那次飞行的原因和我们出这一版的原因。如 果说上面这些我列举的理由还不够, 那么命运在我为本版而进行的调研中给了我 最后的一击, 让我开始写本文: 萨尔门托 - 德贝雷斯给我祖父路易 - 德布里托的 信。

当我读到这封信的时候, 我不仅忆起祖父的音容笑貌和他的工作一一它们在 我生命的各个方面都时时出现, 而且我再次为这些男子在飞往东方的旅程中所表 现出的勇敢而折服。 
Weibo. Recentemente, a mesma obra literária foi votada com 9 pontos numa escala de 0 a 10 no Douban, o portal de crítica literária e artística, onde também foi criado um grupo dedicado à discussão de Pessoa, existente desde 2006. Estes dois últimos casos merecem menção, uma vez que exemplificam a curiosa forma chinesa de consumo de cultura por excelência, por parte das novas gerações - as plataformas digitais - face a uma obra literária tão conceituada.

Todos estes indicadores acima expostos alimentam e confirmam a relevância de se fazer chegar ao Oriente a memória da primeira viagem aérea Portugal - Macau, através das palavras de Sarmento de Beires. Esta memória surge, agora, traduzida para Mandarim simplificado nas páginas que se seguem, lado a lado com a língua portuguesa, representando visualmente o vínculo histórico e secular que nos liga desde o século XVI e que agora sentimos também nós, a WG Books, em colaboração com todos os que contribuíram para esta edição tão especial, continuando o trabalho de aproximação das culturas, ao trazer ao conhecimento do Oriente o relato de uma travessia aérea pioneira que o teve como destino.

Assim, além da tradução para Mandarim simplificado da obra integral, esta edição reúne os prefácios de Isabel Morujão, Mário Correia, Alfredo Gomes Dias e Henriques-Mateus, que completam, através de diferentes perspectivas, a interpretação e leitura desta obra de Sarmento de Beires. Fazemos acompanhar este texto, que agora se reedita, pelas ilustrações especificamente criadas pela mão de Margarida Ferreira para celebrar esta edição bilingue, retratando momentos ou locais emblemáticos de cada capítulo. A quietude do seu traço contrasta com o movimento da narrativa de Beires, e juntos fazem um equilíbrio de forças em conjunto com as fotografias que acompanham esta edição, algumas delas retomadas da terceira edição que seguimos, duas provenientes da primeira edição e uma divulgada pela primeira vez. Todas elas se harmonizam com o desenho de capa realizado pelo comissário de bordo e pintor António Six, prematura e recentemente desaparecido, que, indefectível apaixonado pela aviação, ofereceu o seu desenho do Pátria para a capa desta edição. Aqui lhe queremos, por isso, prestar sentida homenagem.

Finalmente, encaro esta edição bilingue Português - Mandarim, que apresentamos, como um projecto que considero vital e relevante, desde o primeiro dia em que o abracei com a Isabel Morujão. Emocionam-me as sérias dificuldades que Brito Paes e Sarmento de Beires viveram sem apoios alguns, aprecio o tom cinematográfico que cada capítulo tem - os sustos, a queda do Pátria, as simples mudanças de temperatura, as diplomacias em cada cônsul; admiro a irmandade silenciosa entre os dois homens e a lealdade do seu sempre amigo mecânico, Manuel Gouveia -, sem esquecer, obviamente, o objectivo final de chegar ao Oriente, e que justifica a viagem e esta edição.

Não chegassem todas estas razões que atrás expus, o destino atira-me uma última no meio da minha pesquisa para esta edição e que serve de arranque a este texto: a carta de Sarmento de Beires para o meu avô Rui de Brito. Ao lê-la, não só me lembrei da figura, presença e trabalho do meu avô, sempre presente em todas as vertentes do meu percurso, como me aproximei uma vez mais da bravura destes homens na sua missão a caminho do Oriente. Com- 
在这些阅读中, 我也了解了这两位男子 (我祖父和萨尔门托・德贝雷斯) 之间 有着一种联系, 它以某种方式挑战了空间和时间, 而现在, 这次令人愉快的编辑背 景将他们再次聚合在一起。

\section{引用参考书目}

贝雷斯, J. 萨尔门托・德・(1986年), “从葡萄牙到澳门”波尔图: 波尔图人合作出版印刷公司。

布里托, 安娜和路易士 - 维拉洛布斯 (2018年), “17个协议, 中国和葡萄牙在双边关系中迈出了具体 步伐”, 2018年12月5日 “公众报”。可查阅https://www.publico.pt/2018/12/05/economia/noticia/ assinatura-17-acordos-sao-passos-concretos-relacao-china-portugal-1853603

张, 海鹏 (1996年), “关于澳门历史的研究: 进步与困难: 在中国关于澳门历史的研究趋势”, “文化 杂志一葡语版”, 第二集, $27 / 28$ 号 (1996年), 澳门: 文化学院。可查阅http://www.icm.gov.mo/rc/ viewer/30027/1865，4-15页。

奥利维拉, 费尔南多 - 科雷亚 - 德 - (1998年), “中葡500的联系”, 里斯本: 公众报, 社会交流股份有限公 司和东方基金会。

佩索托, M - 莱莫斯 (1980年), “在阿马多拉历史上的人和飞机”, 阿马多拉: 阿马多拉市政厅文化和社会 活动部。

里贝罗, 若昂 - 路埃拉 (2018年), “马塞洛和习近平希望深化葡萄牙和中国质检的政治关系”, 公众报, 2018年12月4日, 可查阅https://www.publico.pt/2018/12/04/mundo/noticia/marcelo-xi-querem-apro fundar-relacao-politica-portugal-china-1853529。

王, 琐瑛 (2001年), “葡萄牙语在中国”, 2001年, 可查阅http://varialing.web.ua.pt/wp-content/ uploads/2017/03/WANG_PLE1.pdf, 1-19页。

周, 克里斯蒂娜 (2016年), “在中国翻译并介绍费尔南多 - 佩索阿的作品”, “多元的佩索阿一一费尔 南多・佩索阿研究学报”, 2016年。可查阅https://repository.library.brown.edu/studio/item/bdr: $757400 /, 270-281$ 页。 
preendi, também, nestas leituras, como estes dois homens (meu avô e Sarmento de Beires) tinham uma ligação que, de certo modo, desafiava o espaço-tempo e que agora os une de novo, nesta feliz circunstância editorial.

\section{BIBLIOGRAFIA CITADA}

BEIRES, J. Sarmento de (1968), De Portugal a Macau (A viagem do Pátria). Porto: Imprensa Social da Cooperativa do Povo Portuense.

BRITO, Ana e Luís Villalobos (2018), «Com 17 acordos, Portugal e China dão passos concretos na relação», Público, 5 de Dezembro 2018, disponível em https:/www.publico.pt/2018/12/05/economia/noticia/assinatura-17-acordos-sao-passos-concretos-relacao-china-portugal-1853603.

HAIPENG, Zhang (1996), «Estudos sobre a história de Macau: Progressos e dificuldades: Tendências da investigação sobre a história de Macau na China», Revista de Cultura - Edição Portuguesa, 2. a série, n. ${ }^{\circ}$ 27/28, (1996), Macau: Instituto Cultural, disponível em http://www.icm.gov.mo/rc/viewer/30027/1865, pp. 4-15.

OLIVEIRA, Fernando Correia de (1998), 500 anos de contactos luso-chineses, Lisboa: Público, Comunicação Social, SA e Fundação Oriente.

PEIXOTO, M. Lemos (1980), Homens e avióes na história da Amadora, Amadora: Câmara Municipal da Amadora, Serviços de Acção Social e Cultural.

RIBEIRO, João Ruela (2018), «Marcelo e Xi querem aprofundar a relação política entre Portugal e a China», Público, 4 de Dezembro 2018, disponível em https://www.publico.pt/2018/12/04/mundo/noticia/marcelo-xi-querem-aprofundar-relacao-politica-portugal-china-1853529.

SUOYING, Wang (2001), «A língua portuguesa na China», 2001, disponível em http://varialing.web.ua.pt/wp-content/ uploads/2017/03/WANG_PLE1.pdf, pp.1-19.

ZHOU, Cristina (2016), «A tradução e a introdução da obra de Fernando Pessoa na China», Pessoa Plural - A Journal of Fernando Pessoa Studies, 2016, disponível em https://repository.library.brown.edu/studio/item/bdr:757400/, pp. 270-281. 


\section{从里斯本到澳门之旅一一 一次胜利航程}

马里奥・科雷亚*

*马里奥 - 科雷亚里斯本大学文学院历史学本科毕业, 曾是飞行员和航空博物馆管理人。他撰写了多篇关于 葡萄牙航空史的著作, 刊登在各类专业杂志上。2016年他出版了 “葡萄牙飞行员”一书, 并正在准备萨卡杜 拉・卡布拉尔的传记。 


\section{A VIAGEM DE LISBOA A MACAU NO EIXO DO TRIUNFO DA AVIAÇÃO}

MÁRIO CORREIA*

\footnotetext{
* Mário Correia é licenciado em História pela Faculdade de Letras da Universidade de Lisboa. Foi aviador e Conservador do Museu do Ar. É autor de vários trabalhos sobre História da Aviação Portuguesa, publicados em revistas da especialidade. Em 2016, publicou o livro Aviadores Portugueses e tem em preparação uma biografia de Sacadura Cabral.
} 
我们在布雷西亚的人群前所未有的多, 甚至连大型汽车比赛都没这么多 人; 来自威尼斯、利古里亚、皮埃蒙特、托斯卡纳、罗马, 甚至那不勒斯 的外国人, 还有来自法国、英国和美国的大人物, 挤满了我们的广场、酒 店和私人住宅的角角落落; 价格飞速上涨; 交通工具都不够, 无法将人们 运送到飞行场。

弗兰兹・卡夫卡 “布雷西亚的飞机及其他文本”

“航空是伊卡洛斯的复仇”

阿尔贝托・德奥利维拉, “信鸽”, 科因布拉, 1913年

\section{航空创始人}

对于人类来说, 飞行, 一直以来都是一个梦想和挑战。人们以古老的方式复制 了鸟类的翅膀, 尝试着模仿鸟类飞翔; 晚些时候, 他们又做出了气球和飞艇。人类 从未放弃这个想法: 建成一种飞行器, 以可控的方式可以越飞越高, 越飞越远, 越飞 越快。

1903年12月17日, 在美国北卡罗莱纳州的小鹰城, 奥威尔・莱特驾着 “飞行者 一号” 2 飞向天空, 这是他和自己的兄弟威尔伯一起制造的、一架由木材和帆布制 成的脆弱飞行器。莱特兄弟二人都是自行车制造商。对于史学而言, 这一刻标志 着人类历史上第一次重于空气的航空器由发动机驱动, 受控地在空中飞行。尽管 飞机几乎触到了地面, 但这次历史性的飞行持续了十二秒, 飞过了三十六米的距离, 航速48公里/小时。自此航空诞生了。三年之后, 即1906年10月, 在巴黎郊区的巴 格特勒, 巴西人桑托斯 - 杜蒙驾驶着他的 “14-bis” 3 飞行。这是第一次一架飞行器 没有弹射器, 仅使用发动机的力量起飞。这架飞机以 30 公里/小时的速度飞行了六 十米。这是两次航空创始人的里程碑事件, 上面凝聚了长久以来所有曾经想实现 飞行梦想的人们的努力。至此, 那些飞行梦想终于得到了回应。

\footnotetext{
1 葡萄牙通过巴托洛米奥 - 洛伦哥 - 德古斯茂神父与浮空器的开端联系在一起。1709年8月8日, 这位神父 在王宫的印度大厅向国王若昂五世、朝臣和教廷大使展示了一个小型热气球。这个热气球是他的飞行器 计划可见的一面, 即可以用于军事目的或是可以帮助有需要的人们的一个飞行机器。古斯茂神父对于航空 工具使用的反思是已知的、首批对于飞行使用情况进行战略评估的文件之一。

2 “飞行者一号” 是一架由木头和棉布制成的双翼飞机, 翼展 12 米, 长 6 米, 配备 4 缸发动机, 功率 12 马力。其重 量为二百七十四公斤, 飞行员躺着驾驶。起飞时需使用弹射器。

3 “14-bis” 是一架用竹子、棉布和丝绸制成的双翼飞机, 翼展12米, 长10米, 重一百七十公斤。它装备了八缸 发动机, 功率50马力。飞行员站在一个柳条篮里驾驶。它是第一架使用发动机动力自主起飞的飞机。在辛 特拉的航空博物馆, 展示了按1:1比例制成的该机复制品。
} 
Temos em Bréscia uma multidão maior do que nunca, nem sequer quando das grandes corridas de automóveis; os estrangeiros de Veneza, Ligúria, Piemonte, Toscana, Roma, mesmo até de Nápoles, os grandes senhores de França, Inglaterra e América, apinham-se nas nossas praças, nos nossos hotéis, em todos os cantos das casas particulares; os preços sobem todos admiravelmente; os meios de transporte não são suficientes para conduzir as pessoas até ao circuito aéreo.

Franz Kafka, Os aeroplanos em Bréscia e outros textos

A aviação é a desforra de Ícaro. Alberto d' Oliveira, Pombos-correios, Coimbra, 1913

\section{FUNDADORES DA AVIAÇÃO}

Voar foi sempre para a Humanidade uma ambição e um desafio. Tentando imitar o voo dos pássaros, reproduzindo de modo arcaico as suas asas, e mais tarde com balões ${ }^{1}$ e dirigíveis, o pensamento humano nunca desistiu de construir um aparelho que de um modo controlado pudesse voar cada vez mais alto, mais longe e mais depressa. Em 17 de dezembro de 1903, em Kitty Hawk, na Carolina do Norte, Orville Wright, foi catapultado para o ar a bordo de um frágil aeroplano de madeira e tela, o «Flyer $1 »^{2}$, construído por si e pelo irmão Wilbur, ambos fabricantes de bicicletas. Para a historiografia, o momento marca o primeiro voo controlado de um aparelho mais pesado do que o ar, propulsionado por um motor. $\mathrm{O}$ histórico pulo percorreu uma distância de trinta e seis metros, quase a tocar o solo, durante doze segundos, a uma velocidade de $48 \mathrm{~km} / \mathrm{h}$. Nascia a Aviação. Três anos depois, em Outubro de 1906, em Bagatelle, nos arredores de Paris, o brasileiro Santos Dumont voou com o seu aeroplano 14-bis ${ }^{3}$. Pela primeira vez uma máquina voadora descolou usando a força do motor sem recurso a catapulta. Pulou sessenta metros a uma velocidade de $30 \mathrm{~km} / \mathrm{h}$. Estes dois marcos fundadores da aviação resumem os esforços de todos os que tentaram, ao longo dos tempos, materializar o sonho de voar de que tantas mitologias fizeram eco.

\footnotetext{
${ }^{1}$ Portugal ficou ligado aos primórdios da aerostação com o Padre Bartolomeu Lourenço de Gusmão, que, no dia 8 de Agosto de 1709, fez uma desmonstração de um pequeno balão de ar quente ao rei D. João V, à corte e ao Núncio Apostólico, na Sala das Índias, no Terreiro do Paço. O balão era a face visível do seu projecto, uma máquina voadora capaz de ser usada para fins militares ou para ajudar as populações necessitadas. A reflexão do Padre Gusmão sobre o uso de um meio aéreo é um dos primeiros documentos conhecidos com uma avaliação estratégica da utilização do voo. ${ }^{2} \mathrm{O}$ avião «Flyer I» era um aparelho biplano construído em madeira e pano de algodão, com doze metros de envergadura e seis de comprimento, equipado com um motor de quatro cilindros com $12 \mathrm{hp}$ de potência. Pesava duzentos e setenta e quatro quilos, e o piloto operava deitado. Para descolar utilizava como sistema uma catapulta com elásticos.

${ }^{3} \mathrm{O}$ avião 14-bis era um biplano construído em bambu, pano de algodão e seda, com doze metros de envergadura e dez de comprimento, com um peso de cento e sessenta quilos. Foi equipado com um motor de oito cilindros com 50 hp de potência. O piloto operava em pé, num cesto de verga. Foi o primeiro avião a descolar de um modo autónomo recorrendo à potência do motor. No Museu do Ar, em Sintra, está exposta uma réplica do aparelho, à escala 1:1.
} 


\section{9年一一航空之年}

1909年7月, 路易 - 布莱里奥驾着他的小型单引擎飞机 “布莱里奥11号”, 用了 三十五分钟多的时间, 以 55 公里/小时的速度, 离海面 20 米的飞行高度飞越了英吉 利海峡, 海峡连接着法国加莱附近的桑加特和英国的多佛尔。这次飞行是到那时 为止距离最长的飞行, 是为了回应英国 “每日邮报” “提出的悬赏挑战。当时这份英 国报纸给出两万五千法郎 (合今天的大约九万欧元) 的奖金, 奖赏那些第一次能够 将英法两国以航空的方式连接在一起的人。该报在头版以醒目的方式写着 “从此 以后, 英国不再是一个孤岛”。这是航空的胜利。

还有两个重要事件标志着1909年这个航空之年。一是当年8月在法国兰斯举 行了大型航空博览会, 所有主要的飞机制造商都出席了盛会, 包括当时正在欧洲推 广、销售自己飞机的莱特兄弟。在博览会上，举行了速度、高度和距离等类别的 飞行大赛, 每个类别的优胜者都获得了丰厚的奖金。最高大奖 10 万法郎的获得者 是距离飞行大赛冠军亨利 - 法尔曼, 他驾着自造的飞机以 60 公里/小时的时速飞行 了180公里, 这个成绩比第二名多飞了30公里。在兰斯航博会后的第二个月, 巴黎 大皇宫世界上第一个 “航空运动大厅” 揭幕。航空首次实现了自主展览, 这里不再 是年度汽车展的保留区域。这个事实有解释: 在初始阶段, 航空业使用了很多汽车 工业转让的技术。在巴黎大皇宫的展览中, 亮点是几个月前布莱里奥飞越英吉利 海峡驾驶的飞机。

对于我们来说, 1909年是葡萄牙航空俱乐部成立之年, 它在葡萄牙扮演了航空 业创立者的角色 ${ }^{5}$ 。当年10月份举行的葡萄牙第一次飞行秀属于这个俱乐部。当 时法国人阿曼德 - 基普菲尔驾驶着一架小飞机 “弗伊松-安托瓦内特” 号从里斯本 的旧贝伦赛马场起飞, 从热情的人群上空飞过。同一年, 葡萄牙人奥斯卡 - 布兰克 ${ }^{6}$ 获得了飞行执照, 并且如法国飞行杂志 “L’Aérophile” 所记载的那样, 1909年10月 和11月他在巴黎附近的伊西雷穆力诺飞行场进行了两次飞行。

\footnotetext{
4一些日报, 特别是英国的 “每日邮报”, 在航空史上扮演了重要角色。这些报纸向飞行者们发出长途飞行的 挑战并提供高额奖金作为回报。1919年第一次飞越北大西洋里斯本段正是为了回应 “每日邮报” 提出的挑 战, 该报为成功完成任务者提供了一万英镑的奖金。美国海军中尉阿尔伯特・瑞德是优胜者。

5 从1909年开始, 葡萄牙航空俱乐部组织了许多航空宣传活动, 如成立葡萄牙军事飞行学院, 它是正式成立 于1914年的军用航空局的前身。此后, 陆军和海军的军官们被派遣到美国、法国和英国等地的飞行学院学 习, 他们被培养成为军事飞行员。1916年, 在拉伊涅新镇创立了军事航空学院, 这个学院培训出了葡萄牙最 早的一批飞行员。在这些最早的飞行者团体当中, 萨尔门托 - 德贝雷斯引人注目。他是 1924 年实现飞往澳 门, 1927年实现飞往巴西的飞行员。

6 奥斯卡・布兰克, 绘画收藏家, 生活在里斯本和巴黎之间。他是第一个获得飞行员执照的葡萄牙人。1 878 年3月3日生于里斯本, 1944年2月16日去世。
} 


\section{9 - O ANO DA AVIAÇÃO}

Em Julho de 1909, Louis Blériot, a bordo do seu pequeno monomotor Blériot XI, voou sobre o Canal da Mancha, ligando Sangatte, perto de Calais, em França, a Douvres, na Inglaterra, em pouco mais de trinta e cinco minutos, a uma velocidade de $55 \mathrm{~km} / \mathrm{h}$ e a vinte metros de altura sobre o mar. O percurso, o mais longo de um avião até à época, foi a resposta ao desafio lançado pelo jornal inglês Daily Mail ${ }^{4}$, que premiava com vinte e cinco mil francos (hoje, aproximadamente, noventa mil euros) quem pela primeira vez ligasse pelo ar a França à Inglaterra. "A Inglaterra já não é uma ilha», noticiava o jornal, em grande destaque, na primeira página. Era o triunfo da Aviação.

Dois outros acontecimentos aeronáuticos importantes marcaram o ano de 1909. Em Agosto, em França, teve lugar a "Grande Semaine d'Aviation de Champagne», em Reims, um festival aéreo onde estiveram presentes os principais construtores de aviões, incluindo os irmãos Wright, que estavam na Europa para divulgar e vender os seus aparelhos. No festival, fizeram-se competições nas categorias de velocidade, altitude e distância, com atribuição de prémios elevados para cada um dos vencedores. O grande prémio do encontro, no valor de cem mil francos, foi ganho, na categoria de maior distância, por Henri Farman, a bordo de um aeroplano de sua construção, que percorreu $180 \mathrm{~km}$, mais trinta do que o segundo classificado, a uma velocidade média de $60 \mathrm{~km} / \mathrm{h}$. No mês seguinte ao festival de Reims, foi inaugurado o primeiro Salão da Locomoção Aérea no Grand Palais, em Paris. Pela primeira vez a aviação apresentava uma exposição autónoma, deixando de ser uma zona reservada nos salões automóveis anuais. $\mathrm{O}$ facto tinha explicação: a aviação, no seu início, usou muita transferência tecnológica da indústria automóvel. Na exposição do Grand Palais o destaque foi para o avião pilotado meses antes por Blériot, na travessia da Mancha.

Entre nós, o ano de 1909 ficou marcado pela criação do Aero Club de Portugal, que desempenhou um papel fundador da aviação no nosso país ${ }^{5}$. A ele se deve a demonstração, em Outubro, do primeiro voo em Portugal, quando o francês Armand Zipfel, pilotando um pequeno avião, «Voisin-Antoinette», descolou do antigo hipódromo de Belém, em Lisboa, e sobrevoou uma multidão entusiasmada. No mesmo ano, em Paris, o português Óscar Blank ${ }^{6}$

\footnotetext{
${ }^{4}$ Alguns jornais diários, nomeadamente o inglês Daily Mail, desempenharam um papel importante na História da Aviação desafiando os aviadores para grandes voos, oferecendo em troca elevados prémios. A escala em Lisboa da primeira travessia aérea do Atlântico Norte, em 1919, foi a resposta ao desafio do Daily Mail, que oferecia um prémio de dez mil libras pelo êxito da missão. O tenente Albert Read da Marinha dos Estados Unidos da América foi o vencedor.

${ }^{5}$ O Aero Club de Portugal, a partir de 1909, organizou muitas ações de divulgação aeronáutica e está na génese da criação do Instituto de Aviação Militar Português, o embrião do Serviço de Aeronáutica Militar, criado formalmente em 1914. Após esta data, oficiais do exército e de marinha foram enviados para escolas de aviação nos Estados Unidos da América, França e Inglaterra, onde se qualificaram como pilotos militares. Em 1916, foi criada a Escola de Aeronáutica Militar em Vila Nova da Rainha, que formou os primeiros pilotos em Portugal. Deste grupo inicial de aviadores, destacou-se Sarmento de Beires, piloto do voo a Macau em 1924 e ao Brasil em 1927.

${ }^{6}$ Óscar Blank, coleccionador de pintura, que vivia entre Lisboa e Paris, foi o primeiro português a obter a licença de piloto de avião. Nasceu em Lisboa em 3 de Março de 1878 e morreu em 16 de Fevereiro de 1944.
} 


\section{4年一一伟大的航空旅行之年}

第一次世界大战推动了军事航空的大规模使用。冲突初期, 对于战斗中飞 行工具能起到的作用, 一些战略视野更为古典的军事首领持保留和不信任的态 度一一他们对于飞行工具的有效性表示怀疑。这种印象很早就消失了, 飞机接管 了战争 ${ }^{7}$ 。战争中生产了几千架飞机, 这为把航空先驱们的业余体育活动转换成 一种大型的、技术先进的航空工业做出了贡献。

航空也有助于强化 “疯狂的二十年代”。在那些年当中, 技术和科学将救赎的 希望融入了和平的欣喜。在冲突后的几年中, 飞机和发动机的制造取得了发展, 飞 行设备的运输能力、速度和自主性都得以提高。随着1918年一战结束, 飞行员和 机械师的复员促进了商业航空活动的飞速发展: 首先是主要大城市之间的邮件运 输, 然后是这些城市间的乘客运输。1919年2月，一架双引擎的法尔芒・歌莉娅飞 机实现了第一次民用客运飞行。它是一架一战中的非军事化轰炸机。这次飞行连 接了英法两国, 载客11人, 耗时两个小时三十分钟。从此, 商业飞行再未停止。到 1924年，已经有多家航空公司在欧洲和美国的主要城市间进行定期的载客和载货 运营。

另一个上个世纪二十年代航空增长的因素是实现了洲际空中旅行。各个飞 机制造大国规划了长途航班，以便在他们的殖民地宣扬自己的声望和权力; 同时, 他们研究了未来航线的线路。然而, 无论如何, 那个时代一些最重要的飞行只是为 了应对一时狂热的社会提出的挑战。这些挑战是通过报纸或提供高额奖金的赞助 商发布的。

1924年, 即萨尔门托・德贝雷斯, 布里托・帕艾斯和曼努埃尔・果维亚飞往澳 门的那年, 还发生了其他一些重要的航空事件。

\footnotetext{
7 非常遗憾在战争中使用飞机, 1918年桑托斯・杜蒙写道: “【……四年了【……戎的心遭受着来自欧洲 的、可怕的死亡消息的折磨, 这些可怕的死亡正是航空器造成的。我们, 上个世纪末航空运动的创始者, 曾 经梦想让航空这个我们悉心照料的“孩子'能够走向和平光荣的未来之路【……戎们曾设想, 也许航空器 未来可以为陆军参谋部服务, 但从未料到它们居然会在战斗中发挥毁灭性的作用。摘自 “我看到了什么, 我 们将看见什么”, 第一页, 网址http://www.dominiopublico.gov.br/download/texto/bi000197.pdf”
} 
obteve a licença de piloto e fez dois voos no aeródromo de Issy-Les-Moulinaux, como dá conta a revista de aviação francesa L’Aérophile, de Outubro e Novembro de 1909.

\section{4, ANO DE GRANDES VIAGENS AÉREAS}

A Primeira Guerra Mundial potenciou a utilização militar da aviação em larga escala. No início do conflito, alguns chefes militares, com uma visão mais clássica da estratégia, viam com reserva e desconfiança o emprego de um meio aéreo em combate, levantando dúvidas sobre a sua eficácia. Muito cedo esta impressão se desvaneceu e o avião impôs-se ${ }^{7}$. A guerra, com a produção de milhares de aviões, contribuiu para transformar a atividade amadora e desportiva dos pioneiros da aviação numa indústria aeronáutica de grande escala e de tecnologia avançada.

A aviação também ajudou a potenciar os «loucos anos vinte» em que à euforia da paz se juntou a esperança de redenção com a técnica e a ciência. Nos anos que se seguiram ao conflito desenvolveu-se a construção de aviões e de motores, aumentando a capacidade de transporte, a velocidade e a autonomia dos aparelhos. A Aviação preparava-se para mais uma etapa da mundialização em que a expansão portuguesa do séc. XV fora pioneira. Com o fim da guerra, em 1918, a desmobilização de pilotos e mecânicos contribuiu para o rápido desenvolvimento da actividade aérea comercial, primeiro com o transporte de correio entre as grandes cidades e, posteriormente, também de passageiros. Em Fevereiro de 1919, realizou-se o primeiro voo civil de transporte de passageiros, um avião bimotor Farman Goliath, um bombardeiro desmilitarizado da Primeira Guerra Mundial, que ligou a França à Inglaterra, com onze pessoas a bordo, em duas horas e trinta minutos. A aviação comercial nunca mais pararia e, em 1924, já muitas companhias aéreas operavam regularmente com passageiros e carga entre as principais cidades na Europa e nos EUA.

Outro dos factores para o crescimento aeronáutico nos anos vinte do século passado foi a realização das viagens aéreas intercontinentais. As grandes potências construtoras de aviões projectaram voos a longa distância para a afirmação do prestígio e do poder junto das suas colónias, estudando ao mesmo tempo os percursos para futuras ligações aéreas. Contudo, alguns dos voos mais importantes neste período foram apenas a resposta aos desafios de uma sociedade momentaneamente entusiasmada, veiculados através dos jornais ou de patrocinadores que ofereciam prémios elevados.

Em 1924, no ano em que Sarmento de Beires, Brito Paes e Manuel Gouveia voaram para Macau, outros acontecimentos aeronáuticos significativos tiveram lugar. Em Março, os

\footnotetext{
${ }^{7}$ Lamentando a utilização do avião num teatro de guerra, Santos Dumont escreveu em 1918: «...o meu coração, [...] há já quatro anos, sofre com as notícias da mortandade terrível causada, na Europa, pela aeronáutica. Nós, os fundadores da locomoção aérea no fim do século passado, tínhamos sonhado um futuroso caminho de glória pacífica para esta filha dos nossos desvelos. [...] Prevíamos que os aeronautas poderiam, talvez, no futuro, servir de esclarecedores para os Estados Maiores dos exércitos, nunca, porém, nos veio à ideia que eles pudessem desempenhar funções destruidoras nos combates». In O que Eu Vi. O que Nós Veremos, pág. 1, acedido em http:// www.dominiopublico.gov.br/download/texto/bi000197.pdf
} 
那年三月, 英国空军飞行员斯图尔特 - 迈克拉伦和威廉 - 普伦德利斯, 加上机 械师安德鲁斯, 从英国起飞, 开始进行一次环球飞行。他们使用的是一架两栖单引 擎 “维克斯 - 维京” 飞机。但是他们失败了, 五个月后, 浓雾使他们不得不在白令海 紧急迫降。在一百三十天飞行了两万一千公里后, 他们被一艘俄罗斯舰艇活着救 起。

在法国, 佩莱蒂埃-杜西和吕西安・贝森驾着一架单引擎布雷盖19飞机于四月 从巴黎起飞, 飞往东京, 其任务是研究创建一条飞往东方的航线。八十四天后, 他 们到达了日本首都。在飞行了一万八千公里和一次没有造成严重后果的迫降后, 他们五月到达了上海。这次事故毁坏了飞机, 为了继续飞行, 他们在中国买了一架 旧的布雷盖 14 飞机。

1924年9月, 两架美国空军的 “道格拉斯环球巡航者” 飞机完成了第一次环球 飞行, 它们在一百七十五天的时间里飞过了四万四千公里。

葡萄牙也为这些航空大冒险做出了贡献, 不过, 那更多的是出于飞行先驱者 们的个人主动性, 而不是为了实现国家的政治承诺。萨尔门托 - 德贝雷斯和布里 托 - 帕艾斯就是这样的例子。他们1920年尝试过飞往马德拉岛; ; 他们的名字, 还 有机械师曼努埃尔 - 果维亚, 由于1924年抵达澳门的飞行, 而被铭记在航空历史的 画卷中。在那趟飞往东方的航行中, 他们和本文上面提到的法国和英国飞行先驱 们曾交错相会。

1924年6月初, 葡萄牙共和国空军中队集团的三十四名飞行员奋起反抗任命一 个非飞行员军官到航空司令部——这个中队集团驻扎于阿马多拉, 是贝拉斯、帕 伊斯和果维亚所属的部队。飞行员们还要求将航空部队视为第五个武装力量, 这 将赋予他们更多的决策自主权。具有现代化效果的飞机航空技术要求新思想。反 抗者们在圣儒利安 - 达巴拉要塞被拘捕。由于民众的压力以及 “消息日报” 和 “世 纪报” 发起的有利于他们强烈的运动, 这些飞行员被释放了, 没有受到任何惩处。 这次事件的结束很好地反映了航空在人群中的普及以及各类报纸的注意力所在。

\footnotetext{
8 1920年10月18日, 布里托 ・帕艾斯和萨尔门托 - 德贝雷斯, 驾驶单引擎布雷盖14飞机, 上午从阿马多拉起 飞, 飞向马德拉。他们成功地飞到了该岛上空, 但由于浓雾无法降落。回程时, 因为缺少燃料, 他们在海上迫 降于英国 “冈比亚河” 号舰艇旁。冈比亚号在离里斯本四百公里, 北纬 $35^{\circ} 11$, 西经 $13^{\circ} 4^{\prime}$ '的位置将他们从海 上救起。德贝雷斯称呼这次航行为 “美丽的冒险”。1927年, 萨尔门托 - 德贝雷斯, 与乔治 - 德卡斯蒂略和 曼努埃尔 - 果维亚一起, 实现了第一次夜间穿越南大西洋上空。这是一次在几内亚布巴克岛到巴西费尔南 多・诺罗涅岛之间进行的, 近18 小时的直飞。
} 
pilotos da Força Aérea Inglesa, Stuart-MacLaren e William Plenderleith, com o mecânico Andrews, descolaram de Inglaterra para uma viagem de volta ao mundo, a bordo de um monomotor anfíbio Vickers Vulture. Falharam o seu objectivo, um forte nevoeiro obrigando-os a uma amaragem de emergência no Mar de Bering, cinco meses depois. Foram recolhidos com vida por um navio russo, depois de terem percorrido vinte e um mil quilómetros em cento e trinta dias.

Em França, Pelletier-Doisy e Lucien Besin descolaram, em Abril, de Paris para Tóquio, num monomotor Breguet XIX, com a missão de estudar a criação de uma linha aérea para Oriente. Chegaram à capital japonesa oitenta e quatro dias depois, com dezoito mil quilómetros percorridos e uma aterragem forçada, sem consequências, em Maio, em Xangai. $\mathrm{O}$ acidente destruiu o avião. Para continuar a viagem compraram, na China, um velho Breguet XIV.

Em Setembro de 1924, dois aviões Douglas World Cruiser, da Força Aérea norte americana, completaram a primeira volta ao mundo, quarenta e quatro mil quilómetros voados em cento e setenta e cinco dias.

Portugal também contribuiu para esta grande aventura das viagens aéreas, mais pela iniciativa individual dos pioneiros do que pelo empenhamento político nacional. É o caso de Sarmento de Beires e Brito Paes, que, em 1920, já tinham tentado um voo à ilha da Madeira ${ }^{8}$ e que, em 1924, com o mecânico Manuel Gouveia, juntaram o seu nome à galeria dos voos históricos com a viagem a Macau. No voo ao Oriente, os portugueses cruzaram-se com os pioneiros franceses e ingleses que referimos anteriormente. É o diário desta aventura a Macau, escrita por Sarmento de Beires, que em boa hora se coloca agora à disposição dos leitores, com esta nova edição.

No início de Junho de 1924, os trinta e quatro pilotos do Grupo de Esquadrilhas de Aviação República, sedeado na Amadora, unidade a que pertenciam Beires, Paes e Gouveia, rebelaram-se contra a nomeação de um oficial não piloto para o Comando da Aeronáutica. Exigiam também que a Aeronáutica fosse considerada a quinta arma do Exército, o que lhes traria uma maior autonomia decisória. A aviação, com o seu efeito de modernidade, obrigava a novos pensamentos. Os revoltosos foram presos no forte de São Julião da Barra. Por pressão popular e pela intensa campanha a favor deles no Diário de Noticias e no Século, foram libertados sem mais punições. O final do incidente espelha bem a popularidade que a aviação tinha entre nós e a atenção com que os jornais a seguiam.

Quase a findar o glorioso ano de 1924, uma tragédia marcou a aviação nacional: Sacadura Cabral e o mecânico Pinto Correia desapareceram no Mar do Norte, a bordo de um

\footnotetext{
${ }^{8}$ No dia 18 de Outubro de 1920, Brito Paes e Sarmento de Beires, a bordo de um monomotor Breguet XIV, descolaram a meio da manhã da Amadora, rumo à Madeira. Conseguiram sobrevoar a ilha, mas um denso nevoeiro não permitiu a aterragem. Já no regresso e com falta de combustível, amararam de emergência junto ao navio inglês Gambia River, que os recolheu do mar na posição 35 11' Norte 13 4' Oeste, a quatrocentos quilómetros de Lisboa. Beires chamou ao voo «a Bela Aventura». Em 1927, Sarmento de Beires, com Jorge de Castilho e Manuel Gouveia, fazem a primeira travessia nocturna do Atlântico sul, um voo directo de quase dezoito horas, entre a ilha de Bubaque, na Guiné, e a ilha brasileira de Fernando Noronha, apoiados apenas na navegação astronómica.
} 
几乎是在1924这个辉煌的年度结束之时, 发生了一起飞行悲剧: 11月15日, 萨 卡杜拉 - 卡布拉尔和机械师平托 - 科雷亚在一架福克 T3水上飞机上在北海上空失 踪了 9 。他们乘坐海军航空部队采购的设备之一从荷兰飞往葡萄牙, 这架飞机正是 为了支持萨卡杜拉 ${ }^{9}$ 制定的环球飞行计划而购买的 ${ }^{10}$ 。

\section{飞往澳门的想法}

在1920年尝试了飞马德拉岛之后，布里托・帕艾斯和萨尔门托・德贝雷斯计 划着第二年进行环球飞行或是飞往巴西 ${ }^{11}$ 。经初步研究后, 他们得出结论, 认为当 时可用飞机的工作范围12不能让他们进行那样的冒险。因此, 他们的目标转为首先 飞抵印度, 然后再飞到澳门。另一方面, 1922年加戈・科蒂尼奥和萨卡杜拉 - 卡布 拉尔抵达巴西的飞行也对他们改变计划产生了影响。德贝雷斯和帕艾斯明白, 葡 萄牙应当为航空进步做出贡献。他们相信, 以他们富有远见的开拓性精神, 洲际航 空旅行将推动技术进步, 并将成为未来商业航空的雉形。这些想法推动了他们, 而 且后来的事也证明了他们是对的。成为先驱就是超越你所在的时代。然而, 在那 个时代, 在葡萄牙飞行员之间开始形成了一种对立: 他们当中的一些人捍卫长途飞 行, 而另一些则对于长途飞行没有表现出热情。那些长途飞行的反对者们贬低长 途任务的价值, 认为那不过是飞行员为了个人出名而做出的行为。让我们回到 “卢 西塔尼亚人之歌”的最后一句。

\footnotetext{
9 费尔南多・佩索阿在 “雅典娜” 杂志上发表了一首纪念萨卡杜拉 - 卡布拉尔的诗歌:

萨卡杜拉・卡布拉尔

在异乡北方冰冷的海中,

波澜不起, 静止不动,

不忠的幸运的奴仆,

幸运带来又带走。

明亮的火焰熄灭了,

夜色笼罩。

陌生的海啊, 陌生的地方,

可曾收留了他?

你在花茎的顶端开花、枯萎,

在那永恒的大海与天空,

你是勇敢的珍宝。

10 萨卡杜拉 - 卡布拉尔在1922年与加戈 - 科蒂尼奥飞往巴西之后, 计划第二年进行环球飞行之旅。这次环 球飞行的飞行距离将会是三万六千公里, 由三架飞机完成。飞行路线分为三大部分, 期间停留数次, 三部分 航程为里斯本一日本, 日本一新大陆, 新大陆一里斯本。这次飞行任务使用的飞机已购买, 然而, 当时由国会 议员安东尼奥・玛亚挑起的, 围绕该计划而产生的政治压力引发了紧张局势, 计划被推迟。

11 关于这一内容请阅读注释8.

12 相较水上飞机或两栖飞机, 萨尔门托 - 德贝雷斯和布里托 - 帕艾斯宁可使用陆地飞机。他们认为陆地飞 机速度更快, 设备更可靠。为完成1921年飞往巴西的航空旅程, 市场上没有任何飞机能够自主从非洲海岸 直飞巴西。
} 
hidroavião Fokker T3, no dia 15 de Novembro'. Voavam da Holanda para Portugal a bordo um dos aparelhos adquiridos pela Aviação Naval para o projecto de volta ao mundo planeado por Sacadura ${ }^{10}$.

\section{A IDEIA DO VOO A MACAU}

Depois da tentativa do voo à ilha da Madeira em 192011, Brito Paes e Sarmento de Beires projectaram para o ano seguinte a volta ao mundo ou um voo ao Brasil. Feitos os estudos preliminares, concluíram que o raio de acção dos aviões ${ }^{12}$ disponíveis na época não permitia tal aventura e o objectivo passou a ser a Índia, primeiro, e depois Macau. Por outro lado, o voo ao Brasil de Gago Coutinho e Sacadura Cabral, em 1922, influenciou também a alteração dos planos. Beires e Paes entendiam que Portugal devia contribuir para o esforço do progresso da aviação. Acreditavam, com o seu visionário pioneirismo, que as viagens aéreas transcontinentais puxariam pela tecnologia e seriam um embrião para futuras ligações aéreas comerciais. Era isso que os movia e o futuro deu-lhes razão. Ser pioneiro é estar à frente do seu tempo. No entanto, nesta época, entre os aviadores portugueses começou a tomar forma a oposição entre os defensores das grandes viagens e os que não mostravam entusiamo por elas. Os opositores desvalorizavam as missões, considerando-as acções de promoção pessoal. Regressamos sempre à última palavra de Os Lusíadas. Por fragilidades várias, a que a situação económica do período da I República não foi alheia, Portugal não foi capaz de desenhar qualquer estratégia sólida com a aviação, pese embora o esforço dos pioneiros. Para voar até Macau, foi necessário adquirir um avião. Com ajuda de uma subscrição nacional muito participada (onde a actriz Amélia Rey Colaço recolheu fundos na baixa de Lisboa), de um elevado prémio em dinheiro

\footnotetext{
${ }_{9}^{9}$ Fernando Pessoa, na revista Athena, publicou um poema à memória de Sacadura:

Sacadura Cabral

No frio mar do alheio Norte,

Morto, quedou,

Servo da Sorte infiel que a sorte

Deu e tirou.

Brilha alto a chama que se apaga.

A noite o encheu.

De estranho mar que estranha plaga,

Nosso, o acolheu?

Floriu, murchou na extrema haste;

Jóia do ousar,

Que teve por eterno engaste

O céu e o mar.

${ }^{10}$ Sacadura Cabral, após a viagem aérea ao Brasil com Gago Coutinho, em 1922, projetou para o ano seguinte uma viagem de circum-navegação aérea. O voo, de 36.000 quilómetros, seria feito em formação, com três aviões. O percurso dividia-se em três grandes blocos com várias escalas: Lisboa-Japão, Japão-Terra Nova, Terra Nova-Lisboa. Os aviões para a missão foram comprados, mas a tensão política criada à volta do projecto, muito criticado pelo deputado António Maya, provocou tensão e o seu adiamento.

${ }^{11}$ Sobre este assunto veja-se nota n. ${ }^{\circ} 8$.

${ }^{12}$ Sarmento de Beires e Brito Paes preferiam a utilização de aviões terrestres aos hidroaviões ou anfíbios. Argumentavam que a velocidade era mais elevada e os aparelhos mais fiáveis do que os hidro. Para o voo ao Brasil, em 1921, não havia no mercado nenhum avião com autonomia para voar direto da costa africana para o Brasil.
} 
我们并不陌生, 在第一共和国时代, 葡萄牙经济状况有着许多弱点。尽管飞行 先驱们做出了努力, 但葡萄牙无力制定任何可靠的航空战略。要飞往澳门, 有必有 购买一架飞机。是全国人民踊跃参加的募捐活动（如女演员阿梅利亚 - 雷伊 - 古 拉苏在里斯本下城区募集资金), 查尔斯 - 布雷克 ${ }^{13}$ 为飞往马德拉岛提供的高额现 金以和各家报纸的大力支持, 帮助他们终于募集够了所需资金。1921年夏天, 他们 在法国购得了一家布雷盖16飞机，这是前几年战争中使用的一架老式轰炸机。为 了适应飞往东方的飞行任务, 在葡萄牙共和国空军飞行中队位于阿马多拉的修理 车间人们改装了飞机。在改装中, 拆除了军事设备以便加装备用燃料箱, 这样飞机 自主飞行距离就达到了两千五百公里。这架飞机没有装备任何无线通讯设备, 因 为当时可用的各种型号的设备昂贵且沉重。飞行中使用的航导航方法完全依靠地 图、指南针和控制时间用的计时器所提供的支持。

1921年8月，飞机已准备好进行试验飞行。布里托 - 帕艾斯进行了几次试飞, 结果令人鼓舞。但11月份袭击里斯本地区的大风刮倒了机库。由于工厂延迟交付 一些零件, 修复工作从1922年6月才开始。1923年, 飞行任务又一次准备完毕, 可以 开始了。但是由于战争部的政治原因, 出发日期又被多次推迟。最后, 1924年4月7 日飞行员们终于起飞, 飞向东方。这就是萨尔门托 - 的贝雷斯撰写的书中叙述的 那次冒险之旅。现在是一个很好的时机, 我们再版了这部书以飨读者。

\section{“祖国号” 的飞行员们: 简短生平 14}

若泽・曼努埃尔・萨尔门托・德贝雷斯1892年9月4日生于里斯本。曾在军 事学校学习。工程兵军官, 于1917年在位于拉伊涅新镇的军事航空学校完成了飞 行课程。在第一次世界大战期间被调往法国, 期间攻读了沙特尔、沙托鲁和阿沃 尔等军事飞行学院。1920年3月13日在葡萄牙使用单引擎布雷盖14飞机进行了第 一次夜间飞行。在其飞行日志上有如下记录：“在里斯本上空进行巡逻飞行，机 械师 $\mathrm{J}$ - 科斯塔, 20 点21分着陆, 飞行持续时间 51 分钟, 飞行高度200米。” 15 .

\footnotetext{
13 查尔斯 - 布雷克, 英国人。他创立了英国-葡萄牙汽车机械公司, 它是晚些时候出现的葡萄牙汽车公司的 起源, 是伊索塔和罗奈恩底垂车型在葡萄牙的代表。查尔斯 - 布雷克是葡萄牙航空业的先驱者, 他在1934 年独自飞向印度。

14 这三位飞行员更为完整的生平可见于: 伊莎贝尔 - 莫鲁让, “萨尔门托 - 德贝雷斯一一书目论文”, 萨尔门 托 - 德贝雷斯, 太阳之城。乔治 - 巴斯托斯 - 达席尔瓦及伊莎贝尔 - 莫鲁让编辑注释。波尔图: 阿弗龙塔 曼多出版社, 2013年 (萨尔门托 - 德贝雷斯); 恩里克斯 - 马特乌斯 “ “祖国号”首航后75年”。里斯本: 格拉蒂 瓦出版社, 1999年 (布里托・帕艾斯); 阿玛特乌・费雷拉, “曼努埃尔・果维亚中校和他的时代”, 空军历史档 案馆, 1995 (曼努埃尔・果维亚)。

${ }^{15}$ 在 “萨尔门托・德贝雷斯中尉的飞行记录” 中, 萨尔门托・德贝雷斯遗产, 陆军档案馆。
} 
oferecido por Charles Bleck ${ }^{13}$ pela tentativa de voo à Madeira e com forte apoio dos jornais, juntou-se a quantia necessária. No verão de 1921, foi adquirido, em França, um avião Bréguet XVI, um antigo bombardeiro usado na guerra, anos antes. Para a missão ao Oriente, o aparelho foi transformado nas oficinas do Grupo de Esquadrilhas de Aviação República, na Amadora. Retiraram-se os equipamentos militares para a colocação de depósitos suplementares de combustível, permitindo aumentar a autonomia para os dois mil e quinhentos quilómetros. $\mathrm{O}$ avião não foi equipado com qualquer sistema de comunicação por rádio, pois os vários modelos disponíveis na época eram pesados e dispendiosos. Os métodos de navegação usados na viagem foram unicamente apoiados na orientação pelos mapas, bússolas e cronómetros para o controle do tempo.

Em Agosto de 1921, o avião ficou pronto para os voos de experiência. No lado direito da fuselagem foi pintado o verso dos Lusíadas, «Esta é a ditosa Pátria minha amada». Brito Paes fez os primeiros voos de ensaio com resultados animadores. Mas em Novembro, o vendaval que atingiu a região de Lisboa derrubou o hangar do avião. A reparação só teve início em Junho de 1922, devido ao atraso da chegada de peças da fábrica. Em 1923, a missão estava mais uma vez pronta a iniciar-se, mas a data da partida foi sendo adiada por várias entropias políticas no Ministério da Guerra. Finalmente, no dia 7 de abril de 1924, os aviadores rumaram a Oriente.

\section{OS AVIADORES DO PÁTRIA: BIOGRAFIAS BREVES ${ }^{14}$}

José Manuel Sarmento de Beires nasceu em Lisboa a 4 de Setembro de 1892. Estudou no Colégio Militar. Oficial da Arma de Engenharia, terminou em 1917 o curso de piloto na Escola de Aeronáutica Militar, em Vila Nova da Rainha. Em França, onde esteve destacado durante a $1^{\text {a }}$ Grande Guerra, frequentou as escolas de Aviação Militar de Chartres, Chateauroux e Avord. Em 13 de Maio de 1920 realizou o primeiro voo nocturno em Portugal, a bordo de um monomotor Breguet XIV. Na sua caderneta de voo consta o seguinte registo: «Voo de patrulha de vigilância sobre Lisboa, com mecânico J. Costa, aterragem às $20 \mathrm{~h}$ e $21 \mathrm{~m}$, duração 50 minutos, altitude 200 metros $^{15}$.»

Em 1920, com Brito Paes, Sarmento de Beires tenta o primeiro voo à ilha da Madeira. Em 1924, realizou a viagem aérea a Macau, com Brito Paes e Manuel Gouveia. Em 1927, com Jorge Castilho e Manuel Gouveia, protagonizou a primeira travessia nocturna do Atlântico Sul.

Colaborou com a revista Seara Nova e pertenceu ao "Grupo da Biblioteca», juntamente com Jaime Cortesão, Aquilino Ribeiro, António Sérgio e Abel Manta. Foi com Sarmento de

\footnotetext{
${ }^{13}$ Charles Bleck, inglês, fundou a Anglo-Portuguese Motor \& Machinery Company que, mais tarde, deu origem à Sociedade Portuguesa de Automóveis, representante em Portugal dos modelos Isottas e Lorraine-Dietrich. Charles Bleck era pai do pioneiro da aviação portuguesa Carlos Bleck, que, em 1934, fez um voo solitário à Índia.

${ }^{14}$ Biografias mais desenvolvidas destes três pilotos podem encontrar-se em: MORUJÃO, 2011 (para Sarmento de Beires); MATEUS, 1999 (para Brito Paes); FERREIRA, 1995 (para Manuel Gouveia).

${ }^{15}$ In «Caderneta de registo de voo do tenente Sarmento de Beires», espólio de Sarmento de Beires, Arquivo Histórico do Exército.
} 
1920年, 萨尔门托 - 德贝雷斯和布里托 - 帕艾斯一起第一次尝试飞往马德拉 岛。1924年, 与布里托 - 帕艾斯及曼努埃尔 - 果维亚一起, 实现了前往澳门的飞行 之旅。1927年与乔治 - 卡斯蒂略和曼努埃尔 - 果维亚一起, 首次夜间飞越南大西 洋。

与 “新希拉尔” 杂志合作, 和雅伊梅 - 科尔特桑, 阿基里诺 - 里贝罗, 安东尼 奥・塞尔吉尔和阿贝尔 - 曼塔一起属于 “图书馆集团”。也是 “新希拉尔” 杂志集 团的若泽 - 罗德里格斯 - 米格斯和萨尔门托 - 德贝雷斯一起, 成功进行了自己的 首飞。这次首飞在 “多棱镜” 中16被这样叙述: “1920年1月一个阳光灿烂的午后, 是 他在中队带我第一次飞行 $\left[\cdots \cdot\right.$ ] 我们飞越了特茹河、首都及其郊区。我戴着护目镜 ${ }^{17}$, 皮飞行帽, 被安全带绑在德贝雷斯后面, 帆布祄里机舱中狭窄的位子上, 他回头对 我微笑着, 比划了一个友好的手势。他的热情让我心潮澎湃。那年我18岁。”

因政治上反对1926年政变产生的制度, 被逮捕。后被流放巴西。1972年以上 校军衔重新加入空军。

在萨尔门托 - 德贝雷斯获得的荣誉中, 包括被授予 “剑与塔军事团” 勋章 (1924年和1928年), 为 “基督军事团” 的指挥官, 为 “圣地亚哥宝剑军事团” 的指挥官 等。

1974年6月8日在波尔图城的博阿维斯塔健康之家逝世。

安东尼奥・雅辛托・德席尔瓦・布里托・帕伊斯1884年7月15日生于千泉新 镇的科洛斯。作为一名炮兵军官, 他是 1917 年第一次世界大战葡萄牙远征军的 一员。在法国阿沃尔军事飞行学院他完成了飞行员课程。回到葡萄牙后, 被安置 于阿马多拉的共和国空军中队, 1923年他任该部队指挥。1920年, 与萨尔门托 - 德 贝雷斯一起, 曾尝试飞往马德拉岛。1924年, 再次与德贝雷斯合作, 加上曼努埃 尔・果维亚, 飞行到达澳门。

被授予 “剑与塔军事团”勋章, “战争十字”勋章和 “法国荣誉军团”勋章。1934 年2月22日, 他驾驶的飞机在奥格朗附近地区失事。他死于该事故, 年仅 49 岁。

曼努埃尔・戈维亚1890年2月4日生于波尔图。1917年作为葡萄牙远征军成 员前往法国并在法国飞机发动机制造商 “Gnome-Rhone” 和 “Hispano-Suisse” 的 工厂中实习。1924年, 和萨尔门托 - 德贝雷斯和布里托 - 帕伊斯一起参与了前往 澳门的飞行。1926年, 在辛特拉的军事航空学院完成了课程。第二年, 与德贝雷 斯及乔治 - 卡斯蒂略一起飞行, 成为这次夜间飞越南大西洋航程的机械师。1935 年, 参与了飞向殖民地的空中巡航。被授予 “剑与塔军事团” 勋章, “战争十字” 勋 章。1966年12月10日逝于里斯本。

16 米格斯, 若泽 - 罗德里格斯, “多棱镜”。里斯本: 色彩工作室出版社, 1972年, 32页。

17 飞行员的护目镜。 
Beires que José Rodrigues Miguéis, também do grupo da Seara Nova, realizou o seu baptismo de voo, que narra nas páginas de $O$ espelho poliédrico ${ }^{16}$ : «Foi ele que me levou, num Domingo de sol, em Janeiro de 1920, a voar pela primeira vez: e em esquadrilha. (...) Sobrevoámos o Tejo, a capital e os arredores. De goggles $^{17}$, barrete de couro, e amarrado pelo cinturão ao estreito assento descoberto da carlinga forrada de lona, atrás de Beires, que se voltava a sorrir-me a fazer-me um gesto amigável, eu delirava de entusiamo. Tinha dezoito anos!»

Por oposição política ao regime nascido do golpe de Estado de 1926, foi preso e, mais tarde, exilou-se no Brasil. Foi reintegrado na Força Aérea, no posto de Coronel, em 1972.

Sarmento de Beires foi condecorado com a Ordem Militar da Torre e Espada (1924 e 1928), foi Comendador da Ordem Militar de Cristo (1925), Comendador da Ordem Militar de Santiago da Espada (1928), entre outras distinções.

Morreu a 8 de Junho de 1974, na Casa de Saúde da Boavista, no Porto.

António Jacinto da Silva Brito Paes nasceu em Colos, Vila Nova de Milfontes, em 15 de Julho de 1884. Oficial da Arma de Artilharia, fez parte, em 1917, do Corpo Expedicionário Português combatente na I Guerra Mundial. Em França, tirou o curso de piloto na Escola de Aviação Militar de Avord. Regressado a Portugal, foi colocado no Grupo de Esquadrilhas de Aviação República na Amadora, que comandou em 1923. Em 1920, tentou um voo à ilha da Madeira, juntamente com Sarmento de Beires. Em 1924, de novo com Beires e com Manuel Gouveia, voou até Macau.

Foi condecorado com a Ordem Militar da Torre e Espada, Cruz de Guerra e Legião de Honra francesa. No dia 22 de fevereiro de 1934, morreu vítima de colisão aérea perto do Algueirão, aos comandos do avião que pilotava. Tinha 49 anos.

Manuel Gouveia nasceu no Porto, a 4 de Fevereiro de 1890. Partiu para França em 1917, integrado nos Serviços de Aviação do Corpo Expedicionário Português. Estagiou nas fábricas francesas de motores de avião Gnome-Rhone e Hispano-Suisse. Em 1924, participou no voo a Macau com Sarmento de Beires e Brito Paes. Em 1926, tirou o curso de piloto na Escola Militar de Aviação em Sintra. No ano seguinte, foi o mecânico da travessia aérea nocturna do Atlântico Sul, com Beires e Jorge de Castilho. Em 1935, participou no Cruzeiro Aéreo às Colónias. Foi condecorado com a Ordem Militar da Torre e Espada e com a Cruz de Guerra. Morreu em Lisboa no dia 10 de Dezembro de 1966.

\footnotetext{
${ }^{16}$ MIGUÉIS, 1972: 32

${ }^{17}$ Óculos de aviador.
} 


\section{参考书目}

AA. VV., “葡萄牙人的航空旅行”。里斯本: 葡萄牙纪念地理大发现国家委员会编辑/航空博物馆, 1997年。

“雅典娜艺术杂志”, 第三期, 里斯本, 1924年12月。

贝雷斯, J. 萨尔门托・德 “沉船之翼”。里斯本: 古典出版社, 1927年。

贝雷斯, J. 萨尔门托・德, “从葡萄牙到澳门”。里斯本: 新塞阿拉出版社, 1925年。

卡里斯托, 瓦斯科, “阿马多拉的飞行”。奥埃拉斯: 奥埃拉斯市政厅, 1975年。

卡尔多佐, 埃德加・佩雷拉, “葡萄牙空军史”, 第三卷。里斯本: 科鲁姆科洛尔出版社, 1981年。

尚贝, 雷内, “航空史”。巴黎: 弗拉玛里翁出版社, 1972年。

杜蒙, 桑托斯, “我看到了什么, 我们将看到什么”, 网址http://www.dominiopublico.gov.br/download/texto/ bi000197.pdf。

费雷拉, 阿玛特乌, “曼努埃尔・果维亚中校和他的时代”, 空军历史档案馆, 1995年。

“L'AÉROPHIL” 杂志, 19期和21期。巴黎: 1909年10月, 11月。

马特乌斯, 洛伦索・恩里克・恩里克斯, “葡萄牙在飞行冒险中”。里斯本: “公众报”出版社, 2009年。

马特乌斯, 洛伦索・恩里克・恩里克斯, ““祖国号”首航后75年”。里斯本: 格拉蒂瓦出版社, 1999年。

米格斯, 若泽・罗德里格斯, “多棱镜”, 里斯本, 色彩工作室出版社, 1972年, 32页。

莫鲁让, 伊莎贝尔, “萨尔门托 - 德贝雷斯——书目论文”, 萨尔门托 - 德贝雷斯, 太阳之城。德贝雷斯, 太阳之城。乔治 -巴斯托斯 - 达席尔瓦及伊莎贝尔 - 莫鲁让编辑注释。波尔图: 阿弗龙塔曼多 出版社, 2013年。

内维斯, 古斯塔夫 - 特德斯奇 - 科雷阿, “巴托洛米奥 - 洛伦哥 - 德古斯茂神父的热空气试验”。里斯 本: 商业印刷出版社, 1911年。

奥利维拉, 阿尔贝托 - 德, “信鸽”。科因布拉: 法兰西 - 阿玛杜出版社, 1913年。

佩索阿, 费尔南多 (1924年) : “萨卡杜拉・卡布拉尔” “雅典娜艺术杂志”, 第三期, 里斯本, 1924年12月。

佩蒂特, 爱德蒙, “新世界航空史”。巴黎: 阿尔宾・米歇尔出版社, 1991年。

平托, 马里奥・科斯塔, “葡萄牙航空简史”。里斯本: 威尔布出版社, 1961莫年。

“飞行史诗”, 第二卷及第三卷。芝加哥: 时间-生活书籍出版社, 1981年。 


\section{REFERÊNCIAS BIBLIOGRÁFICAS}

AA. VV. (1997) - As viagens aeronáuticas dos portugueses. Lisboa: Ed. Comissão Nacional para as Comemorações dos Descobrimentos Portugueses/Museu do Ar.

Athena. Revista de arte, n. ${ }^{\circ}$ 3, Lisboa, Dez. de 1924.

BEIRES, Sarmento de (1927) - Asas que naufragam. Lisboa: Ed. Clássica Editora.

BEIRES, Sarmento de (1925) - De Portugal a Macau (A viagem do Pátria). Lisboa: Ed. Seara Nova.

CALLIXTO, Vasco (1974) - A aviação na Amadora. Oeiras. Ed. Câmara Municipal de Oeiras.

CARDOSO, Edgar Pereira (1981) - História da Força Aérea Portuguesa. 3 vols. Lisboa: Ed. Cromocolor.

CHAMBE, René (1972) - Histoire de l'aviation. Paris: Ed. Flammarion.

CORRÊA, Pinheiro (1966) - Sacadura Cabral, homem e aviador. Rio de Janeiro: Ed. O Cruzeiro.

DUMONT, Santos, O que eu vi, o que nós vimos, disponível em http://www.dominiopublico.gov.br/download/texto/bi000197.pdf FERREIRA, Amadeu (1995) - O tenente coronel Manuel Gouveia e a sua época, Arquivo Histórico da Força Aérea.

KAFKA, Franz (1988) - Os aeroplanos em Bréscia e outros textos. Lisboa: Ed. Livros do Brasil.

L'AÉROPHIL, n. ${ }^{\text {os }} 19$ e 21. Paris: Outubro, Novembro de 1909.

MATEUS, Lourenço Henrique Henriques (2009) - Portugal na aventura de voar. Lisboa: Ed. Jornal Público.

MATEUS, Lourenço Henrique Henriques (1999) - Na esteira do Pátria 75 anos depois. Lisboa: Única.

MIGUÉIS, José Rodrigues (1972) - O espelho poliédrico. Lisboa: Ed. Estúdios Cor.

MORUJÃO, Isabel (2011) - «Sarmento de Beires - Ensaio de uma biobibliografia». In BEIRES, J. Sarmento de - A cidade do sol.

Edição e notas de Jorge Bastos da Silva e Isabel Morujão. Porto: Edições Afrontamento.

NEVES, Gustavo Tedeschi Corrêa (1911) - As experiências aerostáticas de Bartolomeu Lourenço de Gusmão. Lisboa: Ed. Tipogra-

fia do Comércio.

OLIVEIRA, Alberto de (1913) - Pombos-correios. Coimbra: Ed. França Amado.

PESSOA, Fernando (1924) - «Sacadura Cabral». Athena. Revista de arte, n. ${ }^{\circ}$ 3, Lisboa, Dez.

PETIT, Edmond (1991) - Nouvelle histoire mondiale de l'aviation. Paris: Ed. Albin Michel.

PINTO, Mário Costa (1961) - História breve da aviação portuguesa. Lisboa: Ed. Verbo.

THE EPIC OF FLIGHT (1981), vols. II e III, Chicago: Ed.Time-Life Books. 


\section{葡萄牙和澳门, 旅行和移民*}

阿尔弗雷多・戈麦斯・迪亚斯**

*阿尔弗雷多・戈麦斯・迪亚斯

** 阿尔弗雷德 - 戈麦斯 - 迪亚斯本科毕业于历史学, 人类地理学博士学位。他是里斯本大学地理研究中心 及地 理和土地规划研究院研究员。 


\section{PORTUGAL E MACAU, VIAGENS E MIGRAÇÔES}

ALFREDO GOMES DIAS**

\footnotetext{
${ }^{*}$ Cf. DIAS, 2014.
}

** Alfredo Gomes Dias é licenciado em História, doutorado em Geografia Humana e investigador do Centro de Estudos Geográficos e do Instituto de Geografia e Ordenamento do Território da Universidade de Lisboa. 
葡萄牙。澳门。1924年。那是个动荡的时代, 无论是生活在葡萄牙还是在澳 门。在葡萄牙, 社会运动、政治运动和军事运动一个接一个, 令人眼花缭乱。1923 年的里斯本街头到处都充斥着不稳定：政治的，军事的和社会的不稳定。第二年， 葡萄牙第一共和国目睹了其奠基人之一——特奥菲洛 - 布拉加的死亡。当年 11 月, 警察解散了又一次纪念还年轻的布尔什维克革命周年集会游行。在中国, 从 1911年、1912年开始, “不稳定” 也是内战那些日子的标志, 人们感受到了莫斯科 权力的影响。孙中山开始着手让国民党与中国共产党结盟, 但这两个政治势力的 联盟将持续很短的时间。这个如此短暂的联盟促进了中华民国主要形象代言人在 1925年的逝世。

澳门凑巧被这些发生在欧洲和亚洲的时代大潮搅动, 再加上 1923 年 8 月 18 日那 场猛烈的台风蹂路了这座小城。在那个特别动荡的时刻, 罗德里格 - 若泽 - 罗德 里格斯总督向里斯本宣布他想回归葡萄牙, 不过他仍有机会接待两位飞行员: 萨尔 门托 - 德贝雷斯和布里托 - 帕艾斯。面对上海和广东已经发生的和即将发生的事 件, 停泊在澳门的 “祖国号” 炮艇时刻处于警戒状态; 在这艘炮艇上, 总督接待了同 名飞机 “祖国号二” 的两位葡萄牙军人, 他们完成了从千泉新镇到澳门的第二部分 飞行。“这块葡萄牙殖民地在休闲俱乐部接待了我们。在那儿, 葡萄牙领事塞尔韦 拉・德阿布克尔克再次向我们表示欢迎。经历了“祖国号二’1924年6月20日从猛烈 的风暴中起飞, 飞过澳门上空这刚刚描述的事件后, 我们第一次在这位友好的领事 家中安然入眠。”1

澳门、中国大陆和葡萄牙的艰难岁月促进了澳门、葡萄牙和中国大陆的人 口流动。由于 1924 年发生在广东的军事形势, 使许多中国人前往澳门寻找一个避 风港。另一方面, 随着香港城市的诞生, 澳门居民继续着自 1840 年代开始的移居行 动。在葡萄牙, 二十世纪前半叶葡萄牙移民们偏好的移民目的地还是美洲, 包括从 巴西到美国广哀土地, 但他们当中的一些人冒险选择了更为遥远的目的地, 他们踏 上了中国的土地。

从十六世纪中叶建城开始, 澳门城一向都是欧洲移民（他们想要达到遥远的 中国) 和亚洲移民 (他们想寻找更多的生意机会或是仅仅想要工作) 进出的桥头 堡。但一直以来澳门都不只是一个聚集了生意机会的港口城市。

1 德贝雷斯 1925 年。 
Portugal. Macau. 1924. Foram conturbados os tempos que se viveram em Portugal, na China e na cidade de Macau nesta época. Em Portugal, os movimentos sociais, políticos e militares sucederam-se a um ritmo quase vertiginoso. A instabilidade política, militar e social estava instalada nas ruas de Lisboa em 1923. No ano seguinte, a primeira República Portuguesa viu morrer um dos seus fundadores: Teófilo Braga. Em novembro, a polícia dissolveu as manifestações comemorativas de mais um aniversário da ainda jovem Revolução Bolchevique. Também na China republicana, desde 1911-1912, a instabilidade política era a marca dos dias passados em guerras internas, fazendo-se também sentir a influência do poder de Moscovo. Sun Yat-sen iniciou a aliança do Kuomintang com o Partido Comunista Chinês, mas a conjugação entre as duas forças políticas pouco tempo iria durar. Para tão efémera aliança muito contribuiu a morte daquele que foi o principal rosto da República Chinesa, em 1925.

Por sua vez, Macau recebeu os impactes destas ondas que se agitavam, coincidentemente, na Europa e na Ásia, aos quais se juntou mais um violento tufão, que assolou a cidade no dia 18 de agosto de 1923. Num momento particularmente instável, o governador Rodrigo José Rodrigues anunciou, para Lisboa, a sua intenção de regressar a Portugal, mas teve ainda oportunidade de receber os aviadores Sarmento de Beires e Brito Paes. A canhoneira Pátria, estacionada em Macau, mas sempre em estado de alerta face aos acontecimentos que iam ocorrendo em Cantão e em Xangai, recebeu os dois militares portugueses que, a bordo de um avião homónimo, Pátria II, realizaram a segunda parte da travessia aérea que ligou Vila Nova de Mil Fontes a Macau. «A Colónia Portuguesa recebe-nos no Clube de Recreio, onde o cônsul de Portugal, Cerveira de Albuquerque, nos dá comovidamente as boas-vindas. É sob o teto amigo da sua casa que dormimos o nosso primeiro sono, depois do drama que a narrativa mal descreve, desse dia 20 de junho de 1924, em que o Pátria II, em meio à fúria da tempestade, voou sobre a cidade de Macau» ${ }^{1}$.

Os anos difíceis por que passaram Macau, China e Portugal foram favoráveis à mobilidade de macaenses, portugueses e chineses. Devido à situação militar que se vivia em Cantão durante o ano de 1924, muitos foram os chineses que procuraram em Macau um porto de abrigo. Por sua vez, os macaenses davam continuidade à diáspora iniciada na década de 1840, com o nascimento de Hong Kong. Em Portugal, na primeira metade do século XX, os migrantes portugueses continuavam a preferir as Américas, do Brasil aos Estados Unidos, mas alguns arriscavam-se já por paragens mais longínquas chegando a terras da China.

A cidade de Macau constituiu-se sempre, desde a sua fundação em meados do século XVI, como uma porta de entrada e de saída dos migrantes europeus (que almejavam chegar à China longínqua) e dos asiáticos (que nela buscavam concretizar mais um negócio ou, simplesmente, trabalhar). Mas Macau foi sempre muito mais do que uma cidade portuária que se resumia a uma oportunidade de negócios. Para além das trocas comerciais, nela se cruzaram conhecimentos, ideias e tecnologias que dentro dos seus muros conviveram ao longo dos séculos. A

\footnotetext{
${ }^{1}$ BEIRES, 1925.
} 
除了商业交流, 许许多多几个世纪以来形成的知识、理念和技术在这个小城 内交流共存。土生澳门社区的形成就是这种共存的一个例子，特别是在欧洲男子 (葡萄牙人) 和亚洲女子 (直到19世纪, 来自日本、马来亚, 泰国..... 的血统, 从十九 世纪中叶开始, 主要是中国人) 之间的交流共存。

在这个城市的起源和演变中, 总是有来自世界各地不同地区的移民运动, 这或 多或少地取决于它们产生的历史背景。从某种角度来说, 澳门城的历史是一部移 民的历史。

19 世纪末和 20 世纪的头二十五年, 葡萄牙移民基本都是移往巴西, 其余的移民 流往其他大陆。而我们谈论亚洲, 具体来说, 就是中国, 情况更是如此。

我们无法获得这一时期葡萄牙中国移民的定量数据, 但如果我们能够知道在 香港、澳门和上海这三个中国城市定居的葡萄牙 “王国” 居民数量, 则可以勾画出 一个粗略的估值。1 878 年到 1950 年在澳门的非华人居民人口在 3845 人至 4782 人之 间不等, 其中有土生葡人, “王国出生的人” (出生在葡萄牙的巴西白人), 外国人和其 他海外省的葡萄牙人。来自大都市的人口从未超过 $23.3 \%$ 。

因此，当我们把目光聚集于在此时期定居澳门的来自 “王国” 的葡萄牙人身 上一一他们当中大多数是军人和行政人员, 我们可以确认他们的人数一向都是很 少的, 无论是从绝对数量还是从相对数字上来看。这个数字在 1920 年达到了峰值, 这一年有 909 个葡萄牙人, 占澳门非华人数量的 $21.8 \%$ 。

选择中国作为移民目的地的葡萄牙人主要定居在两个由西方人管理的中国 城市, 即香港和上海, 因此这两个城市获得了国际化大城市的称号。总的来说, 对 于分散在这两个城市以及澳门的许多葡萄牙移民来说, 他们在这些地区的存在经 历了通过婚姻融入澳门社区的过程。

自18世纪以来, 葡萄牙人在澳门家庭中的支配地位得到了认可: 他们中的一些 人与 “本土的女儿” 结婚, 融入了已存在的家庭, 为澳门做出贡献; 另一些人建立了 新的家庭。众所周知, 19 世纪和 20 世纪抵达澳门的葡萄牙人, 对于巩固澳门社区中 的葡萄牙特色极具重要性, 这些人主要是军人。我们能够观察到, 直到1960年代, 来自葡萄牙的澳门家庭成员和移民一直存在。从1970年开始, 随着四 - 二五革命 和从1987年开始的去殖民化, 向中华人民共和国移交主权过渡, 葡萄牙人的存在减 少了, 特别是军人, 实际上都消失了, 通过婚姻融入澳门社区的葡萄牙人人数也减 少了。 
formação da comunidade macaense é um exemplo que resulta desse convívio, principalmente entre homens europeus (portugueses) e mulheres asiáticas (até ao século XIX de origem japonesa, malaia, tailandesa... e, a partir de meados do século XIX, fundamentalmente chinesa).

$\mathrm{Na}$ origem e evolução da cidade estiveram sempre diferentes movimentos migratórios oriundos dos mais variados territórios dispersos pelo mundo, que ganharam mais ou menos protagonismo consoante o contexto histórico em que emergiram. De algum modo, a história da cidade de Macau é uma história de migrações.

Nos finais do século XIX e durante o primeiro quartel do século XX, a emigração portuguesa dirigia-se, no essencial, para o Brasil, sendo residual o número de emigrantes que se dirigiram para outros continentes. E esta é uma verdade ainda mais evidente se estivermos a falar da Ásia e, mais concretamente, da China.

Não tendo acesso a dados quantitativos referentes à emigração Portugal-China neste período, podemos traçar um retrato aproximado, se conhecermos o número de portugueses do «Reino» que se fixaram nas três cidades chinesas onde se constituíram os principais núcleos da emigração portuguesa: Macau, Hong Kong e Xangai. No conjunto da população não chinesa de Macau, que, entre 1878 e 1950, oscilava entre as 3845 e as 4782 pessoas, encontravam-se macaenses, reinóis, estrangeiros e portugueses das outras possessões ultramarinas. As pessoas oriundas da Metrópole nunca ultrapassaram os 23,3\%.

Assim, centrando a nossa atenção nos portugueses naturais do «Reino» que se fixaram em Macau neste período, na sua maioria militares e quadros da administração, verificamos que o seu número é sempre muito reduzido, quer em termos absolutos, quer em termos relativos. Atinge o seu pico em 1920, ano em que foram contabilizados 909 portugueses, representando 21,8\% do total da população não chinesa de Macau.

Os portugueses que escolheram a China como destino migratório optaram também por se fixar nas duas cidades chinesas que, sob administração ocidental, ganharam o título de grandes cidades internacionais: Hong Kong e Xangai. Mas, no seu conjunto, para muitos dos migrantes portugueses dispersos por estas duas cidades, e ainda por Macau, a sua presença nestes territórios passou por um processo de integração na comunidade macaense, por via do casamento.

Desde o século XVIII é reconhecido o domínio dos portugueses no seio das famílias macaenses: uns aportavam a Macau e integraram-se nas famílias já existentes, casando com as «filhas da terra»; outros fundaram novas famílias. É também conhecida a importância dos portugueses que chegaram a Macau ao longo dos séculos XIX e XX, onde dominam os militares, na consolidação da vertente portuguesa da comunidade macaense. Podemos observar que os migrantes, membros de famílias macaenses naturais de Portugal, são uma presença constante até à década de 1960. A partir de 1970, com o 25 de Abril, a descolonização e, em 1987, o 
除了澳门之外, 确定来自欧洲或是其他殖民地, 定居香港和上海的葡萄牙人人 数很重要, 这两个城市目睹了来自澳门的两个重要移民社团的存在。

从数量上来说, 来自欧洲的葡萄牙人的存在微不足道。就香港来说, 在 1879 年 到1949年 ${ }^{2}$. 期间, 来自葡萄牙及其殖民地的葡萄牙人加在一起占葡萄牙领事馆登 记人数的 $5.2 \%$ 。在上海, 这个数字还要小, 为 $2.3 \%$ 。香港和澳门在地理上的接近, 以及上海与里斯本更为遥远的距离解释了这一差别。

因此, 葡萄牙人在澳门的存在更为重要, 这不仅是在数量上, 也是在社会和经 济方面 (考虑到葡萄牙人占据了澳门的行政管理岗位并接近经济精英)。所以, 深 入分析这些离开葡萄牙前往澳门的人的来源区域是恰当的, 有助于在土生葡人的 人口和文化长期重组过程中丰富葡萄牙因素 (图1)。

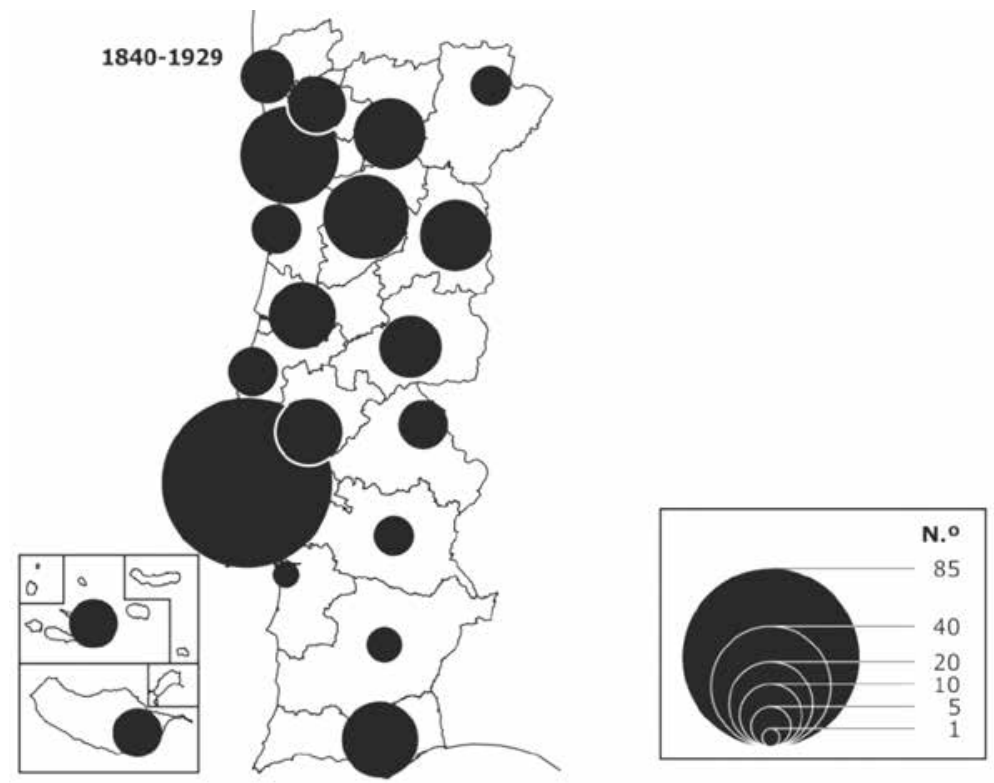

图1 融入澳门家庭的葡萄牙人来源 $(1840 \text { 年-1929年 })^{4}$

\footnotetext{
2 葡萄牙驻香港领事馆登记簿 (1879 1949), 见阿尔弗雷德 - 戈麦斯 - 迪亚斯, “领土, 路程和融 入过程 (1936-1995)”, 澳门, 澳门特区政府文化局, 2016年, 162页。

3 葡萄牙驻上海领事馆登记簿 (1880-1952), 见阿尔弗雷德・戈麦斯・迪亚斯, 同上。

${ }^{4}$ 来源: 若热 - 福尔雅斯 “澳门家庭”, 澳门, 东方基金会/澳门文化学会, 1996年。地图作者: 阿尔弗雷德 - 戈 麦斯・迪亚斯, 同上, 213页。
} 
início da transição da soberania de Macau para a República Popular da China, a presença portuguesa foi diminuindo, nomeadamente a militar que, praticamente, desapareceu e fez reduzir o número de portugueses que, por via do casamento, se integraram na comunidade macaense.

Para além de Macau, é relevante identificar o número de portugueses, europeus ou naturais das possessões coloniais, que se fixaram em Hong Kong e Xangai, cidades que conheceram a presença de duas importantes comunidades migrantes com origem em Macau.

A presença portuguesa de origem europeia é muito pouco relevante em termos quantitativos. No caso de Hong Kong, a percentagem dos portugueses naturais de Portugal e das possessões coloniais, no seu conjunto, ascende a 5,2\% dos matriculados no consulado português, entre 1879 e $1949^{2}$. Quanto a Xangai, esta percentagem é ainda mais reduzida, ficando-se pelos 2,3\% ${ }^{3}$. A proximidade geográfica de Hong Kong e Macau explica esta diferença, assim como a maior distância de Xangai em relação a Lisboa.

É, pois, em Macau que a presença portuguesa assume maior relevo, não só em termos quantitativos, mas também sociais e económicos (considerando as funções ocupadas no quadro da administração portuguesa da cidade e a proximidade das elites económicas). Por isso, é pertinente aprofundar a análise das origens regionais desta população que foi saindo de Portugal, rumo a Macau, contribuindo para o enriquecimento da vertente portuguesa no processo de permanente recomposição demográfica e cultural dos macaenses (Figura 1).

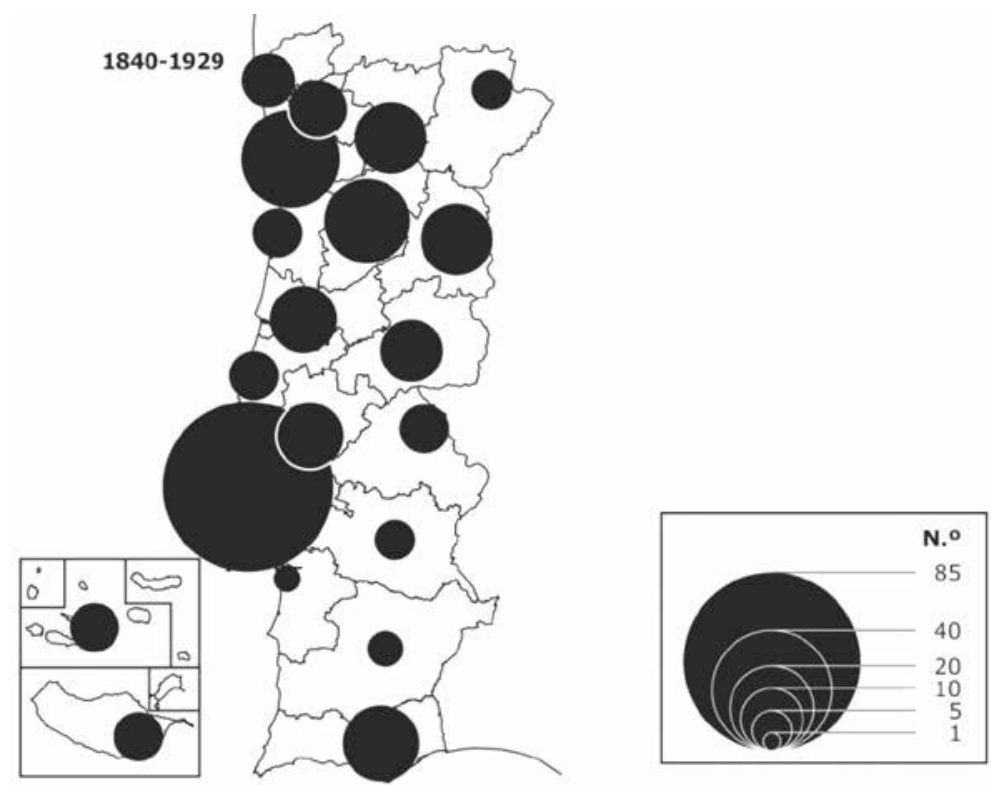

Fig. 1 - Origens dos migrantes portugueses integrados nas famílias macaenses (1840-1929) ${ }^{4}$

\footnotetext{
${ }^{2}$ Cf. Livros de Matrícula do Consulado de Portugal em Hong Kong (1879-1949). In DIAS, 2016: 162.

${ }^{3}$ Cf. Livros de Matrícula do Consulado de Portugal em Xangai (1880-1952). In DIAS, Ibidem.

${ }^{4}$ Fonte: FORJAZ, 1996. Mapa do autor. Cf. DIAS, Ibidem, p. 213.
} 
这一分析解释了里斯本大区的领导地位, 它是帝国首都和主要的军事和行政 管理人员的来源, 而海外省的空间则与它保持着商业网络联系。

1840年到1929年之间, 从第一次鸦片战争后到战后时期 (1920年), 随着澳门移 民的增加, 可以看到加入澳门家庭的葡萄牙人人数有所增长, 其来源则分散在葡萄 牙各地。里斯本保持着作为主要移民输出地的地位, 而在波尔图则诞生了第二大 移民输出中心, 人们离开此地, 前往澳门并在那里定居。这一移民运动在两个群岛 (马德拉群岛和亚速尔群岛) 也十分普遍, 特茹河以北地区成了移民澳门的首要输 出地, 同样的, 沿海地区多于内陆地区。

应当指出的是, 迁往澳门的葡萄牙人所涉及的人数一直都很少, 特别是和其他 移民目的地相比时, 比如巴西和美国, 或是法国和德国, 成千上万的葡萄牙人移居 这些国度。有关离开葡萄牙, 移居澳门的葡萄牙人的信息来源和所有的数据收集 让我们相信面对的是一个可信的样本。这个样本是由军人, 殖民地行政管理人员 和商人们组成的, 他们的生活让他们加入了澳门家庭, 最后也反过来给许多澳门移 民提供了一个目的地, 让最近几代人选择葡萄牙作为他们生活的土地。

在移民流动中, 我们可以确认不同的原因和后果, 强度和方向, 在其中, 有许多 移民移出地和移民目的地。然而, 我们承认在所有这些当中, 伴随移民总体趋势的 是货物、资金的流动, 技术创新和科学进步。

1920年代, 葡萄牙的飞行事业还刚刚开始起步, 但正是在那些年当中, 一些飞 行员创造了辉煌。1922年，加戈・科蒂尼奥和萨卡杜拉 - 卡布拉尔使用水上飞机 “卢西塔尼亚号” 第一次飞越了南大西洋, 6月17日到达了里约热内卢。除了纪念巴 西独立 100 周年, 这还是一次将两个有着悠久历史联系的国家连接在一起的航空之 旅, 在那个时代, 巴西也是一个大量葡萄牙移民流入地。

两年之后, 萨尔门托 - 贝雷斯和布里托 - 帕艾斯飞往世界的另一端。他们通 过这次飞行, 想在空中重新绘制一个新的 “托尔德西里亚斯条约”。这两位飞行员 从千泉新镇出发, 试图发现可以将葡萄牙和澳门连接在一起的航空之路。 
Essa análise revela a liderança do distrito de Lisboa, capital do império e território de origem dos principais quadros militares e administrativos com quem os espaços ultramarinos mantinham a sua rede de negócios.

Entre 1840 e 1929, acompanhando o aumento da emigração macaense, após as Guerras do Ópio, até ao pós-Guerra (1920), observa-se o aumento do número de portugueses que se integraram nas famílias macaenses e a dispersão das suas origens pelo território nacional. Mantendo-se Lisboa como a principal área de partida, nasce no Porto um segundo centro de saída de portugueses com destino a Macau e que lá permaneceram. O movimento generaliza-se aos dois arquipélagos (Açores e Madeira), e acentua-se a primazia a Norte do Tejo na emissão de migrantes com destino a Macau, assim como das regiões do litoral em detrimento das regiões do interior.

De sublinhar que a deslocação de portugueses para Macau sempre envolveu um número muito reduzido de migrantes, principalmente quando comparado com os contingentes migratórios para outros destinos, como o Brasil e os EUA ou a França e a Alemanha, que mobilizaram milhares de portugueses. A fonte de informação e a recolha de todos os dados relativamente à saída de portugueses para Macau levam-nos a acreditar estarmos perante uma amostra credível, constituída por militares, quadros para a administração colonial e homens de negócios cuja vida proporcionou a sua integração nas famílias macaenses, acabando também por oferecer um destino para muitos migrantes macaenses que, nas mais recentes gerações, escolheram Portugal como terra para viver.

Nos fluxos migratórios podemos identificar diferentes causas e consequências, intensidades e direções, neles participando muitos territórios de origem e de destino. No entanto, reconhecemos em todos eles a tendência geral dos migrantes acompanharem o movimento das mercadorias, dos capitais, das inovações tecnológicas e do avanço científico.

Na década de 1920, a aviação portuguesa ainda se encontrava a dar os seus primeiros passos, mas foi nestes anos que alguns feitos relevantes tiveram lugar. Em 1922, Gago Coutinho e Sacadura Cabral fizeram a primeira travessia aérea do Atlântico Sul, no hidroavião «Lusitânia», tendo chegado ao Rio de Janeiro no dia 17 de junho. Para além do assinalar do primeiro centenário da independência do Brasil, foi uma viagem que ligou dois territórios historicamente unidos e que, naquela época, conheciam um intenso fluxo migratório com origem em Portugal.

Dois anos mais tarde, Sarmento de Beires e Brito Paes rumaram ao outro extremo do mundo, como se, com esta viagem, pretendessem redesenhar, agora nos ares, um novo Tratado de Tordesilhas. Partindo de Vila Nova de Mil Fontes, aqueles dois aviadores tentaram descobrir as rotas aéreas que permitiriam ligar Portugal a Macau, a cidade que se mantinha sob administração portuguesa desde o século XVI, onde muitos portugueses, uns nascidos na 
这一分析解释了里斯本大区的领导地位, 它是帝国首都和主要的军事和行政 管理人员的来源, 而海外省的空间则与它保持着商业网络联系。

在澳门一一这个自 16 世纪起就被葡萄牙管理的城市中生活着许多葡萄牙人, 其中有些 是在欧洲出生的, 有些则已经是 “亚洲的孩子”, 他们遇到了澳门这个避 风港得以定居。就像萨尔门托 - 德贝雷斯在书中开篇引用的一次演讲: “我们需要 来澳门, 众多葡萄牙土地中的葡萄牙土地, 卡蒙斯在那里获得灵感写出了 “卢西塔 尼亚人之歌”。这也是为了重返世界做准备……”

1924年6月20日，当萨尔门托 - 德贝雷斯和布里托 - 帕艾斯飞越澳门上空时, 他们的行为有助于确认澳门是葡萄牙在中国的最后边界。

\section{参考书目}

迪亚斯, A, “澳门侨民: 澳门, 香港和上海 (1850-1952)”, 里斯本，澳门科技文化中心，澳门基金会， 2014年。

福尔雅斯. J, “澳门家庭”, 澳门, 东方基金会/澳门文化学会, 1996年。

玛列洛斯, J, “迁徙”, 发表于 “葡萄牙地理, 社会, 景观和城市” 第二卷, 里斯本, 读者圈俱乐部, 2005年, 87-125页。

米兰达, S, “移民与资本流动, 1870-1914”。发表于 “葡萄牙移入和移出移民”。十九世纪和二十世纪葡 萄牙移民和移民问题国际学术讨论会会议记录, 里斯本, Fragmentos, 1993年, 47-62页。

蒙, E, “中国侨民”。“移民地理”, 巴黎, 地理出版社, 2000年。

里贝罗, 0 , “移民”。发表于若泽・瑟朗 (主编) “葡萄牙历史词典”, 第二卷, Iniciativas Editoriais出版社, 1979年, 363-373页。

里贝罗, 0; 劳腾扎哈, H, “葡萄牙地理”, 三, 里斯本, 若奥・萨・达科斯塔出版社, 1989年。

罗兰, $R$, “移民问题: 动态和模式”。发表于F. 贝登古及 $K$. 乔杜里 (主编) “葡萄牙扩张史” 第四卷, 里斯 本, 读者圈俱乐部, 1998年, 304-323页。

\footnotetext{
5 德贝雷斯1925年.
} 
Europa, outros já filhos da Ásia, encontraram um porto de abrigo, uma cidade para se fixarem: «Precisávamos de vir a Macau, terra portuguesa entre as terras portuguesas, onde Camões se inspirou para escrever Os Lusíadas», segundo afirmou Brito Paes, num discurso que o livro cita em abertura. E também como preparação da volta ao mundo... ${ }^{5}$

Ao sobrevoarem Macau, no dia 20 de junho de 1924, Sarmento de Beires e Brito Paes contribuíram para afirmar Macau como a última fronteira de Portugal, na China.

\section{REFERÊNCIAS BIBLIOGRÁFICAS}

BEIRES, J. Sarmento de (1925) - De Portugal a Macau (A viagem do Pátria). Lisboa: Seara Nova.

DIAS, A. (2016) - Territórios, itinerários e processos de integração (1936-1995), Macau: Instituto Cultural do Governo da RAEM.

DIAS, A. (2014) - Diáspora macaense. Macau, Hong Kong e Xangai (1850-1952). Lisboa: Centro Científico e Cultural de Macau, Fundação Macau.

FORJAZ J. (2005) - Famílias macaenses. Macau: Fundação Oriente/Instituto Cultural de Macau.

MALHEIROS, J. (2006) - Migrações. In Geografia de Portugal. Sociedade, paisagens e cidades, vol. 2. Lisboa: Círculo de Leitores, pp. 87-125.

MIRANDA, S. (1993) - Emigração e fluxos de capital, 1870-1914. In Emigração/imigração em Portugal. Actas do colóquio internacional sobre emigração e imigração em Portugal- Séculos XIX e XX. Lisboa: Fragmentos, pp. 47-62.

MUNG E. (1979) - La Diaspora chinoise. Géographie d’une migration, Paris: Ed. Géophrys.

RIBEIRO, O. (1975) - «Emigração». In SERRÃO, Joel (Dir.), Dicionário de História de Portugal, Vol. II. s.l.: Iniciativas Editoriais, pp. 363-373.

RIBEIRO, O.; Lautensach H. (1989) - Geografia de Portugal, III. Lisboa: Edições João Sá da Costa.

ROWLAND, R. (1998) - «O problema da emigração: dinâmicas e modelos». In BETHENCOURT, F. \& CHANDHURI, K. (Dir.), História da expansão portuguesa, Vol. IV. Lisboa: Círculo de Leitores, pp. 304-323.

${ }^{5}$ BEIRES, 1925. 


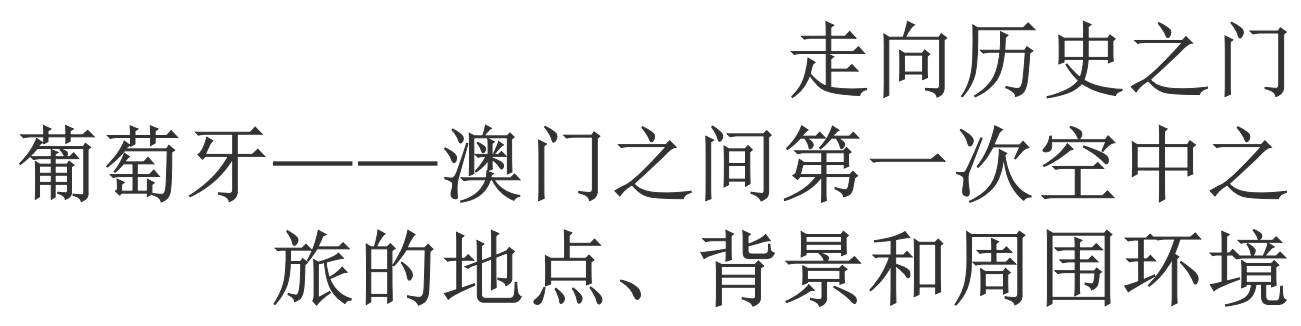

恩里克・马特乌斯* 文化、空间与记忆跨学科研究中心

* 洛伦索 - 恩里克 - 恩里克斯 - 马特乌斯历史科学本科毕业, 是波尔图大学文学院 “文化、空间与记忆” 跨 学科研究中心的研究员, 国家行政研究院艺术管理员。他是葡萄牙独立历史协会巴托米奥 - 德古斯茂研究 院成员和联合创始人, 他还是葡萄牙空军历史文化委员会成员, 葡萄牙航空俱乐部名誉会员。 


\section{AO POSTIGO DA HISTÓRIA. LUGARES, CONTEXTOS E AMBIENTES EM TORNO DA PRIMEIRA VIAGEM AÉREA ENTRE PORTUGAL E MACAU}

HENRIQUES-MATEUS*

CITCEM

\footnotetext{
* Lourenço Henrique Henriques-Mateus é Investigador do CITCEM na Faculdade de Letras da Universidade do Porto, gestor das Artes pelo Instituto Nacional de Administração, licenciado em Ciências Históricas. É vogal e co-fundador do Instituto Bartolomeu de Gusmão da Sociedade Histórica da Independência de Portugal, membro da Comissão Histórico-Cultural da Força Aérea Portuguesa e sócio honorário do Aero Club de Portugal.
} 
“这个人的躯体中究竟住着怎样的一个灵魂?

使得他总是放弃安宁, 让他疲备, 把他置于危险之中, 甚至迫使他冒着几乎确定的死亡风险。”

H. G威尔斯

就像 20 年代葡萄牙空军飞行员为他们的灰色军服新祄里举杯庆祝的恶作剧 一样一一这种军服让人从陆军经典的严格僵硬中解放出来并被赋予了固有的飞行 感, 今天, 所有围绕着首次葡萄牙——澳门航空之旅的地点、背景和环境也已被人 遗忘。当我们拼凑起那1924年4月到6月布里托 - 帕伊斯, 萨尔门托 - 德贝雷斯和 曼努埃尔 - 戈维亚所经历的那 “不确定、不安、艰苦和筋疲力竭斗争的八十天 ${ }^{1}$ ” 当中所发生的一切, 尽管只是些碎片, 却具有说明意义。

在那些岁月中，阿马多拉、里斯本和千泉新城曾是葡萄牙各大报纸头条上被 印刷得最多的名字, 报上的标题把读者们引向地图以外他们触摸不到的青春之地, 那里, 是一个意志与思想激烈对抗的地方, 仿佛一切皆有可能。

那是些灵魂中被深深注入了 “疯狂” 的地方一一只有这样运动才能克服惰性, 热情才能克服冷漠, 永生才能克服遗忘。正如被印在期刊页面上的那样, 当时的里 斯本是几乎所有这一切的世界, 这更多的是因为它汇聚了各种人和计划, 而不是它 是这一切涌现而出的源头; 因为这一切存在于 GEAR ${ }^{2}$ 共和国航空中队之中, 是在那 里, 允许实现葡萄牙——澳门 ${ }^{3}$ 首航的态度和构想得以产生。

但是, 现在当我们寻找与这个史诗般壮举有直接关系的特定地点时, 它就是 “疯狂的二十年代”上半段末期里斯本带给我们的梅耶公园。确切地说, 是 园里 “共和 派老革命” 若昂 - 波尔热斯 ${ }^{4}$ 的餐馆, 他是此处第一个砖石结构建筑 ${ }^{5}$ 的所有人。

\footnotetext{
1 贝雷斯, 1968:11。

2 第一次世界大战之后, 根据1919年2月7日颁布的5141号法令成立了共和国航空中队, 简称G. E. A. R, 驻扎在 阿马多拉, 并于1938年12月5日因被撤销而结束其存在。该中队最初配备SPAD飞机, 他们的编队拥有许多战 争余下的材料, 特别是飞机。然而, 尽管这些飞机质量不错, 还是很快就被战后航空工业所出产的产品超越 了。(参见MATEUS, 1999:77)

3 这次飞行已成为许多描述的对象。我们确认, 萨尔门托 - 德贝雷斯称其为 “从葡萄牙到澳门 (祖国号之旅)”, 正如布里托 - 帕伊斯 (或他的代言人) 将其称为 “里斯本一一澳门奔袭”。(参见 “航空杂志” 第256期161页) PEIXOTO, 1980年: 51.

${ }^{4}$ 关于这个人物和他餐馆的在与第一次葡萄牙——澳门空中之旅时期非常接近的日子里的日常, 请参阅内 格朗的陈述, 1969年: 101页,

若昂・波尔热斯 (他体格外貌与国王卡洛斯一世很相似, 顺便说一句, 这位国王据说是个炸弹客) 是记者 们的好朋友之一, 无论他们是或不是像他一样的共和主义者。他仅仅允许记者叫自己 “炸弹客”。他们当 中从来没人因为缺钱而没有晚餐。(……有时候, 为了支付或者逃避支付晚餐, 这群年轻人, 在纳斯西门 托 - 费尔南德斯的笑话和比阿特丽丝 [科斯塔] 或阿尔瓦罗 - 阿尔梅达的精神格言中, 他们用廉价的骰 子玩儿一种叫 “法国摊子” 的奢博游戏, 并沉浸于令人愤怒的作弊之中。一天, 位于同名花园的托勒尔宫 收到了一份检举一一自1927年起, 刑事调查警署设立在此处。据检举, 在梅耶花园的某处存在一个地下奢 场。为此, 司法警察建立了一个特别部门并于某日凌晨 “抢劫”了波尔热斯的餐馆, 那里人们正热火朝天 地决定谁将是三餐、骰子和夜晚的 “受害人”。警察们不知所措。“奢徒” 都是熟人, 有些甚至是他们的朋 友。赌博的人们面对警察毫不动摇地发出了最后通牒: “要么你们也进来玩儿并且面对支付晚餐的风险, 或者……滚出去!”事实是, 有些警察真的留下了!

5 若昂 - 波尔热斯 $(\cdots \cdots \cdot)$ - - 在梅耶公园中第一个开设石头、石灰建筑餐馆的人 $(\cdots \cdots \cdot)$ 参阅内格朗, 101 页。
} 
Que espírito é este no homem que o força sempre a abandonar o sossego, impelindo-o para as fadigas, pondo-o em perigo e obrigando, mesmo, a correr o risco de uma morte quase certa?

H. G. Wells

Tão esquecido como o soco travesso da praxe com que os aviadores militares portugueses dos anos vinte usavam brindar o forro novo do quépi cinzento da farda, para o desemproar da rigidez clássica de cobertura do Exército e lhe conferir a desenvoltura inerente à Aviação, está hoje o conjunto dos lugares, contextos e ambientes que giraram em torno da primeira viagem aérea entre Portugal e Macau. Resquícios só por si acessórios, mas ilustrativos, quando compaginados com aquilo que se passou em torno desses «oitenta dias de incerteza, de inquietação, de luta árdua e esgotante ${ }^{1} »$, experimentados por Brito Paes, Sarmento de Beires e Manuel Gouveia, entre Abril e Junho de 1924.

Amadora, Lisboa e Vila Nova de Milfontes eram, por esses dias, os nomes das terras que mais se estampavam nos cabeçalhos dos grandes jornais portugueses, com títulos que remetiam os seus leitores para os lugares impalpáveis da juventude, que estavam para além dos mapas, num sítio onde tudo parecia ser possível no confronto fervilhante da vontade com as ideias.

Eram sítios intimamente imbuídos no espírito desse tempo «louco» - para que o movimento se sobrepusesse à inércia, o entusiasmo à indiferença, e a imortalidade ao esquecimento. E, tal como ficou estampado nas folhas daqueles periódicos, Lisboa era então o universo de quase todos esses lugares, mais por se constituir no ponto de encontro de gentes e de desígnios, do que por ser o manancial de onde estes brotavam, porque esse estava no GEAR ${ }^{2}$, onde foram concebidos os gestos e as ideias que permitiram a realização da primeira viagem aérea entre Portugal e Macau³.

Contudo, ao buscar-se agora um lugar específico directamente relacionado com esta épica façanha, é para o Parque Mayer que a Lisboa do final da primeira metade desses «loucos anos vinte» nos remete. Mais precisamente para «o restaurante do velho revolucionário republicano, João Borges ${ }^{4} »$, proprietário do primeiro edifício de alvenaria ali cons-

\footnotetext{
${ }^{1}$ BEIRES, 1968: 11.

2 [...] «O Grupo de Esquadrilhas de Aviação República, conhecido pela sigla G.E.A.R., estava sediado na Amadora e foi criado logo após o termo da Primeira Grande Guerra, pelo decreto 5141, de 7 de Fevereiro de 1919, acabando por ser extinto em 5 de Dezembro de 1938. Originalmente equipado com aviões SPAD, este grupo de esquadrilhas teve na sua formação muito material que sobrara da guerra, nomeadamente os referidos aparelhos, que, embora de qualidade, se viram rapidamente ultrapassados pelos produtos saídos das indústrias aeronáuticas do pós-guerra». (Vide MATEUS, 1999: 77).

${ }^{3}$ Esta viagem tem sido objecto de vários designações. Assim, verificamos que J. Sarmento de Beires a denominou $D e$ Portugal a Macau (A Viagem do Pátria), tal como «Brito Paes (ou alguém por ele) a intitulou «Raid» Lisboa-Macau» (cf. Revista do Ar, separata do n. ${ }^{\circ}$ 254: 161.) PEIXOTO, 1980: 51.

${ }^{4}$ Acerca desta figura e do quotidiano do seu estabelecimento, numa época imediata, mas ainda muito próxima da data da primeira viagem aérea entre Portugal e Macau, veja-se o que afirma NEGRÃO,1969: 101:

João Borges (fisicamente parecido com o rei D. Carlos, de quem, aliás, se dizia ser filho bastardo) foi um dos grandes amigos dos jornalistas, quer eles fossem ou não republicanos, como ele. Eram os únicos a quem permitia que
} 
这个建筑位于一个今日已被毁的地方, 离玛利亚 - 维多利亚剧院几十米远, 该 剧院现在仍然对公众开放 6 。

波尔热斯餐馆位于公园一角, 是一幢两层、有着四面排水坡屋顶的漂亮建 筑 ${ }^{7}$ 。其中, 一楼有四扇动人的门和一对窗户, 入口处上方铺着葡萄藤, 让此处的环 境变得更令人愉悦。二楼一端是一个类似阳台的结构, 有一扇带小阳台的狭窄大 窗和另五扇窗, 前面放着六根略略外倾的杆子, 提醒人们在节庆的日子里要悬挂旗 帜。在这幢建筑物的顶端, 靠近房顶的地方围绕着一圈腰线, 上面是瓷砖上彩绘的 一系列猫——这很好地定义了这幢建筑内部想要表达的精神, 表现出当时流行的 费亚略 - 德阿尔梅达作品 “猫” 中的无政府主义性质。在这些猫中, 这幢楼房的所 有者那叛逆的灵魂可以很好地认同自己的身份, 向世界宣扬那位争议作家的格言: “很少喵喵叫, 总在抓挠, 永不害怕。8” 这种姿态与 1924 年经常光顾参观的客人们肯 定能保持一致, 他们是一些共和派记者, 年轻军人, 音乐家, 法朵歌手, 波西米亚人和 其他有夜生活的人。

在离我们更近的一段时间里, 这个餐馆也曾是我经常去的地方。在那里, 我手 里拿着德贝雷斯的书, 沉浸在过去的时光, 这更多的是为了体验在二十世纪八十年 代 (面对这座楼几成废墟前的时候) 那令人痛苦的苍白中, 餐馆沉默的四壁能向我 诉说什么, 而不是让餐馆平庸的菜单抑制我的食欲。

当时，菜单上的菜式已经与令人怀念的波尔热斯餐馆时期端上餐桌的豪华、 精致、“令人胃口大开的晚餐” 毫无相像之处; 那时, 人们为一块碑 ${ }^{9}$ 揭幕, 这块碑是 为了赞美这个地方 “开设了认捐名册, 以资助萨尔门托 - 德贝雷斯和布里托 - 帕伊 斯实现第一

\footnotetext{
6玛利亚・维多利亚剧院至今仍在营业, 它已成为梅耶公园黄金时代的最后见证。

7 在1990年前一点的时间, 当我去看它的时候, 它被粉刷成深蓝灰色。

8 是我生于 1905 年的祖父——那时他经常光顾里斯本夜生活场所, 提醒我波尔热斯餐馆建筑腰线上的猫和 费亚略文学作品 “猫”之间存在的关系。

9 “ (……) 这样就出现了共和派老革命若昂 - 波尔热斯的第一个建筑物, 在这里开设了一个认捐名册, 用以 资助由萨尔门托 - 德贝雷斯和布里托 - 帕伊斯实现的第一次飞往澳门航空之旅, 并在飞行员的英勇行为之 后, 在此处举行了晚宴致敬他们。直至今日, 还可以看到一块瓷砖, 在瓷砖上, 这一事迹光辉永存。” (内格朗, 引自: 33-34页)。
} 
truído $^{5}$, que se situava num lugar hoje arrasado, a umas escassas dezenas de metros do teatro Maria Vitória, que ainda hoje mantém as portas abertas ao público ${ }^{6}$.

Situado numa esquina, com dois pisos e um telhado de quatro águas, o restaurante do Borges era um edifício simpático ${ }^{7}$, com quatro portas convidativas e um par de janelas no piso térreo, havendo então por lá uma parreira, debruçada sobre as entradas, para tornar mais alegre o ambiente do lugar. No primeiro andar, rematado por uma marquise numa das extremidades, havia um janelão estreito com um pequeno varandim e cinco janelas, diante dos quais se postavam meia dúzia de mastros, ligeiramente tombados para fora, como sentinelas sempre alerta para embandeirar a casa nos dias festivos. Tudo coroado por um friso, na parte superior, junto ao telhado, onde uma sucessão policroma de gatos pintados sobre ladrilhos cerâmicos definia o espírito que se queria no interior daquela casa, ao invocar a natureza anarquista de Os Gatos, de Fialho d'Almeida, obra então muito em voga, e com os quais a alma insurgente do dono daquele espaço poderia muito bem identificar-se para, também ele, proclamar ao mundo a máxima daquele controverso escritor: «miando pouco, arranhando sempre, não temendo nunca ${ }^{8} »$. Postura que estaria certamente de acordo com a maneira de ser de muita da clientela que, em 1924, frequentava aquele espaço: jornalistas republicanos, jovens militares, músicos, fadistas, boémios e outra gente que vivia no mundo da noite.

Este foi um espaço que, em tempos mais recentes, também eu frequentei amiudadamente, entregue ao feitiço do passado, com o livro de Beires na mão, mais para experimentar o que o mutismo das suas paredes teria para me dizer na palidez agónica dos anos oitenta do século XX (quando confrontado com a pré-ruína do espaço) do que para mitigar o apetite nas propostas banais da ementa, que, então, já em nada se pareciam com os caprichos pantagruélicos da «apetecida ceia», por lá servida no tempo do saudoso Borges, quando ali foi inaugurada uma lápide ${ }^{9}$ para enaltecer o lugar «no qual foi aberta uma subscrição para custear a primeira

The chamassem bombista. Por falta de dinheiro, nunca nenhum deles ficou sem a apetecida ceia. [...]. Às vezes, para pagar a ceia - ou fugir de a pagar —, a rapaziada, entre anedotas do Nascimento Fernandes e ditos de espírito da Beatriz [Costa] ou do Álvaro de Almeida, embrenhava-se em furiosa batota, com dados baratos, numa improvisada banca francesa. Um dia, chegou ao Torel palacete situado no jardim do mesmo nome, onde, a partir de 1927, se instalou a Polícia de Investigação Criminal uma denúncia sobre a existência de um casino clandestino, algures no Parque Mayer. A Judiciária montou um serviço especial e, de madrugada, assaltou o restaurante do João Borges, onde se decidia acaloradamente quem seria a «vítima» da ceia, dos dados e da noite. Os agentes ficaram perplexos. Os «batoteiros» eram todos conhecidos e alguns até amigos. Imperturbáveis, os jogadores "fizeram frente» à Policia com um ultimato: «Ou vocês entram também no jogo, e se arriscam a pagar a ceia, ou então...rua!» E a verdade é que alguns deles até ficaram!

${ }^{5}$ João Borges (...) - o primeiro a abrir um restaurante de pedra e cal no Parque (...). In NEGRÃO, op. cit.: 101.

${ }^{6}$ Ainda em funcionamento, o teatro Maria Vitória é hoje a última testemunha dos tempos áureos do Parque Mayer.

${ }^{7}$ Edifício simpático, então pintado de cinzento azulado escuro, quando o frequentei, pouco antes de 1990.

${ }^{8}$ Foi meu Avô, nascido em 1905, e que em tempos também frequentara assiduamente aquele espaço nocturno da cidade, quem me alertou para a relação existente entre os gatos do friso do Borges e «Os Gatos» da obra literária de Fialho.

${ }^{9}$ «[...] Surge então a primeira construção do velho revolucionário republicano, João Borges — no qual foi aberta uma subscrição para custear a primeira viagem aérea a Macau, realizada por Sarmento Beires e Brito Pais (sic), e onde aqueles aviadores, após a sua proeza, foram homenageados, durante um jantar. Ainda hoje lá se pode ver um azulejo que perpetua a memória do glorioso feito» (NEGRÃO, op. cit.: 33-34). 
次飞往澳门的航空之旅, 并且在这些飞行员的英勇行为后, 在此处举行的晚宴 向他们致敬。10”

那时, 我也可以引用专栏作家阿尔巴诺 - 辛克 - 内格朗的话并且告诉所有人: “直到今天, 还可以看到那块把光荣事迹永远镌刻的瓷砖” ${ }^{11}$, 还能够向好奇的人们 展示它。这块 “瓷砖” 实际上是一块蓝白色的长方形小型镶板, 由大约六块或许更 多块 ${ }^{12}$ 小瓷板组成, 精美的边框围着中间的一小段文字。据我所记, 在那个小小的 饭厅一堵破旧的墙壁中间一一今天已经被拆掉了, 其中心位置贴着戏剧杂志的旧 海报, 上面演员们明亮的脸庞上洋溢着欢快的笑容, 被遗忘的黑暗早已裉去。

还得补充一句一一因为我看到了并拍了下来一一在餐馆外面, 斜倚着大门还 有一个首航澳门的纪念物。那是一个灰浆抹的椭圆形纪念碑, 边框上是花卉图案, 中心部分有说明文字。这是个没有明显价值的物件, 因此没有能够逃开二十一世 纪初那拆毁奄奄一息的梅耶公园的铁锤一一但对于那些倾心于围绕着这段历史的 地点、背景和环境的人们来说, 它具有无可争议的价值。碑上不仅包含着对葡萄 牙飞行员出色的空中技巧的敬意, 它还让当时光顾这个里斯本餐馆的客人以及后 来者记起, 这个餐馆在那次令人难以置信的成功飞行中所扮演的角色, 所做出的的 奉献; 此外, 也让人记起曾发生在这里的庆祝仪式。那也还是在 1924 年 $^{13}$, 当三位英 雄回到自己的祖国后, 他们来到这个餐馆, 在许多战友、支持者们和朋友们的簇拥 下参加向他们致敬的晚宴, 还要加上 “葡萄牙人民对这一庄严、勇敢和非凡事业所 表现出的热情洋溢与敬佩之声。14”

对今天来说, 这是一个历史成就, 在武艾拉市, 它曾以一个自主活动的形式被 特别庆祝 (活动以向布里托 - 帕伊斯代表的三位飞行员 “致以问候” 开始, 为他们 1924年9月22日市政会议纪要上记载的赞誉和获得的承认而举杯欢庆 ${ }^{15}$ )。此处, 我 们还要强调一个事实, 那就是: 当时阿马多拉这个共和国航空中队所在地, 行政上 是属于武艾拉市的，所以武艾拉市政厅在同一仪式上授予了他们 “博爱和奉献奖 章”, 以表彰他们为祖国和人类做出的英雄行为和奉献。

\footnotetext{
${ }^{10}$ 内格朗, 引自: 33-34页。

11 内格朗, 引自: 34页。

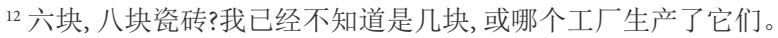

13 根据阿尔巴诺 - 内格朗的说法 (引自: 84页), 在里斯本, 1924年是 “是 ‘波西米亚精英”喜爱法朵的时代。如 果不到梅耶公园与‘先生们’和‘法朵歌手们’相聚, 简直是一个非常糟糕、没有享受的夜晚。”

14 关于这句话, 很好地说明了当时第一次葡萄牙-澳门空中之旅的周围情况, 见注 18 。

15 在原始档案中记录号为 485 号, 这封信上当时的武艾拉市执行委员会主席写给安东尼奥 - 雅辛多 - 达席尔

瓦 - 布里托 - 帕伊斯-一里斯本, 其内容如下: 1924年9月22日, 市议会 尊敬的先生 $(\cdots \cdots \cdot)$
} 
viagem aérea a Macau, realizada por Sarmento Beires e Brito Paes, e onde aqueles aviadores, após a sua proeza, foram homenageados, durante um jantar» ${ }^{10}$.

Nesse tempo, também eu podia fazer minhas as palavras do cronista Albano Zink Negrão e repetir aos quatro ventos que «ainda hoje lá se pode ver um azulejo que perpetua a memória do glorioso feito»" ${ }^{11}$, conseguindo então mostrá-lo à curiosidade alheia. "Azulejo», que era de facto, um pequeno painel rectangular azul e branco, constituído por meia dúzia de unidades - ou talvez um pouco mais ${ }^{12}$ - , com uma cercadura de fantasia e um breve texto no centro. Tanto quanto o recordo, estava a meio de uma das paredes gastas daquela pequena sala de refeições, hoje demolida, num lugar central, ladeado por velhos cartazes de revistas teatrais, onde luziam caras alegres e sorrisos animados que a obscuridade parda do esquecimento há muito esmoreceu.

Acrescento ainda - porque a vi e fotografei - , que também do lado de fora, debruçada sobre a porta da rua, existia uma memória da primeira viagem aérea a Macau. Uma lápide em escaiola, de forma oblonga posta ao alto, com motivos florais na moldura e uma legenda no campo central. Peça sem valor palpável, que não foi poupada pelo camartelo que desvirtuou o moribundo Parque Mayer na alvorada do século XXI - mas que era de incontestável valia para quem se apega aos lugares, contextos e ambientes que giram em torno desta história. Nela, não só se rendia ufana homenagem à gloriosa proeza aérea levada a cabo pelos insignes aviadores portugueses, como se recordava, aos então frequentadores daquele espaço lisbonense e aos vindouros, o papel nesse tempo ali devotado ao sucesso da inédita viagem, assim como a consagração que por lá acontecera, ainda nesse ano de $1924^{13}$, quando, de regresso à pátria, os três heróis se apresentaram naquele restaurante para confraternizar, num jantar de homenagem que lhes fora dedicado, com muitos dos seus camaradas de armas, apoiantes e amigos, que assim se juntavam ao «coro de geral entusiasmo e admiração de que está possuído o povo português, por um tão digno, corajoso e extraordinário empreendimento ${ }^{14}$ ».

Este feito, hoje histórico, foi particularmente festejado no concelho de Oeiras, com uma iniciativa autónoma (que se iniciou com um «voto de saudação» dirigido aos três aviadores na pessoa de Brito Paes, brinde de reconhecimento e júbilo que foi exarado na acta da sessão de 22 de Setembro de $1924^{15}$ ) e à qual damos aqui ênfase pelo facto de, nesse tempo, a localidade da Amadora, onde estava sediado o G.E.A.R., pertencer administrativamente ao con-

\footnotetext{
${ }^{10}$ NEGRÃO, op. cit.: $33-34$.

${ }^{11}$ NEGRÃO, op. cit.: 34.

${ }^{12}$ Seis, oito azulejos? Não sei já quantos teria, ou que fábrica os produziu.

${ }^{13}$ E, segundo Albano Negrão (op. cit.: 84), em Lisboa, neste ano de 1924 «era o tempo, em que a "elite" boémia gostava do fado. Noite em que não se fosse até ao Parque, para um encontro entre "senhores" e "fadistas", era noite mal passada, não vivida».

${ }^{14}$ Sobre esta frase, bem ilustrativa daquilo que então se vivia em torno da primeira viagem aérea entre Portugal e Macau, vd. nota 18.

${ }^{15}$ Registado na origem com o n. ${ }^{\circ} 485$, este ofício, que foi dirigido pelo Presidente da Comissão Executiva da Câmara Municipal do concelho de Oeiras a António Jacinto da Silva Brito Paes - Lisboa, tem o seguinte teor:

Paços do Concelho aos 22 de Setembro de 1924

Exmo. Senhor $[\ldots]$
} 
尽管各地都有点自发的活动, 但是欢迎三位飞行员的庆祝活动根本上是由葡 萄牙航空俱乐部承担的, 国家并没有为推广这些活动出力, 因为这次前往澳门的飞 行完全是私人行为。因此, 今天看来, 这个俱乐部的活动不仅仅是推动并支持当时 来说是难以置信的飞行, 还要为适当地接待三位飞行员做准备。接待活动按照严 格的军事标准提前准备, 以便让所有人和所有一切在那令人无比期待的、飞行员 们到达里斯本的时刻完全就绪。尽管与自封的 “庆祝委员会” 有直接关系的人们 做出了努力而且焦急万分, 但直到1924年上半年之初, 飞行员们到达的确切日期都 没人清楚。这个委员会位于古老的帕梅拉宫 ${ }^{16}$, 航空俱乐部与当时已经富有盛誉的 葡萄牙汽车俱乐部共享他们的总部。

航空俱乐部与军事航空部队密切合作, 为这次成功飞抵澳门贡献良多, 并继 续致力于葡萄牙航空事业的发展。在这次飞行取得令人崇拜的成绩的欢乐时光, 它又采取了这项举动，让全国人民欢欣鼓舞一一这只能归于葡萄牙人民慷慨的灵 魂, 这种心情可以在委员会发给当时的《殖民地宪报》负责人的信件文本中得以 体会:

里斯本, 1924年7月25日

致: 里斯本新闻日报路44号一楼

尊敬的“殖民地宪报”主任

我们正在组织一个委员会, 以便在英雄的飞行员布里托 - 帕伊斯和萨尔门

托・德贝雷斯以及机械师戈维亚先生到达后进行接待活动。

当他们回到祖国时, 迎接仪式不仅应该具有绝对的爱国主义色彩, 因为这是 我们祖国历史上最大的成就之一, 而且还应拥有极高的人气, 这样我们才能向这 些如此荣耀了葡萄牙美名的人们表达自己的敬意。

由执行委员会代表的武艾拉市市政厅在有关会议纪要上向阁下以及您无畏的同伴们致以问候, 祝贺你们 刚刚取得的辉煌成就, 你们不但将葡萄牙的名字提到如此高度, 还极大地激发了爱国热情。我们这个行政 机构诠释了整个理事会的感受, 伴随着葡萄牙人民一起, 对于这一庄严、勇敢、非凡事业抱有极大的热情 和敬佩之情。

此次会议还决定向阁下以及这次光荣的 “里斯本一澳门突袭” 著名的组织者们授予 “博爱和奉献奖章”, 这是 本市政厅创建的奖章以表彰为祖国和人类做出的奉献和英雄行为。

我怀着极为高兴和崇敬的心情向您传达本市政厅的这个决议。

此致敬礼

执行委员会主席

(参见马特乌斯, 引自: 94页)

转录的文件来自费尔南多 - 布里托 - 帕伊斯工程师的私人档案, 他是安东尼奥 - 布里托 - 帕伊斯的儿子; 我们拥有它并将其交给了葡萄牙空军历史档案馆。移交时, 大卫 - 奥利维拉将军在场, 当时他担任空军档 案馆的总监察职务。

16 这幢建筑物位于里斯本卡列里斯广场29号。 
celho de Oeiras, cujo município também lhes concedeu, nesse mesmo instante, a medalha de «Mérito Filantropia e Dedicação», com a qual galardoava os «feitos de heroísmo e dedicação pela Pátria e pela Humanidade».

Embora espontaneamente vividos um pouco por toda a parte, os festejos de acolhimento aos três aviadores foram assumidos de raiz pelo Aero Club de Portugal, que os gizou sem contar que o Estado os promovesse, posto que a viagem aérea a Macau se devera unicamente à iniciativa privada. Assim, verifica-se hoje que coube à actividade deste clube, não só o papel de promover e apoiar esta viagem, até então inédita, mas também o de preparar a condigna recepção dos três aviadores. Tal acolhimento foi delineado com rigor e antecipação militar, para que tudo e todos estivessem prontos no tão aguardado momento da sua chegada a Lisboa, cuja data exacta se desconhecia ainda no início do segundo semestre de 1924, apesar do esforço e da impaciência daqueles que estavam directamente ligados à auto-denominada «comissão dos festejos», constituída no antigo palácio Palmela ${ }^{16}$, onde este clube partilhava a sua sede com o já prestigiado Automóvel Clube de Portugal.

O Aero Club, que tanto se empenhara no êxito da viagem a Macau - em estreita conivência com a Aviação Militar —, prosseguia assim o seu compromisso na senda do progresso da aviação portuguesa, com mais esta iniciativa, na hora feliz do seu desfecho apoteótico, para que o país se regozijasse na exultação pública de um acontecimento grandioso, que só à alma generosa dos portugueses se devera, tal como se percebe pelo texto desta carta, então expedida por aquela colectividade para o director da Gazeta das Colónias:

\section{Lisboa 25 de Julho de 1924}

Illm. ${ }^{\circ}$ e Exm..$^{\circ}$ Snr. Director da «Gazeta das Colónias», Rua Diário de Notícias 44 $-1 .^{\circ}$ Lisboa.

Illm. ${ }^{\circ}$ e Exm. ${ }^{\circ}$ Snr.

Estando em organização uma Comissão que tenha a seu cargo a recepção a fazer na chegada dos heróicos aviadores, Brito Paes e Sarmento de Beires e mecânico Gouveia, quando do seu regresso à Pátria, devendo essa recepção ter não só um cunho absoluta-

\footnotetext{
A Câmara Municipal do concelho de Oeiras, representada pela sua Comissão Executiva, deliberou exarar na acta da sessão respectiva um voto de saudação a V. Exa e seus intrépidos companheiros, pelo feito brilhantíssimo que acabam de praticar, levantando tão alto o nome português e elevando tão patrioticamente a nossa Pátria querida. Este corpo administrativo, interpretando o sentir do Concelho inteiro, acompanha o coro de geral entusiasmo e admiração de que está possuído o povo português, por um tão digno, corajoso e extraordinário empreendimento.

Mais me cumpre participar que, na sessão, foi deliberado conceder a V. Ex a e aos notabilíssimos organizadores do glorioso raid "Lisboa Macau» a medalha de "Mérito Filantropia e Dedicação», criada por esta Câmara para galardoar feitos de heroísmo e dedicação pela Pátria e pela Humanidade.

É com o máximo prazer e com a mais fervorosa veneração que comunico a $V$. Exa estas deliberações camarárias.

Saúde e Fraternidade

O Presidente da Comissão Executiva

(Vide MATEUS, op. cit.: 94).

O documento transcrito é proveniente do arquivo particular do engenheiro Fernando Brito Paes, filho de António Brito Paes, e, tendo estado na nossa posse, foi por nós entregue ao Arquivo Histórico da Força Aérea Portuguesa, na presença do General David Oliveira, que nesse tempo exercia as funções de Inspector Geral da F.A.P.

${ }^{16}$ Este edifício situa-se no Largo do Calhariz, 29, em Lisboa.
} 
因此, 这个委员会应该由国家所有的有生团体和力量的代表组成, 所以我请 求阁下任命一位贵报代表, 届时前往卡拉里兹广场29号的葡萄牙航空俱乐部。

向阁下致以崇高的敬意, 并向您表达感谢关心之情。

斯弗卡・杜阿尔特 17

要在那些天妥善地接待三位飞行员的决定也由委员会发起人向里斯本是市 政厅做了通报, 并且得到了下面这个有利的批示 ${ }^{18}$ :

尊敬的葡萄牙航空俱乐部领导机关 (庆祝委员会):

作为对葡萄牙航空俱乐部为致敬飞行员布里托 - 帕伊斯和萨尔门托・德贝 雷斯 ${ }^{19}$ 而组织的庆祝委员会来信的回复, 我谨告知: 已批准在坎普格兰德围出场 地, 用来举行夜间庆祝活动。借此机会, 我还告知庆祝委员会, 为举行接待英雄们 的庆典, 本市政厅在特雷罗巴索广场搭设了一个凉亭。加戈・科蒂尼奥上将和萨 卡杜拉・卡布拉尔抵达时曾在同一地点搭建凉亭。

此致,

敬礼

1924年8月24日市政议会,

执行委员会主席

这些一致意见和其他出于同样目的的答复汇合在一起, 形成了一种长期以来 由葡萄牙人民承担的 “民族凝聚力” 的承诺。

17 这封公函及随后日期为1924年8月2日的 “殖民地宪报” 主任的赞成意见在马特乌斯被转载和拍摄: (同上) 71页。

转录的文件来自费尔南多 - 布里托 - 帕伊斯工程师的私人档案, 他是安东尼奥 - 布里托 - 帕伊斯的儿子; 我 们拥有它并将其交给了葡萄牙空军历史档案馆。移交时, 大卫 - 奥利维拉将军在场, 当时他担任空军档案馆 的总监察职务。

18 第1431号公函, 宗卷15180/24号, 日期为1924年8月29日。有关本文件的更多信息参见马特乌斯, 引自: 71 页。。(注: 来源于费尔南多 - 布里托 - 帕伊斯工程师的私人档案, 他是安东尼奥 - 布里托 - 帕伊斯的儿子; 我们拥有它并将其交给了葡萄牙空军历史档案馆。移交时, 大卫 - 奥利维拉将军在场, 当时他担任空军档案 馆的总监察职务。)

19 请注意, 这里少量机械师曼努埃尔 - 戈维亚的名字。这里的理由可能上因为他不是飞机驾驶员。尽管他 是飞往澳门航空之旅的机组成员, 而且他跟随了几乎所有的飞行路段, 并为飞行成功提供了必不可少的机械 修理服务。这是由于当时的偏见, 也是因为低阶军人的条件把他和 “军官先生们” 区分开来。但布里托 - 帕 伊斯和萨尔门托 - 德贝雷斯不容许这种事, 葡萄牙航空部队、葡萄牙航空俱乐部和许多其他负责致敬的人 都不容许, 他们三个一起出席了所有场合, 得到了应有的掌声。 
mente patriótico, como merece um dos maiores feitos realizados na História pátria, mas a maior popularidade, para podermos manifestar o nosso reconhecimento aos homens que tão alto souberam honrar o nome de Portugal, e devendo, para tal efeito, a referida Comissão ser constituída por representantes de todas as colectividades e forças vivas da Nação, rogo a $V .^{a}$ Exa se digne nomear um representante do jornal que $V^{a}{ }^{a}$ Ex $x^{a}$ tão dignamente dirige, o qual se deverá apresentar no Aero Club de Portugal, Largo do Calhariz no 29.

Com a mais elevada consideração, subscrevo-me

de V. ${ }^{a}$ Ex. ${ }^{a}$ muito atento, venerado e obrigado,

Cifka Duarte ${ }^{17}$

O propósito de receber condignamente estes três aviadores, que, por esses dias, também fora comunicado à Câmara Municipal de Lisboa pelos promotores da comissão, mereceu desta edilidade o seguinte despacho favorável ${ }^{18}$ :

\section{Ex.ma Direcção do Aero Clube de Portugal [Comissão dos festejos]}

Em resposta à carta da Comissão dos festejos organizada pelo Aero Club de Portugal em honra dos aviadores Brito Paes e Sarmento de Beires ${ }^{19}$, informo de que fica autorizada a vedação do recinto no Campo Grande, onde deverá realizar-se o festival nocturno. Aproveitando o ensejo, informo também essa Comissão de que a Câmara está armando no Terreiro do Paço, com destino aos festejos da recepção dos heróis, o pavilhão que, no mesmo local, foi levantado quando da chegada do almirante Gago Coutinho e [de] Sacadura Cabral.

Saúde e Fraternidade

Paços do Concelho, em 29 de Agosto de 1924

O Presidente da Comissão Executiva

Estas concordâncias juntaram-se a muitas outras respostas com o mesmo propósito, para dar curso a um compromisso «de coesão nacional» há muito assumido pelos portugue-

\footnotetext{
${ }^{17}$ Este ofício e o parecer favorável que então mereceu por parte do director da Gazeta das Colónias, datado de 2 de Agosto de 1924, encontram-se fotografados e reproduzidos na íntegra em MATEUS, op. cit.:71.

O documento transcrito é proveniente do arquivo particular do engenheiro Fernando Brito Paes, filho de António Brito Paes, tal como o que se transcreveu na nota 16. Tendo estado também na nossa posse, foi igualmente por nós entregue ao Arquivo Histórico da Força Aérea Portuguesa, na presença do general David Oliveira, que nesse tempo exercia as funções de Inspector Geral da F.A.P.

${ }^{18}$ Ofício n. ${ }^{\circ} 1431$, processo 15180/24, com a data de 29 de Agosto de 1924. Para mais, vide reprodução deste documento in MATEUS, op. cit.:71. (nota: proveniente do arquivo particular do engenheiro Fernando Brito Paes, filho de António Brito Paes, este documento, que esteve na nossa posse, foi por nós entregue ao Arquivo Histórico da Força Aérea Portuguesa, na presença do general David Oliveira, que nesse tempo exercia as funções de Inspector Geral da F.A.P. ${ }^{19}$ Atente-se aqui na ausência do nome do mecânico Manuel Gouveia. Facto que, possívelmente, se justificava, então, com a circunstância de este não ser piloto-aviador. Isto, apesar de ter feito parte da tripulação da viagem aérea até Macau, ao longo de quase todas as suas etapas, e de ter prestado sempre os serviços de assistência mecânica indispensáveis para o sucesso da mesma. Preconceito daquele tempo, era também a condição de militar subalterno que o arredava dos «senhores oficiais», coisa que Brito Paes e Sarmento de Beires não consentiram, tal como a Aviação Militar Portuguesa, o Aero Club de Portugal e muitos outros responsáveis pelas homenagens, que aos três juntaram, em todas as circunstâncias, para o merecido aplauso.
} 
这一事实让斯弗卡 ${ }^{20}$ 以葡萄牙航空部队和他自己的名义发表了一份向葡萄牙 人民 ${ }^{21}$, 表示 “永远的感谢与认可” 的声明。当时, 这份证词是以号外的形式公开流 通的, 其内容如下 ${ }^{22}$ :

值此盛大的全国认捐活动结束之时一一这个活动是为了支持展开里斯本一 澳门空中之旅并得到了人民极为慷慨的支持, 葡萄牙航空部队及我本人在这次 “突袭” 中所经受的痛苦漫长时刻和惶恐都得到了极大的补偿。在此期间，我们 对葡萄牙人民崇高的的爱国主义抱有不可动摇的信念; 如果没有这一点, 我们英 勇的飞行员布里托 - 帕伊斯, 萨尔门托 - 德贝雷斯和机械师戈维亚不可能完成这 项勇敢的壮举。现在, 他们马上就要抵达里斯本, 将接受同胞们热情而公正的欢 迎。在此, 我必须向葡萄牙海内外、巴西和殖民地所有的葡萄牙人民致以我们最 诚挚的感谢, 感谢你们给子了那么多的关爱、鼓励, 甚至做出了牺牲。

因此, 葡萄牙人民啊, 在过去的航海大发现时代你们历经沧桑, 现在依然保持 着无与伦比的美德。在今天这个时代, 我们的航空勇士一一以加戈 - 科蒂尼奥和 萨卡杜拉 - 卡布拉尔为首载入金黄色纪念册的飞行勇士们, 依旧被你们的信念和 金钱深深地理解和支持着，从而实现了这次飞抵澳门之旅; 你们的支持让一架脆 弱且被许多难以形容的危险所笼罩的飞机飞过了广亭无垠的非洲和亚洲沙漠, 还 有无边无际的大海, 越过了旷野, 把古老的印度冒险之梦编进天空, 到达了远东, 给在远方工作的葡萄牙人带去来自都市同胞的声援与赞叹。所以, 葡萄牙人民 啊, 在这庄严的时刻, 你们可以骄傲自豪地回顾这个军事航空部队的另一壮举, 这 是一向具有非凡民族凝聚力的工作, 它完全属于你们, 并将光耀万代。

我们同样也不能忘记葡萄牙和巴西新闻界, 他们知道怎样以明智而爱国的 方式唤醒全国的敏感, 毫无疑问, 他们是这一令人瞩目的成功创举的传令官。

我以飞行员们的名义, 向全国人们表达永恒的感激认可之情。

斯弗卡

20 阿贝尔托・斯弗卡・杜阿尔特少校。

21 如该号外的所述: 在 “国家印刷公司” 报一一里斯本世纪路59号。

22 由马特乌斯引用, 引用自: 47页。 
ses. Facto que levou Cifka Duarte ${ }^{20}$ a publicar um manifesto de «eterna gratidão e reconhecimento» Ao Povo Português ${ }^{21}$, em nome da Aviação Militar Portuguesa e em seu nome, testemunho que então circulou publicamente, sob a forma de folha volante, com o seguinte teor ${ }^{22}$ :

No momento de ser encerrada a grandiosa subscrição nacional, tão galhardamente acolhida pelo povo em favor da viagem aérea Lisboa-Macau, a Aviação Militar Portuguesa e eu próprio encontramo-nos sobejamente recompensados de todas as horas angustiadas e incertas suportadas durante o «raid», embora nunca nos abandonasse a inabalável fé no excelso patriotismo do Povo, sem o qual não era possível o audacioso feito dos arrojados aviadores Brito Paes, Sarmento de Beires e o mecânico Gouveia. Agora que, dentro em breve, com a sua chegada a Lisboa, eles serão relegados à justa e calorosa consagração dos seus concidadãos, cumpre-me consignar publicamente os nossos mais sinceros agradecimentos por tantas provas de carinho, estímulo e até de sacrifício dadas pelo Povo Português de aquém e de além-mar, no Brasil e nas nossas colónias. Este agradecimento dirige-se com o mesmo fervor tanto aos que, mais bafejados pela fortuna, puderam contribuir com importantes quantias, como aos mais humildes que, contribuindo com o seu óbolo, deram o seu integral apoio moral, absolutamente necessário para a efectivação da patriótica empresa que foi o «raid» aéreo Lisboa-Macau.

Por isso, Povo de Portugal, que através de todas as vicissitudes da vida nacional tens mantido intactas as inigualáveis virtudes que fizeram grandes nos tempos passados os Navegadores do Mar e, nos tempos hodiernos, os Navegadores do Ar, cujo Livro de Ouro abre com os nomes de Gago Coutinho e Sacadura Cabral; tu, que tão bem compreendeste e amparaste, com a tua fé e com o teu dinheiro, a realização dessa maravilhosa viagem, permitindo assim que um frágil avião, rodeado de perigos indescritíveis, pudesse voar através dos desertos africanos e asiáticos, mares sem fim, por sobre terras selvagens e, tecendo pelos ares o antigo sonho aventureiro das indias, atingisse o Extremo Oriente, levando aos Portugueses que ali trabalham a solidariedade e admiração dos seus compatriotas metropolitanos; por isso, Povo de Portugal, nesta hora solene de encerramento da Grande Subscrição Nacional que tão generosamente acolheste, podes reverte com desvanecimento e orgulho neste outro feito da Aviação Militar, obra notável da Coesão Nacional que te pertence inteiramente e que com impagável brilho perdurará através dos séculos.

Não podemos também esquecer a Imprensa portuguesa e brasileira, pela forma inteligente e patriótica como soube acordar a sensibilidade nacional, tendo sido seguramente o Arauto para o bom sucesso do Notável Empreendimento.

A todo o país, em nome dos Aviadores, apresento os protestos da nossa eterna gratidão e reconhecimento.

Cifka Duarte

\footnotetext{
${ }^{20}$ Major Alberto Cifka Duarte.

${ }^{21}$ Tal como consta no dito folheto: Comp. E Imp. Na «Sociedade Nacional de Tipografia» - R. Do Século, 59-Lisboa.

${ }^{22}$ Apud MATEUS, op. cit.: p. 47.
} 
这是祖国的认可, 人们为三位飞行员欢呼, 期待着他们能够做出更多壮举, 因 为在实现葡萄牙——澳门空中之旅的那一年, 安东尼奥 - 布里托 - 帕伊斯只有四 十岁 ${ }^{23}$, 若泽 - 萨尔门托 - 德贝雷斯三十二岁 ${ }^{24}$, 曼努埃尔 - 戈维亚三十四岁 ${ }^{25}$ 。命 运让他们走向不同的生活道路, 尽管历经沧桑, 死后命运却没能给他们戴上历史赋 予他们的桂冠……在这些日子里，通过葡萄牙一一澳门第一次飞行之旅这一丰功 伟绩, 我们在这里纪念他们, 这个事实是一个具体的证明。

如今, 当一切以不可思议的速度旋转, 超出了人类理解的时候, 我们应该及时 强调一下这次飞行的目的, 让我们重温1924年7月布里托 - 帕伊斯在澳门演讲中的 几句话 ${ }^{26}$ :

这些飞行永远都有一个目的。我们的飞行也有目的, 这不是一个官方的目 的。如果没人相信! 在葡萄牙, 人们知道, 美国向全世界派出他们的飞机, 带着无 尽的资源; 人们知道, 英国出于同样的目的, 派出了他们最好的一个团队; 而从法 国, 最杰出的飞行员将飞往日本。当在葡萄牙有人说: “我们也去! 我们不用像他 们那么渴望, 只要有一半就能去澳门!”所有人都笑了。可以吗?没有引擎也没有 飞机可以试验……疯狂啊…… (说的就好像飞行只需要飞机和引擎似的……)

根据睿智的加戈 - 科蒂尼奥上将 ${ }^{27}$ 所言, 这些人一一只有这些人肩负着 “在这 些历史停留的瞬间, 向世界展示现在的葡萄牙人不再掩饰自己的民族传统, 葡萄牙 航海船队的船长和水手后代变成了飞行员, 在葡萄牙保存了同样古老的进步和文 明的圣殿骑士传统。” 这些历史的停留点今天已经超越了简单的地理位置, 成了直 接或间接与第一次葡萄牙一澳门航空之旅有关的地方。有时, 在一些地点, 时间的 无形和地理的有形重叠在一起, 赋予这次壮举一种归属感, 它是如此抽象, 就像 “祖 国” 概念中所凝聚的那样; 它又是如此具象, 就像 1924 年 4 月的一个清晨, 一架飞机 从葡萄牙起飞, 飞往一个记忆中叫澳门的地方。

\footnotetext{
23 安东尼奥・布里托・帕伊斯出生于 1884 年。

24 若泽・萨尔门托・德贝雷斯出生于1892年。

25 曼努埃尔・戈维亚出生于1890年。

26 马特乌斯, 同一著作引用: 95页, 注解10。

27 库蒂尼奥, 1924年: 17-18页。
} 
Era o reconhecimento universal da pátria portuguesa, que aclamava, assim, três homens de quem muitos feitos ainda se esperava, pois, no ano do voo entre Portugal e Macau, António Brito Paes tinha apenas quarenta anos de idade ${ }^{23}$, José Sarmento de Beires, trinta e dois ${ }^{24} \mathrm{e}$ Manuel Gouveia, trinta e quatro ${ }^{25}$. O destino, que se encarregou de lhes dar diferentes caminhos em vida, não conseguiu regatear-lhes na morte os louros merecidos que a História lhes concedeu, apesar de todas as vicissitudes... E o facto de, nos dias que correm, os recordarmos aqui através da grande façanha que foi a primeira viagem aérea entre Portugal e Macau é disso uma prova concreta.

Actualmente, quando tudo gira a velocidades impensáveis, que estão para lá da compreensão humana, afigura-se oportuno sublinhar a finalidade desta viagem, recuperando as palavras de Brito Paes num discurso pronunciado em Macau, em Julho de $1924^{26}$ :

Têm sempre estas viagens um fim. A nossa tem-no também. Não um fim oficial. Se ninguém acreditava! Sabia-se em Portugal que a América mandava à volta do mundo os seus aviões com recursos ilimitados; sabia-se que a Inglaterra enviava para o mesmo fim uma das suas melhores equipes. Da França, um dos melhores pilotos iria ao Japão. E quando em Portugal alguém disse: «Também nós! Não tentamos tanto como os outros, metade basta, iremos a Macau!», toda a gente ri. Pode lá ser? Não há motores nem aviões a experimentar... loucura... [como se para voar fossem precisos só motores e aviões].

Coube aos homens, e só a estes — segundo as palavras do sábio almirante Gago Coutinho ${ }^{27}$ — «demonstrar nessas paragens históricas que os portugueses de agora não desmentem as tradições da sua Raça, e que os descendentes dos capitães e marinheiros das naus se tinham tornado aviadores, mantendo a Portugal os mesmos velhos foros de paladino do Progresso e da Civilização». Paragens históricas que são hoje todos os lugares que transcendem os simples locais físicos directa ou indirectamente relacionados com a primeira viagem aérea entre Portugal e Macau. Sítios onde a imaterialidade do Tempo se sobrepõe, por vezes, àquilo que de corpóreo e palpável há na Geografia, para conferir a esta façanha um sentimento de pertença identitária, tão abstracto como aquele que se cristaliza na noção de Pátria, e simultaneamente tão concreto como aquele avião que partiu de Portugal, numa manhã de Abril de 1924, rumo a um lugar da memória que se chama Macau.

\footnotetext{
${ }^{23}$ António Brito Paes nasceu em 1884,

${ }^{24}$ José Sarmento de Beires nasceu em 1892.

${ }^{25}$ Manuel Gouveia nasceu em 1890.

${ }^{26}$ MATEUS, op. cit.: 95, nota 10.

${ }^{27}$ COUTINHO, 1924: 17-18.
} 


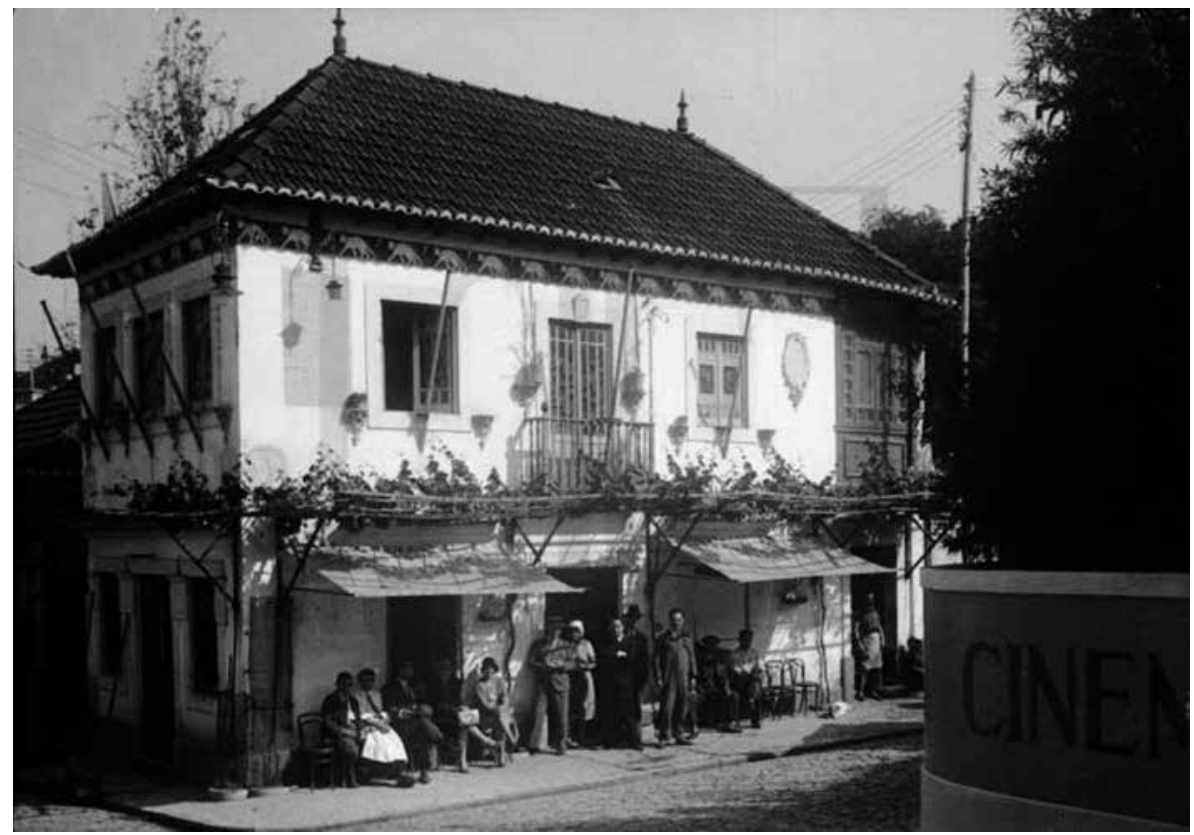

梅耶公园，“老革命若昂 - 波尔热斯的餐馆” 在若泽 - 萨尔门托 - 德贝雷斯和安东尼 奥・布里托经常光顾时的样子。(来源http://restosdecoleccao.blogspot.com/2014/11/ parque-mayer.html)。

\section{引用参考书目}

贝雷斯，J. 萨尔门托・德, 1925年。“从葡萄牙到澳门 (“祖国号”之旅)”。

库蒂尼奥, 加戈 (1924) “里斯本一一澳门奔袭 (圣保罗执行委员会报告)”, 1924年: 17-18页。

马特乌斯, 洛伦索・恩里克・恩里克斯 (1999年), “祖国号”首航后75年”,里斯本: 单版。

内格朗, 阿尔巴诺・辛克, 1969年, “梅耶公园”, 里斯本: 新闻社论出版社。

佩伊斯图, M - 莱莫斯, 1980年, “在千泉新城停留的从阿马多拉到中国之旅”。载于 “阿马多拉历史上的 人与飞机”, 1980年10月。

“航空杂志” 254期: 161页。 


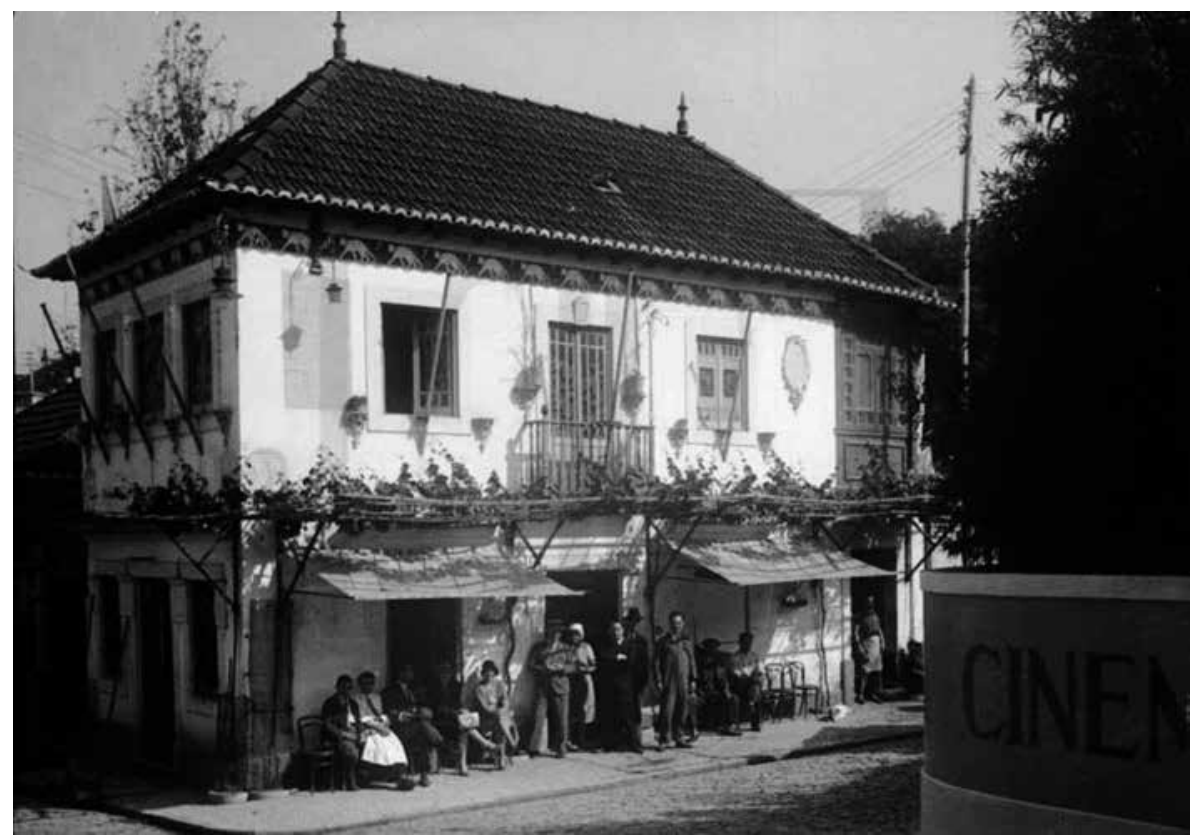

Parque Mayer: «Restaurante do velho revolucionário João Borges» tal como deveria estar no tempo em que foi frequentado por José Sarmento de Beires e António Brito Paes (origem. http://restosdecoleccao. blogspot.com/2014/11/parque-mayer.html)

\section{BIBLIOGRAFIA CITADA}

BEIRES, J. Sarmento de (1968) - De Portugal a Macau (A viagem do Pátria). Porto: Imprensa Social da Cooperativa do Povo Portuense.

COUTINHO, Gago (1924) - Raid Lisboa-Macau. Relatório da Comissão Executiva de S. Paulo. S. Paulo, pp. 17-18.

MATEUS, Lourenço Henrique Henriques (1999) - Na esteira do Pátria 75 anos depois. Lisboa: Edições Única.

NEGRÃO, Albano Zink (1969) - O Parque Mayer. Lisboa: Editorial Notícias.

PEIXOTO, M. Lemos (1980) - «Da Amadora à China com paragem em Milfontes». In Homens e aviões na história da Amadora. Amadora: Câmara Municipal da Amadora, Serviços de Acção Social e Cultural.

REVISTA DO AR, separata do n. ${ }^{\circ} 254$, p. 161. 



\title{
DE PORTUGAL A MACAU (A VIAGEM DO PÁTRIA)
}

\author{
从葡萄牙到澳门 \\ (“祖国号”之旅)
}





\section{DEDICATÓRIA \\ 献词}


致布里托・帕伊斯

已经不在了的忠实伙伴, 这是我们已被删除的旅行记忆最终的版本。

1953年8月

$\mathrm{S}$. 德贝雷斯 
A BRITO PAES,

leal e querido companheiro ausente, a edição definitiva destes apagados restos da nossa viagem.

Agosto, 1953

S. de B. 



\section{DEDICATÓRIA DA PRIMEIRA EDIÇÃO 第一版 献词}


这是一些不太准确的回忆, 是 “祖国号”之旅那些难忘的时光给我带来的回忆一一这本书 只不过是我个人印象的记录, 我们穿过非洲和亚洲那遥远的天空, 从中可以瞥见曾经历过的、许 多极富戏剧性的瞬间。

这一页页的文字组成了一份完全情绪化的记录, 八十天的惊疑、惶恐而艰苦卓绝的斗争 形成了这份不完美的结晶, 它属于葡萄牙人民, 属于祖国, 我把这本书献给他们一一献给葡萄牙 的人民!

献给葡萄牙人民, 正是从他们当中我们获得了极大的力量, 从而战胜了一切; 献给葡萄牙人 民, 在前往澳门的飞行中, 他们强大的能量和热情为澳门之旅作出了巨大的贡献, 让葡萄牙的名 字光芒闪耀。 
Recordações imprecisas que a memória reteve através das horas inolvidáveis da viagem do Pátria este livro não é mais do que o despreocupado apontamento das minhas impressões pessoais, vislumbradas por entre os instantes de dramaticidade intensa que vivemos, singrando os céus longínquos da África e da Ásia.

Essas páginas, que constituem um documentário quase exclusivamente emocional, na cristalização imperfeita de oitenta dias de incerteza, de inquietação, de luta árdua e esgotante, ao Povo de Portugal pertencem, a Ele as dedico.

\section{AO POVO DE PORTUGAL!}

Ao Povo de quem recebemos a força magnética que nos fez triunfar: ao Povo que, na afirmação formidável da sua energia e do seu entusiasmo, concorreu para que, na viagem aérea a Macau, o nome de Portugal se aureolasse de um prestígio maior. 
……我们的飞行有两个目的。

第一: 作为军官和爱国者, 我们需要去澳门, 那是葡萄领土中的一块土地, 正是这片土地激 发了卡蒙斯的灵感, 写出了不朽的“卢西塔尼亚人之歌”。

我们来到了这里。

第二: 众所周知, 所有的国家都在致力于开展大型航空旅行, 葡萄牙航空也不可能对此麻木 不仁, 无动于衷, 它也要保证不间断地参加大型比赛。

这个目的也达到了。

葡萄牙航空的基督十字架标志与北美之星标志在中南半岛的上空交相辉映。在印度, 我们 在英国测绘用的两栖飞机上方飞过, 并从那里飞向巴格达, 向法国的三色徽章致以问候。

布里托・帕艾斯 (选自1924年6月在澳门发表的一篇演讲) 
... A nossa viagem tinha dois fins.

Primeiro: sendo nós oficiais do Exército e patriotas, precisávamos de vir a Macau, terra portuguesa entre as terras portuguesas, onde Camões se inspirou para escrever Os Lusíadas.

Aqui estamos.

Segundo: sabendo-se que todas as nações se empenhavam na realização de grandes viagens aéreas, a Aviação Portuguesa não podia permanecer apática e indiferente e cumpria-lhe não deixar de participar condignamente na grande competição.

Atingimo-lo também.

A Cruz de Cristo cruzou na Indochina com as estrelas norte-americanas. Na Índia, voou sobre o avião anfíbio que a Grã-Bretanha mandou a descrever a circunferência da Terra, e lá para as bandas de Bagdad, saudou a cocarde tricolor da França.

BRITO PAES

(Palavras de um discurso pronunciado em Macau, em Julho de 1924) 
对于葡萄牙飞行员来说, 澳门之旅是什么?

如佩尔蒂埃. 窦昔 ${ }^{1}$ 那样, 开着任何一架飞机, 在三个助手的帮助下一一也许这 三个助手并不专业, 五天里飞行近九千英里, 这相当于葡萄牙到罗安达或者到里约 的往返距离, 是环球飞行距离的一半。

他们要面对无法预料的风险, 从海洋、沙漠和荒凉的土地上空飞过, 同时还要 躲开那些不适合着陆的地方。

在飞往马德拉群岛的空中长途飞行中, 飞行员们已经证明: 他们无比坚韧, 荦 视死亡, 终于战胜了强风、迷雾、沙尘、季风和赤道地区的炎热。

葡萄牙国旗上的盾牌在地中海的上空，在埃及、阿拉伯、印度、孟加拉、暹 罗、中国等地的上空出现, 最后终于到达了葡萄牙在海外最遥远的殖民地。在这 些历史性的停留中, 作为大航海时代船长和水手们的后裔, 如今的葡萄牙人用另一 种方式来保持着他们大航海时代的辉煌, 他们成为飞行员, 继续维持着对葡萄牙海 外殖民地的管理。

前往澳门的航空之旅取得了巨大的实际效果, 它的成功对于唤起我们的骄傲 与钦佩是至关重要的; 所有的一切, 特别是葡萄牙航空, 他们独特的基督十字架标 志被如此荣耀, 我得说: 我们所有人都应该感谢这些英勇的军官们!

里斯本, 1924年10月

卡古・科迪尼奥 “长途飞行”里斯本一一澳门 (圣保罗执行委员会报告), 第17页, 18页

\footnotetext{
1 乔治・佩尔蒂埃・窦昔 (1892年-1953年) 是一位法国航空飞行员。他是飞行先驱, 他被称为 “Pivolo”, 据彭 德尔 (Pendellé) 称, 这个绰号来自一句他总是劝说飞行员们的、被讹用的话: Puis vole haut (意为 “然后飞高”)。 在1924年成功完成巴黎-东京空中突袭之后, 他变得非常有名。(编者注)
} 
O que foi a viagem a Macau dos aviadores portugueses?

Com um aeroplano qualquer - um coucou como the chamou Pelletier-Doisy ${ }^{1}$-, e com o auxilio popular a três homens, que, esses, não eram três homens quaisquer, foram, num total de cinco dias, voadas nove mil milhas, ou seja a ida e volta a Luanda ou ao Rio de Janeiro, quase a metade da volta ao mundo.

Eles afrontaram riscos de que não e fácil fazer ideia, voaram sobre o mar, sobre desertos, sobre terras inóspitas, enfim sobre regiões onde seria impraticável a aterrissagem.

Com a mesma tenacidade e desprezo pela Morte de que já tinham dado provas no «raide» à Madeira, venceram ventos, nevoeiros e areias, monções e calores tropicais.

Ostentando as Quinas Portuguesas, por sobre o Mediterrâneo, o Egipto, a Arábia, a Índia, Bengala, Sião, a China, e atingindo por fim a Colónia Portuguesa mais longínqua, eles foram demonstrar, nessas paragens históricas, que os portugueses de agora não desmentem as tradições da sua Raça, e que os descendentes dos Capitães e Marinheiros das naus se tinham tornado aviadores, mantendo a Portugal os mesmos velhos foros de paladino do Progresso e da Civilização.

Pelos tão elevados resultados práticos da viagem aérea a Macau, cujo sucesso tão fundamente despertou o nosso orgulho e a nossa admiração, todos - e em especial a Aviação Portuguesa, cujo distintivo, a Cruz de Cristo, eles tanto honraram - todos, digo, devemos gratidão a tão valorosos e heróicos oficiais.

Lisboa, Outubro de 1924.

GAGO COUTINHO In «Raid» Lisboa-Macau. (Relatório da Comissão Executiva de S. Paulo), pp. 17 e 18.

\footnotetext{
${ }^{1}$ Georges Pelletier-Doisy (1892-1953) foi um piloto francês, pioneiro da aviação, a quem chamavam Pivolo, alcunha que, de acordo com Pendellé, era uma corruptela da frase com que sempre aconselhava os aviadores: Puis vole haut (depois voa alto). Tornou-se famoso ao realizar com sucesso, no ano de 1924, o raide aéreo Paris-Tóquio. (Nota do editor).
} 


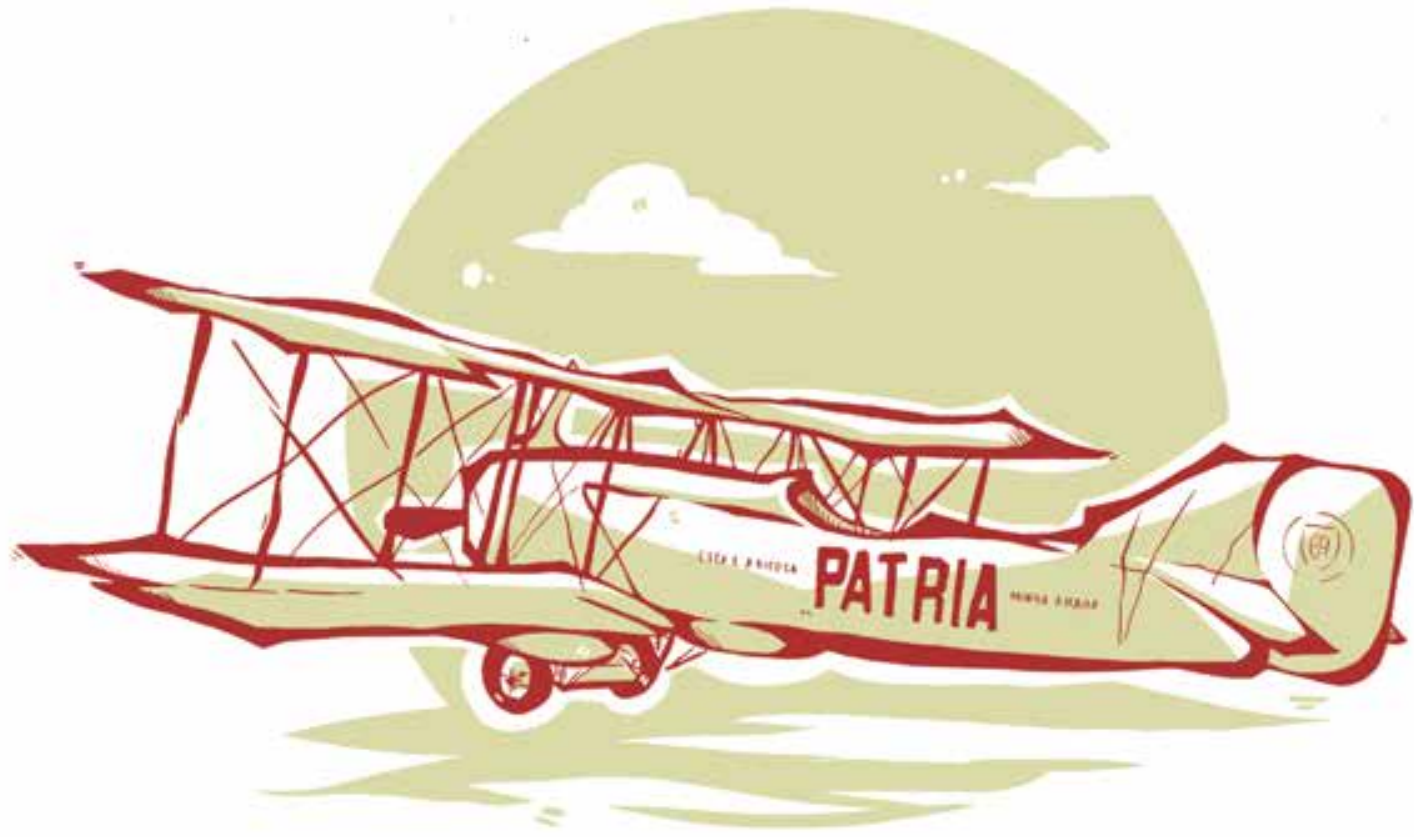




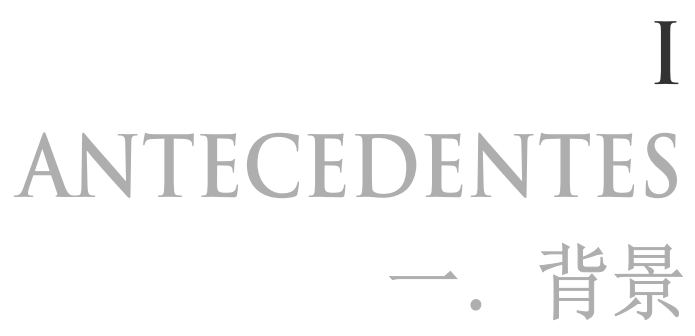


1920年十月一个寒冷的午后, 我们很信任的一架飞机一一“黑色骑士号” 坠 入了大西洋底。那天, 我们在海面上空飞行了 150 公里后, 遇到了飞行员可怕的敌 人一一浓雾, 它使得我们无法在马德拉群岛降落。当时, 我们已经在马德拉群岛的 上空盘旋了几分钟。终于, 这架飞机在离里斯本400公里处坠毁。

救了我和布里托 - 帕伊斯的冈比亚河号 1 。

当时的海军航空兵指挥官阿丰索 - 塞尔奎拉在瓜迪亚娜号驱逐舰 2 上说的 话。他们乘瓜迪亚娜号在特茹河口救起了丧失了希望的我们一一奖金是由查尔 斯 - 布莱克 ${ }^{3}$ 提供的, 将由雅尔丁 - 达 - 科斯塔和皮内罗 - 科雷亚上尉以及乐维 本萨白特少尉决定订购, 以购买可以远距离飞行的飞机。

这一切发生在当年的 12 月。

我和布里托 - 帕艾斯就飞机种类问题进行了咨询。在认真研究了各种机型 的特点之后, 我们得出结论, 认为布雷盖夜间轰炸机是迄今为止最符合条件的飞机, 因为它不仅使用了安全可靠的雷诺300CV发动机, 还因为它的有效载重量也符合条 件。

我们和军官们谈了我们的想法, 购买飞机的步骤立刻就启动了。

1921年6月, 在经过一些小波折后, 飞机终于进入了阿马多拉飞机库, 然后立即 开始安装、调配并准备投入使用。

在葡萄牙共和国空军中队的机械师和装配师的帮助下, 经我们指导, 曼努埃 尔 - 戈维亚和弗朗西斯科 - 德索萨开始了他们的工作。为减轻飞机重量, 他们卸 载了飞机上我们不需要的军事装备, 同时为增加飞机的飞行距离, 又加装了几个咜 油箱。

组装工作终于在八月底完成了。布里托 - 帕艾斯为飞机选了名字, 并在机身 处刻上了“卢济塔尼亚人之歌” 里的一句:

这就是我的挚爱, 被祝福的“祖国”

\footnotetext{
1 找到布里托 - 帕伊斯和萨尔门托 - 德贝雷斯飞机的英国舰船名称, 当时正泊在北纬 35 度西经 13 度离里斯 本500公里处。(编者注)

2 敏捷、操作能力极强的战舰 (驱逐舰), 其功能曾为护送较大的船只, 使它们免受外部攻击。(编者注)

3 查尔斯 - 亨利 - 布莱克 (1877年- - 1934年) 是一位英国运动家, 他与当时的著名工商企业关系密切。他 是葡萄牙壳牌石油的创始人, 是葡萄牙汽车协会的股东, 他还与托尔拉德斯商业公司有关。他练习马术、击 剑、自行车、赛车、帆船和飞行。他是向葡萄牙政府提出第一个公路维修项目的人。布莱克还是里斯本 海军俱乐部 (1911) 的一名准将, 他整合了葡萄牙奥林匹克委员, 并于1922年出资让葡萄牙参加了奥运会。 查尔斯 - 布莱克是查尔斯 - 伊杜阿尔多 - 布拉克的父亲, 查尔斯 - 伊杜阿尔多 - 布拉克是葡萄牙航空的先 驱, 也是葡萄牙第一位民航飞行员。(编者注)。
} 
O Cavaleiro Negro - o avião que, em mil novecentos e vinte, a nossa confiança arrastara, por uma tarde friorenta de Outubro, para o fundo do Atlântico - naufragara a quatrocentos quilómetros de Lisboa, depois de ter percorrido mil e quinhentos quilómetros sobre o mar, impedido pelo nevoeiro - esse terrível inimigo dos aviadores - de aterrar na ilha da Madeira, em cujo céu pairou alguns minutos.

O Gambia River ${ }^{1}$ salvava-me e a Brito Paes.

As palavras pronunciadas pelo comandante Afonso Cerqueira, então director da Aeronáutica Naval, a bordo do destroyer ${ }^{2}$ "Guadiana», que na foz do Tejo nos recolhia depois do acidente em que tinham soçobrado as nossas esperanças - e o prémio oferecido por Charles Bleck ${ }^{3}$ - iam determinar a subscrição levada a efeito pelos capitães Jardim da Costa e Pinheiro Correia e alferes Levy Bensabat, com o produto da qual deveria adquirir-se novo aparelho destinado a longa viagem.

Passava-se isto em Dezembro do mesmo ano.

Consultados, Brito Paes e eu, sobre o tipo de avião que preferíamos, concluímos, depois de estudadas as características de vários tipos, que o aeroplano Breguet de bombardeamento nocturno era, à data, aquele que melhores condições oferecia, não só pela segurança comprovada do seu motor Renault $300 \mathrm{CV}$, como pela carga útil que podia transportar.

Comunicada a nossa decisão aos oficiais comissionados, as diligências para a compra do avião foram imediatamente iniciadas.

E em Junho de mil novecentos e vinte e um, depois de alguns contratempos, o aparelho entrava nos hangares da Amadora, começando imediatamente a proceder-se à sua montagem e adaptação.

Manuel Gouveia e Francisco de Sousa, sob a nossa direcção, efectuavam com auxílio de mecânicos e montadores do Grupo de Esquadrilhas de Aviação República os trabalhos necessários para aliviar o avião de toda a carga militar inútil e instalar alguns reservatórios suplementares que lhe aumentassem o raio de acção.

Em fins de Agosto, terminada a montagem, Brito Paes escolhia-lhe o nome, mandando inscrever na tela da fuselagem o verso dos Lusíadas:

\section{ESTA É A DITOSA PÁTRIA MINHA AMADA.}

\footnotetext{
${ }^{1}$ Nome do navio inglês que localizou o avião de Brito Paes e Sarmento de Beires, que havia amarado a $35^{\circ}$ Norte e $13^{\circ}$ Oeste, a uma distância de quase $500 \mathrm{Km}$ de Lisboa. (Nota do editor).

${ }^{2}$ Navio de guerra (contratorpedeiro) ágil e de grande capacidade de manobra, cuja função era a de escoltar navios maiores, defendendo-os de ataques externos. (Nota do editor).

${ }^{3}$ Charles Henry Bleck (1877-1934) foi um desportista inglês muito relacionado com empresas e sociedades comerciais e industriais de grande prestígio no seu tempo. Foi fundador da Shell portuguesa, director e sócio da Sociedade Portuguesa de Automóveis e esteve ligado à sociedade comercial Torlades. Praticou hipismo, esgrima, ciclismo, automobilismo, vela e aviação. Foi da sua autoria o primeiro projecto de reparação de estradas proposto ao governo português. Bleck foi comodoro no Club Naval de Lisboa (1911), integrou o Comité Olímpico português e, em 1922, custeou do seu bolso a participação de Portugal nos Jogos Olímpicos. Charles Bleck foi pai de Charles Eduardo Bleck, pioneiro da aviação portuguesa e primeiro aviador civil português. (Nota do editor).
} 
9月22日清晨, “祖国号” 进行了它的第一次试飞一一在里斯本郊区上空飞行了 约 30 分钟, 然后又回到了飞机库。如果 11 月的台风没有残忍地毁坏它, 它本应等待 一个好时机, 再次臮翔于天空。

在12月 8 日召开的技术委员会会议中, 当时的军用航空主管, 攻读过参谋课程 的骑兵中校一一安东尼奥 - 玛利亚 - 德弗雷塔 - 苏亚雷斯先生在阐明了这架飞机 的用途并得到了一些委员会成员的支持; 之后会议通过了安东尼奥 - 玛亚上校的 方案: “祖国号”飞机的维修费用将由国家承担。

由于向制造厂商申请的修复材料迟迟没有拿到, 修复工作一直到 1922 年 6 月才 开始进行。

里斯本至里约热内卢之旅被甘谷 - 果提尼奥和萨卡杜热 - 卡布拉两人光荣 地完成了, 这就把我们最初的跨越大西洋计划搁置到了一边。

当 “祖国号” 将要重生之际, 我们产生了一个想法: 飞往印度, 这将是一次具有 历史意义的飞行。晚些时候, 这个飞行计划的目的地延伸到了澳门。我们的心愿 是：让这次旅行成为一次准备, 为那些环球飞行的人所做的准备。因为在中国, 葡 萄牙共和国的颜色不仅要在古老的葡萄牙城市得以彰显, 还要让香港、广东和上 海等具有国际影响的地区相信葡萄牙人的的果敢、䬥智和富于开创的精神 4 。

按照我们选择的路线, 经过改装的 “祖国号” 可以很容易地完成从葡萄牙千泉 新城到澳门之间的航程——如果可以这样表述航班性质的的话。航线将被分成十 六段, “祖国号” 每次飞行2500多公里。

1923年初, 负责募集基金用来购买飞机的委员会决定, 将飞机捐赠给国家。在 4月 4 日举行的技术委员会会议中, 航空局局长主持讨论了我们准备将 “祖国号” 用 作长途飞行的申请, 该提案被与会人员表决通过。同时还批准了在同等情况下, 如 有其他申请人提出申请, 我们的申请拥有优先权。

几天后, 我们提交了报告, 航空局局长把它正式提交给了当时的战争部部长 ${ }^{5}$ 。

\footnotetext{
${ }^{4} 1910$ 年第一共和国成立后, 葡萄牙国旗改变了颜色和图案, 从君主制的蓝白色国旗变成了现在的葡萄牙国 旗。葡萄牙希望在国外确认自己的新形象。展示新国旗项目委员会由作家和政治家阿贝尔・博泰略, 画家 哥伦巴诺・博尔达洛 - 皮涅罗, 海军军官安东尼奥 - 拉迪斯劳・帕雷拉, 陆军军官若泽・阿丰索・德帕拉 以及记者及政治家若昂 - 沙加斯组成。最终选择的图案是由哥伦巴诺・博尔达洛 - 皮涅罗, 若昂 - 沙加斯 和阿贝尔・博泰略设计的。

5 那时是费里亚上校先生
} 
E na manhã de vinte e dois de Setembro, o Pátria efectuava o seu primeiro voo - trinta minutos sobre os arredores de Lisboa -, dando de novo entrada no hangar onde deveria aguardar a boa época para partir, se o tufão de Novembro seguinte o não tivesse ferido barbaramente.

Era então director da Aeronáutica Militar o tenente coronel de cavalaria com o curso de Estado Maior, Sr. António Maria de Freitas Soares, e, na reunião da Comissão Técnica que teve lugar no dia oito de Dezembro, depois de exposto o fim a que o avião se destinava e de defendida por alguns membros, foi aprovada a proposta do Sr. capitão António Maya, para que as reparações do Pátria fossem custeadas pelo Estado.

Só em Junho de mil novecentos e vinte e dois essas reparações se iniciaram, em virtude da inexplicável demora havida na remessa do material solicitado à firma construtora.

A viagem Lisboa-Rio de Janeiro, que gloriosamente estava sendo efectuada nessa ocasião por Gago Coutinho e Sacadura Cabral, levara-nos a pôr de parte o primitivo projecto de tentar a travessia do Atlântico Sul.

Enquanto o Pátria ia renascendo, surgia em nós a ideia de ir à Índia, dada a finalidade histórica de tal viagem, que mais tarde se alongava, em projecto, até Macau, na aspiração de a transformar simultaneamente numa preparação para aqueles que empreendessem a volta ao mundo e ainda porque, na China, as cores da República, veneradas não só na secular cidade portuguesa, mas também em Hong Kong, Cantão e Xangai, teriam desta forma oportunidade para se afirmarem, mais uma vez, nessa zona de influência internacional, como as de um país cheio de energia, vitalidade e espírito de iniciativa ${ }^{4}$.

A distância que separa Vila Nova de Milfontes de Macau, segundo o itinerário por nós escolhido, poderia facilmente - se é que em voos desta natureza pode empregar-se tal expressão - ser transposta em dezasseis etapas pelo Pátria, que, com as modificações introduzidas, ficara dotado de uma autonomia de mais de 2500 quilómetros.

Em princípios de 1923, porém, a comissão que angariava fundos para a compra do aparelho resolvia oferecê-lo ao Estado, e na reunião da Comissão Técnica de 4 de Abril o Sr. Director da Aeronáutica punha em discussão o requerimento em que pedíamos para utilizar o Pátria numa viagem de longo curso, requerimento cujo deferimento foi aprovado pelos membros presentes, que concordaram em conceder-nos a prioridade, em igualdade de circunstâncias com possíveis pretendentes futuros.

Poucos dias depois, o nosso relatório era apresentado, e o Sr. director da Aeronáutica havia por bem enviá-lo a Sua Ex. ${ }^{a}$ o ministro da Guerra ${ }^{5}$.

\footnotetext{
${ }^{4}$ A bandeira portuguesa tinha mudado o seu grafismo e cores, depois da implantação da República, em 1910. À bandeira monárquica azul e branca sucedeu a actual bandeira portuguesa. Portugal queria afirmar a sua nova imagem no estrangeiro. A comissão para a apresentação de um projeto para a nova bandeira foi constituída pelo escritor e político Abel Botelho, pelo pintor Columbano Bordalo Pinheiro, pelo oficial da Armada António Ladislau Parreira, pelo oficial do Exército José Afonso de Pala e pelo jornalista e político João Chagas. O desenho final escolhido foi da autoria de Columbano Bordalo Pinheiro, João Chagas e Abel Botelho. (Nota do editor).

${ }^{5}$ À data, o Sr. Coronel Freiria.
} 
然而意外发生了…...

局长详尽描述了报告, 部长审核了之后, 答复我们: 我们的航程将被作为海军 航空兵的环球飞行。

就我们计划的实施, 战争部和航空局进行了几轮激烈的讨论。

几周后, 战争部答复: 该计划将在第一次内阁会议上讨论。

八次内阁会议过去了。

内阁首长曾向议员安东尼奥 - 玛雅承诺, 一旦报告提交, 战争部部长就会签发 飞行许可, 但他后来却食言了, 说不再参与此事。

时间如流水般逝去…...

直到有一天, 战争部长改变了决定, 他在报告后面批复:

“在不耗费国家财产的前提下, 同意仅可使用航空局已有的资源。”

但是在批复下来的几天后, 部长又要求内阁会议本着对飞行负责的精神, 召集 技术委员会一起召开会议, 并澄清以下几点:
a) 飞行的可行性;
b) 完成飞行的保障;
c) 若 “祖国号” 损坏, 其它可继续完成飞行的飞机;
d) 若遇到故障需修复, 飞行途中可利用的航空资源;
e) 飞行的负责单位。

技术委员会在1923年7月9日召开会议, 部长阁下也出席了会议, 同时出席会议 的还有:

・参谋部中校费塔斯・索亚雷斯先生;

- 骑兵队少校、飞行员席福卡・杜阿尔特先生 ${ }^{7}$;

・炮兵少校佩雷拉・果提纽先生;

・骑兵上尉、飞行员里贝罗・达丰塞卡先生;

• 步兵上尉、飞行员布里托・帕艾斯先生;

\footnotetext{
6 还是费里亚上校

7 斯弗卡 - 杜阿尔特是葡萄牙的骑兵军官和航空先驱。他是里斯本一澳门空中突袭的伟大发烧友和推动者, 他以非凡的活力和坚㓞为此辩护并提供协助。在里斯本一一澳门空中穿越进行时, 他担任军事航空局局 长。(编者注)
} 
E as surpresas começaram...

Sua Ex. ${ }^{a}$ o ministro, depois de compulsado o nosso trabalho, favoravelmente informado pelo Ex. ${ }^{\text {mo }}$ director da Aeronáutica, respondia que a viagem seria considerada quando o fosse a de circum-navegação aérea da Aviação Marítima.

Dava-se uma troca de notas entre o Ministério da Guerra e a Direcção da Aeronáutica, que pugnava pela realização da nossa tentativa.

E o Ministério da Guerra respondia, ao fim de algumas semanas, que o projecto seria discutido no primeiro Conselho de Ministros a reunir.

Oito conselhos passaram.

Sua Ex. ${ }^{a}$ o Presidente do Ministério, que prometera ao deputado António Maya obter do Ex. ${ }^{\text {mo }}$ ministro da Guerra a autorização necessária para que a viagem fosse empreendida logo que o relatório estivesse elaborado, declarava impolítico mexer no assunto.

E o tempo ia desfiando o seu interminável rosário de horas...

Um dia, porém, Sua Ex. ${ }^{a}$ o ministro da Guerra ${ }^{6}$ mudou de resolução, lançando no relatório o seguinte despacho:

«Autorizado, sem dispêndio para a Fazenda Nacional, apenas utilizando os recursos disponíveis da Aviação».

Mas... alguns dias mais tarde, depois de concedida a autorização, Sua Ex. ${ }^{\mathrm{a}}$, que - julgo o Conselho de Ministros responsabilizara pela viagem, convocava uma reunião da Comissão Técnica para se esclarecer sobre os seguintes pontos:

a) Possibilidades práticas de realização da viagem;

b) Garantias de conclusão da viagem;

c) Aviões utilizáveis no caso de se avariar o avião Pátria;

d) Recursos aeronáuticos, no percurso, em caso de avaria susceptível de reparação;

e) Qual a entidade que se responsabilizava pela viagem.

Esta Comissão reuniu no dia nove de Julho de 1923, no gabinete e na presença de Sua Ex. ${ }^{a}$ o ministro, tendo assistido os seguintes oficiais:

- tenente-coronel de Estado-Maior, Sr. Freitas Soares;

- major de cavalaria, aviador, Sr. Cifka Duarte7;

- major de artilharia, Sr. Pereira Coutinho;

- capitão de cavalaria, aviador, Sr. Ribeiro da Fonseca;

- capitão de infantaria, aviador, Sr. Brito Paes;

\footnotetext{
${ }^{6}$ Ainda o Sr. Coronel Freiria.

${ }^{7}$ Cifka Duarte foi oficial de cavalaria e pioneiro da aviação em Portugal. Foi um grande entusiasta e promotor do raide Lisboa-Macau, que defendeu e auxiliou com extraordinário dinamismo e tenacidade. Na altura da travessia aérea, ocupava o cargo de director da Aeronáutica Militar. (Nota do editor).
} 
- 工兵上尉、航空兵马里奥・弗朗萨先生;

- 骑兵中尉、飞行员卡斯特罗・卡布里塔先生。

我在战争部门外焦急等待着布里托 - 帕艾斯, 他出来后告诉了我这场特别会 议的经过。

会议是从最后一点开始讨论的。

布里托 - 帕伊斯宣布自己负责最多可达十万埃斯库多 ${ }^{8}$ 的飞行费用, 因为根据 部长阁下的问题, 可以推断可以使用军事航空局费用的授权已过期, 而政府也婉拒 了我们报告要求的十五万埃斯库多。

关于 “祖国号” 可能发生的、不可修复的损毁问题, 布里托 - 帕艾斯认为: 如 果可以, 就在飞行途中的任何一个国家再申请一架飞机来继续完成飞行, 但波斯和 缅甸除外。他同时还提出了使用任意一架国家空军小分队的布雷盖XIV-A2型飞机 的可行性。

接着，他们开始讨论关于飞行资源的问题。布里托 - 帕艾斯说，在阿尔及利 亚、叙利亚、突尼斯、越南东京以及暹罗, 飞行器所用的材料与 “祖国号” 相似: 而 在的黎波里、伊拉克和印度, 也有英国空军的装备中心; 因此可以说飞行资源是丰 富的。

大家就可能发生的损坏以及资源补给进行了讨论, 但却不能达成一致。

部长阁下最后谈到了第一点: 飞行的可行性。

在最后分析、投票后，只有布里托 - 帕艾斯一人认为计划是可行的。技术委 员会的所有成员中, 唯一继续保持其原有态度的是里贝罗 - 达丰塞卡上尉。

在这种情况下, 战争部部长 ${ }^{9}$ 满意了, 他废除了原先签发的授权许可; 这样, 只有 内阁会议可以签发新的授权许可, 然而一直到七月底此事依然杳无音讯。

然而, 必须要出发了。如果不发生那些事情, 之前援助我们买飞机的出资人所 出的资助, 是足够支持我们的飞行的。

因此, 尽管面临诸多反对, 我们仍然决定申请尝试进行第一段航程。

战争部部长 ${ }^{10}$ 咨询了技术委员会的意见; 委员会成员在 8 月 3 日召开会议, 否决 了试飞第一段航程。投票中, 只有少校席福卡 - 杜阿尔特先生和中尉塞尔吉奥 达席尔瓦投了赞同票。

\footnotetext{
8 折合现在的五百欧元。(编者注)

9 永远是费里亚上校先生

10 临时为安东尼奥・玛利亚 - 达席尔瓦先生。
} 
- capitão de engenharia, aerosteiro, Sr. Mário França;

- e tenente de cavalaria, aviador, Sr. Castro Cabrita.

Brito Paes, que eu esperava ansiosamente à porta do Ministério, contava-me, ao sair, o que fora essa extraordinária reunião.

Começara por discutir-se o último ponto.

Brito Paes declarara responsabilizar-se pelas despesas da viagem até à contingência de Esc. $100000 \$ 00^{8}$, visto que, da pergunta de Sua Ex. ${ }^{\text {a } ~ o ~ m i n i s t r o, ~ s e ~ d e p r e e n d i a ~ t e r ~ c a d u c a d o ~}$ a autorização para que elas fossem custeadas pelas verbas da Aeronáutica Militar, e que o Governo recusava, implicitamente, os Esc. $150000 \$ 00$ solicitados no nosso relatório.

Sobre aviões a utilizar em caso de acidente irreparável do Pátria, Brito Paes, depois de demonstrar que, se tivesse meios, poderia adquirir um avião em qualquer dos pontos do percurso, à excepeção da Pérsia e da Birmânia, expôs a possibilidade de utilizar qualquer dos aviões Breguet XIV-A2 do Grupo de Esquadrilhas de Aviação República.

Passou-se à questão dos recursos aeronáuticos. Brito Paes informou que, na Argélia, na Síria, na Tunísia, no Tonquim e no Sião, o material empregado era do tipo semelhante ao do Pátria; e que, na Tripolitânea, no Iraque e na Índia, havia grandes centros de aviação ingleses; que, consequentemente, os recursos eram abundantes.

Contraditaram-se tais facilidades com este argumento espantoso: a possibilidade de sabotage. E a discussão resultou, evidentemente, estéril.

Sua Ex. ${ }^{\mathrm{a}} \mathrm{o}$ ministro abordou finalmente o primeiro ponto: possibilidades práticas de realização da viagem.

E, em última análise, ao proceder-se à votação, só Brito Paes admitiu a viabilidade do projecto. De todos os membros da Comissão Técnica, um único se conservava coerente com a sua atitude anterior: o capitão Ribeiro da Fonseca.

Nestas condições, Sua Ex. ${ }^{\text {a }}$ o ministro da Guerra ${ }^{9}$ dava-se por satisfeito e suspendia a autorização concedida, fazendo depender nova autorização de uma reunião do Conselho de Ministros que, até fins de Julho, se não efectuou.

Era, porém, necessário partir. Se outras causas não existissem, a nossa situação moral perante os subscritores que tinham concorrido para a compra do avião bastaria para nos forçar a esgotar todos os recursos susceptíveis de nos permitir levar avante a realização da viagem.

Foi por isso que, mau grado tantas contrariedades, decidimos então pedir autorização para tentar a primeira etapa.

Sua Ex. ${ }^{a}$ o ministro da Guerra ${ }^{10}$ consultou a Comissão Técnica; e os seus membros, reunidos no dia três de Agosto, entenderam que a primeira etapa também não devia ser tentada. Votaram favoravelmente, apenas, os Srs. major Cifka Duarte e tenente Sérgio da Silva.

\footnotetext{
${ }^{8} \mathrm{O}$ equivalente, na moeda actual, a quinhentos euros. (Nota do editor).

${ }^{9}$ Sempre o Sr. Coronel Freiria.

${ }^{10}$ Interinamente, o Sr. António Maria da Silva.
} 


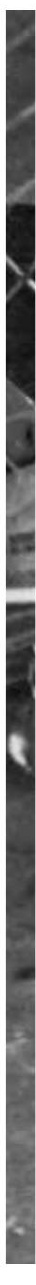




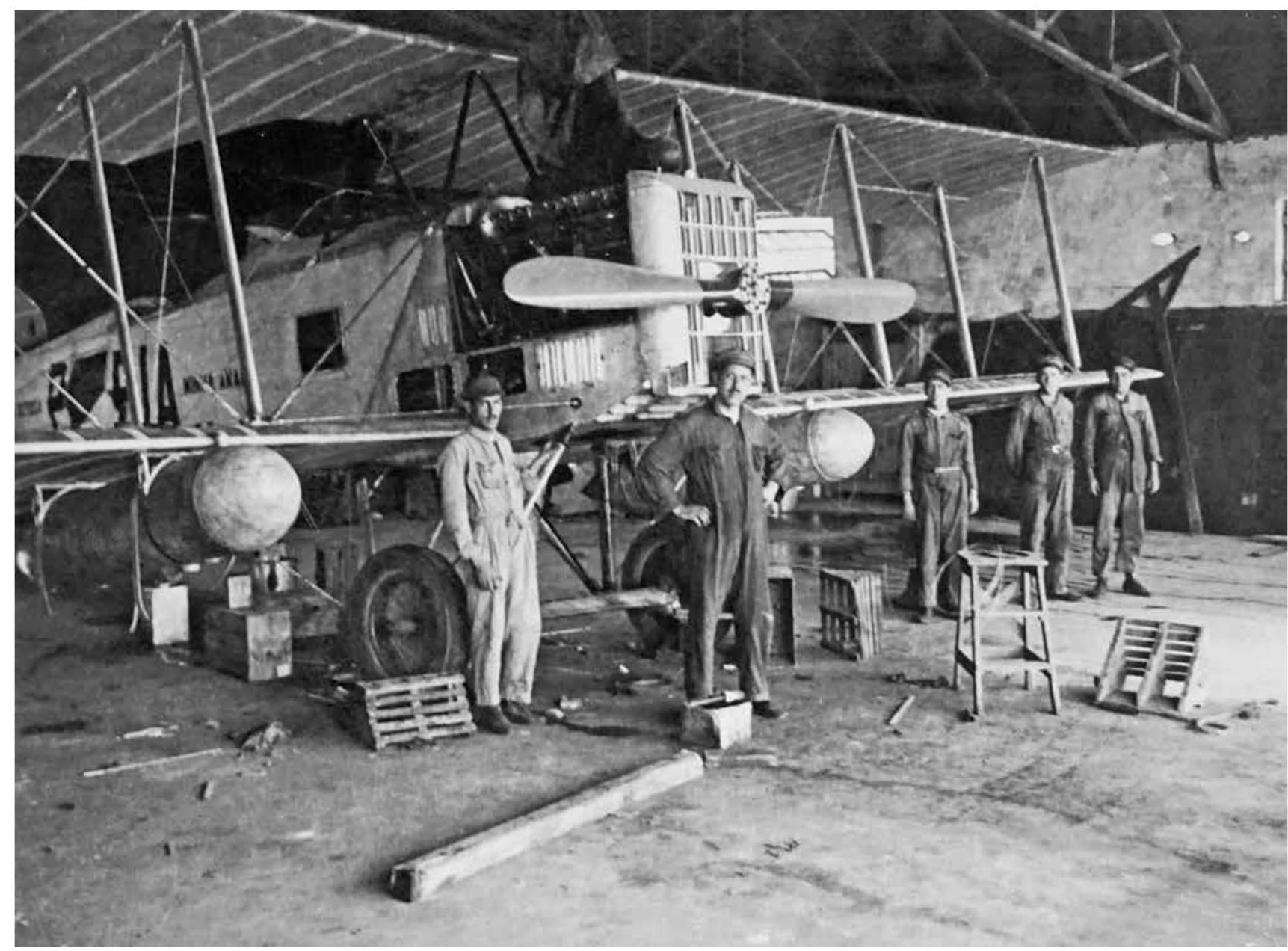

Preparando o Pátria na Amadora: Manuel Gouveia (ao centro e em primeiro plano) e restantes mecânicos 在阿马多拉准备 “祖国号”飞机: 曼努埃尔・戈维亚 (前面中间) 和其他机械师 
考虑到委员会上呈的报告, 部长阁下也许联系到以前所发生的一切, 这次并没 有听从委员会的意见,而是批准了我们的请求。

因此 “祖国号” 全体人员的第一站将是飞往突尼斯的首都突尼斯市。

这是一个几长而令人厌倦的故事，但是有必要澄清一些关于我们与政府间的 流言 ${ }^{11}$ 。当时的战争部长阿梅利哥 - 奥拉夫先生当着议会声称, 我们不曾向国家做 出任何要求的时候, 我们正为到达澳门的飞行得以进行而竭尽全力。

终于, 飞机要起飞了。

经过了一个多月, 在6月28日早上, 戈维亚进行了试飞。但发生了严重的事故, 我们几乎丧命, 而飞机也再次严重损坏。因为降落幅度过大以及飞机机身负载重 量分配的不合理, 飞机着陆时急速下降在了人烟稀少的地方, 机头损毁严重。新一 轮维修马上开始了, 工人们马不停蹄地赶工, 而我们也在为了我们的飞行许可而不 停交涉, 戈维亚和索萨几乎从没休息过。

终于, 我们战胜了所有的艰难险阻, 安东尼奥 - 玛雅也给我们搞到了外交护 照。

10月26日, “祖国号” 在试飞行了一个小时零五分种后, 降落在千泉新城。

现在, 大家都反对我们的想法。充满期待的三周过后, “祖国号” 在11月20日回 到了阿马多拉。我们本想在夏天圣・马尔提纽节出发的想法泡汤了。

布里托・帕艾斯的妹妹玛丽雅 - 多赛乌是一个心性急躁、爱做梦的人, 她认 为我们的飞行是一场吸引人的冒险。她总是给予我们信任。她在阿兰特茹省组织 了一群妇女, 大家一起联名给国家上书, 以期帮助我们获得许可。这群妇女的热情 可称为 “葡萄牙精神”。

马里奥 - 卡斯特罗 ${ }^{12}$, 维南休 - 德莫莱斯 ${ }^{13}$ 和其他一些朋友在收集捐赠, 这些 施舍中蕴含着必胜的萌芽。

\footnotetext{
${ }^{11}$ 原文为法语。(编者注)

12 无法确认谁是马里奥・德卡斯特罗。(编者注)

13 可以确认的是, 根据若阿金・ $A$-卡马拉 - 曼努埃尔发表在 “阿连特茹专辑: 埃武拉大区” (佩德罗 - 穆拉 利亚主编, 里斯本: 贝雷扎出版社, 1931年, 312页) 上的文章 “埃武拉的新闻业” (由于作者按照时间顺序组 织自己的目录, 该报应该是从1923年开始运作), 他可能是埃武拉学术杂志 “卡尔穆” 的主编之一。(编者注)
} 
Atendendo, porém, ao carácter consultivo da Comissão, Sua Ex. ${ }^{a}$, talvez por sentir as causas de tudo o que ocorrera, passou por cima do parecer da Comissão e deferiu o nosso requerimento.

Foi assim que a tripulação do Pátria foi autorizada a partir... para Túnis.

História longa e fastidiosa, mas necessária para destruir certas afirmações menos verdadeiras sobre as nossas démarches ${ }^{11}$ junto do Governo. Quando o Sr. Américo Olavo, então ministro da Guerra, declarava, em pleno Parlamento, que nada solicitáramos do Estado, durante as horas em que, à custa de mil esforços, íamos avançando no caminho de Macau, por certo desconhecia estes factos.

Entretanto, o avião aprontava-se.

Havia pouco mais de um mês, na manhã de vinte e oito de Junho, ao descolar, com Gouveia, para experimentá-lo, um acidente que poderia ter-nos custado a vida avariara-o de novo seriamente. Devido à demasiada «incidência» e a uma incorrecta distribuição da carga, o Pátria, no momento de largar o solo, «cabrou» bruscamente e caiu desamparado sobre o trem de aterragem, que ficou danificado. As novas reparações iniciavam-se a toda a pressa, acto contínuo, e, enquanto nos debatíamos na luta fatigante para conseguir a autorização, Gouveia e Sousa trabalhavam sem descanso.

Vencidos finalmente todos os obstáculos, António Maya conseguia-nos passaportes diplomáticos.

E no dia vinte e seis de Outubro, o Pátria aterrava em Vila Nova de Milfontes, depois de uma hora e cinco minutos de voo, para realizar os ensaios de carga.

Agora, porém, era o tempo que se opunha aos nossos desígnios. Depois de cerca de três semanas de expectativa, o Pátria regressava à Amadora em vinte de Novembro, e a nossa esperança de aproveitar o Verão de S. Martinho para partir esvaía-se desconsoladoramente.

Maria do Céu, a irmã mais nova de Brito Paes - alma inquieta e sonhadora para quem a viagem representava encanto e aventura, e que, por confiar em nós, no sucesso confiara desde a primeira hora -, abria então uma subscrição no Alentejo, agregando a si um grupo de senhoras - e lançava assim a primeira pedra na subscrição nacional, que depois traduziria o fervor da Alma Portuguesa.

Mário de Castro ${ }^{12}$, Venâncio de Morais ${ }^{13}$ e mais alguns amigos iam colhendo dádivas as esmolas em que latejava embrionariamente a certeza do triunfo.

\footnotetext{
${ }^{11}$ Diligências. (Nota do editor).

${ }^{12}$ Não se conseguiu identificar quem era Mário de Castro. (Nota do editor).

${ }^{13}$ Tanto quanto foi possível averiguar, poderá tratar-se de um dos directores da Revista Académica «O Carmo», em Évora, conforme se pode ler no artigo de Joaquim A. Câmara Manuel, «Jornalismo Eborense», in Álbum Alentejano: Distrito de Évora. Dir. de Pedro Muralha. Lisboa: Imprensa Beleza, 1931, p. 312. Tendo o autor organizado o seu elenco por ordem cronológica, a actividade deste jornal ter-se-á situado pelo ano de 1923 em diante. (Nota do editor).
} 
1月28日，趁着合适的季节，“祖国号” 再次起航飞往千泉新城。在随后的 29 、30、31日, 都进行了同样路程的飞行, 并获得了成功 ${ }^{14}$ 。航空局局长 ${ }^{15}$ 出席并观看 了我们的飞行。

我们的飞行的之旅, 其可行性在设备方面现在可以说疑虑尽消, 成功与否主要 取决于飞行员及运气。

我们在做着最后的准备, 并且还要战胜那些剩下的官僚主义上的困难。

3 月 31 号, 曼努埃尔・戈维亚动身前往突尼斯市。

在这里, 我要特别说一下:这位陪同我们飞行的机械师是我们成功飞行的一个 重要因素; 在众多的质疑声中, 他一直坚定地相信、支持我们, 并一心一意帮助我 们的工作。

出发时, 尽管他不能确定我们是否能够到达目的地, 也不能预知可能发生的危 险, 但仍然热心地、全力以赴地帮助我们。

梦想开始变成现实……

\footnotetext{
14 据制造厂商透露, 布雷盖夜间轰炸机已在法国进行过实验, 其每平米表面承重37公斤, 总表面积 73.5 平米, 共能承重2719.5公斤。

从理论上讲 (布雷特轰炸机生产商透露), 实际上每平米承重可达40公斤, 不会对机翼产生任何损坏。

我们的飞机总承重理论上可达到 2800 公斤, 这个数字超过了实验数值。

因此, 机械师曼努埃尔・戈维亚建议我们飞机的每平米承重在39.2公斤。

在千泉新城, 我们的试飞了三次, 分别是:

第一次, 带了860公斤的负荷物。

第二次, 带了1100公斤的负荷物。

第三次, 带了1450公斤的负荷物, 加上飞机本身1350公斤的重量, 在国家空军中队机库中测量其总重量为 2800公斤。

最后一次试飞中, 飞机滑行了 600 米然后起飞, 飞行了一小时十五分钟, 并且达到最高飞行高度一千米。

15 现在是少校斯弗卡・杜阿特先生。
} 
No dia vinte e oito de Janeiro, aproveitando a quadra favorável, o Pátria largava uma vez mais para Vila Nova de Milfontes, onde nos dias vinte e nove, trinta e trinta e um se realizavam com pleno êxito as experiências ${ }^{14}$, na presença do Ex. ${ }^{\mathrm{mo}}$ director da Aeronáutica ${ }^{15}$, que se dignara assistir.

As possibilidades da viagem ficavam assim demonstradas, quanto ao aparelho. $\mathrm{O}$ sucesso dependia agora de nós e da sorte.

Ultimavam-se os preparativos e venciam-se as derradeiras dificuldades burocráticas.

No dia trinta e um de Março, Manuel Gouveia partia para Túnis.

Seria injustiça imperdoável, não fazer aqui referência especial ao mecânico que nos acompanhou e que foi um dos principais factores do bom êxito; e injustiça tanto maior, quanto é certo que, no meio da indiferença e da desconfiança quase gerais, o seu gesto constituiu um exemplo raro de fé, de idealismo e de dedicação.

Ao partir - no início ignorado, obscuro, da realização da viagem -, ele levava na alma a aspiração fremente de nos ver chegar e um abandono inteiro, absoluto, de toda a sua vida ao empreendimento em que, desinteressadamente, íamos comungar os três.

Era o sonho que começava a transformar-se em realidade...

\footnotetext{
${ }^{14} \mathrm{O}$ avião Breguet de bombardeamento nocturno, segundo comunicação da casa construtora, fora já ensaiado em França, com uma carga de $37 \mathrm{Kg}$ por metro quadrado de superfície sustentadora, ou seja, pois que a sua superfície era de $73,5 \mathrm{~m}^{2}$, uma carga total de $2719,5 \mathrm{Kg}$.

Teoricamente, porém (diziam as informações da casa Breguet), essa carga poderia ir até $40 \mathrm{Kg}$ por metro quadrado, sem perigo de ruptura das asas.

O peso total de $2800 \mathrm{Kg}$ com que pretendíamos levantar voo, se bem que ultrapassando aquele com que a casa construtora já conseguira fazer voar o avião, ficava aquém do limite imposto.

Considerando mesmo a hipótese de conduzir a bordo o mecânico Manuel Gouveia, a carga unitária seria de 39,2 Kg. Em Vila Nova de Milfontes, as experiências a que procedemos constaram de três voos, a saber:

$1 .^{\circ}$ Com $860 \mathrm{Kg}$ de carga útil.

$2 .^{\circ}$ Com $1100 \mathrm{Kg}$ de carga útil.

3. ${ }^{\circ}$ Com $1450 \mathrm{Kg}$ de carga útil, que adicionada ao peso do avião vazio (1350 Kg), verificado nos hangares do Grupo de Esquadrilhas de Aviação República, perfazia o total de $2800 \mathrm{Kg}$.

O avião, na última experiência, rolou 600 metros para descolar e comportou-se normalmente durante $1 \mathrm{~h}$. e $15 \mathrm{~m}$. de voo, em que atingiu, sem dificuldade, a altitude máxima de 1000 metros.

${ }^{15}$ Agora o major Cifka Duarte.
} 


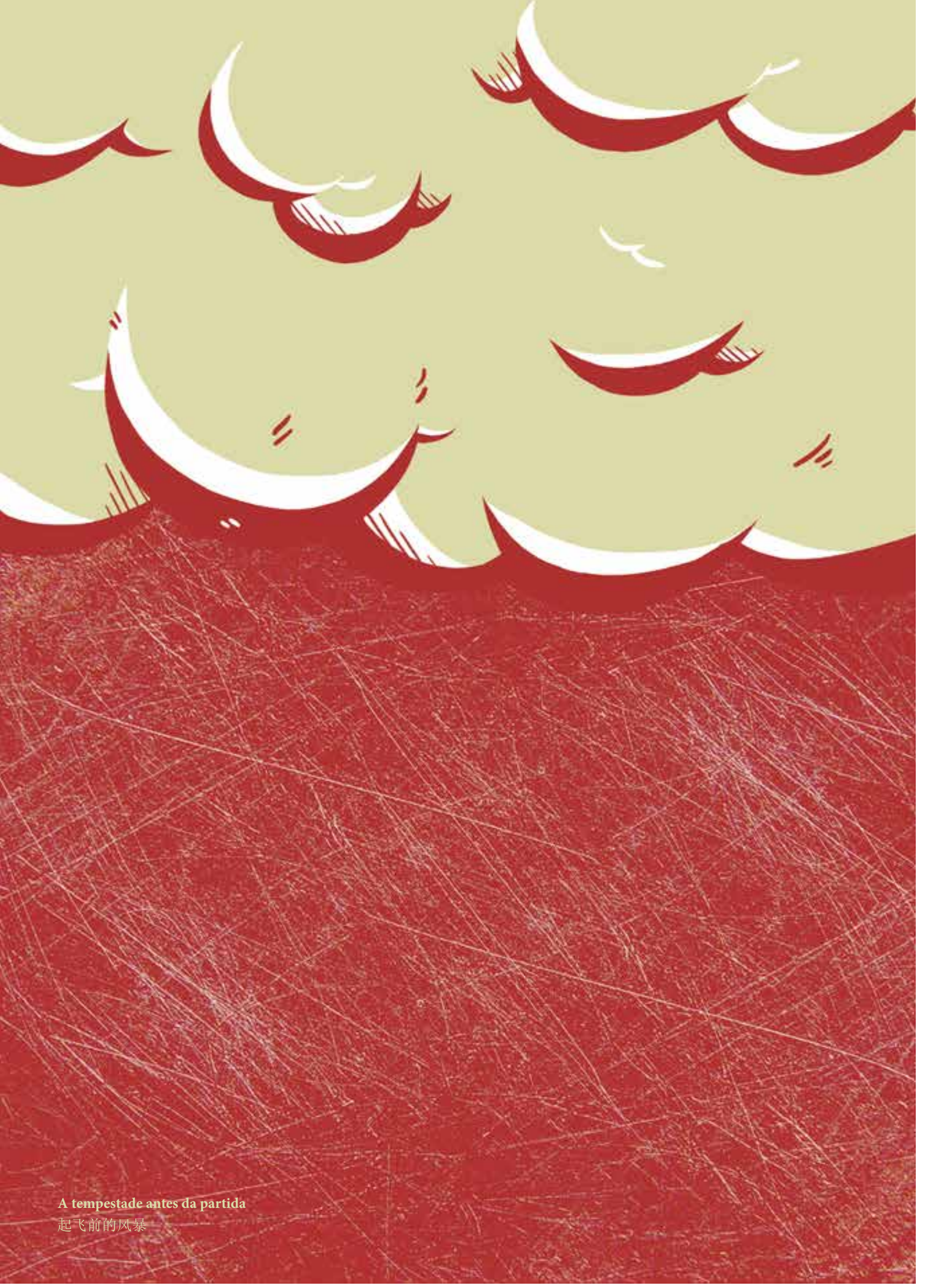




\section{II \\ VILA NOVA DE MILFONTES 二、千泉新镇}


在与阿兰特茹交界处, 一处湿润的小海滩上坐落着二十几座贫苦人家的房子, 它们错落地分布在米拉河口一一这条河安静地亲吻着一座破败的十七世纪城堡那 腐坏的地基。千泉新镇, 这个被很多考古学家认就是当年著名的汉尼拔港的地方, 如今只是一个平静的乡村小角落。这里几乎没被文明触及, 但或许徘徊着对萨格 雷斯角未知的回忆。

铁路距此五十公里。公路则近些, 在十五公里以外......

这里只有蜿蜒的小路, 嵌在峭壁上的洞穴, 河流, 在蓝天的映衬下, 那破碎的山 脉显现出了轮廓; 还有充满大西洋气息的海。

我们选择千泉新镇作为出发点的原因之一, 是因为这件事需要保持低调, 也是 因为我们的资金极其有限。

在里斯本, 人们都对此的表现出不信任、质疑、几近嘲讽的态度。这使得我 们在那里无法把起飞的数据隐藏在公众视线之外。

另一方面, 那条跑道是唯一一条能够确保飞机在满载的情况下安全起飞的跑 道。

而” 祖国号” 的机舱中装了1500升汽油, 这使得它需要宽阔的场地来为此项壮 举比较轻松地进行助跑。

异常隐秘地, 我们为 4 月 2 日离开阿马多拉做好了所有准备。

在起飞的前夜以及在那之前的一夜里, 我们去战争部和外交部进行了觐见, 然 而却没能向各位相关长官递上我们的辞别。第一位没有接见我们; 第二位不在内 塞西达迪什宫。战争部部长阁下的办公室主任也通知我们: 共和国总统阁下已经 表示, 不能应我们向国家元首辞行的要求接见我们 ${ }^{16}$ 。

只有第一陆军司令罗贝尔托 -巴蒂斯塔将军和安东尼奥 - 玛利亚 - 达席尔 瓦工程师接见了我们。他们热情地拥抱了我们并祝我们旅行愉快。

在蓝天、旭日与和风中, 4 月 2 日的早晨来临了。

在此之前我们并没有定下起飞的具体时间, 但是确定了日期。神奇的是, 媒体 竟然向公众宣布我们将在下午四点起飞。这是对我们的一种背叛, 使得我们不得 不按照这个时间来行动。

\footnotetext{
16 尊敬的共和国总统, 曼努埃尔 - 特谢拉 - 戈麦斯先生在1924年9月14日授予我们剑塔荣誉勋章的的前一刻
} 声称, 当时他在 4 月 1 日夜里才收到我们的请求。 
Praiazinha humilde dos confins do Alentejo - duas dúzias de casas pobres, atiradas sem ordem para junto da embocadura do Mira, que beija silenciosamente os alicerces cariados de um arruinado castelo do século XVII -, Vila Nova de Milfontes, que alguns arqueólogos pretendem ter sido outrora o famoso Portus Hannibalis, é hoje um remansoso cantinho provinciano, onde a civilização quase não chegou, mas onde esvoaçam talvez rememorações ignotas do promontório de Sagres.

O caminho-de-ferro fica a cinquenta quilómetros. A estrada mais próxima, a mais de quinze...

Ali há só caminhos sinuosos, grutas cavadas na falésia abrupta, o rio, a serra traçando no azul do céu a linha quebrada das suas arestas, e o mar, enchendo o espaço do seu respirar atlântico...

A necessidade de dar à partida um carácter íntimo e modesto que se coadunasse com o nosso magríssimo pecúlio foi um dos motivos que nos levaram a escolher a charneca de Vila Nova de Milfontes para partir.

A atmosfera de descrença, de dúvida, quase de ironia, que em Lisboa se respirava impelia-nos a ocultar de todos a data da largada.

Por outro lado, aquela pista era a única, em Portugal, que permitiria, em segurança, a descolagem do avião completamente carregado.

E, com mil e quinhentos litros de gasolina no ventre, o Pátria necessitava de terreno largo, para correr e tomar alento para tamanha empresa.

Muito em segredo, pois, tudo se preparou para sairmos da Amadora no dia 2 de Abril.

Nas véspera e ante-véspera, peregrinámos pelos Ministérios da Guerra e dos Estrangeiros, sem conseguir, porém, apresentar as nossas despedidas aos respectivos titulares. O primeiro não quis receber-nos; o segundo não se encontrava no Palácio das Necessidades. $\mathrm{O}$ chefe do gabinete do Ex. ${ }^{\text {mo }}$ ministro de Guerra informava-nos também que a Presidência da República havia comunicado ser impossível a concessão da audiência por nós solicitada, para

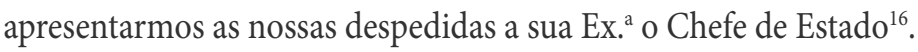

Receberam-nos apenas os Srs. general Roberto Baptista, comandante da Primeira Divisão do Exército, e o engenheiro António Maria da Silva, que, abraçando-nos efusivamente, nos desejavam feliz viagem.

Cheio de sol, vento fraco, céu azul ansiando asas, o dia dois de Abril amanheceu.

Numa fantasia, porque não marcáramos hora para largar, mas que era inconfidência ao mesmo tempo, visto que fixáramos aquela data para seguir, os jornais anunciavam a

\footnotetext{
${ }^{16}$ Sua Ex. ${ }^{a}$ o Sr. Presidente da República, Dr. Manuel Teixeira Gomes, declarou-me, porém, pouco antes de condecorar-nos com a comenda da Torre e Espada, no dia 14 de Setembro de 1924, que a nossa solicitação apenas chegara ao seu conhecimento, já noite, no dia 1 de Abril.
} 
三点, 我乘坐出租车前往阿马多拉。

与之前矛盾的是, 在最后时刻, 公众的好奇心战胜了他们的质疑和冷漠。

路上有汽车、火车、满员的电车以及步行的人们, 这一切几乎形成了一条庞 大的随行队伍。人们到东北方不规则的跑道处纳凉, 那里有个小公园, 里面高大的 桉树在风中沙沙作响。

加戈・科蒂尼奥和萨卡杜拉・卡布拉尔 ${ }^{17}$, 阿丰索・塞尔奎拉和安东尼奥・ 玛亚 ${ }^{18}$, 安东尼奥 - 玛利亚 - 达席尔瓦和罗贝尔托 - 巴普蒂斯塔将军的代表, 海军 和陆军飞行员们, 在那个时刻, 他们想给我们带来告别时道义上的支持。

四点整, “祖国号” 的发动机开始运转。

拥抱, 握手, 甘谷・果提尼奥满怀真挚的感情, 高喊着:

“一路顺风! 一路顺风!”然后, 我们开始了第一阶段的飞行。

人间万物的意外! 飞行事务中无限的意外! 我们的希望, 我们经年累月、每时 每刻都如同宗教般虔诚的梦想, 可能在一开始就被摧毁, 可能在飞行期间、在降落 时就变得一无所有: 引擎故障 ${ }^{19}$,一阵疾风, 驾驶失误.......

飞机升向澄澈的天空, 跃过里斯本, 飞向萨度河口。下午恶劣的天气粗暴地晃 动着我们的飞机。

跨越130公里后, 我们来到了阿马多拉和千泉新镇交界处的塞图巴尔。50分钟 后, 我们在草原上降落。落日的余晖铺在大海上, 像是柔软的丝绸和锦䌸。

过了一会儿, 由葡萄牙共和国空军航空中队塞尔吉奥 - 达席尔瓦中尉驾驶的 布雷盖13号飞机也降落了, 然后我们一起返回阿马多拉。我们在那里停留了7 小时 10 分钟。这时, 黑夜已经笼罩了里斯本, 模糊了它的轮廓, 只剩点点灯光在这片灰 影上闪胨。

\footnotetext{
17 卡洛斯 - 维埃加斯 - 加戈 - 科蒂尼奥 (1869年——1959年) 是一位地理学家、葡萄牙海军军官、航海家和 历史学家。1922年他与飞行员萨卡杜拉 - 卡布拉尔 (1891年一一1924年) 一起驾驶一架水上飞机 “卢西塔尼 亚号” 首次飞越了南大西洋, 从而成为一位航空先驱。萨卡杜拉 - 卡布拉尔是一位航空先驱, 也是位于女王 新镇的军事航空学校的教练, 在这个学校, 萨尔门托・德贝雷斯是他的门徒。(编者注)

18 阿丰索 - 塞尔奎拉 (1872年- - 1957年) 是葡萄牙海军少将, 他参加了第一次世界大战的安哥拉南部战 役。安东尼奥 - 索萨 - 玛亚 (1888年-一1969年), 葡萄牙航空先驱, 在第一次世界大战期间他服务于西部 前线。安东尼奥 - 玛利亚 - 达席尔瓦 (1872年-一1950年), 陆军学校的采矿工程师, 第一共和国政治家, 曾 任葡萄牙烧炭党领导。在1920年至1926年期间曾多次担任部长, 但1924年他不是部长。罗贝尔托 - 达库尼 亚・巴普蒂斯塔 (1874年-一1932年) 是炮兵军官, 1915年任辅助司令部参谋长, 1917年他同样担任此职, 成 立了葡萄牙远征军。1919年他再次担任该职务, 当时的任务是发生君主制动荡时负责组织战斗力量。(编者 注)

19 原文为法语。(编者注)
} 
nossa partida para as quatro horas da tarde. Surpresa desagradável, com a qual foi forçoso conformarmo-nos.

Às três horas, tomava eu um táxi para a Amadora.

Paradoxalmente, no último momento, a curiosidade do público vencia o cepticismo e a indiferença.

Pelo caminho, automóveis, trens, eléctricos à cunha, gente a pé formavam quase um cortejo até à pista irregular onde o Noroeste que refrescara fazia ramalhar os altos eucaliptos do pequeno parque.

Gago Coutinho e Sacadura Cabral ${ }^{17}$, Afonso Cerqueira e António Maya ${ }^{18}$, António Maria da Silva e o representante do general Roberto Baptista, aviadores do Exército e da Marinha, quiseram vir trazer-nos, naquela hora, o apoio moral do seu adeus.

O motor do Pátria foi posto em marcha às quatro horas em ponto.

Abraços, apertos de mão, um grito de Gago Coutinho, vibrante de sinceridade:

- Boa viagem! Boa viagem! - e largávamos para a nossa ante-primeira etapa.

Contingência das coisas humanas! Contingência infinita das coisas da aviação! A nossa esperança, o sonho acalentado religiosamente horas, meses, anos, podia destruí-lo à partida, durante o percurso, ao aterrarmos, um nada: panne $e^{19}$ do motor, golpe de vento, erro de pilotagem...

O avião subiu na atmosfera límpida, passou sobre Lisboa e aproou à foz do Sado.

A tarde agreste sacudia-nos desabridamente.

Galgando os cento e trinta quilómetros, que, via Setúbal, separam Amadora de Vila Nova de Milfontes, o Pátria aterrava, cinquenta minutos depois, na estepe, a que o sol, já de bruços sobre o mar, dava maciezas de brocado e seda.

Alguns instantes mais tarde, o Breguet n. ${ }^{\circ} 13$ do Grupo de Esquadrilhas de Aviação República, pilotado pelo tenente Sérgio da Silva, aterrava também, regressando em seguida, comigo, à Amadora, onde poisávamos pelas sete horas e dez minutos, já quando a escuridão

\footnotetext{
${ }^{17}$ Carlos Viegas Gago Coutinho ( 1869-1959) foi um geógrafo, oficial da Marinha Portuguesa, navegador e historiador. Em 1922, juntamente com o aviador Sacadura Cabral (1881-1924), tornou-se um pioneiro da aviação ao efetuar a Primeira travessia aérea do Atlântico Sul, no hidroavião Lusitânia em 1922. Sacadura Cabral foi pioneiro da aviação e instrutor do primeiro curso da Escola de Aviação Militar de Vila Nova da Rainha, onde teve como discípulo Sarmento de Beires. (Nota do editor).

${ }^{18}$ Afonso Cerqueira (1872-1957) foi contra-almirante da Marinha portuguesa. Participou na Primeira Guerra Mundial na campanha do Sul de Angola. António Sousa Maya (1888-1969) foi pioneiro da aviação em Portugal. Prestou serviço na Frente Ocidental durante a Primeira Grande Guerra. António Maria da Silva (1872-1950), engenheiro de minas pela Escola do Exército, foi político da Primeira República, tendo sido líder da Carbonária. Foi várias vezes ministro entre 1920 e 1926. Não o era neste ano de 1924. Roberto da Cunha Baptista (1874-1932), militar da Arma de Artilharia, foi Chefe de Estado Maior da Divisão Auxiliar, em 1915, cargo que assumiu também em 1917, com a formação de um Corpo Expedicionário Português. Em 1919 voltou a assumir as mesmas funções, cabendo-lhe organizar as forças de combate na altura da sublevação monárquica que então ocorreu. (Nota do editor).

${ }^{19}$ Avaria. (Nota do editor).
} 
“祖国号”终于来到千泉新镇, 等候着飞向东方的时刻。

第二天中午, 我驾着布雷盖二号起飞, 载着代表航天俱乐部为 “祖国号” 送行 的雅尔丁 - 达科斯塔上校和皮涅罗 - 古雷亚上校。他们也是允许 “祖国号” 购买 设备的认购发起人。

在千泉新镇新镇, 我们遇到了尊敬的贝雅主教: 唐 - 若泽・杜帕特洛西尼奥・ 迪亚斯，他应好友布里托 - 帕艾斯的请求为飞机主持洗礼。他们曾经在法国战场 前线共同战斗。

在 4 日的细雨下一一天气出人意料地变暗了, 在上百人的注视下, 开始给飞机 洗礼。首先是宗教仪式, 然后布里托 - 帕伊斯的姐妹玛利亚 - 多塞乌斯用酒神为 飞机洗礼, 她在飞机螺旋桨的外觳上磕破了一瓶神圣的香槟 ${ }^{20}$, 在人群激动的欢呼 声中把它抛向大海咸咸的迷雾中, 选定的名字是:

\section{“祖国号”!}

下午, 我们在坏天气的阻挠中加满了燃料。大雨时不时淹没这片平原, 而被不 祥的东南风不断推高的大浪冲击着岸边岩石时并随即飞溅开来。

在大雾与暴风雨的交替中, 两天过去了……

足以让任何人备受折磨与痛苦的、怒号着的狂风抽打着“祖国号”。

6 号, 我们的紧张与不安上升到了顶点。

由于飞机不能无限期地暴露在露天中 (因为在千泉新镇没有机库), 我们决定 无论发生什么, 明早都要出发。由于无法继续向突尼斯的方向前进, 我们决定绕过 塞维利亚和马拉加。

出发前夜那柔软时光中的想法还活着!

我们在自己的身边感受到了爱、希望与担忧。周围充满了虔诚的祈祷和对 我们凯旋而归的热切盼望。

人们默默地望向天空, 祈祷天公作美。

在无边无际的旷野之上, “祖国号” 被船索固定在地面, 在风中颤抖。

20 这个香槟瓶的上面部分至今仍保存在辛特拉市格兰热・多马尔克斯的航空博物馆。(编者注) 
começava a diluir os contornos da paisagem e a cintilação dos revérberos polvilhava a mancha acinzentada de Lisboa a anoitecer.

O Pátria aguardava finalmente, em Vila Nova de Milfontes, o momento de rumar ao Oriente.

No dia seguinte, ao meio-dia, pilotado por mim, o Breguet $n .^{\circ} 2$ descolava, levando a bordo os capitães Jardim da Costa e Pinheiro Correia, delegados do Aeroclube à partida do Pátria, promotores da subscrição que permitira a aquisição do aparelho.

Em Vila Nova de Milfontes, já então se encontrava o Reverendíssimo Bispo de Beja, D. José do Patrocínio Dias, que, acedendo ao pedido de Brito Paes de quem era amigo e antigo companheiro da frente de batalha em França, vinha baptizar o avião.

E no dia quatro, debaixo de chuviscos - o tempo toldara-se inesperadamente -, na presença de um centenar de pessoas, o aparelho foi baptizado, religiosamente primeiro, dionisiacamente depois, quando a madrinha, Maria do Céu, irmã de Brito Paes, quebrando no cubo da hélice a consagradora garrafa de champanhe ${ }^{20}$, atirava num grito cheio de emoção às emanações salinas do mar o nome escolhido:

\section{- Pátria! -}

Pela tarde, procedia-se aos plenos de combustível, que o mau tempo dificultava. Aguaceiros alagavam de quando em quando a planície, e o Sudoeste desencadeado avolumava sinistramente as vagas, que vinham explodir de encontro aos rochedos.

Dois dias passaram, nevoentos, borrascosos ...

A fúria da ventania açoitava as asas do Pátria com uma ferocidade que a todos confrangia e torturava.

No dia seis, o nosso enervamento atingia o auge.

E como o avião não podia conservar-se indefinidamente ao desabrigo (visto não haver hangar em Vila Nova de Milfontes), resolvíamos partir na manhã seguinte, impreterivelmente, decididos a arribar a Sevilha ou Málaga, na impossibilidade de prosseguir na direcção de Túnis.

Como ainda vivo pelo pensamento as horas suaves dessa véspera de partida!...

À nossa volta sentia-se amor, esperança, receio. Andavam pelo ar orações de bocas piedosas, vibrações ruivas de vontades fortes, ânsias de triunfo e de vitória.

Os olhos erguiam-se para o céu, numa súplica silenciosa de bom tempo.

O Pátria, no descampado imenso, preso à terra por cordame de navio, estremecia a cada rajada.

${ }^{20}$ A parte de cima desta garrafa de champanhe conserva-se ainda no Museu do Ar, na Granja do Marquês, em Sintra. (Nota do editor). 
当下午过去了一半的时候, 大风渐息, 夜幕在一片宁静中降临一一这将是我们 在葡萄牙度过的最后一晚。

大海亦改变了往昔的怒号, 他像一位老者, 在庙宇中低声祈祷。

天空中, 半透明的雾气飘过, 一时间模糊了繁星, 随即又被疾风吹走。

大地上, 一片恬烅。

布里托 - 帕艾斯一家人和几个朋友让晚饭的亲密氛围中充满了感动——在 每道目光中, 每个笑容中, 每句话中……我们干杯, 欢呼, 甚至默默哭泣。

渐渐地, 寂静吞没了围栏和泥沼, 塞尔卡山似乎在模糊的远方注视着这片静 滥。 
Pelo meio da tarde, porém, a ventania acalmou, e a noite caiu, serenamente - essa nossa última noite de Portugal.

O mar já não bramia com a voz colérica dos outros dias. Rezava baixinho, como um velho no templo.

Névoas translúcidas passavam, embaciando as estrelas por momentos, e lá iam levadas pelo vento alto.

Cá em baixo, uma doce tranquilidade.

Ao jantar, na intimidade afectiva da família de Brito Paes e de alguns amigos, uma atmosfera comovida pairou - em cada olhar, em cada sorriso, em cada palavra... Houve brindes, hurrahs e até lágrimas escondidas.

E a pouco e pouco, o silêncio fez-se mais profundo sobre cercas e brejos, que a Serra do Cercal parecia vigiar dos longes indistintos. 


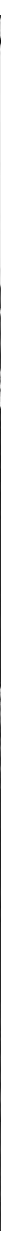

O baptismo do Pátria

O Rev.mo. Bispo de Beja procede à cerimónia. A seu lado vê-se a madrinha, Maria do Céu, irmã de Brito Paes, e o comandante Cifka Duarte

“祖国号” 的洗礼

尊敬的贝雅主教主持仪式。他的旁边是 “祖国号” 的教母, 也是布里托・帕艾斯的妹妹, 玛丽雅・多赛乌和司令官席福卡・杜阿尔特 


$$
a^{m}
$$




$$
\begin{array}{r}
\text { III } \\
\text { SETE DE ABRIL } \\
\text { 第三章 四月七日 }
\end{array}
$$


曙光初现。在蒙蒙细雾与微冷的天气中, 我们的飞机起飞了, 仿佛某个人的叫 喊声穿越过黑暗。在吃过热腾腾的鸡蛋, 喝过一杯咖啡后, 我们的飞机滑向跑道。

谁能明白我此刻焦虑的心情,一如起笔作画般小心翼翼。

没有人, 只有我们一一布里托・帕艾斯和我。

我们需要经过这些时刻, 犹如穿越黑夜期待黎明, 听到阴影里的各种声音, 却 分辨不清。

犹如看到玛丽雅 - 多赛乌那双焦躁的手一一她为我们准备了热鸡蛋、咖啡 和面包作早餐, 仿佛一种典礼。

犹如听到马嘶声, 一匹灵敏的马儿拉着一辆阿兰特茹吱呀作响的小车, 带我们 沿着弯曲细长的小路直通向海边的眺望台。

空中, 仍然还是黑夜——雾蒙蒙的开始透出一丝丝光亮。

“祖国号”像是一只铝制的、丝绸般光亮的巨大神鹰, 冲破昏暗的阴影。

仿佛是秋天, 空气中满是潮湿泥土的气息。我们驾驶飞机冲破这沉默……

人山人海, 披肩和手帕在舞动, 到处都是形形色色的大人和孩子的面孔。

人们的低语声淹没在大西洋的波涛声里。

仿佛人与海连成一片, 难以分辨......

弗兰西斯科・德索萨是与曼努埃尔・戈维亚一起修理 “祖国号” 的机械师, 他绕着这架雄鹰走来走去, 仔细地检查螺旋桨、电缆和控制装置。

在这谦卑而慷慨的人群中, 有人想把自己的名字写到飞机上, 我为自己与他们 是同一个民族感到自豪。

又有一个人, 又一个……那是几十个与飞机同在, 与我们一起忍耐、死亡或是 胜利的灵魂。

天色渐明, 是起飞的恰当时机了。

他们给了我们紧紧的拥抱, 里面满是挂念、紧张与关心。

还有件值得一提的事情: 布里托 - 帕伊斯的父亲取下手上带有家族徽章印记 的戒指, 并把它交到了即将飞行 ${ }^{21}$ 的儿子手上。那一瞬间, 在帕伊斯上校身上聚集 了整个家族的神圣传统。

${ }^{21}$ 在本书最后复制了一张这枚戒指的照片。(编者注) 
Dealbar. Névoa ténue a desprender-se da paisagem friorenta. Vozear de alguém que passa na escuridão. Ovos quentes e uma chávena de café. A aranha em que a Boneca nos vai levar à pista.

Quem poderá compreender as pinceladas nervosas que estou lançando ao papel?

Ninguém... só nós... só Brito Paes e eu.

É preciso ter vivido esses momentos, ter visto a manhã mal transparecendo ainda através da noite moribunda, ter ouvido essas vozes que, veladas, diziam não sei o quê na sombra em que as formas mal se distinguiam!

É preciso ter visto as mãos inquietas de Maria do Céu, preparando-nos a pequena refeição - ovos quentes, café e pão de trigo - como se consumassem um rito litúrgico.

É preciso ter ouvido o relinchar sonoro da Boneca, a égua inteligente que, puxando a frágil carrinha alentejana, nos levou pelo caminho sinuoso e estreito à esplanada cortada a prumo sobre o mar.

Lá em cima, era a noite ainda - noite brumosa, a desabrochar em pálidas claridades foscas.

O Pátria, condor gigante de alumínio e seda, recortava-se na sombra agonizante, como fantasma estranho.

Parecia Outono. Cheirava a terra húmida. Andavam pelo espaço profecias mudas...

Gente, muita gente, não sei quanta. Chailes, lenços, vultos masculinos, crianças.

E o murmúrio das vozes brancas mal se distinguia do respirar do Atlântico.

Se era quase tudo gente do mar!...

Francisco de Sousa, o mecânico que, com Manuel Gouveia, trabalhara na preparação do Pátria, andava em torno da águia, verificando a hélice, os cabos e os comandos, cuidadoso e apreensivo.

Alguém quis escrever o seu nome na tela do avião. Alguém do povo, desse povo generoso e humilde a que me orgulho de pertencer.

E outro, e outro... São dezenas de almas a prender-se, a esconder-se na fuselagem, para sofrer, morrer ou triunfar connosco.

A claridade soa uma oitava acima. São boas horas para levantar voo.

Outros abraços que nos estreitam, mais cheios de saudade, mais cheios de temor e de solicitude.

Há um gesto que recorda páginas longínquas da nossa História: o pai de Brito Paes tira do dedo o anel brazonado da família e entrega-o ao filho que vai partir ${ }^{21}$. No capitão Brito Paes concentrava-se, naquele instante, a tradição impoluta de uma família inteira.

\footnotetext{
${ }^{21}$ Uma fotografia deste anel encontra-se reproduzida no final do livro. (Nota do editor).
} 
“祖国号” 的教母玛丽雅 - 多赛乌, 是一个热情而虔诚的人, 她是一个民族的代 表。

“出发!”

是谁发出的指令?我不知道。因为有几秒钟我的大脑是空白的。

发动机隆隆作响, 小行李被装上了飞机, 飞行线路图已放在驾驶舱, 那条红色 线路十分鲜明。

我们坐在自己的位置上, 调试发动机。

跑道上具有纪念意义的障碍与石头被撤走了 (为什么没有把它们珍藏起来?)。

六点零二分。

斯弗卡・杜阿特发出指令出发。

慢慢地, 我们与葡萄牙大地告别, “祖国号” 在第一缕晨光中开始飞翔。在飞行 了八百米后, 我们开始平稳飞行, 就像整个葡萄牙都在呼喊:

“前进!” 机转了两圈, 上升到了平流层, 朝东飞去。太阳还没完全升起, 但是, 在西班牙的方向, 我们已经看到了光亮。

在飞机的一边, 米拉被深蓝色的海浪拍打, 而另一边暴雨倾斜在塞尔卡山上。

奥德米拉镇只是景色中的一个白色斑点。

我们飞进了一片云中, 弗伊亚的象牙色的云朵, 大地消失在视线里。

太阳升起的景色让人讶异甚至感觉有点恐怖, 我们仿佛是走在地狱中一般。 那些颜色令人难以想象: 死尸般的绿色, 火一样的色斑, 浸渍过的紫罗兰色, 螺旋状 的烟雾, 金黄色, 宝石蓝, 宝石橙……

这些色彩随意地组合起来, 就像一位疯狂的画家在远方的背景处, 用涂满颜料 的双手把画布浸透, 然后在暴风雨的天空中将它弯成椭圆的弧线晾干。

在天边, 浓云越积越厚。我们飞机的最高飞行高度是700米。

维拉雷奥 - 德 - 桑托安东尼奥市与瓜地安那河相连, 仿佛一个刚出浴的美妙 少女。窗口和门边的人开始激动起来, 也许是被发动机那异常的噪音惊吓到了。

在进入西班牙的时候, 下了些小雨。

在韦尔瓦上空, 因为大雾, 我们下降到了50米的高度, 几乎紧贴着地面飞行。

飞机左侧的篷子开始变得松解并抖动起来, 几乎有些要触到螺旋桨。我看向 指引航向的布里托 - 帕艾斯, 我们总是能在对视中明白彼此。

还是那个声音对我们呐喊:

“前进!”

葡萄牙人民与我们同在, 指引我们前进。

我们继续前进了一点, 下面是一片湿地。 
Maria do Céu, a madrinha do Pátria, é uma alma de mãos postas, é o fervor de uma raça.

- Vamos!

Quem disse a palavra? Nem sei... Há segundos que são vácuo na memória.

O motor está em marcha, a minúscula bagagem a bordo, a carta onde a rota sangra, num traço rubro, colocada num tablier.

Tomamos os nossos lugares. Ensaio o motor.

Os calços, duas pedras da pista inolvidável (por que as não guardaram?) são retirados.

Seis horas e dois minutos.

Cifka Duarte dá o sinal da partida.

Lentamente, muito lentamente, como se lhe custasse aquele adeus à terra portuguesa, o Pátria começa a rolar na primeira luminosidade pérola da manhã. E ao fim de oitocentos metros de corrida, libertado enfim da gravidade, solta-se do terreno macio, e é como se Portugal inteiro lhe gritasse:

- Avante! - que em dois grandes círculos suaves se eleva no ar calmo e aproa a Oriente, ao sol que não nasceu ainda, mas que dos lados de Espanha nos atira já claridades frouxas.

O Mira, muito enrodilhado entre as margens, lá fica a chorar, a correr, azul-ferrete, enquanto, por bombordo, um aguaceiro espesso desaba sobre a Serra do Cercal.

Odemira é apenas uma nódoa esbranquiçada na paisagem.

Cabeleira ebúrnea na Fóia. Uma toalha de nuvens que avança esconde-nos a terra.

O nascer do Sol é como surpresa de assombro. Dir-se-ia que caminhamos para o inferno. Há tonalidades de cor inconcebíveis: verdes de cadáver, laivos de incêndio, violetas macerados, volutas de fumo, amarelos de oiro, azuis de safira, alaranjados de opala.

As cores são lançadas à toa, como se além, no cenário distante, um pintor em delírio tivesse encharcado as mãos na tinta da sua paleta e as enxugasse à curva elíptica do céu tempestuoso.

Grandes nuvens acumulam-se no horizonte. O nosso plafond é de setecentos metros.

Vila Real de Santo António a escorrer, junto ao Guadiana, parece uma garota que acabasse de sair do banho. Assoma gente às portas e às janelas, surpreendidas talvez pelo ruído insólito do motor.

E ao entrar em Espanha, alguns chuviscos caem.

Sobre Huelva, descemos para cinquenta metros, forçados pela chapa da névoa, que nos comprime contra o terreno alagado.

A capota esquerda do avião solta-se e começa a bater, ameaçando a hélice. Olho Brito Paes, que me vai indicando a rota, e os nossos olhares compreendem-se.

É a mesma voz a gritar-nos:

- Avante! 
河水泛滥, 绿色树丛、成群的红色屋顶、一段段的公路都浸在泛滥的洪水 中。

骤雨再次降落, 这次更加猛烈, 像鞭子一样抽打在我们脸上。在我们的前方, 雨连成一片, 越下越密。只在东北方, 留出一道空隙, 仿佛空中的一道云拱, 在黑暗 的天空中撑出一道亮光。

布里托・帕艾斯指给我: 那就是塞维利亚方向。

我们保持着 30 米高的飞行高度。起先是飞在水面之上, 然后经过了起伏极大 的大地和安塔露西亚大片大片的果园, 在若隐若现的晨光中, 它们仿佛是互相对立 的一块块生满铁锈的板子, “之”字行的铁路线蜿蜒其中。

突然间, 我们冲破了浓雾, 塞维利亚大教堂的尖塔出现在视野里。这是第一个 对我们敞开怀抱的港口。在西南方, 天空中云层已散去, 希望在我们两个心中升起, 我们大喊起来:

“马拉加!”

在布里托・帕艾斯的指挥下, “祖国号”偏离了原航线, 寻找新的航线。

寒冷的西南风剧烈地摇晃着我们的飞机, 让我们的航速减慢, 并且感觉到紧张 与压力。朝西南方的飞行中, 我们的飞机开始剧烈晃动, 我们有些气馁了。

我们每时每刻都需要摆脱那些危险的群山, 有时我们几乎贴着它们飞过, 还有 成片的乌云, 它们在尼亚加拉才散去。

在大约半个小时的时间里, 我们徒劳地试图穿过更加密集的暴风雨之后, 不得 不继续向西南方飞行。大约半小时后, 穿过了更加密集的暴风雨, 我们继续向西南 方飞行。

我们极目远望, 望向地平线处, 渴望能看到海岸线。

终于, 我们看到了海, 狂怒的、低沉咆哮的海, 灯塔在上面显得格外渺小, 若隐 若现, 仿佛烛台上燃烧的蜡烛。

苍白的太阳透过云层, 透出光芒, “祖国号”爬升了一段距离, 看到了雨后晴 天。

卡迪斯山脉的支脉出现在我们眼中。

在直布罗陀出海口, 地中海亲吻着大西洋; 斯帕特尔角在远处的薄雾中突兀企 立; 绿黑色的英伦小山曲线起伏。在青灰色的光线中, 它们共同组成了一幅大吉涅 尔式22的舞台布景。

“祖国号” 快速前进, 以八百米的飞行高度, 穿过暴风雨。

22 源自法国大吉涅尔剧院 (1897年一一1962年) 的形容词。该剧院位于巴黎皮加勒区, 上演自然主义恐怖戏 剧。(编者注) 
É o Povo de Portugal quem vai connosco e quem manda.

Um pouco mais longe, o terreno é um pântano.

Os rios transbordaram. Copas de arvoredo, telhados rubros de casario, pedaços de estrada emergem aqui e além, na imensidade da inundação.

Os aguaceiros repetem-se, agora mais violentos, fustigando-nos a cara como chicotadas. $\mathrm{Na}$ nossa frente, a chuva densifica-se assustadoramente. Apenas para Nordeste, como rasgão nas cortinas de água, um arco sombrio de nuvens abre uma claridade na cinza escura do céu.

É o caminho de Sevilha que Brito Paes me aponta.

Voamos a trinta metros, a princípio sobre toalhas de água, depois sobre as ondulações agressivas do terreno e os grandes pomares da Andaluzia, que na luz dúbia da manhã, têm o aspecto sinistro de vastas placas ferrugentas eriçadas de pontas hostis, entre as quais a linha férrea ziguezagueia.

Subitamente, como arrancadas da bruma, as torres da Catedral de Sevilha surgem no horizonte. Era o primeiro porto a abrir-nos os braços. Para Su-sudoeste, porém, o céu parece desanuviar-se. Trespassa-nos a ambos um frémito de esperança, a traduzir-se em grito que não chega a articular-se:

- Málaga!

E ao gesto de Brito Paes, o Pátria guina, para soltar novo rumo em demanda da rota abandonada.

O Sudoeste fresco sacode-nos furiosamente e demora-nos a marcha que enerva e deprime.

A cada minuto é preciso fugir aos montes que quase rasamos por vezes, fugir às nuvens, esponjas negras que se desfazem em Niagaras.

Durante cerca de meia hora, somos forçados a manter-nos proa a Su-sudoeste, depois de ter tentado, debalde, romper o temporal que redobra.

O nosso olhar perscruta o horizonte, sequioso de enxergar a costa.

Finalmente, o mar. Um mar de procela, enraivecido e cavernoso, onde o farol de Tarifa, na sua ilha circular e minúscula, parece uma vela de estearina num castiçal.

O sol anémico, doentio, reluz por entre nuvens, e o Pátria sobe um pouco na acalmia súbita.

Os últimos contrafortes da Serra de Cádiz balouçavam-nos implacavelmente.

E a boca de Gibraltar - o Mediterrâneo beijando o Atlântico -, o cabo Espartel, a distância destacando-se na bruma, o morro inglês, verde-negro e corcovado, formam um conjunto cénico gran-guinholesco ${ }^{22}$, na lividez da luz.

O Pátria avançava agora velozmente, impelido pela ventania desabrida, a oitocentos metros de altitude.

\footnotetext{
${ }^{22}$ Adjectivo formado a partir do nome do teatro francês do Grand-Guignol (1897-1962), localizado em Paris no bairro de Pigalle, onde se representavam peças de horror naturalista. (Nota do editor).
} 



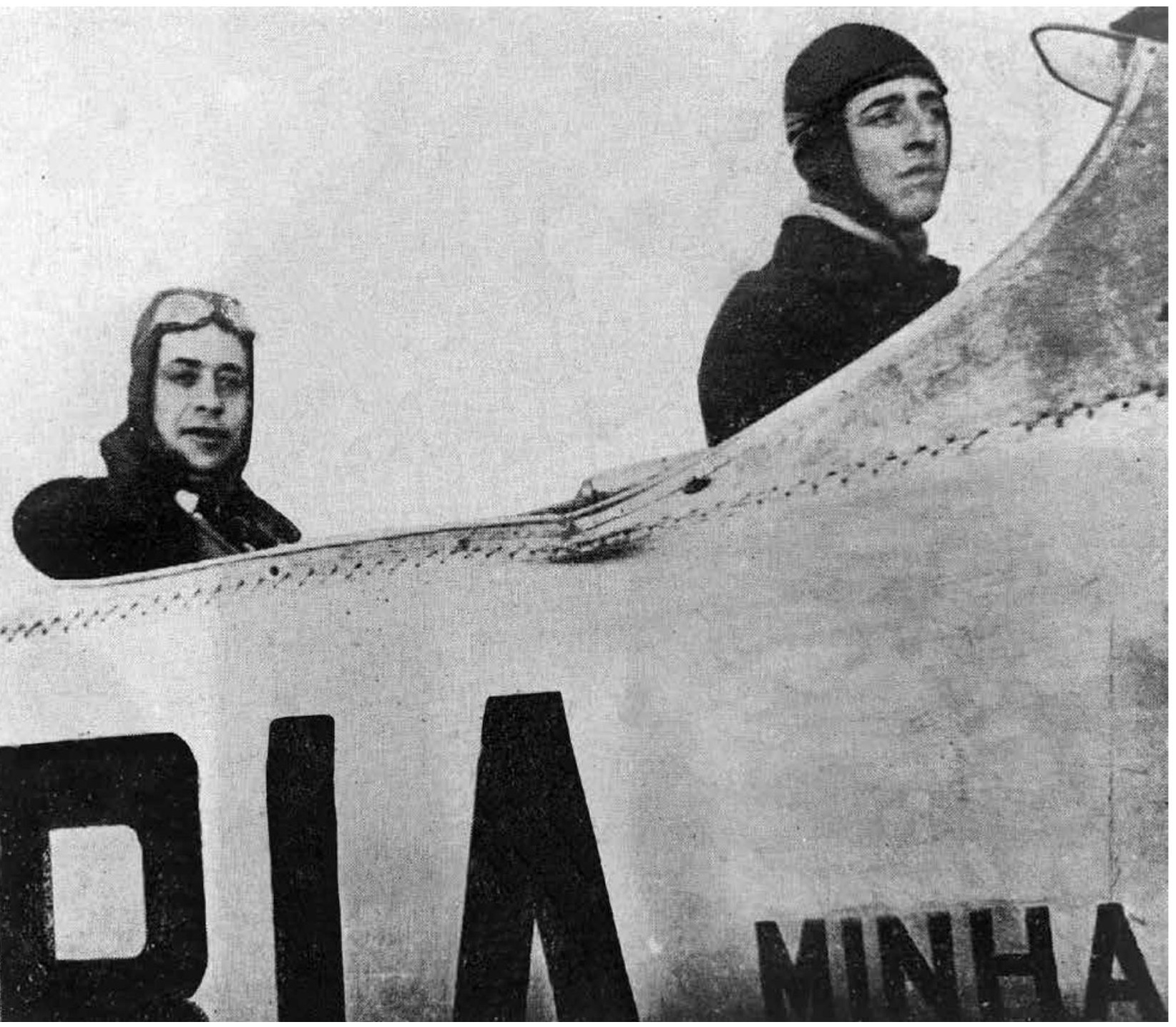

Os aviadores Brito Paes (à esquerda) e Sarmento de Beires (à direita) na hora da partida

飞行员布里托 - 帕伊斯 (左) 萨尔门托 - 德贝雷斯 (右) 在出发时刻 
我们飞过阿尔赫西拉斯湾上空, 那是一片平静的大湖, 大湖与先前狂怒的大海 形成了鲜明对比。但忽然, 我们经历了惊心的一幕: 机尾突然下垂, 我们顿时陷入 了深洣。

仪表盘上的速度指针显示航速超过了每小时 220 公里。金属弦发出嗡嗡的响 声, 机翼也发出了巨大的响声, 一切都在发出噪音。我握着控制杆的手在颤抖, 我 们感觉到飞机在坠落, 有失重的感觉, 我们的身体与座椅不再紧靠, 仿佛整个飞机 要解体了。我的椅垫已经从身下飘到了空中, 机身里的底部残留的、从葡萄牙带 来的尘土从我们的头顶飞过。因为油路不通, 供油出了问题, 发动机产生了故障。

哥梦持续了不到几秒钟……

在四百米的高度, “祖国号” 恢复了正常, 天气也仿佛在狂怒后, 出现暂时的温 和, 但在我们到了马尔贝拉后, 又重新发起疯来。

雨又开始不停地下。地中海在愤怒地咆哮。我们要被迫在马拉加降落了。

透过云层, 我们看到了城市。在起伏不定的跑道上空盘旋了两圈之后, “祖国 号”降了下来, 飞机触到了柔软的地面, 但轻微地陷入了泥中。

至此, 我们四个半小时内飞行了630公里。

第一段航程就这么悲伤地结束了。对于大部分人而言, 降落在西班牙也许意 味着失败。

但对于我们, 在阿尔赫西拉斯, 经历了暴风雨, 与死神擦身而过后, 现在的着陆 可以说是成功的。

飞机着陆后, 几位法国机械师围了上来, 跑道的负责人范尼尔先生立刻准备好 帮助我们, 他还拿来了所有的物资以及我们可能缺少的汽油和机油。

“祖国号” 飞机如果没有戈维亚的精心调试以及外国机械师的细心准备, 是不 可能飞行这么远的。

因为飞机库已满, “祖国号” 不得不再次露宿野外, 但这次露水没有损害飞机, 因为外面的遮盖物能让水汇集流走。

下午我们得知, 属于法国拉特克艾拉 (Latecoere) 系列的那架飞机也因为暴风 雨被迫降落在附近。

葡萄牙驻马拉卡的领事埃杜阿尔多 - 弗拉波利非常热情地接待了我们。他 是个温文尔雅的西班牙人, 待我们极其真诚, 超过了任何我们接触过的其他外国领 事, 他是葡萄牙真正的朋友。 
Sobre a baía de Algeciras, que é um lago de serenidade a contrastar com o desespero enfurecido do mar, há um momento de angústia ulcerante: o avião, cauda a prumo, mergulha repentinamente no abismo.

A agulha do indicador de velocidade ultrapassa, no mostrador, a graduação dos duzentos e vinte quilómetros à hora. As cordas zunem, as asas estalam, tudo range. Mãos crispadas nas alavancas de comando, sentimos o aparelho que se despenha, que se furta debaixo de nós, que nos abandona no espaço, que parece ir despedaçar-se em pleno voo. A almofada da minha cadeira escapa-se no ar: cai-nos sobre as cabeças a terra de Portugal que restava ainda no fundo da fuselagem. O motor falha, à míngua de gasolina, que, devido à inércia, não corre na tubagem.

E o pesadelo dura alguns segundos...

A quatrocentos metros, o Pátria retoma a linha de voo normal, e a atmosfera, como fatigada pelo esforço homicida, abranda por instantes a epilepsia da sua raiva, para começar de novo a sacudir-nos em frente de Marbella.

A chuva cai, ininterrupta, impiedosa. O Mediterrâneo regouga, irado. É forçoso aterrar em Málaga.

A cidade surgiu sob o céu mascarrado; depois de duas voltas sobre a pista ondulada, o Pátria desce, toca o terreno macio, e atola-se um pouco.

Tínhamos percorrido seiscentos e trinta quilómetros em quatro horas e trinta minutos.

A primeira etapa terminava assim dolorosamente. Para a maioria, a aterragem em Espanha representava, talvez, um fracasso.

Para nós, que víramos a Morte de perto ao passar sobre Algeciras, e que nos empregáramos a fundo para escapar da tormenta, ter salvo o avião fora quase uma vitória.

Logo que o aparelho aterrou, rodearam-nos alguns mecânicos franceses, que o chefe de pista, Mr. Vanier, punha imediatamente à nossa disposição, bem como todo o material, gasolina e óleo de que pudéssemos carecer.

E o Pátria, se não teve nesse momento a olhá-lo a inigualável solicitude de Gouveia, encontrou, contudo, mãos adestradas que, embora estrangeiras, o prepararam cuidadosamente para largar na primeira aberta do tempo.

Como o hangar estava cheio, ficou mais uma vez ao relento, o que, de resto, o não prejudicou, porque a cobertura deixava entrar água a jorros.

E pela tarde, davam-nos conhecimento de que o avião francês da linha Latecoére aterrara próximo dali, forçado pelo temporal.

O cônsul de Portugal em Málaga, D. Eduardo Frapoli, recebia-nos com gentileza verdadeiramente carinhosa. Espanhol finíssimo, o seu procedimento excedeu grandemente, em lhaneza, em dedicação, em hospitalidade, o de alguns outros cônsules estrangeiros com quem tivemos relações. É um amigo de Portugal. 
接下来的两天里, 我们焦急地等待着重新飞行, 无心欣赏我们所在的这座古老 而美丽的西班牙城市。

但是, 拉康塞普西翁庄园是如此的迷人, 在参观后给我们留下了难以忘却的印 象。

拉康塞普西翁庄园坐落在欧洲, 但却是一座具有亚洲特色的植物园。

园内植被茂盛: 有棕㭣树、竹子以及潺潺流水 ...... 园林所有者拉蒙 - 埃切 瓦利亚 - 阿斯卡拉特以他艺术家的品味, 将他的住宅成功变为了一所掩盖在茂密 树从中的真正博物馆。

下面摘录一段埃杜阿尔多 - 弗拉波利对那个迷人植物园的描述, 这段描述远 胜于我所写:

园林属于混合风格, 比法式或英式园林更美。值得一提的是, 园丁在种植植物 时, 会顺应气候, 种植相应季节的植物。正因如此, 院内总是花团锦族, 其中也不乏 名贵品种, 也有热带森林的珍惜品种。这些热带植物, 茂密而华丽, 它们的祖国用 火热的气候赋予了他们迷人的光彩。

马拉加的美妙气候啊! 仿佛一个神奇的魔术师向我们展示大自然的奇妙, 仿佛 一个令人目眩的梦境, 让我们对此着迷。那片黑、绿、黄相间的竹林, 在沙沙作响, 仿佛一支无休止的歌、一汪流水, 不见其物, 只闻其声, 又像印度那些神秘的地区, 让人着迷。

这就是这天堂般植物园的特点: 到处都是珍稀物种的植物。

据说拉康塞普西翁庄园中有非常古老而珍贵的藏品。

值得一提的是, 在二世纪末期时, 博物馆中用来铺路的珍贵的马赛克图案, 这 些图案都来自罗马 23 。

${ }^{23} 1923$ 年6月21日 “球体” 杂志上发表的一篇文章。 
Durante os dois dias que ali permanecemos, o enervamento e a ânsia de partir não nos deixaram apreciar a beleza da velha e interessante cidade espanhola.

No entanto, a visita que fizemos a Hacienda la Concepción deixou-nos no espírito uma recordação de encantamento, que jamais se apagará.

La Concepción é uma incrustação da Ásia na Europa.

A mesma vegetação exuberante - palmares, bambuais, águas correntes... O gosto artístico de D. Ramón Echevarría y Azcarate, proprietário da quinta, conseguiu transformar a vivenda que se abriga sob a espessura do arvoredo num verdadeiro museu.

E o trecho que transcrevo de D. Eduardo Frapoli poderá, melhor do que a minha descrição, deixar entrever a maravilha da formosíssima Hacienda:

O traçado dos jardins incomparáveis pertence, melhor que aos estilos inglês ou francês, ao estilo misto. Com um louvável critério, o jardineiro que executou o plano tomou deles o que julgou aplicável às condições especiais deste clima privilegiado. E que assim é prova-o a exuberância destas flores que contemplamos extasiados, entre as quais se encontram os mais raros, os mais delicados e os mais belos exemplares da flora tropical, sem que o seu vigoroso desenvolvimento tenha que invejar o que quer que seja à esplêndida frondosidade que adquirem no cálido país de sua origem.

O clima de Málaga!... É o mago poderoso a quem devemos esta maravilha da Natureza, que encanta o nosso espírito, alucinando como um deslumbramento de sonho. Porque, quem pode admirar estes abundantes bosques de altíssimos bambus, negros, verdes, amarelos, por entre os quais desliza, rumorejando a sua eterna canção, um fio de água, sem sentir-se transportado, como por encanto, às misteriosas regiões da Índia sugestiva?

E é isto que predominantemente caracteriza este lugar paradisíaco: a raridade especial da sua vegetação.

Conta a Hacienda La Concepción com uma valiosa colecção de objectos de grande antiguidade...

Merece especial menção, pelo seu inestimável valor, o precioso mosaico dos fins do século II, colocado como pavimento do museu, restaurado por um artista idóneo que, para esse fim, veio expressamente de Roma ${ }^{23}$.

${ }^{23}$ De um artigo publicado na revista La Esfera, de 21 de Julho de 1923. 
直到 9 号, 天气才转好。梅里亚节前夜, 我们从军方T. S. F收到天气预报, 天气 利于飞行。

早上十点三十一分, “祖国号” 再次起飞, 飞向东方, 在白色的机翼上, 基督十字 架鲜艳欲滴, 还是那个声音回响在耳边, 像一种超自然的力量推动我们前进。 
Só no dia nove a face do tempo sorriu. As informações meteorológicas recebidas na véspera de Melila, pela T.S.F. militar, eram favoráveis.

E assim, pelas dez horas e trinta e um minutos da manhã, o Pátria retomava a sua marcha para Oriente, Cruzes de Cristo sangrando nas asas brancas, e a mesma voz soando na amplidão, a impelir-nos como força sobrenatural. 


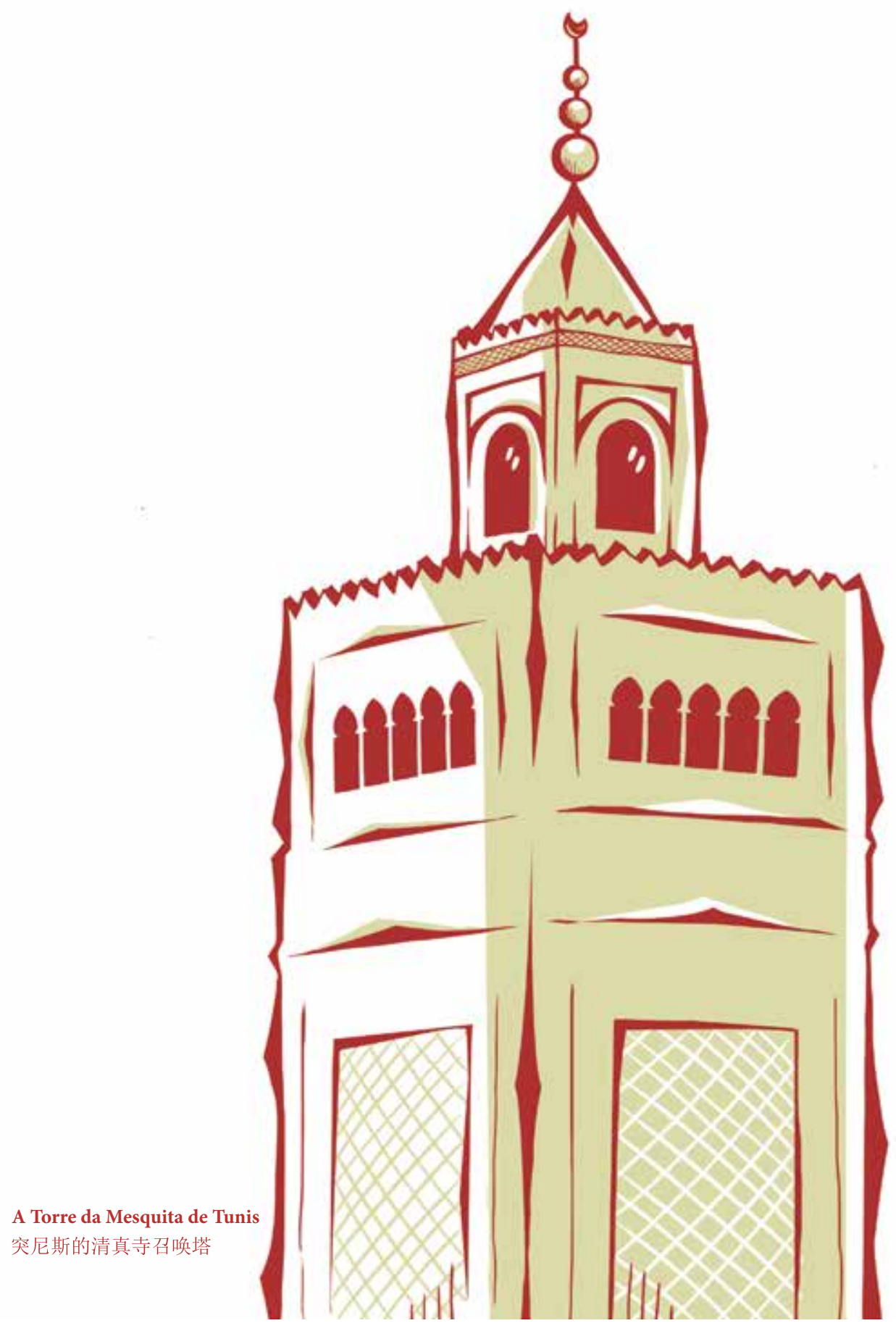




\section{IV \\ O MEDITERRÂNEO E A ARGÉLIA \\ 四、地中海和阿尔及利亚}


减轻了四百升汽油的负担, “祖国号” 轻松地飞离了地面。它飞翔在一片蔚蓝 中, 飞过贝莱斯 一马拉加和梅利利亚, 开始远离海岸。

然而, 突然间, 发动机出现了故障, 螺旋桨转速下降, 面临令人痛苦的迫降的可 能性, 我们的心紧张了起来。

除了回荡在整个机舱里的引擎声外没有别的声音。飞机猛然转弯, 需要降落, 并重新向公海驶去。

但是很少有人能估测出这些充满不确定性的时刻对于飞行者意味着什 么一一不管身在何处, 只要螺旋桨发生了故障, 飞机都必须下降。可是很多时候, 比如此时此刻, 根本没有可以让我们降落的地方! 如果这样的话, 我们一直以来的 梦想将会毁于一旦。

地中海在我们的前方, 泡沫点缀着它蓝绿色的海水。浓雾遮住了我们的视 线。几分钟后, 内华达山脉微白的轮廓出现在眼前。

此刻, 我们被隔离在海天之间。没有令人安心的接连不断的海浪声, 四周一片 寂静。

两艘船正向东行驶, 它们在水面上留下了燃煤排放的缕缕烟雾。

十一点半, 阿尔伯蓝岛的黑色身影出现在飞机左舷。这样, 我们就确定了方 向。十五分钟后, 我们看到了三叉海角, 它像是被石化的怪兽利爪。“西班牙”号战 舰在它旁边缓慢而痛苦地驶过, 离开了这片海浪。

远处的梅利利亚像一片不甚明亮的光。

“祖国号” 转舵 ${ }^{24}$, 远离了奇怪的拉马奇卡潟湖, 飞向亚瓜海角。在海上飞了将 近两个小时之后, 我们又一次开始沿着充满恶意的、曲折的海岸线飞行。

内穆尔被包围在在一片葱茏中, 它充满了欧洲小城的高贵气质。

一点一刻, 我们在奥兰的天空中飞翔, 在绕跑道一圈后, 降落在东北方向 8 公 里、宏伟的拉塞尼亚机场 ${ }^{25}$; 在那儿, 非洲第一航空中队的军官们和司令官向我们 致以热烈的祝贺。“祖国号”毫不耽搁地进入了机库。

飞机离开阿马多拉一个礼拜了。当看到它终于找到了遮风挡雨的地方，我们 的心中升腾起了一丝苦涩, 这丝苦涩从 4 月 2 日起就一直如哥梦般折磨着我们。

我们成功飞过了地中海。下一步, 戈维亚。

之前从未有人尝试过飞跃非洲北海岸。我们这次的航行让葡萄牙有机会为 世界打开一条新的空中航道。

24 原文使用了一个航海术语, 意思是为了尽量利用风的作用改变航向。(编者注)

25 今天的塞尼耶在法国殖民期间的名字。(编者注) 
Aliviado de quatrocentos litros de gasolina, o Pátria soltou-se da terra sem dificuldade. Asas no azul, passou sobre Vélez-Málaga e, aproando a Melilla, começou a afastar-se da costa.

Subitamente, porém, o motor falha, as rotações da hélice diminuem, e os nossos corações confrangem-se, na expectativa angustiosa de uma aterragem forçada.

Mudo de depósitos. A canção do motor volta a ressoar em pleno espaço, e o avião que, numa brusca viragem, demandara a terra, singra de novo em direcção ao alto mar.

Mas poucos podem avaliar o que representam para quem voa esses instantes de incerteza em que, desfeita a estrela de ar da hélice, é preciso descer, seja onde for e, muitas vezes, como naquele momento, sem um palmo de terra onde poisar! E, para nós, seria o ruir de tudo o que sonháramos.

O Mediterrâneo, glauco, salpicado de espuma, estava na nossa frente. A neblina escondia-nos, minutos depois, a silhueta alvacenta da Serra Nevada.

Agora era o isolamento entre céu e mar. Seria o silêncio, sem a sonoridade confortante das explosões sucessivas.

Dois navios, navegando lentamente para Leste, deixavam sobre as águas a mancha carbonífera das suas volutas de fumo.

Às onze e meia, a ilha de Alborán, negrejando por bombordo, confirmava o rumo; e um quarto de hora mais tarde, o Cabo das Três Forcas aparecia, monstruosa garra petrificada, junto à qual o casco do couraçado España agonizava lamentavelmente, abandonado às ondas.

Melilla, a distância, era uma claridade baça.

O Pátria orça ${ }^{24}$, deixando ao longe a lagoa estranha de Mar Chica, aproa ao Cabo da Água e, depois de quase duas horas de voo sobre o mar, recomeça a seguir a costa que se crispa progressivamente, em ondulações hostis.

Nemours lá fica muito aninhada entre arvoredo, com seu ar senhoril de pequenina cidade europeia.

À uma hora e um quarto, sulcávamos o céu de Orã, aterrando, depois de uma volta de pista, no magnífico aeródromo de La Senia ${ }^{25}$, oito quilómetros a Sudeste, onde o comandante e os oficiais do $1 .^{\circ}$ Grupo de Esquadrilhas de Aviação de África nos felicitavam calorosamente; e o Pátria recolhia sem demora a um hangar.

Havia uma semana que o avião saíra da Amadora. Ao vê-lo abrigado enfim, do nosso espírito evolava-se a amargura que, desde a tarde de 2 de Abril, nos atormentava como pesadelo.

Vencêramos o Mediterrâneo. A próxima etapa era o Gouveia.

Na travessia da costa Norte do continente africano, que pela primeira vez ia ser tentada, Portugal teria novamente oportunidade de abrir ao mundo rotas aéreas ignoradas ainda.

${ }^{24}$ «Orçar» é um termo náutico, que significa mudar de rumo, para aproveitar melhor a acção do vento. (Nota do editor).

${ }^{25}$ Nome da actual Es Sénia, durante a colonização francesa. (Nota do editor). 
瓦赫兰城是一个大型的商业枢纽, (别人告诉我们) 它的发展十分迅速。法兰 西的殖民精神在这里展现出的精细和技巧成功地平定了周围的反政府武装。

作为航空中心, 它的重要性可通过其可用的设施来评估：它是菲斯-一奥兰， 马赛——奥兰和阿利坎特一一奥兰三条航线的终点站。拉塞尼亚 ${ }^{26}$ 除了有八个机 库之外, 还拥有一个大吨位飞艇用的机库和储备充足的车间, 它也是两个观察和轰 炸航空中队的总部。

在这些单位正在做的工作中，值得一提的是消耗了巨大力量建立起来的阿尔 及利亚一一塞内冈比亚空中航道。这条航道穿越了撒哈拉, 它代表了法国政府对 空中交通经济价值的充分认识，还代表了葡萄牙参谋部对保持第五军战斗力的充 分理解 27

加略特司令和他的随同官员对我们十分客气。

11 日, 布里托 - 帕艾斯遇到了洛尔卡一一那个在遥远的战争时期, 在雨维西教 会他飞行的人 28 。这位法国老飞行员在时救出了自己曾经的学生, 对此, 他丝毫不 掩饰他的骄傲。

古略特也来了。他是非斯一瓦赫兰航线的飞行员, 曾与乌利西斯 - 阿尔维斯 ${ }^{29}$ 同时在于维西学校。还有邓格拉德队长, 一位典型的高雅的巴黎人, 他在一战期 间在空军部队战斗。这两位在与我们握手时都着重谈到了我们飞越地中海的事 情。这让我们觉得, 在那一刻, “祖国号” 的飞行已经为葡萄牙空军增添了荣耀。

由于12日的天气非常好, 加略特司令乘他们组的车来宾馆接我们。

有一个军事管理部门的官员, 在我们来时就告诉我们, 必须支付各种费用。他 杞人忧天地怕我们没结账就走了, 大清早六点钟就来等着。

\footnotetext{
26 今天的塞尼耶在法国殖民期间的名字。(编者注)

27 最近航空秘书处启动的的法国空军在乍得湖的任务证实了我们的话。

28 萨尔门托 - 德贝雷斯提到的、位于瑞维西的初级飞行教练学校。无论是法国还是英国都在葡萄牙培训 了未来的航空教练, 从而在女王新镇诞生了第一个航空学校, 从这个学校中走出了萨尔门托 - 德贝雷斯。葡 萄牙当时的战争部长在1916年要求进行这种培训, 由于没有成果而结束了一一因为在参加第一次世界大战 的葡萄牙远征军中没有一个葡萄牙自己的中队。1918年3月31日, 战争部长命令在法国的葡萄牙军人回国, 但他们当中的许多人没有返回, 而是在法国中队中任职,服务于法国联合办公室。(编者注)

29 我们在文中提到的曾乌利西斯 - 阿尔维斯中尉是少数参加过第一次世界大战的葡萄牙飞行员之一。他 当时加入了一个法国的空军小队, 后来回到葡萄牙, 在一次不光彩的事故中死亡。(第二版注释)
} 
A cidade de Orã é um grande núcleo comercial cujo desenvolvimento (dizem-nos) se opera a olhos vistos, e onde o espírito colonizador da França manifesta a finura e o savoir-faire que lhe têm permitido realizar, com êxito, a pacificação das regiões rebeldes das cercanias.

Como centro aeronáutico, a sua importância pode avaliar-se pelas instalações de que dispõe - estação términos de três linhas aéreas, Fez-Orã, Marselha-Orã, Alicante-Orã - La Senia $^{26}$ conta, além de oito hangares para aviões, com um hangar para dirigíveis de grande tonelagem e oficinas bem providas de material de reserva, sendo também sede de duas esquadrilhas de observação e bombardeamento.

Entre os trabalhos que estas unidades estão levando a efeito, merece mencionar-se, pelo esforço formidável que representa, a ligação da Argélia com a Senegâmbia, através do Saara, ligação que sintetiza a nítida compreensão, por parte do Governo Francês, do valor económico das comunicações aéreas e, por parte do Estado-Maior, da utilidade e da necessidade de manter em forma a $5 .^{\text {a }}$ Arma $^{27}$.

O comandante Gallet e os seus oficiais cumulam-nos de gentilezas.

No dia onze, Brito Paes encontra Lorca, o homem que o ensinou a voar durante a guerra, no tempo distante de Juvisy ${ }^{28}$. O velho piloto francês não dissimula o orgulho que sente, ao encontrar, em pleno raide, o seu antigo aluno.

Aparece também Collet, da linha Latécoere Fez-Oran, contemporâneo de Ulisses Alves ${ }^{29}$ na Escola de Juvisy, e o capitão Danglade, protótipo do parisiense requintado, que durante a Grande Guerra combatera na aviação. Ambos eles, ao apertarem-nos a mão, frisando a travessia do Mediterrâneo, nos mostram que já naquele momento a viagem do Pátria honrava a Aviação Militar Portuguesa.

Como no dia doze as informações meteorológicas fossem excelentes, o comandante Gallet vinha buscar-nos ao hotel, no automóvel do Grupo.

Um oficial da administração militar que, à chegada, nos advertira de que teríamos de pagar as despesas esperava-nos apesar da hora matinal - seis da manhã -, num receio inconfessado de que partíssemos sem liquidar a conta.

\footnotetext{
${ }^{26}$ Nome da actual Es Sénia, durante a colonização francesa. (Nota do editor)

${ }^{27}$ A missão aérea ao Lago Chade, ultimamente tentada pela Aviação Francesa, por iniciativa do Subsecretariado da Aeronáutica, vem confirmar as minhas palavras.

${ }^{28}$ Sarmento de Beires refere-se à Escola de Instrução Elementar de Voo em Juvisy. A França, tal como a Grã Bretanha, formou os instrutores dos futuros aviadores portugueses, facto de que resultará a primeira Escola de Aviação de Vila Nova da Rainha, de onde sairá Sarmento de Beires. Esta formação, solicitada por Portugal pelo então ministro da Guerra em 1916, acabou por não ter resultados, pois Portugal não teve uma esquadrilha própria entre o Grupo Expedicionário Português que foi mobilizado para participar na Primeira Grande Guerra. A 31 de Março de 1918, o ministro da Guerra dá ordem de regresso aos militares portugueses em França, mas muitos deles não regressam, colaborando em esquadrilhas francesas, ao serviço do Bureau des Alliés. (Nota do editor).

${ }^{29} \mathrm{O}$ tenente aviador Ulisses Alves, que mencionamos, foi um dos poucos aviadores portugueses que combateram na I Grande Guerra, integrados numa esquadrilha francesa. Veio morrer a Portugal num desastre inglório. (Nota da $2 .^{\text {a }}$ edição).
} 
由于之前他通知了我们, 我们就去找他。这个小个子男人挠着头, 以他列在办 公桌上的一大本一大本规范条例为由, 让我们签了无数张单子, 然后给我们报销了 2000法郎……

“祖国号”在跑道上焦急地等待着。

发动机开始运转, 我们表达了谢意并与送行的人互致告别, 带着 1000 升汽油, 在两艘法国飞机的短暂陪同下离开了瓦赫兰。

早晨天气晴朗, 酒满温和阳光的大海如同流金一般, 在飞机平稳地经过时沉睡 着。

我们的下方是契立夫河谷, 它就像同一条绿色的䌸带, 而蜿蜒的河流则为它镶 上了一条泥土色的花边。

南面, 永恒仁立的群山漠然地守望着神秘而无垠的大沙漠。

沿着河边，因科曼、卡戎、奥良维尔、胡伊那、拉凡罕德和其他有着奇怪的 阿拉伯味道名字的小城, 像是一条浅色珠子连成的珠串。

窄窄的铁路与白色的公路交错, 在农田上画出红木和珍珠母颜色的、细长的 阿拉伯式花纹。

在扎卡山脚下, 米莉安娜小镇闪伢着雪花石的光彩。在这里, 这幅阿拉伯风格 的花纹图案消失在树林中, 并在远处重新出现在通往阿尔及尔的路上。远远看去, 阿尔及尔就像一粒珍珠, 闪耀在贝壳形的蓝色海湾中。

然后我们来到了大、小卡比里, 这里地表粗䊁, 布满岩石, 一片寂静。群山与 大海相邻, 几个悲惨的小村子零星分布在此处。

在得利斯和布吉之间是一片长度超过一百公里的荒芜地带。

拉莱海迪贾峰的尖顶被冰雪覆盖着, 仿佛是一把要将天空翟破的七首。这 片可怕的铅灰色景象出现在我们左翼, 像是高峻的朱尔朱拉山脉上一颗流脓的肿 瘤。

前方, 萨赫勒河谷在险峻的地形上勾勒出一条绿色的带子。从此处到菲利普 维尔之间的凄凉地带挑眫着来到这里的人们。

一千多米高的古飞山垂直于海面。

“祖国号”在2200米的高度, 以每小时150公里的速度沿航线向前飞去。

机翼上, 一片撕裂的布篷飘扬在风中。

庞大的艾道夫山从我们的左舷掠过, 我们飞过古老的费扎哈湖湖床, 它就像伯 恩平原上的一道白色伤口。

每座我们遥望到的城市就像是一道突然在从林景观上闪过的生命之光。

下午一点, 塔巴尔卡告诉我们: 到突尼斯了。

我们飞过一片开采中的铁矿时, 指南针失灵了。 
E como, já prevenidos, o procurássemos, o homenzinho, coçando a cabeça, desculpando-se com os volumosos regulamentos que se alinhavam sobre a sua secretária, obriga-nos a assinar uma interminável série de impressos e desembolsa-nos de dois milhares de francos...

Na pista, o Pátria era uma ansiedade.

Motor em marcha, agradecimentos, despedidas, e com mil litros de gasolina a bordo, saímos de Orã, escoltados durante alguns minutos por dois aviões franceses.

A manhã transparente, com o sol morno polvilhando a paisagem de oiro fluído, era um mar adormecido que o avião sulcava sem o mais leve estremecimento.

O vale de Oued Cheliff corria sob nós, larga faixa verde em que as sinuosidades do rio desenhavam um bordado cor de barro.

Para Sul, a imobilidade eterna das montanhas velava, impassível, as vastidões misteriosas do Grande Deserto.

Junto ao rio, desfiava-se um rosário de contas claras: Inkermann, Charon, Orleansville, Rouina, Lavarande, e outras de nomes estranhos e sabor árabe.

A linha estreita da via férrea, entrelaçada na estrada branca, traçava nas culturas um arabesco alongado de pau santo e nácar.

Nas faldas do monte Zaccar, onde Miliana tem cintilações de alabastro, o arabesco perde-se entre o arvoredo, para surgir ao longe, coleando, a caminho de Argel, que, a distância, reluz como pérola ao fundo da concha azul da baía.

Depois, são a Grande e a Pequena Kabylie, de relevo áspero, pedregosas e soturnas. As montanhas aproximam-se do mar, cariadas de onde a onde por aldeias miseráveis.

Entre Dellys e Bougie, alongam-se mais de cem quilómetros de região escalvada e erma.

Visão que horripila, o pico de Lella Kredidja, apunhalando o céu, coberto de neve no topo agudo, jorra lividamente no horizonte de estibordo, como tumor purulento da alta cordilheira da Djurdjura.

Adiante, o vale do Sahel abre uma traça de verdura no terreno alcantilado, que retoma o carácter agressivo e desolante até Philippeville.

E o Djebel Goufi são mais de mil metros caindo a prumo sobre o mar.

A dois mil e duzentos metros de altitude, o Pátria singra na rota, à velocidade de cento e cinquenta quilómetros por hora.

$\mathrm{Na}$ asa superior, um pedaço de tela rasgada tremula ao vento.

Deixamos por bombordo o maciço de Edough, passando sobre o leito do antigo lago Fezzara, que tem o aspecto duma chaga esbranquiçada na planície de Bône.

Cada cidade que avistamos põe na paisagem selvática um relâmpago de vida.

Pela uma da tarde, Tabarca anuncia-nos a Tunísia.

Por momentos a bússola endoidece, ao voarmos sobre o polígono sombrio de uma mina de ferro em exploração. 
过了一会儿, 让人惊讶的是, 在我们的左侧, 加力它岛出现在地平线上, 像悬在 一片蓝色中的黑色钻石。大海的蓝色与天空的蓝色交融在一起。远处, 一片天鹅 线般的小小阴影如同幻影般令我们颤抖。

比塞大与安克杰迈勒这对双子湖像被抛光的钢板一样反射着阳光。青铜色 的安克尔山像一座巨大的驼峰。

最后, 远处出现了一片白色痕迹, 就像挥舞致意的白手绢。这片白色渐渐从海 湾的水中浮现出来, 它的轮廓清晰起来一一那是白得发亮的突尼斯, 城中白色的房 子在午后的柔光中闪闪发亮。

“祖国号” 开始降落, 我们像远古时代的巨乌一样, 在卡萨尔赛义德的田野上兒 了两大圈后, 平静地降落在地面。

在六小时五十分钟的时间里, 我们竟然飞了1100公里。

几个法国机师跑过来迎接我们, 他们告诉我们, 由于等待迎接我们的人都在艾 尔阿洛伊纳 ${ }^{30}$ 机场, 卡萨尔萨德这里没有任何官员。

于是电话联系。

半小时后, 两辆汽车带来了拉法格福来勒的两位 “司令”: 一位是塔波内先生, 他是葡萄牙驻突尼斯领事; 另一位是曼努埃尔・戈维亚。

法国官员们中肯而真诚地称赞我们, 言辞中洋溢着他们对葡萄牙在航空领域 取得的成功的认可。领事先生也来问候我们。然后, 这三位通情达理地离开了, 我 们得以与戈维亚独处。

我们在久别重逢带来的激动中让拥抱了好一会儿。

此时此刻对于我们来说, 戈维亚有点儿象征着葡萄牙, 象征着我们航空力量的 一部分, 而至关重要的是, 从今往后他是与我们并肩奋斗的伙伴。

他连珠炮式的问题让我们来不及回答, 他的眼中含着笑意, 忘记了旁边有人在 看着我们, 只有我们此时的感受在不断蔓延。

塔波内先生是个有趣的人物。他生在马耳他, 幼时来到突尼斯, 国籍上是英国 人, 性格中却充满了法国人的特点。

戈维亚用䇣䇣几句话给我们讲了塔波内先生给予他的支持和关注。

这让我们想起了与其形成对比的葡萄牙驻瓦赫兰领事的态度。我们去找他 时, 他马上摆出一副对我们毫不关心的嘴脸。

我们还记得, 在瓦赫兰时, 葡萄牙的代表抛弃了我们。如果没有加略特司令的 话, 我们可能会遇到无数的麻烦。

30 艾尔阿洛伊纳在突尼斯以北九公里处, 目前为非洲航空中队第四小队的总部, 因此, 卡萨尔赛义德的跑道 被弃用了。 
Instantes depois, como surpresa de assombro, destaca-se no horizonte, por bombordo, a ilha de Galita. É um diamante negro em suspensão no azul; mar e céu fundem-se em sincronismo incomparável de tons, e o floco de sombra, aveludado, distante, faz-nos estremecer como se presenciássemos uma aparição.

Junto aos lagos gémeos de Bizerta e Garaet-el-Achkel, chapas de aço polido a reverberar a luz do Sol, o Djebel Achkel destaca-se pela coloração bronzeada da sua corcunda enorme.

Enfim, ao longe, uma nódoa branca - branca como o lenço a acenar - começa a emergir das águas do golfo. Pouco a pouco vai-se definindo, contornando, detalhando, e Túnis surge, alvíssima, quase luminosa, com seu casario a cintilar na luz macia da tarde.

O Pátria desce, descrevendo dois grandes círculos sobre o campo de Kassar-Said, e aterra docemente, como gigantesca ave de outra era.

Em seis horas e cinquenta minutos, acabávamos de percorrer mil e cem quilómetros.

Alguns mecânicos franceses correm a receber-nos e informam-nos de que, como nos esperam no aeródromo de El Alouina ${ }^{30}$, nenhum oficial se encontra em Kassar-Said.

Telefona-se.

Meia hora mais tarde, dois automóveis chegam, trazendo os comandantes de La Fargue e Frère, Mr. Tabone, cônsul de Portugal em Túnis, e Manuel Gouveia.

Os oficiais franceses têm, ao saudar-nos, sóbrias mas sinceras palavras de elogio, em que perpassa o reconhecimento tácito do triunfo das asas portuguesas. O cônsul associa-se e, num gesto que diz delicadeza e sensibilidade, os três afastam-se, para deixar-nos sós com Gouveia.

O nosso abraço prolonga-se um instante, na emoção invencível do encontro tão longamente esperado.

Para nós, Gouveia simbolizava, nesse minuto, um pouco de Portugal, uma parcela da nossa Aviação e, acima de tudo, uma dedicação de ora avante ao nosso lado.

As perguntas afluíam-nos desordenadamente aos lábios sem esperar resposta, e os olhos riam, esquecidos de que alguém nos observava, deixando expandir tudo o que sentíamos.

Mr. Tabone é uma figura interessante. Nasceu em Malta, veio para a Tunísia muito novo e, embora de origem inglesa, tem todas as características do francês.

Gouveia conta-nos, em poucas palavras, o auxílio e as atenções que dele tem recebido.

E a gente recorda, num contraste, a atitude do cônsul de Portugal em Orã, que, ao ser procurado por nós, manifestava imediatamente o mais completo desinteresse.

E a gente lembra-se de que, em Orã, o representante de Portugal nos abandonou e que, sem a gentileza do comandante Gallet, teríamos lutado com dificuldades sem número.

\footnotetext{
${ }^{30}$ El Aouina, nove quilómetros a Nordeste de Túnis, é actualmente a sede do $4^{\circ}$ Grupo de Esquadrilhas de Aviação
} de África, devendo, por isso, ser abandonada a pista de Kassar-Said. 
是加略特司令把我们介绍给了军事广场的总司令; 是他给了我们珍贵的气象 信息, 使我们得以漂亮地完成瓦赫兰一突尼斯段的飞行; 是他向我们提供了当地的 照会; 是他让第一小队的飞行员在军事俱乐部向我们敬上一杯香槟。

至于那位我们选择性遗忘其名字的领事, 在他的船舶代理公司总部接见了我 们。当我们向他询问当时获得经济支援的最好途径时, 他先是让我们等了半个小 时, 并表现了出对我们所带来的不便的厌烦, 然后派一个仆人陪我们去了趟银行。

与之形成鲜明对比的是塔波内先生一一这位受过良好教育的外交家与突尼 斯最上流的社会有着来往。他向戈维亚提供了各种便利以及各种第一次来这片陌 生土地的人所需要的一切指引和帮助后, 又以最真挚的热情迎接了我们, 并且一刻 不停地陪在我们身边。他把我们介绍给了驻突尼斯的法国外交官 ${ }^{31}$ 卡思蒂龙 - 德 森特维克多先生, 并想尽一切办法确保我们这段时间在这法属殖民地首都过得愉 快。

戈维亚因为再一次触摸到了 “祖国号” 的引擎, 为这架遭受了各种恶劣天气虐 待的飞机进行检修。他的眼中充满了喜悦, 因为这台引擎即将带着他同行。与此 同时, 我们则去城里转了一圈。

白色的突尼斯像极了欧洲城市。只有红色的土耳其帽和飘舞的土著服装暴 露了大街小巷展现不出的异国风情。

阳光灼热而刺眼, 白人们不得不戴上墨镜。

在宽阔而低矮的艾尔巴黑拉湾, 长长的人工运河像马里昂上的一条僵直的线 条。

在这座现代城市的中心是一座保存得十分完好的阿拉伯小城, 如化石一般, 在 这仿佛不流动的时间中令往昔重现。走过湖上的尖拱桥, 我们就进入了一条蜿蜒 的小巷, 这时, 环境突然变了。

欧洲人少了。

各种各样的商店在门前招揽着客人。有阿拉伯商店, 土耳其商店, 犹太商店, 他们卖香水, 铺展开挂毯, 展示各种奇特的东西, 提供异国的美食。

我们漫步在 “苏克” (即窄小的的道路, 有的上面会有拱顶, 形成回廊) 上, 观察 原住民们小心翼翼保护着的原始工艺流程一一他们完全无视现代科技的进步。尽 管如此, 我们仍被这里的美丽、温柔与异域风情震撼了。

每条 “苏克” 都有它的卖点: 有卖香水的, 有买鞋子的, 有卖烟草的, 也有卖珠宝 的。

31 原文中使用了外交法规中的一个术语, 指的是居住在东道国的外交官的状态。(编者注) 
Foi o comandante Gallet quem nos apresentou ao general comandante da Praça Militar; foi ele quem nos conseguiu as preciosas informações meteorológicas que deviam permitir-nos a esplêndida etapa Orã-Túnis; quem nos forneceu cartas da região; quem nos conseguiu alojamentos no hotel; quem promoveu a taça de champanhe que os aviadores do Primeiro Grupo nos ofereceram no Clube Militar.

O cônsul, cujo nome deliberadamente esqueci, recebeu-nos na sede da sua agência de transportes marítimos e, como lhe pedíssemos uma indicação sobre a melhor maneira de adquirir francos àquela hora, mandou-os acompanhar a um banco por um criado, depois de nos ter feito esperar quase meia hora e de nos ter manifestado o seu enfado pelo incómodo que lhe causávamos.

Mr. Tabone, ao contrário, é um diplomata finíssimo, relacionado com a melhor sociedade de Túnis. Depois de ter dado a Gouveia todas as facilidades, todas as indicações e todo o auxílio de que sempre necessita quem pela primeira vez põe pé em terra estranha, recebia-nos com sincero entusiasmo, não deixando de nos acompanhar um só instante, apresentando-nos a Mr. Castillon de Sant-Victor, Residente ${ }^{31}$ da França na Tunísia, e procurando por todos os meios tornar aprazível a nossa passagem pela grande capital do Protectorado.

Enquanto Gouveia iniciava a revisão do Pátria, tão rudemente maltratado pelo tempo, - alegria a bailar-lhe nos olhos, a tocar de novo aquele motor que agora ia levá-lo também dávamos uma volta pela cidade.

Túnis, a branca, é quase um burgo europeu. Apenas os fez vermelhos e as roupagens flutuantes dos indígenas quebram o aspecto inexpressivo das ruas e avenidas.

O sol, já ardente, morde a vista, obrigando o branco a usar óculos pretos.

E na baía vasta e baixa de El Bahira, o longo canal artificial tem a rigidez de uma recta sobre um marion.

Ao centro da cidade moderna, a cidade árabe quase intacta, como fossilizada, é uma incrustação anacrónica onde o Passado ressuscita. Passa-se um arco ogival que abre sobre um largo, entra-se num beco tortuoso, e o ambiente transforma-se repentinamente.

Os europeus rareiam.

À porta de loja dos mais variados tipos aparecem árabes, turcos, judeus, convidando a entrar, oferecendo perfumes, desenrolando tapetes, mostrando curiosidades, propondo exóticas guloseimas.

Através dos souks - ruelas estreitas a que, por vezes, uma abóbada dá um recolhimento de claustro -, a gente caminha, observando os processos primitivos que o indígena conserva ciosamente, numa indiferença absoluta pelos processos da técnica moderna. Apesar disso, tudo impressiona pela beleza, pelo exotismo, pela suavidade.

Cada souk tem a sua especialidade: há o souk dos perfumes, o do calçado, o do tabaco, o das jóias.

${ }^{31}$ Termo do código diplomático que se refere à situação do diplomata que reside no Estado que o acolhe. (Nota do editor). 
我们所驻足的这条卖挂毯的 “苏克”, 它用魔法般的惊人鬼力留驻在了我的灵 魂当中。这条 “苏克” 非常宽, 被简约的圆柱分成三部分, 路上装饰有阿拉伯地毯。 从天窗射进来的朦胧光线像是为它铺上了一层闪闪发亮的天鹅线, 仿佛梦中见到 的来自东方的闪电。

我们进入了一家挂毯店。

店主为我们送上了香气扑鼻的美味土耳其咖啡, 两个阿拉伯人在我们面前展 开一张张精美的挂毯。这些色彩和图案, 展现出艺术和想象的天分, 从绘制者对色 调的选择到对色温与色彩平衡的掌握, 无一不展示出他在艺术上和想象力上的天 分。

回到毫无特点和色彩的林荫大道上, 下午强烈的阳光灼烤着我们, 整个老城区 似乎成了潜意识里的回忆, 就像梦中出现过的鬼惑景象。

法国空军请我们在马杰斯提克酒店喝茶。

曼当队长也在这些飞行员中。几个月后, 在比塞大, 在加洛斯横渡成功的庆祝 中, 曼当死在了一场悲剧的事故中。他是一位拥有首创精神和丰富知识的飞行员, 曾驾驶 “思派德号” 开始了一场环游世界的飞行, 却因为他人的原因不得不在突尼 斯中断。他给了我们友善的建议, 使我们在接下来的旅途中受益良多。

他们告诉我们, 佩尔蒂埃・窦昔 ${ }^{32}$ ——他的同志们都叫他 “高飞的喜鹊” 在一周前去了巴黎, 为从巴黎到东京的飞行做最后的准备。

我们能够感到周围的这些人, 他们对这次飞行的成功有着热切期盼, 这盼望持 续了好一会儿。

这些飞行员的壮举令整个飞行员大家庭为之关心, 为之担忧。

启程进行环球飞行的美国飞行员们因为恶劣天气停在了西雅图; 英国的飞行 员们在克基拉岛等待修复飞机的材料——他们的飞机再一次在强行降落中受到了 严重的损伤; 而我们, 在向飞往东方的路上, 没有得到政府的支持一一这令其他国 家的飞行员惊讶极了; 佩尔蒂埃 - 窦昔即将飞往日本; 意大利飞行员卢卡特里 ${ }^{33}$ 正 准备横渡大西洋; 阿根廷的扎尼少校 ${ }^{34}$ 正在试验他的福克飞机, 他也将乘着它环游 世界; 最后是荷兰飞行员们, 他们正在准备从阿姆斯特丹到巴达维亚的飞行。

32 乔治・佩尔蒂埃・窦昔 (1892年-1953年), 法国航空先驱飞行员。他被称为Pivolo, 据彭德尔 (Pende11é) 称, 这个绰号来自一句他总是劝说飞行员们的、被讹用的话: Puis vole haut (意为 “然后飞高”)。他以成功完 成1924年的巴黎-东京空中突袭而闻名。(编者注)

33 安东尼奥 - 路易奇 - 卢卡特里是一名意大利飞行员和一位飞行先驱。他以 1918 年在同是飞行员, 也是诗 人和政治家的加布里埃尔 - 邓南遮的指挥下, 成功飞抵维也纳而闻名。在维也纳上空, 他投下了著名的意大 利激进主义宣传单, 以寻求在奥匈帝国的一些地区协助意大利。

34 佩德罗・里安德罗・扎尼 (1891年- - 1942年), 是一位阿根廷军人和飞行员。在多次开拓性飞行中, 他于 1924 年试图环游世界。这一年的7月26日他从阿姆斯特丹出发, 10 月 11 日飞抵东京, 但当时的天气状况迫使 他放弃了继续飞行。(编者注) 
O souk dos tapetes, onde nos demoramos, vinca-se-me no espírito, num estonteamento de magia. Excepcionalmente largo, guarnecido de colunas simples que o dividem em três naves, apainelado com alcatifas árabes a que a luz dúbia das clarabóias imprime cintilações veludíneas, é um relâmpago do Oriente visionado em sonho.

Entramos numa tapeçaria.

O proprietário oferece-nos café turco, saboroso, perfumado, enquanto dois árabes vão estendendo diante de nós tapetes magníficos. As cores e o desenho revelam prodígios de arte e de imaginação, no calor e no equilíbrio da combinação e da escolha das tonalidades.

Ao regressar aos boulevards, às avenidas sem carácter e sem cor, a luz crua do sol da tarde fere e magoa, e toda a velha cidade desliza em rememorações inconscientes, como visão de encanto entressonhada algum dia...

A aviação francesa oferece-nos um chá, no Magestic Hotel.

Entre os aviadores, encontra-se o capitão Madon, o ás que, em Bizerta, devia morrer meses depois, num trágico acidente durante a consagração de Garros. Piloto de iniciativa e conhecimentos profundos, que num avião Spad iniciara a volta ao mundo, interrompida em Túnis por motivos alheios à sua vontade, dá-nos conselhos amigos que muito hão-de aproveitar-nos no prosseguimento da viagem.

Ali nos contam que Pelletier-Doisy ${ }^{32}$ - Pivolo, como é conhecido entre os seus camaradas partira uma semana antes para Paris a fim de ultimar os preparativos para a viagem Paris-Tóquio.

São minutos em que sentimos à nossa volta almas ansiando o triunfo das asas.

Os grandes empreendimentos em curso preocupam e interessam a grande família humana dos que voam.

Os americanos, que partiram para a volta ao mundo, imobilizados em Seattle pelos temporais; os ingleses, esperando em Corfu material para reparar o avião, seriamente avariado numa aterragem forçada; nós, a caminho do Oriente, desamparados do Governo - facto que surpreende profundamente o estrangeiro; Pelletier-Doisy em vésperas de partir para o Japão; o italiano Locatelli ${ }^{33}$, preparando a travessia do Atlântico; o major argentino Zanni ${ }^{34}$ ensaiando o Fokker em que vai também largar para a volta ao mundo; e, finalmente, os holandeses, organizando a viagem Amsterdam-Batávia.

\footnotetext{
${ }^{32}$ Georges Pelletier-Doisy (1892-1953) foi um piloto francês, pioneiro da aviação, a quem chamavam Pivolo, alcunha que, de acordo com Pendellé, era uma corruptela da frase com que sempre aconselhava os aviadores: Puis vole haut (depois voa alto). Tornou-se famoso ao realizar com sucesso, no ano de 1924, o raide aéreo Paris-Tóquio. (Nota do editor).

${ }^{33}$ Antonio Luigi Locatelli foi um aviador italiano, pioneiro da aviação. Ficou sobretudo conhecido pelo facto de, em 1918, sob o comando do também aviador, poeta e político Gabriel d’Annunzio, ter realizado o raide sobre Viena, lançando sobre a cidade os célebres boletins propagandistas do irredentismo italiano, que procurava anexar à Itália algumas regiões do império austro-húngaro. (Nota do editor).

${ }^{34}$ Pedro Leandro Zanni (1891-1942) foi um militar e piloto argentino que, entre vários voos pioneiros, em 1924 tentou a volta ao mundo, saindo de Amesterdão a 26 de Julho e chegando a Tóquio a 11 de Outubro do mesmo ano. As condições meteorológicas que então encontrou levaram-no a desistir de continuar a viagem. (Nota do editor).
} 


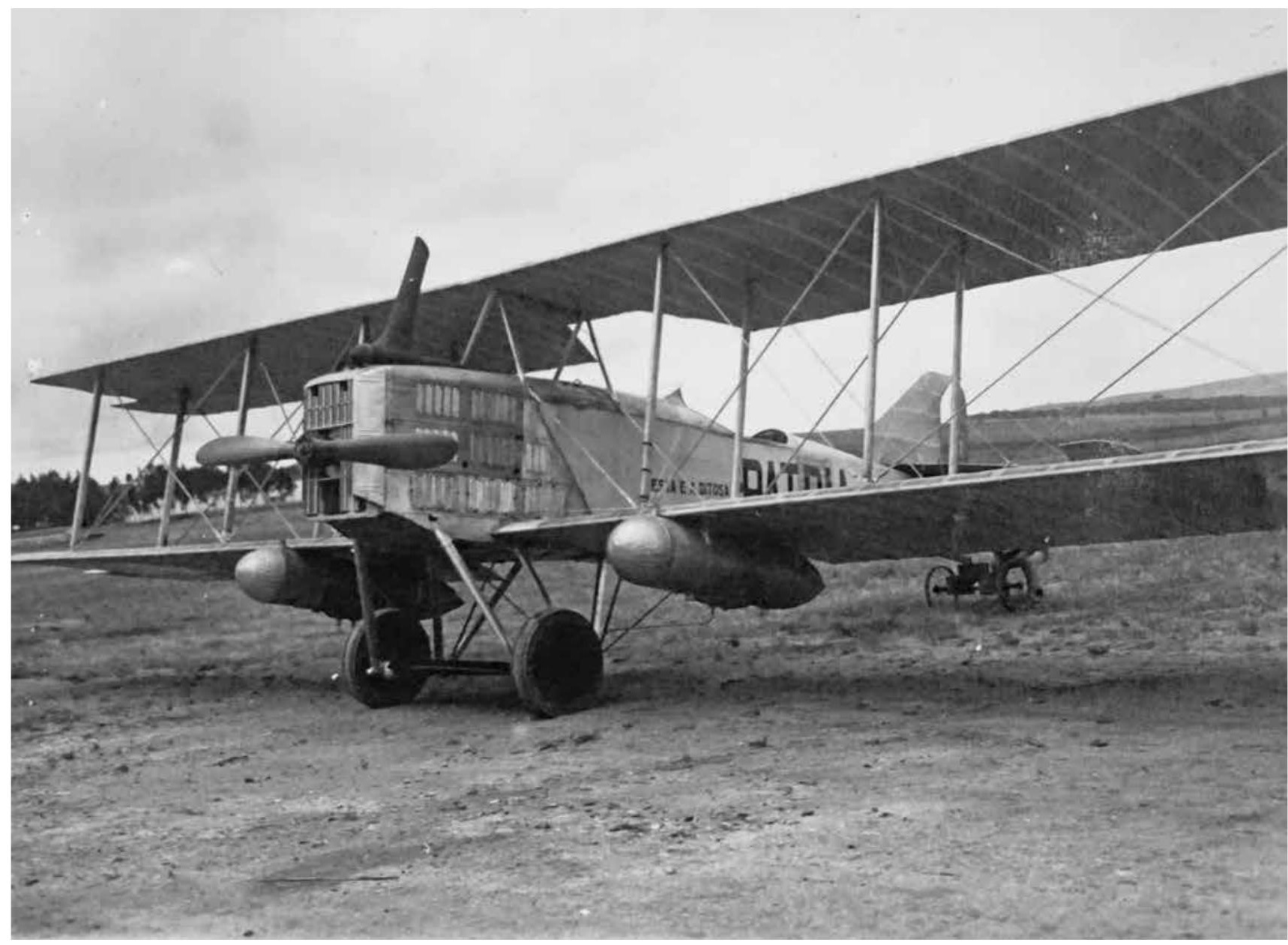

\section{O avião Pátria}

(Tipo Breguet 16BN 2. Motor Renault 300CV. Modelo de 1919)

“祖国号”飞机

(布雷盖16BN2型飞机。雷诺300CV发动机。1919年样式) 
DE PORTUGAL A MACAU (A VIAGEM DO PÁTRIA) | 从葡萄牙到澳门（ “祖国号”之旅）

螺旋桨在蓝天中旋转。

每个人的胸中都涌动着对野外, 对广阔天空的热爱之情。

而在我们的心中则升腾起一阵骄傲, 因为葡萄牙也参与到了这飞行员们组成 的世界性的兄弟会中, 与大家共同完成这至高无上的壮举。 
Giram hélices no azul.

Há uma aspiração de ar livre, de céu profundo, vibrando intensamente em cada peito.

E nos nossos corações, uma rajada de orgulho passa, ao sentir que Portugal trabalha também na obra sublime de fraternização universal, que é a obra dos aviadores. 


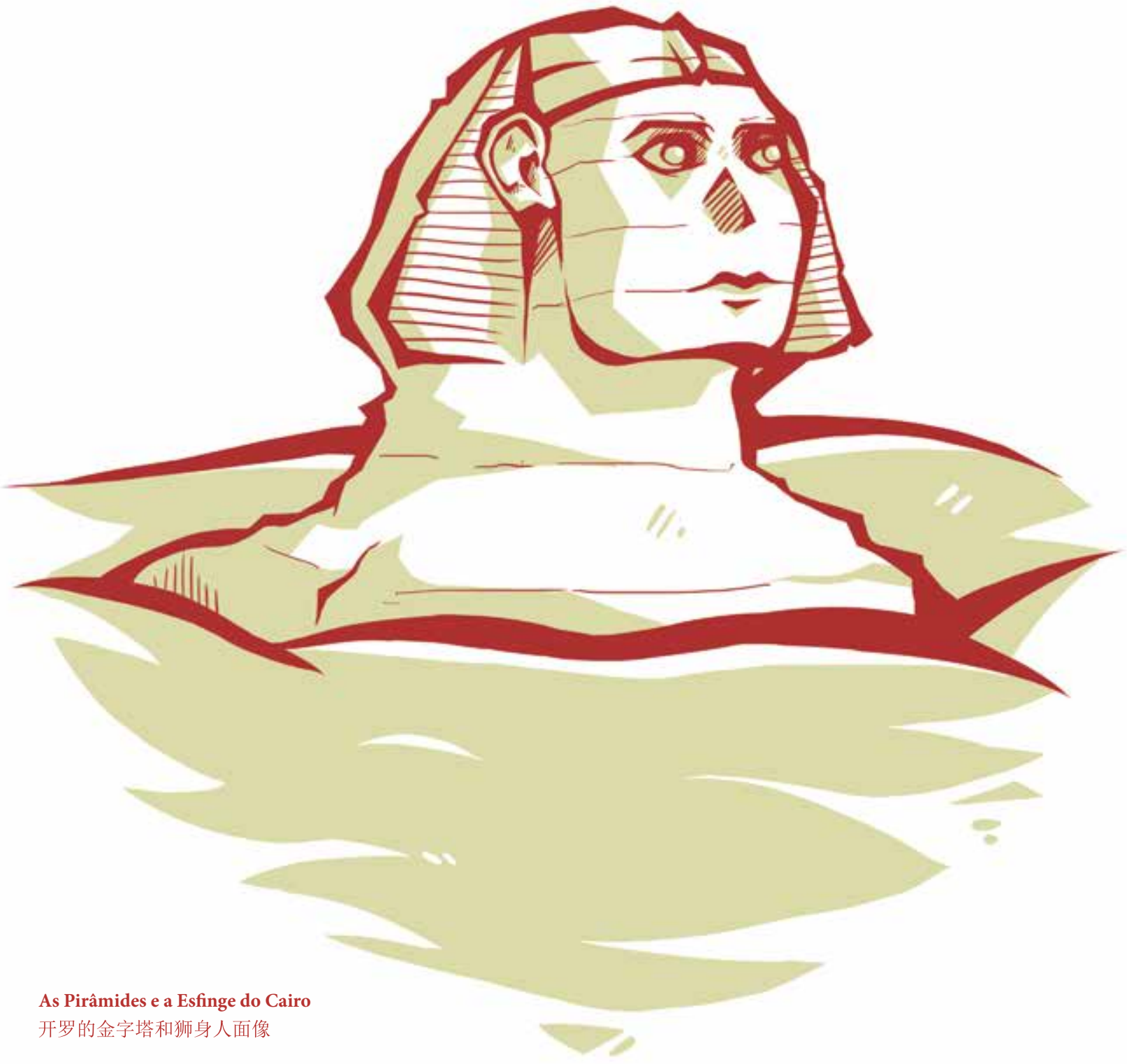




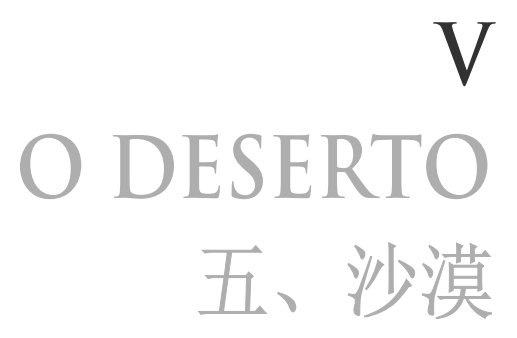


4月 14 日。在卡萨尔赛义德巨大的四边形场地上, “祖国号” 反射着太阳的光 芒。有人会说戈维亚灵魂散发出的能量在机身中鼓动着。发动机还能感受到他轻 柔的抚摸，仿佛我们的机械师用他灵巧的双手在上面留下了烙印。这是个问热的 早晨, 在清晨的强光中, “祖国号” 看起来愈发年轻, 愈发斗志昂扬。

几辆车来了。

那位法国外交官 ${ }^{35}$, 拉法格福来勒的司令们, 塔波内先生, 记者们和摄像师们都 到了。

就像在瓦赫兰一样, 此时也有一位军事管理部门的官员。这个形式主义和官 僚主义的幽灵走在我们身边, 告诉我们得付汽油费。

拉法格福来勒的司令试图反对他, 但这个小个子男人向他阐述了走程序的重 要性, 要负责, 要守章程.......

我们的资金缩减到了一个新的低谷。我们怀着担心检查了仪器。这是我们 第一次全员集合, 一起起飞。我们用微笑掩饰着心中的不安, 但是却不能骗过彼 此。现在是早上 9 点。

我们向那些给予我们帮助和关怀的人们表示了诚挚的谢意, 然后向他们告 别。我们走上飞机, 试启动引擎。

跑道的主管给了我们起飞的信号。

“祖国号” 的螺旋桨开始转动, 飞机离地, 并毫不费力地升向仿佛然烧着的天 空。

在我们飞过布克米恩山的顶峰时, 飞机强烈地摇晃起来。苍穹在展示着它的 威力。这段飞行可能会很艰难。随着我们的前进, 气温不断升高。

飞过则吉坦恩山脉最后的支脉形成的高墙时, 突然, 景色发生了变化一一这里 像一片无边无际的大草原, 边上是海边的植被, 就像一条巨大的、沙子做成的绿色 毛巾, 上面还饰有花边。

姆萨肯, 埃尔德吉姆, 斯法克斯是一颗颗遗失在黄褐色平原上的珍珠。在这 里, 石灰色的赛迪艾尔哈尼大盐湖闪㷧着耀眼的光芒。

西斯德鲁斯的古罗马遗迹被我们甩在身后, 那是对过去许多个世纪的时光的 记忆。

时不时地刮起的一阵阵红色沙暴, 像是在蔚蓝的天空中撒下了血迹。风从南 方刮来, 带来撒哈拉大沙漠灼热的气息。

当我们飞向那片灼热的空气时, 我的思绪突然退回到了过去的时代, 潜意识 里, 福楼拜和德克布拉的小说场景浮现在脑海一一传说中的亚特兰蒂斯, 塔奈兹鲁 夫特的奥秘, 安西尼亚美丽的狮身人面像, 还有几天前我们到突尼斯时没有注意到 的迦太基古国, 萨兰波, 马拖, 塔尼特的长袍……

35 原文中使用了外交法规中的一个术语, 指的是居住在东道国的外交官的状态。(编者注) 
Catorze de Abril. No quadrângulo imenso de Kassar Said, o Pátria rebrilha ao sol. Dir-se-ia que vibram nele eflúvios enérgicos da alma de Gouveia, que o motor sente ainda a carícia dedicada, o carinho hábil das mãos do nosso mecânico. $\mathrm{O}$ avião tem hoje, na luz forte da manhã abafada, uma atitude mais marcial e juvenil.

Alguns automóveis chegam.

O Residente ${ }^{35}$ francês, os comandantes de La Fargue e Frère, Mr. Tabone, jornalistas, fotógrafos.

Como em Orã, há também um oficial da administração militar, fantasma da burocracia formalista e zelosa, que esvoaça em torno de nós. É preciso pagar gasolina e óleo.

O comandante de La Fargue pretende opor-se, mas o homenzinho expõe-lhe a gravidade de tal procedimento, a responsabilidade, os regulamentos...

E é novo alcance no nosso reduzidíssimo pecúlio. Num íntimo receio, examinamos o aparelho que, pela primeira vez, vai descolar com a equipe completa. Preocupação silenciosa que disfarçamos sorrindo, mas não conseguimos esconder uns dos outros. São nove horas da manhã.

Despedimo-nos, agradecendo sinceramente todo o auxílio e carinho que nos dispensaram e, instalados a bordo, ensaiamos o motor.

O chefe de pista dá o sinal de partida.

O Pátria começa a rolar, descola e eleva-se sem dificuldade na atmosfera calma que parece arder.

Sobre os picos do Djebel bou Kournine somos sacudidos violentamente. Há uma agressividade manifesta no firmamento. Sente-se que a etapa vai ser dura, e a temperatura sobe, à medida que avançamos.

Para lá da muralha que os últimos contrafortes da Zeugitane formam, a paisagem transforma-se bruscamente. Parece agora uma estepe indefinida que as culturas do litoral marginam - imensa toalha de areia, franjada a verde.

Msaken, El Djemm, Sfax são pérolas perdidas na cor fulva da planície, onde a grande Sebkha Sidi el Hani é uma alvura de cal a refulgir.

As ruínas romanas de Thysdrus ficam para trás, irradiando rememorações de passados séculos.

De quando em quando, torvelinham tempestades de areia rubra, que mancham de sangue o céu cobalto. O vento sopra do Sul, trazendo-nos o hálito esbraseado do Saara.

E enquanto vamos singrando na atmosfera tórrida, o pensamento evoca, num inesperado retrocesso a outras eras - Flaubert e Dekobra no subconsciente -, a legendária Atlântida, o mistério do Tanezrouft, a beleza esfíngica de Anthinea, Cartago que não apercebêramos dias antes, ao chegar a Túnis, Salammbô, Mathô, o manto de Tanit...

${ }^{35}$ Termo do código diplomático que se refere à situação do diplomata que reside no Estado que o acolhe. (Nota do editor). 
表面完全平坦的科卡纳三岛像黑色铁臂似的伸入海中, 就像浮在铅色地中海 里的巨大尸体的背脊。

我们飞离了在烈日下闪着强光的马哈雷斯海岸。

此刻, 海天之间只有我们的身影, 一瞬间, 孤独的感觉掠过心头, 直到德杰巴岛 出现在我们前方, 但它的海岸线在远处模糊不清。过了一会儿, 这座几乎呈圆形的 岛屿的轮廓清晰起来。岛上有一些零星的棕㭣树林, 树林间有穆特苏克土著聚居 区。

这座小岛以白色为主, 上面的风景勾起了我们对过去记忆中斑斓色彩的怀 念。

“祖国号” 掠过左边布格拉拉海波澜不惊的海水, 飞向杰尔吉斯城。这座城市 被困在撒哈拉的白沙中, 向四周传递着它出痛苦和干渴的感受。

南面是一片无尽的沙漠, 它在傆气中延伸到天际。而被当地人叫做 “吉卜力” 的大风则成了我们无法战胜的阻碍, 不但令我们速度减慢, 还令我们窒息。

在接下来令人疲倦的飞行中, 我们飞过了荒芜干燥而凄凉的海岸。我们飞在 700米的高度上, 向下望去, 西迪萨义德和左阿拉就像被遗弃村庄的废墟。

这片土地的外表无法令人感到亲切, 它是一片没有绿色的广衰高原, 地表的颜 色像是融化的黄铜, 向我们发出无声的威胁。

在这艰难的时刻, “绝望” 拍打着它邪恶的双翼, 时不时飞到我们身边, 令我们 士气低落。

终于, 在东北方, 坐落在的黎波里的一座座房子的轮廓清晰起来, 阳光下, 又是 一片纯白。在飞近这座城市的过程中, 我们不安的灵魂得到了它给予的慰藉。这 座紧邻大海的城市, 其港口像两条花岗岩手臂, 拥抱着少量海水。这里有几艘船。 向东六公里开外, 一片棕榈林间的空地上是一座在沙地上建成的飞机场。

“祖国号” 缓缓下降, 来到海拔两百米处地狱般的大气层带。我们在晃动中下 降, 来到两个机库间的狭窄跑道上, 在两下猛颤之后触地了。终于, 在与大沙漠的 敌意抗争中飞行了6小时55分钟后, 我们可以在意大利领土上休息一下了。

一些官员和机师来把我们的飞机停到了其中一个机库里, 然后陪着我们去司 令办公室见马里奥・斯坦扎尼上校。

尽管这位 “战前号” 36 的飞行员很年轻, 但不知道为什么, 他接待我们的方式 让我们感觉他像一位朋友, 非常可亲。与之形成对比的是, 他的行事方式让他看起 来像是个严肃而不懂变通、习惯强迫别人做事的人。

他和这里的一些官员与我们共进午餐, 其中包括莫拉塞拉, 他是罗马一东京 长途飞行 ${ }^{37}$ 的实施者之一。

36 第一次世界大战之前的时期。字面表达的意思是 “战前”。(编者注)

${ }^{37}$ 这次长途飞行是航空英雄时代上最引人注目的一次, 它发生在 1912 年 (第二版注释) 
Inteiramente planas, as três ilhas Kerkenah, de um negro baço, parecem na lividez do Mediterrâneo dorsos gigantes de cadáveres flutuando.

Largamos a costa sobre Maharés, que fulgura, iluminada em cheio pelo sol já alto.

Decorre um minuto de solidão, entre céu e mar, antes que a ilha Djerba surja pela proa, quando a costa se esfuma na distância. Depois, quase circular, salpicada de palmares, a ilha contorna-se, e a aglomeração indígena de Houmt Souk branqueja entre arvoredo.

A predominância do branco na paisagem desperta saudades do colorido que a nossa nostalgia começa a recordar...

O Pátria deixa por estibordo as águas mortas do Mar de Bougrara, aproando a Zarzis que, engastada nas areias saarianas, expande em torno uma vibração de miséria e sede.

Para Sul, o areal interminável sobe no horizonte por efeito da miragem, e o vento ghibli, como lhe chamam - é um freio invencível que nos retarda e sufoca.

Depois é o voo enervante, seguindo a costa árida, deserta, lúgubre, onde Sidi-Said e Zouara, dos setecentos metros de altitude a que voamos, parecem ruínas humildes de aldeias abandonadas.

O terreno perde o aspecto carinhoso das grandes planuras verdejantes, para atingir tons do cobre em fusão, gritando ameaças mudas.

São horas extenuantes, em que o desespero voeja por vezes a nosso lado, num cadenciar de asas sinistro e desmoralizante.

Por fim, a Nordeste, o casario de Trípoli define-se - nova brancura, na luz do Sol. E de passo que nos aproximamos, a cidade é um conforto para os nossos espíritos inquietos, disposta em anfiteatro à beira-mar, com seu porto - dois braços de granito abraçando um pouco de água -, alguns navios e o aeródromo arenoso, seis quilómetros a Leste, numa clareira cercada por palmares.

O Pátria perde altura lentamente, entra a duzentos metros numa camada atmosférica infernal, candente, revolta, e, passando entre dois hangares - a pista é estreita -, toca o terreno em dois saltos bruscos, descansando enfim sobre o solo italiano, depois de, durante seis horas e cinquenta e cinco minutos de voo, ter lutado contra a primeira hostilidade do Deserto.

Acorrem oficiais e mecânicos que, após ter conduzido o avião para dentro de um dos hangares, nos acompanham ao gabinete do comandante, o coronel Mário Stanzani.

Novo ainda, piloto d'avant guerre $^{36}$ no entanto, a maneira como nos recebe tem um não sei quê de amigo e de afável, a contrastar com a correcção um pouco rígida e solene que imprime ao seu porte uma atitude que se impõe.

Almoçamos com ele e com os seus oficiais, que nos apresenta, e entre os quais conhecemos Monacella, um dos realizadores do raide Roma-Tóquio ${ }^{37}$.

${ }^{36}$ Período que precedeu a Primeira Guerra Mundial. À letra, a expressão significa «de antes da guerra». (Nota do editor).

${ }^{37}$ Este raide, um dos mais notáveis da Idade Heróica da Aviação, foi realizado em 1920. (Nota da 2.a edição). 
然后，他们邀请我们参观了机场的几个附属区域。我们对所见到的这些堪称 典范的设施赞叹不已。

的黎波里航空是军用的。卡普罗尼和SVA两个战斗机组经常执行对阿拉伯叛 军的袭击任务。意大利军政府为这两个战斗机组争取到了政府的长期支持。

当我们参观城市、兵营和港口工程时, 渐渐的, 一个印象深深地植入了我们的 心间, 就是这片荒凉而令人不快的土地将发展成为一片富饶的殖民地。1923年, 在 已平定的地区他们修建了 3000 公里的公路, 并在这片荒漠中征服了不知道多少公 顷的土地。

人与流动的沙丘间的斗争真是一件不可思议的事情! 为此, 需要具备伟大民族 所特有的性格: 坚韧, 意志力强。

在两天之内应该会投降的厄立特里亚营部, 官员们请我们看了一场原汁原味 的土著演出。

当这些黑人们组成不规则的圆圈跳着火热的舞蹈时, 他们野性的吟唱在空气 中炸开, 其中充满刺耳的拟声词。在他们之中, 最引人注目的是一个小个子, 这个 家伙长着一张精明的脸, 眼神躁动不安。他扮演狮子一一这是一段象征性的奇异 舞蹈, 里面充满了猫科动物的情态和突然的跳跃。这质朴的模仿企图展现的是野 兽与人类的斗争。

的黎波里总督, 塔兰托将军和各部队的司令都来迎接我们, 后者请我们在他们 华丽的宫殿中饮茶。

晚上, 应的黎波里航空的邀请, 我们在市剧院欣赏了小歌剧 “艺伎”。但是当时 我已经累得眼睛都快睁不开了。幸好布里托 - 帕艾斯时不时用胳膊肘撞我一下, 免得我完全睡过去。

因为天气的关系, 我们在这里停留了 48 个小时。在此期间, 我们丝毫没有感到 厌倦。因为可以感到真诚的同志感情一直围绕在我们身边。这让我们对这里开始 产生的思念中多了一份甜蜜。

一份电报发来, 这是对 “世纪日报” 的订阅的开始。

这是第一次闪电般掠过的信任一一这不但证明了我们之前的猜想, 而且再一 次展现了葡萄牙人民的感受, 对于那些想要颂扬” 祖国号” 壮举的人们所作所为的 感受。

16 号上午八点, 飞机才再次起飞, 为这次注定将把葡萄牙和东方连在一起的旅 程迈出了新的一步。

意大利飞行员莫拉塞拉队长和蒙迪尼中尉驾驶者SVA双翼侦察机陪我们飞了 到霍姆斯并降落在那里。我们则迎着东南来的强风继续前进。

十点半, 距的黎波里220公里的米苏拉塔在我们下方掠过。为了寻找对飞行更 有利的风, 我们提升了飞行高度。但是 8 公里外的塔乌尔基亚在 11 点时才出现在遥 远的地平线上。现在最明智的决定就是停止前进。 
Depois convida-nos a visitar as diferentes dependências do aeródromo, e a gente pasma diante das instalações modelares.

A aviação da Tripolitânia é uma aviação de guerra. As duas esquadrilhas de Caproni e SVA efectuam frequentes missões contra os árabes rebeldes, e o Estado Maior Italiano tem conseguido para as duas unidades o auxílio constante do Governo.

Ao visitar a cidade, os quartéis, as obras do porto, aprofunda-se em nós a impressão de que do solo árido e hostil do deserto vai desabrochar uma colónia rica. A Itália é um país que trabalha. No ano de 1923, construíram-se na região pacificada três mil quilómetros de estradas e conquistaram-se ao deserto não sei quantos hectares de terreno.

Esta luta do homem contra as dunas movediças é qualquer coisa de inconcebível, que exige a pertinácia e a força de vontade características dos grandes povos.

No quartel do batalhão eritreu, que dentro de dois dias devia ser rendido, os oficiais ofereceram-nos o espectáculo original de uma fantasia indígena.

Enquanto os negros dançam numa ronda irregular e fogosa, os cânticos selvagens explodem no ar, dissonantes e onomatopaicos. Entre todos, destaca-se um tipo baixo, de rosto astuto, olhar agitado, que executa o bailado do leão - dança simbólica, extravagante, cheia de atitudes felinas e saltos bruscos, em que a mímica ingénua pretende figurar a luta da fera e do homem.

O Governador da Tripolitânia recebe-nos, assim como o general Taranto, comandante das tropas, que nos oferece um chá no seu luxuoso palácio.

À noite, no Teatro Municipal, assistimos, a convite da Aviação, à representação da opereta «Gueisha». Mas o cansaço mal me deixa manter os olhos abertos. É Brito Paes que se encarrega de me acotovelar de quando em vez, não vá eu adormecer de todo em todo.

As quarenta e oito horas que, por causa do tempo, ali somos obrigados a permanecer, passam sem tédio, porque à nossa volta sentimos, ininterrupta, uma camaradagem sincera a envolver-nos, lançando um pouco de doçura na saudade que começa a invadir-nos.

Um telegrama chega, anunciando o início da subscrição do Século.

Era o primeiro relâmpago de confiança - a confirmação de um facto que antevíramos e que vinha demonstrar mais uma vez quanto o Povo de Portugal sente os feitos de quem procura enaltecer a Pátria.

No dia 16, pelas oito horas da manhã, novamente o avião levantava voo, a descrever mais um arco, nessa ponte de asas que havia de unir Portugal ao Oriente.

Acompanham-nos os aviadores italianos, capitão Monacella e tenente Mondini, num SVA que aterra em Homs, enquanto nós prosseguimos, contrariados pela forte ventania de Sudeste.

Misurata, a duzentos e vinte quilómetros de Trípoli, passa sob nós às dez horas e meia. Subimos, procurando melhor vento, mas Taurgha, oitenta quilómetros mais longe, só surge no horizonte limitado que descortinamos pelas onze horas. É prudente não continuar. 
布里托 - 帕艾斯做出了这样的决定: “祖国号” 转向, 重新飞向出发的方向。这 样, 做了四个小时的无用功后, 我们仅用一个小时飞回了 200 公里远的霍姆斯, 并在 这里降落。

这个小村庄由零星的几座房子组成, 静静地坐落在荒无人烟的非洲腹地。在 这寂静的环境中, 骆驼和棕榈树为它增添了一些色彩, 军队和土著居民则是唯一的 人类生命迹象

这座机场的机库都是由砖石砌成的。看守它的 “法西斯” 战斗排士兵向我们 行纳粹礼。

莫拉塞拉和蒙迪尼在我们降落不久后就出现了, 他们命令此地的人向戈维亚 提供所需的所有东西。

与此同时, 这些黑衣党 ${ }^{38}$ 员中的一位———位能讲对战壕暗号 39 的、十足的 “巴黎人” 40 ———边向我们夸赞墨索里尼, 一边向我们展示为防止阿拉伯人袭击跑 道而建的小要塞, 他还跟我们讲了他在意大利用菎麻油的 “力量” 平定群众时做出 的 “壮举”。

我们在一家极其简婳的旅馆吃了午餐。那也是这里唯一的一家旅馆。

阳光采烤着棕㭣林, 蜿蜒的小道曲曲折折出没其间, 送我们的卡车穿行在这些 小道上。

这里的一切都让人感到我们正处在一个到处都是叛乱的国家中。所以, 最好 不要毫无戒备地去冒险。

由于在第二天 “吉卜力” 大风令人窒息地狂刮着, 我们趁机去参观了距机场一 公里的莱布达 ${ }^{41}$ 遗迹。

这座罗马古城被时间埋葬了。如今, 意大利人正从它沙子做成的坟墓里把它 挖出来。各种遗迹已经开始显现出来。拥有多利安柱头的大理石柱从土地上坚起 并绽放开来; 没有拱顶石支撑的拱门现出它的形状。

在一个平拱上刻着铭文:

\section{塞普蒂米乌斯・塞维鲁 42}

不知不觉, 我们的精神集中在了来自那遥远时代的无声召唤中, 生命在这些石 块旁边经过, 激荡着伟大和苦难。

\footnotetext{
38 “黑衣党人” 是来自意大利法西斯的准军事集团, 后来成为军事化组织。他们是墨索里尼的工具, 对其政权 的反对者采取暴力行动。这个名称来自他们制服的颜色。(编者注)

39 原文为法语, 意为俚语或者军事俗语 (根据上下文而定)。(编者注)

40 原文为法语, 意为出生或居住在巴黎的人。(编者注)

41 大莱普提斯的本地名称, 它是罗马帝国是一座富裕的城市。其遗址位于距的黎波里 130 公里的胡姆斯, 该 遗址于1982年被宣布为联合国教科文组织世界遗产。(编者注)

42 是公元193年至 211 年间的罗马皇帝路西欧・塞普蒂米乌斯・塞维鲁。(编者注)
} 
Brito Paes assim o resolve, e o Pátria, virando, aproa de novo ao ponto de partida, vindo aterrar em Homs, depois de quatro horas de voo quase inútil, em que os duezentos quilómetros de regresso foram percorridos numa hora.

Em pleno sertão africano, a vilória humilde não passa de um amontoado de casas caiadas, sarapintado de camelos e palmeiras, onde as tropas e os indígenas são a única nota de vida e cor no ambiente tranquilo.

O aeródromo, com seu hangar de alvenaria, está sob a guarda de um pelotão de «fascistas», que nos saúda à romana.

Monacella e Mondini aparecem pouco depois da aterragem e dão ordens imediatas para que Gouveia possa dispor de tudo o que necessitar.

Entretanto, os camisas pretas ${ }^{38}$, entre os quais há um autêntico parigot ${ }^{39}$, que fala correctamente o $\operatorname{argot}^{40}$ das trincheiras, vão-nos fazendo o elogio de Mussolini, ao tempo que nos mostram o fortim que defende a pista em caso de ataque dos árabes e nos contam façanhas da época em que, na Itália, se acalmavam multidões à força de óleo de rícino.

Vamos almoçar a um modestíssimo albergue, o único da terra.

O camion que nos transporta, através da pista sinuosa que serpeia entre os eternos palmares, a escalar ao sol, leva uma guarnição de quatro homens armados.

Sente-se em tudo que estamos em país rebelde, onde não seria prudente aventurar-se alguém desprevenido.

Como no dia seguinte o ghibli soprasse, sufocante e violento, aproveitamos o tempo para visitar as ruínas de Lebda ${ }^{41}$, a um quilómetro do aeródromo.

Velha cidade romana que o tempo sepultou e os italianos estão actualmente exumando do seu túmulo de areia, as ruínas começam já surgindo, colunas de mármore a erguer-se do solo e a florir em capitéis dóricos, arcos partidos a abaular-se sem o apoio do fecho.

Numa platibanda, uma inscrição é um atestado:

\section{SEPTIMIUS SEVERUS ${ }^{42}$}

Inconscientemente, o nosso espírito concentra-se na evocação silenciosa dessa época longínqua, em que, junto àqueles blocos a vida passou, fremente de grandezas e misérias.

\footnotetext{
${ }^{38}$ Os «camisas negras» eram um grupo paramilitar da Itália fascista, que mais tarde se organizou militarmente. Foram instrumentos de Mussolini, actuando violentamente contra os opositores ao seu regime. Devem o seu nome à cor do uniforme que envergavam. (Nota do editor).

${ }^{39}$ Parigot: que nasceu ou viveu em Paris. (Nota do editor).

${ }^{40}$ Argot: gíria ou calão militar (no contexto em que ocorre). (Nota do editor).

${ }^{41}$ Nome local para Leptis Magna, uma rica cidade do Império Romano, cujas ruínas se localizam em Homs, a cento e trinta quilómetros de Trípoli. O local foi declarado pela Unesco, em 1982, Património da Humanidade. (Nota do editor).

${ }^{42}$ Trata-se de Lúcio Septímio Severo, imperador romano entre 193 e 211. (Nota do editor).
} 
我们每个人, 都虔诚地保存了一块这古城的残骸, 尽管已经无人知晓是谁的手 雕刻了这些大理石碎片。

18 号清晨, 火漆色的太阳那青灰色的光线几乎不闪炼, 但似乎在向我们射来一 支支火焰般的箭。我们起飞去征服班加西的天空。也许，此时它正在苏特湾的另 一头向我们挑畔地微笑着。

米苏拉塔已经在我们身后一一 那依旧是一片白色的房屋一一 我们进入了沙 漠腹地。

“祖国号” 向高空爬升, 保护我们远离周围的 “敌人” : 颠箐的气流, 极度的炎热, 不时划过的流弹, 因为我们仍处在 “安全” 的地区。

塔乌尔吉亚, 干旱荒凉景色的最后第二个信号, 在沼泽地的阴影下退缩。

几分钟过去了, 塞尔塔一一卡比拉 ${ }^{43}$ 叛军的总部, 在沙丘之间突然就变成了白 色 ${ }^{44}$ 。

大地现在成了无声咒骂的海洋。沙滩、叛军、几乎黑色的大海, 充满了恐惧 的气氛。能见度下降。垂直看下去有点费劲。

在两千四百米的高度, 不祥的大风令人室息; 一阵狂舞过后, 留下血色的浓雾, 那是漂浮在空中的沙粒, 吹得我们眼睛疼痛不已。

布里托・帕艾斯, 努力沿着模糊不清的海岸线飞行。

下降很危险。炎热、沙土或稀薄的空气或许会迫使我们降落 45 。

红色浓雾和强光令人炫目, 有一段时间, 我都没法分辨飞机的水平度。

还得是布里托 - 帕艾斯, 依靠指南针的气泡, 他控制住了飞机并调整方向, 使 得我避免继续让飞机过渡倾斜。

我们沿着海岸线飞行, 海湾的海水颜色越来越深, 我们的纬度降低了。灰色 的, 死气沉沉的荒芜水域, 看不到一只活生生的水鸟。而海岸一一那炽热的、裸露 的和一望无际的沙滩一一就像在远处笔直坚起的一堵墙, 散发出刺眼而炫目的亮 色。

飞到了海湾的深处, 此刻, 我们处在恐惧中。空气稀薄, 每一分钟我们都得喝 水。血液在太阳穴剧烈搏动, 汗渍无法滋润肌肤。

\footnotetext{
43 卡比拉人是柏柏尔人的一支, 传统上他们居住在阿尔及利亚东北部的卡比拉山区。这是个源于阿拉伯语 的单词, 意思是 “部落”。(编者注)

${ }^{44}$ 1924年12月, 苏特被意大利人占领。

${ }^{45}$ 大约两年前, 一名意大利飞行员在同样情况下死于空难。
} 
Cada um de nós guarda religiosamente um destroço da cidade antiga: fragmento de mármore esculpido por mãos que ninguém sabe.

E na madrugada de dezoito, sob a luz lívida de um sol cor de lacre, que quase não brilha, mas parece irradiar flechas de fogo, partimos à conquista de Bengazi, que, além do Golfo de Sirte, nos envia talvez àquela hora um sorriso de desafio.

Deixávamos para trás Misurata - sempre a mesma alvura de casario - e entrávamos em pleno deserto.

O Pátria sobe, para proteger-se contra as hostilidades que o cercam: a agitação atmosférica, o calor tórrido, alguma bala que poderia ser disparada quando voarmos sobre a região ainda não «pacificada».

Taurgha, penúltimo sinal de vida na aridez desoladora da paisagem, encolhia-se por seu turno junto à mancha sombria de um paul.

Alguns minutos mais, e Sirte - o quartel general das cabilas ${ }^{43}$ revoltadas - branquejou por instantes entre as dunas ${ }^{44}$.

O solo, agora, era um praia-mar de vozes invisíveis praguejando. A areia, os rebeldes, o mar quase negro toldam de pavor a atmosfera lúgubre. A visibilidade diminui. Vê-se na vertical e a custo.

A dois mil e quatrocentos metros de altura, o vento sinistro, asfixiante, chega em golpes de rajada, e a bruma sanguínea, que é areia em suspensão, venda-nos os olhos doloridos.

Brito Paes, num esforço extenuante, procurava seguir a costa que mal se distinguia.

Era perigoso descer. $\mathrm{O}$ calor, a areia, a rarefacção atmosférica poderiam forçar-nos a $\operatorname{aterrar}^{45}$.

Perco por momentos a noção de horizontalidade do aparelho, de tal maneira me entontece a névoa rubra e a luz ardente do sol doentio.

É Brito Paes quem, pela bolha de ar da bússola, vai controlando e corrigindo, quando eu deixo inclinar exageradamente o avião.

As águas do golfo enegrecem à medida que, seguindo a linha do litoral, a nossa latitude diminui. Águas desertas, plúmbeas, inanimadas, onde se não enxerga asa viva. E a costa areia em brasa, areia nua, areia sempre -, na claridade que fere e que deslumbra, oferece-se ao nosso olhar como se fosse um muro erguido ao longe, quase a prumo...

Ao atingir o fundo do golfo, vivemos instantes horrorosos. Falta-nos o ar. Bebemos água a cada minuto. $\mathrm{O}$ sangue lateja-nos violentamente nas fontes. A transpiração não chega a humedecer a pele.

\footnotetext{
${ }^{43}$ Cabilas são um povo berbere que habita tradicionalmente a região montanhosa da Cabília, no Nordeste da Argélia. Trata-se de uma palavra que provém do árabe, onde significa «tribos». (Nota do editor).

${ }^{44}$ Sirte foi tomada pelos italianos, em Dezembro de 1924.

${ }^{45}$ Há cerca de dois anos, um aviador italiano morreu num acidente, ocorrido em circunstâncias idênticas.
} 
带着多热气息的狂风, 发疯似地晃动着 “祖国号”。

在一个锐利的拐点, 海岸线向北延伸, 而飞机则更和缓也更迅速地向北拐去。

景色逐渐发生了变化。村落已经开始出现, 还有阿吉达比亚一一意大利人在 昔兰尼加的前方哨所, 仿佛向我们露出了笑容, 似乎在远处邀请我们降落。

终于, 一副印象派色调的甜美水彩画出现在眼前, 班加西在绿洲的花坛中绽 放。

在跑道上空我开始减速, 和往常一下, 我请求布里托 - 帕艾斯协助我控制飞机 的平衡。靠近地面时, “吉卜力” 大风把我们鞭打得近乎窒息, 犹如马匹愤怒的躁动, 将我们剧烈地推到空中, 吸了出来。

我们终于降落了。

跳出飞机时, 我抱怨飞机的高度控制仪异常生硬。尽管天气炎热, 机械师戈维 亚脸色却有点儿苍白, 他用简单的话语评论着那个假想:

“要不是直到现在都抓得紧, 我早就跳出飞机了!”

接着又回忆起遭遇的严寒:

“那是多大的气旋啊!!!”

他提到的气旋就是我们在阿尔热希拉的时候几乎让我们丧命的那次……

“祖国号” 飞行了900公里, 与“萨姆”46 狂风的兄弟 “吉卜力”一路搏斗了六小 时二十分钟。

我们再一次诧异于意大利空军的英勇、热情和他们设施的精良与使用的完 备。

毫无例外, 军官们都问候我们, 感情真挚。“祖国号” 的行程表现优异, 我们在 飞行中累积的有限资源成了他们日后飞行的资料。

航空中队的汽车把我们送到了一家不错的旅馆。午饭后我们小睡了一会儿, 之后军官们过来拜访, 大家共进晚餐。夜间我见识了最凶残的蚊子, 让人无法入 睡。

第二天我们游览了班加西, 其美景无可争议。这个城市坐落在绿洲之中, 树林 点缀其间, 白色的盐滩 47 和淡黄色的沙子交相辉映。 
E o vento, exalando bafos de incêndio, sacode o Pátria, em paroxismos de louco.

Numa inflexão brusca, a costa corria agora para Norte, e o voo tornava-se um pouco mais suave e mais rápido.

Lentamente, a paisagem modificava-se. De quando em quando já alvejavam povoações, e Agedábia - posto avançado dos italianos na Cirenaica - sorriu-nos, distante, como a convidar-nos ao repouso.

Finalmente, uma telazinha impressionista, de tons doces de aguarela, recorta-se, e Bengazi floresce no seu canteiro de oásis.

Reduzo o motor sobre a pista e, como de costume, peço a Brito Paes que me auxilie a dominar os caprichos do avião que, ao aproximar-se do solo, chicoteado pelas lufadas asfixiantes do ghibli, tem movimentos assustadores de cavalo furioso, tão depressa impelido para o ar, como «chupado» por sucções violentas.

Conseguimos aterrar.

E ao saltar do avião, ao passo que me queixo da dureza anormal do comando de profundidade, Gouveia, um pouco pálido apesar do calor, comenta com a simplicidade de quem acha natural a hipótese:

- Se me não agarro, ainda agora, tinha saltado fora do avião!

E a relembrar o calafrio que sentira:

- Mas que grande poço!!!

Contudo, o golpe de ar a que ele se referia fora um arremedo vago do que em Algeciras nos fizera entrever a morte...

O Pátria percorrera novecentos quilómetros lutando contra o ghibli - irmão gémeo do simum $^{46}-$, em seis horas e vinte minutos.

Mais uma vez, a aviação italiana nos surpreende pela galhardia, pela gentileza, pelas instalações, pela aplicação ao trabalho.

Os oficiais, sem excepção, felicitam-nos com aquele entusiasmo em que transparece a sinceridade. A viagem do Pátria é já considerada uma bela performance, e a exiguidade dos nossos recursos dá-lhe categoria entre as tentativas em curso.

O automóvel da esquadrilha depõe-nos no excelente hotel - e depois de um almoço seguido de uma sesta reparadora, são as visitas oficiais, o jantar e uma noite em que os mosquitos mais encarniçados que ainda vi nos impedem de dormir.

No dia seguinte damos uma volta por Bengazi, cujo pitoresco é incontestável. Aninhada entre oásis que mancham a planura de arvoredo, com as sebkhas ${ }^{47}$ silhuetando-se a cal na coloração amarelenta das areias, a cidade alegre evola em torno um frémito de vida, que contrasta

46 «Simum» é um vento muito quente, seco e arenoso, que sopra do centro da África em direção ao Norte. (Nota do editor)

${ }^{47}$ Termo árabe para designar um deserto de sal. (Nota do editor). 
它被欢乐所环绕, 而周围那无尽的沙漠却显得孤独悲凉, 二者形成了独一无二 的对比。沙漠中, 阿拉伯人和骆驼描绘出了有着浓重地域性色彩的一笔。

无数堡垒形成了一条钢带。道路终日封锁, 夕阳西下, 铁丝网和远处明晃晃的 刺刀形成了一道风景。满载士兵的卡车呼啸而过, 为了和敌视意大利人的土著作 战。

每天清晨, 都有飞机起航执行轰炸任务, 这将大大减轻地面作战的难度。每两 周, 有军官驾驶的邮政飞机从这里飞往扎海纳。

我们身处战乱之国。

班加西是第一个当地空军免费提供给我们柴油、航油、机械维护和酒店的 地方, 如果不在这里强调一下, 那就太不厚道了。

我们非常欣赏意大利人的慷慨, 当然我们的资源也给了他们不少。

在告别晚宴上, 让人更觉亲密。而且还有巴托力中尉, 简直就是加布里埃尔・ 德阿努奇奥 ${ }^{48}$ 的翻版, 他操着皮埃蒙特方言和戈维亚聊得火热, 还问候了布里托・ 帕艾斯。他可真是墨索里尼的翻版。

20 日清晨, 天空透明而深遂, 预示着这将是一次平静的旅程。我们准备开始最 长的一段飞行, 戈维亚还没忘记着陆时我的抱怨, 让我试了试高度控制仪, 说道:

“检查完毕, 没有异常。”

我惊讶地发现操作很轻便。

戈维亚试了几下后, 启动了螺旋桨一一但发动机似乎有些抗拒。和大家告别 之后, 我们进入了狭小的驾驶舱。

我再次在身后听到了他在发动机的噪音中大喊:

“我的机长, 试一下!”

在试的时候, 有一次我感到了不寻常的生硬, 觉得很难操控飞机。

但是戈维亚带着苦笑, 和我说:

“卡住了, 是吧?”

在他的脑子里, 哪里有困惑, 哪里就有解决办法。

“我的机长, 知道怎么回事吗? 是我的腿! 现在你试试!”

没错, 生硬感消失了。

飞机指挥系统的电缆遍布机舱, 缠住了戈维亚的腿, 他必须小心翼翼地缩成一 才, 才能不妨碍到驾驶系统的运行。

$\overline{48}$ 加布里埃尔 - 德阿努奇奥 (1836年-一1938年), 意大利诗人、作家、记者和剧作家。第一次世界大战后, 他也积极参与政治活动。(编者注) 
singularmente com a impressão de isolamento e de tristeza das grandes extensões desérticas, onde os árabes e os camelos põem um traço de cor mais forte e mais regional.

Redutos numerosos formam-lhe uma cintura de aço. As estradas são diariamente fechadas, ao pôr-do-sol, com arame farpado, e sente-se na paisagem onde baionetas rebrilham de longe a longe, ou buzinam comboios de camiões carregados de tropas, a hostilidade do indígena que o italiano combate.

Todas as manhãs os aviões partem em missões de bombardeamento que facilitam as operações e, bi-semanalmente, segue para Zouaina um avião postal tripulado por oficiais.

Estamos num país em guerra.

Seria ingratidão não frisar que Bengazi foi o primeiro local onde gasolina, óleo, serviço de mecânicos e hotel nos foram gratuitamente oferecidos pela Aviação Militar.

A generosidade italiana apreciamo-la tanto mais, quanto é certo estarem já enormemente desfalcados os nossos recursos...

Ao jantar de despedida, uma intimidade maior descera, e um sósia de Gabriel D’Annunzio ${ }^{48}$, o tenente Bartholi, que no seu dialecto piemontês se entendia maravilhosamente com Gouveia, saudou em Brito Paes o sósia de Mussolini.

Quando na manhã do dia vinte - céu hialino e profundo a prenunciar-nos uma jornada serena - nos preparávamos para partir para o nosso mais longo voo, Gouveia, que não esquecera a minha queixa ao aterrarmos, pede-me que experimente o comando de profundidade, acrescentando:

- Verifiquei-o e nada descobri de anormal.

Com espanto, porém, encontro-o leve.

Gouveia lança a hélice, depois de algumas tentativas - o motor mostra-se um pouco renitente - e, despedidas feitas, vem introduzir-se no seu microscópico lugar.

Uma vez mais, ouço-o atrás de mim, gritando através do ruído do motor:

- Experimente agora, meu Capitão!

E ao experimentar, sinto de novo a prisão insólita que me dificultava a manobra do avião.

Mas Gouveia, com um sorriso triste, já me dizia:

- Estão presos, não é verdade?

No seu cérebro, onde a preocupação andara rondando desde que o informara, fizera-se luz.

- Sabe o que é, meu Capitão?... São as minhas pernas!... Ora veja agora!

De facto, a prisão desaparecera.

Os cabos de comando, correndo ao longo do interior da fuselagem, roçavam nas pernas de Gouveia, que, desde então, comprimindo-se, contorcendo-se, encolhendo-se, conseguiu viajar de modo a não prejudicar a pilotagem.

${ }^{48}$ Gabriele D’Annunzio (1863-1938) foi um poeta, escritor, jornalista e dramaturgo italiano. Teve também grande actividade política, a seguir à Primeira Guerra Mundial. (Nota do editor). 
如此长的旅程, 如此不舒服的姿势, 那是多大的牺牲啊!

最终着陆的时候, 离开那个隐形的夹板, 他浑身疼痛, 面部被阳光灼伤, 被狂风 如刀割掠过, 敏感的神经绝不离你而去。需要钢铁一般的意志去精心和细心地检 查飞机, 倾听发动机的声音……

我们出发了。

现在我们身处利比亚的沙漠, 目的地是埃及开罗。

这是超过一千三百公里的贫㾑地区, 而且, 降落地取决于我们手中的操纵杆。 平稳地飞吧。

气流平稳, 能见度好极了。只是在飞越阿卜杜勒 - 卡迪尔山脉时, 强烈的北风 夹杂着山涧中的水汽, 吹得我们愤怒不已。

德尔纳, 一种小型气泡状植被, 反射出大海的平静。

之后的飞行显得单调而乏味。泛出白色的平原被一条条道路像尺子一样划 过, 显得有点神经质又有点压抑。

时不时的, 我们还远远看到一辆又一辆大篷车缓慢地驶过, 大小犹如模型一 般。

锯齿状的海岸线上仅有几个村落，让我们想起了因为迷路而临时小啟的白色 鸽群。

当我们飞抵艾尔 - 达巴上空，感受到了难以形容的美丽。阳光反射在如镜面 一般的海面上,海底的沙石散发出玻璃的色彩, 将 “祖国号”环绕在一片光亮之中。 铝制机身闪亮得犹如透明的蓝宝石。机翼犹如一道月光……

我们忘乎所以, 沉浸在这不可思议的美丽瞬间。

我们的视野中出现了三角洲, 像上面印着格子图案的巨型三角型围巾。似乎 有人将它遗忘在那里, 终日暴晒在日光下。那是绿柱石的王冠, 是黄金披风上的祖 母绿宝石。河流蜿蜒曲折, 就像化石树的枝权, 岁月将它镶嵌在大地上。

在飞机的左舷处, 人口密集的坦塔城显现在一片绿色之中。

“祖国号” 继续飞往尼罗河边的开罗。这城市好像是一只巨大的白色蜘蛛, 有 着粗壮的腿, 紧挨着金字塔——那是三座盐丘, 似火的骄阳多烤着它们。

飞机划过一道弧线, 在赫利奥波利斯的跑道上降落。采热的空气让我们摇摇 欲坠。

机场没有发出任何信号。

飞机在晃动中着陆了, 由于发动机还很惣而没人出现, 我们切断了联系。 
Mas que sacrifício enorme, o desses longos voos, na posição incómoda em que os realizou!

E no fim, quando, ao aterrarmos, saía daquelas talas invisíveis, corpo dorido, faces queimadas pelo sol e cortadas pelo vento, nunca os nervos o abandonaram. Com energia de ferro, lá ia sempre a vistoriar o avião, a auscultar o motor, carinhosamente, cuidadosamente...

\section{Partimos.}

Agora era o deserto da Líbia, até ao Egipto, até ao Cairo.

Mais de mil e trezentos quilómetros de região erma, onde, contudo, aqui e além, um campo de aterragem nos estendia os braços, tranquilizador.

A atmosfera estava morna e a visibilidade era óptima. Apenas sobre as serranias de Abdelkader, o vento Norte, torcido pelos córregos da montanha, nos atira meia dúzia de rajadas irritantes.

Derna é um pequenino alvéolo de vegetação, a reflectir-se na mansidão do mar.

Depois a viagem monotoniza-se. A planície sablonosa, que algumas pistas cortam, mais esbranquiçadas e como feitas à régua, neurasteniza e deprime.

De quando em quando, avistamos caravanas que passam, miniaturais, vagarosas, intermináveis.

$\mathrm{E}$ as raras povoações da costa recortada lembram pequenos bandos de pombas brancas que se tivessem perdido no caminho e ali descessem para repousar.

Sobre El Daba, vivemos minutos de encanto indescritível. A luz do Sol, reflectida pela superfície espelhada de um mar ao qual o fundo baixo de areia dá tonalidades de vidro, envolve o Pátria num clarão de jade. O alumínio dos mastros e dos depósitos atinge transparências de safira. As asas parecem de luar...

A gente esquece tudo, na fascinação desses instantes de beleza inconcebível.

O Delta surge, lenço triangular, enorme, axadrezado, que alguém parece ter esquecido ali, a secar ao sol. É um diadema de berilos e esmeraldas, num manto de oiro. Os braços do rio, sinuosos e divergentes, são como ramos de uma árvore fóssil que o tempo tivesse deixado engastados no solo.

A aglomeração mais densa da cidade de Tanta destaca-se na verdura de em torno, por bombordo.

O Pátria sobe até ao Cairo, que, à beira-Nilo, parece uma aranha esbranquiçada, de grandes pernas, ao lado das Pirâmides - três montículos de sal, que o sol bate em chapadas de fogo.

Descemos sobre a pista de Heliópolis, em grandes curvas lentas. $\mathrm{O}$ ar quente balouça-nos agressivamente.

Do aeródromo, nem um sinal.

Aterramos por palpite e, como o motor está quente e ninguém aparece, cortamos o contacto. 
在炎热天气下九小时十五分钟的飞行让我们筋疲力尽。飞机似乎也在大口 地喘气, 像一头疲惫的动物。

在阳光的暴晒下等候了几分钟后, 戈维亚决定去看看机库。只见远处发白的 地面上泛出一条巧克力色的条纹。

十多分钟过去了, 我们看到他和一个身着便装的人在一起, 不知那人是否在用 拜伦勋爵的语言向他解释着什么。

“那是我唯一遇到的人!”戈维亚告诉我们。

“他不愿意过来, 他听不懂我说的话, 但是我说服他了!”他犹豫地说: “好像是个 工程师! ……手势上看……”

那个小个子继续喋喋不休, 其实我一句都没听懂。

我在脑海中搜寻着盎格鲁撒克逊人可能使用的单词, 试图表达我们是谁和需 要见到谁。我终于蹦出了一句整句, 小个子似乎听懂了, 过了一会他带着三个身着 卡其色衣裤的大个子过来了, 他们很不耐烦。

当他们听明白需要人力把 “祖国号” 拉到飞机库时, 眉毛不由得紧锁起来。接 着我们用 “超外交” 的笑容表示慊意, 并解释道没有任何更好的办法了。同时, 布里 托 - 帕艾斯用葡萄牙语讨好对方, 而戈维亚已是满头大汗, 附和着我的解释, 极富 表现力的 “yes” 是他唯一能沟通的英语。即便在树荫底下, 气温仍高达四十六度。

一共七个人, 我们三个筋疲力竭, 他们四个出离愤怒。在下午三点灼热的阳光 下, 大家将 “祖国号”拖到了赫利奥波利斯众多飞机库中的一个, 享受阴凉。

任务完成后, 工程师带我们到了梅斯 ${ }^{49}$ 餐厅, 那里一个棕色皮肤、包着头巾的 印度人给我们准备了上好的下午茶。

当我们享用美味的下午茶时一一我们早上五点半匀勿用过早餐一一对方冷 冷地告诉我们说, 他准备通知指挥官和埃及当局。这甚至改变了我们的状况, 觉得 自己被囚禁在这里。没人想到在开罗着陆会需要着陆许可和履行海关手续, 此外, 我们还担心戈维亚鼻子的状况, 觉得他应该去看医生。

飞行中, 戈维亚蜷缩着坐在后座, 没有挡风玻璃 ${ }^{50}$ 的保护, 还要经受日光的暴 晒。

\footnotetext{
${ }^{49}$ 指为军官和中士们提供餐饮服务的地方。(编者注)
}

50 原文为法语。(编者注) 
A viagem - nove horas e quinze minutos sob a canícula feroz - extenuou-nos. O próprio avião parece resfolegar, como animal cansado.

Depois de alguns minutos de espera, à torreira do sol, Gouveia decide-se a partir em exploração até aos hangares, que, à distância, põem uma faixa cor de chocolate no terreno esbranquiçado.

Mais dez minutos passam, e vê-mo-lo aparecer então com um tipo à paisana, que lhe vem explicando não sei o quê na língua de Lord Byron.

- Foi o único que encontrei! - diz-nos Gouveia. - Não queria vir. Não me percebia, mas lá o convenci! - E acrescenta a medo: - Parece que é engenheiro!... Pelos gestos...

O homenzinho continuava a sarrazinar-nos os ouvidos sem que toda a minha boa vontade conseguisse apreender uma só palavra.

Rebuscando na memória elementos anglo-saxónicos susceptíveis de esclarecê-lo sobre quem éramos e o que queríamos, consegui construir uma frase que deu lugar a que o homem se afastasse e voltasse de ali a poucos momentos com três mastodontes em camisa e calções caqui, bastante mal humorados - visto ser Domingo, e de Páscoa.

Quando, porém, compreenderam que era preciso levar o Pátria, a braço, para o hangar, os sobrolhos franziram-se, e foi com sorrisos ultra-diplomáticos que, pedindo desculpa, expliquei a impossibilidade de agir de outra forma - enquanto Brito Paes, para o lado, os mimoseava em Português, com epítetos pouco amáveis, e Gouveia acompanhava as minhas explicações, a suar em bica, com os yes mais expressivos que lhe era possível articular. Estavam quarenta e seis graus à sombra.

E fomos os sete, nós três a cair de cansaço e os quatro a espumar de cólera, que sob o sol calcinante das três horas da tarde, arrastámos o Pátria para a sombra amiga de um dos numerosos hangares do aeródromo de Heliópolis.

Terminada a tarefa, o engenheiro conduziu-nos à mess $^{49}$, onde um indiano bronzeado e de turbante nos serviu um excelente «chá das cinco».

Enquanto íamos mastigando com sofreguidão - tomáramos um sumário pequeno almoço às cinco e meia da manhã -, comunicou-nos fleugmaticamente que ia telefonar ao comandante do Centro e às autoridades egípcias. Até que estivesse regularizada a nossa situação, teríamos de considerar-nos detidos no campo. Ninguém sabia que devíamos aterrar no Cairo, e havia que obter uma autorização de permanência, formalidades aduaneiras a cumprir, além de uma visita médica que nos preocupava um pouco, dado o estado deplorável do nariz de Gouveia.

No lugar de trás, sem a proteção do pare-brise $e^{50}$, apertado, encolhido, apanhando em cheio o dilúvio de sol, já em Bengazi começara a queixar-se do apêndice frontal que engros-

\footnotetext{
${ }^{49}$ Espaço onde se servem refeições a oficiais e a sargentos. (Nota do editor).

${ }^{50}$ Pára-brisas. (Nota do editor).
} 
在班加西的时候, 他已经抱怨鼻子异常肿大, 显现出西班牙辣椒那种吓人的颜 色。在刚才的飞行中, 炎症加剧了。戈维亚感到鼻子的很痛, 加上当时那段毫无把 握的时间, 尽管现在看起来很可笑, 但当时却是他忧虑的原因。

我们等待了数个小时。

夜幕来临时, 一个偶然的机会, 葡萄牙驻开罗领事埃黎耶・莫塞利出现了。没 人通知他, 我们的电报写着已经离开班加西, (路线要比 “祖国号” 的复杂得多), 尚未 到达目的地; 而且, 葡萄牙方面也只是笼统地提到一架葡萄牙飞机沿着东方之路飞 行, 应该经过埃及。

埃黎耶 - 莫塞利在埃及人脉广泛, 打了一通电话请求帮助后, 他乘坐着高级轿 车 ${ }^{1}$ 出发了。他帮我们在大陆萨瓦酒店预订了房间, 我们在那里无聊地打发时间, 等待重获自由。

不一会儿, 海关人员到了, 他们仔细检查了我们的行李 52 , 似乎怀疑我们夹带了 重要的走私物品, 接着又询问我们飞机上装运的货物, 最后终于被我们有限的行李 和大量的飞行文件说服了。

关于就诊, 推迟到了第二天, 不过庆幸的是并没有去。

我们被告知: 英国飞行员麦克拉伦刚离开赫利奥波利斯, 在我们出发前两周, 他从伦敦开始环球飞行。

八点钟的时候, 来了一辆卡车, 将近乎虚脱的我们带到了酒店。领事先生在那 里等着我们, 让我们好好休息。安顿下来后, 大家洗了温水澡, 精神又恢复了过来, 接着在房间的阳台上我们享用了晚餐。

我们飞行了旅程中的第一个五千公里。

远处传来一阵爵士乐的旋律, 我们的心灵激荡起首度胜利的欢喜。寂静的夜 晚圆月高挂, 淹没在薄纱之中, 后边是细长的清真寺尖塔和窗饰, 在我们心中, 葡萄 牙的声音回响在夜空, 那是自信, 是勃发向上, 脑海中那如闪电般的嗓音, 呼喊出奇 妙的声音: 前进!

我们的呼吸甜美而宁静。怀旧的思绪在乳白色的月光下散发, 大家缓缓地交 流着思乡, 疑问和渴望。

葡萄牙驻埃及代办雅克斯 - 苏阿雷斯先生第二天早上抵达了亚历山大，他有 着意大利人啰嗦的言行, 不过他认识所有的人。

\footnotetext{
${ }^{51}$ 指的是非常豪华的超长轿车, 一般为白色或黑色, 通常是很有钱的人或是在特别的聚会场合才使用。 (编者注)

52 原文为法语。(编者注)
} 
sara anormalmente, tomando assustadoras colorações de pimento espanhol. A inflamação agravara-se durante o último voo; o nariz doía-lhe e, com o pessimismo das horas de incerteza, o que agora nos parece cómico era naquele momento motivo de preocupação.

Esperámos horas.

Ao cair da noite, apareceu Elie Mosseri, cônsul de Portugal no Cairo, que vinha ao campo como curioso, por acaso. Ninguém o prevenira; o nosso telegrama anunciando a saída de Bengazi (cujo itinerário era muito mais complicado que o do Pátria), não chegara ainda; e, de Portugal, apenas lhe tinham noticiado vagamente que um avião português partira, a caminho do Oriente, devendo passar pelo Egipto.

Elie Mosseri, que tem relações nas altas esferas egípcias, telefona e solicita, partindo de novo na sua luxuosa limousine $e^{51}$, a reservar-nos aposentos no Continental-Savoy, enquanto nós ficamos, aborrecidos e sonolentos, à espera da liberdade.

Pouco depois, as autoridades alfandegárias chegavam, passando uma revista minuciosa às nossas minúsculas valises ${ }^{52}$ onde pareciam suspeitar a existência de importante contrabando e, interrogando-nos com sub-reptícia insistência sobre as mercadorias que transportávamos no avião, dão-se finalmente por convencidas perante a pobreza franciscana das bagagens e a abundância de documentos.

Quanto à visita médica, adiam-na para o dia seguinte e não chega, felizmente, a realizar-se.

Somos informados de que MacLaren, o aviador inglês que, duas semanas antes de nossa largada, partira de Londres para a volta ao mundo, deixara Heliópolis na véspera.

Às oito horas da noite uma camioneta transporta-nos - quase cadáveres - ao hotel, onde o cônsul nos espera e nos deixa descansar, depois de instalados, após um banho tépido e restaurador e um jantar em família, na varanda de um dos nossos quartos.

Estavam percorridos os primeiros cinco mil quilómetros da viagem.

Enquanto, de longe, os acordes de um jazz nos chegam aos ouvidos, as nossas almas deixam expandir a alegria íntima do primeiro triunfo e, no silêncio da noite abafada e tranquilíssima - a lua cheia nasce, afogada em tules, por detrás de um minarete esguio e rendilhado -, a voz de Portugal ecoa no espaço, confiante, animadora, relâmpago de som a gritar-nos a palavra mágica: Avante!

Respira-se doçura, serenidade. Há eflúvios de nostalgia dispersos na claridade láctea do luar e, nas palavras lentas que trocamos, rondam saudades, interrogações, anseios.

O Encarregado dos Negócios de Portugal no Egipto, Mr. Jacques Suarez, italiano prolixo de palavras e de gestos, que conhece toda a gente, chega de Alexandria na manhã seguinte. Todo ele é surpresa, admiração, estranheza pelo facto de termos aterrado em Heliópolis, não

${ }^{51}$ Carro muito longo e luxuoso, normalmente de cor branca ou preta, geralmente usado por pessoas muito ricas ou em ocasiões de festa muito especiais. (Nota do editor).

${ }^{52}$ Malas. (Nota do editor). 
所有这一切是惊喜、赞叹和陌生感, 我们降落在赫利奥波利斯, 得知埃及政府 已经照会葡萄牙外交部, 允许我们在亚历山大降落, 但是我们禁止飞越开罗上空。

我们去了离金字塔仅半公里之遥的美娜酒店, 这是一家英式酒店, 一般在旅游 旺季接待美国游客。我们在酒店享用了午餐。那是一间类似庙宇的餐厅, 有醒目 的柱子, 圆形的穹顶和色彩柔和的光线。

我们参观了花园, 那里, 各色鲜花映祄在绿叶之。我们还惊喜地从平台看到远 处的沙丘和浩瀚的沙漠。

接下来, 我们当然要参观吉萨金字塔了! 在安静的驴队中前行, 我们想起了卡 西拉斯。不过回程时却带着失望, 因为我们之前期待的庄严、壮丽和伟大, 像幻觉 一样破灭了。一百五十米高的大金字塔并没有让我们感到不同, 就像一堆巨石胡 乱堆砌而成的一样。

但是神秘的狮身人面像保留了它永恒不变的谜题, 即便是岁月的侵蚀也未能 改变。

沙漠绵延向西, 一望无垠, 现在太阳将从地平线慢慢消失, 棕㭣树的影子形单 影只, 单峰驼的阿拉伯主人正在祈祷, 留下一个三角形的影子: 金字塔的精髓在于 数位法老和延续了几个世纪的木乃伊......

我们回到开罗时, 埃及国王福阿德一世在王宫里接见了我们。

那是一个巨大的宫殿, 里面充斥着帝国和路易十五时代的家具, 威尼斯的镜 子, 意大利的大理石和青铜, 塞弗尔和利摩日华丽的瓷器, 奥比松和士麦精致的地 毯, 总之, 就像一座冷峻而高雅的博物馆。

国王是个胖胖的小个子, 蓄着凯撒式 ${ }^{53}$ 的胡须, 小眼睛昫畑有神, 看上去相当 的朴素和有亲和力。他说着一口地道的法语, 好奇地询问我们的旅途、飞行和葡 萄牙的情况。与此同时, 我们还品尝了最为香浓的咖啡, 回味无穷。

国王陛下也端起一杯咖啡细细评味, 出于礼节, 我们没有尽情品味咖啡的香 浓。

礼节性的会见持续了一刻钟, 最后以例行的法语句子结束:

“那就不耽误您的时间了。54”

53 指威廉二世 (1859年1月27日出生于柏林) 1941年6月4日在多恩去世时所戴的小胡子样式。自1888年起, 至 1918年第一次世界大战结束时退位, 他是最后一个德国皇帝和普鲁士国王。(编者注)

54 翻译: “我不想再握住它们。” (编者注) 
obstante a comunicação que, por indicação do Governo Egípcio, enviara para Lisboa, informando o Ministério dos Negócios Estrangeiros, para nosso conhecimento, que fôramos autorizados a aterrar em Alexandria, mas notificando a proibição expressa de sobrevoar o Cairo.

Leva-nos a Mena House, hotel inglês que, a meio quilómetro das Pirâmides, costuma albergar os touristes americanos durante a season, e ali almoçamos numa sala de jantar que mais parece um templo, com suas colunas sóbrias, as suas abóbadas e o colorido suave dos tons de luz.

Visitamos os jardins, onde flores sarapintam de cores vivas grandes maciços de verdura, e é uma surpresa quando, de sobre um patamar, alongamos a vista para além do muro que os protege: o mar de areia solta, as dunas, o deserto...

Depois realiza-se a inevitável excursão às Pirâmides de Gizé, numa pacata burricada que nos recorda Cacilhas. Mas voltamos tristes, porque a impressão de grandeza, de imponência, de majestade que nos habituáramos a esperar, se desfez numa derrocada de ilusões. A Grande Pirâmide, com seus cento e cinquenta metros de altura, deixa-nos indiferentes, como se fosse um simples amontoado de pedregulhos.

Mas a Esfinge mantém inalterável a rigidez enigmática da sua interrogação eterna, que a corrosão do tempo não conseguiu destruir.

Na paisagem perturbante do deserto, que para Oeste desenrola a sua infinita vastidão, contorna-se de longe a longe, agora que o sol vai baixando no horizonte indeciso, o perfil raquítico de uma palmeira isolada, de um dromedário com seu árabe em atitude de oração ou de um triângulo de sombra: pirâmide em cujo âmago mais um faraó repousa talvez, mumificado há séculos...

Ao regressar ao Cairo, recebe-nos em audiência particular o Rei do Egipto, Fuad I.

O palácio monumental, pejado de mobílias Império e Luís XV, espelhos de Veneza, mármores e bronzes de Itália, riquíssimas porcelanas de Sèvres e de Limoges, belos tapetes de Aubusson e Smirna, tem o aspecto frio e grave de um museu.

E o rei - homem baixo e gordo, de bigodes à kaiser $^{53}$ e olhinho esperto, bastante simples e simpático, que fala francês correctamente - interroga-nos curioso e interessado sobre a nossa viagem, sobre aviação, sobre Portugal, enquanto nos faz servir o mais perfumado café que saboreámos até à data.

Sua Majestade toma também uma xícara que saboreia lentamente, e nós só não repetimos por constrangimento.

Demora-nos um quarto de hora e põe fim à visita, protocolarmente, com o sacramental: - Je ne veux pas vous retenir plus longtemps ${ }^{54}$.

\footnotetext{
${ }^{53}$ Referência ao tipo de bigode usado por Guilherme II (ou Wilhelm II), nascido em Berlim a 27 de Janeiro de 1859 e falecido em Doorn a 4 de Junho de 1941. Foi o último Imperador alemão e Rei da Prússia entre 1888 e a data da sua abdicação em 1918, no final da Primeira Guerra Mundial. (Nota do editor).

${ }^{54}$ Tradução: «Não quero retê-los por mais tempo». (Nota do editor).
} 
苏亚雷斯先生和我们共进晚餐, 接着带我们去了一家很普通的电影院一一这 样的电影院在里斯本任何一个区都随处可见。第二天下午, 苏亚雷斯安排我们拜 会了英国人阿伦比将军 ${ }^{55}$, 埃及外交部长和裁缝。布里托 - 帕艾斯花了九镑, 订做 了一套崭新的卡其色制服, 替代被油渍弄脏的旧制服。

葡萄牙驻埃及代办之子一一费迪南德 - 苏阿雷斯, 陪伴我们参观了老城。那 是突尼斯阿拉伯人遥远的记忆。狭窄的街道, 懒散的生活, 聚集着目不暇接的精 彩。那是伟大民族后代的艺术灵感, 可惜的是我没法带走它。

路上遇到的埃及妇女依旧身着传统服装, 不过在上流社会, 用来遮挡住脸庞下 部的厚厚面纱已经被白色的面纱代替, 这样几乎能够看清楚整个脸庞。有些脸庞 非常迷人, 黑色和畑畑有神的眼睛, 高贵的姿态.......

我们从葡萄牙收到了第一批电报。平托 -巴斯图和索托 - 梅尔的公司寄来 了一笔钱给我们应急, 比钱更重要的是: 在葡萄牙, 斯福卡 - 杜阿尔特的声音已经 传遍全国, 我们的飞行已经唤醒了葡萄牙人民的慷慨。

戈维亚来到赫利奥波利斯, 在炎症的疼痛和我们无法理解的机械工作的折磨 中度过了一天, 接着, 来了一条好消息:

“我们可以继续飞行了, 钱到啦!”

当布里托 - 帕艾斯让他去吃点东西的时候已经是下午五点了, 他早上就没吃 饭。放下手里的活儿, 他向茶房走去, 目光呆滞, 鼻子肿大, 却露出满意的神色—— 那是成就感和自信心的恢复。

飞机已经准备好可以出发了。指挥官莫丁以英国人的实用精神提供给我们 一切便利, 他知道如何雪中送炭。

我们来到英国人舒适的家中, 以机组的名义向他表示感谢。莫丁夸奖了葡萄 牙飞行员们, 还特别表达了对前任指挥官萨卡杜拉 - 卡布拉尔的尊敬和友谊。

事实再度证明, 即使是在国外机场, 也不必担心那里的条件。

我们清楚何时出发。

对于这一切我们心存感激。

55 原文中使用了外交法规中的一个术语, 指的是居住在东道国的外交官的状态。(编者注) 
Mr. Suarez janta connosco, leva-nos a um cinema vulgar como qualquer cinema de bairro em Lisboa, e não nos deixa senão pelo meio da tarde seguinte, depois de nos ter feito visitar o general Allenby, Residente ${ }^{55}$ inglês, o ministro dos Negócios Estrangeiros do Governo Egípcio e o alfaiate, onde Brito Paes se enfarpela de novo, num fantasista uniforme caqui, que vem substituir, por nove libras, a farda que o óleo inutilizou.

Ferdinand Suarez - o filho do Representante de Portugal - acompanha-me à cidade velha, reminiscência longínqua da Túnis árabe - ruas estreitas, vida indolente -, onde pululam maravilhas que os olhos cobiçam, que reflectem a intuição artística dos descendentes da grande raça, e de onde tenho pena de não poder levar algumas recordações.

A mulher egípcia, que por vezes cruzamos, usa ainda o traje tradicional; mas na alta sociedade, o véu espesso sob o qual a mulher do povo oculta ainda a parte inferior do rosto foi substituído por um véu de tule branco, que o deixa quase a descoberto. Há rostos encantadores, olhos negros e penetrantes, atitudes imperiais...

De Portugal recebemos as primeiras ordens telegráficas. As firmas Pinto Basto e Sotto Mayor enviam-nos, no punhado de libras que vem restaurar o nosso cofre exausto, alguma coisa mais do que dinheiro: a certeza de que, em Portugal, a voz de Cifka Duarte se faz ouvir, e que a nossa viagem despertou já a vibratilidade generosa do Povo Português.

Quando Gouveia chega de Heliópolis, onde passou o dia trabalhando, atormentado pela inflamação dolorosa e pelos mecânicos que o não compreendem, é a nossa primeira notícia:

- Já podemos continuar afoitamente. Chegou dinheiro!

E só quando Brito Paes lhe dá ordem para ir comer qualquer coisa - eram cinco horas da tarde, e nada comera desde pela manhã - é que ele, interrompendo a catadupa das interrogações e a descrição dos seus trabalhos no campo, se afasta em direcção ao tea-room, olhos esgazeados, nariz volumoso e carmesim, a irradiar satisfação - a satisfação do dever cumprido e da confiança renascente.

O avião ficara pronto a partir. O comandante Modin proporcionara-nos todas as facilidades, com aquele espírito prático britânico que, sem exuberância, sabe ser útil quando quer.

Quando o procurei no seu confortável home, para lhe agradecer em nome da tripulação, o inglês, elogiando a nossa tentativa, teve palavras de elogio para os pilotos portugueses, entre os quais destacou, pelo seu valor e pela amizade que a ele o ligava, o malogrado comandante Sacadura Cabral.

Mais uma vez os factos tinham demonstrado que não havia razão para temer actos de sabotage em aeródromos estrangeiros.

Nós sabíamo-lo quando partimos.

Mas é sempre grata a confirmação dos factos.

\footnotetext{
${ }_{55}^{5}$ Termo do código diplomático que se refere à situação do diplomata que reside no Estado que o acolhe. (Nota do
} editor). 


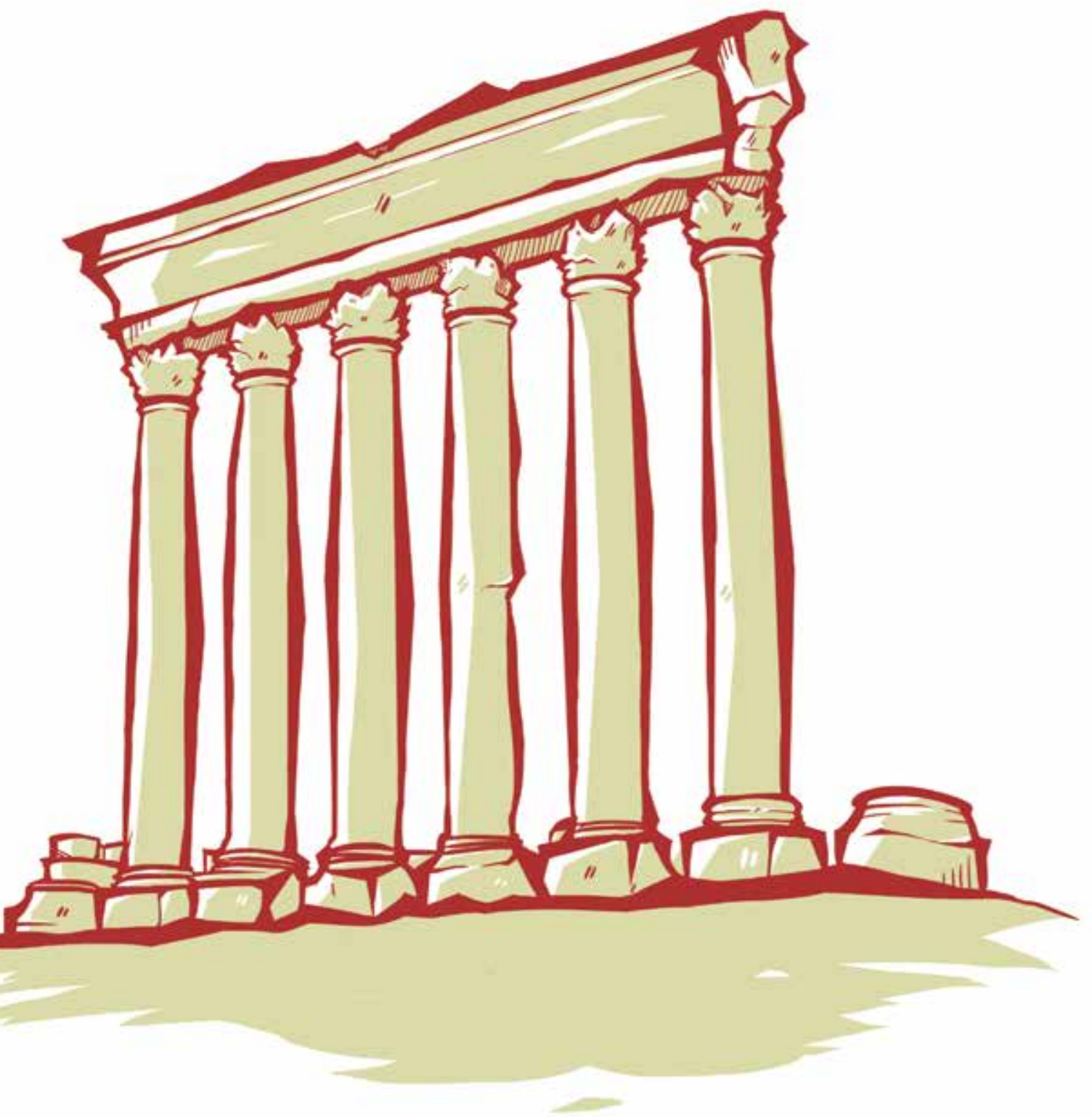




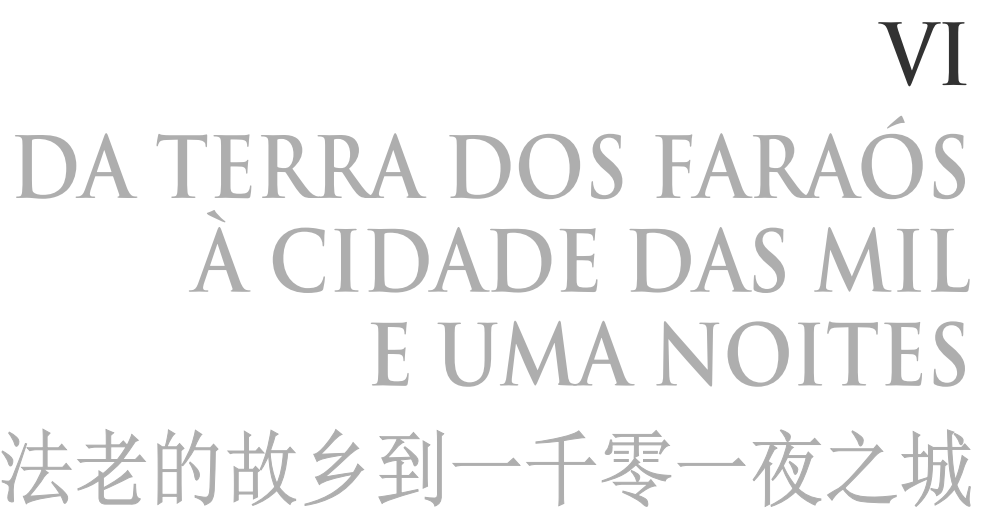


4月23日一早五点左右, 当第一缕曙光出现在天际的时候, 埃黎耶 - 莫塞利 的加长轿车 ${ }^{5}$ 来到酒店接我们, 以便让我们在 20 分钟后能够到达赫利奥波利斯机 场。“祖国号”还静静地躺在机库中, 戈维亚前去做飞机出库的准备工作。我和莫 汀司令去沙质的跑道上走了一圈。与此同时, 泰晤士报的记者采访了布里托 - 帕 艾斯, 这位记者一大早就来拍摄我们。

五点半刚过就开始了发动机试验, “祖国号”开始运转。

跑了200米后, 当飞机已经与地面分离时, 一个轮胎的气密层轰隆一声爆了。

我断开接触, 希望飞机能够停下来, 左翼不要触及地面。

情况很复杂, 我们没有备用轮胎。但同样的倾覆事故在降落时几乎是不可避 免的。

困惑了几分钟之后, 布里托 - 帕艾斯用一架DH9的轮胎更换了” 祖国号” 的轮 胎, 那是一架英国轰炸机, 它几乎和布雷盖XVI BN2飞机一样重。

莫汀司令立刻允许了, 但他拒绝了布里托・帕艾斯为此支付费用。

戈维亚在一些机械师的协助下开始了工作。飞行中心的一些飞机时不时地 在跑道周围打个圆圈或是做个螺旋式下降 ${ }^{57}$, 与阴沉的天空交错而过, 机翼划出了 一个个漩浴。

一个小时之后, 重新换上轮胎的飞机开始滑行了。

我们从葡萄牙出发时用的轮胎就留在了那里一一这是搭载我们的神鹰最先 损坏的地方。

最后一次拥抱了尼罗河三角洲的右岸之后, 我们离开了扎加齐格, 经过了塞得 港的南部。

弓形的上空中, 雨水将地平线变得很暗。在发棕的晨光中, 暗绿色的原野看起 来像糖果般柔滑。

苏伊士运河像一条亮闪闪的钢铁臂膀, 在沙漠中将亚洲和非洲分开。

此外, 还有一条铁路蜿蜒而过。密集的雨水形成了的云朵, 所以我们有时不得 不在没有植被的沙丘上方 200 米处飞过。

我们进入圣地了。

在清晨柔和的曙光中, 受膏者般纯洁的美景吸引了我们的目光。

\footnotetext{
56 非常豪华的超长轿车, 一般为白色或黑色, 通常是很有钱的人或是在特别的聚会场合才使用。(编者注)
}

57 这是两种空中特技。(编者注) 
No dia 23 de Abril, pelas cinco horas, quando alvorecia o primeiro lusco-fusco, a limou$\operatorname{sine}^{56}$ de Elie Mosseri vinha buscar-nos ao hotel, para depor-nos, vinte minutos depois, no aeródromo de Heliópolis. O Pátria dormia ainda no seu hangar, e enquanto Gouveia ia dirigindo os trabalhos de saída do aparelho e eu dava, com o comandante Modin, uma volta pela pista, bastante arenosa, Brito Paes concedia uma entrevista ao correspondente do Times, que madrugara para nos fotografar.

Pouco depois das cinco e meia, ensaiado o motor, o Pátria começa a rolar.

Ao fim de duzentos metros de corrida, quando o avião já leve se desprendia do terreno, uma câmara de ar rebenta com fragor.

Corto o contacto e espero que o avião pare, conseguindo a custo que a asa esquerda não toque no solo.

A situação era difícil. Não havia rodas de reserva. Mas o mesmo percalço, ao aterrar, teria tido como consequência quase inevitável a capotagem.

Depois de alguns minutos de perplexidade, Brito Paes resolve substituir as rodas do Pátria pelas de um DH9, avião de bombardeamento inglês quase tão pesado como o Breguet XVI BN2.

O comandante Modin cede-as imediatamente e recusa, quando Brito Paes se dispõe a pagá-las.

Gouveia, auxiliado por alguns mecânicos, lança-se à tarefa. Entretanto, os aparelhos do centro cruzam a atmosfera sombria, em voltas de pistas onde, de quando em quando, um looping ou uma vrille $e^{57}$ destacam o seu rodopio de asas.

Uma hora depois, calçado de novo, o avião descola.

As rodas com que partíramos de Portugal lá ficam - primeiros despojos do condor que nos leva.

Seguimos o último braço oriental do delta, que abandonamos sobre Zagazig, para passar a sul de Porto Said.

Pela proa, faixas de chuva obscurecem o horizonte. E a cor verde-negra da planura fértil toma, na luz difusa da manhã pardacenta, tons veludíneos de doçura suave.

O canal de Suez é uma longa barra de aço polido, colocada sobre o areal, a dividir a África da Ásia.

Uma via férrea serpenteia para além, e temos por vezes que voar a duzentos metros, sobre dunas sem vegetação, por causa das nuvens que nos fustigam com aguaceiros densos.

Entramos na Terra Santa.

Sob a meiga claridade da manhã que alivia, a paisagem, ungida de beleza, prende o olhar. Inconscientemente, rememoramos páginas da vida do Nazareno. Um sopro de bondade

\footnotetext{
${ }^{56}$ Carro muito longo e luxuoso, normalmente de cor branca ou preta, geralmente usado por pessoas muito ricas ou em ocasiões de festa muito especiais. (Nota do editor).

${ }^{57}$ Looping e vrille são exercícios de acrobacia aérea. (Nota do editor).
} 
不知不觉, 拿撒勒生活的一页页仿佛又一次在我们的脑海中翻过。一阵良善 的气息拂面而来……主耶稣, 他所说的比喻, 他对人类无限的爱, 他曾如此强烈提 倡的世界大同, 至圣的平等主义心愿等等, 在那极为平静的气息中悸动着。这气息 笼罩着魔幻般的花园, 在园中, 雪松林仿佛是山丘上的片片阴影, 粉刷过的村庄有 一种集中了回忆与沉思的态度……

加沙, 雅法, 海法和阿卡, 静静地散落在海边。

而悲伤也降临到了我们的心间, 那是一种无法言说的乡愁。山的那边是我们 无法看见的耶路撒冷。

“祖国号”飞在600米的高度上, 这是一次充满了宁静的飞行。

远处的太巴列湖让人眼前一亮。

突然, 一幅美景出人意料地展现在了我们眼前。只见高高的山峰斑斑驳驳, 顶 上白雪皑皑, 那千年积雪的颜色像是旧象牙色, 太阳把雪一点点地融化, 让雪水充 满鸟语花香的山谷。

贝鲁特。地中海地区一个古老的市镇, 位于黎巴嫩山脚下。

向东, 那崎岖陡峭的山脊迫使我们爬升到2200米的高度。

我们的飞机遇到了一定的困难, 有些微微的抖动。根据布里托 - 帕艾斯的指 示, 我沿着铁路线向里亚格飞去。时间一天天过去, 他将证明自己是一个卓越的飞 行者。我们下方的铁路像是盘旋在山间的蓝色带子。

我们飞过了海拔较高的 400 米, 冰川的气氛令人不寒而栗。

我们的下方都是山润峡谷, 突元的山峰和大块的花岗岩绵延不绝, 皑堭白雪点 缀其间。

当黎巴嫩山谷那肥沃的平原仿佛翠绿色的花冠一般在我们脚下展开, 歌梦终 于结束, 一段难以言述的俯冲下降就要开始一一那是整个旅程中最糟糕的一段。

受气流漩涡的影响, 飞机从我们的掌控中逃脱开去, 不断地被从中吸入、抛 出。气流凶猛而自相矛盾。飞机震颤着, 抽搐, 昏厥, 坦率地说, 令人恐慌。

在跑道上方飞过的那最后一圈200米是悲惨而痛苦的。在愤怒的寒风吹袭中, “祖国号” 就像是一块破布。我和布里托 - 帕艾斯尽管有着经过千百次锤炼的本能 努力, 依旧无法控制飞机。“祖国号”随心所欲地转弯、服从。

飞机在 900 米的高度, 广阔的机场在北面与一条公路相接, 两条深沟顺路而 去。 
passa... E a figura de Jesus, as suas parábolas, o seu infinito Amor pela Humanidade, a Fraternidade Universal que tão veementemente pregou, numa aspiração de igualitarismo sacrossanto, pairam invisíveis, latejantes, na atmosfera tranquilíssima que envolve aquele jardim encantado, onde as matas de cedros são flocos de sombra a prender-se nas colinas e onde as aldeias caiadas têm uma atitude concentrada de recolhimento e de meditação...

Gaza, Jafa, Haifa e Acre, junto ao mar, irradiam não sei que vibração silenciosa, de claustro.

E no nosso coração desce uma tristeza, uma nostalgia invencível e funda dessa Jerusalém que, para além das montanhas, fica escondida ao nosso olhar.

O Pátria navegava a seiscentos metros de altitude, num voo cheio de serenidade.

O Lago Tiberíade, ao longe, reluz por momentos.

Zebrando os altos cumes, a neve branqueja diante de nós, inesperadamente. Velha neve, cor de marfim velho, que o sol vai fundindo a pouco e pouco, a encher o vale de cantilenas de água.

Beirute. Velho burgo acaçapado ao fundo do Mediterrâneo, no sopé do Líbano.

Para Leste, a cordilheira áspera e alcantilada força-nos a subir a dois mil e duzentos metros.

O avião, vibrando um pouco, ganha altura com certa dificuldade e, de acordo com as indicações de Brito Paes, que, dia a dia, vai confirmando as suas qualidades excepcionais de navegador, aproa a Rayak, seguindo a linha férrea, fio azul de retrós enrodilhados nos torcicolos da montanha.

Passamos a quatrocentos metros da cota mais elevada, numa atmosfera glacial que nos faz tiritar.

Lá em baixo, tudo são ravinas, picos agressivos, blocos de granito que a neve entremeia de alvuras imaculadas.

Só para além, quando o vale do Líbano abre, a nossos pés, a corola esmeraldina das suas planícies fecundas, o pesadelo termina, para começar uma descida inenarrável, a pior de toda a viagem.

O avião escapa-se-nos das mãos. Chupado, sacudido, jogado por correntes de ar turbilhonantes, raivosas, contraditórias, tem estremecimentos, crispações, desmaios, que, - sinceramente - apavoram.

A última volta, a duzentos metros sobre a pista, é trágica e martirizante. A fúria do vento frígido brinca com o Pátria como se ele fosse um farrapo de papel. Brito Paes e eu, numa congregação de esforços que o instinto de conservação centuplica, não conseguimos dominá-lo. $\mathrm{O}$ avião vira e obedece quando quer.

O aeródromo extenso, a novecentos metros de altitude, é delimitado a Norte por uma estrada que duas valas fundas marginam. 
我们终于降落了一一风是南风一一当我们经过公路时, 觉得自己被猛烈地抛 向地面…… 一秒钟令人痛苦的等待。跳跃了一下, “祖国号” 终于超越了一个跳马 ${ }^{58}$ 障碍, 着陆了。

我的胳膊像是力气被抽尽了的两条死肉; 我的身体, 被粉碎了似的疼; 我的口 腔, 完全是干的。尽管很冷 (温度计指着8度), 浑身却被汗水湿透了。

我把飞机开到机库旁, 乌尔德里司令和他的军官们接待了我们并向我们致以 祝贺。

我们注意到, 随着离葡萄牙越来越远, 人们对我们的祝贺程度是越来越强烈 了。

在美斯 ${ }^{59}$ 午饭后, 我们回到了“祖国号” 停泊的机库。戈维亚立刻开始检修发 动机, 就像我们为此次停留筹划的那样。

里亚格飞行中心是叙利亚法国航空中队的物资存放处。

根据凡尔赛和约的授权, 在法国领导的临时军营暂时占据了该地区一一停机 坪上的十个机库中停满了飞机。

所有储备物资都任由我们取用, 有汽油、润滑油和机械零件等。

在到达中印半岛前, 在这个我们最后可以遇到布雷盖飞机的地方, 乌尔德里司 令慷慨大方的友情是一种非常宝贵的帮助。我们之所以能够前行, 很大程度上要 归于他的协助。

在离开开罗之前, 戈维亚做出了一个英勇的决定一一剃掉自己的胡子。现在, 他穿着日常的衣服, 鼻子已经恢复到了正常尺寸, 多多少少有点神甫的面相。一如 既往, 他依然是一个热情专注的机械师。

在空中, 是布里托 - 帕艾斯如父亲般地亲手带领 “祖国号”。我协助他爬升和 下降。在地面上, 我们把飞机交给 “医生” 戈维亚, 他是这方面的专家, 极其小心地 照料着 “祖国号”。

当戈维亚留在此地专注于他的工作时, 飞行中心的汽车把我们带到了贝鲁特, 法国空军在叙利亚的主任在那里等待我们。

公路向上爬升到了扼住黎巴嫩咽喉地方。地平线在我们眼前扩展, 呈现出一 幅雄伟的景色, 但是却让我们忆起另外一些风景一一那些遥远的葡萄牙风景, 万千 思绪就像丝丝阴影和犹豫不决的鬼魂一般轻轻滑过。

\footnotetext{
58 就像马匹突然跳跃想甩下骑手。(编者注)

59 专有名词, 指为军官和中士们进行餐饮服务的地方。(编者注)
} 
Aproamos enfim - o vento é Sul - e, ao passar sobre a estrada, sentimo-nos projectados violentamente contra o solo... Um segundo de expectativa angustiosa. Ressaltando, o Pátria ultrapassa o obstáculo numa upa de cavalo ${ }^{58}$ e aterra finalmente.

Os braços pareciam-me dois farrapos de carne morta. O corpo, triturado, dolorido. A boca, inteiramente seca. E apesar do frio (o termómetro marcava oito graus), estava alagado em suor.

Conduzi o avião para junto dos hangares, onde o comandante Hourdry e os seus oficiais nos recebiam, felicitando-nos.

Tornava-se curioso observar que a intensidade das felicitações ia aumentando à medida que nos distanciávamos de Portugal.

Almoçamos na mess $^{59}$, voltamos ao hangar onde o Pátria descansa, e Gouveia inicia imediatamente a revisão do motor que planeáramos para aquela escala.

O Centro de Aviação de Rayak é o depósito de material das esquadrilhas francesas da Síria.

Acampamento militar provisório, visto que a França, pelo mandato que lhe foi conferido pelo tratado de Versailles, ocupa temporariamente a região - os dez hangares do Parque estão repletos de aviões.

Todo o material de reserva, gasolina, óleo e mecânicos, são postos à nossa disposição.

Último local até à Indochina onde encontraríamos aviões Breguet, a gentileza amiga do comandante Hourdry foi um precioso auxílio que muito devia contribuir para o prosseguimento feliz da viagem.

Em mangas de camisa, nariz reentrado já nas dimensões normais, Gouveia, que antes de sair do Cairo tomara a decisão heróica de rapar o bigode e agora tinha na fisionomia qualquer coisa de sacerdotal, continuava sendo o mecânico solícito e dedicado de sempre.

No ar, era Brito Paes quem, paternalmente, ia levando o Pátria pela mão. Eu ajudava-o a subir e a descer. Em terra, entregávamo-lo ao médico, a Gouveia, que é especialista e que o tratava com cuidado extremo.

E enquanto ele fica, alheio a tudo, absorto no seu trabalho, o automóvel do Centro leva-nos até Beirute, onde nos espera o director da Aeronáutica Francesa na Síria.

A estrada sobe para a garganta em que atravessa o Líbano, e o horizonte alarga-se num panorama grandioso, fazendo-nos recordar outras paisagens, essas paisagens de Portugal distante, em que deslizam como sombras fantasmas indecisos de milhares de pensamentos fervorosos.

\footnotetext{
${ }^{58}$ Pinote, salto brusco do cavalo, com a intenção de derrubar o cavaleiro. (Nota do editor).

${ }^{59}$ Espaço onde se servem refeições a oficiais e a sargentos. (Nota do editor).
} 
透过茂密的拱形树从和灌木从, 可以听见种种声音: 水流, 麦田, 雪松和松树林, 玉米地, 被山坡遗弃的村庄和小镇……

渐渐的, 定居点稀疏了, 山脉变得都是裸露的石头, 象牙色的古老积雪在突兀 的山峰上画出了一条条大理石般的纹路。

我们到达冰寒地冻的一千五百米高处时, 在仿佛滴着眼泪的天空下, 地中海朦 朦胧胧地出现了, 一轮血红的夕阳嵌在深处。

下面的贝鲁特城若隐若现, 正被这一天当中最后的悸动撞击着。

在这令人不爽的下午, 周围的景色在不断震颤着变动着。群山褪去颜色。水 彩和彩色玻璃般的五颜六色退成了丁香色和靛青色。山脉直直地倾向狭窄的河 谷, 定居点那分散的灯光在跳动着。一片已经睡去的松林呈现出深绿色。寂静扼 住了生命的节奏, 暮色在慢慢消失。潮湿甜美的夜色降临, 这買动着的迷人全景在 我们面前闭上了眼睛。

现在, 公路在不断地拐着弯下降, 汽车的两个大灯已经打开, 像两把移动的弯 刀一样划开了黑暗。

当汽车进入城市繁华的街道, 在一辆辆车厢周围, 在汽车的卡莱克森喇叭声 60 中, 生命的活力再次跳动起来。在灯光照出的长方形中阴影中, 楼房的库门打开 了。我们下午曾经历的全部美丽留在了身后……

航空理事会和占领军指挥官接待了我们。他们向我们表示了钦佩尊敬之情, 还告诉我们说飞行家佩尔蒂埃・窦昔 61 在飞往东京的途中要来阿勒颇。

从人们对我们说的言语当中, 能够感觉到一种强烈的愿望, 希望在法兰西的蓝 白颜色旁边, 我们的基督十字标志所代表的拉丁飞机能够获取胜利。

我们也路过了葡萄牙领事馆。领事先生长着一副犹太人的外貌, 身材却是叙 利亚式的瘦高, 他冷淡地接待了我们, 对于我们正在进行的飞行行程, 他表示毫无 所知。

由于检修发动机, 我们在里亚格不得不比预期的多逗留了一天, 因此, 有人想 我们建议可以参观一下巴勒贝克遗址。

在那里, 希腊、罗马和拜占庭等各种风格混搭在一起。在朱庇特神庙中, 石头 的风貌清晰地保留了曾发生在这里的、令人激动的战斗痕迹。在那些曾经的争斗 中, 血流成河。

\footnotetext{
60 指刺耳的汽车喇叭声。原文为英语单词, 来源于克莱克森牌商标。(编者注)

61 乔治・佩尔蒂埃・窦昔 (1892年-1953年), 法国航空先驱飞行员。他被称为Pivolo, 据彭德尔 (Pendellé) 称, 这个绰号来自一句他总是劝说飞行员们的、被讹用的话: Puis vole haut (意为 “然后飞高”)。他以成功完成 1924年的巴黎-东京空中突袭而闻名。(编者注)
} 
São abóbadas de arvoredo, bosques densos através dos quais se ouvem marulhos de água, trigais, maciços de cedros e pinheiros, campos de milho, aldeias e vilas alcandoradas pelas encostas...

A pouco e pouco as povoações rareiam, a montanha torna-se pedregosa e escalvada, e a neve ebúrnea, secular, põe nódoas de mármore nos cumes agudos.

Ao atingir o colo - mil e quinhentos metros de altitude regelante -, o Mediterrâneo aparece, brumoso, sob um céu gotejando lágrimas, que o doce magenta de um sol-pôr de iluminura ensanguenta ao fundo.

Beirute alveja em baixo, batida pelas últimas palpitações do dia.

$\mathrm{Na}$ agonia da tarde, a paisagem estremece, em transformações sucessivas. Os montes esmaecem, lilases e anilados, com um colorido de aguarela e de vitral. Polvilhando a serra que cai a prumo sobre o vale estreito, palpitam luzes de povoados dispersos. Há tons de esmeralda num pinheiral que adormece. O silêncio abafa o ritmo da vida, que se perde em gamas lentas, de passo que o crepúsculo vai morrendo. E a noite alastra, vaporosa e doce, a fechar-nos os olhos sobre o encantamento desse panorama embalador.

A estrada descia agora em lacetes contínuos, e os faróis do automóvel, acesos já, apunhalavam a escuridão, como dois alfanges de luz em movimento.

Ao entrar nas ruas buliçosas da cidade, de novo a vida lateja, no rodar das carruagens, nos klaxons ${ }^{60}$ dos automóveis, nos rectângulos de luz que a portas dos armazéns abrem nos prédios sombrios. Toda a beleza da tarde que vivêramos ficava para além...

A Direcção de Aeronáutica e o general comandante das tropas de ocupação recebem-nos com demonstrações de admiração e de afabilidade, informando-nos da próxima chegada de Pelletier-Doisy ${ }^{61}$ a Alepo, a caminho de Tóquio.

Nas palavras que nos dirigem, sente-se o desejo ardente de triunfo das asas latinas que a nossa Cruz de Cristo representava, ao lado das cores de França.

Passamos também pelo Consulado português. $\mathrm{O}$ cônsul - perfil de semita em corpo esgrouviado de sírio - recebe-nos com uma indiferença glacial, manifestando completa ignorância acerca da viagem que estamos realizando.

A revisão do motor força-nos a permanecer em Rayak um dia mais do que contávamos, e alguém nos sugere que aproveitemos para visitar as ruínas de Baalbek.

Amálgama monumental de estilos grego, românico e bizantino, a fisionomia da pedra conserva, no Templo de Júpiter, o traço nítido e impressionante das lutas remotas que ali fizeram correr sangue a jorros.

\footnotetext{
${ }^{60}$ Buzina estridente dos automóveis. Palavra inglesa, derivada de Klaxon, que era a sua marca comercial. (Nota do editor).

${ }^{61}$ Georges Pelletier-Doisy (1892-1953) foi um piloto francês, pioneiro da aviação, a quem chamavam Pivolo, alcunha que, de acordo com Pendellé, era uma corruptela da frase com que sempre aconselhava os aviadores: Puis vole haut (depois voa alto). Tornou-se famoso ao realizar com sucesso, no ano de 1924, o raide aéreo Paris-Tóquio. (Nota do editor).
} 


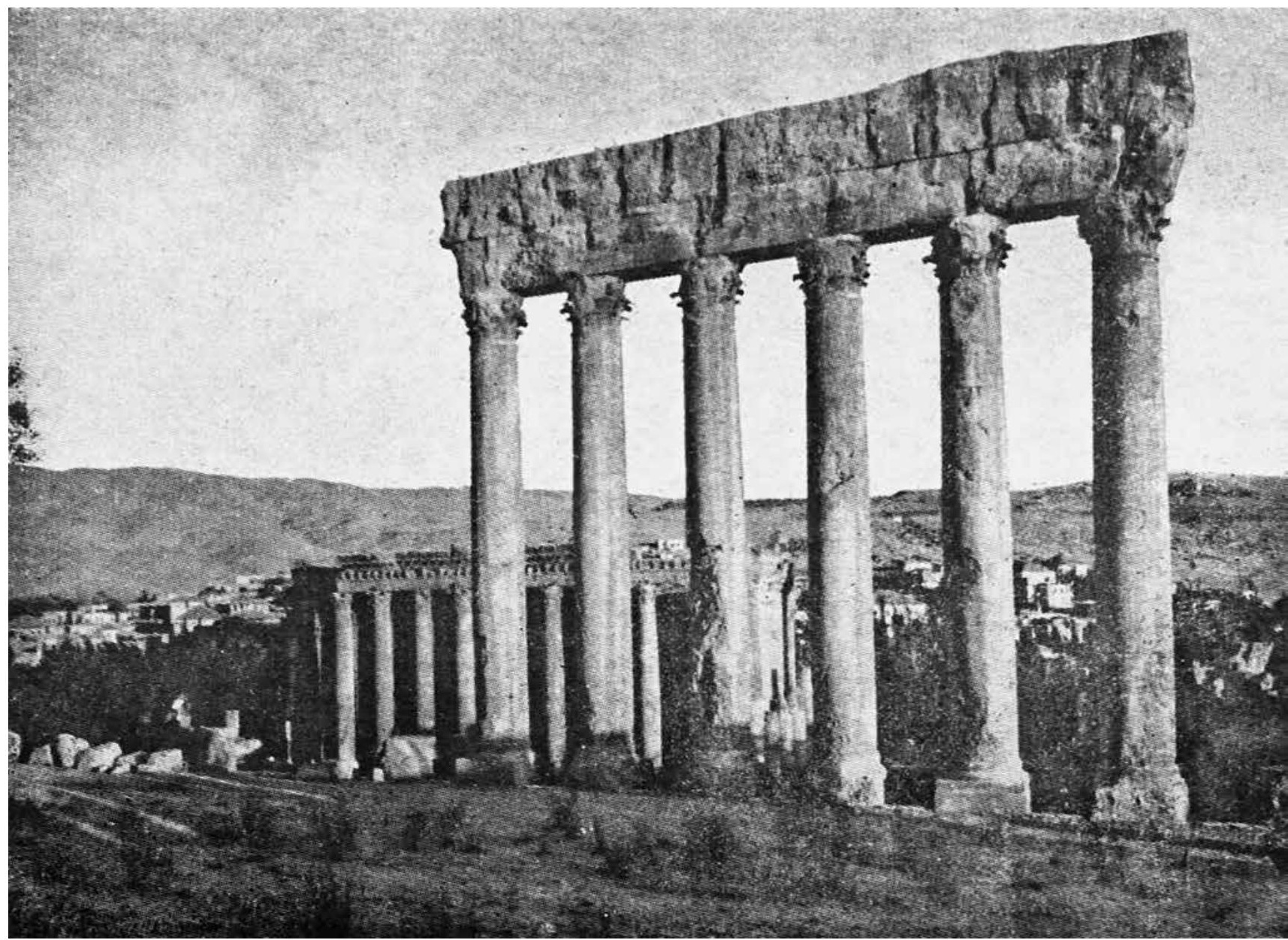

Baalbeck (Síria)

Ruínas do Templo de Júpiter

巴勒贝克 (叙利亚)

朱庇特神庙废墟 
就像在莱巴达 62 一样, 许多古老的回忆被空间阻断。

4月26日早7时左右, “祖国号” 再次起飞。

在清新的空气中, 飞机飞了半个小时, 飞机缓慢地螺旋式上升到了 2700 米的高 度, 俯瞰着杰拜尔 - 伊什 - 沙特克的沟壑。我们告别了那片好客热情的、可爱的 土地和高峰上的白雪, 向东到达了叙利亚沙漠。灰绿色的粉末酒满了地平线。

山坡上的大马士革就像是一只高贵的天鹅, 静静地浮在绿树组成的翡翠湖面 上。

突然, 景色为之一变。沙漠仿佛开始在我们的脚下展开了一卷单调的古铜色 毛巾。

偶尔的, 尘土飞扬一一贝都因游牧部落反抗法国占领的游牧骑兵不时穿插而 过。

地面的起伏很大, 到处都是干涸的河床。人们往往已经忽略, 这里曾有河流淌 过。

温度有所上升, 在大气中点燃了热血。

北部, 在灰暗荒凉的沙漠中, 幼发拉底河像是亮闪闪的金色带子。

忽然, 三个小黑点梦幻般地出现天穹尽头的地平线上, 它们渐渐飞近, 从 “祖国 号” 的右翼掠过。那是三架飞往开罗的英国飞机。

我们孤独的感觉被打破了, 不禁发出了高兴的呼喊。这三架飞机飞过同样的 天空, 这炎热的阿拉伯蔚蓝天空, 机翼散发强烈的生命的振动, 在它们航班细长的 曲线中, 预示出未来惊人的成就。

我们彼此挥舞着白色手帕, 那是希望旅途顺利的祝福……

他们越飞越远, 渐渐消失在远方的地平线上, 蓝色的天空再次恢复了宁静。

在正午地狱般炎热的阳光中, 我们接近了拉马迪艾, 艾豪尔湖像是一面闪亮的 金属镜子。南边, 滚滚沙尘在天空中坚起了三根火柱。

下午二时, 在沙漠那恶魔般的、令人窒息的阵风中, 我们飞抵了巴格达。“祖 国号” 终于降落在巨大的、四方形的机场上。30分钟后, 从阿勒颇飞来的佩尔蒂 埃・窦昔63那让人羡慕的 “杰奎琳号” 飞机也在此降落。

\footnotetext{
62 大莱普提斯的本地名称, 它是罗马帝国是一座富裕的城市。其遗址位于距的黎波里 130 公里的胡姆斯, 该 遗址于1982年被宣布为联合国教科文组织世界遗产。(编者注)

63 乔治・佩尔蒂埃・窦昔 (1892年-1953年), 法国航空先驱飞行员。他被称为Pivolo, 据彭德尔 (Pendellé) 称, 这个绰号来自一句他总是劝说飞行员们的、被讹用的话: Puis vole haut (意为 “然后飞高”)。他以成功完成 1924年的巴黎-东京空中突袭而闻名。(编者注)
} 
Como em Lebda ${ }^{62}$, há evocações de outros séculos, suspensas pelo espaço.

E pelas sete horas da manhã de vinte e seis de Abril, o Pátria mais uma vez arranca para novo salto.

$\mathrm{Na}$ atmosfera fresca, durante meia hora, o aparelho descreve uma lenta espiral ascendente, e a dois mil e setecentos metros, sobranceiro enfim às ravinas do Djebel-esh-Shurk, diz adeus àquela terra hospitaleira e adorável, diz adeus à neve dos altos píncaros, e aproa ao deserto da Síria que, para Leste, empoa de cinza esverdeada o horizonte indefinido.

Damasco, nas faldas da montanha, é como um cisne imóvel no lago de jade do arvoredo.

Bruscamente, o tom da paisagem modifica-se, e o deserto começa desenrolando sob nós a toalha brônzea da sua monotonia hostil.

De longe a longe, salpicando o terreno, grupos de cavaleiros - tribos nómadas de beduínos em revolta contra França - passam em pistas caprichosas.

O terreno tem ondulações largas, sulcadas de onde a onde por leitos secos de rios que a gente ignora se algum dia correram.

A temperatura, subindo, acende reverberações de sangue na atmosfera.

Ao Norte, o Eufrates surge, fita de oiro a cintilar, inscrustada na chapa escura do deserto.

E alucinantemente, nascidos do horizonte, três pontos negros se destacam no docel acqua marina da abóbada celeste, a definir-se em linhas de asa à medida que se aproximam, passam a estibordo do Pátria. São três aviões ingleses que singram rumo ao Cairo.

A nossa impressão de isolamento quebra-se, num grito irreprimível de alegria. Esses três aviões, sulcando o mesmo céu, sulcando o mesmo azul tórrido da Arábia, irradiavam intensa vibração de vida e prenunciavam, na curva alongada do seu voo, todo um Futuro de realizações surpreendentes.

Lenços brancos acenaram, em recíproco voto de boa viagem...

E os aviões afastaram-se, diminuindo no horizonte, até se perderem ao longe e ficar de novo ermo o céu azul.

Próximo de Ramadi, já sob a queimadura infernal do sol do meio-dia, o lago de El Khor parece um polígono metálico, faiscando. Para Sul, turbilhões de areia erguem no céu três colunas de fogo.

Pelas duas horas da tarde, depois de ter sobrevoado Bagdad sob as rajadas diabólicas do vento asfixiante do deserto, o Pátria poisa no imenso quadrilátero do aeródromo, onde, trinta minutos mais tarde, vindo de Alepo, Pelletier-Doisy ${ }^{63}$ aterra também no seu admirável

\footnotetext{
${ }^{62}$ Nome local para Leptis Magna, uma rica cidade do Império Romano, cujas ruínas se localizam em Homs, a cento e trinta quilómetros de Trípoli. O local foi declarado pela Unesco, em 1982, Património da Humanidade. (Nota do editor). ${ }^{63}$ Georges Pelletier-Doisy (1892-1953) foi um piloto francês, pioneiro da aviação, a quem chamavam Pivolo, alcunha que, de acordo com Pendellé, era uma corruptela da frase com que sempre aconselhava os aviadores: Puis vole haut (depois voa alto). Tornou-se famoso ao realizar com sucesso, no ano de 1924, o raide aéreo Paris-Tóquio. (Nota do editor).
} 
“杰奎琳号” 优美的线条与 “祖国号” 笨重的轮廓形成了鲜明对比。

与前面所有的停留处类似，罗斯比司令也让我们使用这个飞行中心丰富的资 源。而戈维亚忘却了疲劳, 为了让 “祖国号” 第二天一早就能出发, 他立刻投入工 作, 一直干到天色变暗。旅途节奏比我们预期的慢多了, 我们需要加快进度, 而最 重要的是要到达澳门。

罗斯比司令把我们带到了一千零一夜之城。我们觉得空气中尘土飞扬, 污浊 不堪。当汽车驶过城中道路, 安东尼奥 - 帕特里西奥 ${ }^{64}$ 的某些定义掠过我们的记 忆深处: 旅行就是品尝失望的艺术......

在既不富丽堂皇也没有任何风格可言的黄色建筑群中，一群奇怪的、异常的 人互相推搡着, 喧闹地进行着斋月的庆祝活动。

夜幕降临, 一个有着细长尖塔的建筑物的阳台上挂了几十个灯泡, 在浓重的夜 色中划出一串圆圈。一个穆斯林神职人员在大声呼喊, 提醒人们做礼拜, 就像是波 斯科特尔贝 ${ }^{65}$ 市场那样。

但在我们身边, 人们没有停止走动。我们被告知, 因为白天禁止进食, 所以从 日落开始, 那些人就不停地走动。

返回营地时, 幻想都破灭了, 这让我们感到心碎。

我们曾经多少次梦见巴格达: 到处都是宫殿, 清真寺, 美丽的妇女……

在军官的梅斯 ${ }^{66}$ 餐厅, 我们遇见了从阿勒颇来到佩尔蒂埃 - 窦昔 ${ }^{67}$, 他几乎在 怀疑我们怎么能够完成这几段飞行。

在与我们的交谈中 (此时, 戈维亚和布里托 - 帕艾斯正舒舒服服地躺在吸烟 室的扶手椅上), 我能感觉到他作为一个职业飞行家的钦佩与尊重, 没有任何一个 人可以像他那样评估我们为之战斗的种种困难 68 。

\footnotetext{
64 安东尼奥 - 帕特里西奥是一位葡萄牙诗人和剧作家, 1878年出生于波尔图, 1930年在澳门逝世。他医学本 科毕业, 但 1910 年决定投身外交生涯。在那一年, 他被任命为驻广东总领事。20年之后, 他的去世震惊了澳 门, 当时他正准备担任葡萄牙驻北京部长。(编者注)

${ }^{65}$ 阿尔伯特 - 威廉 - 凯特尔比 (1875年8月9日一-1959年11月 26 日) 是一位英国作曲家、指挥家和钢琴 家。他以创作较短的管弦乐作品脱颖而出, 如 “波斯市场”。这些作品的成功和其作品不断被出版, 使得凯 特尔比在二十年代末期就变成了一位极为富有的作曲家。“在波斯市场” 作于 1920 年, 是他最为成功的作品 之一, 它描绘了异国情调的场景。(编者注)

66 专有名词, 指为军官和中士们进行餐饮服务的地方。(编者注)

67 参阅前面的注解。(编者注)

68 佩尔蒂埃・窦昔撰写了题为 “我的突袭” 的文章, 描述巴黎一东京的旅程, 发表在 “Petit Parisen”上, 我们转 述如下:

“我检查了一下布里托 - 帕艾斯, 贝雷斯以及机械师驾驶的飞机, 愣住了。这是一架装备了雷诺 $300 \mathrm{CV}$ 发动机 的布雷盖夜间轰炸机, 它小得几乎像是只布谷鸟, 而里面却装了三个人。飞机外壳的机翼下有两个大大油 罐, 容量有 1600 升, 像是两个与轮胎相连的漂浮物。
} 
aparelho - o «Jacqueline» -, cujas linhas elegantes contrastavam violentamente com a pesada silhueta do Pátria.

Semelhantemente ao que ocorrera em todas as escalas precedentes, o comandante Crosbie põe à nossa disposição os abundantes recursos do Centro, e Gouveia, esquecendo a fadiga, mete ombros à tarefa, trabalhando até ao escurecer, para deixar o Pátria pronto a partir na manhã seguinte. $\mathrm{O}$ ritmo das nossas jornadas tem sido bastante mais lento do que prevíramos, e é preciso acelerar a marcha, se bem que, acima de tudo, o que mais importe seja chegar a Macau.

O comandante Crosbie leva-nos à cidade das Mil e Uma Noites, que do ar nos parecera poeirenta e suja. Enquanto o automóvel desliza através das ruas, aflora-nos à memória certa definição de António Patrício ${ }^{64}$ : «Viajar é a arte de saborear desilusões»...

Por entre o aglomerado de edifícios amarelentos, sem estilo nem grandeza, uma multidão heteróclita e estranha acotovela-se, na celebração ruidosa do Ramadan.

Ao cair da noite, do varandim de um minarete esguio que dezenas e dezenas de lâmpadas eléctricas desenham a reticências de luz na sombra que adensa, um sacerdote muçulmano clama, convidando à oração, como no Mercado Persa de Ketelbey ${ }^{65}$.

Mas em torno de nós o movimento não cessa e, ao que nos contam, é a partir do pôr-do-sol que toda aquela gente começa a movimentar-se, pois lhes é vedado comer durante o dia.

Ao voltar ao acantonamento, pungia-nos o desgosto de uma ilusão perdida.

Tantas vezes sonháramos Bagdad cheia de palácios bizantinos, mesquitas, lindas mulheres...

Na $m e s s^{66}$ dos oficiais, encontramos Pelletier-Doisy ${ }^{67}$, que quase duvida da possibilidade do percurso já efectuado por nós.

Nas frases que trocámos (enquanto Brito Paes e Gouveia conversavam, recostados nas confortáveis poltronas da smoking room), sinto a sua admiração e o respeito de um profissional que, como ninguém, pode avaliar as dificuldades com que lutávamos ${ }^{68}$.

\footnotetext{
${ }^{64}$ António Patrício foi um poeta e dramaturgo português, nascido no Porto em 1878 e falecido em Macau em 1930. Licenciado em medicina, decide contudo seguir a carreira diplomática em 1910, ano em que é nomeado cônsul em Cantão. Vinte anos mais tarde, a morte surpreende-o em Macau, quando se preparava para tomar posse como ministro de Portugal em Pequim. (Nota do editor).

${ }^{65}$ Albert William Ketelbey (9 de Agosto de 1875 - 26 de Novembro de 1959) foi um compositor, maestro e pianista britânico que se destacou pela composição de peças orquestrais breves de que Mercado Persa é um exemplo. O sucesso destas obras foi tal, que, no final dos anos vinte, Ketelbey tornou-se um músico riquíssimo, com a sua obra sucessivamente editada. In a Persian Market, que compôs em 1920, foi um dos seus grandes sucessos, sugerindo cenas exóticas. (Nota do editor).

${ }^{66}$ Espaço onde se servem refeições a oficiais e a sargentos. (Nota do editor).

${ }^{67}$ Ver nota da página anterior. (Nota do editor).

${ }^{68} \mathrm{Da}$ descrição da viagem Paris-Tóquio, publicada no «Petit Parisien», por Pelletier-Doisy, sob o título «Mon raid», transcrevemos o seguinte trecho:

«Examinei, estupefacto, o aparelho que tripulavam Brito Paes, Beires e o seu mecânico. Era um velho Breguet de bombardeamento de noite, com motor Renault de $300 \mathrm{CV}$. Quase um «coucou». E eram três ali dentro. Sob as asas
} 
与这位高级飞行家的接触是短暂的, 但他杰出的行动能力足以在我的心灵中 留下深刻的印象。他的这些能力是如此出色, 将继续在巴黎一东京长途飞行中闪 耀。

第二天, 出发后一刻钟, 一个火花塞穿孔 ${ }^{69}$ 了, 我们被迫重新降落在巴格达。当 时我们已经飞出了四十公里。出发被推迟到了下一天。

我们看到佩尔蒂埃 - 窦昔的飞机十点钟起飞了, 像箭头一样很快消失在前往 的布什尔方向。

又是一夜。我们再度受挫, 面前又是一个需要战胜的障碍。我们也应该在这 一天到达布什尔。如果我们到了, 或许不用忍受正在忍受的一切。但 “运气”这个 因素并不站在我们这一边。

此刻, 我们细淢而浓烈的乡愁与思念之情都飞向了世界的一角。那里, 所有人 都在紧盯着 “祖国号” 的飞行过程,在自信而不安的时光中焦急地等待着消息。

远方的气息扑面而来, 那是希望, 是信念, 是勇气。在夜晚, 我们思念朋友们, 他们几乎都出现在极为甜蜜的梦境中。

我没有向我的葡萄牙同行隐藏自己的钦佩之情。从里斯本驾机飞到巴格达是个壮举。他们将驾着这架飞 机一直飞到澳门, 对我来说, 这好像是很鲁莽疯狂的事。要知道, 很少有飞行员有勇气用这么不适当的飞机 做出类似的尝试。然而, 帕艾斯和他的同伴实现了这个计划。这是多么不易啊!” (第二版注)

69 原文为法语单词。(编者注) 
Foram breves momentos de contacto com um homem superior, suficientes, todavia, para me deixar no espírito a impressão exacta das suas capacidade de acção e de realizações práticas, que tão brilhantemente havia de confirmar na continuação desse maravilhoso raide Paris-Tóquio.

No dia seguinte, um quarto de hora após termos descolado, uma panne ${ }^{69}$ de velas obrigava-nos a fazer meia-volta, para aterrar de novo em Bagdad - havíamos percorrido já quarenta quilómetros -, e a adiar para o dia seguinte a nossa partida.

Vimos o avião de Pelletier-Doisy descolar pelas dez horas e desaparecer a caminho de Bushire, como flecha veloz.

Era mais uma noite, mais uma contrariedade, mais um obstáculo a vencer. Nós também devíamos chegar naquele dia a Bushire. Se tivéssemos chegado, talvez ali não sofrêssemos o percalço que sofremos. Mas o factor «sorte» interviera contra nós.

Nestes momentos, a nossa nostalgia requinta, e a saudade evola-se para o cantinho do mundo onde todo um Povo, de olhos fitos no Pátria, espera ansiosamente notícias, a um tempo confiante e inquieto.

Chegam-nos eflúvios distantes de esperança, de fé, de coragem e, durante a noite, pensamentos amigos, quase se materializam em sonhos de doçura extrema...

da sua casca de noz tinham instalado dois enormes depósitos cilíndricos, com capacidade para 1600 litros, e que pareciam flutuadores ligados às rodas.

Não escondi aos meus camaradas portugueses a admiração que me causava a sua façanha. Ter conduzido um BN2 de Lisboa a Bagdad era qualquer coisa. Querer conduzi-lo até Macau parecia-me temeridade louca. Não conheço muitos pilotos que tivessem ousado semelhante tentativa com meios tão pouco apropriados. No entanto, Paes e os seus companheiros realizaram o seu projecto. Realizá-lo não era proeza fácil». (Nota da 2. ${ }^{\text {a }}$ edição).

${ }^{69}$ Avaria. (Nota do editor). 


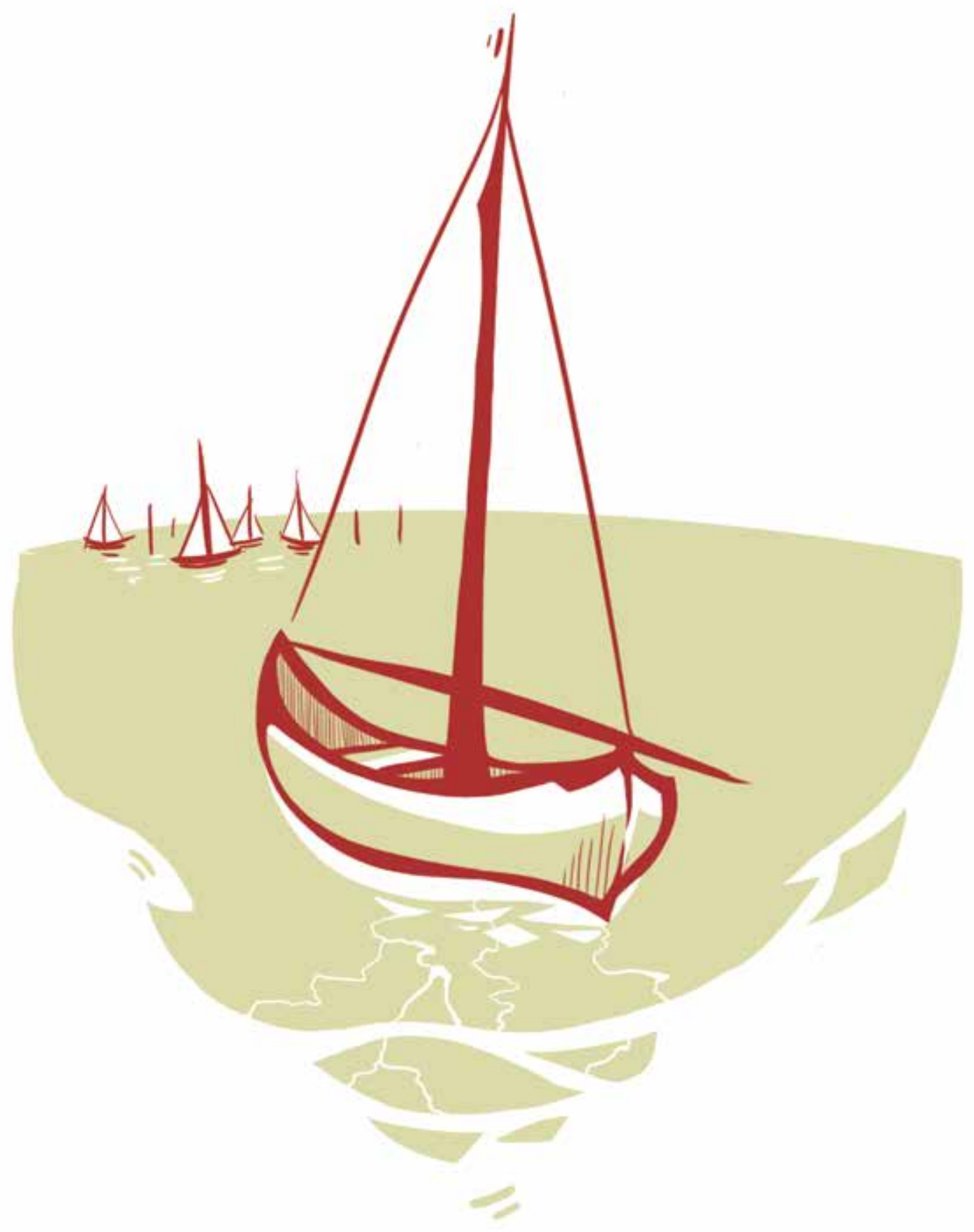

O porto de Bushire

布什尔港 


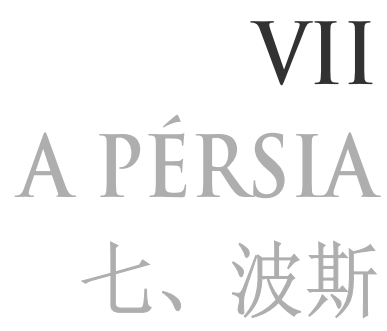


4月26日。巴格达, 库特阿马拉, 阿玛拉, 巴士拉, 本德尔里克, 布什尔一一 900 公里, 900 米。6:15。天气闷热, 令人窒息, 但有点躁动不安。东南风。晴空。

那一天我祈祷着。我飞行日志中那简洁、没有感情色彩的四行字浓缩概括 了这一切, 尽管这样, 在度过了苦涩的几个小时后, 我们第一次在波斯的土地上降 落了。

旅程非常疲㤂。在途中, 高温又一次敲打着我们的神经。

伊拉克让人想起尼罗河三角洲, 但却没有那里的多彩活力。这是一片冲积平 原, 被许多农田和渠道割成一块块的, 仿佛是一块奢侈的土地。两条大河像是泥泞 的穗子一样绕过这片土地, 将它与旁边的沙漠隔绝开。

我们沿着幼发拉底河前进, 但不久就放弃了。我们相信指南针, 尽管知道它所 指的北也只是个大概的方位, 不过参照物比比皆是。因为穿行在两条大河之间, 所 以我们确信没有走错路。

我们没有看到巴比伦废墟, 虽然我们知道它位于底格里斯河以西。又一次, 那 几乎是神话般的过去从石块中脱颖而出, 唤醒了记忆。

沿着右舷看到的巴士拉的高度, “祖国号” 迎着东南风70 离开了拥有众多机库 的军用机场。

我们再次进入了沙漠。这片沙漠的沙子很潮湿, 上面有一大片一大片的盐渍, 与浅海那蓝绿色狭窄 “臂弯” 形成了鲜明的对比, 带来一种阴森的腐烂的感觉。

糟糕的化油作用时不时地引发了干扰, 打乱了发动机的运转。

但飞机划过炽热的天空, 继续向前飞行, 背后是静寂忧伤的波斯湾。葡萄牙人 曾经在此秉承着自己国家的伟大辉煌乘风破浪一一此刻, 还是同样的葡萄牙, 她慷 慨豪迈的人民推动着我们向印度前进。

正午时分, 在一个小小的、风景如画的港口, 布什尔城出现在河边, 像是一条 微微发白的花边织物, 正晾晒在阳光下。

跑道被标得很清楚, 东边半公里处浓重的石灰线画出了一个三角形。

“祖国号” 轻柔地触碰着地面降落了, 一条雪尼尔花线 ${ }^{71}$ 拉着它从营地前行, 停 在了一个正在修建的机库旁。

70 原文使用了一个航海术语, 意思是为了尽量利用风的作用改变航向。(编者注)

71 原文为法语单词, 用以称呼车轮上带有金属履带的拖车机器。(编者注) 
Vinte e seis de Abril. - Bagdad, Kut-el-Amara, Amara, Bassora, Bender-Rig, Bushire. 900 km. - 900 m. - 6h15m. Tempo abafado e sufocante, mas pouco agitado. Vento SE. Céu aberto.

Assim reza, naquela data, a minha caderneta de voo, lacónica, inexpressiva, que, nessas quatro linhas, para mim sintetiza, apesar disso, as horas ásperas que precederam a nossa primeira aterragem em território persa.

Viagem fatigante, durante a qual, mais uma vez, a temperatura brutal da atmosfera põe à prova os nossos nervos.

O Iraque faz lembrar o delta do Nilo, sem ter, no entanto, a vivacidade do seu colorido. Terreno de aluvião, cortado de culturas e canais, é um tapete extravagante que a franja barrenta dos dois rios contorna bizarramente, como a protegê-lo do deserto que fica para além.

Começamos por seguir o curso do Eufrates, que abandonamos pouco depois, confiando-nos à bússola, sabendo embora que o seu Norte é apenas aproximado. Mas as referências não faltam. E como navegamos entre dois cursos de água confluentes, temos a certeza de não errar o caminho.

Não avistamos as ruínas da Babilónia, que sabemos localizadas algures, para Oeste do Tigre. Mas, uma vez mais, a evocação de um Passado quase lendário desprende-se das pedras a acordar memórias.

Por alturas de Bassora, que avistamos a estibordo, o Pátria orça ${ }^{70}$ a Sudeste, deixando longe o aeródromo militar com seus numerosos hangares.

Entramos novamente em contacto com o deserto, um deserto de areia húmida, ao qual grandes manchas de sal, contrastando com o verde-azulado de estreitos braços de mar pouco profundos, davam um aspecto lúgubre de podridão.

A carburação péssima origina, de quando em quando, inquietantes baixas de regime, que perturbam o funcionamento do motor.

Mas o avião prossegue, cruzando o céu candente, sobre o fundo soturno do golfo pérsico, onde outrora portugueses se bateram pela grandeza de Portugal - o mesmo Portugal que naquela hora, pela voz do seu Povo generoso, nos impele para a Índia.

Pelo meio-dia, num portozinho minúsculo e pitoresco, a cidade de Bushire surgiu à beira de água como renda alvadia a secar ao sol.

A pista bem marcada, grandes traços de cal delineando os ângulos, fica meio quilómetro a Leste.

E o Pátria toca suavemente o terreno, enquanto de um abarracamento distante uma chenille $e^{71}$ avança e o reboca para junto do hangar em construção.

\footnotetext{
${ }^{70}$ «Orçar» é um termo náutico, que significa mudar de rumo, para aproveitar melhor a acção do vento. (Nota do editor).

${ }^{71}$ Palavra francesa que designa uma máquina de reboque com lagartas metálicas no rodado. (Nota do editor).
} 
这个营地保管了波斯所有的航空力量一一两架斯帕德飞机。十个全副武装 的护卫在下面守护着它们, 其中包括两个政府雇佣的法国机械师。他们是这个国 家善战的军队的样本。

过了一会儿, 法国领事苏德诺先生和英国领事加德纳先生, 还有一位英国军队 的工程师上校戈弗雷先生等人, 乘坐两辆福特汽车到来了。戈弗雷先生在这里的 电报和无线电报站的技术部门任职。

此外, 还来了一位值得一书的少尉。这是个瘦高的金发小伙, 头上戴着一顶奇 怪的圆柱形皮质软帽一一在这种热带气候中, 看见这帽子都让人觉得热。他脚上 穿着一双闪闪发光的马靴, 敬礼的时候, 两个脚跟一并, 靴子上的马刺叮当作响, 仿 佛阿根廷歌曲式的颤音在空中停留了好几秒。他过分的礼貌让那位高卢长官立刻 说: “说实话, 您太客气了。”72 当我们握手时, 阿尔法 - 默克 (这位有趣的少尉叫这 个名字) 用力紧握我的手, 好像在说:

“他们在等你回来呢。”

因为此地没有酒店, 我们就住在领事的屋子里: 布里托 - 帕艾斯和戈维亚住在 法国领事那里, 而我, 因为粗通英语, 就住在英国领事那儿。

欧洲人之间的殷勤礼貌让我们感动。住在 “祖国号” 飞过的, 文明程度不那么 高的偏僻角落, 过路的欧洲人相互依存, 对抗变化无常的气候和同样暴烈的人们。

下午一一布里托 - 帕艾斯后来告诉我说, 阿尔法 - 默克在法国领事馆的官方 任务是负责检查护照。

他那温存油滑的目光掠过护照蓝色的页面, 仔仔细细地检查着我们的护照, 用 正确的法语说护照上缺少欧洲有关领事机构的签证。

布里托 - 帕艾斯怀着对官僚主义的愚蚌而产生的紧张情绪, 解释道: 在里斯本 没有波斯领事馆。

阿尔法 - 默克始终很温和地抱兼着, 结结巴巴地说着有关国际航空条约的规 定。

第二天, 布什尔总督向我们告知: 没有波斯政府的许可, 我们不得起飞。

飞行被迫中断, 因为一个公务员借口文明而产生的愚蚌的形式主义。

这是波斯缺少飞机所产生的无可争辩的后果。

为了缓解我们由于收到这个意外通知而产生的担心情绪, 苏德诺先生把我们 带到了城里, 让我们得以近距离地观察那些肮脏的茅舍, 曲折的小巷, 里面蚁群般 的人们衣衫褴褛。

72 为了显得诚实而过于礼貌。(编者注) 
O abarracamento alberga toda a aviação persa - dois aviões Spad, sob a guarda de dez homens armados, que, no dizer dos mecânicos franceses contratados pelo Governo, são exemplares do aguerrido exército daquele país.

Dois Fords trazem, momentos depois, o cônsul de França, Mr. Sudreau, o cônsul inglês, Mr. Gardner, e um capitão de engenharia do Exército Britânico, Mr. Godfrey, que ali tem a seu cargo os serviços técnicos do posto telegráfico e radiotelegráfico.

Aparece também um alferes persa que merece descrição. É um rapaz alto, loiro, magro, com um estranho barrete cilíndrico, de peles, que naquelas paragens quase tropicais faz calor só de olhar para ele. Usa botas altas de polimento, a rebrilhar, e, ao fazer a continência, bate de tal maneira os calcanhares, que as esporas tilintam ruidosamente, numa sonoridade argentina que fica trilando durante alguns segundos. A sua exagerada polidez sugere imediatamente aquela máxima gaulesa «Trop poli pour être honnête ${ }^{72}$ ». E, nos apertos de mãos que trocamos, Arfa-al-Molk (que assim se chama o interessante alferes) põe uma energia que poderia significar:

- Esperem-lhe pela volta.

Como não havia hotel, ficamos aboletados em casa dos cônsules: Brito Paes e Gouveia sob o tecto da França, e eu, como arranhava inglês, sob o tecto da Inglaterra.

A amabilidade dos europeus sensibiliza-nos sinceramente. Residindo no recanto remoto da terra menos civilizada que o Pátria sobrevoou, adivinha-se neles o desejo de solidarizar-se com os europeus que passam e de os defenderem contra as intempéries do clima e da população, bastante tempestuosa também.

Pelo meio da tarde - contou-me Brito Paes depois -, Arfa-al-Molk apresentou-se no Consulado francês com a missão oficial de verificar os passaportes.

Melífluo e untuoso, passou os olhos sobre a folha azul e, no seu francês correcto, arriscou uma observação delicada, ao verificar que nos documentos faltava o visto das autoridades consulares persas na Europa.

Brito Paes, com o nervosismo que nele suscitam as imbecilidades burocráticas, explicou a não existência de Consulado persa em Lisboa.

E, sempre melífluo, Arfa-al-Molk lamentou, gaguejando, o que quer que fosse sobre a convenção internacional aeronáutica.

No dia seguinte, o Governador de Bushire, comunicava-nos que, sem autorização do Governo Persa, não poderíamos levantar voo.

Era a interrupção forçada da viagem imposta pela estupidez formalista de um funcionário público com pretensões a civilizado.

Era a consequência incontestável da carência de aviões na Pérsia.

Para distrair-nos da preocupação em que nos lançara a notificação inesperada, Mr. Sudreau, leva-nos à cidade, que se converte, observada de perto, num amontoado de casebres sujos, entrecortado por vielas tortuosas onde formiga gente esfarrapada.

\footnotetext{
${ }^{72}$ Demasiado educado para ser honesto. (Tradução do editor).
} 
我们曾经以为这是个充满鬼未的城市, 这种想法在此时瞬间崩溃了。

在这种贫困悲惨的环境中, 地泩之都、梦幻般的宫殿, 东方式性感的波斯, “鲁 拜集” 作者欧玛尔 - 海亚姆 ${ }^{73}$ 笔下的波斯, 此时向我们展现的却是一个原始、酷热 的贫穷市镇, 它呈现出一幅令人失望的样貌。

我们去了总督府, 总督用茶和香烟招待了我们。

总督外貌瘦削, 胡子拉碴, 面容疲倦, 脸部棱角突出。他讲法语时有一定的困 难, 但是足以让我们向他说明所处的困境。他静静地听着, 这沉默可能意味着他 对事实一无所知。但是在场的阿尔法 - 默克向总督阁下做了澄清, 细节丛生的澄 清……他们两人合唱出了一长串遗憾之词。

我们气馁地解释说, 在启程之前, 里斯本的军用航空理事会接到了沙阿国王陛 下一封极为亲切的信件, 此信授权我们可在波斯领空飞行、降落。

总督啜了一口茶, 吸吮着烟蒂, 干嚼着, 用左手慢慢地骚了下头皮屑后, 用难以 听清的声音, 不好意思地张口结舌地嘟囔着:

“这……这……我不知道……是的! 我不知道沙阿国王陛下是否依然可以提 供这样的授权……您理解……沙阿国王陛下, 我相信, 不再掌管波斯! 好像是这 样……我不太确定! ”4

呵! 真是个轻歌剧和喜剧的国家! 如果在我们的前方, 没有你那不友好的海岸 的残酷从林一一一千百多公里的沙漠, 如果不是因为在灼热而又无情的阳光下, “祖国号”没有燃油了, 我们就会放声大笑。

波斯! 动员了五十万人, 而当我们经过时, 有二十万逃兵的地方!

有两架飞机, 有法国机械师但却没有飞行员的波斯。

一个因为沙阿国王的心血来潮, 只在德黑兰郊区铺设了一点点窄轨轻便的德 考维尔 ${ }^{75}$ 铁路的波斯!

一个没有公路的波斯! 在这里, 俄国人俘获了一架因发动机被击穿而迫降的飞 机, 因为没有一个飞行员会修理被严重损坏的飞机, 它被送到了步兵营!

\footnotetext{
${ }^{73} 11 、 12$ 世纪 (1048年- - 1131年) 的波斯诗人、数学家和天文学家。在西方, 他首先以诗人而闻名。他是 著名的 “鲁拜集” 作者 (葡语为 “四集” 或 “四重奏”), 标题来自 “鲁拜”一词, 意思是两行一节, 每节有两个部 分。自1859年爱德华・菲茨杰拉德翻译了这部作品之后, 它在欧洲变得非常有名。(编者注)

74 “这……这……我不知道……是的! 我不知道沙阿国王陛下是否依然可以提供这样的授权……您理解…… 沙阿国王陛下, 我相信, 不再掌管波斯! 好像是这样……我不太确定!”原文为法语。(编者翻译)

75 德考维尔是一种窄轨铁路系统名称, 由方便拆卸的部件组成, 其铺设工作很容易。其名称来自它的发明 者。(编者注)
} 
Desfazia-se o encanto da visão que tivéramos, ao passar sobre a cidade.

E, naquele ambiente de miséria, a Pérsia dos tapetes, dos palácios de sonho, do orientalismo sensual e embalador - a Pérsia de Omar Khayyam ${ }^{73}$ e do Rubaiyat - revelava-nos o aspecto decepcionante de um pobre burgo primitivo e canicular.

Passamos pela residência do Governador, que nos recebe, oferecendo-nos chá e cigarros.

Magricela e mal barbeado, olhar sonolento e apático, ângulo facial bastante agudo, fala francês com certa dificuldade, mas compreende o bastante para nos permitir expor-lhe a situação crítica em que nos encontramos. O homem ouve, num silêncio que poderia dizer ignorância dos factos. Mas Arfa-al-Molk, presente, esclarece Sua Excelência, com profusão de detalhes... E ambos fazem coro na litania de lamentações.

Explicamos, bastante enervados, que na Direcção da Aeronáutica Militar, em Lisboa, se recebera, antes de partirmos, uma gentilíssima carta do Xá, autorizando-nos a voar e a aterrar em território persa.

O Governador sorve um gole da beberagem, chupa a ponta reduzida do cigarro, e mastigando em seco, depois de coçar lentamente a caspa com a mão esquerda, numa voz que mal se ouve, diz timidamente esta coisa estupenda:

- C'est que... c'est que... je ne sais pas... oui! Je ne suis pas sûr si Sa Majesté le Shah peut encore donner des auctorisations pareilles... Vous comprenez... Sa Majesté, je crois, ne gouverne plus la Perse! Il me semble... je ne suis pas sûr!" ${ }^{74}$

Oh, país de opereta e de comédia! Como a gente riria à gargalhada, se não tivesse diante de nós a sarça cruel da tua costa inimiga - mais de mil e oitocentos quilómetros de areias desertas -, se não tivesse o Pátria sem gasolina, sob o sol calcinante e impiedoso!

A Pérsia! Onde se fez uma mobilização de quinhentos mil homens e onde havia, quando por lá passámos, duzentos e cinquenta mil desertores!

A Pérsia, que tem dois aviões, que tem mecânicos franceses, mas que não tem aviadores!

A Pérsia, cuja rede ferroviária se reduz a um Decauville ${ }^{75}$ minúsculo que se construiu por capricho do Xá, nos arredores de Teerão.

A Pérsia que não tem estradas! A Pérsia onde, porque um piloto não soube reparar um avião seriamente avariado, capturado aos russos por ter aterrado em território nacional, forçado por um desarranjo no motor, o irradiaram para a infantaria!

\footnotetext{
${ }^{73}$ Poeta, matemático e astrónomo persa dos séculos X-XI (1048-1131). No Ocidente, ficou conhecido sobretudo como poeta, autor do célebre Rubaiyat (em Português, «quadras» ou «quartetos»), título formado a partir do termo «ruba’i», que designa uma estrofe de duas linhas, com duas partes (hemistíquos) cada. A obra ficou célebre na Europa, a partir da tradução que dela fez Edward Fitzgerald, em 1859. (Nota do editor).

${ }^{74}$ «-É que... é que... não sei... sim! Não tenho a certeza se Sua Majestade o Shah ainda pode conceder autorizações semelhantes... Compreende... Sua Majestade, julgo eu... já não governa mais a Pérsia! Parece-me... não tenho a certeza!» (Tradução do editor).

${ }^{75}$ Decauville é o nome de um sistema de caminho-de-ferro de via muito estreita e composta por elementos de ferro facilmente desmontáveis, que exigem pouco esforço de colocação. A designação deriva do nome do seu inventor. (Nota do editor).
} 
这样的一个波斯: 因为我们的护照上少了个签证, 就愚蚌地不让我们前行的当 局! 丝毫不考虑我们已经做出的努力和正在进行的尝试! ${ }^{76}$

这一切让我们觉得如此乏力, 厌倦而愤怒……

此刻, 恳求的想法占据了我们的思绪, 这种思绪弥漫开来, 焦急而隐秘地飞向 葡萄牙。我们度过了毫无把握而充满疑问的若干个小时, 在此期间, 我们的责任心 膨胀, 几乎将我们淹没。

如果葡萄牙政府也抛弃了我们……

麦克拉伦 ${ }^{77}$ 曾经想过要做同样的事。然而, 第二天早晨, 一艘英国炮舰偶然地 出现在布什尔湖上, 麦克拉伦既不尴尬也不困难地出发了。

戈维亚利用这个令人疲乏的机会检修了发动机, 法国机械师热诚地辅助他进 行检修。

30 号下午六时, 布里托・帕艾斯来到跑道测试发动机。

卫队长看到了,打着手势告诉他飞机不能起飞。

暮色渐渐降临, 天色越来越暗。

布里托 - 帕艾斯也比划着相让队长平静下来, 他试图解释我不在飞机上, 现在 几乎是夜晚了,他不过是要测试一下飞机。

但那个人摇着头, 命令自己的属下列队并把扛好步枪。

76 许多年过去了, 波斯变了。我们能够肯定, 现在再也不能像我们曾经写过的那样进行描写。(第二版注释)

77 英国飞行员。他在1924年这年企图环游世界。(编者注) 
A Pérsia, onde, porque nos faltava o visto nos passaportes, uma autoridade nos retinha estupidamente, sem consideração pelo esforço realizado e pela tentativa em curso! ${ }^{76}$

Que enervamento, que tédio, que cólera tudo isto provocava em nós!...

Nesses momentos, o pensamento toma colorações de súplica, evolando-se no espaço, ansioso e invisível, a caminho de Portugal. Vivendo horas de incerteza e dúvida, a nossa responsabilidade avoluma-se e quase nos esmaga.

Se o Governo Português nos abandona...

A MacLaren ${ }^{77}$ tinham querido fazer a mesma coisa. Como por acaso, porém, na manhã seguinte, uma canhoeira inglesa aparecia a largo de Bushire. E MacLaren partiu, sem embaraços nem dificuldades...

Entretanto Gouveia aproveitava a enervante oportunidade para rever o motor, secundado pelos mecânicos franceses que o auxiliam dedicadamente.

No dia trinta, pelas seis horas da tarde, Brito Paes foi até à pista no intuito de ensaiar o motor.

O chefe da guarda, ao vê-lo chegar, explica por gestos que o avião não pode partir.

O crepúsculo descia lentamente, num brando declinar da claridade.

Por mímica também, Brito Paes tenta sossegá-los, explicando que falto eu, que é quase noite, procurando fazer-lhes compreender que se trata apenas de uma experiência.

Mas o homem, com uma oscilação de cabeça significativa, manda alinhar os seus extravagantes subordinados e carregar as carabinas.

\footnotetext{
${ }^{76}$ Os anos passaram, e a Pérsia transformou-se. Hoje - temos a certeza -, não poderíamos escrever o que escrevemos. (Nota da $2 .^{\text {a }}$ ediçãa).

${ }^{77}$ Piloto inglês que, nesse ano de 1924, tentava dar a volta ao mundo. (Nota do editor).
} 
$s$

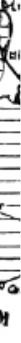




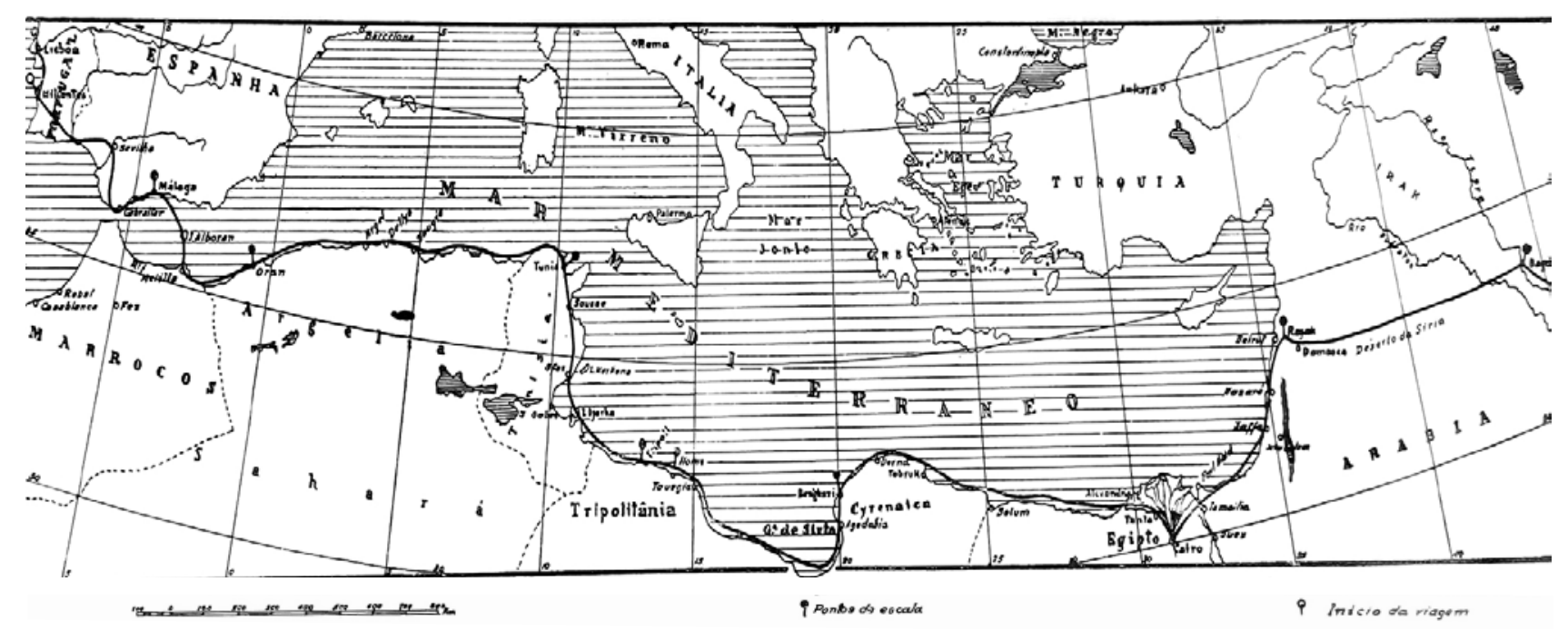

Croquis do itinerário da Viagem (I)

(Lisboa-Vila Nova de Milfontes-Bagdad)

行程路线草图 (I)

(里斯本一千泉新镇一巴格达) 
在十几支准备好射击的步枪前面, 在那些执行阿尔法 - 默克的命令而又无知 的人们面前, “祖国号” 的发动机转速达到了其正常的 1450 转, 整个金属机身在蓝天 下焦急地咆哮着, 震动着。

我们在布什尔所度过的几个小时当中, 精神上的压力, 因为没有把握而产生的 煎鳌折磨, 意外中断旅途的可能性, 这一切都让我们倍感痛苦。

我们的言语和思绪都受到了这种情况的不利影响。

加德纳先生, 戈弗雷先生和苏德诺先生的友爱都无法抹去我们的悲伤。

招待我们的英国领事给了我完全的自由。他是个有趣的家伙, 有着几乎是拉 丁式的外貌, 下巴的胡须拉长了他那张苍白的脸。当他在书房忙碌时, 在那幢小屋 ${ }^{78}$ 中陪伴我度过孤独时光是他的两条狗: 一条狐狸犬和一条爱尔兰梗, 它们分别叫做 斯罗什和杰夫。我写作时, 它们在我的脚旁打盹。一台宏伟的留声机划破了寂静, 混合着夏威夷哀怨的旋律, 一种温暖的忧郁从一些古典曲目中弥漫开来。就是在 布什尔, 我认识了德沃夏克 ${ }^{79}$ 的作品。

戈弗雷先生是这幢小屋的另一位居住者, 他是个沉默的人, 藐视言语而沉默 地行动。他像是加德纳先生的儿子, 不过年长 10 岁。他有一辆已经跑了 10 万公里 的、著名的福特汽车, 在性情冷漠缓慢的英国上校指挥下, 这辆车发出可怕的噪音, 加德纳先生将其称之为 “飞行的雷暴之音” 80 。

苏德诺先生和夫人是一对平和幸福的夫妇, 两个人深情地彼此关怀对方。布 里托・帕艾斯和戈维亚是他们小屋的客人。

得知法国和英国领事的努力失败了, 布里托 - 帕艾斯将在私下重新燃起的愤 怒隐藏在讯讽的笑容之下, 给里斯本拍了一个电报。

我们每个人都气馁地呆在屋子里, 被德黑兰那令人难以理解的缓慢反应打击 到了。

晚九时, 有人似乎有些害怕地敲响了法国领事馆的大门。

领事夫人打开了们, 是阿尔法・默克, 他低声问起了布里托・帕艾斯。

苏德诺夫人回答说她去叫布里托・帕艾斯。

“不, 不! 我只想知道他是否……”他又开始说波斯语。

“可为什么呢?”

“我给他带来了一个重要的信息。”

\footnotetext{
78 通常用于旅游而且不太大的单层房子。但是在印度, 这个词有社会阶层的含义, 它指的是与公寓楼相对 的、只属于一个家庭的房子, 是一种典型的中产阶级住宅。在这个国家, 这种房子带有身份地位的象征。 (编者注)

79 捷克作曲家 (1841-1904)。(编者注)

80 飞行风暴。(编者注)
} 
E é diante de uma dezena de espingardas prontas a disparar, em frente daquelas criaturas boçais que cumpriam ordens de Arfa-al-Molk, que o motor do Pátria atinge as suas mil quatrocentas e cinquenta rotações normais, num frémito de todo o seu cavername metálico ansioso de céu azul.

A depressão moral das horas que passamos em Bushire, o suplício torturante da incerteza, as possibilidades da interrupção inesperada da viagem ferem-nos dolorosamente.

As nossas palavras, os nossos pensamentos ressentem-se da situação.

O carinho de Gardner, Godfrey e Sudreau não bastam para destruir a nossa tristeza.

O cônsul inglês de quem sou hóspede dá-me absoluta independência. É um tipo interessante, de fisionomia quase latina, perinha mefistofélica a alongar-lhe a face pálida. Nas horas de solidão que passo no seu bungalow ${ }^{78}$, enquanto as suas ocupações o retêm no escritório, fazem-me companhia dois cães - um fox e um irish terrier -, Slosh e Jaff, que dormitam a meus pés de passo que escrevo, e um magnífico fonógrafo vai lançando no silêncio, de mistura com plangentes melodias hawaianas que uma quente melancolia impregna, alguns trechos clássicos. Foi em Bushire que travei conhecimento com Dvorak ${ }^{79}$.

Godfrey, o outro habitante do bungalow, é um indivíduo calado, que despreza as palavras e age em silêncio. Parece filho de Gardner e tem mais dez anos. Possui um famoso Ford, com perto de cem mil quilómetros percorridos, que rola com uma barulheira infernal, sob o comando fleumático do capitão inglês, e que Gardner baptizara com o ruidoso epíteto de flying thunderstorm ${ }^{80}$.

Mr. e M. ${ }^{\text {me }}$ Sudreau, em cujo bungalow estiveram hospedados Brito Paes e Gouveia, constituem um casal pacato e feliz, que tem para ambos solicitudes carinhosas.

Brito Paes, escondendo sob um sorriso de ironia a cólera que lhe referve no íntimo, telegrafou para Lisboa, ao saber do insucesso dos esforços dos cônsules francês e inglês.

E cada um de nós recolheu a casa, desanimado já, batido pela incompreensível demora da resposta de Teerão.

Pelas nove horas da noite, porém, alguém bateu, como a medo, à porta do Consulado francês.

A consulesa foi abrir, e Arfa-al-Molk saiu da sombra, perguntando em voz baixa por Brito Paes.

Respondeu-lhe M. ${ }^{\text {me }}$ Sudreau que o ia chamar.

- Não! Não! Eu desejava apenas saber se ele está... - volveu-lhe o persa.

\footnotetext{
${ }^{78}$ Casa não muito grande e de um único piso, destinada normalmente ao turismo. Na Índia, no entanto, o termo adquire uma conotação social, ao referir-se a qualquer residência pertencente a uma só família, por oposição ao edifício de apartamentos, que é a residência típica da classe média. Neste país, bungalow traz consigo um símbolo de status. (Nota do editor).

${ }^{79}$ Compositor checo (1841-1904). (Nota do editor).

${ }^{80}$ Tempestade voadora. (Tradução do editor).
} 
“你说……”, 领事夫人好奇地要求道。

“就是, 如果他们愿意的话, 我明天可以搞到许可!”

“为什么你不马上搞到?需要做些什么?”

“发一封电报。”

被这个神秘的小心弄得很不安的领事夫人呆住了。

“为你什么现在才说?”

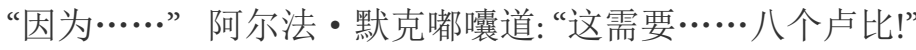

领事夫人跑去告诉了布里托 - 帕艾斯。除了那八个卢比, 布里托 - 帕艾斯还 给了阿尔法・默克两个卢比的小费。

托卢比的福! 第二天, 许可证到了。

我们利用那天的下午去向总督先生致以问候, 这次, 他在政府宫接待了我们。 这是幢楼梯破烂而狭窄的建筑, 在一些地方, 褴褛的粗麻布充当了过道地毯。

一位高级官员向我们表示, 他对所发生的的事深感悲伤。这个人骨瘦如柴, 瘦 削的身体在一件宽大的白色长袍中扭动着, 那长袍活像是个防尘罩。还有一些具 备某种重要性却有着微不足道外貌的人物驻守在办公室那些破破烂烂的沙发中。

或许是为了说服我们, 说明自己在此事件中是无辜的, 前一天还气愤地向我们 讲述战争场面的总督阁下让人把阿尔法・默克叫来, 严厉斥责了他。

5 月2日早六点启程时, 我们的朋友加德纳先生, 戈弗雷先生, 苏德诺先生和法 国机械师们热情拥抱了我们。

阿尔法 - 默克再次碰响了他的靴跟, 他跟我们握手, 那黄色的笑脸上流淌着虚 伪。

“祖国号”飞机在清晨炎热而异常平静的天空下开始滑行。

到阿巴斯港的旅程仿佛是在砂砾的披风上张开翅膀滑翔，下面是沟壑纵横、 到处是悬崖峭壁的沙漠。地狱般的气息向大地四散传来, 让我们的眼睛充血, 四周 的风景一片炽热。同样的, 那个鲜红的太阳直直地照耀着 “祖国号”, 让我们头晕目 眩。

跑道上, 灼热的沙子起伏不一, 飞机被强风晃动着, 跳动着, 最后终于停了下来, 发动机还最后喘息了几声。

英国领事理查森先生接待了我们, 他是一个可爱但俗气的人。在我们逗留领 事馆期间, 他不停地用他的钱, 他拥有的特权, 他的府邸, 还有他纯净的英国血统敲 击着我们耳朵的鼓膜。

这里也有一些果阿人, 这些单纯的人们由于环境的影响已经英国化了, 说不好 我们的语言。 
- Mas porquê?

- Trazia-lhe uma informação importante.

- Diga!... - exclamou a consulesa, toda curiosidade.

- É que, se quiserem, arranjo autorização para amanhã!

- Porque a não arranjou já? O que é preciso fazer?

- Mandar um telegrama.

Enervada por aquele mistério, a consulesa estava suspensa.

- Mas porque só agora o diz?!

- É que... - e Arfa-al-Molk gagueja - são necessárias... oito rupias!

A consulesa correu a informar Brito Paes que, além das oito, lhe mandou duas de gorjeta. Abençoadas rupias! No dia seguinte, a autorização chegava.

Aproveitamos a tarde para ir apresentar os nossos cumprimentos de despedida ao Governador, que, desta vez, nos recebeu no Palácio do Governo, casarão de escada estreita e carcomida, onde um farrapo de sarapilheira fazia as vezes de passadeira.

Corpo esquelético dançando dentro de um amplo balandrau alvadio, género guarda-pó, o alto funcionário manifestava-nos o seu pesar pelo sucedido. Alguns personagens, por certo de importância mas de aspecto insignificante, guarneciam os sofás esfarrapados do gabinete.

E, talvez no intuito de nos convencer da sua inocência no caso, Sua Excelência, a quem narráramos indignadamente a cena bélica do dia anterior, mandou chamar Arfa-al-Molk e repreendeu-o com energia diante da assistência.

Pelas seis horas da manhã de dois de Maio, à partida, os nossos amigos Gardner, Godfrey, Sudreau e os mecânicos franceses abraçavam-nos efusivamente.

Arfa-al-Molk, batendo mais uma vez os calcanhares, apertava-nos a mão com um sorriso amarelo a ressumar falsidade.

E o Pátria descolou na atmosfera abafada da madrugada muito calma.

A viagem até Bandar-Abbas é um deslizar de asas pandas sobre montes de areia, desertos ravinados e escarpas abruptas. O mesmo hálito de inferno a evolar-se da terra, a ensanguentar-nos os olhos, a esbrasear a paisagem. O mesmo sol rubro-branco caindo a prumo sobre o Pátria, a entontecer-nos.

Na pista, areia a arder, em ondulações inconsistentes, o avião, sacudido pela ventania, ressalta e fica imóvel, ofegando ainda nas últimas explosões do motor.

Alberga-nos Mr. Richardson, o cônsul britânico, homem amável mas primata, que, durante a nossa permanência no Consulado, nos martela os ouvidos com o seu dinheiro, os seus privilégios, o seu palacete, o seu puro sangue inglês. 
我们吃了一顿丰盛的午餐, 餐后甜点是美味的金色香蕉。接着, 我们在床上睡 了一个长长的午觉。睡觉时不需要毛牛炎, 只要床垫和床单就行了。我们休息时没 有用防寒外套, 因为室温是那样高, 根本感觉不到寒冷。

这一天平静地过去了, 喝过下午茶后, 我们去露台上透透气。

在不太纯净的半透明的大气中, 金顺, 霍尔木兹海峡和拉猎克拉岛装扮着风 景, 就像是蓝绿色平原上熟睡着的史前动物一般, 光线在这平原上凝固了。

在悠长的黄昏之后, 夜色终于严密地包围了一切。被深深的宁静和沉默的温 柔所感动, 生活暂停了。

沙地上, 远处是陡峭的基奇瑙山, 近处, 直线组成的线条勾勒出 “祖国号” 那优 雅坚硬的轮廓。

5 月3日。拂晓。几乎无人。

螺旋桨转动, 飞机起飞。

我们怀着同样的渴望向东前进。风景还是同样奇怪, 让人想起月亮的一部 分一一这一部分掉到地球上几千年了, 上面布满了怪异的陨石坑, 一片荒凉。

有时, 下面的景象仿佛变得有些不真实, 像是根据一部无人书写的悲剧所要求 的, 布置出来的一个巨大的舞台布景。

它完全是个不毛之地, 毫无生气, 令人沮丧。

途中某个时刻, 一座葡萄牙纪念碑泛着白光一闪而过, 那是属于创造了历史的 阿方索・德・阿尔布克尔克时代的纪念碑。

德亚斯科不过是个孤立的四边形砌石建筑。

早九点。恰赫巴哈尔的跑道在电报站旁, 那发白的 $\mathrm{T}$ 形跑道接纳了我们的飞 机, 葡萄牙的飞机。

十几个生活在这个半沙漠地区的欧洲人来到了这里, 向我们表达他们的钦佩 之情。我们在自己的周围感受到了他们的热情, 在 “祖国号” 崎岖不平的朝圣之旅 中又画上了一个火热的记号。 
Aparecem também alguns goaneses, gente simples, que mal sabe falar a nossa língua, de tal maneira estão britanizados pela influência absorvente do meio.

Depois de um lauto almoço cuja sobremesa foi constituída por deliciosas bananas-ouro, dormimos uma longa sesta, em leitos de campanha. Não são necessários cobertores. Apenas o colchão e um lençol. Repousamos sem o menor agasalho, e a temperatura ambiente é de tal maneira elevada, que não sentimos frio.

O dia passa tranquilamente e, ao cair da tarde, depois do chá, vimos respirar um pouco para o terraço.

Na fosca translucidez da atmosfera impura, Quishum, Ormuz e Larak decoram a paisagem, como animais pré-históricos adormecidos na planície glauca que a luz parece solidificar.

A noite acaba por fechar, depois de um crepúsculo interminável. Suspensão de vida que impressiona pela quietude profunda, pela suavidade silenciosa.

E no areal, com a montanha escarpada do Ki-Ginao por fundo, o perfil do Pátria destacava a rigidez graciosa das suas linhas rectilíneas.

Três de Maio. Alvorada. Quase ninguém.

Hélice em marcha, o avião descola.

A abalada para Leste prossegue, sob a mesma ardência, sobre a mesma paisagem estranha que faz lembrar um pedaço de lua caído na terra há milénios, com suas crateras bizarras e a sua aridez desolante.

Por vezes o panorama torna-se irreal. Parece que se trata simplesmente da decoração de um palco imenso, segundo as exigências cénicas de qualquer tragédia que ninguém escreveu.

É tudo glabro, inanimado e lúgubre.

A certa altura do percurso, fazendo História, branqueja um padrão português do tempo de Afonso de Albuquerque.

Jask é, simplesmente, um quadrilátero de alvenaria isolado.

E às nove horas, a pista de Chahbar desenha junto ao posto telegráfico o seu T esbranquiçado e recebe as nossas asas, que são asas de Portugal.

À nossa volta sentimos o entusiasmo de uma dezena de europeus que ali vivem num semi-desterro e que vêm render-nos preito de admiração, pondo mais uma nota de calor na acidentada peregrinação do Pátria. 


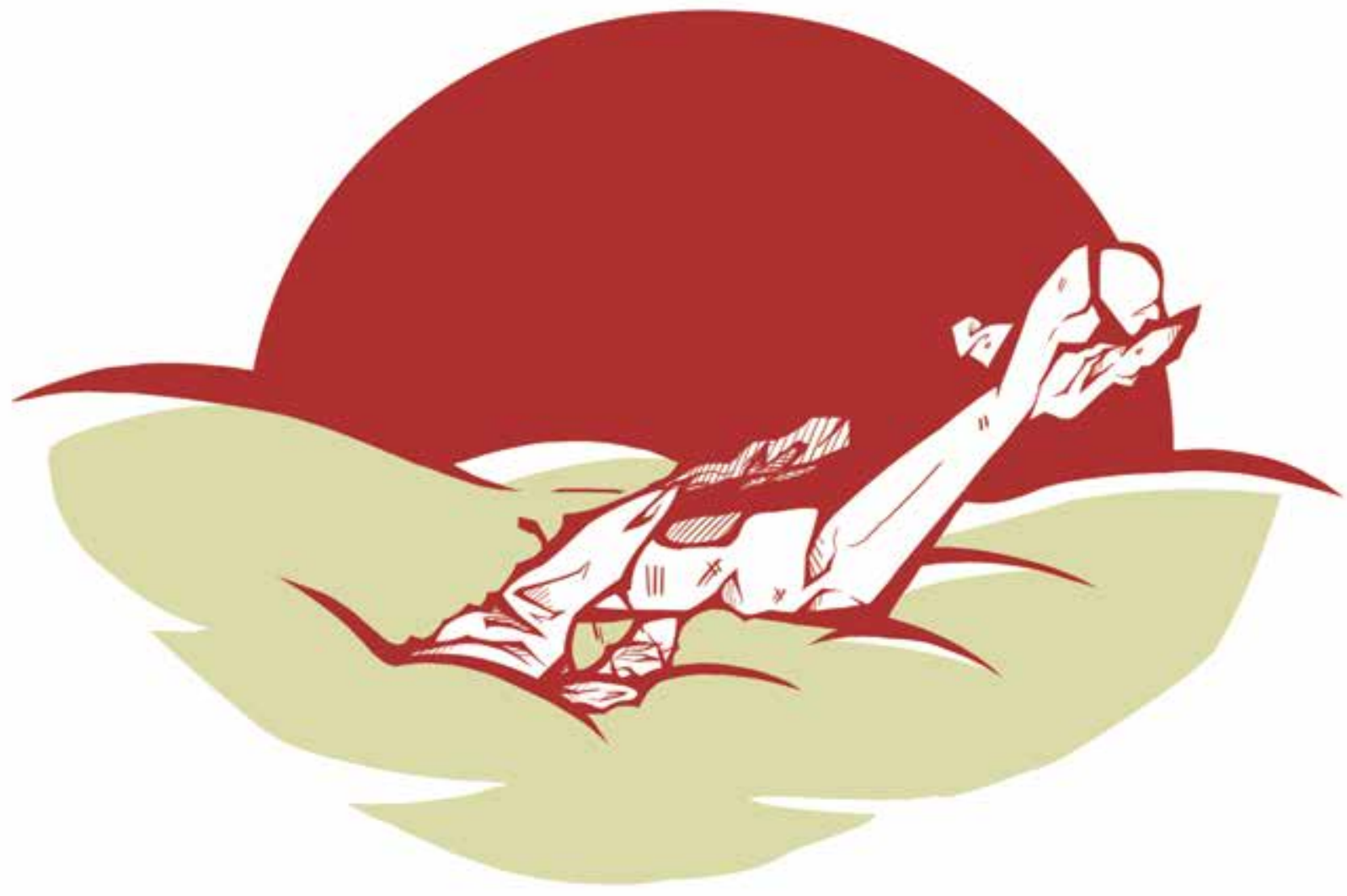




\section{VIII \\ HORAS TRÁGICAS \\ 八、悲剧性的时刻}


在这波斯的一角, 当拂晓的第一缕曙光慢慢洒向灰暗的天空, 我们告别了居住 在当地的几个欧洲人一一这应该是我们最后一次触碰这里的土地, 他们陪我们到 了跑道。因为住的地方离跑道就两步路, 我们是走着去的。

检查飞机时, 我们注意到一颗眼泪般的水滴从散热器上淌了下来。我们担心 地瞪大了眼睛, 但什么也做不了。在恰赫巴哈尔, 由于缺乏资源, 哪怕是轻微的故 障也完全无法进行维修。

大家试验了一下发动机, 它继续沿着不可改变的规律运转。接着我就起飞 了。

我们的前方是七百五十公里的航程。途中的加瓦特, 瓜德尔, 伯斯尼, 奥尔马 拉等地可以被比作是沙漠中的绿洲。在这些地方, 虽然并不总是, 但如果我们降落, 就会受到热情的款待。

遥远的印度! 在这个困难的阶段, 我们实现了梦想的第一部分, 这就像是在一 切都无法把控的黑暗中发出的炼炼光芒。

一直到加瓦特, 我们都在一千五百米的高度上飞行。

尽管还是清晨, 一股仿佛是冒着火焰的气息已经从大地升起。

海岸线划过浑浊的大气层, 在我们前方, 气流层像是一块暗淡的赫石色窝幕似 的很快向我们压过来。

“祖国号”穿过这片陶土粉末似的气流时, 我们就像是被暮色包围了。

天空和大地从我们的视野中消失, 隐藏进了一片沙子和水蒸汽组成的奇怪的 迷雾中, 狂风像皮鞭 ${ }^{1}$ 一样抽打着这片迷雾。“祖国号” 就像一列火车进入了黑暗 的隧道。

我们需要飞得低一点。

在墨黑的海水上方五十米处, 那令人窒息的空气吐出的炽热气息把飞机弄得 猛烈地晃来晃去, 就像是在跳舞。

布里托・帕艾斯全神贯注地盯着前方。戈维亚开始觉得恶心。

而我, 正在与窒息作战, 在狂风的抽打中全力捍卫 “祖国号”。我有一种发烧似 的灼热感。

在我们的下方, 温度达到了烤箱里的度数。海岸上, 沙子组成的云层正在燃 烧, 我们被无情地卷入其中; 飞机那令人钦佩的发动机拖着 “祖国号” 沿着不规则的 轨迹前进一一现在是十米, 接着猛冲了八十米, 下降了二十米一一它就像是一颗跳 动的心脏。

远处, 太阳瞬间迸发出的火焰像是一支支火红的箭, 间或向我们飞速射来。大 风有时会把迷雾撕裂, 沙质的荒漠出现在我们的视野, 它在昏暗的地平线上脱颖而 出, 沙子卷起的三角形朱红色旋风也在上升。

81 鞭子 (来源于俄语的术语)。(编者注) 
Quando as primeiras claridades da luz de alva começam a tingir timidamente o céu ferrete desse recanto da Pérsia - o último em que devíamos tocar -, despedimo-nos da meia dúzia de europeus que ali residem e que nos acompanham à pista. Como fica a dois passos dos alojamentos, vamos a pé.

Ao examinar o avião, notamos uma gota de água, lágrima que cai do radiador. Olhámo-nos apreensivos, mas nada há a fazer, visto em Chahbar ser totalmente impossível, devido à falta de recursos, reparar a pequena avaria.

Ensaiado o motor, que continua a funcionar com inalterável regularidade, descolamos.

Diante de nós, setecentos e cinquenta quilómetros de trajecto, onde Gwatar, Gwadar, Pasni e Ormara, se podem comparar aos oásis de um deserto onde nem sempre, porém, se aterrássemos, seríamos recebidos hospitaleiramente.

Para além, a Índia! A realização da primeira parte do sonho concebido, cintilando nas trevas de incerteza dessa difícil etapa ...

Até Gwatar, voamos a mil e cem metros.

Apesar da hora matinal, a terra exala já um hálito de labareda.

A linha da costa recorta-se através da atmosfera impura e, na nossa frente, uma cortina baça, ocre, aproxima-se rapidamente.

O Pátria penetra naquela massa que parece de barro em pó, e é como se o crepúsculo descesse sobre nós.

Céu e terra desaparecem ao nosso olhar, ocultos pela névoa estranha de areia e vapor de água, azorragada pelo $k n o u t^{81}$ furioso de um vento colérico, onde o Pátria entra como um comboio num túnel.

É preciso voar mais baixo.

Até cinquenta metros do mar cor de tinta de escrever, o avião baila, diabolicamente balouçado pela brasa daquele ar que asfixia.

Brito Paes concentra no olhar toda a sua energia. Gouveia sente as primeiras náuseas.

E eu, lutando contra a sufocação, esforçando-me por defender o Pátria do chicote do vento, tenho a sensação de arder em febre.

Em baixo, a temperatura atinge uma intensidade de alto forno. Da costa, vêm nuvens de areia a ferver, a envolver-nos sem piedade; e o motor admirável lá vai arrastando o avião, na sua trajectória irregular - agora dez metros, a seguir, violentamente, oitenta, para descer a vinte -, pulsando como um coração vivo.

De longe a longe, o sol flameja por momentos, dardejando sobre nós flechas ígneas. E nas bocarras da bruma que o vento por vezes rasga, o areal deserto aparece e, a destacar-se no horizonte fosco, turbilhões de areia erguem no espaço triângulos de cinábrio.

\footnotetext{
${ }^{81}$ Chicote (termo de origem russa). (Nota do editor).
} 
突然, 在我们前方若干米处一一 20 米, 15 米左右, 或许更短一一奥尔马拉半岛 那些悬崖峭壁像是超自然的恐怖幽灵一样出现了。

一瞬间, 令人痛心、苦恼的焦急, 还有痛苦的期待掠过所有人的心间。在一秒 钟的时间里, 我们的声音汇成一声大喊: “山啊!”这声音在某一瞬间甚至超过了发动 机的噪音。

群山!

“祖国号”倾斜了, 最后一圈几乎是擦着危险的悬崖而过。

但是，在我们那没有详细标注的，比例为1：4000000地图上的半岛又扑面而 来。

飞机被毁灭性的风暴抽打着, 但它再次从中逃逸了出来。

我们围绕着海岸的曲线, 向奥尔马拉海湾拐去。在这哥梦的东边, 在孤独中有 一道生命的闪电在徘徊: 一艘独木舟, 一个印度人在上面打渔。

在松米亚尼湾上方, 普拉里河口, 天气有所好转, 我们能够在 200 米的高度飞 行。发动机四次熄火发出的轰鸣 82 像是宽广的沟壑中子弹的声音。

我们的心脏痛苦地收缩起来; 我们正处在敌对的俾路支地区上方, 离卡拉奇 还有250公里呢。

此刻, 我们的双手已经下意识地去自动确认并修正燃油阀的位置, 大脑从中无 意识地分离开来。大家都没说出口, 但都很快就盘算出:

“二百五十公里啊! 如果走路……要走60个小时。因为如果我们迫降, 飞机非 得散架不可! 三天或四天挨饿……而我们拥有的水就是散热器里的那点儿!”

当发动机恢复正常时, 我们已经能够在精神上面对各种可能, 但是死亡的想法 并没有拂过我们的心灵。死亡是唯一把我们遗忘了的。

在相对的平静中向前飞行了二十分钟之后, 发动机故障再次打破了这平静, 此 时我们正在哈勃河口莫泽角的上方。

这个地区已经不是一片荒漠了。这里有一些渔村, 零零星星地散布在沙质海 滩那些低矮的山丘上。

尽管我尽了全力, 但发动机系统依旧不能正常运转。我用身体语言告诉布里 托 - 帕艾斯正在发生的事情。面对这种情况, 我们得准备降落一一没有任何其他 办法了。一片略有起伏的土地出现在我们面前。

炎热, 现在再加上潮湿, 让我们大汗淋漓。戈维亚在旅途中吐得一塌糊涂, 几 乎失去了意识的他蜷缩在飞机舱的底部。

我下意识地做了个手势, 这个手势中包含了我所有的不安一一也就是我们的 不安。在这一瞬间, 所有的飞行运气都掌握在我的手中。我再次试着改变油阀。

82 原文为法语, 意为由于内燃机故障引起的不正常噪音。(编者注) 
Subitamente, diante de nós, a alguns metros - vinte, quinze, talvez menos -, os morros abruptos da Península de Ormara surgem, como aparição medonha de monstro sobrenatural.

Instante de expectativa dolorosa, de ansiedade aflitiva e de angústia. É um segundo em que, sobrepondo-se ao ruído do motor, as nossas vozes uníssonas se fundem num só grito:

- Os montes!

O Pátria inclina-se, numa volta que é o último recurso, e passa, quase roçando a escarpa ameaçadora.

Mas a península espalma-se num alargamento que a nossa carta de 1:4.000.000 não detalha.

E de novo o avião se escapa, batido mais furiosamente pela ventania demolidora.

Cingimos a curva da costa e, ao cortar a baía de Ormara, já para Leste do pesadelo, há um relâmpago de vida na solidão que paira: uma piroga fundeada, onde um indiano pesca.

Sobre Sonmiani, na embocadura do Pourali -, o tempo melhorara um pouco, permitindo-nos duzentos metros de altitude - quatro ratés ${ }^{82}$ do motor atroam como tiros de peça os recôncavos da amplidão.

Os nossos corações confrangem-se; estamos a duzentos e cinquenta quilómetros de Karachi, sobre a região hostil do Beluchistão.

E enquanto as mãos, já habituadas, vão automaticamente verificando e modificando a posição das torneiras de gasolina, os cérebros abstraem-se inconscientemente, em cálculos íntimos, rápidos, que se não chegam a articular:

- Duzentos e cinquenta quilómetros! A pé ... sessenta horas! Porque se aterramos, o avião parte-se fatalmente! Três ou quatro dias de fome ... Água temos no radiador!

Quando o motor retoma o seu giro normal, mentalmente têm-se encarado as hipóteses prováveis, mas a ideia de morrer não aflorou a nossa mente. Foi a única que nos esqueceu.

Seguem-se vinte minutos de sossego relativo que, de novo, o mau funcionamento do motor interrompe, sobre o cabo Monze, na foz do Hab.

A região já não é deserta. Há aldeias de pescadores, dispersas pelas colinas baixas do litoral arenoso.

Como, apesar de todas as minhas tentativas, o regime do motor continua baixando, exponho por mímica a Brito Paes o que se passa e, em face das circunstâncias, dispomo-nos a aterrar - não há outro remédio -, num terreno ligeiramente ondulado que se nos depara.

$\mathrm{O}$ calor, agora húmido, alaga-nos em transpiração. Gouveia, que durante a viagem enjoou horrorosamente, quase não se apercebe, amarfanhado no fundo da carlinga.

Num gesto automático em que se contém toda a minha inquietação - síntese da nossa inquietação, nesse instante em que a sorte da viagem estava nas minhas mãos -, tento uma vez mais mudar de depósitos.

\footnotetext{
${ }^{82}$ Barulho anormal devido ao mau funcionamento de um motor de explosão. (Nota do editor).
} 
油阀开关被然油弄得油淢淢的，从我的手中滑开。最后我终于把开关放到了 希望的位置。

我们的飞行高度一百米; 接近地面的气流比较平静, 地面也较规则, 这让我们 获得了某种自信和安宁, 发动机会降慢转速 ${ }^{83}$, 我们将要降落。

飞机已经飞得很低了, 地面仿佛有点远, 然后我完全无意识的开启了油门 ${ }^{84}$, 忘 了有故障 85 。

发动机重新哼唱起它欢快的歌儿, 当我们听到时, 心中重又燃起了希望。被中 断的航程又被恢复了, “祖国号”向上爬升了八十米。

现在这段航程还有最令人痛苦的、最后的五十公里。

飞机继续沿海飞行, 它总是被浓雾那癫㾁似的狂暴和阵阵疾风抽打着。

干早荒芜的土地令人悲伤, 搅动的气流发出地狱般的气息, 我们被这气流弄得 摇来晃去, 仿佛要被消灭了。我们甚至没有时间确认查找那些罕见的、极为贫困 的村庄, 它们被抛在了后面。

马努拉的港口是个螺旋状的火山。

卡拉奇位于印度河三角洲。在惨淡的日光下，这座炽热的城市有着邪恶的一 面。在东边五公里处铁路线的旁边, 飞机跑道就像是一座大火炉敞开的炉门那样 躺在那里。

阳光异常灼热, 让我们的视野支离破碎。

风抽打着干燥的大地, 一阵阵沙子组成的烟雾腾空而起, 仿佛是浓密的云朵, 一种无法看见的 “火灾” 发出的鲜红火苗照亮了这些它们。

“祖国号” 埅入了这烟云的深渊, 令人惊奇地摇晃着, 掉入了真空中, 重又爬升 到了上升气流上, 最后飞机终于到达了跑道上方, 轻轻地降落在德赖罗德机场。炽 热的阳光灼烧着机场。

在这段艰苦行程中度过的可怕的几个小时里, 我有了一种从未有过的感觉, 觉 得我们似乎将无法到达终点。

我们三个从备受折磨的肌肉疲劳中恢复了一点, 开始谈论在这六个半小时的 旅程中发生的这些插曲。布里托 - 帕艾斯说了句令人钦佩的话, 让奥尔马拉的鬼 影永远留在了我们当中:

“卡蒙斯在描写巨神马达马斯托的时候应该看见了类似的景象! ${ }^{86}$ ”

\footnotetext{
83 原文为意大利语减缓之意。(编者注)

84 原文为法语, 拉杆之意。(编者注)

85 原文为法语, 故障之意。(编者注)

86 在那次恐怖的下降之后, 我很高兴地记得布里托 - 帕伊斯在 “祖国号” 降落在卡拉奇时说的话。当时他向 我走来, 拥抱着我说: “像您这样的手, 世上没有第二双了!” (第二版注)
} 
A torneira engordurada pelo óleo escorrega-me nas mãos. Consigo finalmente colocá-la na posição desejada.

Estamos abaixo de cem metros; a atmosfera mais calma perto do solo e o campo aparentemente regular consentem-nos certa confiança e tranquilidade, e o motor vai girando ao ralenti ${ }^{83}$, visto que vamos aterrar.

A pequena altura já, o terreno parece-me melhor um pouco mais longe e, inconscientemente, esquecido de que estamos em panne $e^{84}$, abro a manette ${ }^{85}$ do gás.

O motor entoa de novo a sua canção sonora e cadenciada e, ao ouvi-la, renasce a esperança nos nossos corações. Retomando a rota interrompida, o Pátria volta a subir a oitocentos metros.

Faltam agora cinquenta quilómetros, os últimos, os mais torturantes da jornada.

$\mathrm{O}$ avião singra, seguindo a costa, castigado sempre pelo furor epiléptico da bruma e das rajadas.

A aridez do terreno entristece, e a agitação do ar assume proporções infernais, sacudindo-nos, como decidida a abater-nos. Nem tempo temos para localizar as aldeias raras e misérrimas que deixamos para trás.

O porto de Manora é um vulcão de redemoinhos.

Karachi, junto ao delta do Indus, na luz coada do sol lúgubre, tem um aspecto sinistro de cidade incandescente. E cinco quilómetros a Leste, à margem da linha férrea, a pista aparece como a porta aberta de uma fornalha.

A luz magoa, queima, dilacera a vista.

Da terra ardente, evolam-se, batidas pela ventania, nuvens de areia que parecem nuvens de fumo denso, iluminadas pela chama rubra de um incêndio invisível.

O Pátria mergulha no abismo, balouçado espantosamente, caindo no vácuo, para subir de novo na corrente ascendente de um turbilhão atmosférico e, aproando enfim, aterra suavemente no aeródromo de Drigh Road, que o sol calcina.

Nunca como nas horas trágicas dessa etapa esgotante tive a impressão de que não chegaríamos ao fim.

E quando, refeitos já da fadiga que nos martirizava os músculos, conversámos os três sobre os incidentes ocorridos durante as seis horas e meia de viagem, Brito Paes teve esta frase admirável, a eternizar em nós o fantasma de Ormara:

- Camões, para descrever o Adamastor, deve ter visto uma coisa assim ${ }^{86}$ !

\footnotetext{
${ }^{83}$ Em desaceleração. (Nota do editor).

${ }^{84}$ Avaria. (Nota do editor).

${ }^{85}$ Alavanca. (Nota do editor).

${ }^{86}$ É-me grato recordar também as palavras que Brito Paes me dirigiu, ao abraçar-me, quando o Pátria poisou em Karashi, depois daquela descida tormentosa:

- Mãos como as suas não se encontram duas! (Nota da 2. ${ }^{a}$ edição).
} 


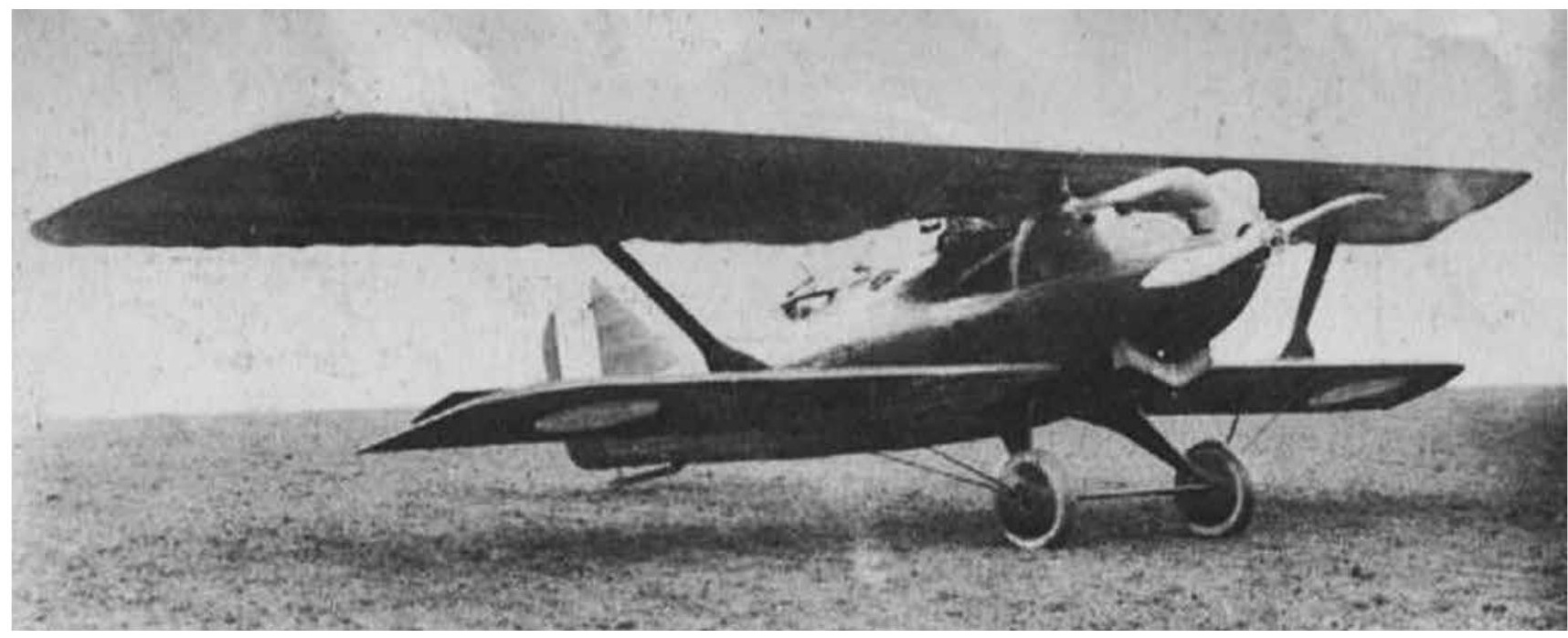

\section{Jacqueline}

O sequisplano de Pelletier-Doisy, que nos ultrapassou em Bagdad.

(Tipo Breguet XIX-A2. Motor Lorraine Dietrich 400 CV. Modelo de 1924)

“杰奎琳号飞机”

佩尔蒂埃・赎昔的复翼机, 他在巴格达超过了我们

(布雷盖XIX-A2型飞机, 罗奈恩・底垂400CV发动机, 1924年款)

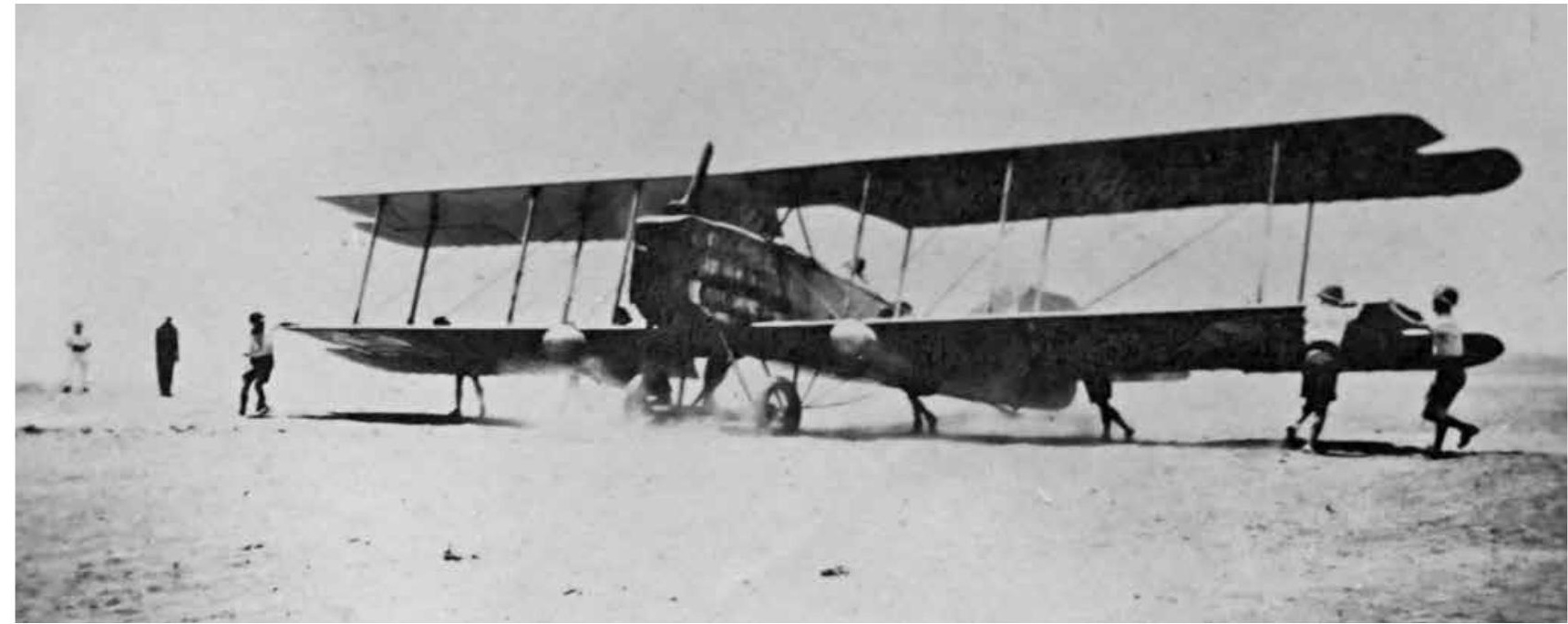

\section{A aterragem do Pátria em Karachi}

“祖国号”降落在卡拉奇 
有几十个果阿人接待了我们一一在殖民地一共有五千果阿人一一他们的欢 呼和致敬彰显出了他们对于葡萄牙的自豪感, 他们在世界航空大事件中看到了代 表葡萄牙胜利的颜色。

罗伯特 - 耶茨上尉以该飞行中心司令官的名义向我们致以欢迎的问候，并允 许我们使用这个机场所有的资源。在印度服役的英国飞机就是在这里维修、组装 和建造的。

而筋疲力尽的我们, 此时最大的愿望就是睡觉。

我们看到 “祖国号” 被停到了几个大机库中的一个, 不再被太阳直射; 而挤得 水泄不通的摄影师们也允许我们能够坐进飞行中心的汽车中。我们马上乘车离开 机场, 到达卡尔顿酒店。在酒店里, 我们沉沉睡去, 恢复体力。

醒来后, 我们出席了第一批接待活动和宴会。对于那些人来说, “祖国号” 代表 着葡萄牙, 他们激动地向我们致以祝贺, 虽然这些人都不太会说葡萄牙语……

戈维亚按照他的习惯, 第二天一大早就去了德赖罗德机场。

修理散热器需要几个小时, 因此我们无法在5月6日离开。

那天下午, 我们到达机场时决定在此过夜, 以便能够第二天凌晨就起飞。此 时, 在我们面前的 “祖国号”已经被维修、抛光、喷好颜色了。它静静地停在那里 闪闪发光。

在最后一段航程中, 让发动机不能正常运转的神秘原因 (戈维亚没有发现任何 不正常之处) 只能归处于汽化作用不足, 这是在那种炽热的气流中可接受的假设。

我们在野营帐篷中入睡。第二天早晨, 在拥抱了耶茨先生, 并与希克斯司令官 握别之后, 我们于早七点登机向阿格拉飞去。像我们已经过的所有英国机场的军 官们一样, 希克斯司令官阁下也非常仁慈友好。

一直到早九点半, 我们的航行都很顺利。我们沿着铁路线前行, 铁路线弯弯曲 曲地穿过塔尔沙漠。尽管有点儿雾, 飞行正常。

海得拉巴 (信德) 位于宽广的印度河流域。在我们的下方, 它那一片片田地, 贫 穷的人, 还有浅浅的绿色都非常引人注目。我们用了半个小时的时间飞越这里。

从卡拉奇的东边开始就有沙漠了。此时, 沙漠在我们的面前向远方延伸开去, 里面点缀着一个本地村落形成的黑圈, 那是一个绿洲。

舒丹和西瓦纳黑暗中的山丘仿佛是奇特的突起物一样出现在地平线上, 正在 召唤着山峰。这些山完全浸在大量的沙子中间。 
Recebem-nos algumas centenas de goaneses - a colónia tem cinco mil - que, nas suas aclamações e homenagens, manifestam o orgulho de ver as cores portuguesas triunfantes no grande certame travado entre a aviação mundial.

Em nome do comandante do Centro, o tenente Robert Yates apresenta-nos os cumprimentos de boas-vindas e põe à nossa disposição todos os recursos do Parque, onde a aviação inglesa da Índia repara, monta e constrói os seus aviões.

Extenuados como estamos, a nossa maior aspiração é dormir.

Logo que vemos o Pátria ao abrigo do calor, num dos grandes hangares, e que a avalanche dos fotógrafos nos permite tomar lugar no automóvel do Centro, largamos para o Calton Hotel, onde, durante algumas horas, mergulhamos num profundo sono que nos restaura.

Depois são as primeiras recepções e os primeiros banquetes. E essa gente, para quem Portugal representa a Pátria e que vibra de comoção ao festejar-nos, mal sabe falar Português...

Gouveia, conforme os seus hábitos, lá segue para Drigh Road no dia seguinte, manhã cedo.

A reparação do radiador exige algumas horas de trabalho que nos impedem de partir no dia seis de Maio.

Mas nessa tarde, ao chegar ao aeródromo onde decidíramos passar a noite para poder descolar de madrugada, encontramos um Pátria novo, reparado, polido, pintado, brilhante.

As irregularidades misteriosas do funcionamento do motor, verificadas no decurso da última etapa (Gouveia nada encontrara de anormal), só podiam atribuir-se a deficiências da carburação, hipótese admissível naquela atmosfera candente.

Dormimos sob tendas de campanha e, na manhã seguinte, depois de abraçar Yates e apertar a mão ao comandante Hicks, cuja gentileza igualara, se não excedera, a dos oficiais dos diferentes aeródromos ingleses por onde passáramos, instalamo-nos a bordo pelas sete horas, e largamos, com destino a Agra.

O nosso voo é esplêndido até às nove e meia. Vamos seguindo as curvas da via férrea que ondulam através do deserto de Thur e, apesar da ligeira bruma, a viagem decorre normalmente.

Haiderabad (Sind), que junto à fita larga do Hindus, se destaca com seus terrenos de cultura, pobres, verde-claros, passa sob nós meia hora depois.

E o deserto, que começa para Nascente de Karachi, prolonga-se na nossa frente, salpicado de onde a onde pelo círculo negro de uma aldeia nativa, que é um oásis.

No horizonte surgem, como excrescências extravagantes, os morros sombrios de Chotan e Siwana, a evocar cumes de montanhas submersas num inconcebível dilúvio de areia.

As curvas da linha férrea contorcem-se um pouco mais e quando, ao longe, a mancha rubra de Jodhpur começa a definir-se, a atmosfera transforma-se de súbito num mar de fogo, 


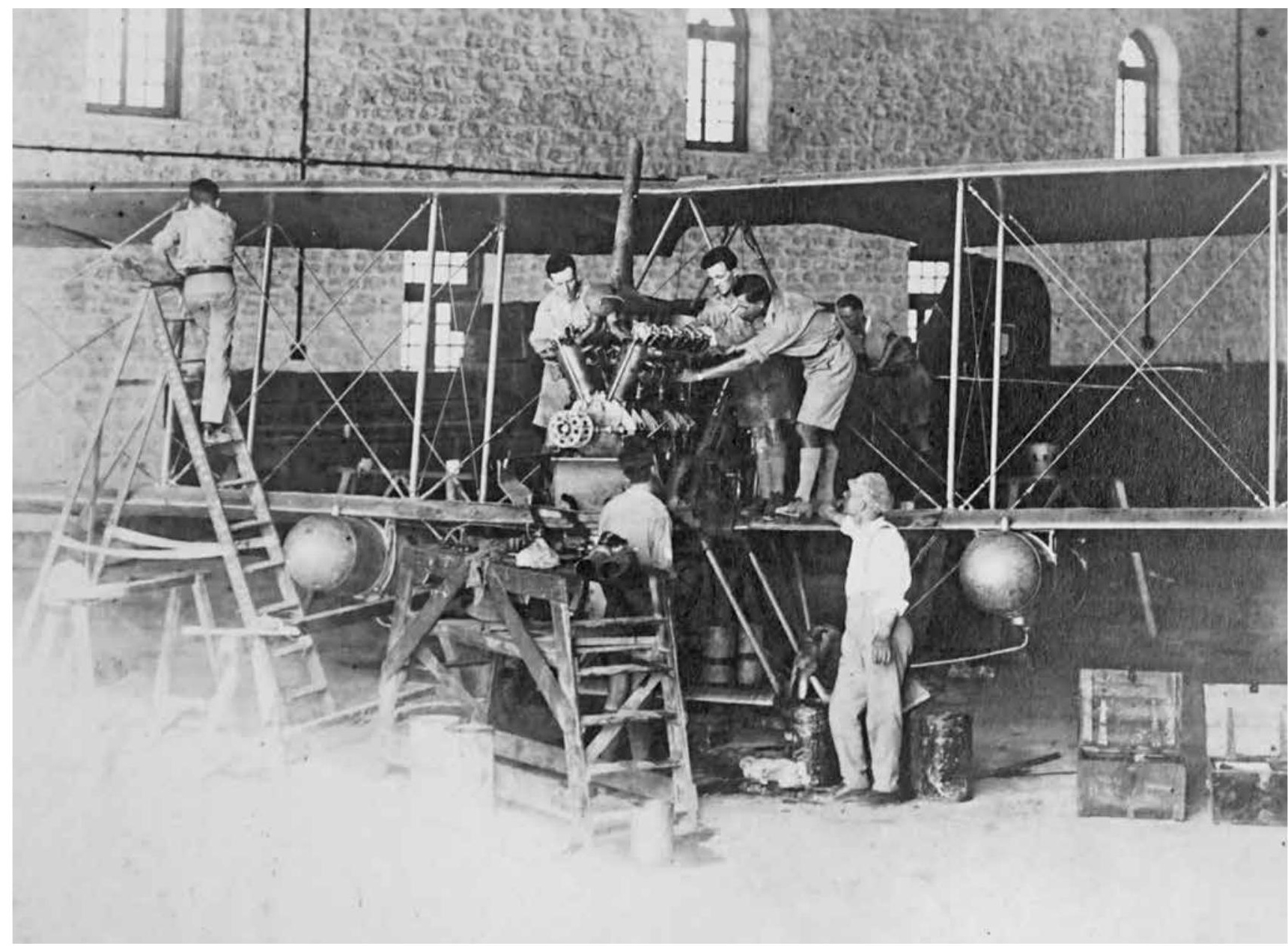

O Pátria a ser reparado em Karachi

在卡拉奇修理“祖国号” 
铁路的曲线扭动了一点, 当焦特布尔城那红色的印迹开始出现时, 大气层突然 变成了火热海洋: 混乱, 凶猛而暴烈, “祖国号” 发狂般地扭来扭去, 就像是一双谋杀 的手把它放在一扇愤怒的旋转门上拼命地挥舞。

我们从拉贾拉斯邦首府的南边飞过, 在巨大的金色湖面上, 荷花盛开。

它是一座陡峭的城市, 有着郁郁憼葱的花园, 巨大的古炮台装饰着陡峭的山 丘。焦特布尔城就这样坚立在血红的沙漠中, 风景中透出一种神秘鬼力, 让整个城 市有一种我所不知道的, 不真实的, 奇迹般的面貌。它将在记忆深处永存, 尽管此 刻野蛮的风鞭答着我们, 就像熔铅朝我们飞溅而来。

我们每时每刻都在喝水, 就像在撒哈拉的艰难时刻, 但是阳光咬噬着我们的脖 子, 我们从没感到阳光是如此可怕。

视野越来越不好。

我们试图向上爬升, 比便能够遇到清凉一些的气流层。

发动机全速运转, 已经达到了1500转。

你会说我们是在一个火山口上,被一个耀眼的火炬不可思议地照耀着。

我们拒绝屈服, “祖国号”无法保持相同的飞行高度, 它开始慢慢下降, 降到了 火热的大气层。

指示水温的温度计指出, 散热器中的水温已经高达 88 度到 90 度。

布里托 - 帕艾斯艰难地帮助我战胜狂风带来打击。他不完善的指挥不允许 他充分利用自己全部的力量。此外, 艰巨的领航任务让他必须随时全神贯注; 在帮 助我的同时, 他还能够面对地形和那张有缺陷的地图, 这真是非常令人钦佩的。

十点半, 高度计指出我们处于海拔一千米, 地面上方七百米。

戈维亚几乎无法呼吸。布里托 - 帕艾斯大汗淋漓, 而我需要集中全部的精力 继续战斗。有时, 我真想撒开双手, 就让 “祖国号” 随便去吧, 这无法形容的苦难也 就结束了。

我们行进在惊险刺激的疯狂气氛中。

飞机的操纵杆 87 滚菏, 紧绷的机篷好像要爆裂似的, 只有发动机一一这台发动 机是戈维亚的灵魂, 它继续发出单调的、隆隆的钢铁轰鸣声, 但现在这已经不能激 起我们的希望。因为飞机在加速下沉, 不停地朝着更低的气流层下降。这些塔尔 沙漠魔鬼般的气流层空气稀薄, 温度更高, 也更活跃。

87 原文为法语术语, 指操纵飞机的拉杆, 其运动可以控制飞机爬升、下降并使飞机保持平衡。(编者注) 
delirante, feroz, tempestuoso, onde o Pátria dança desenfreadamente, como se mãos assassinas o brandissem em molinetes furibundos.

Passamos a Sul da capital da Rajputana, flor de lótus aberta em lago imenso de oiro líquido.

Alcantilada, com jardins frondosos, grandes fortificações antigas rendilhando colinas abruptas, a cidade de Jodhpur emerge do deserto com a violência de um grito cor de sangue, arrancada à paisagem por misterioso encantamento, que lhe imprime não sei que aspecto de maravilha irreal. É um espectáculo que se grava para sempre na memória, não obstante o vento bárbaro que nos fustiga e parece dardejar sobre nós jactos de chumbo derretido.

Bebemos água a cada instante, como nas horas cruéis do Saará, mas a mordedura do sol que sentimos na nuca é mais terrível que nunca.

A visibilidade piora a cada momento.

Procuramos subir, apesar disso, na esperança de uma camada atmosférica mais fresca.

O motor, a pleno regime, trabalhando como um cronómetro, atinge mil e quinhentas rotações.

Dir-se-ia que entramos numa cratera de vulcão, incompreensivelmente iluminada por um archote deslumbrante.

E, recusando obedecer, o Pátria, sem conseguir manter-se à mesma altitude, começa a afundar-se lentamente na atmosfera rarefeita e ardente.

Os termómetros indicadores da temperatura da água, no radiador, acusam $88^{\circ}$ e $90^{\circ}$.

Brito Paes auxilia-me com dificuldade a vencer os golpes traiçoeiros da ventania. $\mathrm{O}$ seu comando defeituoso não lhe permite a utilização total do enorme esforço que despende. De resto, a orientação difícil exige-lhe uma atenção constante; e é realmente admirável como ele consegue, sem deixar de auxiliar-me, confrontar o terreno e a carta deficiente.

Às dez horas e meia, os altímetros marcam mil metros relativamente ao nível do mar, setecentos, relativamente ao solo.

Gouveia mal pode respirar. Brito Paes transpira copiosamente, e eu necessito de toda a energia dos meus nervos para continuar lutando. Por vezes, sinto desejos de cruzar os braços e abandonar o Pátria no espaço, para pôr termo ao suplício indescritível.

Andam no ar frémitos de loucura.

O manche ${ }^{87}$ escalda, a tela tensa parece querer estalar, e só o motor - esse motor que era a alma de Gouveia - continua ronronando impassível a monótona cantilena de aço, que agora já não nos incute esperança, porque o avião desce sempre, afundando-se mais rapidamente, ao passo que vai entrando nas camadas atmosféricas mais baixas, mais quentes, mais agitadas e mais rarefeitas dessa atmosfera satânica do deserto de Thur.

${ }^{87}$ Termo francês que designa a alavanca para pilotar aviões e cujos movimentos controlam a subida, a descida e o equilíbrio da aeronave. (Nota do editor). 
我们携带的水很快就用完了。

而我们可以降落的最近的一个机场一一纳吉拉巴德机场, 在一百公里以外。 我让“祖国号” 以最低的速度飞行, 为了让飞机下降的慢一些, 要出现神迹。

但飞机在继续下降, 令人痛苦而致命地下降……

我的感觉更糟糕了, 喘不上气来, 沙漠像是血海浪潮一样映在我那布满血丝的 视网膜上。我的头像是一簇燃烧的火焰。在巨大的努力下，我的神经试图让自己 不要放弃操纵飞机。

十点三十五分, 我们在地面上方三百米处。在一阵沙尘卷起的风暴中, “祖国 号”加速下降, 它悲伤地抗争着。

我的坚持已经到了极限。

我的手紧紧地握着操纵杆, 手上一根根粗大的青筋暴了出来, 像是马上要炸裂 开来一样。

我筋疲力尽, 尽可能地向布里托 - 帕艾斯解释了我们的状况, 而他的意见也与 我完全一致。因为无法保持飞行高度, 我们决定降落。

紧挨着当地一个的村庄, 有一块比较平坦但倾斜度很大的三角地带, 我觉得跟 个悬崖似的。我降低了发动机的转速, 准备降落。此时, 我那残余的一点精力只剩 下最后的一点力量了。

但是在这并不浓密的大气层中, “祖国号” 飞速下降, 地面不见了, 发动机重又 满负荷运转, 飞机再次开始飞行, 它所有的部件发出绝望的颤抖。

因此, 在这我们将铭记终生的时刻, 不得不绕着跑道打转。我们被火热的沙尘 包围了,被狂风抽打着; 出人意料的真空, 下行的气流, 猛烈的吸附, 气流漩涡……这 一切将我们吞没。我们不知如何才能摆脱这地狱般的境地。

布里托・帕艾斯做出了超人的努力来帮助我。

在这次几乎是令人胆战心惊的飞行中, 有一些东西让人发狂。这寂静的、悲 剧性的五分钟仿佛永远不会结束，惊恐每秒钟都浮现出来。希望挽救飞机的强烈 情绪弥漫在我们的当中。

巴丁仪 ${ }^{8}$ 指着时速 100 公里。飞机失速了, 像一片落叶一样摇晃着。

尽管散热器中的水都快沸腾了, 发动机依然沉着地运转着, 不停的唱着自己的 歌。

最后, 我终于到达了之前选择的那片土地。

在离地两米高处, 一阵突然的疾风袭来, 把我们向地面抛去。这时, 一个填砂 支柱 ${ }^{89}$ 爆了, 飞机出乎意料地被沙暴勒住。此时, 它已经少了一个轮子, 机头向下, 整个机身好像要翻转过来。当机尾抬起来时, 随着一声巨响, 机身的桁条断裂, 飞 机不动了。“祖国号” 身受重伤, 我们的抱负和希望都破碎了。在炎热的沙漠中, 巨 风卷起野性的狂怒。

\footnotetext{
88 飞机的速度表。(编者注)

${ }^{89}$ 具有一定弹性的缆线, 可以增加机翼篻布的张力。(编者注)
} 
A água que trazíamos não tarda a esgotar-se.

Nazirabad, o primeiro aeródromo em que poderemos aterrar, fica ainda a mais de cem quilómetros.

Fazendo prodígios para tornar mais lenta a descida, levo o Pátria no limite da velocidade mínima.

Mas o naufrágio continua, patético e fatal...

Sinto-me pior. Falta-me o ar e, na retina dos meus olhos injectados, o deserto parece um praia-mar de sangue. A minha cabeça é uma labareda. Os nervos tendem-se, no esforço supremo de não abandonar os comandos.

Às dez horas e trinta e cinco minutos, encontramo-nos a trezentos metros do solo. A descida acelera-se, num furacão de areia em que o Pátria se debate lastimosamente.

Atinjo o extremo limite da resistência.

Nas mãos que se enclavinham no manche, as veias desenham uma rede de grossos cordões azuis, como se estivessem prestes a romper-se.

Exausto, explico como posso a Brito Paes a situação de que ele tem uma noção bastante exacta e, dada a impossibilidade de manter a altura, resolvemos aterrar.

Junto a uma aldeia nativa, um rectângulo mais plano, bem delineado, parece-me propício. Reduzo o motor e preparo a aterragem, na tensão derradeira de toda a energia que me resta.

Mas naquela atmosfera sem densidade, a descida do Pátria é fulminante, o terreno furta-se e, o motor de novo a pleno gás, o avião retoma o voo, num estremecimento desesperado de todas as suas nervuras.

A volta de pista que, por esse motivo, somos obrigados a dar, é um desses lapsos de tempo que se vincam em nós para toda a vida. Envolvem-nos lufadas de poeira em brasa, açoita-nos o vento, sacodem-nos vácuos inesperados, correntes ascendentes, sucções bruscas, redemoinhos ciclónicos - um inferno de que a gente não compreende como conseguiu escapar.

Brito Paes realiza esforços sobre-humanos para me ajudar.

Há o quer que seja de demência nesse voo quase apavorante. São cinco minutos de tragédia muda, que nunca mais acabam, com interrogações pávidas a eriçar-se de segundo em segundo. E tudo em nós é ânsia de salvar o avião.

$\mathrm{O}$ badin ${ }^{88}$ marca cem quilómetros à hora. O aparelho oscila, como folha morta em perda de velocidade.

E o motor, fantástico e sereno, entoa sempre a sua canção metálica, apesar da água do radiador ter atingido quase a temperatura de ebulição.

Por fim, consigo aproar ao campo que escolhi.

A dois metros de altura, uma rajada brutal projecta-nos contra o solo, um sandow ${ }^{89}$

\footnotetext{
${ }^{88}$ Velocímetro dos aviões. (Nota do editor).

${ }^{89}$ Cabo provido de alguma elasticidade, o que permitia aumentar a tensão da tela das asas. (Nota do editor).
} 
我们从飞机中艰难地爬了出来。打击, 疲劳, 紧张的神经, 让我们无法动弹。

布里托 - 帕艾斯眼中含着泪, 瞳孔里满是绝望, 他的声音表达出了所有的酸 楚:

“如果你在另一块地上降落”, 他指着什么地方: “祖国号就不会断裂!”

我精疲力尽, 勉强地保持着站姿: “我, 是我把祖国号弄断的。” 我听到了非难, 就像一条胳膊被扭弯。

但是我不会责备这非难。我知道那是痛苦的尖叫; 那是梦想之舟倾覆在绝望 的海洋中。总之, 在那一刻, 我的灵魂被扭曲了, 抽成一团, 在痛苦地颤抖着; 悲伤 的弥漫在心间, 它让我的嘴唇发木。

戈维亚在我们旁边静静地流着泪, 看着飞机残骸。

我压抑着心中的不快……

我询问他们是否受伤了。

布里托 - 帕艾斯抱怨说左腿疼, 他的左腿有个很大的伤口在流血。戈维亚似 乎毫不在意地说身体疼。

热乎乎的血从我的头上流下。我觉得周围的一切都在旋转。

我的喉头发干, 牙齿发粘, 嘴唇干裂, 身体被疲劳撕碎; 我觉得自己要晕倒了。

但是布里托 - 帕艾斯的声音依然能够传到我的耳中, 他捶胸顿足, 哽咽着说:

“完了! 一切都完了!”

布里托 - 帕艾斯支撑着向前走, 他保持着体力。充沛的体力是他的一个重要 的性格特征。戈维亚跟在后面, 我们朝绿洲村庄走去, 村庄中的印度人跑了过来。

这些善良热情的人给我们拿来水一一沙漠水井中的水暖而咸一一村民们通 过肢体语言和一种我们听不懂的美妙语言, 试图向我们表达和善、款待之情。他 们用铜质容器装水。我们喝完后想把容器还给他们, 他们不接受, 也许是因为碰过 我们的嘴唇后, 这些容器已经被玟渎了。

我们渴望阴凉。在一片光秃秃的沙漠中, 三棵巨大的树木几乎就是个名胜 了。

我们朝树荫下走去, 那些印度村民马上把我们围住了。怀着友爱、关怀之情, 他们拿来了简陃的活动床铺以便我们休息, 还带来了水、牛奶、黄油、一个大面 饼似的印式面包, 而我们只是咬了两口, 因为悲伤盖过了饥渴, 也感受不到正在忍 受的四十六度高温。 
rebenta, e o aparelho, repentinamente sofreado pela prisão da areia, agora que uma roda lhe falta, baixa a fronte como se fosse capotar. Quando, porém, a cauda se levanta, as longarinas da fuselagem partem com fragor, e o avião fica imóvel, ferido de morte, farrapo de aspirações e esperança no areal escaldante que o furacão revolve com ira selvagem.

Saímos de bordo a custo. O choque, o cansaço, os nervos em feixe tolhem-nos os movimentos.

Brito Paes, que tem lágrimas nos olhos, o desespero a transparecer-lhe nas pupilas, exclama numa voz que diz toda a sua amargura:

- Se você tem aterrado naquele outro campo - e apontava algures -, o Pátria não se tinha partido!

Completamente exausto, mal podendo conservar-me de pé - eu, que parti o Pátria -, ouço a censura como se me torcessem um braço.

Mas não lha exprobo. Sei que era uma dor gritando. Sei que era o sonho a soçobrar num mar de desespero. Contudo, naquele instante, a minha alma contorce-se, crispa-se, vibra torturadamente, e emudece-me nos lábios encortiçados a expansão de tristeza que me aliviaria.

Gouveia, próximo de nós, chora em silêncio, olhando os destroços do aparelho inerte.

O meu desgosto, recalco-o dentro de mim.

Pergunto-lhes se se magoaram.

Brito Paes queixa-se de dores na perna esquerda, onde uma grande ferida sangra. Gouveia fala, como se não fosse nada, do corpo dorido.

O sangue lateja-me na cabeça que escalda. Tudo parece girar em torno de mim.

Sinto a garganta seca, os dentes gomosos, os lábios fendidos, o corpo triturado pela fadiga. Tenho a impressão de ir cair sem sentidos.

Mas até aos meus ouvidos chega ainda a voz de Brito Paes, que diz compungidamente, numa irreprimível convulsão de soluços:

- E não tem conserto! Está todo partido!

Amparado a Brito Paes que, no meio do drama, conserva aquela energia física que é um traço característico da sua personalidade, e seguidos por Gouveia, dirigimo-nos para a aldeia-oásis, donde vem acorrendo uma centena de indianos.

É uma gente hospitaleira e boa que nos oferece água - a água salobra e morna dos poços do deserto - e que, através da sua mímica e numa linguagem harmoniosa que não compreendemos, pretende manifestar-nos sentimentos benignos e acolhedores. Trazem-na em recipientes de cobre, que não aceitam, quando pretendemos restituí-los, talvez porque fiquem profanados depois de tocados pelos nossos lábios.

Estamos ávidos de sombra. Em meio à calvície de em torno, três árvores enormes são quase monumentos.

Encaminhamo-nos para elas, e logo os indianos nos cercam, com demonstrações de carinho e de solicitude, leitos rudimentares trazidos numa lufa-lufa para descansarmos, 
有人出神地看着我们, 另一些人想要触摸我们。但所有望向我们的目光都表 达出无法形容的和蔼善良之情。

我们渐渐平静下来。布里托 - 帕艾斯缠了个简单的绷带。我觉得好点了, 就 去寻找能说英语的人。我们不能留在此地, 让折磨自己的悲伤困住。这时, 从人群 中一一这个村庄一共有五十个居民, 走出了一个瘦弱的男孩, 深色的眼睛中透着聪 明, 他立刻准备好帮助我们。

这个男孩叫纳努・拉姆, 他说这个我们无意中到来的村庄叫布达纳。

他向我询问有关事故的情况, 然后把我的回答翻译给印度村民们, 他们全神贯 注地听着。

我们问谁是这个村的村长。

纳努 - 拉姆把一位颤巍巍的老者指给我们看, 这位老者头上缠着浅色的包头 巾, 留着白色的大胡子, 他毫不迟疑地让村民们去守护 “祖国号” 的残骸。

在和塔库尔大人一一他们这样称呼村长, 交谈之后, 纳努 - 拉姆向我们传达了 下面这句简单而迷人的话，这句话充分体现了拉杰普塔纳地区这个高贵的民族热 情好客的特性。

“布达纳村的村民们请求我告诉你们, 我们非常高兴能够接待你们; 但同时, 对 于你们的飞机摔坏之事我们深感悲伤!”

他的话语淳朴, 几乎是幼稚的语气加强了他的诚意, 我将永远不会忘怀。我 把这句话告诉了布里托 - 帕艾斯, 他请我向村民们表达我们的衷心感谢之情。 纳努 - 拉姆用他们的语言向村民们重复了我的话, 所有人都含着温柔的微笑倾听 着。

布里托 - 帕艾斯和戈维亚一起去 “祖国号” 里拿我们的行李。我不想看到它, 光是想到把它摔断了就已经让我心痛难忍。

两个小时后, 也就是下午一点钟, 一辆由两头小瘤牛拉着的本地牛车在阳光下 摇晃着把我们送到了十公里外的帕帕尔罗德。

我们仿佛是一个无法描述的可笑的沙漠车队: 三个浑身灰尘的人坐在牛车 里, 纳努 - 拉姆给他们举着把遮阳伞, 他的叔叔在赶着牛前进, 牛肩上的肉瘤晃动 着……这幅画面减轻了我们的悲痛。

几十个几乎裸身的男人走在我们的周围, 闪闪发光的红铜色皮肤祄着白色的 包头巾, 他们交谈着, 笑着, 时不时地递给我们一些甜果子, 这些果子长在道路两旁 一些罕见的灌木丛中。 
e água, leite, manteiga, queijo, o pão indígena, espécie de hóstia enorme que mordiscamos apenas, porque a nossa tristeza estancou a fome e estancaria a sede, sem os quarenta e seis graus que suportamos.

Há figuras que nos olham em silencioso êxtase, outras que desejariam tocar-nos. Mas todos aqueles olhos descansam sobre nós com indefinível expressão de simpatia e bondade.

Pouco a pouco acalmamos. Brito Paes procede a um curativo rudimentar. E, como me sinto melhor, procuro alguém que fale inglês. Não podemos ficar ali, amarrados ao pesar que nos confrange. É então que surge de entre o grupo - cinquenta almas que constituem toda a população da aldeia - um rapazito franzino, de olhos escuros e inteligentes, que se coloca imediatamente à nossa disposição.

Chama-se Nanu Ram e encontra-se acidentalmente na povoação, que nos diz chamar-se Budhana.

Faz-me perguntas sobre o desastre, traduzindo as respostas aos indígenas que o ouvem atentamente.

Perguntamos pelo chefe da aldeia.

Nanu Ram indica-nos um velhote trémulo, de turbante claro e grandes barbas brancas, que se prontifica sem demora a manter sob a guarda dos seus homens os destroços do Pátria.

E Nanu Ram transmite-nos então, depois de trocar algumas palavras com Thakur Sahib - que assim designam o chefe - esta frase encantadora e singela, que reproduzo fielmente, e tão bem exprime o carácter hospitaleiro e a sentimentalidade afectiva dessa raça nobre dos rajputans:

- O povo da aldeia de Budhana pede-me para lhes dizer que está muito contente por poder dar-lhes hospitalidade, mas que está muito triste por se ter partido o vosso avião!

Conservo-lhe o sabor ingénuo, a contextura quase infantil que intensifica o cunho de sinceridade com que foi pronunciada e que nunca mais poderei esquecer. Traduzo-a para Brito Paes, que me pede para lhes expressar a nossa gratidão comovida. Nanu Ram, na sua língua, repete as minhas palavras, que todos ouvem com um sorriso suave.

Brito Paes e Gouveia vão buscar ao Pátria - que não desejo ver, de tal forma me dói a ideia de o ter partido - as bagagens que lá deixámos.

Duas horas depois, pela uma da tarde, um carrito indígena, que dois pequeninos zebús vão arrastando sob o sol que zimbra, conduz-nos à estação de Pipar Road, a dez quilómetros de distância.

No cómico indescritível da caravana que avança pelo caminho árido - os três empoleirados na carriola, ao abrigo de um guarda-sol que Nanu Ram segura; o tio deste adiante, conduzindo os bois cuja corcunda oscila -, atenua-se um pouco a nossa tristeza.

Em volta caminham algumas dezenas de homens quase nus, turbantes brancos contrastando com a cor vermelho-cobre da pele reluzente, falando, rindo, e trazendo-nos de quando em quando uns frutos adocicados que brotam nos arbustos do caminho. 
到达车站时, 我们都筋疲力尽了, 贪婪地享受着车站的宁静与清凉。此时此 地, 他们依然怀着同样的友爱、好客和关怀之情。

纳努 - 拉姆是一个淳朴人, 他心怀博爱。在一种承诺与喜悦境界中, 聪慧唤醒 了他的生命。

在两个小时的路途中, 我们进行了交谈。他用不太正确的英语和亲近感让我 毫无困难地理解了他。

他有一种狂热的求知欲, 这让他发出了许多好奇的, 同时也是幼稚却富有逻辑 性的提问。他显示出的知识面令人惊异, 而他许多方面的敏感也让人感动。

我向他谈到圣雄甘地。

在他线条单纯、几乎是贵族的古铜色脸上, 闪过一道尊重和敬仰的表情。

这声音直到今天依然回响在我的耳畔。他用柔和的声音跟我说:

“圣雄甘地是伟人! 他是一位导师! 印度一定要独立!”

沉默了几秒钟后, 他用一种忧伤而含蓄的声音说道:

“我多么希望能认识他!”

纳努 - 拉姆18岁了, 此时, 他正放假呆在自己的村庄里, 这个村庄是沙漠中遗 失的那个绿洲。到了冬天, 他在焦特布尔的帕塔布爵士高中念书。

他已经掌握了一些梵文, 立志要学习印度古典文学。

我向他谈起了葡萄牙, 告诉他葡萄牙位于欧洲的角落, 俯瞰着大西洋, 是一个 梦想和冒险之乡。他的双眼盯着空中, 仿佛在看着地图, 回忆学过的地理知识, 然 后缓缓说道:

“法国……然后是西班牙……最后是葡萄牙, 一个非常小的国家!”

可能对他来说, 很难相信葡萄牙这么一个小国可以派出三个人驾着飞机去征 服东方, 他刚刚见证了那架令我们痛苦的飞机芏落……不过, 他对于达 - 伽马的名 字并不陌生; 他知道, 在印度, 到处都能碰到葡萄牙名字。

我问他是够愿意去欧洲。

“愿意!”短暂地思考后他回答说: “去看看, 然后回来!”

接着他跟我谈到了自己的村庄、亲戚和部落, 他对于部落的穷困感到非常遗 憾, 这并不是因为金钱可以带来幸福, 而是如果他们比较富裕, 就能更好地接待我 们。

在帕帕尔车站, 我们想要付钱以回报他们向我们提供的交通, 然而, 他们的目 光是如此悲伤, 由于我们不理解他们所做的一切只是出于好意, 只是出于他们神圣 的好客律条......90

五点半有开往焦特布尔的火车。

90 所有这个地区现在都是巴基斯坦的一部分。(第三版注) 
E na estação onde chegamos exaustos, sôfregos de frescura e de tranquilidade, é ainda o mesmo carinho, a mesma hospitalidade, a mesma solicitude.

Nanu Ram. Alma ingénua a desabrochar em florescências de altruísmo. Inteligência a despertar para a vida, num horizonte de promessas e triunfos.

Durante as duas horas do trajecto, conversamos. O seu inglês incorrecto e simplista permite-me compreendê-lo sem dificuldade.

Há nele um febril desejo de saber que o leva a interrogações curiosas, ao mesmo tempo infantis e lógicas. Manifesta conhecimentos que surpreendem e facetas de sensibilidade que impressionam.

Falo-lhe de Mahatma Ghandi.

Na sua face brônzea de linhas puras, quase aristocráticas, passa um relâmpago instantâneo de respeito e de veneração.

E diz-me nessa voz suave que ainda hoje ressoa aos meus ouvidos:

- Mahatma Ghandi é grande! É um mestre! Há-de fazer a independência da Índia!

E, após dois segundos de silêncio, numa voz velada de tristeza:

- Quem me dera conhecê-lo!

Nanu Ram tem dezoito anos. Encontra-se em férias, na sua aldeia, que é aquele oásis perdido no deserto, pois, de inverno, frequenta, em Jodhpur, a Sir Patab High School.

Tem já umas pequenas noções de sânscrito, e todo o seu entusiasmo tende para o estudo da antiga literatura hindu.

Falo-lhe de Portugal, do cantinho da Europa, onde, debruçada sobre o Atlântico, a nossa terra é uma ânsia de sonho e de aventura. Os seus olhos fixam-se no espaço e, como se estivesse olhando a carta, na recordação da geografia que lhe ensinaram, diz lentamente:

- A França... depois a Espanha... e no fim, muito pequenino, Portugal!

Dir-se-ia que lhe custa a crer que desse Portugal pequenino pudessem ter partido três homens, à conquista do Oriente, naquele avião cuja agonia breve presenciara... No entanto, não ignora o nome de Vasco da Gama e sabe que, na Índia, por toda a parte, se encontram nomes portugueses.

Pergunto-lhe se gostaria de vir à Europa.

- Sim! - responde após curta reflexão. - Ir, ver e voltar!

Depois fala-me da sua aldeia, dos seus parentes, da tribo cuja pobreza lamenta, não porque o dinheiro traga felicidade, mas porque lhes teria permitido receber-nos com mais conforto.

E quando, na estação de Pipar, pretendemos retribuir o trabalho que tiveram com o nosso transporte, os seus olhos dizem tristeza, por não compreendermos que aquela gente faz tudo por bem e subordina todos os seus actos à lei sagrada da hospitalidade. ${ }^{90}$

$\mathrm{O}$ comboio para Jodhpur passa às cinco e meia.

\footnotetext{
${ }^{90}$ Toda esta região está actualmente integrada no Paquistão. (Nota da 3. ${ }^{a}$ edição).
} 
我们告别了纳努 - 拉姆, 走进烤箱般的车厢。两个小时后, 我们到了血红色的 城市焦特布尔, 焦特布尔一比卡内尔铁路主管沃伦先生在这里等着我们。

我们从帕帕尔罗德拍往卡拉奇的电报要从焦特布尔中转, 沃伦先生立刻来找 我们, 向我们提供协助。在此地, 还有一位当地国王的使者。

我们被告知, 这个城市没有酒店。为了执行这好客的法则, 当地国王有一所宏 伟的宫殿用来招待路过此地 的陌生人, 这座宫殿就仿佛是一个高级宾馆。

国王的汽车在等着我们, 要把我们送到那座宫殿去。

在寂静的夜晚深处, 瞪羚跑着穿过公路, 它们都被闪伢的灯光吓坏了......朝着 我所不知道的, 不真实的, 美好的地方拔腿狂奔而去。

一刻钟后, 汽车停了下来。

一扇门在我们面前打开, 我们进入了国王招待客人的奢华小屋 ${ }^{91}$ 。

在晚餐前, 我们向里斯本发了一封痛苦的电报, 报告飞机事故。此电报反映了 我们不得不放弃此次航行的痛苦, 由于风的背信弃义, “祖国号”螺旋桨上的星光永 远熄灭了。

餐后，来到了为我们准备的休息地。在这里，我们被一种不熟悉的舒适包围 了。舒适的环境与沉痛心情引起的失眠形成了鲜明对比，我们的脑海中各种乱七 八糟的想法在不停地旋转, 重温着这个应该已经结束的巨大冒险。

91 通常用于旅游而且不太大的单层房子。但是在印度, 这个词有社会阶层的含义, 它指的是与公寓楼相对 的、只属于一个家庭的房子, 是一种典型的中产阶级住宅。在这个国家, 这种房子带有身份地位的象征。 (编者注) 
Despedimo-nos de Nanu Ram com saudade, entramos na carruagem que mais parece um forno e, depois de duas horas de viagem, chegamos à cidade cor-de-sangue, onde somos esperados por Mr. Warren, director do Jodhpur Bikaner Railway.

O telegrama que de Pipar Road enviáramos para Karachi fora interceptado ao passar em Jodhpur, e Mr. Warren apressava-se a vir oferecer-nos o seu auxílio. Encontrava-se ali, também, um enviado do marajá.

Somos informados de que não há hotel na cidade. No cumprimento dessa lei acolhedora da boa hospitalidade, o marajá possui um palácio magnificente, a Guest House, onde alberga os forasteiros que passam.

O seu automóvel espera-nos, para ali nos conduzir.

Na imobilidade profunda da noite calada, o torpedo larga através da estrada que as gazelas atravessam correndo, assustadas pela luz faiscante dos faróis... Aquela abalada tem não sei o quê de inverosímil e maravilhoso.

Ao fim de um quarto de hora, o automóvel pára.

Uma porta abre-se diante de nós, e entramos no luxuoso bungalow ${ }^{91}$ dos hóspedes do marajá. Ainda antes de jantar, enviamos para Lisboa o doloroso telegrama que anuncia o desastre. Nele se reflecte o nosso desgosto por ter de abandonar a viagem, visto que a perfídia do vento extinguira para sempre a estrela de ar da hélice do Pátria.

E quando, após a refeição, recolhemos aos aposentos que nos prepararam, e onde nos sentimos rodeados de um conforto que desconhecíamos, o contraste entre o ambiente e o nosso estado de espírito suscita insónias em que o pensamento rola tumultuosamente, a reviver o drama que supúnhamos ter posto ponto final na nossa grande aventura.

\footnotetext{
${ }^{91}$ Casa não muito grande e de um único piso, destinada normalmente ao turismo. Na Índia, no entanto, o termo adquire uma conotação social, ao referir-se a qualquer residência pertencente a uma só família, por oposição ao edifício de apartamentos, que é a residência típica da classe média. Neste país, bungalow traz consigo um símbolo de status. (Nota do editor).
} 


$$
\begin{array}{r}
\text { IX } \\
\text { O PÁTRIA II } \\
\text { 九、“祖国二号” }
\end{array}
$$


第二天, 阳光把我们唤醒。时不时的, 有一只燕子从打开的窗户飞进来, 在房 间里跳来跳去, 转了一圈又飞出去了。

我起身走到阳台向外望去, 周围都是成片的大树。在忍受了旅程带来的极度 紧张和强烈震撼之后几个小时, 此时四周一派甜美的宁静, 简直能让人变得永恒。 帕帕尔罗德的灾难令人如此伤心, 使得我们的航程被突然中断。

这时, 天空已经发出强烈而炎热的光芒, 所有的景色都被笼罩在阳光那火热的 光晕中。

我参观了一下这个 “酒店”。这是一座豪华的独立小屋 ${ }^{92}$, 地方特色与室内的 舒适相得益彰, 家具都是欧式的。整座房子里有一个皇家大厅, 体现出精致的品味 和对于美的敏感。

为了对抗室外的炎热, 房子的天花板上吊着长方形的巨型扇叶, 上面连着一根 绳子, 一个十二岁或者十三岁的小男孩有节奏地拉着绳子; 在窗户上, 还有一些木 质框架, 它们由两个平行的长方形组成, 中间由横杆连接形成了网格, 里面许多枝 条交错缠绕。在这个设备上, 有一条锌制的檐沟, 上面布满小孔, 它每十五分钟会 接收一壸水, 当水被篮过时, 湿润了枝条, 通过此处的空气被冷却了。

厨房完全是法式厨房。这让人觉得很遗憾, 因为我希望能品尝异国风味的菜 有。

管家 ${ }^{93}$ 直挺挺地站在那儿, 穿得像任何一个别致餐厅的领班, 夸张地问候着我 们, 他并不䒼视布里托 - 帕伊斯的赏金, 这一切让我们想起了布达纳……

我们十点钟出门了, 一辆汽车在等候我们的命令。

在广亭的、荒无人烟的印度沙漠中, 焦特布尔是一座生活沸腾的城市。它也 是一座奇怪的城市, 城中的建筑风格各异, 使用的都是红色砂岩。红色的砂岩让色 彩的旋律在城市中跳跃, 这种红色的振动仿佛能够刺伤了人们的双眼。

现在, 古老的要塞像是妖怪下领那口乱七八糟的牙齿嵌在那里。

我们坐着汽车, 飞快地从这个城市宽阔的道路上开过。此时, 我们曾经在空中 获得的对于这个城市的印象得到了验证。

政府宫有多个宽广的大厅, 我们来到了其中之一。在此, 我们向首相致以问 候, 并向他说明了我们的境况, 表达了我们的需求。他告诉我们, 国王正在奎达度 过这炎热的季节, 所以无法荣幸地接待我们。

\footnotetext{
92 通常用于旅游而且不太大的单层房子。但是在印度, 这个词有社会阶层的含义, 它指的是与公寓楼相对 的、只属于一个家庭的房子, 是一种典型的中产阶级住宅。在这个国家, 这种房子带有身份地位的象征。 (编者注)

93 原文为法语, 意为管家。这个术语已经被作者在句子开头使用。此处使用是为了强调这个地方的法国传 统。(编者注)
} 
Na manhã seguinte é o sol que nos acorda. De quando em quando, pelas janelas abertas, uma andorinha, um pardalzito entra, saltita, dá uma volta e sai.

Levanto-me e chego à varanda. Em volta, grandes massas de arvoredo e uma calma onde seria doce a gente eternizar-se, depois das horas de forte vibração e de tensão nervosa da viagem, tão triste e bruscamente interrompida pelo drama de Pipar Road.

O céu irradia já uma luz intensa e quente, que envolve a paisagem num halo de chama.

Visito o Guest House. É um bungalow ${ }^{92}$ principesco, onde o carácter regional se afoga no conforto das acomodações interiores, mobiladas à europeia. Há um Salão Império, em que transparecem gosto requintado e sensibilidade estética.

Para proteger o ambiente contra o calor externo, havia as pankas, espécie de enormes ventarolas rectangulares suspensas do tecto, accionadas por uma corda que um garotito de doze ou treze anos puxa cadenciadamente; e havia também nas janelas uns caixilhos de madeira, compostos por dois rectângulos paralelos e unidos por travessas, formando grade, dentro dos quais se entrelaçavam ramos. Sobre este dispositivo, uma goteira de zinco, crivada por uma série de orifícios, recebe de quarto em quarto de hora um jarro de água que, ao escorrer pelo crivo, humedece os ramos através dos quais o ar passa e arrefece.

A cozinha é por demais francesa, o que lamento, porque esperara poder saborear pratos exóticos.

O mordomo, aprumado e vestido como qualquer maître d' hote ${ }^{93}$ de restaurante chique, é todo salamaleques, e não desdenha a gratificação de Brito Paes, o que nos faz pensar em Budhana...

Às dez horas saímos, no automóvel que espera as nossas ordens.

Jodhpur é um borbulhar de vida, na imensidão erma do grande deserto índico. Cidade estranha, cujos edifícios estilizados, de arquitectura característica, são construídos em grés sanguíneo - de toda ela se exala, como nota insistente numa melodia de cor, essa vibração rubra que fere o olhar.

As velhas fortificações parecem agora uma dentadura irregular de mandíbulas monstruosas.

A impressão que nos deixara a cidade, ao avistá-la em voo, confirma-se nessa rápida corrida do automóvel, através das ruas largas.

Num dos grandes salões do Palácio do Governo, cumprimentamos o Primeiro Ministro, que se informa com interesse da nossa situação e das nossas necessidades e nos comunica que o marajá se encontra passando em Quetta a estação calmosa e que, por isso, não poderá ter o prazer de nos receber. Diz-nos ainda que, embora grande parte das forças do Estado da

\footnotetext{
${ }^{92}$ Casa não muito grande e de um único piso, destinada normalmente ao turismo. Na Índia, no entanto, o termo adquire uma conotação social, ao referir-se a qualquer residência pertencente a uma só família, por oposição ao edifício de apartamentos, que é a residência típica da classe média. Neste país, bungalow traz consigo um símbolo de status. (Nota do editor).

${ }^{93}$ Maître d'hotel significa mordomo, termo que já foi usado pelo narrador logo no início da frase. Trata-se aqui de enfatizar a tradição francesa do local (Nota do editor).
} 
他还说, 尽管拉杰普塔纳邦的军队大部分在帕鲁一一就是迈克拉伦 ${ }^{94}$ 因故障 ${ }^{95}$ 降落的那个地方, 所有清运飞机所需的人员都马上可供我们调配。

然后我们去了沃伦先生家。在那里, 大家商定, 戈维亚和铁路公司的职员塔尔 顿工程师一起, 第二天前往布达纳拆分 “祖国号” 飞机, 并将它运往卡拉奇。沃伦先 生告诉我们, 无需支付任何费用。

正午时分, 我们又回到了 “酒店”, 在那里, 我们吃到了很像样的午餐, 像是巴黎 最好的酒店提供的似的。

飞机的悲剧让我们精神抑郁, 谈话也受到了影响。

布里托 - 帕艾斯的目光中透露出无法言说的抗拒。戈维亚的目光中满是悲 伤和痛心。

大家不可避免地谈到了飞机事故, 谈到了葡萄牙和回家。

布里托 - 帕艾斯抱怨着自己的腿伤; 戈维亚说他在自己身上发现了无数黑色 的瘀伤。

午餐在沉默中结束, 我们无法战胜痛苦的压迫。

半小时后, 当戈维亚已经开始午睡时, 一个仆人给我们送来了一份电报。

布里托・帕艾斯急切地打开了电报, 喊道:

“是从葡萄牙来的!”

我们俩人一起读了起来。席福卡 - 杜阿尔特向我们宣布, 如果我们愿意继续 下去的话, 葡萄牙政府可以向我们提供一架新飞机。

我叫醒了戈维亚, 当他得知电报内容, 立刻就不困了。我们将召开一个庄严的 会议, 讨论怎样回复。

布里托・帕艾斯询问我的意见。

“季风已经到孟买了。”我回答说: “一个月之内, 将到达加尔各答。如果我们等 着从葡萄牙运来一架飞机, 那么我们这次飞行就失去迅速的特点了。除此之外, 我 还要问: 有可能两个月之后前进吗?气候条件允许吗?……我相信, 这太难了, 我们 应该放弃!”

“戈维亚, 你说呢?”布里托・帕艾斯询问道。

“我的司令官先生: 感谢您重视我的想法, 还有您给予我的友情, 也感谢您询问 我。一切问题都将被很好地解决......”

“我叫您来, 是为了听到您的意见!”布里托・帕艾斯坚持道。

“司令官先生: 我做好了一切准备。我的司令官先生和机长先生, 你们比我更 清楚两个月内的气候条件是否允许航程继续! 我们不能预先就指望着能前进, 因为 飞机还没准备好呢!

94 英国飞行员。他在1924年这年企图环游世界。(编者注)

95 原文为法语, 意为故障。(编者注) 
Rajputana se encontre em Parlu, onde MacLaren ${ }^{94}$ aterrou em panne ${ }^{95}$, todo o pessoal de que carecêssemos para a remoção do avião ficava desde logo ao nosso dispor.

Com Mr. Warren, a casa de quem vamos depois, combina-se que Gouveia partirá no dia seguinte para Budhana com o engenheiro Tarleton, funcionário da Companhia de Caminhos de Ferro, a fim de desmontar o Pátria e de o embarcar no comboio para Karachi. Mr. Warren informa-nos de que nenhuma despesa teremos a fazer.

E ao meio-dia regressamos ao Guest House, onde nos servem um almoço digno dos melhores hotéis de Paris.

A conversação ressente-se da depressão moral em que nos deixou a tragédia.

Há revoltas mudas no olhar de Brito Paes. Há tristeza e desgosto no olhar de Gouveia.

Irresistivelmente, fala-se do acidente, fala-se de Portugal, fala-se do regresso.

Brito Paes queixa-se da sua perna ferida, e Gouveia conta que descobriu numerosas nódoas negras tatuando-lhe a pele.

O lunch termina em silêncio, na opressão torturante que não conseguimos vencer.

Meia hora mais tarde - já Gouveia dormia a sua sesta -, um criado traz-nos um telegrama.

Brito Paes abre-o sofregamente, exclamando:

- É de Portugal!

Lemos ambos. Cifka Duarte anuncia-nos que o Governo põe à nossa disposição novo aparelho, para o caso de querermos continuar.

Acordo Gouveia, que perde o sono ao saber do que se trata, e é uma reunião de conselho, magna e solene, em que vai discutir-se a resposta.

Brito Paes pede a minha opinião.

- A monção - respondi - já chegou a Bombaim. Dentro de um mês estará em Calcutá. Esperar que mandem um avião de Portugal é tirar à viagem todo o seu carácter de velocidade. Além disso, pergunto: será possível prosseguir de aqui a dois meses? .... Permiti-lo-ão as condições atmosféricas? ... Julgo que será difícil e que devemos, portanto, desistir!

- E você, Gouveia? - inquire Brito Paes.

- Meu Comandante: agradeço-lhe a prova de consideração e amizade que me dá, consultando-me. O que resolverem estará bem resolvido...

- Se o chamei, foi para ouvir a sua opinião! - insiste Brito Paes.

- Meu Comandante: eu estou por tudo. O meu Comandante e o nosso capitão sabem melhor do que eu se as condições atmosféricas dentro de dois meses permitirão que a viagem continue! Não podemos contar com a possibilidade de prosseguir antes, porque o avião não está preparado ainda e não poderá estar na Índia antes de um mês... De modo que não sei!... Peço apenas para lembrar que, depois do desastre de ontem, uma nova interrupção da viagem

\footnotetext{
${ }^{94}$ Piloto inglês que, nesse ano de 1924, tentava dar a volta ao mundo. (Nota do editor).
}

${ }^{95}$ Avaria. (Nota do editor). 
我只想请求大家记住: 在昨天的灾难之后, 如果新的航程再次中断, 那会更加 令人遗憾, 特别是如果由于现在就可预见的某些因素的话……

“但你们没看到席福卡给我们拍来的电报吗?在葡萄牙, 所有人都希望我们继 续前进!”

争论开始了。我们编写了好几份电报稿, 讨论考虑了各种前进的可能性, 还有 困难, 还计算着季风的日期, 出发……

布里托・帕艾斯的坚韧执着支配了答案。

发出电报之后, 忽然, 一个念头在我脑中闪过:

“如果印度政府能卖给我们一架飞机呢! ?”

我向布里托 - 帕艾斯和戈维亚解释了自己的想法，他们都认为我的建议棒极 了。

下午三点, 我们决定当晚就前往卡拉奇去办这件事。戈维亚留在焦特布尔, 以 便拆分“祖国号”飞机。

我们度过了二十三个小时枯燥的旅程。火车在荒凉而单调的沙漠中行进, 偶 尔一群瞪羚会出现在植被旁, 证明了这大漠中也存在生命。

火车在月台旁等着我们结束用餐。

5月9日下午六点我们终于再次到达了卡拉奇, 这是一个平坦却没有阴凉的城 市, 沙漠的热风不停地掠过它。

此后, 关于购买新飞机的谈判开始了。

像所有地方一样, 官僚主义非常压制积极性。

我们找到了机场的司令官希克斯先生, 他立刻为我们的缘故辩护, 如同他就是 当事人似的。

我们与罗伯特 - 耶茨先生交流得更为顺畅, 因为他会说葡萄牙语。他有着真 正勤奋的头脑, 在接下去的十五天中, 我们对他极为欣赏, 他是一位忠实、高贵和 诚挚的同伴。

戈维亚在完成任务之后, 也于 11 日到达了卡拉奇。

旅行让他疲惫不堪, 吃晚饭时, 他向我们介绍了“祖国号” 的拆分和运输。

“前天凌晨, 我和塔尔顿工程师去帕帕尔罗德, 一头骆驼驮着我到了布达纳村, 还是叫布塔纳什么的……我开始工作, 可是天气太热了! 所以, 我不得不随时把工 具浸在水里, 否则这些工具菏得没法拿。印度人时刻都在帮助我, 在他们当中, 那 位曾经陪伴我们的小男孩向你们二位致以良好的问候。”

“我与那位英国工程师的交流极为困难, 为了把飞机运到铁路线旁, 他竭尽全 力。” 
pode ser muito para lamentar, sobretudo se resultar de qualquer factor que devesse ter sido previsto neste momento...

- Mas vocês não vêem que, se o Cifka nos manda este telegrama, é porque em Portugal todos querem que vamos para diante?!

A discussão estabeleceu-se. Redigiram-se vários telegramas, argumentou-se, ponderaram-se as possibilidades de prosseguir, as dificuldades, calcularam-se datas de monção, de partida...

E a tenacidade persistente de Brito Paes ditou a resposta.

Foi depois de enviarmos o telegrama, que, subitamente, me ocorreu:

- Se fosse possível conseguir que o Governo da Índia nos vendesse um avião?

Expus a ideia a Brito Paes e Gouveia, que acharam óptima a sugestão.

E resolvemos - eram três horas da tarde - partir nessa mesma noite para Karachi a tratar do assunto, deixando Gouveia em Jodhpur, para proceder à desmontagem do Pátria.

Vinte e três horas de viagem sem encanto, rolando no deserto monótono e estéril, onde de quando em quando surgia uma nota de vida e movimento, um grupo de gazelas junto a uma ilha de vegetação.

O comboio esperava, nas gares, que terminássemos as nossas refeições.

Pelas seis horas da tarde do dia nove de Maio, chegámos de novo a Karachi - a cidade plana, a cidade sem sombra -, que o vento quente do deserto não deixa de fustigar.

Depois iniciam-se as negociações para a compra do avião.

Como em toda a parte, a burocracia é o grande freio das iniciativas.

O comandante do Parque, Mr. Hicks, que procuramos, presta-se imediatamente a advogar a nossa causa, como se fosse ele próprio o interessado.

E Robert Yates, com quem melhor nos entendemos porque fala Português, é a mola real das diligências, começando desde logo a afirmar-se o companheiro leal, nobre e dedicado que em quinze dias tivemos ocasião de apreciar.

Gouveia chega no dia onze, depois de terminada a sua tarefa.

Vem arrasado da viagem e, ao jantar, descreve-nos a desmontagem e embarque do Pátria.

- Na madrugada de anteontem, seguimos, o engenheiro Tarleton e eu, para Pipar Road, onde me encarrapitaram em cima de um camelo que me levou até à aldeia de Budhana, Badana ou lá o que é ... Comecei a trabalhar, mas estava tanto calor, que a todo o instante era preciso meter a ferramenta dentro de água para lhe poder pegar. Os hindus estiveram sempre a ajudar-me e, entre eles, aquele pequeno que nos acompanhou à estação e que manda muitas saudades para ambos.

«O engenheiro inglês, com quem me entendia com imensa dificuldade, fez tudo o que era possível para facilitar o transporte do avião para junto da via férrea. 
“下午, 为了能在车站睡觉, 我们骑上骆驼去帕帕尔。我可再也不骑骆驼了! 那 份颠簸, 那骨头!”

“因为那会儿还很热, 我请身边的两个印度人给我送张床到站台来。因为累, 我睡得很沉。”

戈维亚停了一会儿, 深呼吸了一下, 然后接着说:

“你们不想知道发生什么了吗?”

“深夜一一凌晨三点或四点, 我睡眼惺忪地醒来, 床剧烈地摇晃了四下。我睁 开眼睛, 只见几头巨大的动物靠我很近! 我吓坏了, 一下子朝床的深处跳过去, 就像 一个十五岁的小伙子一样利索! 一眨眼间的功夫, 我已经逃到了售票室, 使劲摔上 门!”

他放下刀叉, 打着手势继续述说。

“我的脑子里想着: 我这是在印度呢! 毫无疑问, 我被凶猛的动物包围了一一老 虎啊, 狮子啊, 豹子或是豹狼什么的……候车室的四面墙壁保护着我, 我安全了, 脑 中一个声音高叫着: 总算是摆脱了! 要是我不那么快地醒来, 它们能把我吃了, 是不 是! ? 我好奇地观察着野兽, 战胜了恐惧, 大着胆子从半开的窗户望去。那些野兽依 然还在那儿, 肥肥胖胖的, 好像正在等我……明白自己安全了, 我立刻感到了阵阵 寒意。我的眼睛渐渐适应了黑暗, 我好像看见这群动物中的一些正栖息在一堵松 动的石墙上, 嚼着树叶子。这种平静给了我勇气。我把门打开了一下, 吆喝了一声, 那些动物受到了惊吓。我赶紧把门关上, 从门里偷偷地往外看。只见动物们都跑 远了, 只有一头, 一头又大又固执的动物留了下来, 正在床腿上蹭痒痒。我冒险走 了出去, 在适应了黑暗之后, 终于, 我确认了, 那些野兽不过是……不过是些驯服的 山羊!”

戈维亚跟我们一起大笑他经历的冒险。最后, 他说:

“第二天, 我们把飞机运了出去。因为 “祖国号” 的缘故, 铁路线的交通中断了 两个小时。你们知道那位工程师跟我说什么吗? 为了让人明白, 他的汗都出来了: 在印度, 他不记得天气这么热过, 就像我们飞机出事那天似的。”

日子一天天过去了, 前景不明。谈判进行得很缓慢。在几分钟的满怀希望之 后, 就是几个小时的沮丧。来往电报的速度就像是普通信件那么慢。 
«À tarde, tornamos a montar nos camelos para vir para Pipar, a fim de dormir na estação. É animal em que não me apanham mais! Que solavancos, que ossos, que temporal!

«Como, mesmo àquela hora, ainda estava muito calor, pedi a dois hindus que trouxessem a cama para o cais. E a cair de cansaço, adormeci profundamente.

Gouveia interrompe-se um momento, para acrescentar depois de respirar fundo:

- E não querem saber o que me aconteceu?

«Altas horas - três ou quatro da manhã -, acordo estremunhado, com quatro fortes abanões na cama. Abro os olhos e deparo, próximo de mim, com meia dúzia de animais enormes! Com os cabelos em pé, dou um salto para o fundo da cama, como se fosse um rapaz de quinze anos! Num abrir e fechar de olhos fujo para a sala de espera, atirando a porta brutalmente!

Pousara o talher e acompanhava a narrativa com profusão de gestos.

- Pela cabeça, passa-me a ideia de que estou na Índia, cercado sem dúvida por animais ferozes - tigres, leões, leopardos ou chacais... E ao ver-me a salvo, entre as quatro paredes da sala de espera, penso em voz alta: "Olha de que eu me livrei! Se não acordo tão depressa, era capaz de ter sido comido, hein!?» $\mathrm{Na}$ curiosidade de observar as feras, venço o receio e arrisco-me a olhar pela janela que entreabri. Elas lá estavam ainda, corpulentas, como se me esperassem... Mal seguro, senti de novo um calafrio. Mas na escuridão a que os meus olhos se iam agora habituando, pareceu-me ver que alguns dos bichos se empoleiravam num muro de pedra solta, mastigando folhas de árvore. Aquela pacatez deu-me coragem. Abri a porta um momento, para atirar um «chó!» enérgico que os atemorizasse, e tornei a fechá-la rapidamente, espreitando do lado de dentro. Os animais afastaram-se, à excepção de um, renitente e maior, que se ficou, coçando o lombo na perna da cama. Arrisquei-me então a sair e, habituado já à escuridão, verifiquei que, afinal, as feras não passavam de... cabrinhas mansas.

Gouveia ri connosco da aventura. E termina:

- No dia seguinte embarcámos o avião. O tráfego esteve suspenso na linha durante duas horas, por causa do Pátria. E sabem o que me disse o engenheiro, que suou para se fazer compreender: que não se lembra de ter sentido, na Índia, um calor tão forte como o que esteve no dia do desastre!

Os dias passam numa expectativa enervante. As negociações prosseguem lentamente. A minutos de esperança seguem-se horas de desalento. Os telegramas parecem trocar-se com a velocidade de cartas ordinárias. 
为了打发时间, 我们参观了卡拉奇。这个城市没有什么令人好奇的建筑, 没有 美感, 没有花园。我们满怀厌倦。

棱形的、细长的寂静之塔零零星星地分布在城里。帕西人 ${ }^{96}$ 把死者的遗体摆 在上面, 在安葬骨架前, 让秃鹰吃掉尸体的肉。

布里托・帕艾斯的伤加重了一点。热带气候让他的㾏疾时有发作。

我们去参观了克里夫登, 开放的露台像是面朝海湾露天剧场, 海水呈一种不纯 净的绿色, 海面在疲劳缓慢地起伏着。

乳白色的阳光下, 印度人和帕西人穿着独特的民族服饰在乘凉。黄昏时分, 出 现了一群群祈祷的人, 他们的礼拜仪式要崇拜太阳。

通往城中的那条公路建在地势较低的土地上，涨潮时会被淹。这条路笔直宽 广, 上面布满了各种汽车和畜力车, 车上载着四海为家的人, 他们在酷暑中贪婪地 享受着清凉, 呼吸着海边清新的空气。

一些果阿人对我们多有照顾, 试图为我们被延长了的旅途助兴。他们把我们 带到了马诺拉岛, 这个岛是卡拉奇港的天然屏障。

大风拍击着宽广的印度洋，朵朵浪花盛开在海面。这让我们开始思念大西 洋一一那目送我们踏上征途的大西洋。

岛上, 灯塔像一把七首似的直插云天。这个岛是个大炮的巢穴。海湾内, 水面 晦暗而平静, 布满牡蚛的岩石像是大泥点。

每到一处一一就像后来我们在全印度看到的那样一一无论是办公室, 房间, 酒 店客房, 政府机关还是寺庙, 天花板上都装着吊扇。这些吊扇边转边发出低低的噪 声, 像是一首单调㝋长的歌。在每天最热的时候, 它们就像是作用温和的生物碱, 让人昏昏欲睡。

96 帕西人, 印度的宗教族群, 他们实践琐罗亚斯德教教义。这是源于公元前 7 世纪的波斯宗教教义, 其创始人 是波斯哲学家琐罗亚斯德 (或称扎拉图斯特拉)。(编者注) 
No intuito de combater a inactividade forçada, visitamos Karachi, que sem curiosidades arquitectónicas, sem beleza, sem jardins, nos enche de tédio.

Aqui e além, uma torre do silêncio, prismática e esguia, a erguer-se acima do casario. É ali que os pársis ${ }^{96}$ depõem os cadáveres dos seus mortos, para os abutres lhes virem devorar a carne, antes de dar sepultura aos esqueletos.

A ferida de Brito Paes agrava-se um pouco. E o clima tropical ocasiona-lhe alguns acessos de impaludismo.

Visitamos Clifden, esplanada aberta como um anfiteatro sobre a baía, onde o mar verde-sujo se cava em ondulações lentas de fadiga.

Hindus e pársis vêm tomar o fresco, pondo na luz opalina da tarde o folclore dos seus trajos característicos. Ao cair da tarde, há grupos em oração, nos ritos litúrgicos dos que adoram o Sol.

A estrada que nos traz à cidade, longa recta nos terrenos baixos que a maré alta inunda, é uma galeria de automóveis e landaus, onde, ansiosa de frescura, a turba cosmopolita repousa da canícula, respirando o ar do mar.

Alguns goaneses, que nos cercam de atenções e procuram amenizar o nosso estágio que se prolonga, levam-nos a Manora Island, defesa natural do porto de Karachi.

O mar largo - o Oceano Índico - batido pelo vento, florindo de espuma o quebra-mar, desperta em nós saudades do Atlântico - desse Atlântico que nos viu partir.

A ilha, onde o farol parece a lâmina de um punhal apontado ao céu, é um ninho de artilharia. E as rochas ostreiras, dentro da baía, são quatro nódoas de barro, no quadro das águas baças e tranquilas.

Por toda a parte - o que, de resto, observaremos em toda a Índia -, escritórios, salas e quartos de hotel, repartições públicas e templos têm o tecto eriçado de ventiladores que giram com um murmúrio que é quase melopeia e que, às horas de maior calor, narcotizam como alcalóide de efeito suave.

${ }^{96}$ Plural de pársi ou parse, grupo étnico religioso da Índia que pratica o zoroatrismo, doutrina originada na Pérsia, no século VII a.C., com o filósofo persa Zoroastro (ou Zaratustra). (Nota do editor). 
每天早晨, 一辆汽车把我们送到德赖罗德机场, 了解谈判进度。

罗伯特 - 耶茨先生告诉我们相关情况。他毫不沮丧, 敉开消极的抵抗, 提出主 张, 令人信赖。

耶茨! 他快乐、精力充沛、充满青春活力, 我们思念他! 他的目光坦率, 坚定的 望向前方。他的性格快活、真诚、顽强。在他灵魂深处, 似乎有一种与生俱来的 要帮助人的需求。

他出生在瑞士, 但并不是瑞士人。所以, 他跟我们解释说, 就像有的猫把烤箱 当做猫窝, 但烤箱里的猫并不是小蛋糕。

他三岁来到葡萄牙, 会说一口流利的葡萄牙语。

耶茨。圣克拉拉甜点。罗伯特。甜梨。

这是四个我们可以用来形容他的近义词。圣克拉拉甜点, 就是他。

某天早晨, 那时我们已经很亲近了, 我们向他表示感谢, 感谢他的奉献; 对于他 如此倾尽全力地协助我们, 我们也表达了感激之情。而他则操着浓重的波尔图口 音回答说:

“我就是 97 一块圣克拉拉甜点! 非常好!”

后来我们发现, 我们居然是表亲: 他是我表兄弟的外甥。这件事让我们的友谊 更加牢固。我们甚至得出结论: 相对来说, 世界真的很小。到处都能遇到家人。

耶茨有一句极具个性的话, 他总说:

“这叫什么事! 真见鬼!”而且他用受洗时的名字称呼戈维亚, 就是曼努埃尔。

他会的俚语极多。他把印度人称作 “没有尾巴的沙丁鱼”- - - 这一点是他的 英国性格特征, 就是对于所有有色物种怀有一种深刻的蔑视。

他勤劳而积极, 为了航空事业而活。

18日, “祖国号” 的残骸被运送到了德赖罗德机场。在机场, 很方便把飞机残骸 装箱运往里斯本 ${ }^{98} / 99$ 。

20 日，我们终于收到了来自德里的电报。他们向我们提供了一架D哈维兰 $9 \mathrm{~A}$ 型飞机,售价 4700 英镑。耶茨愤怒地大叫:

“这叫什么事! 这帮政府养的无尾沙丁鱼全都是印第安人! 在英国, 这款飞机才 值3500英镑!”

耶茨总是把印度人叫成印第安人, 并以此结束自己的话。

\footnotetext{
97 在所有版本中这个葡语单词都被写作SIC。这是作者为了表现北部人的口音, 北部人发双元音时都好像有 一个闭音a。(编者注)

${ }^{98}$ 内含飞机残骸, 还有两箱衣服, 测量用六分仪, 第一次旅程的信件。这些信件是布里托・帕艾上校完成官方 报告所需要的, 曾被委托给卡拉奇的葡萄牙领事馆, 但直到三月末, 还未送达里斯本。

99 没有向我们提到是否在葡萄牙收到了上述箱子, 尽管布里托 - 帕艾斯多次给领事写信, 要求寄送, 他还向 外交部发出了同样的呼吁。(第二版注)
} 
Todas as manhãs, um automóvel nos conduz ao aeródromo de Drigh Road, para saber do andamento das negociações.

Robert Yates é quem nos informa. Sem desanimar, remove resistências passivas, propõe alvitres, inspira confiança.

Yates! Com que saudade nos recordamos da sua figura alegre, enérgica, radiosa de juventude! Olhar franco, fitando bem de frente. Carácter jovial, sincero, pertinaz. Parece haver na sua alma uma necessidade inata de ser prestável.

Nasceu na Suíça, mas não é suíço, explica ele, pela mesma razão que se uma gata tiver uma ninhada dentro dum forno, os gatinhos não são queques.

Veio para Portugal com três anos e fala Português correctamente.

Yates. Pastel de Santa Clara. Roberto. Pera doce.

Quatro sinónimos que nos serviam para designá-lo, Pastel de Santa Clara é dele.

Quando certa manhã, já íntimos, lhe agradecíamos a sua dedicação e lhe comunicávamos o nosso espanto pela maneira como nos auxiliava, respondeu-nos, na sua pronúncia de sotaque acentuadamente tripeiro:

- Eu sao ${ }^{97}$ um pastel de Santa Clara! Muito bão!

Descobrimos, mais tarde, que somos quase primos, visto que ele é sobrinho de primos meus, e esse facto cimenta entre nós uma verdadeira amizade. Chegámos mesmo a esta conclusão: que o mundo é relativamente pequeno. Encontra-se família por toda a parte.

Yates tem frases muito pessoais. Diz constantemente:

- Que cuâisa! Que diatcho! - e trata Gouveia pelo nome do baptismo. É o Manuel.

O seu vocabulário de calão é completo. Chama aos indianos sardinhas sem rabo e nesse ponto é caracteristicamente inglês - tem por todo o ser de cor um infinito desprezo.

Trabalhador e activo, vive para a aviação.

No dia dezoito chegam os destroços do Pátria, que são removidos para o aeródromo de Drigh Road e, ali, convenientemente encaixotados para serem embarcados para Lisboa ${ }^{98 / 99}$.

Quando, no dia vinte, se recebe enfim o telegrama de Delhi propondo-nos um D. Haviland, tipo 9A, ao preço de 4700 libras esterlinas, Yates vocifera indignadamente:

- Que cuâisa! Isto são aqueles sardinhas sem rabo do governo que são todos índios! Em Inglaterra o avião custava 3500 .

Yates teimou sempre em chamar índios aos hindus.

\footnotetext{
${ }^{97}$ Sic em todas as edições. Trata-se da forma encontrada pelo autor para traduzir a pronúncia nortenha, que transforma o ditongo /ou/, lendo-o como se nele houvesse um - a fechado (/aw/). (Nota do editor).

${ }_{98}$ Os volumes contendo os restos do avião, bem como dois caixotes com roupas, sextante e as cartas da primeira parte da viagem, necessárias ao major Brito Paes para a elaboração do relatório oficial, foram confiados ao cônsul de Portugal em Karachi, mas até ao fim de Março não tinham ainda chegado a Lisboa.

${ }^{99}$ Não nos consta que os referidos caixotes algum dia tivessem sido recebidos em Portugal, apesar de Brito Paes ter escrito várias vezes ao cônsul, pedindo a sua remessa, e instado junto do Ministério dos Estrangeiros no mesmo sentido. (Nota da 2. ${ }^{a}$ edição).
} 
在几封电报来往之后, 终于有了解决方案。席福卡 - 杜阿尔德通知我们接受 这个方案, 布里托 - 帕艾斯和戈维亚乘火车去拉合尔, 出席 “祖国二号” 的装配。我 们都同意新飞机依旧叫 “祖国号”。

我留下来进行训练并付清飞机的账单。

在这些孤独的日子里为了让我有时间训练, 布里托 - 帕艾斯给丰塞卡先生写 信, 请求他完成购买飞机的谈判。他是葡萄牙驻卡拉奇领事, 果阿人。我确认, 领 事馆绝对没有任何兴趣给予我们任何协助。

布里托 - 帕艾斯把这些信留在酒店给我转交; 我就得机场酒店来回跑, 两者之 间的距离有十公里。我必须办这件事, 为此, 我耗费了三天的时间……

奥兰领事, 是有道理的。

1923年 6 月, “祖国号” 准备离开的时候, 神智学协会葡萄牙分会 (我是该协会 成员 ${ }^{100}$ ) 通过其秘书长若昂 - 安图内斯交给我一个任务, 让我在印度向安妮 - 贝 赞特夫人提交葡萄牙神智学会会员的一封信函, 这位夫人是该协会久负盛名的会 长。

“祖国号” 发生事故, 我们无法前往瓦拉纳西。应我的请求, 布里托 - 帕艾斯曾 计划前往此地, 当时神智学会的大本营坐落在那里。

因此，我向卡拉奇市长、神智学会信德省秘书长贾姆希德・梅塔先生传达了 葡萄牙神智学会会员的问候。当我们路过埃及时, 我也跟神智学会开罗分部总秘 书处的一位官员交谈了几分钟。

这样我完成了交待给我的任务。

我们在卡拉奇逗留期间, 发生了一件令人好奇的事, 我在旅行日志中记载了 它。

那是一个下午, 我正要按照习惯躺下午睡的时候, 一个小男仆跑过来告诉我: 有两个印度人找我, 他们是神智学会的会员, 想问候一下我。

两个人中年轻的那位向我询问旅行的有关细节, 询问葡萄牙, 还有我们的计划 等等。首先, 我就如此简慢地接待他们致兼, 然后我们愉快地进行了交谈; 他鼓动 我再次来印度, 并多呆些时间以便能够更好地参观美丽的印度, 无论是自然风光还 是名胜古迹。而那位看起来有 75 岁左右的老者静静地听着我们谈话, 眼睛盯着 我, 脸上露出微笑。

他们的来访不超过二十分钟。然后, 我困极了, 睡了一个半小时。在睡眠期 间, 一种无限的平静之感包围了我。我永远也无法忘记此时做的一个梦。

100 从1926起, 我不再是会员。(第二版注) 
E depois de uma troca de telegramas, em que, posto ao corrente da solução encontrada, Cifka Duarte nos comunica aceitá-la, Brito Paes e Gouveia seguem de comboio para Lahore, para assistirem à montagem do Pátria II. Concordáramos em manter o mesmo nome ao avião.

Eu fico, para me treinar e liquidar o pagamento do aparelho.

Nesses dias de solidão, em que, a fim de me deixar tempo livre para os treinos, Brito Paes escreve ao Dr. Fonseca, goanês, cônsul de Portugal em Karachi, pedindo-lhe que ultime as negociações para a compra do avião, verifico que aquela entidade se desinteressa em absoluto de todas as diligências com que poderia auxiliar-nos.

As cartas que Brito Paes lhe envia deixa-mas ele no hotel; e sou eu que, correndo do banco ao aeródromo e do aeródromo ao banco - dez quilómetros de distância - tenho de tratar do assunto, perdendo desta maneira três dias...

O cônsul de Orã estava justificado.

Quando, em Julho de 1923, o Pátria se aprestava para partir, a Secção Portuguesa da Sociedade Teosófica, de que faço parte ${ }^{100}$, confiava-me, por intermédio do seu Secretário Geral, Dr. João Antunes, o encargo de entregar na Índia uma mensagem dos teósofos portugueses dirigida a Mrs. Annie Besant, veneranda presidente da Sociedade.

O desastre do Pátria impedia-nos de tocar em Benares, como Brito Paes resolvera, acedendo ao meu pedido, visto que à data ali se encontrava o Quartel General da Sociedade.

Foi por isso nas mãos do Presidente da Câmara Municipal de Karachi, Mr. Jamshed Mehta, secretário provincial da Sociedade Teosófica no Sind, que depus a saudação dos teósofos portugueses e, bem assim, um ofício do Secretário Geral da Secção da Sociedade Teosófica do Cairo, com quem me fora dado conversar alguns minutos, ao tocar no Egipto.

Assim dei cumprimento à missão de que fora incumbido.

Durante a nossa permanência em Karachi, verificou-se um caso curioso, que assinalei nos meus apontamentos de viagem.

Era de tarde e, como de costume, deitara-me para a sesta, quando o boy veio anunciar-me a visita de dois hindus, teósofos, que desejavam cumprimentar-me. Duas figuras curiosas, diferentes, de olhar franco e firme.

Pediu-me o mais novo detalhes sobre a viagem, sobre Portugal, sobre os nossos projectos. Desculpei-me da sem cerimónia da recepção e animadamente conversámos, incitando-me ele a voltar à Índia com mais demora, para ver tudo o que de belo ali existe, desde a natureza, aos monumentos e ao pitoresco dos costumes. O mais velho, que aparentava uns setenta e cinco anos, ouvia-nos em silêncio, com indizível sorriso, sem deixar de fitar-me.

Terminada a visita que não excedeu vinte minutos, invadiu-me profunda sonolência e durante hora e meia repousei, envolto numa infinita sensação de calma. E não mais poderei esquecer o sonho que tive.

${ }^{100} \mathrm{E}$ à qual deixei de pertencer em 1926. (Nota da 2. ${ }^{\mathrm{a}}$ edição). 


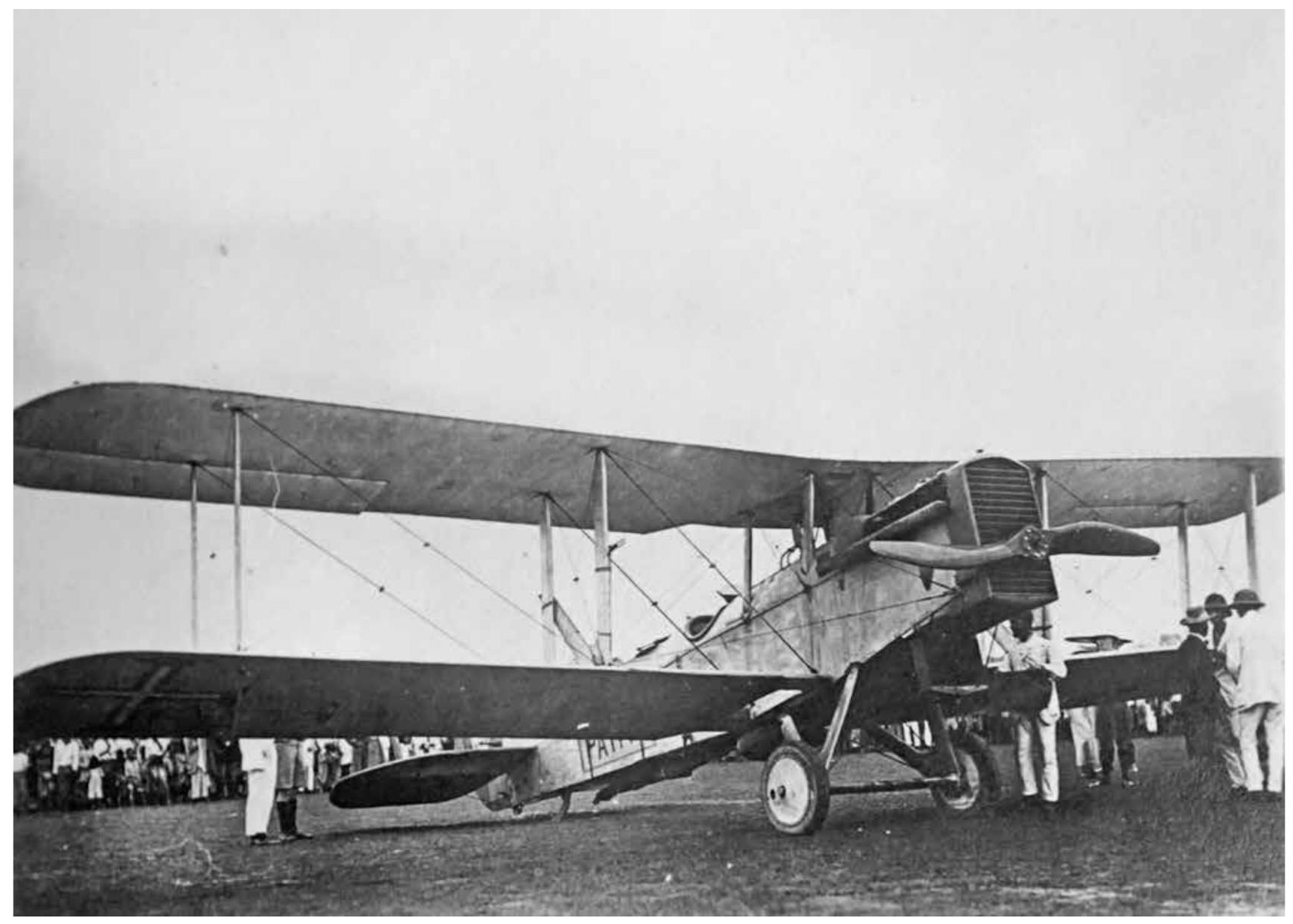

O avião Pátria II, adquirido na Índia, para prosseguir a viagem até Macau

为飞抵澳门, 在印度购买的 “祖国二号” 
我梦见那位年长的印度人有回来了, 他让我起来, 把我带到了一个满是树荫 湖泊的公园。在公园里, 我们两个坐在一颗古老的树干上, 他向我谈起生命, 谈起 生命的意义, 我们必须要履行的善良义务, 要宽容, 要理解, 为了让灵魂更完美而工 作。接着, 他给了我一些建议, 并暗示我在不久的将来会发生一些事。他的话语中 洋溢着甜蜜与宁静, 但是充满了令人激动的说服力。

我醒来的时候, 不禁微微地笑了。

那两个印度人的名字我都没记住。但是在梦中听到的话却深深地刻在了我 的记忆中, 三件或是四件那位印度老者预言的事都在不久后发生了。

28 日, 我离开卡拉奇, 那天下午, 令人窒息的狂风席卷了整个城市。

铁路线从德赖罗德机场旁边穿过。耶茨和其他军官都在机场, 站在第二司令 官的帐篷旁, 向我们挥舞着白手帕。

我带走了思念。我已经习惯生活在他们中间, 现在满怀感激地离开了这些朋 友, 或许是永远告别了他们。

我不得不在车厢里呆上二十四个小时。一个巨大的箱子里装满冰块，散发出 一点凉气, 预防中暑。

我独自一人, 当夜幕降临时, 我想起了飞行员大家庭。在这个大家庭中, 实际 上是存在团结的; 在这个家庭里, 还有慈爱和无私, 这些品质应该把人们团结到一 个很大的基督团契中。

火车穿过闷热的夜晚, 灼热的白天, 终于到达了拉合尔。

布里托 - 帕艾斯和戈维亚在车站接我。他们两个人都很急切, 因为那让人神 经衰弱的, 无所事事的折磨结束了。

五月二十九日, “祖国二号” 进行了第一次试飞, 我作为乘客登上了飞机。驾驶 飞机的是奥利弗上尉, 他是一位杰出的英国飞行员。我跟他共进行了三次飞行。

我无限思念我们的布雷盖飞机, 思念之情让我的心脏都抽痛了。当想到曾在 我手中的四千七百英镑时, 一股深切的恐惧之情忽然涌上心头。

我们回到了城中。

拉合尔。郁郁葱葱的花园中, 凉风吹过, 仿佛在唱一支悲伤的歌。在这里, 水 流从看不见的地方潺潺流过, 可以想见, 这里有一些人们看不见的湖泊, 古老的吠 陀印度, 释迦牟尼佛陀, 薄伽梵, 泰姬陵在空气中飘荡…… 
O velho hindu voltara, fizera-me levantar e conduzira-me a um parque cheio de sombras e lagos. E ali, sentados os dois junto ao tronco de uma árvore secular, falou-me da Vida, do seu significado, do dever que temos de praticar o Bem, de ser tolerantes, de compreender e de trabalhar pelo aperfeiçoamento do espírito. Depois deu-me alguns conselhos e aludiu a certos incidentes que deveriam ocorrer num futuro próximo. As suas palavras impregnavam-se de doçura e serenidade, mas tinham um poder de persuasão impressionante.

Ao acordar, sorri.

Não tornei a ver os dois hindus, cujos nomes nem sequer fixei. Mas as palavras que ouvira em sonho ficaram-me gravadas na memória, tanto mais que os três ou quatro incidentes a que o velho hindu aludiu se verificaram passado pouco tempo.

No dia vinte e oito deixo Karachi, que um vento sufocante varria nessa tarde.

A linha férrea margina o aeródromo de Drigh Road. Yates lá estava, com outros oficiais, junto da tenda do segundo comandante, acenando-me com lenços brancos.

E eu levava saudades. Habituara-me a viver entre eles e partia cheio de gratidão por aqueles amigos de quem me afastava provavelmente para sempre.

Na carruagem onde o destino me condenara a viver vinte e quatro horas, uma grande caixa de gelo, preventivo contra as insolações, exalava um pouco de frescura.

Sozinho, enquanto a noite descia serenamente, penso na grande família dos aviadores, em que a solidariedade existe de facto, onde se encontra o carinho recíproco e a abnegação que deveria unir os povos numa grande fraternidade cristã.

O trem rolou, através da noite abafada e do dia tórrido, até Lahore.

Brito Paes e Gouveia esperavam-me na estação, ambos ardendo por terminar o suplício daquela inacção neurastenizante.

Foi no dia vinte e nove de Maio que o Pátria II, levando-me como passageiro, realizou o seu primeiro voo de ensaio, pilotado pelo tenente Olivier, excelente aviador inglês, com quem seguidamente efectuei três voos.

Uma saudade imensa do nosso Breguet confrangia-me o coração. E, ao pensar que a sorte de quatro mil e setecentas libras esterlinas estava nas minhas mãos, assaltou-me traiçoeiramente um íntimo receio.

Voltamos à cidade.

Lahore. Jardins exuberantes, onde uma brisa quase fria murmura toadas dolentes. Escutam-se murmúrios de água correndo escondida, adivinham-se lagos que se não vêem, e palpitam no espaço as vibrações da milenária Índia dos Vedas, do divino Gautama Buddha, do Bhagavad Gita, do Taj Mahal... 
下午, 由戈维亚陪同, 我再次试飞了“祖国二号”。

这架飞机中装备着丰富的储备物资：一个螺旋桨，一个起落架，填砂支柱 ${ }^{101}$, 蜡烛, 电瓶等等……在拉合尔的天空中拐了个小弯, 掠过机轮仓库, 在暮色中降落 了。

在这次旅行中, 这是我最后一次和自己空中的兄弟一一戈维亚一起飞行。

我从他的眼中看出了一种沉重。我忍着眼泪, 第二天, 我不得不哭了出来。在 那一刻, 我整个灵魂都深情地环绕着他, 怀着忍耐顺从之心 ${ }^{102}$ 。

101 具有一定弹性的缆线, 可以增加机翼篻布的张力。(编者注)

102 当我回顾这一页的时候, 再次记起了这位葡萄牙航空界伟大的机械师一一曼努埃尔 - 戈维亚, 他的工作 生前并没有得到适当的回报。现在, 他已经不在这个世界, 当我再次忆起他的时候, 我无法抑制自己的钦佩 与悲伤之情。(第三版注) 
De tarde, ensaio de novo o Pátria II, acompanhado por Gouveia.

O aparelho, ajoujado ao peso de abundante material de reserva - uma hélice, um trem de aterragem, sandows ${ }^{101}$, velas, bateria, etc. -, descreve uma pequena curva no céu de Lahore e, armazém volante, aterra na luz crepuscular do anoitecer.

Foi o último voo que, durante a viagem, o nosso irmão do ar realizou comigo.

Leio-lhe nos olhos um profundo pesar. Pressinto lágrimas que há-de chorar no dia seguinte. E toda a minha alma o envolve afectuosamente nesse instante, numa aspiração de conformidade e resignação $0^{102}$.

\footnotetext{
${ }^{101}$ Cabos providos de alguma elasticidade, o que permitia aumentar a tensão da tela das asas. (Nota do editor). ${ }^{102}$ No momento em que revejo as provas desta página, relembro o grande mecânico que foi Manuel Gouveia, uma das grandes figuras da aviação portuguesa que não viu, em vida, devidamente recompensados os seus serviços. E ao relembrá-lo, agora que ele desapareceu do mundo, não posso deixar de recordá-lo com admiração e tristeza. (Nota da $3 .^{\mathrm{a}}$ edição).
} 


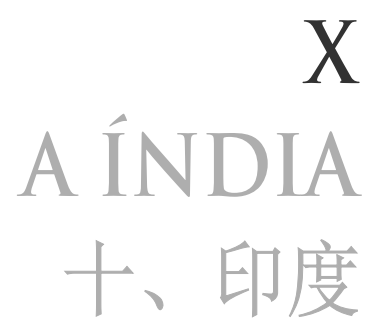


5月30日, 早五点半。机场的车把我们从酒店送到停机坪, “祖国二号” 正在那 里待命。终于我们将再次启程, 继续前往澳门的旅程 ${ }^{103}$ 。

戈维亚走向我们,他沉默而悲伤。

在宏伟的公路上, 晨犧初露, 凉爽清新。我们呼吸着纯净的空气, 呼吸着茂密 的植被释放出的能量。这植被让整个拉合尔城变成了一个巨大的绿色湖泊。

跑道上, “祖国二号”机身那笨拙的雉形三角骨线条引人注目。

现在是六点一刻。我们得出发了。

我们告别了英国军官们, 拥抱了戈维亚。

他们微笑着祝我们旅途顺利, 我们也感到了同样的别离之痛。

我们登上了飞机, 心脏令人不安地砰砰直跳。

螺旋桨开始转动。

飞机开始滑行时, 还能看到我们的朋友戈维亚在偷偷地擦去擦眼睛。

他的牺牲和我们的牺牲都是葡萄牙人民作出的牺牲的一部分, 为了葡萄牙的 福音能够实现, 曾把所需要的宝贵事物交给席福卡・杜阿尔特司令交。

在飞安巴拉的两个小时中, 我们 “防御飞行”104, 奥利弗在右舷为我们护航。

风景在炎热的迷雾中若隐若现, 大块大块的植被黑影和聚居点的灰色影子不 时出现在我们的视野。

但这让热窒息的高温让人难以忍受, 它在不断地折磨着我们, 耗尽我们的精 力。

降落前, 我们在跑道上方绕了一圈。一想到 “祖国二号” 的运气掌握在自己的 手中, 我的情绪就会被干扰。这一圈就是我的情绪象征。

103 最初, 为了线路不被中断, 我们想执飞拉合尔一布达纳一阿格拉。但是后来确认了一下拉合尔到阿拉哈 巴德的距离超过了拉合尔到布达纳的距离, 我们放弃了这个想法, 因为我们觉得这不能增加这次旅行的价 值。(第二版注)

104 这是一个现在航空术语中没有相应表达的词组。但是, 很可能像其他许多在航空中使用的语言一样, 它 来自航海环境中语言的转变, 很可能是来自古代古代航海语言, 植根于 “防御守卫”。就其航海起源来看, 它 的意思是伴随另一艘船航行的船, 其任务是在必要时保护那艘船。因此, “防御飞行”应该是指一架飞机被 另一架飞机支持或护送飞行以让前者在面对某些机械问题或是任何其它风险时能保持健全。这个词组曾 被拉斐尔・布鲁特在他自己编辑的 “葡萄牙语词典” (里斯本: 西蒙・塔黛乌・费雷拉印刷室, 1789年) 第一 卷第314页, 作为 “共同”、“在一个联合中”、“伴随” 的近义词收录。(编者注) 
Trinta de Maio. Cinco e meia da manhã. No automóvel do aeródromo, seguimos do hotel para o Campo de Aviação, onde, no Pátria II, íamos finalmente largar de novo a caminho de Macau. ${ }^{103}$

Gouveia vai connosco, silencioso e triste.

Pela estrada magnífica, na frescura tépida do dia que desponta, respira-se pureza, respira-se a energia da vegetação luxuriante que faz de Lahore um grande lago de verdura.

Na pista, o Pátria II destaca-se, nas linhas deselegantes da sua fuselagem tronco-piramidal.

São seis e um quarto. É preciso partir.

Despedimo-nos dos oficiais ingleses e abraçamos Gouveia.

No sorriso com que nos deseja boa viagem, sentimos o mesmo pesar que nos confrange.

Subimos para o avião - corações pulsando forte, num enervamento.

Lançam a hélice.

E, quando o aparelho começa a rolar, ainda vemos o amigo que deixamos, a enxugar os olhos disfarçadamente.

O seu e o nosso sacrifício eram a nossa quota-parte no sacrifício do Povo de Portugal que, num rasgo de entusiasmo, entregara a Cifka Duarte o ouro necessário para que o Evangelho de Portugal se cumprisse.

Um salto de duas horas até Ambala, voando de conserva ${ }^{104}$ com Oliver, que nos escolta por estibordo.

Paisagem coada pela bruma do calor, através da qual negrejam maciços de vegetação e há nódoas alvadias de povoados.

Mas a mesma temperatura asfixiante, insuportável, sempre, numa tortura contínua que nos esgota.

A volta de pista que damos antes de aterrar é o símbolo da emoção que me perturba ao pensar que, das minhas mãos, depende a sorte do Pátria II.

\footnotetext{
${ }^{103}$ Era nossa intenção, inicialmente, realizar o voo Lahore - Budhana - Agra, para eliminar a solução de continuidade que cortaria, de outro modo, o nosso itinerário. Mas depois de verificar que a distância Lahore - Allahabad excedia a que separava Budhana desta cidade, desistimos da ideia, por entendermos que ela nada acrescentava ao valor da viagem. (Nota da 2. ${ }^{a}$ edição).

104 «Voar de conserva» é uma expressão que não tem aplicação na linguagem aérea actual. Contudo, é provável que, à semelhança de tantas outras utilizações linguísticas da aviação que resultam de uma transferência do contexto náutico em que se originaram, também esta será, provavelmente, originária da linguagem naval antiga, e que se radica em «contra-guarda». Significava, na sua origem náutica, o navio que acompanha outro para o proteger em caso de necessidade. Assim, «voar de conserva» deverá significar voar apoiado ou escoltado por outro aparelho, para preservar a integridade do primeiro, neste caso face a algum problema mecânico ou a qualquer outro risco. «De conserva com» aparece já registado em Rafael Bluteau, como sinónimo de "de mão comum», «numa liga», «em companhia», na p. 314 do primeiro volume do seu Dicionário da Língua Portuguesa, Lisboa: Simão Tadeu Ferreira, 1789. (Nota do editor).
} 
飞机轮子不可思议地切向地面, 飞机进入了机库。英国机械师们全力以赴, 以 便我们第二天一早能够出发。

围绕着我们的是同样的善良, 同样的无私协助, 同样的自然、自发的友爱。

晚上, 我们陪同一位安巴拉中心的军官飞行员到了车站前往加尔各答, 他要去 那里准备跑道好让我们可以降落。

火车经过时, 我们跟戈维亚交谈了一小会儿。他去阿拉哈巴德, 因为那儿没有 机械师, 所以他的出现是不可缺少的。

这是让人快乐的时刻, 但这种快乐很快就变成了了私下的了。在空中飞行时, 我们的朋友不再出现。在 “祖国二号” 的飞行途中, 在每一个停留点, 他都用自己的 经验照看着这架飞机。

此后, 摆在我们面前的又是四个半小时、八百公里的飞行, 直到阿拉哈巴德。

天气好极了, 视野极佳。

风景五光十色。

勒克瑙在我们的左边, 它洁白无瑕, 像是轻轻扇动的白翅膀静静地坐落在铁路 线旁。我们远远看到了坎普尔, 它让我想起自己读儒勒 - 凡尔纳 ${ }^{105}$ 的 “蒸汽之家” 的时光; 此外, 还有一个大纪念碑, 是献给上世纪末此地大屠杀受害者的。

而在拉埃巴雷利上空, 我们看见了的恒河, 神圣而富饶, 像一条懒洋洋的蛇睡 着了盘踞在那里, 蜿蜒曲折, 亮闪闪的像是金属的背面, 流过手掌似的大片平坦土 地。

“祖国二号” 顺利地降落在布玛里机场, 那是块手掌般平坦的一平方公里土 地。

没人在机场等我们。

英国空军驻印度的军官飞行员应该在那里为我们提供协助, 给飞机加油, 在机 场给我们打出信号, 可他们以为我们一个小时后才到 (这是我们后来才知道)。

飞机被一百来个印度人围住了, 我们跟他们语言不通, 无法交流。他们在我们 周围发出的喧器, 还有盯着我们的样子, 都让人头军眼花; 我们打着手势, 几乎是在 求他们别碰飞机, 可他们毫不理会。他们证明了一件事: 那就是我们已经不在拉吉 普塔纳邦, 居住在这里的人是属于另一个种族的了。

105 儒勒 - 凡尔纳 (1828年-1905年) 是举世闻名的法国作家。他的作品被认为是科幻文学的先驱, 因为在那 些真实事件发生之前很久, 儒勒 - 凡尔纳就叙述并描绘了潜水艇和飞行器, 他还描述了奔赴月球的旅行。比 如, 大家可以参阅他的作品 “从地球到月球”或是 “海底两万里”。(编者注) 
Como por milagre, as rodas tocam tangencialmente o terreno, e o avião entra no hangar onde os mecânicos ingleses iniciam os plenos, para que possamos partir na manhã seguinte.

Em torno de nós, a mesma gentileza, o mesmo auxílio desinteressado, a mesma simpatia espontânea e natural.

À noite, acompanhamos à gare um oficial aviador do Centro Ambala, que parte para Calcutá, a fim de ali preparar a pista para nela podermos aterrar.

Durante a passagem do comboio, conversamos alguns instantes com Gouveia, que segue para Allahabad, onde, como não há mecânicos, a sua presença se torna indispensável.

São alguns minutos de alegria, essa alegria de que em breve seríamos privados, quando, prosseguindo, a figura do nosso amigo deixaria de aparecer, com a sua experiência, a cuidar do Pátria II nos restantes pontos de escala.

Depois, é um novo salto de oitocentos quilómetros, até Allahabad, em quatro horas e meia.

O tempo está óptimo e a visibilidade é excelente.

Há notas de colorido na paisagem.

Lucknow, que nos fica por bombordo, parece pela brancura um frémito de asas brancas, junto de um grande entroncamento de linhas férreas. E Cawnpore, que avistamos ainda, a distância, recorda-me o tempo em que li A Casa a Vapor, de Júlio Verne ${ }^{105}$, e o grande monumento às vítimas do grande massacre que ali se verificou em fins do século passado.

De sobre Rae Bareli, avistamos o Ganges, sagrado e fértil, em atitudes lânguidas de cobra adormecida, dorso metálico, sinuoso, a descrever as margens.

O Pátria II aterra sem dificuldade no aeródromo de Boumari, quilómetro quadrado de terreno liso como a palma da mão.

Ninguém nos espera no campo.

O oficial aviador que a Direcção da Aeronáutica Inglesa na Índia destacara, para ali nos prestar auxílio, fornecer combustível e proceder à sinalização do campo, calculava (soubemo-lo depois) que chegássemos uma hora mais tarde.

$\mathrm{O}$ avião é rodeado por uma centena de hindus, com quem não conseguimos entender-nos. Mas a algazarra de entontecer que fazem à nossa volta, e a maneira como nos olham, não atendendo às recomendações quase suplicante, que lhes fazemos por mímica, para não tocarem no avião, demonstram-nos que já não estamos no Estado de Rajputana, que a raça já é diferente.

\footnotetext{
${ }^{105}$ Júlio Verne (1828-1905) foi um escritor francês de grande divulgação em todo o mundo. As suas obras podem ser consideradas precursoras da ficção científica, pois, muito antes de tais acontecimentos ocorrerem, Júlio Verne narrou e descreveu viagens em submarinos e máquinas voadoras, tendo também narrado viagens à Lua. Ver as suas obras Da terra à Lua ou Vinte mil léguas submarinas, por exemplo. (Nota do editor).
} 
附近有一个铁路停靠站, 里面有部电话, 还有会说英语的人。它的北面是跑 道。热浪滚滚, 我们终于能够与军事司令官交谈, 他告诉我们, 一位军官已经离开, 去了勃玛力。

我们大汗淋漓。热气简直让人窒息。

半小时后, 一辆福特汽车到来……随车来了一位记者。我们原谅了他, 因为他 带来了水。水?不, 他带的是苏打水……种温暖而无法解渴的液体。

我们躲在车棚的阴凉下, 靠着车, 接受采访。我们告诉这位记者, “祖国二号” 用了四个半小时的时间从安拉巴拉飞到阿拉哈巴德, 他表示极为钦佩。

几分钟后, 另一辆福特车到了。我们看到从车上下来一位涁涁有礼 ${ }^{106}$ 的金发 少尉。看到他, 我们对于飞行员是专为飞行而被发明的信念产生了猜测。

他干巴巴地问了我们一下旅途是否顺利, 抱怨了一下我们所忍受的四十五摄 氏度高温, 然后就用一种不耐烦的口气告诉我们:

“所有东西都准备好了! 汽油, 油, 水!”

因为戈维亚一点才能到, 我们就前往位于东边五公里外的城市。

又是热得令人窒息的一天, 从的黎波里开始, 我们就仿佛一直在穿行在这些火 炭组成的念珠串中。

在这个时间，空荡荡的城市被包裹在悬浮的尘土中，风温柔的气息烧灼着它， 无法弥散。

戈维亚到了,我们三个人再次兴奋地拥抱在一起。

在他来的火车上, 皇家空军的劳上尉祝贺我们已经飞完了一些航段, 然后就接 着前往加尔各答了。

因为城中没有酒店, 汽车把我们送到一家俱乐部, 这里像个修道院收容所似 的, 没有床单, 没有枕头, 没有蚊帐。在此过夜的旅人, 如果想要享受这里的 “奢华”, 得自备床上用品。

下午, 我们又回到了勃马力, 在那里准备好 “祖国二号”。戈维亚仔细地检查了 飞机。

晚饭时, 军事司令官和我们干了一杯波特酒, 说了一些祝福的话。他是一位长 着粉色秃顶, 蓄着茂密的唇髥的老将军。

餐桌都摆在户外草坪 107 上, 英国人到哪儿都保留着这些完美的草坪。小灯泡 组成的宋子下, 一支皇后军团的乐队在演奏着平淡的音乐。

一位健谈的军官跟我解释说:

106 原文单词为另一种拼写方式。(编者注)

107 原文为法语。(编者注) 
Próximo, há um apeadeiro da linha férrea que, a Norte, limita a pista, um telefone e alguém que fala inglês. Sob a canícula a gente avança e consegue comunicar com o Comando Militar, donde nos informam que um oficial partira já para Boumari.

Transpiramos como esponjas. A atmosfera sufoca.

E meia hora depois, um Ford chega... com um jornalista. Perdoamos-lhe porque traz água. Água? Não. Soda... um líquido morno que não mata a sede.

Abrigados sob a capota do automóvel, suportamos uma entrevista. E o repórter é todo admiração, quando lhe dizemos que o Pátria II gastou quatro horas e meia para percorrer a distância que separa Ambala de Allahabad.

Alguns minutos mais tarde, outro Ford aparece, e vemos apear-se um alferes louro, ameinarado ${ }^{106}$, em quem a gente adivinha a convicção de que os aviadores foram exclusivamente inventados para voar.

Depois de nos perguntar polidamente se fizemos boa viagem e de se queixar dos quarenta e cinco graus centígrados que suportamos, comunica-nos, num suspiro de tédio:

- Está tudo preparado! Gasolina, óleo e água!

Como Gouveia só chega à uma hora, seguimos para a cidade, cinco quilómetros a Leste.

O dia asfixiante é mais uma conta, no rosário de brasas que vimos desfiando desde Trípoli.

Àquela hora, a cidade deserta está envolta numa nuvem de poeira em suspensão, que o bafo manso do vento que queima não consegue dissipar.

Gouveia chega, e é nova explosão de alegria o abraço que nos estreita os três.

No comboio que o trouxe, o tenente Lawe, das Reais Forças Aéreas, segue para Calcutá, depois de nos felicitar pela etapa efectuada.

Como não existe hotel na cidade, conduzem-nos ao clube, espécie de albergue de terceira ordem, onde não há lençóis, não há almofadas, não há mosquiteiros. O viandante que ali pernoita deve fornecer a roupa de cama, se quiser gozar desse luxo...

Pela tarde, voltamos a Boumari, onde aprontamos o Pátria II, que Gouveia vistoria cuidadosamente.

Ao jantar, o comandante Militar, velho general de calva rósea e bigodeira farta, oferece-nos um cálice de Porto, com algumas palavras de felicitação.

As mesas acham-se ao ar livre, numa dessas pelouses ${ }^{107}$ impecáveis que os ingleses conseguem manter em toda a parte. Há bambinelas de lâmpadas eléctricas e um concerto insípido, pela banda do Regimento da Rainha.

Um oficial mais loquaz elucida-me:

\footnotetext{
${ }^{106} \mathrm{O}$ mesmo que «amaneirado». (Nota do editor).

${ }^{107}$ Relvado. (Nota do editor).
} 
“这个军团是为保卫非斯城和丹吉尔城而建, 当时英国的查尔斯二世迎娶了葡 萄牙公主——布拉甘萨的卡特琳娜, 那两座非洲城市是公主嫁妆的一部分。”

他把加了苏打水的威士忌加 (因为波特酒已经被喝光了) 端到嘴边, 缓缓地 抿着嘴唇品味着, 动作简直有些性感。似乎在说约翰 - 布尔在品味非斯和丹吉 尔......

第二天, 6 月 1 日早, 我们启程前往加尔各答。

航程为八百五十公里。我们从一个极为富庶的地区上空飞过, 但它秀丽的风 景却消失在迷雾之中, 高速飞行让风从我们身边肆无忌惮的狂掠而过。

在恒河旁闪炼了一下的瓦拉纳西呈一种奇怪的几何图形状, 坐落在恒河同心 圆形的拐弯处。

我们离开了恒河上空, 向北飞去。

我们飞越了帕瑞内斯山, 这座巍峨的大山高一千九百米, 像一根阴沉的大鞭刺 似的直立在平原上, 呈暗绿色的金字塔状, 山顶一个纯白色的小小村庄闪闪发光。

在一条铁路线上, 时不时的有玩具似的火车开过。我们在两千二百米的高度 飞行。最后, 我们终于到了加尔各答。

这是一个散落在平原上的巨大城市, 在不透明的大气中很难看清。

古老的要塞旁, 降落场地像是一个装备着树从的坦克, 一个长着草坪的平行 四边形。场地的东西边界是两个茂密的灌木丛, 南边的界限是一些房屋, 北边则是 起伏不定的地面, 非常危险。在场地中央, 有两从树木, 还有一个足球场的球门标 杆。

我们在安巴拉用过的机场据说是800X400米, 还要加上其他因素: 总是刮向有 利方向的风。

很显然, 我们到达时, 风反常地斜着吹过。

在惯常的热旋风中, “祖国二号” 开始下降。它几乎都失速了, 从树从顶上掠 过, 开始接近地面, 到了......

我们前面, 两棵粗大的树木堵在降落场的中央, 让人觉得这两棵树在向我们撞 过来, 非常危险。

为了避免成为 “回归的装饰” 108 (这是法国飞行员的俚语 ${ }^{109}$ ), 在绝望中拉动了 操纵杆 ${ }^{110}$, 再次启动了发动机。这架装着 400 马力发动机的飞机猛烈而紧张地改变 了方向, 陡然上升, 贴着树梢飞过。

108 这个俚语的意思是迷路, 由于偏离正途而发生事故 (编者注)

109 原文为法语, 指俚语, 特定人群用语。(编者注)

110 原文为法语术语, 指操纵飞机的拉杆, 其运动可以控制飞机爬升、下降并使飞机保持平衡。(编者注) 
- Este regimento foi fundado para defender Fez e Tânger, quando Carlos II de Inglaterra desposou Catarina de Bragança, a princesa portuguesa cujo dote era constituído por aquelas duas cidades africanas!

E o homem, levando à boca o whisky and soda (porque o Porto já lá vai), saboreia o líquido num movimento de lábios vagaroso e quase sensual! Dir-se-ia John Bull saboreando Fez, saboreando Tânger...

Na manhã seguinte - um de Junho -, saímos para Calcutá.

Oitocentos e cinquenta quilómetros de voo sobre uma região fertilíssima, cujo pitoresco se perde na bruma e na velocidade a que nos arrasta uma ventania desabrida.

Benares, na margem do Ganges, é uma estranha figura geométrica que cintila um instante, nas curvas harmoniosas das suas avenidas concêntricas.

Abandonamos o rio, que inflecte para Norte.

A montanha de Parasnath, mil e novecentos metros agressivos, ergue-se na planície como esporão sombrio, pirâmide gigantesca e verde-negra, com uma aldeiazinha miniatural e alvíssima a rebrilhar no topo.

Numa linha férrea, alguns comboios se avistam, de tempos a tempos, rodando como brinquedos. Voamos a dois mil e duzentos metros.

E, finalmente, Calcutá, enorme, pulverizada na planície, mal se define na opacidade atmosférica.

Junto ao velho forte, de magistral em estrela, o campo de aterragem parece um tanque de arvoredo, paralelogramo relvado que, a Leste e Oeste, dois bosques maciços limitam, que a Sul um grupo de casas fecha, e que a Norte uma nítida ondulação do terreno torna perigoso. Ao meio, dois grupos de árvores e os postes do goal de um campo de futebol.

As dimensões que em Ambala nos tinham sido fornecidas, diziam oitocentos por quatrocentos metros, acrescentando: «Ventos, sempre na melhor direcção».

É claro que à hora a que chegamos, excepcionalmente, o vento sopra atravessado.

O Pátria II desce, nos habituais turbilhões da atmosfera tórrida, passa, quase em perda de velocidade, sobre as copas altas do arvoredo, e aproxima-se do solo, pairando...

$\mathrm{Na}$ nossa frente, os grossos troncos dos dois grupos de árvores que atravancam o centro do campo dão-nos a impressão de avançar contra nós ameaçadoramente.

Para evitar la rentrée dans le décor ${ }^{108}$ (como dizem os aviadores franceses no seu pitoresco $\left.\operatorname{argot}{ }^{109}\right)$, remeto o motor e, num gesto desesperado, puxo pelo manche $e^{110}$. Inflectindo brusca e nervosamente, o avião, accionado pelos quatrocentos cavalos do seu motor Liberty, atira-se para cima, em subida íngreme, e passa resvés da ramaria alta.

\footnotetext{
${ }^{108}$ Rentrer dans le décor significa despistar-se, ter um acidente por perder a trajectória. (Nota do editor).

${ }^{109}$ Gíria, linguagem própria de um grupo específico. (Nota do editor).

${ }^{110}$ Termo francês que designa a alavanca para pilotar aviões e cujos movimentos controlam a subida, a descida e o equilíbrio da aeronave. (Nota do editor).
} 
在城市热腾腾的烟雾中在跑道上绕了一圈, 随着从右舷吹来的风, 为了避开那 些在地面上悠闲吃草的羊群, 我转了个 “马棍” 111 式的弯, 终于降落了。

我们平均飞行速度是每小时二百公里。

过了一会儿, 特谢拉神父, 葡萄牙领事和一些英国军官到了。这些人中还包括 在这里协助我们的飞行员。巴西领事也来了, 这位葡萄牙的好朋友热情地拥抱了 我们。

此时, 在阴凉处的温度是四十二度。

飞机停在树从组成的绿拱下, 四个“高地人” 112 守卫着飞机。

在各位领事, 还有空军的劳上尉, 麦克唐纳上尉, 苏格拉高地人一一他们称为 梅丹 ${ }^{113}$ 的, 我们离开了跑道, 前往酒店。

接着是正式的官方招待，庄严的仪式由果阿殖民地主导。仪式中，作为纪念， 向我们每个人赠送了精美的银质奖杯; 戈维亚也到了。在外交宴会上, 我们很惊异 地看到, 英国人同意坐在有色人种的旁边。

实际上，特谢拉神父向我们提供的协助令人感动。他是个好脾气的后山省人, 有一颗坦率的牧者心灵, 行动迅速、聪明, 他是我们真正的朋友。我有种感觉, 似 乎跟他认识很长时间了。

宴会上, 加尔各答所有的领事人员都来了, 有两点值得记下: 因为一个很简单 的理由一一敢于驾着一架从未开过的飞机继续相似的航程, 劳上尉举杯向我们敬 酒, 是他给我们取了有趣外号的; 还有就是麦克唐纳上尉, 在喝了许多酒之后, 他 向我们展示他的铁头功, 他用额头瞄准, 使劲撞向核桃, 想用额头的撞击力砄开核 桃。

加尔各答是个大城市。如果不是因为炎热, 我们会以为自己是在欧洲。

至于其他的事, 所有人都说这个温度很反常。糟糕的是, 在安巴拉和安拉拉巴 德人们已经跟我们说过同样的话; 我们不由自主地开始得出结论, 就是在我们停留 的地方, 反常就是经常。

这个城市的一切一一铺好的宽阔大道, 辉煌的建筑, 美丽的花园等等, 无不透 出英国文明的影子。但是, 这种文明的影响无法将环境中那些突出的特点掩盖消 灭, 无论是通过建筑, 诗歌, 宗教, 甚至是印度服饰, 这一切都让城市的特点保留了 下来。

111 马棍: 飞机滚转运动时, 划出的紧迫而猛烈的曲线。不要忘记, 那时的飞机时没有刹车的。(第二版注)

112 属于苏格兰军团的个人。(编者注)

113 波斯语词汇, 用来称呼广场、公共地点。(编者注) 
Uma volta de pista em meio às emanações tórridas e tempestuosas da cidade e aterramos finalmente, com vento por estibordo, provocando um cavalo de pau ${ }^{111}$ para evitar o rebanho de vacas pacíficas que se encontrava pastando no local.

A nossa velocidade média fora de duzentos quilómetros à hora.

Pouco depois, chegam o Rev. Padre Teixeira, cônsul de Portugal, e alguns oficiais ingleses, entre os quais o piloto para ali destacado para nos prestar auxílio. Vem também o cônsul do Brasil, grande amigo do nosso País, que nos abraça com entusiasmo.

Quarenta e dois graus à sombra.

O avião recolhe ao arco de verdura de um dos maciços de arvoredo, e fica sob a guarda de quatro highlanders ${ }^{112}$.

Acompanhados pelos cônsules, pelo tenente Lawe das Forças Aéreas e pelo tenente Mac Donald, dos highlanders, deixamos a pista - o Maidan ${ }^{113}$, como lhe chamam -, seguindo para o hotel.

Depois são as recepções oficiais, a sessão solene promovida pela colónia goanesa (durante a qual nos oferecem, a cada um, como recordação, delicadas taças de prata), a chegada de Gouveia e um banquete diplomático, em que, por consideração por nós, os ingleses consentem em sentar-se à mesa com elementos de cor.

O auxílio que nos presta o Padre Teixeira é, na verdade, comovente. Transmontano de boa têmpera, alma de patriota sincero, de uma iniciativa inteligente e expedita, procede para connosco como verdadeiro amigo. Tenho a impressão de conhecê-lo há séculos.

Durante o banquete, ao qual compareceu todo o Corpo Consular de Calcutá, há duas notas interessantes a registar: o brinde do tenente Lawe, que nos cobre dos epítetos mais lisonjeiros, pela simples razão de termos ousado continuar semelhante viagem num tipo de avião que nunca tínhamos pilotado, e o original processo usado pelo tenente Mac Donald para quebrar nozes, quando, já sob o efeito das libações, nos demonstra a resistência da sua caixa craniana, estalando-as à força de pancadas assestadas com a testa.

Calcutá é uma grande cidade. Sem o calor, poder-nos-íamos julgar na Europa.

De resto, dizia toda a gente, aquela temperatura era excepcional. O pior é que já em Ambala e Allahabad, nos tinham dito a mesma coisa; e a gente, involuntariamente, começa a concluir que, nestas paragens, a excepção é frequente.

Nas amplas avenidas asfaltadas, nos esplêndidos edifícios, nos jardins encantadores, em quase tudo se observa a influência da civilização britânica. Todavia, essa influência não conseguiu eliminar do ambiente aquilo que nele se projecta através da arquitectura, da poesia, da

\footnotetext{
${ }^{111}$ Cavalo de pau: Curva apertada e brusca descrita pelo avião ao rolar. É de lembrar que, ao tempo, os aviões não possuíam travões. (Nota da 2. ${ }^{a}$ edição).

${ }^{112}$ Indivíduo que pertence ao regimento escocês. (Nota do editor).

${ }^{113}$ Palavra persa que designa praça, local público. (Nota do editor).
} 
布里托 - 帕艾斯被可怕的炎热折磨坏了, 他到达时有了个简单的愿望: 洗个冷 水澡。

领事为我们在城里最舒适的酒店预订了房间。我看到布里托 - 帕艾斯跑进 房间去, 兴高采烈地打开凉水龙头, 这是他期待已久的快乐! 因为非常怀疑, 他伸出 两根手指试了下温度, 然后迅速地全力缩了回去。我听见他用一种现在常有的忧 郁声音, 泄气地说:

“水在沸腾!”

酒店上面露台上的储水箱从早到晚都被太阳晒着。

布里托 - 帕艾斯并不是容易放弃的男人。他让酒店送来几公斤的冰块, 把冰 块倒在澡盆里。冰块化了, 水还是热的。

有如此之多的词语用来描绘夏天加尔各答火炉般的炎热。

为了满足向我们致敬的人, 我们不得不在此度过了三个夜晚。但我们很想离 开, 实在是难以忍受这里的高温。高温让我们旅游的热望凉了下来。因为担心季 风, 我们急切地想要离开。季风的季节正在逼近。

四日, 我们起飞前往阿恰布。

戈维亚留了下来。在当天黎明的微曦中, 飞机就要起飞了, 我还看见他在 “祖 国二号” 旁。我们应该只有到了澳门才会再次见到他。压抑着心中强烈的不舍之 情, 我们让飞机开始滑行, 他挥着手, 跟我们告别, 祝我们旅途顺利。

在狭窄的跑道上, “祖国二号” 腾空而起, 牛奶色的晨雾依偎着大地, 飞机向上 爬升, 到了恒河三角洲上空, 布里托・帕艾斯注意地看着地图。

支流和运河组成了复杂的河网, 交织成一个解不开的迷宫。看清它需要强大 的眼力。

每一段我们完成的航程都再一次证明了布里托 - 帕艾斯作为领航员的杰出 能力。

地平线上, 出现了季风114最早的信号。

114 季风季是一年当中大风猛烈吹来的季节。这个术语源自阿拉伯语, 用来称呼那些在印度洋上和东南亚能 够感受到的强烈的季节性风, 它与雨季和旱季之间的交替有关; 在此期间, 风从印度西南部吹来, 引起强降 雨。(编者注) 
religião e, até, da indumentária, que se mantém, imprimindo-lhe sempre a sua nota característica.

Brito Paes, horrivelmente atormentado com o calor, tem esta aspiração bem simples ao chegar: tomar um banho frio.

Ao entrar nos aposentos reservados pelo cônsul no hotel mais confortável da cidade, vejo-o correr ao quarto de banho e abrir a torneira de água fria com essa alegria que traduz o antegozo de um prazer longamente esperado. Como duvidando de tanta ventura, avança dois dedos a verificar a temperatura, que o força a retirá-los apressadamente. E ouço-o dizer desanimado, com aquela hipocondria que agora o invade mais a miúdo:

- Está a ferver!

Os reservatórios do hotel, em cima, nos terraços, apanham sol de manhã à noite.

Brito Paes não é homem que desista facilmente. Manda vir alguns quilos de gelo e despeja-os na banheira. O gelo funde, e a água permanece quente.

Tanto basta para descrever o que é, no verão, a fornalha de Calcutá.

Ali somos forçados a passar três noites, para satisfazer aqueles que desejam render-nos homenagem. Mas o nosso desejo de partir e a temperatura insuportável arrefecem em nós qualquer veleidade turística. Vivemos ansiosos por largar, preocupados com a monção, cuja época se aproxima.

No dia quatro, levantamos voo para Akyab.

Gouveia fica. Estou a vê-lo ainda, na madrugada translúcida, acompanhando o Pátria II, que vai tomar posição para descolar. Só devíamos tornar a vê-lo em Macau. E a gente recalca bem fundo a nossa mágoa, de passo que o avião começa a rolar, e ele agita os braços, em gesto de adeus que é um voto de boa viagem.

Na pista escassa, o Pátria II consegue desprender-se do solo, subindo através da névoa matinal, tule cor-de-leite a aconchegar a terra, e avança sobre o delta do Ganges, que Brito Paes atentamente vai confrontando com a carta.

A rede complexa dos braços do rio e dos canais entrecruza-se em labirinto inextricável, que exige uma formidável tensão do olhar.

Cada etapa cumprida, porém, é mais uma prova da extraordinária competência de Brito Paes como observador.

No horizonte, aparecem os primeiros sinais de monção ${ }^{114}$.

${ }^{114}$ A monção é a época do ano em que os ventos sopram em fortes rajadas. O termo, de origem árabe, designa os fortes ventos sazonais que se fazem sentir no oceano Índico e no Sudeste da Ásia, associados à alternância entre 
从吉大港上空经过时, 下面的风景让我记起葡萄牙米尼奥地区的一个小镇 子。只见大块的厚厚的积雨乌云 ${ }^{115}$ 飘在山峰的上方。

“祖国二号” 飞进了阵阵雨中, 旁边是一个个阳光反射出的彩虹圈。彩虹时隐 时现, 发出的光芒映出了飞机的剪影, 圆润的云朵祄在后面。

东南风减慢了我们的航速。

旅程很单调, 我们飞在同样的树木繁茂的地区上空, 沿海散落着一个个小村庄 和袖珍小岛。

我们已经到阿恰布省, 这里平原面积扩大了, 大地上的池塘一个接一个。最后 城市终于出现了。尽管贫穷, 混乱, 但整个城市仿佛镶嵌在一个由清澈的海水和茂 盛的植被组成的画框中。

港口是一个极大的滨海湖, 湖中布满了大大小小的岛屿, 或陡峭, 或平坦, 或荒 凉, 或酒落着小屋, 岛上多石的山峰消失在低云缠绕中。

我们在一片狭窄的土地上降落了, 一个又矮又壮的小伙子跑过来接待我们并 协助我们。这个小伙子一张䵢黑的脸庞被茂密的大胡子遮着。他是潘德雷斯, 陪 伴麦克拉伦环游世界的飞行员。

他立刻准备好帮助我们, 还向我们简要地讲述了英国队的征程:

“在科孚岛我们有了第一次故障 ${ }^{116}$ 。这个时候, 纳皮尔-里昂发动机开始显示 出一些缺点。降落时, 下方的机翼、螺旋桨和起落架都断了。我们不得不等着从 伦敦运来替换零件修复这些故障。飞机被修好了之后, 一直到印度都只发生了一 次故障。那是在从开罗到巴格达的途中, 不过我们还是撑到了拉马迪埃, 并在那儿 把飞机修好了。从卡拉奇到阿格拉, 飞机在帕鲁又发生了故障, 本来因为酷热稀薄 的大气, 我们就很难保持飞行高度。” 潘德雷斯强调说: “即使没有故障, 我们也必须 降落了。因为发动机运转不良引起了新的延误, 我们必须要更换新的发动机, 这样 就不得不等着在巴格达订购的发动机到来。因为第二个发动机不是全新的, 我们 决定在加尔各答进行更换。在阿恰布, 飞机起飞时赶上了下雨, 飞机变得沉重而不 好控制, 因为没有足够长的地面用来滑行, 飞机在地面上达不到足够的速度, 结果 掉到了海滩旁的港口……运气太糟了!”他若有所思地结束了自己的话:

115 一种云, 其特点是垂直扩展明显, 其厚度可高达15公里, 其形状让人想起铁砧的形状。这种云可产生强降 雨, 特别是在炎热的月份, 其内部的风力可达一百五十公里/小时。(编者注)

116 原文为法语, 故障之意。(编者注) 
De sobre a cidade de Chittagong, que faz lembrar, pela paisagem que a envolve, uma vilazinha do Minho, avistam-se grandes massas de cúmulos-nimbos ${ }^{115}$, poisadas sobre as montanhas.

O Pátria II singra entre aguaceiros, acompanhado pelo círculo irisado que é a reverberação da luz solar a decompor-se e a aureolar a silhueta do avião de um resplendor de arco-íris, a acompanhar a sombra sobre as convexidades arredondadas das nuvens.

$\mathrm{O}$ vento Sudeste retarda-nos a marcha.

E a viagem é monótona, sobre a região igualmente arborizada, com povoados que se repetem e pequenas ilhotas guarnecendo o litoral.

Ao atingirmos a província de Akyab, a planície alarga-se, o terreno transforma-se numa série de charcos consecutivos e a cidade aparece enfim, humilde, desordenada, numa curiosa moldura de mar límpido e vegetação pujante.

O porto é uma ria imensa, onde se engastam ilhas grandes, pequenas, alcantiladas, planas, desertas ou polvilhadas de casario, cujos cimos pedregosos se perdem na poalha marfinada das nuvens baixas.

Aterramos no campozito estreito, onde um rapaz baixo e musculado, de rosto moreno sombreado por uma barba fortíssima, acorre a receber-nos e a felicitar-nos. É Panderleith, o piloto que acompanha MacLaren na volta ao mundo.

Põe-se imediatamente ao nosso dispor e conta-nos sucintamente o que tem sido a viagem da equipe inglesa:

- Em Corfu tivemos a primeira panne $e^{116}$. O motor Napier-Lyon começou nessa ocasião a manifestar os seus defeitos. Ao aterrar, partiam-se as asas inferiores, a hélice e o trem de aterragem. Foi necessário esperar que, de Londres, nos mandassem material para substituir o que se avariara. Feitas as reparações, e até à Índia, apenas tivemos uma pequena panne entre o Cairo e Bagdad, conseguindo, no entanto, chegar a Ramadi, onde a reparámos. De Karachi para Agra, nova panne em Parlu, que veio sobrepor-se à dificuldade de manter a altura de voo, devida à rarefacção da atmosfera quentíssima. Creio - acentuou Panderleith que, mesmo sem panne, teríamos sido forçados a aterrar. $\mathrm{O}$ mau funcionamento do motor, porém, implicou nova demora, pois foi preciso substituí-lo e esperar, por isso, a chegada do que tínhamos de reserva em Bagdad. Como o segundo motor não era novo, decidimos substituí-lo em Calcutá. Aqui em Akyab, o avião apanhou chuva e, ao descolarmos, pesado e desregulado, teve de ser arrancado do terreno em perda de velocidade, por não ter campo para rolar, indo cair no porto, junto à praia... Very bad luck! - terminou melancolicamente.

a estação das chuvas e a estação seca, durante a qual os ventos sopram do Sudoeste da Índia, originando chuva intensa. (Nota do editor).

${ }^{115}$ Tipo de nuvem que se caracteriza por uma significativa expansão vertical que atinge até 15 quilómetros de altura e cuja forma lembra a de uma bigorna. Produz chuvas intensas, sobretudo nos meses quentes, e no seu interior os ventos podem atingir até cento e cinquenta quilómetros por hora. (Nota do editor).

${ }^{116}$ Avaria. (Nota do editor). 
“现在我们在等待从东京预订的飞机。一艘美国驱逐舰 ${ }^{117}$ 会把这架飞机我们 运来。”

他的讲述没有丝毫奢望, 甚至是谦逊的。

四个发动机, 一个起落架, 一个螺旋桨, 两架飞机, 在双倍的时间里飞的距离跟 “祖国号”已经飞过的差不多。

英国很大, 英国政府没有干涉过远航的组织工作, 但是这次航程一开始, 英国 政府就向航空队提供了所有的航空资源。

潘德雷斯认为这很自然。

当我们向他讲述自己在航程中经历的事时, 他的嘴唇怀疑地尧了起来, 成了 0 形。

他还是问出来了:

“那葡萄牙战争部呢?”

我们沉默了, 没有勇气告诉他真相。

那天下午, 在不像信德省那么炎热的阳光下, 我们正在准备 “祖国二号” 飞机, 以便第二天可以起飞离开。雷暴正在接近, 我们被压在下面。这时, 下面这封电报 到了:

\section{“请将所有信件交付航空俱乐部。 \\ 席福卡・杜阿尔特”}

我们感到了一种悲伤的预感。各种可能性都有, 但是真相, 令人痛苦的真相 并没有浮现在我们的脑海。那时，我们无法相信葡萄牙会用自己的手试图消灭空 军。

那是一种激情, 其他那么多人都加入进来。我们拒绝担心, 重新沉默地投入了 被中断的任务。

第二天早晨我们要离开的时候, 我们的信心加强了。尽管当潘德雷斯指着有 威胁的天气说了一句话, 使我们的意志力仿佛受到了鞭打。他说:

“季风的迹象……你们得利用季风还没到的开放空间。可是我觉得你们过不 去了!”

东南风卷着灰色的云朵, “祖国二号”起飞之后立刻就要沿着山脊飞行。在一 个小时的时间里, 我们沿着航线飞行, 想要飞行三万零二百米, 突破云雾, 冲向仰 光。这根本不可能。我们机翼的下方, 一块块稻田好像是玻璃组成的网格, 人们哦 叫着禁止我们降落。

117 原文为英语。(编者注) 
- Agora estamos à espera do avião que tínhamos de reserva em Tóquio. É um destroyer ${ }^{117}$ americano que no-lo traz.

A narrativa é feita sem pretensão, quase com modéstia.

Quatro motores, um trem de aterragem, uma hélice, dois aviões para percorrer, no dobro do tempo, uma distância quase igual à que o Pátria percorrera.

A Inglaterra é grande, e o Governo Britânico, que não teve interferência na organização da viagem, pôs, no entanto, desde que ela se iniciou, todos os recursos da aeronáutica à disposição da equipe.

Panderleith acha natural.

E quando lhe contamos as circunstâncias em que fazemos a viagem, dos seus lábios evola-se um oh!? que diz quase cepticismo.

Arrisca mesmo uma pergunta:

- Mas então... o Ministério da Guerra!?

E nós calamo-nos, porque não temos coragem para lhe dizer a verdade.

Nessa tarde, quando, sob um sol que, sem a violência do sol do Sind, pesava contudo sobre nós como à aproximação duma trovoada, preparávamos o Pátria II para partir no dia seguinte, chegava-nos este telegrama enigmático:

«Dirijam toda correspondência Aero Club.

\section{Cifka Duarte»}

Assaltava-nos um triste pressentimento. Hipóteses múltiplas nos ocorreram, mas a verdade, a dolorosa verdade, não aflorou o nosso pensamento. Não podíamos supor que mãos portuguesas pretendessem aniquilar, naquela hora, a Aviação Militar.

Era uma emoção mais a juntar-se a tantas outras. Reagindo contra a preocupação, remergulhamos, em silêncio, na tarefa interrompida.

E à hora da largada, na manhã seguinte, a nossa confiança recrudescera, como se a nossa força de vontade tivesse recebido uma chicotada, mau grado a frase de Panderleith, a apontar-nos o tempo ameaçador:

- Sinais de monção... É preciso aproveitar uma aberta! Mas parece-me que vocês já não passam!

O Pátria II descola sob a cinza das nuvens que o Sudoeste varre, e aproa imediatamente à cordilheira. Durante uma hora, navegamos no rumo, procurando de trinta a mil e duzentos metros, um rasgão da névoa, por onde romper para Rangoon. Impossível. Sob as nossas asas, o terreno encharcado é uma quadrícula de vidro, no recorte dos arrozais, a gritar-nos a proibição de aterrar.

\footnotetext{
${ }^{117}$ Navio de guerra. (Nota do editor).
} 
东北风推动着风暴, 与我们迎面相撞, 就像被一种听不见的声音控制的、长着 翅膀的妖魔似的。渐渐的, 就像埃德加 - 爱伦坡的 “陷阱与钟摆” 118 中描写的那样, 云雾开始下降到了水田上方, 抓住了我们, 包围了我们, 迫使我们后退。

布里托 - 帕艾斯以一贯的冷静地站在自己的位置上, 似乎在读取这些沿海列 岛的每一个岛屿, 他在地图上读出的每一个名称都浮现在我眼前, 当听到他的声音 向我指出路线, 我听到的是一个在大风大浪中指挥若定的船长。

我们飞过宽阔的海上通道, 绕过多山的岛屿, 有时岛上有些小村庄, 如画的风 景消失在我们的惶恐不安中。最后, 看到了艾雷瓦岛那狭窄的怀抱向我们敞开, 我 们终于在云拱下跨入了岛上的咽喉之地, 阿恰布再次收容了我们, 最后一缕被遗忘 的阳光照在跑道上。

因为还早而且天气有变坏的趋势, 我们立刻加满了汽油和润滑油。

一群好奇的缅甸人围住了我们的飞机, 他们穿着古怪的服装一一颜色鲜艳的 宽裤子, 中国式遮阳帽, 深色的和式上衣。在晴朗的早晨, 他们的衣服在深翡翠色 的大海上背景下脱颖而出, 把风景描画得五颜六色。

缅甸人长着一张男子气概的脸, 口腔由于不停地嚼摈榔 ${ }^{119}$ 变黑了, 厚厚的嘴唇 中间总是叺着长长的雪茄, 让人有种丑婳的印象。我们不明白怎么可能对缅甸会 产生喜爱之情, 但缅甸人并不这么想, 这是子午圈的问题……

这群人兴奋地蹲在地上, 似乎有些目瞪口呆。

我们被招待住在高级专员的独立屋中。下午, 他带我们去郊区转了一圈。

热带植被让公路和道路变成了树叶组成的高䇯的殿堂, 让我们产生了一种这 是陌生的巴西亚马逊的感觉。

下午降临时, 我们的心灵感受到了一种宁静。但这宁静消失在一种柔和的 色调中, 坠入了雷暴的天空。人们能听到大海在近处缓慢地呼吸, 发出奇怪的回 声.......

当天晚上我们跟迈克拉伦 ${ }^{120}$ 进行了交谈。

118 埃德加 - 爱伦坡 1842 年出版的短篇小说。爱伦坡是一位美国作家、诗人和文学评论家, 他不但创立了犯 罪小说, 也是美国第一位短篇小说家。(编者注)

119 槟榔果是槟榔树的种子, 由于其刺激和促进兴奋的作用而在这群亚洲人中被广泛使用。长时间使用会使 唾液呈红色, 牙齿发黑。(编者注)

120 英国飞行员。他在1924年这年企图环游世界。(编者注) 
A tempestade, que o vente impele para Nordeste, caminha ao nosso encontro, como teoria de monstros alados que uma inaudível voz comande. A pouco e pouco, como em $O$ poço e o pêndulo, de Edgar Poe ${ }^{118}$, a chapa da névoa desce sobre a chapa quadriculada da inundação, aperta-nos, faz-nos cerco e força-nos a recuar.

Com o sangue frio de sempre, parecendo ler em cada ilha desse arquipélago costeiro o nome que lê na carta, Brito Paes, de pé, no seu lugar, afigura-se-me, quando o olho, ao ouvi-lo indicar-me a rota, um comandante de navio em horas de vendaval.

Passamos sobre largos canais marítimos, contornamos ilhas montanhosas, por vezes tatuadas de aldeolas, cujo pitoresco se perde na incerteza dos momentos que vivemos, penetramos finalmente na goela hiante que o colo estreito da ilha Aleywa escancara para nós, sob uma arcada de nuvens, e Akyab acolhe-nos de novo, quase sorrindo numa última réstia de sol que se ficou, esquecida, sobre a pista.

Como é cedo ainda, e o tempo ameaça piorar, completamos imediatamente os plenos de gasolina e óleo.

Em torno do aparelho, reúne-se uma curiosa turba de birmaneses, cujos trajos extravagantes - calções largos de cores vivas, guarda-sóis chineses, quimonos sombrios - pintalgam a beleza da paisagem que, na luz dúbia da manhã coberta, destaca sobre o mar o seu forte colorido de esmeralda.

A birmanesa, de rosto másculo, boca enegrecida pelo betel ${ }^{119}$ que não cessa de mascar, longo charuto constantemente espetado nos lábios grossos, impressiona pela fealdade. A gente não compreende como pode haver paixões na Birmânia. Contudo, os birmaneses não pensam da mesma maneira. Questão de meridiano...

Aquela multidão, acocorada em êxtase, parece petrificada de admiração.

De tarde, com o Alto Comissário, em cujo bungalow estamos hospedados, damos uma volta pelos arredores.

A vegetação tropical transforma estradas e caminhos em altíssimas naves de folhagem e suscita em nós imagens amazónicas de um Brasil desconhecido.

Há tão grande serenidade no cair da tarde, a esvair-se em tonalidades macias e a escorrer no céu de trovoada, que a gente sente na alma, repercutindo estranhamente, a respiração lenta do mar que se ouve perto...

Falamos, nessa noite, com MacLaren ${ }^{120}$.

\footnotetext{
${ }^{118}$ Conto de Edgar Allan Poe, publicado em 1842. Poe foi um escritor, poeta e crítico literário americano, criador da ficção policial, tendo também sido o primeiro escritor americano de contos. (Nota do editor).

${ }^{119}$ A noz de betel é a semente da palmeira de areca, muito usada por esta população asiática pelas suas propriedades estimulantes e propiciadoras de bem-estar. $\mathrm{O}$ seu uso prolongado concede à saliva um tom avermelhado e aos dentes, uma cor negra. (Nota do editor).

${ }^{120}$ Piloto inglês que, nesse ano de 1924, tentava dar a volta ao mundo. (Nota do editor).
} 
他的言语中透出一种钢铁般坚韧的意志。他的眼中则反射出一种不是气馁 而是令人不安的悲伤情绪, 因为他看到了残酷的现实正在摧毁一个人的梦想, 而这 个满怀梦想的人在忍受着痛苦。

我们告诉他自己想要飞越若开山脉, 前往仰光。这座山的山脊把我们和伊洛 瓦底河谷分开。他坦言不同意:

“现在这季节太可怕了。山脉总是被云雾环绕, 整座山脉没有一块巴掌大的地 方让你们可以稍作休整……” 他犹豫了一下, 仿佛有些担心, 但是最后还是说了出 来: “我打算沿着海岸走。我认为这个季节不可能越过山脊。”

外面雷声隆隆, 回声绵延不绝。大雨倾盆而下, 一道道闪电不断地划过天际。

在电闪雷鸣之间的空隙, 外面听到雨水敲在窗上。

麦克拉伦 ${ }^{121}$ 做了个手势, 他没确认是什么意思……

饮用了一杯鸡尾酒之后, 这个夜晚结束了。这杯酒是为庆祝在这次航行中, 我 们已经取得的成绩。告别时, 无论如何我们都和这位英国飞行员相约 6 月 20 日下午 茶的时间在香港相见。

早晨六点的天空显得很慈悲, 让我们在起飞后不久就能够爬升到四千米。

若开山脉那充满敌意的沟壑开始在 “祖国二号” 的机身下展开。蓝天下, 飞机 在高空卷云和低空积云之间滑过, 机翼擦着云飞过。

下方茂密的森林像是乱七八糟卷成一团的狮髦毛, 似乎有野兽在里面呼吸…… 不可抑制的, 飞机有故障 ${ }^{122}$ 的想法在我们脑中一闪而过。

山上的一道洪流就是一道伤口。从林中一条窄窄的小道蜿蜒曲折, 好像到处 都是老虎, 猎豹……

若开山的沟沟壑壑都在退去, 飞机在棉花般的云朵下飞行, 阳光强烈地照射着 云彩。飞机装备的自由神发动机毫不含糊地发出欢快的金属震动声。

山的高度在渐渐降低; 伊洛瓦底河谷在山脚下蔓延, 巨大的积云影子映在上 面。

兴时达地区坐落在泥泞汹涌的河水旁, 它金色的佛塔和庙宇曲线优美的屋顶 都深受中国艺术的影响。

我们降到了一千米的高度; 热浪逼近我们; 疲劳的感觉阵阵来袭。 
As suas palavras denotam a tenacidade de uma vontade férrea. Nos seus olhos, reflecte-se uma tristeza que não é desânimo, mas que perturba, porque traduz o sofrimento de alguém que teve um grande sonho e vê a realidade obstinada em destruí-lo.

Quando o informamos da nossa intenção de seguir para Rangoon, sobrevoando o Arakan Yoma - a cordilheira que nos separa do vale do Irrawaddy - discorda francamente:

- A época é terrível. A montanha está sempre coberta de nuvens e não há, em toda ela, um palmo de terra onde pousar... - Tem uma hesitação, como se receasse falar, e termina, vencendo-se: - Eu tenciono seguir a costa. E não julgo possível fazer, nesta época, a travessia da cordilheira.

Fora, os trovões ribombam, prolongados por ecos soturnos, e um aguaceiro cai, iluminado pelos relâmpagos que esfuziam ininterruptamente.

Quando, a espaços, súbitos silêncios se alargam por instantes, ouve-se o cantarolar da chuva nas vidraças.

MacLaren ${ }^{121}$ tem um gesto que não chega a definir-se...

A noite termina com um coktail bebido pelo êxito das nossas viagens e, à despedida, 0 aviador inglês, apesar de tudo, marca-nos rendez-vous em Hong Kong, no dia 20 de Junho, à hora do lanche.

O céu, benévolo na manhã do dia seis, permite-nos atingir quatro mil metros, pouco depois de partirmos.

O Arakan Yoma começa a desenrolar sob o velame do Pátria II, que sulca o espaço entre os cirros tenuíssimos que empedram o azul e os altos cúmulus que as asas roçam, a hostilidade das suas ravinas.

A floresta densa, em baixo, tem o aspecto emaranhado de uma juba da cordilheira. Pressente-se a respiração das feras... E irresistivelmente, a ideia de panne ${ }^{122}$ crepita um segundo na nossa mente.

Uma torrente é um gilvaz da montanha. Na selva, onde as sinuosidades de uma pista estreita parecem rastos de traça, aqui e além, há tigres, panteras, jaguares...

Os recôncavos do Arakan vão passando, sob o algodoado das nuvens fortemente iluminadas, onde a canção metálica do Liberty ressoa sem o menor desfalecimento.

Pouco a pouco, a altitude da montanha diminui; o vale do Irrawaddy alastra no sopé, manchado a nanquim pela sombra de cúmulus agigantados.

Henzada, com seus pagodes dourados e seus templos de tecto curvilíneo, onde se nota já a influência da arte chinesa, dormita junto ao rio barrento e caudaloso.

Descemos para mil metros; o calor aperta; a agitação do ar fatiga.

\footnotetext{
${ }^{121}$ Ver nota anterior. (Nota do editor).
}

${ }^{122}$ Avaria. (Nota do editor). 
在通往仰光的路上, 风景变得单调。我们离开了伊洛瓦底河, 沿着曲折的铁路 线向前飞, 弯弯的铁路线跟一条公路白色的犁沟交织在一起, 旁边是细水长流的小 河一一荷朗河。

在永盛州上空, 我们遇到了两场密集的大雨。一座座紫褐色的斜塔直指天 穹。

在树从中仰光那发红影子出现了。城中湖光点点, 到处都是佛塔, 在我们的 高度看这些像是在看金色的微型装饰品。

让我们用来降落的跑道是一条赛马道, 比加尔各答的梅丹 ${ }^{123}$ 还差: 长七百米, 宽 三百米, 坐落在城市正中心, 周围都是树木, 教堂的塔, 佛塔和小屋的顶部。

像往常一样, 风横着吹过来, 尽管从我们得到的信息来看这种情况从未发生 过。

6 月 6 日是特别的一天。

驾着飞机从大佛塔的顶尖下面飞过并躲过蜘蛛网一般的电话线之后，我终于 在第三次尝试时降落了下来。

人们立刻围了过来, 包括葡萄牙驻缅甸领事阿莱舒・德索萨先生; 民用水上飞 机站站长坎普先生; 飞行员帕特里克少校; 高级专员处和军事司令部的代表; 记者, 摄影师和警察等等。

因为长时间飞行在高空四千米处且无补充氧气, 我们觉得特别累。

我们以此为由去了“标准酒店”。在酒店, 吃了一顿美味的午餐后, 我们像块石 头一样在床上沉沉睡去, 沉浸在比铅块还重的困倦中。

我们醒来的时候, 外面大雨倾盆; 我们想起了放在露天的飞机一一因为没有机 库, 此时它正被大雨浇着一一不由不安地互相望着。可是我们什么也做不了, 为了 不在无用的意志消沉中失去活力, 我们只有屈从。

我们回到了飞机场, 坎普先生和他的机械师们正在维护准备 “祖国二号”。他 很惊讶, 因为我们把自己的飞机交到了陌生的手中; 如果我们这么做了, 那是因为 能够感觉到, 人们是那样热情谨慎地向我们提供协助。

据说全世界的飞行员和机械师从公元1924年开始在飞行比赛中都致力进行 合作。

尽管没有从里斯本收到过任何官方消息, 但从 “祖国号” 离开千泉新城起, 葡 萄牙领事就一直在等着我们。他交给我们一张二十英镑的支票并告诉我们说, 这 些钱是他在全国认捐中所负担的份额, 而认捐活动是为了资助我们这次飞行。在 他的眼中, 闪着激动和热情, 充满了爱国情怀的光芒。我们沉默地紧紧握了握彼此 的手, 这比任何能说出的言语更加雄辩。

123 波斯语词汇, 用来称呼广场、公共地点。(编者注) 
A paisagem monotoniza-se e, a caminho de Rangoon, deixamos o Irrawaddy, para seguir a linha férrea que coleia, entrançada no sulco branco de uma estrada, junto ao riacho delgado que é o rio Hlang.

Sobre Insein, passamos entre dois aguaceiros espessos, altas torres inclinadas, de uma cor castanho-alilazada, onde se apoia a abóbada do céu.

A mancha de Rangoon vermelheja enfim, envolta no arvoredo de em torno, com seus lagos e o seu notável pagode, que, da nossa altitude, fica reduzido às proporções de um pequeno bibelot em oiro.

A pista - um campo de corrida de cavalos - é pior ainda que o Maidan ${ }^{123}$ de Calcutá: setecentos metros de comprimento por trezentos de largura, em pleno centro da cidade, entre árvores, torres de igreja, pontas de pagode e casario.

Como de costume, o vento sopra transversalmente, muito embora das nossas informações constasse que tal circunstância se não dava nunca.

O dia seis de Junho era, portanto, outro dia excepcional...

Consigo aterrar à terceira tentativa, depois de passar mais baixo que o alto minarete do Grande Pagode e de escapar à teia de aranha dos fios telefónicos.

Rodeiam-nos imediatamente o Dr. Aleixo de Sousa, cônsul de Portugal na Birmânia; Kemp, chefe de uma estação civil de hidroaviões; o major Patrick, aviador; os representantes do alto comissário e do comandante militar; jornalistas, fotógrafos e polícia.

A viagem cansou-nos extraordinariamente, devido à longa permanência a quatro mil metros, sem oxigénio suplementar.

Desculpando-nos, por isso, seguimos para o Hotel Criterion, onde, depois de um bom almoço, caímos na cama como duas pedras e mergulhámos num sono de chumbo.

Ao acordarmos, chove a cântaros; olhamo-nos inquietos, ao pensar no avião, que, desabrigado - não há hangar -, apanha o aguaceiro em cheio. Mas nada há a fazer; e a gente resigna-se, para não perder energia em enervamentos vãos.

Voltamos ao campo, onde Kemp, com os seus mecânicos, está tratando de preparar o Pátria II. Surpreenderá que assim o abandonássemos a mãos estranhas; se o fazíamos, é porque sentíamos quanto era solícito e escrupuloso o auxílio que nos prestavam.

Dir-se-ia que todos os aviadores e mecânicos do mundo estavam empenhados em colaborar na grande competição aérea desse ano da graça de 1924.

O cônsul de Portugal, que, desde a partida do Pátria de Vila Nova de Milfontes, nos espera, muito embora nenhuma comunicação oficial tenha recebido de Lisboa, entrega-nos um cheque de vinte libras. Essa importância é - diz-nos ele - a sua quota na subscrição nacional que tem subsidiado as despesas da viagem. Adivinha-se-lhe no olhar a comoção, o entu-

\footnotetext{
${ }^{123}$ Palavra persa que designa praça, local público. (Nota do editor).
} 
仰光是缅甸首都, 人口稠密。它是优秀的商业中心, 各种商业活动的熔炉。居 民们很能适应此地让人衰弱的气候条件。

路上很热闹, 人和车都川流不息。汽车、人力车和大木车混在一起。人力车 只有两个轮子, 一个中国人在拉着; 而拉大木车的都是一些肌肉发达的男人, 他们 像活动铜雕似的走在路上。

我们参观了皇家湖, 它有一种东方诗歌似的神秘。这里, 有一些意想不到的角 落, 树荫点缀着小路, 这些树木只有赤道两旁才有。

夜晚降临, 巨大的吸血鬼们慢慢拍打着翅膀, 掠过城市, 像巨大的黑色果实似 的悬在最高的树枝上。

缅甸人在世界化的环境中迷失了, 这里中国人占主导地位, 欧洲人则以军人为 主。

在两天的时间里, 大雾和雨水紧紧相随, 跑道被淹没, 我们看不到蓝天。

跑道变得泥泞不堪, 起飞很困难。为了方便起飞, 我们把后备的螺旋桨和起落 架从飞机中拿了出来, 把它们交给了领事先生; 而领事则将把它们交给戈维亚。

尽管天空被雾笼罩, 我们还是决定 9 日离开。带着抽紧的心脏, 口中念着信经, 我们沿机场边缘驾着飞机, 一丝不苟地利用每一厘米的跑道。

这是最后的告别, 我们开始滑行。

飞机紧张地爬升了三百米, 向一颗弹丸似的射了出去, 从新教徒哥特式教堂的 尖顶勉强飞过, 飞上天空。空中, 太阳把厚厚的云层撕开了一个大口。接着, 我们 一直在爬升, 绕梅丹124一圈, 告别了缅甸, 向东南方的曼谷飞去。

124 参阅前面的注解。(编者注) 
siasmo, o fervor patriótico. E nos silenciosos apertos de mão que trocamos há mais eloquência do que em todas as palavras que pudéssemos dizer.

Rangoon, capital da Birmânia, é um agitado formigueiro humano; centro comercial por excelência, cadinho de actividades, cuja população vive adaptada às condições climatéricas debilitantes.

Nas ruas, o movimento é intenso e ininterrupto. Aos automóveis misturam-se rikshós pequeninos carros de duas rodas para uma só pessoa, que um chinês puxa - e grandes carroças tiradas por homens musculados quase nus, que se deslocam como estátuas vivas de bronze.

O Lago Real, que visitamos, tem o mistério de um poema oriental, com recantos inesperados, caminhos matizados de sombras, aquelas sombras que projectam árvores como só há para os lados do Equador.

Ao cair da noite, vampiros enormes esvoaçam num lento bater de asas e poisam, ficando suspensos, como grandes frutos negros, dos galhos mais altos.

O birmanês perde-se no cosmopolitismo do ambiente onde predomina o chinês e os europeus se contam por milhares.

Durante dois dias, nevoeiro e chuva se sucedem, encharcando a pista e vedando-nos o azul.

A fim de facilitar a descolagem difícil, na pista exígua que a humidade amoleceu, a hélice e o trem de aterragem que trazíamos de reserva são retirados de bordo e entregues ao cônsul, que por seu turno os entregará a Gouveia.

E no dia nove decidimos partir, não obstante o céu enevoado. Com o coração apertado e o credo na boca, conduzimos o aparelho à orla do campo, no meticuloso aproveitamento de todos os centímetros.

Os últimos adeus, e começamos a rolar.

$\mathrm{O}$ avião galga nervosamente trezentos metros, lança-se no espaço como um projéctil, passando quase tangente às agulhas góticas da catedral protestante, e entrega-se ao sol que brilha num largo rasgão das nuvens. Depois, subindo sempre, dá uma volta sobre o Maidan ${ }^{124}$, despede-se da Birmânia, e aproa a Sudeste, rumo a Bangkok.

${ }^{124}$ Ver nota anterior. (Nota do editor). 


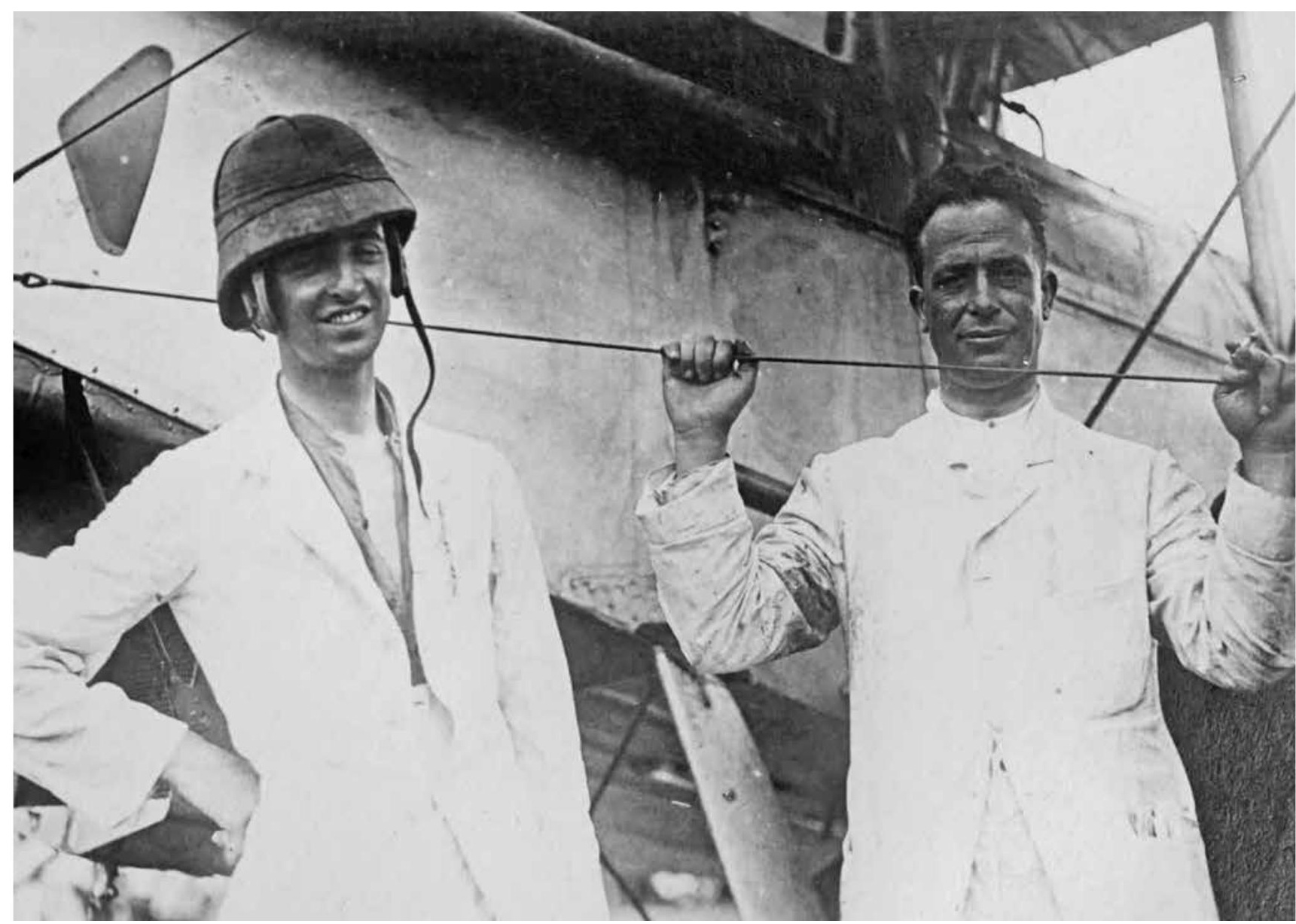

Sarmento de Beires e Brito Paes na chegada a Rangoon

萨尔门托・德贝雷斯和布里托 ・ 帕伊斯抵达仰光 


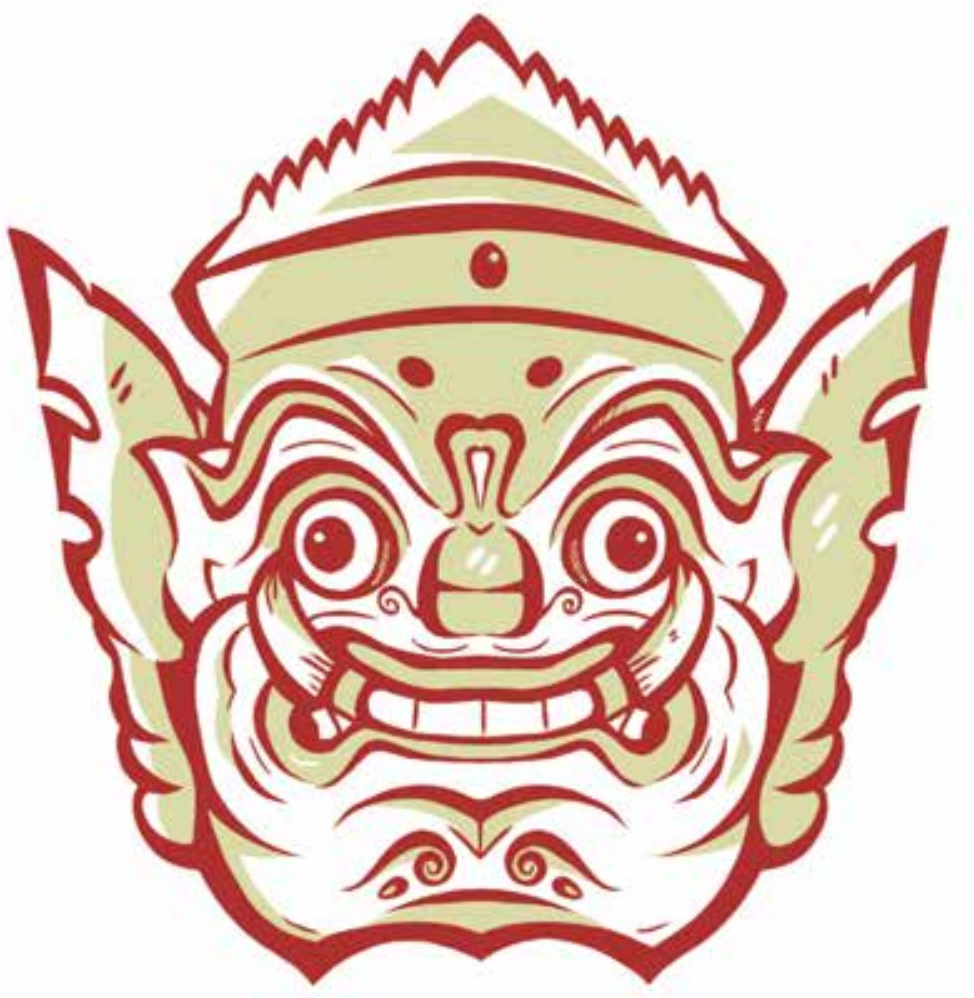




\section{XI \\ DA BIRMÂNIA AO TONQUIM 十一、从缅甸到越南东京}


我们在仰光以东四十公里处离开了海岸。当时, 飞机左舷的一股海龙卷风水 柱正被强风卷着远去。

我们再次飞行在海面与天空之间。在这个暴风雨的清晨灰色的光线下, 水面 像是一块锈迹斑斑的板, 上面洒满了硝石结晶。

在一刻钟的时间内，地面从地平线消失了。接着，我们朝白色的毛淡棉市飞 去一一这座城市坐落在翠绿色的平原上, 平原上散落着一块块玻璃似的水田。

在更远的地方, 特纳瑟利姆山愤怒地隆起, 像是白鼠斗篷上的一条带子, 这里 或那里被一些险要、高䇯的山峰撕裂。

穿过云层, “祖国二号”爬升到了四千五百米的高度, 飞在皑皑白雪的上方。清 澈的天空中, 太阳在闪耀。

一股钻心的冷气穿透了我们, 让人冷得直打颤。我们都有点思念曾在印度忍 受的炎热了......

偶尔的, 在大块的水积云中间, 可以远远望见山脉的两侧都被茂密的森林覆 盖。

下方似乎有野兽的气息, 传到我们耳中就成了一种奇怪的声音。

随着 “祖国二号” 向前飞, 云变少了, 风暴渐消。

当我们进入湄南河流域后, 平原开始延伸成了一片片种植着低矮植被的广亭 大地。我们被它吸引住了, 为了离得近些, 就降低了飞行高度。天空湛蓝, 一如葡 萄牙的天空。

这里没有公路, 只有一条铁路线, 像是煤做的黑线似的蜿蜒在五颜六色的土地 上。

在阿瑜陀耶上空, 又可以看到水田了, 这时航程恢复了令人恼火的特性。

快两点的时候, 廊曼机场的露台像个白色的四边形在地平线上显现出来。我 们高兴地降落了, 因为跑道棒极了, 而且, 五个小时多一点的航程相对来说是很平 静、安宁的。

暹罗航空的工作人员像所有曾经接待过我们的航空人员一样, 有着高贵的灵 魂, 他们用亲密、友爱、充满热情的态度接待了我们。

此地航空中心的司令官将军和许多军官一起在机场等待我们, 他用法语告诉 我们: 一支机械师团队, 还有飞机所需的燃料, 都可归我们调配使用。

飞机需要更换升降舵舵柄的一条电缆, 修补机篷。我们向修理车间的主管说 了一下情况, 这位空军少尉全神贯注地听着我们的话。我们把 “祖国二号” 交到了 他的手中。 
Quarenta quilómetros a Leste de Rangoon, largamos a costa, enquanto por bombordo uma espessa tromba de água se afasta, turbilhonada pela ventania.

Mais uma vez navegamos entre céu e mar. Na luz cinza da manhã tormentosa, a superfície das águas tem o aspecto de uma chapa de ferrugem salpicada por cristais de salitre.

Durante um quarto de hora, a terra desaparece do horizonte, para surgir depois, na alvura de Moulmein, incrustação na planura esmeraldina, de onde a onde manchada pelas nódoas vítreas da inundação.

Mais longe, a cordilheira de Tinasserim soergue-se como enraivecida, toda envolta num manto de arminho, esfarrapado aqui e além pelos cumes mais agudos e mais altos.

Voando através das nuvens, o Pátria II atinge quatro mil e quinhentos metros, sobre uma toalha de neve, no templo infinito do céu límpido onde o sol rebrilha.

E quase temos saudades do calor que suportámos na Índia... Um frio penetrante trespassa-nos e faz-nos tiritar.

De quando em quando, os flancos da cordilheira cobertos pela floresta densa apercebem-se por entre nuvens de grandes ventres hidrópicos.

E a respiração das feras parece ainda desprender-se lá de baixo, e chegar até nós, por uma bizarra anomalia acústica.

À medida que o Pátria II avança, as nuvens rareiam, e dissipa-se a tempestade.

Quando entramos no vale do Mae Nam Chao Phraya - riozito pouco mais largo que o próprio nome -, a planície alonga-se em vastas campinas de vegetação baixa que nos atraem, num convite mudo a voar mais perto, sob um céu de iluminura, tão azul como o céu de Portugal.

Não há estradas. Apenas uma linha férrea risca, no colorido uniforme do terreno, um traço de carvão.

Sobre Ayutia, os campos alagados recomeçam, e o voo retoma o seu carácter de farândola irritante.

Próximo das duas horas, a esplanada do aeródromo de Dawn Muang recorta-se como quadrilátero alvacento no horizonte. E aterra-se com prazer, porque a pista é magnífica e o voo, que durou pouco mais de cinco horas, foi relativamente calmo e repousante.

A aviação siamesa recebe-nos como todas as aviações nos receberam: com espírito de classe, carinho, simpatia e amizade.

O general comandante do Centro, que nos esperava no campo com vários oficiais, informa-nos em francês de que temos à nossa disposição uma equipe de mecânicos e todo o combustível de que necessitarmos.

É necessário substituir um cabo do comando do leme de profundidade e remendar a tela da fuselagem. Disso informamos o director das oficinas, oficial piloto que nos escuta atentamente e a quem deixamos entregue o Pátria II. 
我们四点钟乘上了火车, 前往位于此地南边二十公里处的曼谷。在曼谷, 接待 我们的是军队参谋长一一他是国王的兄弟; 还有葡萄牙代理领事, 他是个温存而做 作 ${ }^{125}$ 的意大利人, 对待我们有一种特别重视礼仪、注重阶层的态度。

为了能够在领事馆被接待, 我们需要提前若干分钟请求, 然后在一间大厅中再 等上长长的十五分钟。那间大厅很没有品味。

在酒店, 领事向我们赠送了晚宴。他很小心地刮过了胡子, 刮得干干净净的面 孔像是女性的一样。为了让脸变得柔软, 他在上面敷了一层薄薄的米粉。这张脸 上同时透出对我们的冷漠和殷勤, 前者是我们应得的, 后者则是他的官方职位所 必须要有的。

不过在俱乐部里我们度过了充满真挚情感的时刻。当时, 英国人, 法国人和暹 罗飞行员为了我们所取得的成绩热情地举杯庆祝。

从我们到达此地, 一位谦逊, 近乎谦恭的澳门土生葡人, 名叫若阿金 - 安东尼 奥的领事馆员工就一直陪着我们。当他想把自己的感觉用话语表露出来时, 那是 一种发自内心的喜悦。

出自这种自发的热情和朴实, 他的双手放在向我们赠送的纪念品上摩挲着。

第二天, 即6月10日, 我们再次乘火车回到了廊曼机场。我们还不能离开, 因为 检查飞机发动机时, 发现一个抽油洜坏了。在指示了应该怎样维修之后, 我们信任 地把修理任务交到了暹罗机械师们的手中。

为了消磨时间, 打发无聊, 我们把廊曼机场的修理和储备设施走了一遍。我们 非常惊讶, 目瞪口呆——我们有什么可不信任的呢?而想起自己国家的航空事业状 况时, 我们不禁悲从中来。

这个机场的跑道十分大一一有两平方公里，机场拥有八个砖石结构的机库。 向机库敞开的大门里望去, 只见里面停满了各种各样的飞机, 有教练机, 战斗机, 轰 炸机, 观测机, 豪车 ${ }^{126}$ 等等。这些五花八门的飞机代表了三个品牌: 双操纵杆的纽波 特飞机; 纽波特-德拉热战斗机; 其它用途的布雷盖飞机。

不远处, 车间里在有条不紊地进行着加工工作, 充满了机器嘈杂的轰鸣声, 它 们正在为飞机准备制造材料。所有的部件都是在这里被制造组建起来的, 只有发 动机和一部分原材料是进口的。

定期空中邮政服务是由军队的军官们来执行的, 邮政收入是空军收入的一个 重要来源。

暹罗全境散落着七十二个飞机场, 这鼓舞起航空爱好者们的信心, 乘客人数日 益增加。

125 原文为法语。(编者注)

126 指的是非常豪华的超长轿车, 一般为白色或黑色, 通常是很有钱的人或是在特别的聚会场合才使用。 (编者注) 
Pelas quatro horas, tomamos lugar no comboio que nos leva a Bangkok, vinte quilómetros a Sul, e ali somos recebidos pelo Chefe do Estado-Maior, irmão do Rei, e pelo cônsul interino de Portugal, italiano melífluo e poseur ${ }^{125}$, que tem para connosco atitudes cerimoniosas e ultra-protocolares de ministro importante e cioso da hierarquia.

Para sermos recebidos no Consulado, precisamos de fazer-nos anunciar com alguns minutos de antecedência e de esperar quinze minutos largos, num salão de mau gosto, com pretensões a Luís não sei quantos.

Oferece-nos um jantar no hotel e reflecte-se-lhe na face bem barbeada, cuidadosamente barbeada, femininamente escanhoada, que uma leve camada de pó de arroz amacia, a indiferença que lhe merecemos e a amabilidade forçada do cargo oficial.

No clube, porém, há um minuto de sincera emoção, entre franceses, ingleses e aviadores siameses, que brindam pelo nosso êxito, calorosamente.

Modesto, quase humilde, o macaense Joaquim António, empregado do Consulado que nos acompanha desde a chegada, é uma alegria íntima a querer traduzir-se em palavras, a querer expandir o que sente.

Nas lembranças que nos oferece, as suas mãos põem uma vibração de entusiasmo espontâneo e de simplicidade cativante.

Na manhã seguinte - 10 de Junho -, o comboio leva-nos de novo a Dawn Muang, donde não conseguimos descolar, por verificarmos, ao experimentar o motor, que uma das bombas elevatórias de gasolina se encontrava avariada. Depois de indicarmos como deve ser feita, confiamos a reparação a um dos mecânicos siameses.

Para matar tempo e tédio, percorremos as instalações das oficinas e depósitos de Dawn Muang, que nos surpreendem, que nos maravilham e - por que não confessá-lo? - que nos entristecem, ao recordar a miséria em que vive a nossa aviação.

Na pista imensa - dois quilómetros quadrados -, os oito hangares de alvenaria deixam ver, pelas grandes portas abertas, numerosos aviões de instrução, caça, bombardeamento, observação, limousines ${ }^{126}$ e ambulâncias. Esta multiplicidade de tipos representa, todavia, três únicas marcas: Nieuport, para o duplo comando; Nieuport-Delage para caça; e Breguet para os restantes serviços.

Não muito longe, as oficinas em cujo acabamento se trabalha estão cheias do labutar ruidoso das máquinas que preparam material para os aparelhos, cuja célula é inteiramente construída ali, sendo exclusivamente importada uma parte das matérias-primas e o motor.

O serviço-postal aéreo, executado por oficiais do exército, funciona regularmente, constituindo para a Aeronáutica Militar uma importante fonte de receita.

E como os setenta e dois aeródromos que polvilham o território siamês inspiram confiança aos dilettanti do ar, o número de passageiros aumenta de dia para dia.

\footnotetext{
${ }^{125}$ Pessoa afectada, pedante.

${ }^{126}$ Carro muito longo e luxuoso, normalmente de cor branca ou preta, geralmente usado por pessoas muito ricas ou em ocasiões de festa muito especiais. (Nota do editor).
} 
我们观察着, 倾听着, 比较着。

实际上, 暹罗政府的标准和葡萄牙大多数政府的标准之间差别很大……

关于这个遥远的亚洲国家, 我们习惯把它想象成一个民智落后的国家, 但其航 空业却被视为是在战争与和平中不可或缺的武器。确实, 它不能跟大国空军相比, 这是一个跟我们一样的小国, 然而, 它的航空业已经值得一提。

而在我们的国家……国会1921通过的年度预算，现在已经被不相称地、荒谬 地削减了, 由于飞行员们的善意和他们作出的牺牲, 这预算才能让葡萄牙空军依然 保持活力 127 。

当钱瑞夫盖恩上尉领着我们穿过一个个车间时，这些想法在我们的脑海中闪 过。

午后的天空, 沉重的乌云在翻滚, 我们怀着惆怅的思乡之情想念葡萄牙故 乡.......

11日，天气不好不坏一一风雨交加中我们到了乌汶。这段航程我们的航速为 每小时183公里, 布里托・帕艾斯再次展示出他永远都是一个伟大的航行者。

在这段航程中, 在呵叻有一个备用机场, 巨大的白色十字架标示出了它。

下方, 两座高算的山脉之间一条狭窄的通道, 茂密的森林覆盖了它, 上面是铁 路线蓝莹莹的路轨, 一列火车沿着铁轨那平缓的曲线慢慢前行。

乌汶是暹罗内部一个简朴的小城, 几乎就是个小村庄。

在这里接待我们的是一位飞行员中士，他只会说两三个法语单词。一位让人 无法理解的翻译协助我们。

尽管如此, “祖国二号” 立刻就进入了机库。在机库中, 人们对飞机进行了全面 的清洗和清洁。

在乌汶, 人们向我们提供协助, 他们的善意已经弥补了语言带来的困难。我们 又一次确认了航空界的团结一致。航空在和平中可以扮演多么重要的角色啊 $128 !$ 这个印象在我心灵深处刻下了不可磨灭的印迹。

127 本书付印的时候, 我得知了战争部1925-1926年的建议预算额。根据这个建议,给予葡萄牙空军的金额 (材料供给) 为2368康多。这微薄的预算。根据空军航空督查部提出的, 完全合理、必要的预算, 仅仅航空材 料园一项就需要4500康多,而全部整个空军则需7171康多。无言以对。

128 很明显, 航空战争的职业化和发展毁灭了这种几乎是梦幻般的可能性。尽管如此, 我们相信, 未来当战争 结束后, 空军必将完成其终极使命。(第二版注) 
A gente observa, escuta e compara.

Como é grande, na realidade, a diferença entre o critério dos governos siameses e o da maioria dos governos portugueses...

Ali, naquela nação longínqua dos confins da Ásia, onde nos habituamos a imaginar um povo atrasado, a aviação é olhada como arma indispensável na paz e na guerra. Por certo se não pode comparar com os exércitos aéreos das grandes potências. Pequena potência como nós, no entanto, a sua aviação pode ser considerada já modelar.

No nosso país... as verbas que, em 1921, o Parlamento aprovou são, hoje, reduzidas por incongruentes e absurdos cortes àquelas que, mercê da boa vontade e do espírito de sacrifício dos aviadores, conseguem ainda manter activa a Aeronáutica Portuguesa ${ }^{127}$.

Tudo isto nos passa pelo cérebro, enquanto o tenente Chandraveguine nos vai ciceronando através das instalações.

Sob o céu da tarde, que pesadas nuvens de tempestade assaltam, pensamos em Portugal com nostálgica melancolia...

No dia onze, por tempo medíocre - aguaceiros e ventania -, atingimos Oubon, depois de uma viagem efectuada à velocidade média de 183 quilómetros à hora, em que Brito Paes, mais uma vez, se manifesta o grande navegador de sempre.

Durante o voo, um campo de recurso, em Korat, faz-se assinalar pela sua grande cruz branca.

E, como nota de beleza, a passagem entre duas montanhas, num colo estreito coberto de floresta espessa, onde avistamos um comboio que rola devagarinho, nas curvas suaves dos carris muito azuis.

Oubon é uma cidadezinha modesta, quase uma aldeola, no interior do Sião.

Somos recebidos por um sargento aviador, chefe de pista, que apenas conhece duas ou três palavras de francês. Assiste-nos um intérprete incompreensível.

Apesar disso, porém, o Pátria II é recolhido sem demora ao hangar, onde o lavam, limpam e procedem aos plenos.

No auxílio que nos prestam em Oubon, onde a boa vontade tinha de suprir a possibilidade de nos compreendermos por palavras, verificávamos mais uma vez a grande solidariedade aeronáutica e vincava-se-me mais profundamente no espírito a impressão do papel pacificador que poderia caber à Aeronáutica ${ }^{128}$.

${ }^{127}$ Estava a imprimir-se este livro quando chegou ao meu conhecimento a proposta orçamental do Ministério da Guerra para 1925-1926. Por essa proposta, arbitra-se à Aeronáutica Portuguesa (dotação material) uma verba de 2.368 contos. O orçamento escasso, imperiosamente necessário, apresentado e justificado pela Inspecção Aeronáutica Militar, era, só para o Parque de Material Aeronáutico, de 4.500 contos e, na sua totalidade, de 7.171 contos. Sem comentários.

${ }^{128}$ O profissionalismo e o desenvolvimento da aviação de guerra destruíram, aparentemente, esta possibilidade quase visionária. Cremos, apesar de tudo, num futuro em que, findo o ciclo das guerras, a Aeronáutica cumprirá a sua missão definitiva. (Nota da $2 \cdot^{\mathrm{a}}$ edição). 
飞行员是没有国界的。我们的世界就是天空, 牺牲的精神压倒其他一切情 感。无论是哪个国籍的飞行员实现了一个飞行目标, 都能让整个飞行大家庭震动, 因为这个大家庭中每个成员都懂得什么是飞行!

跑道的负责人是一位真正的战士, 他沉默寡言, 沉着专注, 用一辆带边斗的车 把我们送到了高级专员府邸。高级专员是一位精明、活泼的老者, 他只会说自己 国家的语言, 牙齿因为咀嚼槟郎 ${ }^{129}$ 已经变黑。他穿着这个地区的特色服饰接待我 们: 白色外衣, 紫色的七分裤, 奶油色的丝质袜子和带银扣的鞋子。

高级专员阁下通过一位军官跟我们交谈, 这位军官说一口语法正确的法语。 阁下请我们吃午餐, 他没有出现但向厨师致了敬; 晚上, 在一幢公共建筑中, 我们 出席了晚宴, 其他客人穿着色彩鲜艳、花哨的制服, 衬得我们这三身制服是那么暗 淡。

风景, 一种难以形容的如画风景在这里, 在乌汶达到了美的顶峰。我们身处丛 林, 周围的植被茂盛得密不透风。

当我们乘着边斗车经过狭长的道路时, 土著人停了下来, 毫不在意地看着我 们。尽管他们的文明程度不高, 飞机和飞行员不能引起他们的好奇心。

这些在地里干活的人, 服装减少到了只是一条裹住臀部周围的带子; 而女人, 则用一条肮脏的带子缠住乳房, 下面穿一条及膝打褶短裙。

在这些女性的面孔上, 我看不出一点美的迹象。她们都长着一张土黄色的圆 脸, 斜斜的眼睛, 一口因为嚼槟榔变得漆黑的牙齿。

他们的问候方式是如此独特而令人好奇: 男人像祷告似的合上手, 把手伸向陌 生人路过的方向, 同时低下头, 头越低说明越尊重被问候人; 女人则是先屈下身体, 也要合上双手, 谦逊地垂下目光。

我们在一间为飞行员和飞机乘客准备的木质凉亭中度过了夜晚。12日，我们 动身前往越南北部的东京。

航程漫长而困难, 我们差不多用了六个小时。 
Para os aviadores não há fronteiras. O nosso mundo é o céu. O espírito de sacrifício prevalece acima de todos os outros sentimentos. E um feito aeronáutico, qualquer que seja a nacionalidade de quem o realiza, faz vibrar sempre a grande família daqueles que sabem o que é voar!

O chefe de pista, tipo de verdadeiro soldado, taciturno, concentrado, leva-nos num sidecar ao Palácio do Alto-Comissário, velhote esperto e vivo, que só conhece a língua nacional, que masca betel ${ }^{129}$ patrioticamente, tem os dentes lacados e nos recebe no trajo regional: casaco branco, calções roxos pelo meio da perna, meia de seda creme e sapatos de fivela de prata.

Sua Excelência, que conversa connosco através de um oficial cujo francês é gramaticalmente correcto, oferece-nos um almoço a que não comparece, mas que faz honra ao cozinheiro; e à noite, num edifício público, assistimos a um banquete em que as nossas três fardas contrastam sombriamente com o colorido berrante dos uniformes que envergam os outros convivas.

A paisagem, de um pitoresco indescritível, atinge em Oubon o auge do esplendor. Estamos em plena selva. A vegetação que nos rodeia parece impenetrável, de tão densa.

Quando passamos no sidecar, pelos caminhos estreitos, os indígenas param, olhando-nos com indiferença, apesar do seu estado de civilização rudimentar. Aviões e aviadores não despertam, entre eles, a menor curiosidade.

A indumentária do homem do campo reduz-se à espécie de tanga que enrolam em torno dos quadris; e a da mulher, à faixa suja que lhe esconde os seios, e ao saiote curto, até ao joelho.

Não se descortina o menor vestígio de beleza nesses rostos femininos, terrosos, bolachudos, de olhos oblíquos e boca negra de betel.

A maneira de saudar é original e curiosa. O homem põe as mãos, como se fosse a orar, avança-as na direcção do forasteiro que passa, e baixa a cabeça tanto mais, quanto maior consideração lhe merece a pessoa a quem saúda. A mulher acocora-se primeiro e junta também as mãos, baixando o olhar pudicamente.

Passamos a noite num pavilhão de madeira, destinado aos pilotos e passageiros das carreiras aéreas e, no dia doze, partimos para o Tonquim.

Viagem longa e difícil, em que gastamos perto de seis horas.

\footnotetext{
${ }^{129}$ A noz de betel é a semente da palmeira de areca, muito usada por esta população asiática pelas suas propriedades estimulantes e propiciadoras de bem-estar. $\mathrm{O}$ seu uso prolongado concede à saliva um tom avermelhado e aos dentes, uma cor negra. (Nota do editor).
} 


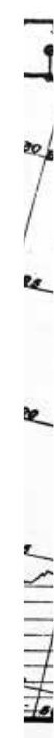




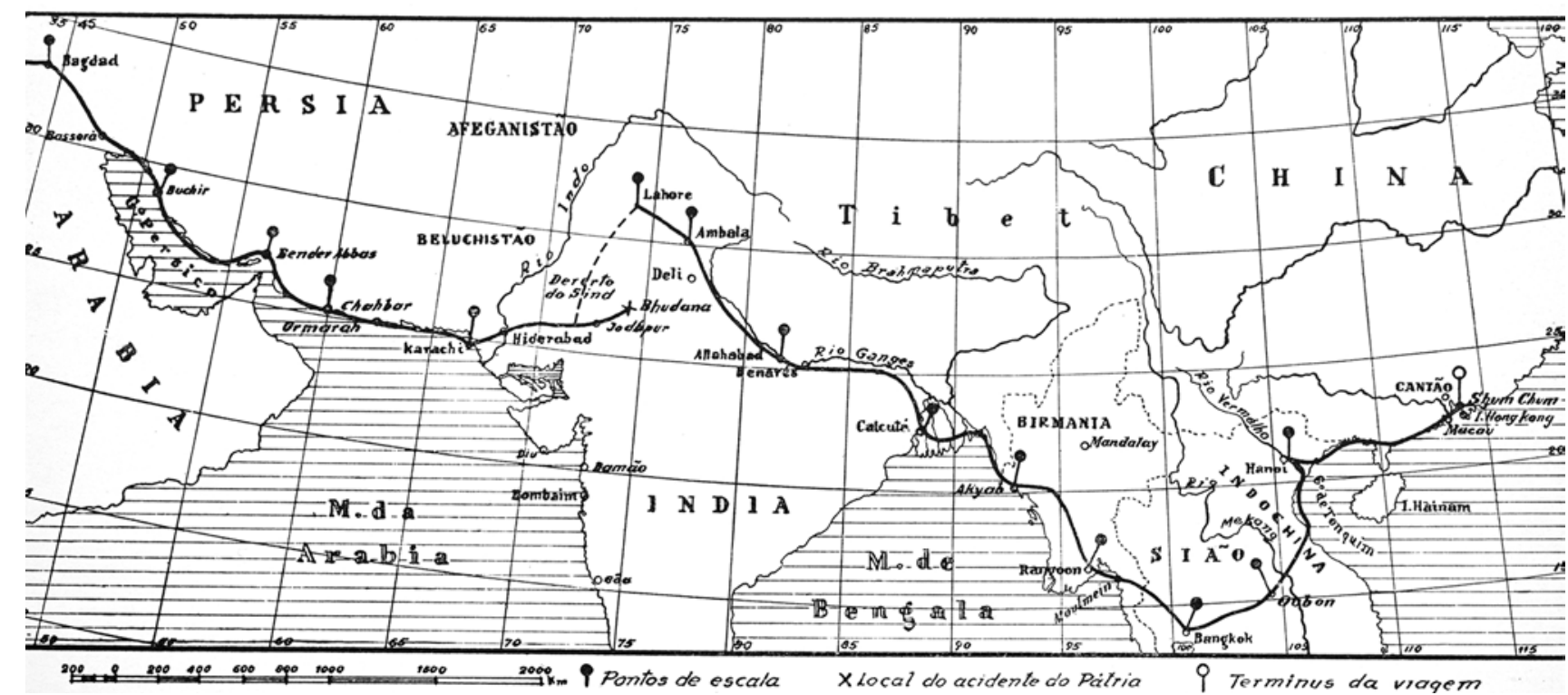

Croquis do itinerário da Viagem (II)

(Bagdad - Budhana, Lahore - Macau)

飞行路线草稿 (二)

(巴格达一布达纳, 拉合尔一澳门) 
在乌汶和他曲之间, “祖国二号” 掠过了由一块块支离破碎的云朵组成的巨大 云层, 在云与云的缝隙间, 我们瞥见了泥泞而凹凸不平的地面。

此后, 最后的那些丰富雨水让弯弯曲曲的湄公河发黄。

雨云渐渐变厚, 他曲成了我们在云的缝隙中看到的最后一个定居点。

为了越过安南山脉那些岩石组成的障碍, 我们向东北偏东方向飞去, 飞行高度 两千五百米。此时, 我们北边一点的地方, 一道道瀑布从天空倾泻而下, 像是一条 绉纱的幕帘。

我们盲飞了一个小时 ${ }^{130}$, 山间的一条条沟壑藏在密实的云层下。

偶尔的, 一座更高、石头更多、更尖锐的山丘在满是泡沫的海面上像一个布 满阴影的小岛剪影一般朝我们尖叫着、诅咒着扑过来!

云层形成了一块大幕, 在这大幕的流苏上, 在地平线上, 大海变蓝了一一那是 我们渴望已久的中国海! 白色的浓雾变得稀薄, 开始减轻、消散; 深谷, 宽阔的沟壑, 畸形的岩石等等阴沉地标记着我们的航程。

我们到达了一座小城海岸的上空, 布里托 - 帕艾斯认出了这个城市: 河静。

“祖国二号” 131 迎着风向北飞去。在飞机的右舷, 太平洋那平静的海面仿佛给 我们带来了对兄弟海洋一一大西洋一一的思念。

飞机兴奋地划开长空, 飞行在东方的天空中。这里的天空阳光闪亮, 到处都是 光明与快乐的景观。

只是飞机的发动机会有突发的、令人不寒而栗的颤抖，还有让我担心的、小 小的停顿。随着我们向前飞, 颤抖增大了。我跟布里托 - 帕艾斯有了以下的对话, 我将逐字复制。

萨尔门托・德贝雷斯: “发动机运转不良。我不知道它能否坚持到河内。”

布里托 - 帕艾斯回答说: “发动机是你的事。如果你认为方便降落, 你的前方 有荣市机场。”

萨尔门托・德贝雷斯: “审慎起见, 应该降落。但这太讨厌了。”

布里托・帕艾斯: “就是。100公里外我们有另一个机场。”

我们继续前进, 飞过了另一个机场。此时, 我们的愿望把我们带到了达红河三 角洲上空。这里, 一个新的灰色的、不透明的云层迫使我们下降, 以便让视线与地 面保持接触。

130 那时还没有带P. S. V设备的飞机。(第二版注)

131 原文使用了一个航海术语, 意思是为了尽量利用风的作用改变航向。(编者注) 
Entre Oubon e Takhek, o Pátria II navega rasando um vasto lençol de nuvens em farrapos, cujo tecido esburacado nos deixa entrever as ondulações encharcadas do terreno.

Mais adiante, o rio Mekong ziguezagueia, avolumado pelas águas abundantes das últimas chuvas.

A pouco e pouco, a toalha de nimbos engrossa e Takhek é a última povoação que avistamos, num rasgão boquiaberto.

Aproamos a És-Nordeste, voando a dois mil e quinhentos metros de altitude, para saltar a barreira de penedias da cordilheira anamítica, enquanto, um pouco a Norte, catadupas de água descem no céu uma cortina de crepe.

É uma hora de navegação cega ${ }^{130}$, em que os córregos da montanha se escondem ciosamente sob o manto compacto das nuvens.

De longe a longe, a gritar-nos imprecações, um cerro mais alto, pedregoso e aguçado, recorta-se como ilha de sombra em mar de espuma.

E já quando no horizonte, nas franjas do lençol das nuvens, o mar se azula - o Mar da China tão desejado! -, a albumina da névoa adelgaça-se, começa a romper-se, dilui-se, e ravinas profundas, abismos hiantes, rochas disformes passam a marcar sombriamente o nosso itinerário.

Atingimos a costa sobre uma cidade minúscula, que Brito Paes reconhece: Ha Tinh.

O Pátria II orça ${ }^{131}$, aproando a Norte. A estibordo, as águas tranquilas do Pacífico parecem trazer-nos saudades do seu irmão, o Atlântico.

E o avião voa contente por sulcar o céu oriental, onde o sol cintila, enchendo a paisagem de luz e de alegria.

O motor, porém, tem estremecimentos bruscos, pequenas suspensões que me preocupam. E como, à medida que avançamos, a vibração aumenta, troco com Brito Paes a seguinte correspondência, que reproduzo textualmente:

«Brito Paes: O motor trabalha mal. Não sei se chegará a Hanói».

Resposta de B. P.: «Motor é consigo. Se lhe parece conveniente, aterre. O campo de Vinh está na sua frente».

S. B.: «A prudência manda aterrar. Mas é uma chatice».

B. P.: «Lá isso é. A cem quilómetros, temos outro campo».

E prosseguimos, e o outro campo passa, e o nosso desejo de chegar leva-nos até ao delta do Rio Vermelho, onde um novo banco de nuvens, pardacento e opaco, nos força a descer para manter o contacto com o solo.

${ }^{130}$ Sem os aparelhos da P. S. V que não existiam ainda. (Nota da 2. ${ }^{a}$ edição).

131 «Orçar» é um termo náutico, que significa mudar de rumo, para aproveitar melhor a acção do vento. (Nota do editor). 
我们潜到下方一一我们的飞行高度曾是一千八百米一一只有二十米的高度, 才能再次看到地平线, 恢复视野。

这最后的一百公里, 我们超低空 ${ }^{132}$ 飞行在泥泞的稻田上方, 在这里降落意味着 转向倾覆, 这是令人激动的事。

不时的, 浓雾那毛茸茸的触角擦过潮湿的土地, 即使处在我们这样的高度, 一 瞬间眼睛也什么都看不见。

在水的迷宫中, 领航任务让布里托・帕艾斯工作繁重。

到了中午, 在半透明的大气层中, 河内城白色的痕迹终于在被水淹没的平原上 脱颖而出。我们从机库和高高的、插着天线的无线电报站中认出了白梅机场, 它 们在低空的迷雾中几乎都消失了。

雨水把跑道变成了名副其实的泥潭。在跑道上绕了一圈之后, “祖国二号” 降 落了。居然没有转向倾覆, 我也不知道为什么。

法国机械师和安南人朝飞机跑过了, 我把飞机从泥泞中开到了机库。(越北) 东京空军的主管, 葡萄牙领事, 飞行员, 记者和摄影师等人向我们致以拉丁式的热 烈祝贺, 我们有很长时间没有感受过这种方式了。

这段航程让我们累极了。

领事贾斯珀先生是一位比利时公民, 从与他的初步接触中, 就能感到他的善 良、友好、礼貌和外交手腕。他用自己的潘哈德汽车把我们送到大都市酒店, 在 那里, 在一系列提前准备好的宴会开始之前, 他让我们睡了几个小时 ${ }^{133}$ 。

第二天早晨, 在私人召见中, 驻河内的法国驻扎官阁下 ${ }^{134}$ 向我们致以热烈的 祝贺并向我们授勋, 我们被授予柬埔寨皇家军团骑士的称号。

在酒店, 人们请我们出席了一场官方宴会, 一场在机场举行的午餐会, 还有在 亲密友好的贾斯珀家族中举行的一次午茶。把我们与他们联合在一起的是那种深 深的亲和力。

河内是个拥有 120000 居民的城市, 其中 12000 人是欧洲人。居民中, 安南人占 统治地位, 他们显然都是些懒惰且不太聪明的家伙, 最担心的事好像仅限于无事可 做 ${ }^{135}$ 。

\footnotetext{
132 原文为法语。(编者注)

133 贾斯珀先生是另一位同名的比利时政治家的兄弟。(第二版注)

134 原文中使用了外交法规中的一个术语, 指的是居住在东道国的外交官的状态。(编者注)

135 1929年, 当我在流亡中为Lui-Siang元帅服务时, 在河内度过了一年的时间。因此, 有机会纠正自己错误的 表面印象。在这明显的懒惰和缺乏智慧的面具下面, 隐藏着反抗运动。在以后的岁月中, 这种反抗将会爆 发, 把越南拖入战争。(第二版注)
} 
Mergulhámos - estávamos a mil e oitocentos metros - e só a vinte metros de altura conseguimos recuperar horizonte e visibilidade.

Esses últimos cem quilómetros, voando em rase-mottes ${ }^{132}$ sobre arrozais lamacentos, onde aterrar significava capotar, foram qualquer coisa de emocionante.

De quando em quando, cabeleiras desgrenhadas da névoa que roçam a terra húmida envolvem-nos, mesmo àquela altura, afivelando-nos instantâneas vendas sobre os olhos.

A orientação, no labirinto de água, exige de Brito Paes um trabalho insano.

Ao meio-dia, na translucidez da atmosfera, a mancha clara de Hanói destaca-se, por fim, sobre a planície inundada e, junto ao campo de Bac-Mai, que reconhecemos pelos hangares, os altos postes da T.S.F. com sua antena quase se perdem no nevoeiro baixo.

Depois de uma volta sobre a pista, que as chuvas transformaram em autêntico atoleiro, o Pátria II aterra e não capota nem sei porquê.

Mecânicos franceses e praças anamitas correm para o aparelho que, rolando na lama, conduzo até ao hangar, onde o director da Aeronáutica do Tonquim, o cônsul de Portugal, aviadores, jornalistas e fotógrafos nos felicitam com aquela exuberância latina que há muito tempo não sentíamos junto de nós.

$\mathrm{O}$ voo fatigou-nos bastante.

Mr. Jaspar, o cônsul - cidadão belga, cuja afabilidade, simpatia, delicadeza e tacto diplomático se adivinham ao primeiro contacto -, conduz-nos no seu Panhard ao Hotel Métropole, onde nos deixa dormir algumas horas, antes de encetar a série de banquetes antecipadamente $\operatorname{preparados}^{133}$.

Na manhã seguinte, em audiência particular, S. Ex. ${ }^{a}$ o Residente ${ }^{134}$ da França em Hanói apresenta-nos as suas congratulações e condecora-nos com o grau de cavaleiros da Ordem Real do Cambodge.

Oferecem-nos um banquete oficial no hotel, um almoço no Campo de Aviação, um chá na delicada e simpática intimidade da família Jaspar, à qual ficamos ligados pelo impulso de afinidades profundas.

Hanói é uma cidade de cento e vinte mil habitantes, dos quais, doze mil europeus. Predomina, pois, o elemento anamita, tipo aparentemente preguiçoso e pouco inteligente, cuja preocupação suprema parece resumir-se em não fazer coisa alguma ${ }^{135}$. Responde invariavel-

\footnotetext{
${ }^{132}$ A baixa altitude. (Nota do editor).

${ }^{133} \mathrm{Mr}$. Jaspar era irmão do conhecido político belga do mesmo nome. (Nota da 2. a edição).

${ }^{134}$ Termo do código diplomático que se refere à situação do diplomata que reside no Estado que o acolhe. (Nota do editor).

${ }^{135}$ Quando, em 1929, como exilado, ao serviço do marechal Lui-Siang, passei um ano em Hanói, tive oportunidade de verificar o erro desta apreciação superficial. Sob essa aparente indolência, sob essa capa de falta de inteligência, ocultava-se então o movimento de rebeldia que explodiria, anos depois, através dos vários episódios que levaram à guerra do Vietnam. (Nota da 2. ${ }^{\text {a }}$ edição).
} 
如果我们问他们一个问题, 他们总是毫无变化地回答不。如果向他们下达一 个命令, 我们还没说完, 他们就肯定地点着头说:

“来接我……” (原文为法语) ${ }^{136}$

“是, 先生!” (原文为法语) 同时, 不管我们想要的是什么, 他们随便去取点什么 就给我们。

本地土著妇女一般都不漂亮, 她们让人想起更为纤弱的進罗人, 顶着一头油 油的头发, 一口漆黑的牙齿。

她们就像是混血杂交中意外绽放的花, 是一种有着奇怪的美感的形象。

我们参观了两个鸦片馆 ${ }^{137}$ 。

第一个坐落在一个妓院里, 它让我们在精神上感觉到痛苦、怜悯和厌恶。

鸦片馆里有一个巨大的、几乎是方形的、像板子一样坚硬的矮榻 ${ }^{138}$, 较低那 一侧向吸食者那边延伸, 旁边, 在一个有雕刻的铜方盘或是非洲黑木方盘中, 放着 全套吸食用具: 鸦片灯; 柚木鸦片箱, 上面镶着珍珠贝母; 小银棒, 这是用来把鸦片 膏挑到鸦片灯的火苗旁进行加热, 然后把它挑到鸦片枪的管道中; 鸦片枪, 它的样 子让人想起长竹笛, 有镶银边的, 象牙或玉制的鸦片枪。

进门处, 我们被介绍给一位法国军官。这位半醉的法国军官面色憔悴, 贪婪地 伸展在烟榻, 起身用含糊的声音告诉我们 “鬼米力”139 所在。他的神情中透出一股痛 苦和舒适混合在一起的迷惘。

在烟盘的另一侧, 一个中国女人在重新准备烟枪。她让烟枪倒向一侧, 在火苗 的热度中让生物碱形成的水珠渗出。吸食者大口地吸着。

我们在里面待了一小会儿, 好奇看着吸食者沉醉其中的过程。只见他们用小 棍四次把新的鸦片膏挑到瓷制烟枪中。吸食者的表情渐渐变化, 直到他们清醒的 洞察力淹没在无意识的恐慌中。

这让人感到遗憾; 为了不要看到最终的结果, 我们出去了。结果在另一位军官 的车中, 他向我们讲述了奇妙的品味和奇特的生活方式。

透过迷蒙的夜晚, 我们被带到了郊区, 那里有一个特别面向 “文明人” 的大烟 馆。

\footnotetext{
136 翻译: - 来接我……

一是, 先生! (编者注)

137 原文为法语。(编者注)

138 架高而倾斜的平台, 可作为床用。(编者注)

139 原文为法语。(编者注)
} 
mente que não, se lhe fazemos uma pergunta. E quando se lhe dá uma ordem, acena afirmativamente com a cabeça, antes de acabarmos de a formular:

- Va me chercher ${ }^{136}$...

- Oui, monsieur! - e parte a buscar o que quer que seja, indiferente ao nosso pensamento.

A mulher indígena, geralmente, não é bonita; faz lembrar a siamesa num tipo mais franzino, cabelos oleosos, dentes negros de laca.

Como florescências de excepção, no entanto, encontram-se, entre as mestiças, figuras de beleza estranha.

Visitamos duas fumeries ${ }^{137}$.

A primeira, instalada num lupanar, deixa-nos no espírito uma impressão dolorosa, de piedade e repulsa.

Num enorme divã baixo e quase quadrado, duro como laje - o bat-flanc ${ }^{138}$-, estendem-se os fumadores, ao lado de um tabuleiro de cobre trabalhado ou de pau preto, no qual se encontra toda a palamenta: a lamparina de azeite, a caixa de ópio, em teca, com aplicações de madrepérola, as pequeninas hastes de prata que servem para levar a pérola do ópio ao calor da chama que a recoze e para introduzi-la em seguida no fornilho do cachimbo, que lembra uma comprida flauta de bambu onde há incrustações de prata e remates de marfim ou jade.

Ao entrar, somos apresentados a um oficial francês, que, semi-ébrio já, olhar esgazeado, se levanta para dizer-nos, numa voz arrastada, o "enchanté» ${ }^{139}$ da praxe, e torna a estender-se sofregamente no bat-flanc. Na sua expressão reflecte-se um confuso misto de angústia e de bem-estar.

Do outro lado do tabuleiro, uma chinesa prepara novamente o cachimbo que, deitado de lado, de modo a expor a gota coagulada do alcalóide ao calor da chama, o fumador aspira a grandes haustos.

Nos rápidos momentos que ali nos demoramos, curiosos de assistir ao progresso da embriaguez, por quatro vezes a hastezita minúscula transporta nova esfera de ópio ao fornilho de porcelana. E a expressão do fumador vai-se modificando a pouco e pouco, até que a sua lucidez se submerge no pântano da inconsciência.

Aquilo causa lástima, e para não ver o fim, saímos, entrando no automóvel de um outro oficial, de quem nos contam maravilhas de gosto e originalidades na maneira de viver.

Através da noite brumosa, levam-nos a um arrabalde, onde fica a fumerie particular do «civilizado».

\footnotetext{
${ }^{136}$ Tradução: - Vai-me buscar...

- Sim, Senhor! (Nota do editor).

${ }^{137}$ Casa de ópio. (Nota do editor).

${ }^{138}$ Estrado sobrelevado e inclinado, que serve de cama. (Nota do editor).

${ }^{139}$ Encantado. (Nota do editor).
} 
一条小路从公路中叉出去, 一堵高墙出现在前面, 上面画着一只稚气的大象。 拍了拍门环, 那扇神秘的们打开了。我们觉得自己进入了一个小型的中国艺术博 物馆。五颜六色的灯笼发出柔和的光, 怯怯地照着吸烟室, 那个装饰得富丽堂皇的 佛像仿佛要脱颖而出。瓷制的大佛表达了喜悦与满足。因为原本严肃、深刻、高 度专注的印度神祗, 被移植到中国的乐观环境中后, 变成了一个胖胖的、笑容快乐, 透着知足的形象。这座佛像的塑造技法㜀熟, 色彩鲜艳, 是一件令人钦佩的瓷塑作 品。武器, 香水瓶, 鸦片枪, 水果满得快溢出来的大银果盘等等, 都是吸鸦片仪式的 供品。

在大厅深处, 一盏昏暗的小灯发出影影绰绰的光, 灯下一张宽大的烟榻上依次 摆放着铜制烟盘, 全套吸鸦片设备, 一套鸦片枪收藏品。此外, 还有一些瓷制棱柱 形物体, 两边微微凹陷, 这是用来支撑头部的。

中式床是一种只有中国人才能在里面睡着的柜子: 一张婴儿床被封闭在鸟笼 形的拥挤空间中。

另一间大厅也是同样的风格, 陈设精致, 品味高尚。

这里到处都是老虎皮, 长线地毯上的斑纹和阴影淹没在人们的脚步声中。

室外, 一道窄窄的石梯伸到下面, 石梯的最后一级没入了碧绿的湖水中。湖中 大朵的荷花正在盛开。

在夜晚坚不可摧的静默中, $c a i-n h a ́$ (小房子) ${ }^{140}$ 有一个收容隐士的地方, 我们 被笼罩在一种无法言说的麻木和异化了现实中.......

两天过去了。

当天下午, 雷声隆隆, 天空不断地被大块乌云遮盖, 暴雨倾盆而下。

稻田中的泥浆要把白梅机场变成一个大泥潭了! 在此处起飞是不明智的 ${ }^{141}$ 。

所以，参阅了中印半岛的可降落机场并听取了罗杰 - 吉亚莫特中尉提供的特 别变化条件之后, 我们决定前往宗, 确认当地机场的位置。

这一天, 当地报纸上登载了一封电报, 它让我们目睹了正在里斯本发生的事件 的严重性。这封电报是这样的:

${ }^{140}$ Cai-nhá: 安南语, 小房子的意思。

141 正是由于这个原因, 一架福克飞机侧翻了, 当时阿根廷飞行员扎尼少校正驾着此机尝试做环球飞行。 
Um atalhozinho desprende-se da estrada, segue um muro alto onde negreja o desenho infantil de um elefante, bate-se à aldraba de uma porta que se abre misteriosamente, e temos a impressão de entrar num pequeno museu de arte chinesa. No salão de fumo - timidamente iluminado por lanternas de colorido suave -, o altar de Buda destaca-se na opulência da ornamentação. A imagem de porcelana exprime alegria, satisfação plena. Porque a divindade hindu, grave, extática, profundamente concentrada, transfigurou-se, ao ser transplantada para o ambiente optimista da China, nessa figura obesa de sorriso prazenteiro, irradiante de contentamento. Como execução e como colorido, a porcelana é admirável. Armas de guerra, perfumadores, o cachimbo de ópio, grandes salvas de prata a abarrotar de frutos, «pivetes» são as oferendas rituais.

Ao fundo da sala, na penumbra que a luz débil de uma lamparina não consegue dissipar, o tabuleiro de cobre, a complexa palamenta e a colecção de cachimbos repousam em ordem, sobre o vasto divã. Há também uns prismas de porcelana, de faces laterais ligeiramente côncavas, que servem para apoiar a cabeça.

O leito chinês é uma espécie de armário dentro do qual só um chinês conseguirá dormir: catre minúsculo, encerrado num apertado recinto com jeito de gaiola.

Nas outras salas, o mesmo requinte, o mesmo bom-gosto, o mesmo estilo.

Por toda a parte, peles de tigre, zebrando os tapetes felpudos e sombrios que afogam o ruído dos passos.

Do terraço exterior desce uma escada estreita de pedra, cujos últimos degraus mergulham nas águas verdes de um lago, entre lótus enormes, sangrando flores.

E no silêncio da noite impenetrável, a cai-nhá $a^{140}$ tem um recolhimento de eremitério, que nos envolve num indefinível manto de torpor e alheamento das realidades...

Dois dias passam.

Pela tarde, do céu que trovoadas sucessivas mascarram a grandes manchas de carvão, desabam aguaceiros.

E o campo de Bac-Mai, círculo de lama no meio dos arrozais, vai-se transformando num lodaçal cada vez maior, donde não é prudente descolar ${ }^{141}$.

Por isso, depois de compulsado o indicador dos campos de aterragem da Indochina e de ouvir as informações fornecidas especialmente pelo tenente Roger Guillaumot, decidimos ir a Tong reconhecer o aeródromo da localidade.

Foi nesse dia que um telegrama publicado no jornal local começou a deixar-nos entrever a gravidade dos acontecimentos que se estavam desenrolando em Lisboa. Rezava assim:

\footnotetext{
${ }^{140}$ Cai-nhá: pequena casa, em língua anamita.

${ }^{141}$ A capotagem que inutilizou o Fokker em que o piloto argentino, major Zanni, estava tentando a volta ao mundo foi certamente devida a este facto.
} 
英雄飞行员 ${ }^{142}$

“巴黎来电: 葡萄牙飞行员被困滞留在里斯本的周边, 他们通知政府, 希望把他们的 要求传达给国会, 他们至死也不会放弃自己的要求。”

从这段简洁的消息中，我们不可能不明白其中的奥妙。这又为我们的澳门之 旅增添了一个动力。直观地来说, 我们意识到, 为了将葡萄牙空军从耻辱和暴力中 解救出来, 我们有必要到达澳门 ${ }^{143}$ 。

参观了位于山西市社四公里外的宗机场后, 法国驻扎官 ${ }^{144}$ 温托拜尔先生, 一 位法国空军的“老人” 145 , 马上打开了自己家的大门, 招待收留了我们。我们回到了 白眉机场, 减轻了“祖国二号” 多余的负荷。

布里托 - 帕艾斯决定, 他搭乘陪伴我们的普伊帕罗中尉的布雷盖飞机。他让 我跟机械师梅森在一起飞, 这位机械师可比他轻多了。

飞机停在一条跑道尽头, 跑道长一百米宽二十米。跑道的地面还算结实。

但是, 仅仅携带着一百升汽油的 “祖国二号” 是如此轻盈, 只需五米就离开了 地面, 它起飞的样子让法国人目瞪口呆。

在短短的四十五分钟航程中, 发电机停止运转了。

对于我们来说, 这是第一次严重故障 ${ }^{146}$ 。尽管如此, 我们正常降落了。机械师 得到命令, 明天早晨飞机要被修好。然而, 发动机拒绝了。我们焦虑了好几个小时, 觉得有必要等待戈维亚的到来。

19日下午, 当我们进行新一轮试验时, 一切都正常运转了。在暗淡而甜蜜的暮 色里, 飞机发出的美妙声音回响在巴维和谭岛遥远的山坡间。这里不规则的地形 在红河三角洲上开出了一个露天剧场般的空间。

东京 (越南) 的天空! 色调柔和的天空。阳光仿佛让透明的湖水变得更为深 遂……

\footnotetext{
142 原文为法语。

一封来自巴黎的电报宣布, 在里斯本附近被包围、封锁的葡萄牙飞行员们向政府宣告: 他们将誓死抵抗, 要 把自己的愿望传达给议会。(编者翻译)

143 这条消息提到的是发生在1924年6月10日到 15 日间的空军飞行员反抗事件。(第二版注)

144 原文中使用了外交法规中的一个术语, 指的是居住在东道国的外交官的状态。(编者注)

145 原文为法语。(编者注)

146 原文为法语, 故障之意。(编者注)
} 


\section{DES AVIATEURS HÉROIQUES ${ }^{142}$}

Un télégramme de Paris annonce que les aviateurs portugais bloqués et assiegés près de Lisbonne, ont communiqué au Gouvernement qu'ils voulaient que leur desideratum fut transmis au Parlement et qu'ils résisteraient jusqu’à la mort.

No seu laconismo, a notícia, que nos era impossível compreender em toda a sua latitude, foi mais um impulso no caminho de Macau. Intuitivamente, percebíamos que era necessário chegar, para salvar da violência e do opróbrio a Aviação Portuguesa ${ }^{143}$.

Depois de ter visitado o campo de Tong, a quatro quilómetros da cidade de Son Tay, onde Wintrebert, Residente ${ }^{144}$ da França, vieille tige ${ }^{145}$ da Aviação Francesa, nos abria desde logo as suas portas, para em casa dele nos hospedar, voltámos a Bac-Mai, a aliviar o Pátria II de toda a carga supérflua.

Brito Paes decide tomar lugar a bordo do Breguet do tenente Puyperou, que nos acompanha, deixando ir comigo o mecânico Maison, bastante menos pesado do que ele.

E o avião é colocado na extremidade da faixa exígua de cem metros de comprido e vinte de largura, em que a consistência do terreno ainda se mantinha.

Mas, leve como estava, o Pátria II, com cem litros de gasolina apenas, não precisou de mais de cinco metros para se soltar do terreno; e a maneira como descola deixa os franceses estupefactos.

Durante a curta viagem - quarenta e cinco minutos -, a geradora deixa de funcionar.

É a nossa primeira panne ${ }^{146}$ séria. Aterramos normalmente, apesar disso, e o mecânico recebe ordem para ter o avião pronto na manhã seguinte. O motor, porém, recusa-se. Vivemos horas de ansiedade. Julgamos que vai ser necessário esperar a chegada de Gouveia.

No dia dezanove à tarde, contudo, ao proceder a novo ensaio, tudo funciona normalmente. E, na doçura do crepúsculo morrente, a cantilena sonora ecoava, a repercutir nas encostas distantes do Ba Vi e do Tham Dao, cujos perfis irregulares abrem um anfiteatro sobre o delta do Rio Vermelho.

Céus do Tonquim! Céus de aguarela, que o sol aprofunda em transparências de lago...

\footnotetext{
${ }^{142}$ Aviadores heróicos.

Um telegrama de Paris anuncia que os aviadores portugueses bloqueados e cercados perto de Lisboa comunicaram ao Governo que pretendiam que o seu desiderato fosse transmitido ao Parlamento e que resistiriam até à morte. (Tradução do editor).

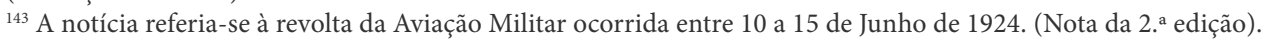

${ }^{144}$ Termo do código diplomático que se refere à situação do diplomata que reside no Estado que o acolhe. (Nota do editor).

${ }^{145}$ Velha carcaça. (Nota do editor).

${ }^{146}$ Avaria. (Nota do editor).
} 
从水彩绘出般的天空中, 泻下一缕彩色玻璃般的光线, 下面是一块块水波荡漾 的稻田, 像是织出了一幅幅波斯地毯……

当然也有一些铁青色的灰暗时刻——就像日食时, 阴暗的天空那种青灰色 那是暴风雨就要来临, 紫色的闪电已经发出了最初的信号, 阵阵沉闷的雷声从远方 传来......

东京 (越南) 的天空! 这反复无常的天空, 刚刚还是水洗般的湛蓝, 一瞬间, 你就 让我们如此震惊, 闪电猝不及防地就打碎了漂浮在空中的宁静!

我们和温托拜尔先生在山西市呆了两天, 他待我们如兄弟。在这两天当中, 我 们休息并做准备。

在我们面前的一千公里航程充满了各种威胁和台风。

躺下时, 我们两个人的脑海中飘过了一样的想法:

“我们需要明天就走。迈克拉伦 ${ }^{147}$ 跟我们约好喝下午茶的。”

147 英国飞行员。他在1924年这年企图环游世界。(编者注) 
Céus de aguarela, a escorrer uma luz de vitral, tecendo tapetes persas na paisagem de arrozais, vidrada pela inundação...

Há momentos de penumbra lívida - lívida como a penumbra arrepiante dos eclipses quando a tempestade está para explodir, faíscam já os primeiros clarões violáceos dos relâmpagos e se ouvem ribombos surdos e distantes de trovões...

Céus do Tonquim! Céus inconstantes, na serenidade ilusória do seu azul lavado, que, instantes depois, nos fulminam de surpresa, quando a descarga eléctrica estilhaça, abruptamente, o silêncio abafado que flutua!

Esses dois dias de permanência em Son Tay, junto de Wintrebert, que nos trata como irmãos - a mesma fraternidade de sempre, - são de repouso e de preparação.

Diante de nós alongam-se mil quilómetros, povoados de ameaças e tufões.

Ao deitar-nos, ocorre-nos a ambos a mesma ideia:

- É preciso partir amanhã. MacLaren ${ }^{147}$ marcou-nos encontro para o lanche.

${ }^{147}$ Piloto inglês que, nesse ano de 1924, tentava dar a volta ao mundo. (Nota do editor). 


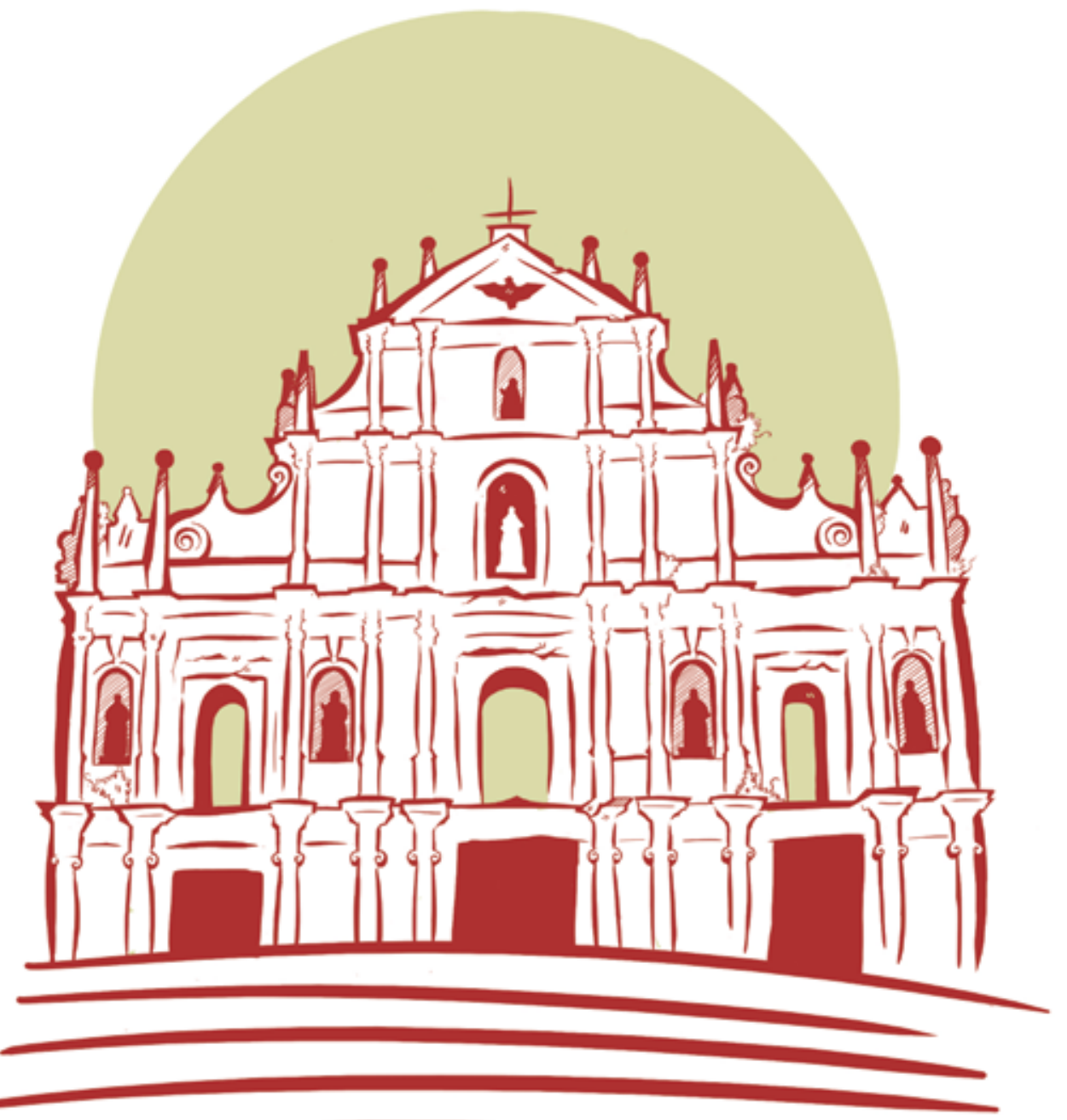


XII

A ÚLTIMA ETAPA

十二、最后一段航程 
清晨的天空泛着乳白色, 充满了希望。山脉无力地伸展着, 阳光要把它们从浓 雾中解放出来。云雾像一条项链一样缠绕着一座比较高、比较细长的山峰上。

跑道上, “祖国二号” 在等待我们。

天空万里无云。

我们已经不会因为当初出发时的那种情感而感到激动, 而只是用一种隐蔽的 声音下意识地嘟囔着一些不安和焦虑的话。

温托拜尔, 贾斯珀, 普伊帕罗中尉和梅森跟我们握手告别。然后, 我们都来 到了自己的岗位, 把飞机开出机库, 开始了最后一段航程。

最后一段航程! 这几个词让我们浑身有一种神秘的颤抖! 这巨大的饥渴, 总算 是要到头了!

“祖国二号” 朝着火热的大气层中飞去。尽管还是早晨, 热浪已将我们震撼。

速度指示器不运转了, 但是我们可以听到, 自由神发动机正在英勇地响起, 唱 着有节奏的歌。

明亮晴朗的天空是一种诱人的暗示, 在邀请我们。

十五分钟后, 像所有醒来很晚的大城市一样, 在我们的下方, 河内城在稻田上 伸展开来。

美国飞行员 ${ }^{148}$ 三天前离开的海防是一个笪立在大平原上的陶土堆。在这个城 市的天然港口中, 微小的船儿随着河水温柔的波浪起伏着。

布里托・帕艾斯告诉我: 我们的平均速度是大约每小时一百七十公里。

在我们的前方, 就是东京湾 (北部湾) 水域, 下龙湾、拜子龙洒落其间, 光滑如 镜的水面倒映出幽灵般一动不动的鸿基礁石, 像是悬浮在深渊中的黑色石块, 这一 切让我们有一种飞出地球的感觉。

鸿基和阿图的煤矿给沟攴纵横的海岸装饰了黑色的花边。

“祖国二号” 顺风而行, 在左舷, 棉花般的积云被甩在宋铁山的后面, 飞机将犁 开那清澈透明的天空。天空向东画了个椭圆形的弯, 消失在地平线的尽头。

强烈的西南风推着我们飞过从蒙凯到北海的上空。这个地区风景如画, 但是 有海盗出没, 如果降落将会非常危险。

不过, 发动机运转良好。十一月的天空, 大气层清澈透明, 我们的思绪只痴迷 于一个想法: 我们迫不及待地想要到达澳门。

${ }_{148}$ 三架进行周游世界的美国飞机。(第二版注) 
A manhã era um dilúvio de opalas, um frémito de esperança. As montanhas espreguiçavam-se com languidez singular, sob a luz do Sol que as ia despindo da bruma. Sobre um pico mais alto e mais esguio, poisava, esquecido, um colar de névoa.

Na pista, o Pátria II esperava-nos.

Nem uma nuvem no céu.

E em nós, se não vibrava já aquela emoção das horas da partida, falava, porém, inconscientemente, uma voz oculta, a murmurar palavras de inquietação e ânsia.

Wintrebert, Jaspar, Puyperou e Maison apertam-nos as mãos; tomamos os nossos lugares, e o avião larga para a última etapa.

A última etapa! Dessas duas palavras evolava-se uma vibração misteriosa! Que sede imensa, a nossa, de chegar ao fim!

O Pátria II solta rumo na atmosfera quente, que, apesar da hora matinal, nos sacudia com violência.

O indicador de velocidade não funcionava, mas, aos nossos ouvidos, soava heroicamente a canção rítmica do Liberty.

O céu luminoso e límpido era um convite, era uma insinuação.

Quinze minutos depois, Hanói que, como todas as grandes cidades, se levanta tarde, espalmava-se em baixo, no seu leito de arrozais.

Haifongue, que os aviadores americanos ${ }^{148}$ haviam deixado três dias antes, era um montículo de barro a emergir da planície alagada. No seu porto natural, os navios microscópicos deixavam-se embalar pela mareta suave do rio.

Brito Paes comunica-me a nossa velocidade média: cento e setenta quilómetros à hora.

Adiante de nós, espraiam-se agora as águas do golfo do Tonquim, onde as rochas de Hon Gay, polvilhando as baías de Ha Long e de Fai Tsi Long, reflectem a sua imobilidade espectral na superfície espelhenta, como se fossem blocos de negrume em suspensão no abismo, dando-nos a impressão de voar fora do planeta.

Hon Gay e Há-tu, com as suas minas de carvão, tarjam de luto a costa ravinada.

E o Pátria II, vento em popa, deixando por bombordo a massa algodoada dos cúmulos acastelados por detrás da Serra Songtieu, ia sulcando o céu diáfano, que, para Leste, se encurvava elipticamente até perder-se nos confins do horizonte.

O Sudoeste fortíssimo impelia-nos sobre a pitoresca região que se alonga de Mon-Kay a Pakhoi, zona infestada de piratas, onde seria perigoso aterrar.

Mas o motor funcionava admiravelmente, a atmosfera conservava a transparência de um dia de Novembro e, no nosso pensamento, como obsessão, só uma ideia, só uma ansiedade: chegar a Macau.

\footnotetext{
${ }^{148}$ Os três aviões americanos que tinham empreendido a viagem de circum-navegação. (Nota da 2.a edição).
} 
我们预感到了英勇的葡萄牙人的热情, 率性真诚的人民在大冒险的时刻所迸 发出的热情; 我们仿佛还听到了充满力量和勇气地大喊, 就像出发时最重要的那一 瞬间:

\section{“前进!”}

北海是一个重要的中国城市。直到现在, 这里每年还有一个野蛮的集市, 妇女 在集市上被按体重买卖, 就像食用肉一样 ${ }^{149}$ 。下方, 红色的土地从我们的机翼下滑 过, 上面有着稀疏的植被, 大块大块的裸露土壤不时显现期间。一些迎风招展的旗 帜肯定了一些欧洲人的存在。

然后出现的是法国租借地: 位于雷州半岛的广州湾, 它向我们送上了一个苍白 的微笑, 祝我们旅途顺利。

能见度有所降低, 但飞机依旧在快速、正常地前进。

我们注意着方位, 对于下方的单调景色无动于衷一一都是些带状的海岸线, 土 黄色的大海。

渐渐地, 雷电开始让天空或明或暗。一些具有威胁的障碍让导航工作变得更 为困难。

下午一点, 阳江从云中出现, 点然了我们暗淡的生活, 一种悸动在我们的脑海 中闪胨了几秒。

布里托・帕艾斯递给我一片纸:

“阳江, 每小时208公里。还差150公里。”

斜斜的、粗绳一般的雨柱开始让我们浑身湿透, 密密麻麻地敲在机蓬上, 机翼 上。闪电把暴风雨中的黑暗天幕撕开了一个个大口。“祖国二号” 在雨中摇摆着, 在风中上下翻飞着, 如同被妖魔缠身。

后退的想法闪过我的心中。在广州湾有个着陆点。但布里托 - 帕艾斯否定 了:

“广州湾200公里, 逆风。澳门150公里。”

我们爬升到了一千八百米的高度, 绝望地想要越过暴风雨, 可是我们悲剧性地 被它包围了。

没有用。

暴风雨更大了, 连续不断的之字形闪电晃花了我们的眼睛。

突然, 发动机发出了略显犹豫的声音, 只见电压表的指针残酷地自动指出: 发 电机停止运转了。

149 这个原始传统在1930年被废除了。(第二版注) 
Pressentíamos o entusiasmo da brava gente portuguesa, do povo rude e sincero que sente as horas grandes da aventura, e ouvíamos, como no instante supremo da partida, o mesmo grito de força e de coragem:

- Avante!

Pakhoi, a importante cidade chinesa onde anualmente se realiza ainda uma bárbara feira, com mulheres vendidas a peso como carne de consumo ${ }^{149}$ deslizando sob as nossas asas, grandes calvas a manchar a vegetação frouxa, no terreno avermelhado de em torno. Algumas bandeiras, ondulando ao vento, confirmavam a presença de europeus.

Depois foi a concessão francesa de Kouang-Tchéou-Wan que, a Leste da Península de Leizhou, nos enviou um pálido sorriso de boa viagem.

A visibilidade diminui ligeiramente, mas o voo prossegue, veloz e normal.

Atentos ao rumo, desinteressamo-nos da paisagem que se monotoniza - litoral rendilhado e mar barrento.

A pouco e pouco, porém, começam a alargar-se os claros-escuros da trovada. Há já grandes barricadas hostis, que dificultam a orientação.

Pela uma hora da tarde, Yang Kiang, numa clareira de nuvens, acende palpitações da vida anémica, instantânea, que bruxuleiam segundos.

Brito Paes passa-me um pedaço de papel:

«Yang Kiang. 208 kms. à hora. Faltam 150».

A viagem continua por entre a turba de monstros que enegrece o horizonte. Grossas cordas de água oblíquas começam a encharcar-nos, rufando na tela tensa das asas. Relâmpagos lívidos abrem fauces hiantes na obscuridade tempestuosa. E o Pátria II baila, endemoninhado, nos remoinhos do vento.

Passa-me pela mente a ideia de retroceder. Em Kouang-Tchéou há um campo de aterragem. Mas Brito Paes pondera:

«Kouang $200 \mathrm{kms}$. Vento contra. Macau 150».

Subimos a dois mil e oitocentos metros, numa tentativa desesperada para ultrapassar a tempestade que nos envolve mais tragicamente.

Em vão.

O temporal aumenta e as faíscas ziguezagueiam, num contínuo relampejar que nos encandeia.

De súbito, o motor hesita ligeiramente, e o ponteiro do voltímetro acusa, com cruel automatismo, que a geradora deixou de funcionar.

\footnotetext{
${ }^{149}$ Esta tradição primitiva foi suprimida em 1930. (Nota da 2. ${ }^{\text {a }}$ edição).
} 
从理论上来说, 我们应该还能使用蓄电池中的电力, 再飞两个小时; 但是, 一种 模模糊糊的预感渐渐地进入到了我的内心深处。总之, 我们觉得半个小时之内就 能到澳门。

恶劣的天气在继续, 而且比之前更加肆无忌惮了。但我们的飞机勇敢地顶住 了大风的袭击, 冷静地穿越云层, 并以疯狂的速度飞过最后的几十公里。

二十分钟后，布里托 - 帕艾斯请求我立刻下降。他模糊地瞥见了海岸的一角 并认出了它, 他不想失去联系。“祖国二号” 摇晃着, 大雨形成的水井开了个口, 飞 机利用了这个口子。在很低的高度, 若干米开外, 路环岛圆圆的脊背隆起在飞机的 右舷, 沉浸在浓雾之中。

暴雨愤怒地抽打着飞机, 我们冲进了澳门地峡, 飞过青州岛和关闸。

此时是下午两点半左右。

密集的雨点像是一道无法穿越的厚窝子。

飞机飞了个半圆形, 但强风把 “祖国二号” 推远了一点。我们尝试着再次俯冲, 却遇到了一道黑色的、不透明的移动水墙, 不得不中止行动。

情况更严重了。我们需要摆脱被阻的困境。

布里托・帕艾斯写道:

“试着往广东飞, 方向北, 广东河。”

我试着往前飞，但是雨水把我们包围得越来越紧，狂风似乎就是想要毁掉飞 机。 着我们。

我们在海面以上十米处飞行; 现在已经没有闪电了; 然而暴雨继续残酷地惩罚

有时, 一些有着丘陵和陡坡的岛屿突然出现在我们的视野中。

布里托・帕艾斯再次写道:

“飞往香港。方向东。这似乎更轻松。”

又调整 ${ }^{150}$ 了一下, “祖国二号”顺风而去。

这是五分钟古怪的飞行。我们的飞机似乎是狂暴的风县风中一片飘零的树 叶……尽管飞行高度低至只离地面数米, 但是大地却像是在云层和龙卷风水柱中 一个支离破碎的碎块, 无法辨认。人们会说, 那是让人神经错乱的时刻。

${ }_{150}$ 原文使用了一个航海术语, 意思是为了尽量利用风的作用改变航向。(编者注) 
Teoricamente, devemos poder voar ainda duas horas, utilizando a carga da bateria: mas um pressentimento vago instala-se-me no espírito. Contudo, dentro de meia hora, pensamos estar em Macau.

$\mathrm{O}$ mau tempo continua, mais desabrido que nunca. $\mathrm{O}$ avião, porém, resiste galhardamente aos golpes da ventania e, indiferente às nuvens que atravessa, galga a uma velocidade doida as últimas dezenas de quilómetros.

Vinte minutos mais tarde, Brito Paes pede-me precipitadamente que desça. Vislumbrou um ponto da costa que reconheceu e não quer perder o contacto. O Pátria II pica, aproveitando a goela aberta de um verdadeiro poço de chuva. A poucos metros de altitude e de distância, a ilha da Lapa soergue-se por estibordo, dorso arredondado a mergulhar na névoa.

Sob o açoite furioso dos aguaceiros densos, rompemos para o istmo de Macau, e passamos sobre a Ilha Verde e as Portas do Cerco.

Eram aproximadamente duas horas e meia.

A água caía em cortinas espessas, intransponíveis.

Descrevendo um semi-círculo, que o vento furioso alarga, o Pátria II afasta-se um pouco e, ao tentar de novo romper, encontra a muralha líquida que avança, negra e opaca, barrando terminantemente a passagem.

A situação agrava-se. Precisamos de libertar-nos da tenaz que ameaça fechar-nos sem remissão.

Brito Paes escreve:

«Tente seguir Cantão, rumo Norte, rio Cantão».

Aproo, tento avançar, mas o círculo de água aperta-nos cada vez mais, e a fúria do vento parece apostada em esfacelar o avião.

Voávamos a dez metros do mar; já não havia relâmpagos; só os aguaceiros continuavam a castigar-nos sem piedade.

De vez em quando, inesperadamente, uma ilha aparecia, montanhosa e abrupta.

Brito Paes volta a escrever:

«Siga Hong Kong. Rumo Este. Parece mais aliviado».

Orçando ${ }^{150}$ uma vez mais, o Pátria II aproa ao rumo, vento em popa.

São cinco minutos de voo desvairado. O aparelho parece levado como folha de árvore na violência do furacão... O terreno que, apesar de voarmos a poucos metros, se avista como fragmentado por entre nuvens e trombas de água, é irreconhecível. E aqueles momentos dir-se-iam vividos em plena alucinação.

\footnotetext{
$\overline{150}$ «Orçar» é um termo náutico, que significa mudar de rumo, para aproveitar melhor a ação do vento. (Nota do editor).
} 


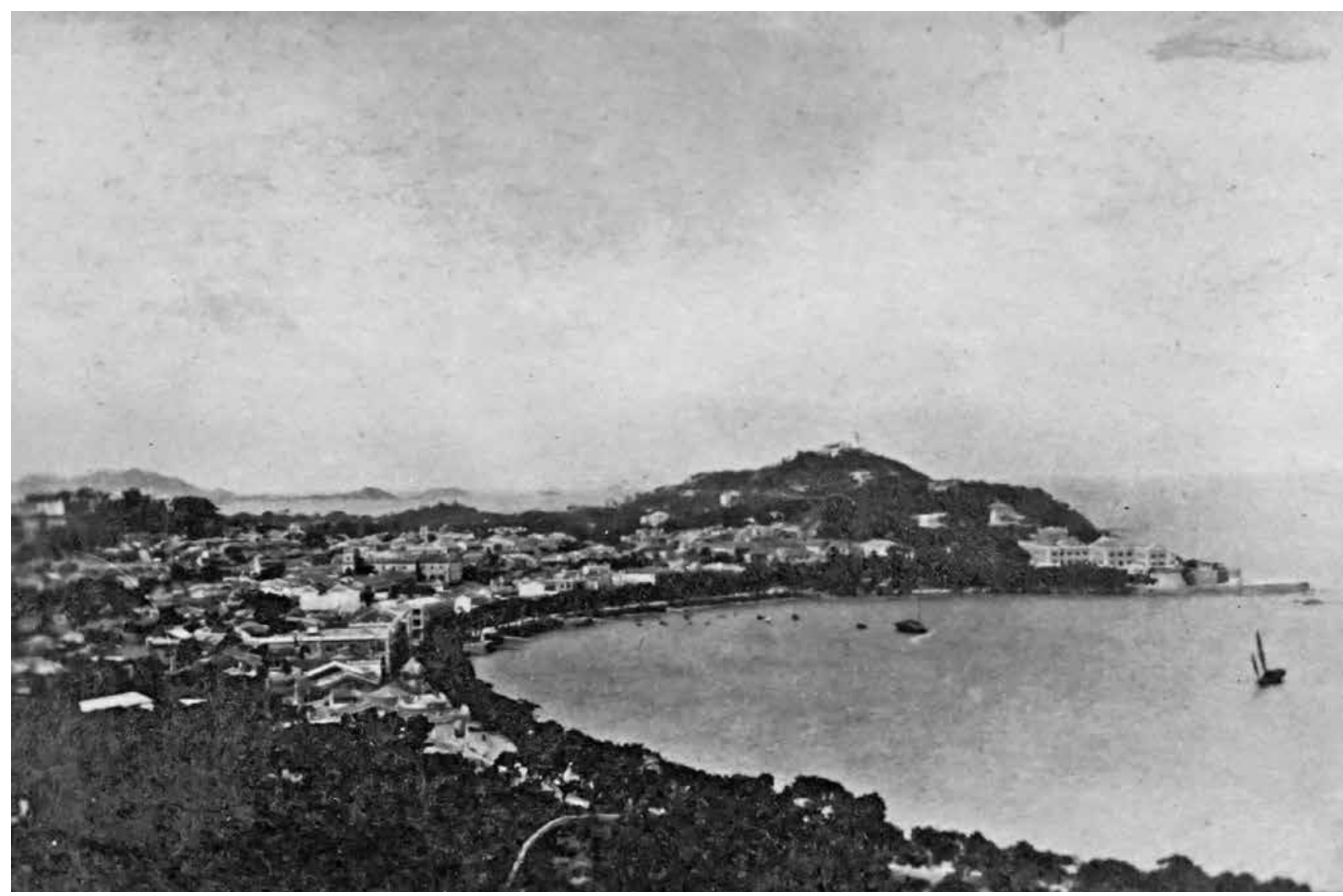

Macau

(Em 1924)

澳门

(1924年) 
突然, 布里托 - 帕艾斯指着在大地上闪闪发亮的九龙铁路线, 高喊着让我转 弯。

但发动机系统停滞了, 它吓人地振动着, 我试图让发动机保持转速, 但这要求 被否定了。

我向布里托 - 帕艾斯很快地做了个手势告诉他情况。此时, 大雨暂停后的天 空下, 一块一块的稻田无边无际, 像个象棋盘似的映入我们的眼窝。深色的泥泞土 壤引人注目, 我隐约看见一小块凹陷的场地, 它是周边唯一一块这样的场地。

发动机的转速在减缓, 我转了一圈要降落时, 螺旋桨停了。

所有我的小心......

因为这块着陆地很小———百米长, 八十米宽, 飞机在一个土丘上跳了几下之 后, 撞到了一块台地上, 螺旋桨和起落架都断了。

布里托 - 帕艾斯从飞机中走了出来, 我听到他尖叫着, 那声音透出由于无能为 力而产生的怒气:

“下降! 下降! 下降!”他只是必须要说些什么。

航程结束了。我们驾着布雷盖飞机从千泉新城出发, 完成了葡萄牙一一印度 的航线之后, “祖国二号” 在澳门上空飞翔。

在我们降落之后一小会儿, 倾盆大雨继续浇下来, 一个中国士兵向我们这边跑 过来。他手中拿着武器, 赤着脚, 穿了一件让我们想起睡衣的浅色衣服, 头上扣着 一顶篮子似的宽边帽。

我们试着跟他讲葡萄牙语, 法语, 英语……他怀疑地望着我们, 好像一个词都 没懂。我们只好使用尽可能想象出来的身体语言, 请求他在我们回来之前, 看管一 下飞机。像安南人一样, 这个小男人也摆动他的头部表示肯定, 但我觉得他什么都 没听懂。

两公里外一个古老肮脏而贫穷的城郊村镇是岑覃 (Shum-Chum) 城。布里托・ 帕艾斯给我看他的地图, 英国人的领土离得很近。

抱着能有人给指路的希望 (地图的比例尺很大, 上面只有铁路线, 应该离这儿 不远)。我们坚决地走向房屋群, 走进迷宫般的狭窄街道, 这些街道弯弯曲曲, 令人 作呕, 有些刺眼的店招在风中摆动, 一群脏脏的小孩在门口牙牙学语。

我们进到一间不知做什么生意的商店, 我甩出的一句 “你会说英语吗?” 柜台 后接待我们的两个中国人对此无动于衷。

我们接着往前走进一个杂货店中。老板向我们亲切地微笑着, 说着冗长押韵 的话, 他说的应该是中文吧。 
De repente, Brito Paes grita-me que vire, apontando a linha férrea de Kowloon a brilhar sobre o terreno a escorrer.

Mas o motor baixa de regime, vibra assustadoramente e, ao tentar conservar-lhe o número de rotações, nega-se a responder.

Em gestos rápidos, informo Brito Paes, lançando a vista sobre a região que, numa aberta do tempo, nos deixa ver o interminável xadrez dos arrozais. Destacando-se pelo colorido limoso-escuro, enxergo um campozito côncavo, único nas cercanias.

O número de rotações diminui e, ao dar uma volta para aterrar, antes ainda de ter aproado ao vento, a hélice pára.

Todo eu sou cuidado...

Mas o avião ressalta num montículo de terra e, como o campo é pequeníssimo - cem metros de comprido por oitenta de largo -, vai bater de encontro a um socalco que lhe parte a hélice e o trem de aterragem.

Brito Paes sai do aparelho e ouço-o gritar naquela voz em que transparece toda a sua cólera impotente:

- Desça! Desça! Desça! - e era apenas a necessidade de dizer alguma coisa.

A viagem estava terminada. O Pátria II voara sobre a cidade de Macau, depois de ter completado o percurso Portugal-Índia, efetuado no avião Breguet em que saíramos de Vila Nova de Milfontes.

Poucos instantes depois de aterrarmos - a chuva torrencial continuava caindo a cântaros -, um soldado chinês aproximou-se correndo. Trazia a arma na mão, vinha descalço, vestia uma roupa clara que lembrava um pijama, e poisava-lhe no alto da cabeça um largo chapéu que mais parecia um cesto.

Tentámos falar-lhe em português, francês, inglês. Ele olhava-nos desconfiado, sem dar sinal de entender palavra. Usando então da mímica mais expressiva que nos foi possível imaginar, pedimos-lhe para guardar o aparelho até voltarmos. E, como os anamitas, o homenzinho oscilou a cabeça num movimento afirmativo, mas julgo que não percebeu nada.

A dois quilómetros, um velho burgo sujo e miserável era a cidade de Shum Chun. Brito Paes mostrou-mo na carta; o território inglês ficava próximo.

E na esperança de encontrar alguém que nos indicasse o caminho (o mapa, de escala reduzida, apenas dava notícia da linha férrea, que não devia estar longe), avançamos resolutamente para a aglomeração do casario, dédalo de ruas estreitas, tortuosas, nauseabundas, com letreiros berrantes balouçando ao vento e uma garotada imunda palrando às portas.

Entramos numa loja cujo negócio não conseguimos definir, e atiro um Do you speak english? que deixa impassíveis os dois chineses que nos atendem por detrás do balcão.

Seguimos adiante, a uma mercearia. O proprietário sorri amavelmente e dispara-nos uma lengalenga, que deve ser chinês. Como o que pretendemos saber é onde fica a linha férrea, 
因为我们想知道火车线在哪里, 我尽可能地模仿号角声, 火车的鸣笛声和蒸汽 机的喘息声。这个男人目瞪口呆地盯着我们, 他一定是觉得这是两个疯子。

我们只好再走向别的店: 一间小百货店, 在那里, 我又把那些动作重复了以便, 但一点用也没有。布里托 - 帕艾斯在一边用流利的葡语称他们是粗人。

这时, 我脑中飘过一个绝妙的主意, 我指出自己想写字。那个中国人给我带来 了一支蘸满墨汁的毛笔, 这是中国人用来勾画他们的文字的。

我画了连一个孩子都能懂的简单线条, 勾出一列火车一一冒着热气的牵引车 ${ }^{151}$, 有窗户的车厢, 乘客等等一切。

我们的 “对话者” 终于长呼一声 “啊”, 总算是懂了! 然后他就去给我们取香烟。

我们从早晨起就没有吃过东西。在漫长、坎坷的飞行之后, 我们从飞机着陆 的地方一直走到这个城市一一两公里的路, 这让我们胃口大开, 而预计在此过夜则 让人感到不太愉快。

阴沉的下午正在来临, 我们依旧在雨中, 已经厌倦了那些让人百思不得其解的 问题, 因此我们决定去城市的另一端探索一下。

我们看到在二百米远的地方有个火车站。我们赶紧跑过去, 到了一个雨篷的 下面一一雨一直都没停, 而我们在这里遇见的依然是中国人。

月台上, 一个看守阻止我们通过。但是从车站里面出来了一群人, 应该是官员 吧。他们很和气地欢迎我们, 给我们端来不加糖的茶, 拿来英国香烟, 还兴高采烈 地向我们展示了一面黑色的大旗, 上面有白色的奇怪的中国字。

或许是因为他们更为敏锐, 或许是因为我们的手势更富表现力, 他们向我们指 出了一座八百米外的小房子一一那是位于香港边境地区的中国海关。在海关, 一 位粗通英语的工作人员建议我们前行。我们又走了五百米, 到了粉岭站, 这里是英 国领土了。

布里托 - 帕艾斯不断抱怨胸疼, 胳膊疼, 特别是脚踝疼, 这让他行走不易。

我把他留在车站, 这时一列火车到了。我坐进一把竹子和藤编的椅子里, 由两 个苦力 ${ }^{152}$ 搬运着, 回到了飞机降落的地方。我们现在知道了, 那是一个中国坟场。

在行进途中, 我被关在这个竹藤的架构中颠来颠去, 比在波浪起伏的海上坐船 还难受。我都快吐了。

151 原文是英语术语, 指的是一列蒸汽机车的牵引车, 其作用是运送驱动机器所需要的燃料和水。(编者注)

152 术语, 指的是 19 世纪和 20 世纪中国和印度的体力劳动者。(编者注) 
imito o melhor que posso o som de uma corneta, o apito de uma locomotiva e o resfolgar do vapor. O homem fita-nos boquiaberto e, provavelmente, julga-nos doidos.

Transpomos novos umbrais: os de um estabelecimento com pretensões a capelista, onde repito a mesma mímica sem resultado. Brito Paes, do lado, chama-lhes brutos em bom Português.

E, julgando que me ocorria uma ideia genial, indico que desejo escrever. O chinês traz-me papel e o pincelzinho molhado em tinta nanquim de que se servem para desenhar os caracteres da sua escrita.

A traços simples, que uma criança compreenderia, esboço um comboio - máquina fumegando abundantemente, tender ${ }^{151}$, carruagens com janelas, passageiros e tudo.

O nosso «interlocutor» deixa escapar um - ah! - de quem compreendeu enfim, e vai buscar cigarros.

O jejum em que nos mantínhamos desde pela manhã, o longo e acidentado voo e, finalmente, a caminhada desde o campo onde aterrámos até à cidade - dois quilómetros puxados - abrira-nos o apetite e tornava pouco aprazível a perspectiva de passar ali a noite.

A tarde sombria ia caindo, estávamos num pingo e, fartos de interrogações baldadas, decidimos ir em exploração até à extremidade oposta da cidade.

A duzentos metros, avistámos uma estação de caminho-de-ferro. Corremos para lá debaixo de um lençol de água - a chuva não pára - e, ai de nós! encontrámos chineses ainda.

No cais, uma sentinela pretende impedir-nos a passagem. Mas de dentro sai um grupo, certamente de oficiais, que nos acolhem com simpatia, nos oferecem chá sem açúcar, cigarros ingleses e nos mostram com grandes demonstrações de alegria uma grande bandeira preta, pintalgada por estranhos caracteres chineses desenhados a branco.

Ou porque sejam mais argutos, ou porque a nossa gesticulação seja mais expressiva, apontam-nos um casinhoto a oitocentos metros, a Alfândega Chinesa, na fronteira dos territórios de Hong Kong, onde um empregado que arranha vagamente o idioma de Shakespeare nos aconselha a prosseguir. Quinhentos metros mais longe, entramos na gare de Fan Ling, em território inglês.

Brito Paes queixa-se frequentes vezes de dores no peito, nos braços e, sobretudo, num tornozelo, que lhe dificultam o andar.

Deixo-o na estação onde um comboio chega e, tomando lugar numa cadeirinha de bambu e verga que dois coolies ${ }^{152}$ transportam, volto ao local onde aterráramos, que é, sabemo-lo agora por informações, um cemitério chinês.

A caminhada, nos solavancos da caranguejola, é pior que uma viagem de barco, em mar agitado. Enjoo quase.

151 Tender é um termo inglês que designa o vagão-reboque de uma locomotiva a vapor, usado para transportar o combustível e a água necessários para a alimentação da máquina. (Nota do editor).

${ }^{152}$ Termo que, entre os séculos XIX e XX, designava os trabalhadores braçais da China e Índia. (Nota do editor). 
当我来到 “祖国二号” 的旁边, 偶然遇见了一帮中国人。他们对于飞机的出现 很吃惊, 为了避雨, 这些人带着让我心碎的无意识跑到了下方的机翼上。

在一些士兵当中, 我好不容易才认出之前的那一位 (第一眼看上去, 所有的中 国人都像是双胞胎), 当时我将 “祖国二号” 交付给他并让他看管。士兵们和民众亲 密相处。我用手势命令机翼上的人下来，可是这些无畏的人不明白或是不想明白 我的意思。

我从飞机中尽可能地拿了些东西出来 (行李, 地图, 飞机中一些替换了我的椅 子的设备等), 回到了粉岭。两个苦力在后面飞跑, 就像是脚上长了翅膀。

到了之后, 我才想起来: 自己没有中国货币。用一种高姿态, 我给了他们在河 内用剩的银子。可是他们抗议不要! 在吵闹中, 我们通过电话得到了铁路督查的仁 慈帮助, 他让站长付给苦力们钱。障碍消除了, 我们终于平静地走进车厢。晚七点, 火车把我们带到了九龙, 此时, 我们已经极为疲惫, 浑身湿透。

“迈克拉伦呢? ${ }^{153}$ ” 我们到达的时候问

“没有消息……”某人回答我们说。

英国缺席了。葡萄牙尽管迟了一点点, 但是在约定好的日子里出现了。

葡萄牙移民在休闲俱乐部接待了我们。葡萄牙领事塞尔韦拉 - 德阿布克尔 克先生激动向我们表示欢迎。晚上, 我们睡在他家。自从那小说难以描写的戏剧 性一幕之后一一就是1924年6月20日, 在暴风雨的狂怒中, “祖国二号” 在澳门城的 上空飞过那一幕——我们终于在领事家友好的屋檐下睡了第一个觉。

这次的飞行时间是四小时五十分钟。我们飞过了 1050 公里, 平均速度为每小 时 217 公里。在最后一个小时当中, 我们的平均速度达到了 262 公里。

153 英国飞行员。他在1924年这年企图环游世界。(编者注) 
E, ao chegar junto do Pátria II, deparo com um bando de chineses que, para se abrigar da chuva, tomou de assalto o avião e se instalou nas asas inferiores, com uma inconsciência que me confrange.

Alguns soldados, entre os quais a custo reconheço aquele a quem confiáramos a guarda do aparelho (à primeira vista, os chineses parecem todos gémeos), confraternizam com o povoléu. Intimo-os por gestos a descer. Mas a malta impávida não entende ou não quer entender.

Tiro o que posso (bagagens, cartas e alguns instrumentos de bordo que me substituem na cadeirinha) e regresso a Fan Ling, correndo atrás dos coolies que deslizam como se tivessem asas nos pés.

Só ao chegar me lembro que não temos dinheiro chinês. Num gesto superior, entrego-lhes a prata que nos sobrou de Hanói. Mas os demónios protestam, numa algazarra, e é necessário que, pelo telefone, consigamos da gentileza do inspector dos Caminhos-de-Ferro que o chefe da gare lhes pague, para o berreiro cessar, e podermos entrar tranquilos na carruagem que, pelas sete horas da noite, nos depõe em Kowloon, exaustos e encharcados.

- MacLaren ${ }^{153}$ ? - perguntamos ao chegar.

- Não há notícias... - responde-nos alguém.

A Inglaterra faltara ao rendez-vous. Mas Portugal, embora com ligeiro atraso, não deixara de comparecer no dia marcado.

A Colónia Portuguesa recebe-nos no Clube de Recreio, onde o cônsul de Portugal, Cerveira de Albuquerque, nos dá comovidamente as boas-vindas. É sob o tecto amigo da sua casa que dormimos o nosso primeiro sono depois do drama, que a narrativa mal descreve, desse dia 20 de Junho de 1924, em que o Pátria II, em meio à fúria da tempestade, voou sobre a cidade de Macau.

$\mathrm{O}$ voo durara quatro horas e cinquenta minutos. Percorrêramos mil e cinquenta quilómetros à velocidade média de duzentos e dezassete quilómetros à hora. E a velocidade média, na última hora, atingira duzentos e sessenta e dois quilómetros.

\footnotetext{
${ }^{153}$ Piloto inglês que, nesse ano de 1924, tentava dar a volta ao mundo. (Nota do editor).
} 


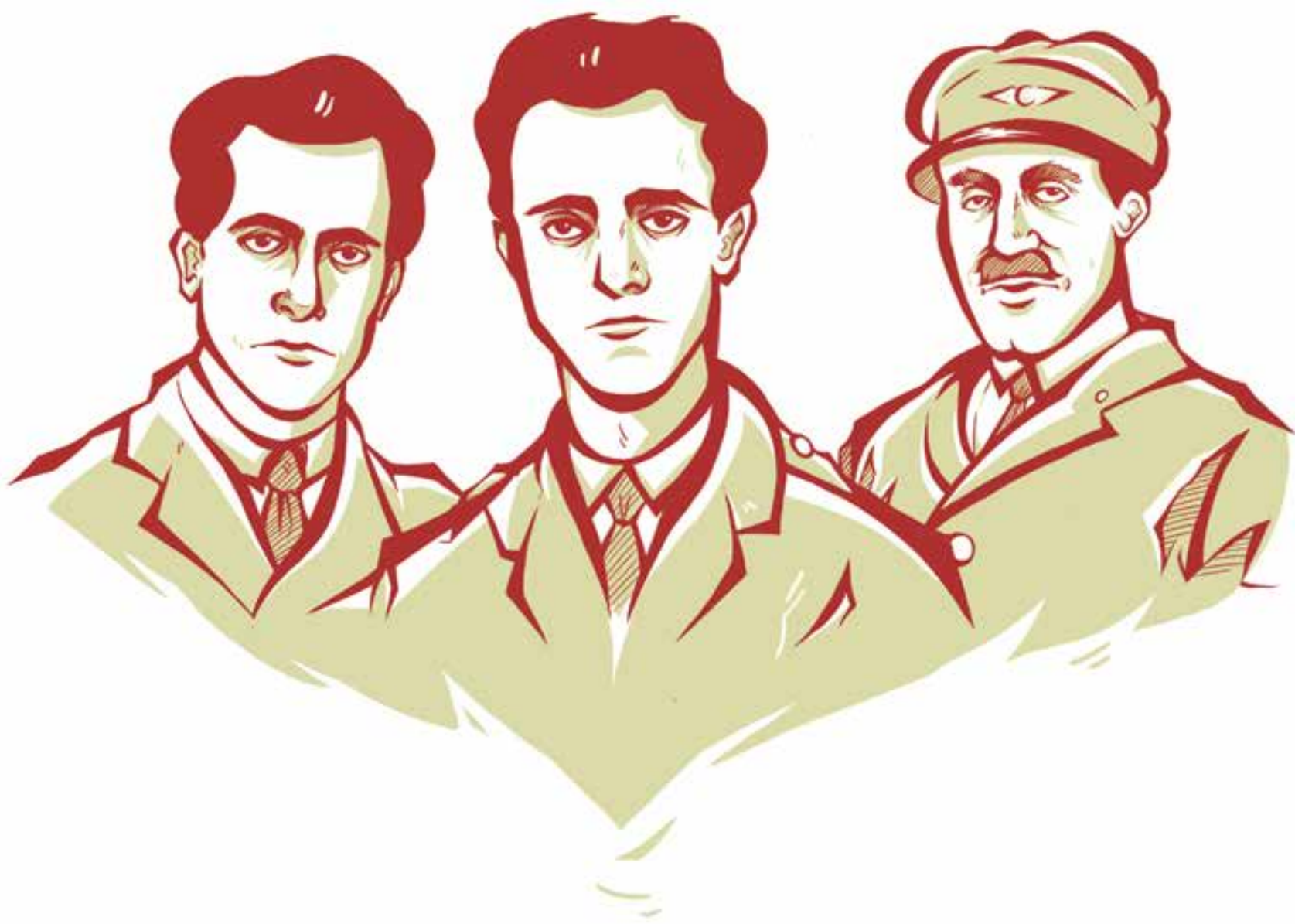




\section{XIII CONCLUSÃO 十三、结论}


6月21日早晨, 暴风雨继续扫过这一带的群岛。葡萄牙领事向我们宣布: “澳门 号”马达巡逻舰进入香港港。

这艘舰在桑托斯 - 佩德罗中尉的指挥下, 前一天下午从澳门出发去接我们。 这50英里的水上航程就像赫茨司令官说的那样, 这艘平底船 “在潮湿中航行”, 历史 将不会记载这段历险记, 因为舰上的船员是如此谦逊, 没有突出这次航行的真正价 值。

一位在舰上的记者跟我们简洁地说了一下情况: 夜里, 气旋风暴在波涛翻滚的 大海上挖出一个个深坑, 大浪拍打着舰艇, 就像拍在薄薄的蛋壳上; 满载着澳门葡 萄牙人的热望, 这艘船乘风波浪, 航行在到达英国港口最短的航线上。

只是到了深夜, 这艘舰的肋材不祥的嘎吱作响, 这是沉船的预兆。司令官安详 地命令所有人穿上救生衣……

桑托斯 - 佩德罗司令温和地微笑着, 仿佛没有做过任何值得一书的事情。他 长时间地紧紧拥抱我们, 流露出因为我们的胜利飞行而感到的激动。他告诉我们, 对于澳门来说, 这次可怕的航程是怎么样的:

“大约中午的时候, 澳门城收到了电报, 这封电报宣布 “祖国二号” 已从山西市 离开。尽管当时有暴风雨, 但兴奋的人群还是向飞机着陆场跑去。所有人的眼中 都流露着不安, 其中夹杂着希望, 希望能看到飞机顺利到达。”

“几个小时过去了……”

“哪怕是最有信心的人, 怀疑之情也开始侵入他们的心灵。”

“大约在三点差一刻的时候, 有些人听到了飞机发动机的金属震动声。人们不 禁喜悦万分, 但这喜悦之情很快就弥散在乌云密布的天空中了。飞机的声音消失 在大风忧伤的嗡嗡声中。慢慢的, 所有人都悲伤地四散开去, 怀着沮丧和担心之情 回到了自己的家中。”

“两个小时后, 总督府的旗帜降了下来, 降半旗了。人们对于这个致哀标志的 原因毫不知晓 (最终人们得知, 那是因为越南东京总督在广东被袭身亡), 都以为是 你们的飞行以一次致死的灾难事故而结束了。热望变成了一种痛苦折磨。”

“然而, 下午六点, 我接到了命令, 让我们驶向香港去接我亲爱的朋友们。这个 消息在城中传开, 所有人再次兴奋不已。”

“这次航行很可怕, 不过幸运的是, 我们都还在。”

关于那夜, 这些就是从一位水手口中说出的所有话。哪怕他曾经那么多次地 怀疑自己是否能到达目的地。 
No dia vinte e um de Junho pela manhã - o temporal continuava azorragando o arquipélago -, o cônsul de Portugal anuncia-nos a entrada da lancha-canhoneira Macau no porto de Hong Kong.

O barco, do comando do Primeiro tenente Santos Pedro, saíra na véspera à tarde de Macau para vir buscar-nos. E essa viagem de cinquenta milhas, naquela embarcação de fundo chato, que, como diz o comandante Herz, «navega numa humidade», é uma página de assombro que a história não registará, porque a modéstia dos seus tripulantes lhe não realçou o verdadeiro valor.

Um jornalista que vinha a bordo diz-nos, resumidamente, que, durante a noite, enquanto a ventania ciclónica cavava abismos no mar encapelado, a casca de ovo, gemendo, batida pelos vagalhões, singrou a rota mais curta para chegar à feitoria inglesa, trazendo nela toda a ansiedade dos portugueses de Macau.

Apenas quando, altas horas, o cavername rangeu mais sinistramente, num prenúncio de naufrágio, o comandante, com serenidade, ordenara que todos vestissem os cintos de salvação...

Sorrindo modestamente, como se nada houvesse feito de notável, o Comandante Santos Pedro estreita-nos num abraço que se prolonga, a reflectir a emoção que lhe causa o nosso triunfo, e conta-nos o que foi, para Macau, essa terrível jornada:

- O telegrama anunciando a partida do Pátria II de Son Tay foi recebido na cidade por volta do meio-dia, e a população alvoroçada acorreu ao campo, em massa, apesar do temporal desenfreado. Sentia-se em todos os olhares uma inquietação imensa, a que se aliava a esperança de ver chegar o avião.

«E as horas passaram...

«A incerteza começou a invadir os espíritos mais confiantes.

«Pelas três horas menos um quarto, pouco mais ou menos, algumas pessoas ouviram a trepidação metálica de um motor. Foi um clarão de alegria que logo se esvaiu no negrume do céu. O ruído perdeu-se no zumbido soturno da ventania e, a pouco e pouco, tristemente, todos debandaram, desanimados e apreensivos, para suas casas.

«Duas horas depois, a bandeira foi içada, a meia haste, no Palácio do Governador. Ignorando o motivo do lutuoso sinal (que afinal era o atentado que vitimou o Governador do Tonquim, em Cantão), toda a gente supôs que a viagem tivesse terminado por um desastre fatal. A ansiedade transformou-se em confrangimento.

«Pelas seis horas da tarde, porém, recebi ordens para levantar ferro rumo a Hong Kong, em busca dos meus amigos. E a notícia, espalhada pela cidade, alvoroçou de novo toda a gente». «A viagem foi tremenda. Mas, felizmente, aqui estamos!»

E é tudo quanto os seus lábios de marinheiro nos dizem sobre aquela noite no mar, em que tantas vezes duvidara da possibilidade de chegar ao seu destino. 
凌晨, 当 “澳门号” 进入香港湾风平浪静的水面上时, 船员们的脸上应该还带 着夜晚危险带来的冰冷气息, 那危险持续了整晚……

这一壮举, 今天那些没有经历过的人或已经将它遗忘了, 或冷漠得不知怎样估 量它。但这一切都被保存在了时光中, 只是我们人类的双眼还没有学会破译它。

下午, “祖国号” 巡逻舰进入港口, 皮瓦尔司令和他的军官们亲切友爱地接待了 我们。

在巡逻舰上, 我们自离开千泉新城后第一次又踏上了一小片葡萄牙领土。

人们都下意识地感觉到了各种感情, 有骄傲、爱国和思念之情, 所有的人一一 军官, 士官, 水兵一一眼中都噙着热泪。我们模模糊糊地看见, 这次飞行尝试, 一次 飞往海外省份的年度空中飞行带来了多么正面的后果! 我们的飞机机翼带着祖国 旗帜的颜色来到了这个海外省份, 它们被祖国的阳光照耀。

日子一天天过去，拆分飞机的任务被交托给了两个葡萄牙海员和已解散的殖 民地航空的机械师们, 一些澳门人和英国人辅助他们。

某个清晨，他们遇到了困难。我们降落地点所在的地区被孙中山 ${ }^{154}$ 和陈畑明 的军队占领了一些日子, 这个地区依然位于两军有小规模军事冲突的地带。那位 将军司令官通知机械师们: 他不知道飞机是属于谁的。而且有一些为陈昫明服务 的西方飞行员不准移动 “祖国二号”。

因此, 一个人员众多的考察队 23 日早十点登上了火车, 到达粉岭站。在中方司 令部, 司令长官接待了我们。

翻译们向他转达了我们的指示, 司令官微笑着, 看起来很满意的样子。对于自 己所做出的照顾, 他仅仅要求我们正式表示感谢, 并将此刊登在香港读者最多的报 纸上。

24 日, 戈维亚到了。他的脸红扑扑的, 上面的小汗珠发着光, 他拥抱了我们, 叹 息着抱怨着, 擦着额头上的汗说:

\footnotetext{
154 孙中山 (1866年-一1925年), 中国政治家、革命家, 现代中国国父。他是第一位主张推翻清朝帝国体制, 建立民主共和国的革命者。孙中山先生是1911-1912年推翻清王朝革命的主要领导者。1924年, 民主主义 革命者陈昫明 (在德贝雷斯的文中将其名字拼写为Chien-Ki-Ming) 拒绝孙中山的向中国中部进发的命令, 孙中山被暂时逐出自1920起占领的广州。为了更广泛地理解这个问题, 请参阅黎涛 (Lai To) 和李福源 (Lee Hock Guan) 编纂的、有关孙中山的研究汇编 “孙中山, 南洋和1911年革命”, 新加坡, 中国文化遗产中心出 版。感谢阿尔弗雷德・戈麦斯・迪亚斯为本条注解提供的信息。(编者注)
} 
Quando, de madrugada, a Macau fundeou nas águas mansas da baía de Hong Kong, a tripulação devia trazer ainda na face o sopro glacial do perigo que a bafejara durante a noite ...

O feito, hoje esquecido por aqueles que o não viveram ou cuja indiferença o não soube avaliar, lá ficou impresso em letras de luz, nos registos do Tempo, que tudo arquivam, mas que os nossos olhos humanos não aprenderam a decifrar ainda.

Pela tarde, entra a canhoeira Pátria, onde o comandante Bivar e os seus oficiais nos recebem com vivas demonstrações de amizade e carinho.

Aquela tolda é a primeira parcela de território português que pisamos, depois da largada de Vila Nova de Milfontes.

E, inconscientemente, ao sentir o orgulho, o patriotismo e a saudade que se reflete em todos aqueles olhos rasos de água - oficiais, sargentos, marinheiros -, vislumbramos as benéficas consequências que resultariam do empreendimento de uma viagem aérea anual às nossas Províncias Ultramarinas, que ali levasse, nas asas de um avião, as cores da bandeira, ungidas pelo sol da Pátria distante.

Os dias que se seguem destinam-se à desmontagem do aparelho, de que se encarregam dois marinheiros portugueses, mecânicos da extinta Aviação Colonial, com alguns auxiliares macaenses e ingleses.

Certa manhã surgem dificuldades. O terreno em que aterráramos, incrustado numa zona conquistada havia alguns dias às tropas de Ch'ien Chiung-ming pelo exército de Sun Yat-sen ${ }^{154}$, encontrava-se ainda sob o regímen de escaramuças, e o general comandante comunicara aos mecânicos que, não sabendo a quem pertencia o avião, e havendo aviadores europeus ao serviço de Ch'ien Chiung-ming, não autorizava a remoção do Pátria II.

Por esse motivo, no dia vinte e três, uma numerosa expedição tomava lugar no comboio que, pelas dez horas da manhã, chegava a Fan Ling e era recebida, no Quartel General chinês, pelo comandante em chefe.

Os intérpretes transmitiram-lhe as nossas indicações, e o general, sorrindo, deu-se por satisfeito, pedindo apenas que a sua amabilidade lhe fosse agradecida oficialmente, e que o facto fosse publicado nos jornais mais lidos de Hong Kong.

No dia vinte e quatro, chega Gouveia. Rosto afogueado, camarinhas de suor a reluzir, abraça-nos e lamenta-se, esponjando a testa:

\footnotetext{
${ }^{154}$ Sun Yat-sen (孫中山) (1866-1925) foi um militar e estadista chinês que ficou conhecido como o pai da Nação Moderna (國父), uma vez que foi o primeiro revolucionário a defender o derrube do sistema imperial Qing e a fundação de uma república democrática. Sun foi o principal líder da revolução de 1911/1912 que derrubou a dinastia Qing. Em 1924, o revolucionário nacionalista Ch’en Chiung-ming (que o texto de Beires grafa Chien-KiMing) recusa-se a avançar pela China central, como lhe sugeria Sun Yat-sen, e expulsa temporariamente este último de Guangzhou, que ocupava desde 1920. Para uma compreensão mais alargada, veja-se a compilação de estudos sobre esta figura, editada por Lee Lai To e Lee Hock Guan (2011): Sun Yat-Sen. Nanyang and the 1911 Revolution, Singapura, Chinese Heritage Center. Agradece-se a Alfredo Gomes Dias as informações que permitiram a redacção desta nota. (Nota do editor).
} 


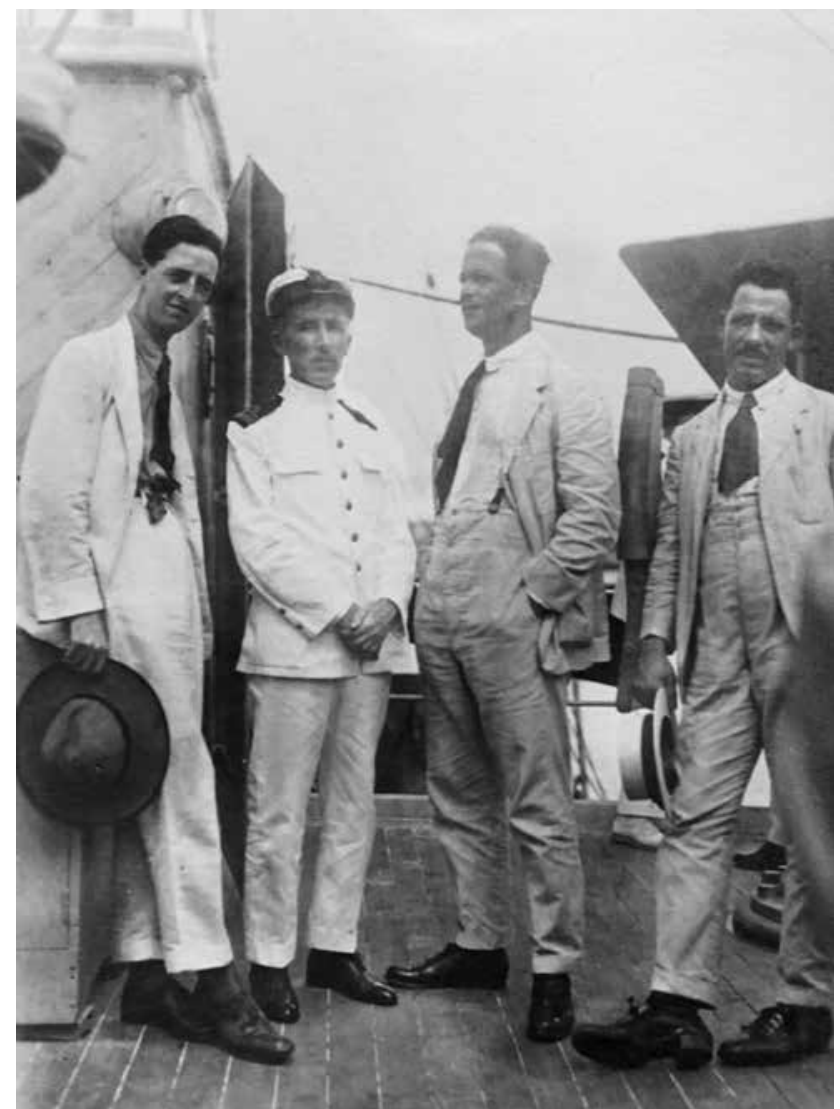

A bordo da canhoneira Pátria com o comandante Bivar

在 “祖国号” 巡逻舰上与皮瓦尔司令在一起

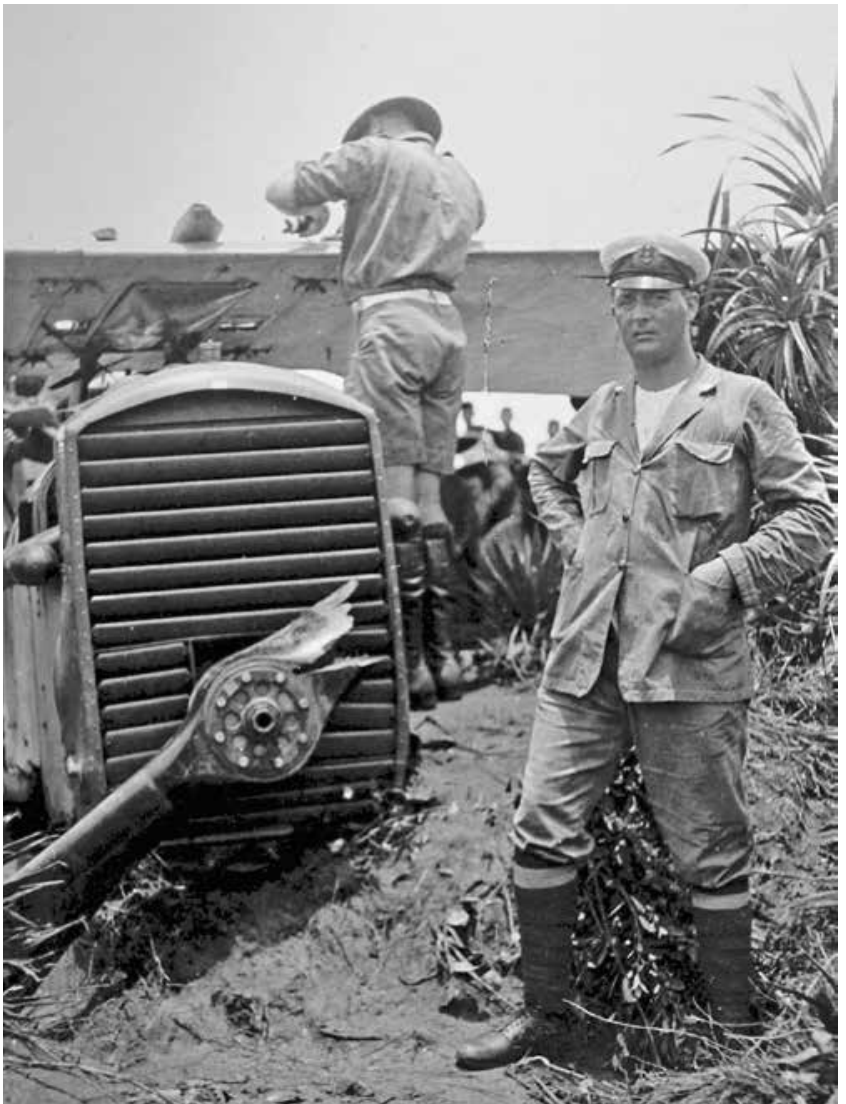

O Patria II acidentado a ser desmontado no cemitério chinês

㞧毁的 “祖国二号” 在中国墓地被拆解 
“每次我都会出点事! 你们不想知道我是怎么进入中国的吗? ……”他很紧张, 立刻接着讲述: “船靠岸了, 因为我带着一个箱子, 里面是你们在仰光留下的螺旋桨 和起落架, 我叫了个中国人来, 让他把箱子弄到前往澳门的船码头。这个搬运工要 七美元, 我觉得好像贵了, 就还价说 “五美元! 五!” 戈维亚伸出右手掌, 张开手指比 划着: “最后问题解决了, 我向他指了指箱子。当我看到一大堆人去搬箱子的时候 有些惊奇, 不过我想 ‘显而易见, 他们都太瘦弱了……”

“搬完箱子了, 我抽出一张五美元递给那个跟我讨价还价的中国人。这人开始 说着什么, 我听不懂。为了避免冲突, 又给了他两美元。这时, 出现了一个英国人, 当他明白发生了什么事的时候, 他用手势告诉我, 不要这么做。然后他走开去为我 叫出租车。这是一位警察。”

“他转身走后, 这些中国人开始了一阵震耳欲狵的喧闹。多少人啊! 就像夏天 围在糖盘旁边的苍蝇似的。”

“他们当中的一个人向我走近了一点, 举起了拳头。我本来已经很紧张了, 一 看这情形, 我无法控制自己, 给了他一耳光! 打得不是很重, 但那家伙大概没站稳, 就……跳在了地说, 额头上蹭破了一块。”

“他站起来, 用手捂着脸, 流血了, 天啊! ……他好像要把我给吃了。”

“幸运的是, 这时候出租车到了。我用尽胳膊的力量拉开车门, 对司机喊着, 让 他赶快走。可是那个坏蛋, 别的中国人跟他一样吗?! ……我拽着外衣领子把他甩 开, 冲他用葡萄语大叫着放开, 然后钻进了出租车, 从正在增长的骚动中逃离。”

“可是, 我的司令官, 您想我是坐在车座的垫子上吗? ……不, 我记起了过去在 里斯本电影院看过的中国电影......我蹲在车的底部迎接要到来的一切! 还好, 我这 么做了。因为出租车还没开, 一把七首就刺破了后座的填充物......”戓维亚直到现 在还在出汗, 他结束道: “每次我都会出点事......”

25日, 我们踏上 “祖国号” 巡逻舰, 下午三点半, 我们换到军士们划的一艘小艇 上, 在澳门登陆。

在这小小的半岛上, 古老的葡萄牙城市直立在这亚洲的尽头。不规则的街区 排列在关闸和大海之间, 仿佛是中国大陆伸向太平洋的一只手掌, 向自己富庶、阴 凉的岛屿乞讨几个小钱。 
- Sempre me acontece cada uma! Então não querem saber como é que eu fiz a minha entrada na China?... - Nervosamente, foi logo contando: - O navio acostou, e como eu trazia o caixote com a hélice e o trem da aterragem que deixaram em Rangoon, chamei um chinês para justar com ele o frete para o cais da carreira de Macau. O carregador pediu-me sete dólares, o que me pareceu caro, e por isso discuti: «Five dollars! Five!» - E Gouveia espalma a mão direita, dedos afastados, a reforçar a explicação. - Por fim lá se resolveu, e indiquei-lhe o caixote. Admirou-me ver a chusma que lhe pegou, mas calculei: «Provavelmente são fraquitos...»

«Terminado o trabalho, tiro uma nota de cinco dólares e entrego-a ao chinês com quem tinha justado. O homem começa a dizer não sei o quê e, para evitar questões, disponho-me a dar-lhe mais dois dólares, quando aparece um inglês que, percebendo do que se tratava, depois de me indicar por gestos para não fazer caso, se afasta à procura de um táxi para mim. Era um polícia.

«Quando o viram pelas costas, os chineses começaram numa gritaria de ensurdecer. E depois, que quantidade! Pareciam moscas, no Verão, à volta de um açucareiro.

«Um deles, avançou um pouco para mim, de punhos levantados e, ao ver aquilo, eu, que já estava nervoso, não me contive: preguei-lhe uma bofetada! Não foi grande... Mas o tipo estava provavelmente mal seguro nas pernas, e zás... estatelou-se no chão, fazendo um arranhãozito na testa.

«Quando, ao levantar-se, passa a mão pela cara e vê sangue, caramba!... parecia que me queria comer.

«Felizmente o táxi chegou naquela altura e, abrindo alas à força de braço, gritei ao chauffeur que se despachasse. Mas o malandro, que era chinês como os outros!?... Sacudo-o pela gola do casaco, berro-lhe em Português que largue, e entro no táxi, fugindo à zaragata que aumentava.

«Mas o meu Comandante pensa que me sentei na almofada? É o sentas!... Não, que eu lembrava-me das fitas passadas na China, que tinha visto nos cinemas de Lisboa... Acocorei-me na fundo do carro para o que desse e viesse. E fiz bem, meu Comandante! Porque o táxi ainda não começara a andar, e já uma lâmina de punhal atravessava o estofo do assento de trás... - Gouveia transpira ainda e termina: - A mim sempre me acontece cada uma...

No dia vinte e cinco, embarcávamos na canhoneira Pátria e, às três horas e meia da tarde, num escaler em que os sargentos de bordo pediram para ocupar o lugar dos remadores, desembarcávamos em Macau.

A península minúscula em que a secular cidade portuguesa dos confins da Ásia se comprime, na desordem dos seus bairros, entre as Portas de Cerco e o mar, parece a palma da mão que a China estende ao Pacífico, como a mendigar-lhe a esmola das suas ilhas aveludadas e sombrias. 
在南湾, 那条几乎是圆形的大道像是手腱和拇指间的弧线; 圣母雪地殿小教堂 静静地真立在一座山丘的顶部 155 。

这里的风景有着中国版画的含蓄色调。周围, 水的颜色发红, 广东和西边的河 流带来了大量的冲积土, 舢舨 ${ }^{156}$, 三桅快速帆船 ${ }^{157}$ 和漂泊者的无龙骨小船 ${ }^{158}$ 让人 仿佛朦朦胧胧地忆起曾经的快帆船。这些船的船头低低的, 上面长方形的船帆被 风吹得鼓了起来, 英姿飒爽地在海中摇动。

我们在这里度过的日子是欢宴不断的日子。所有人对待我们的那种友爱之 情是任何言语都无法表达的。女士们 ${ }^{159}$, 陆上和海上的军官们, 军队和海上的士官 们, 水手和士兵等人 ${ }^{160}$, 都向我们赠送贵重的纪念品, 用另一种方式表达着他们的钦 佩、热情和令人愉快的尊重与热爱。

火把游行深深地刻在了我的记忆中, 因为它是一个令人好奇、真正极具特色 的演出。在游行 161 中, 到处都是光亮, 到处都是色彩和生命, 火把在黑暗中滑行, 其 中还夹着鞭炮的爆裂声。在这里, 很多场合人们都要放鞭炮: 庆生, 表达快乐或悲 伤, 驱邪, 治疗疾病等等。

当“祖国号” 巡逻舰带着我们离开澳门前往广东时, 我们的心中充满了真诚而 深厚的谢意。

我们对于中华民国南部首府的访问是短暂的, 但是却让我们再次意识到, 这次 飞行对于把居住在海外的葡萄牙人凝聚起来来说是多么重要!

葡萄牙领事菲利克斯 - 奥尔塔先生用甜蜜的语言向我们介绍了在此城中居 住的五十个葡萄牙人。

\footnotetext{
155 因为不断的填海造土以扩大城市面积, 所有景观都变了。文中的描写已经与现状不符。(第二版注) 156 也叫 “三板”, 中国式木制平底小船, 使用船桨或是风帆行驶。它的葡语名字 “san-pan”来自中文 “三板”, 其 含义是 “三块木板”。这种船是用来在平静的水面进行运输或是捕鱼的。(编者注)

157 一种快速而形体较长 (其长度可达二十五至三十米) 的中式船只, 较为容易驾驭。这种船身上融合了中国 和欧洲的航海技术, 它将葡萄牙轮船的船体形状和中国帆结合在一起。(编者注)

158 一种小型平底无骨船, 传统上使用船桨划行, 带有圆形遮阳棚, 并且由妇女驾驶。有时这种船也作为住房 使用, 特别是在澳门。(编者注)

159 参见伊莎贝尔・莫茹让撰写的介绍中公布的这些女士们的签名。(编者注)

160 有些获赠礼品现在还在位于辛特拉的航空博物馆中。(编者注)

161 原文为一种法语表达方式, 意思是夜间游行, 在游行中, 参与者手持火炬或是彩色灯笼。(编者注)
} 
A Praia Grande, avenida quase circular, faz a curva entre a chave da mão e o polegar, onde a capelinha da Guia se alcandora no topo de uma colina ${ }^{155}$.

A paisagem tem veladas tonalidades de gravura chinesa. No colorido avermelhado das águas em torno, onde os rios de Oeste e de Cantão vão despejando colossais massas de aluvião, os sampans ${ }^{156}$, as lorchas ${ }^{157}$ e os tancares ${ }^{158}$ de linha extravagantes, a revelar reminiscências de caravelas, balouçam bizarramente, proas baixas, velas rectangulares enfunadas pelo vento.

Os dias que ali passámos são de festa ininterrupta, e a afectividade carinhosa com que toda a população sempre nos envolveu tornaria injusta qualquer citação especial. As senhoras $^{159}$, os oficiais de terra e mar, sargentos do exército e da marinha, marinheiros e soldados ${ }^{160}$ oferecem-nos recordações valiosas, que são outros tantos padrões de admiração, de entusiasmo, de consoladora estima.

Como espectáculo curioso, extravagante, verdadeiramente característico, recordarei a marcha aux flambeaux ${ }^{161}$, cheia de luz, de cor e de vida, deslizando na sombra, por entre o estralejar contínuo dos panchões, os estalinhos chineses, que ali são utilizados para múltiplos fins: celebração de nascimentos, manifestações de regozijo ou de pesar, exorcismos, tratamento de enfermidades, etc.

Ao deixar a cidade a bordo da canhoneira Pátria, que nos conduz a Cantão, levamos os corações cheios de gratidão sincera e profunda.

A nossa visita à capital da República Chinesa do Sul, apesar de breve, permitia-nos avaliar mais uma vez a importância da nossa viagem para os núcleos de portugueses residentes no estrangeiro.

Félix Horta, cônsul de Portugal, apresenta-nos aos cinquenta portugueses da cidade, com palavras lisonjeiras em que põe toda a sua alma e, durante as quarenta e oito horas que

\footnotetext{
${ }^{155}$ Com os aterros destinados a alargar a área da cidade, tudo se modificou, e a descrição não corresponde à realidade actual. (Nota da $3 .^{\mathrm{a}}$ edição).

${ }^{156}$ Embarcação chinesa pequena, em madeira, de fundo chato, movida a remos ou à vela. O seu nome provém do chinês «san-pan», que significa «três tábuas», e é utilizada quer para o transporte, quer para a pesca em águas calmas. Em Português, diz-se «sampana». (Nota do editor).

${ }^{157}$ Embarcação chinesa rápida e comprida (podia atingir entre os vinte e cinco e os trinta metros de comprimento), de fácil navegação, que resultou da conjugação das técnicas navais europeias e chinesas, combinando a forma portuguesa do casco com as velas chinesas. (Nota do editor).

${ }^{158}$ Pequeno barco de fundo chato, sem quilha, tradicionalmente movido a remo, com toldo arredondado e tripulado por mulheres. É às vezes usado também para habitação, sobretudo em Macau. (Nota do editor).

${ }^{159}$ Veja-se a assinatura de várias dessas senhoras nas imagens publicadas na introdução de Isabel Morujão. (Nota do editor).

${ }^{160}$ Algumas dessas ofertas encontram-se no Museu do Ar, em Sintra. (Nota do editor).

161 «Marche aux flambeaux» é uma expressão francesa que significa desfile nocturno, durante o qual os participantes transportam na mão tochas ou lanternas multicolores. (Nota do editor).
} 
我们在此逗留了四十八个小时, 在此期间, 他的和蔼善良让我们近距离地领略 了中国的异国情调。在这里, 人们也向我们赠送了可爱的纪念品: 刺绣华丽的大批 肩, 玉器饰品 ${ }^{162}$, 展示了中国人无限耐心的象牙项链和牙雕一一它们是一种高尚的 艺术。

这个城市布局混乱, 街道弯弯曲曲, 类似于岑覃 (Shum-Chum)。

在一些罕见的大道上, 美国的影响力将穿过这古老的城市。大道上, 时不时 地有运兵的汽车通过, 车上的士兵整装待发, 手枪做好了射击准备, 一副好战的样 子一一一个重要角色正在路上。

时不时的, 喃喃私语声, 喧嚷声, 一些子弹……

就这样, 孙中山 ${ }^{163}$ 的中国将在未来的重生中苏醒。

像在澳门一样, 这儿有许多人都生活在船里。

欧洲人居住在沙面岛上。这个小岛只有两端连着城市, 让它变成了一个被遗 忘的欧洲角落。一条运河将这个地区与河岸分开, 上面挤满了舢舨, 芸芸众生蜂拥 而至。

6月7日, 我们乘 “祖国号” 巡逻舰离开, 前往香港并于第二天早晨到达。

应葡萄牙领事的邀请, 我们对这块葡萄牙殖民地的访问是再启澳门的庆祝和 致敬活动。

在东方的英国领地由一些岛屿和一块宽广的大陆领土构成一一这是中国割 让给英国的, 这块领地将渐渐扩大。

这里的风景迷人: 海水有着艳丽清澈的颜色, 宏伟的道路通向浅水湾、粉岭和 山巅, 人们在悬崖峭壁上开出了令人惊奇的、迷人的观景台。

香港湾应该是世界上最美的海湾之一。

我们在塞尔韦拉・德阿布克尔克家度过了八天的时间。期间，英国官方机构 和侨民们以及塞尔韦拉・德阿布克尔克先生全家的关怀让我们深受感动。

\footnotetext{
162 用作装饰的物体或零件, 特别是在家具上。(编者注)

163 孙中山 (1866年-—1925年), 中国政治家、革命家, 现代中国国父。他是第一位主张推翻清朝帝国体制, 建立民主共和国的革命者。孙中山先生是1911-1912年推翻清王朝革命的主要领导者。1924年, 民主主义 革命者陈昫明 (在德贝雷斯的文中将其名字拼写为Chien -Ki-Ming) 拒绝孙中山的向中国中部进发的命令, 孙中山被暂时逐出自1920起占领的广州。为了更广泛地理解这个问题, 请参阅黎涛 (Lai To) 和李福源 (Lee Hock Guan) 编纂的、有关孙中山的研究汇编 “孙中山, 南洋和1911年革命”, 新加坡, 中国文化遗产中心出 版。感谢阿尔弗雷德・戈麦斯・迪亚斯为本条注解提供的信息。(编者注)
} 
ali passamos, as suas afabilidades e gentileza, permitem-nos apreciar de perto o exotismo da China. Ali nos oferecem também adoráveis recordações: xailes de bordados vistosos, bibelots $^{162}$ de jade, colares e esculturas de marfim em que se revela a minuciosa paciência chinesa, ao serviço de uma arte superior.

A cidade é um labirinto de ruas tortuosas, semelhantes às de Shum Chun.

Nas raras avenidas que a influência norte-americana vai cortando através da antiquíssima cidade, vêem-se passar, de quando em quando, automóveis com soldados nos estribos, pistolas aperradas, atitude bélica: - um importante personagem que se desloca.

Por vezes um burburinho, uma algazarra, alguns tiros...

É assim que a China de Sun Yat-sen ${ }^{163}$ vai acordando para um futuro renascimento.

Como em Macau, grande parte da população vive em barcos.

Os europeus, instalados na Shameen, ilhazita que duas pontes ligam à cidade, transformaram-na em recanto da Europa perdido naquelas paragens. E o canal que separa o bairro da margem do rio está coalhado de sampans, onde formigam milhares de seres.

No dia sete de Julho, partimos na canhoneira Pátria para Hong Kong, onde chegámos na manhã seguinte.

A nossa visita à colónia portuguesa, a convite do cônsul de Portugal, é a reedição das festas e homenagens de Macau.

A feitoria britânica do Oriente, constituída por algumas ilhas e por um vasto território continental - concessão da China à Inglaterra -, vai alargando lentamente.

A paisagem fascina: o mar tem uma cor límpida de esmalte, e as estradas magníficas que levam a Repulse Bay, a Fan Ling e ao cimo da montanha abrem nos alcantis encantadores mirantes de surpresa.

A baía de Hong Kong deve ser uma das mais belas do mundo.

As entidades oficiais britânicas associam-se às manifestações da colónia, e a família de Cerveira de Albuquerque, em casa de quem passamos esses oito dias, é para nós de uma solicitude afetiva que nos sensibiliza profundamente. E até uma personalidade chinesa cujo nome

\footnotetext{
${ }^{162}$ Objeto ou peça que se usa como adorno, sobre o mobiliário. (Nota do editor).

${ }^{163}$ Sun Yat-sen (孫中山) (1866-1925) foi um militar e estadista chinês que ficou conhecido como o pai da Nação Moderna (國父), uma vez que foi o primeiro revolucionário a defender o derrube do sistema imperial Qing e a fundação de uma república democrática. Sun foi o principal líder da revolução de 1911/1912 que derrubou a dinastia Qing. Em 1924, o revolucionário nacionalista Ch’en Chiung-ming (que o texto de Beires grafa Chien-KiMing) recusa-se a avançar pela China central, como lhe sugeria Sun Yat-sen, e expulsa temporariamente este último de Guangzhou, que ocupava desde 1920. Para uma compreensão mais alargada, veja-se a compilação de estudos sobre esta figura, editada por Lee Lai To e Lee Hock Guan (2011): Sun Yat-Sen. Nanyang and the 1911 Revolution, Singapura, Chinese Heritage Center. Agrade-se a Alfredo Gomes Dias as informações que permitiram a redacção desta nota. (Nota do editor).
} 
甚至还有一位中国人宴请了我们, 我不记得他的名字了。宴会上我们品尝了 许多珍贵的中国美食: 燕窝木耳汤, 烤乳猪, 松花蛋, 蛇肉, 海鲜沙拉, 海参, 还有许多 我不认识的东西。

我们离开香港时, 已经有了许多朋友; 我们最大的愿望是: 所有人都能感受到 来自我们心灵深处的, 对于他们的无限认可。

我相信, 塞尔韦拉 - 德阿布克尔克先生感受到了, 他知道我们带走了思念。

澳门总督罗德里格 - 罗德里格斯对待我们的方式是一种真正的、迷人的礼 遇。在他的命令下, 为了看望居住在上海、东京和美国的葡萄牙侨民, 能够有机会 满足他们拥抱我们的温柔愿望, 在侨民中重振爱国之情, “祖国号” 飞行团队将经过 北美回到祖国。

在上海的狂热气氛中, 葡萄牙领事卡萨诺瓦在葡萄牙租界前以高贵的风度接 待了我们; 在一场有趣的游园会 ${ }^{164}$ 中, 人们祝福我们, 向我们赠送了纪念品; 在日本, 我们看到了颜色阴沉的富士山幽灵般的变幻, 一瞬间, 白雪皑皑的山头出现在浓雾 之上; 太平洋上, 32000 吨的 “加拿大皇后号”165 用自己低沉刺耳的汽笛发出凄楚的 警报声, 在不间断的浓雾中, 我们在船上领略了太平洋的温柔; 还有温哥华的美景, 在冰冷纯净的空气中闪闪发亮维多利亚岛……都像闪电冒出的火花般出现在我们 的思念中 ${ }^{166}$ 。

然后是西雅图一一征兆着美国不安生活的第一缕微光, 那里的摩天大楼直刺 云霄。

旧金山, 奥克兰, 圣何塞和萨克拉门, 冒着快乐的火焰接待了我们。

葡萄牙驻加利福尼亚总领事欧科里德斯 - 戈拉特 - 达科斯达是我们在美国 交的一个好朋友, 我们永远无法忘记他。他有着有教养的心灵, 出众的才智, 在我 们经过美国的这个州时, 欢迎仪式上, 他用自己的外交手腕和爱国精神引领了仪 式。

在他和他的家人旁边, 我们度过了令人慰藉的几个小时, 感受到了我们周围浓 浓的友爱之情, 那不仅仅是因为戈拉特 - 达科斯达的道德观和知识观所体现的深 刻的葡萄牙主义, 也是由于我们之间的亲近之情很快就转变成了友谊。

\footnotetext{
164 在花园中举行的派对。(编者注)

165 著名的穿越太平洋蒸汽邮轮, 建于1920年。其目的是自加拿大西海岸 (温哥华) 航行至日本、香港和中 国大陆。它的首航是在 1922 年 5 月 5 日。晚些时候, 在第二次世界大战期间, 这艘船被用作运送军队的战 舰。1943年, 在运送意大利战争战俘和波兰及希腊难民时, 在帕尔玛斯角以南640公里处被意大利潜艇达芬 奇号击沉。(编者注)

166 因某些乘客的要求, 应 “加拿大皇后号” 指挥官的邀请, 我在这艘英国大邮船的宴会厅就本次飞行举行了 一次讨论会。这次讨论会引起了人们很大的兴趣, 以至指挥官请我重复此次讨论会, 而且为了给他留下原始 的记录, 我用还可接受的英语进行了记录一一这给我带来了巨大的工作量。还有一次, 我介绍了当时作为对 于一个国家的宣传, 长途飞行代表着什么。(第三版注)
} 
não recordo nos ofereceu um banquete onde saboreamos as iguarias mais raras da culinária chinesa: sopa de ninhos de andorinha e de alga preta, leitão lacado, ovos podres, cobra, marisco em salada, holotúrias, e não sei que mais.

Ao deixar Hong Kong, deixávamos amigos. A nossa maior aspiração era a de ter a certeza que todos sentiam o infinito reconhecimento das nossas almas.

Creio que Cerveira de Albuquerque o sentiu, e sabe que trouxemos saudades.

Por ordem de S. Ex. a o governador de Macau, Dr. Rodrigo Rodrigues, cujo procedimento para connosco foi de uma cortesia verdadeiramente cativante, a equipe do Pátria ia regressar à Metrópole via América do Norte, a fim de, visitando os núcleos portugueses de Shangai, Tóquio e Estados Unidos, ter ocasião de satisfazer-lhes a aspiração enternecedora de nos abraçar, revigorando neles o sentimento pátrio que, naquelas paragens, atinge proporções verdadeiramente tocantes.

O delírio frenético de Shangai, onde Casanova, cônsul de Portugal, nos recebe fidalgamente, à frente da Colónia Portuguesa, cujas felicitações e lembranças nos são ofertadas num interessante garden-party ${ }^{164}$ - a visão espectral do Fujiyama negrejando, por instantes, com sua coifa de neve, acima da bruma; a mansidão do Pacífico, com suas névoas constantes, através das quais as trinta e duas mil toneladas do Empress of Canada ${ }^{165}$ lançam o alarme lúgubre dos seus apitos roucos; a beleza da paisagem de Vancouver, com Vitória reluzindo na atmosfera glacial e pura - são relâmpagos que faíscam na onda avassalante da nossa nostalgia ${ }^{166}$.

Depois é Seattle, primeiro vislumbre da irrequieta vida norte-americana, sky-scrapers perfurando o céu.

São Francisco, Oakland, São José e Sacramento são labaredas de alegria a receber-nos.

Euclides Goulart da Costa, Cônsul Geral de Portugal na Califórnia, é um grande amigo que ali deixamos e nunca mais poderemos esquecer. Espírito culto, inteligência excepcional, o seu tacto diplomático e o seu espírito patriótico revelaram-se na maneira como orienta as cerimónias que assinalaram a nossa passagem por aquele Estado Norte-Americano.

Junto dele e de sua família passamos horas de consolador convívio, sentindo no ambiente carinhoso de que nos rodeiam, não só o profundo portuguesismo de Goulart da Costa, que

\footnotetext{
${ }^{164}$ Festa de jardim. (Nota do editor).

${ }^{165}$ Célebre paquete trans-pacífico, construído em 1920, para fazer a travessia desde a costa Oeste do Canadá (Vancouver) até ao Japão, Hong Kong e China. A sua viagem inaugural foi a 5 de Maio de 1922. Mais tarde, durante a segunda guerra mundial, foi usado como navio de guerra, para transporte de tropas. Em 1943, quando transportava prisioneiros de guerra italianos juntamente com refugiados polacos e gregos, foi torpedeado e afundado pelo submarino italiano Leonardo da Vinci, a $640 \mathrm{Km}$ a Sul do Cabo Palmas. (Nota do editor).

${ }^{166}$ A convite do comandante do Empress of Canada, baseado no desejo manifestado por certo número de passageiros, pronunciei no salão de festas do grande paquete inglês uma conferência sobre a viagem, a qual despertou tanto interesse, que o comandante me pediu para repeti-la e, ainda, para lhe deixar guardar o original que tanto trabalho me dera a redigir num inglês aceitável. Ainda uma vez se demonstrou o que representava ao tempo, como propaganda para um país, uma viagem aérea de longo curso. (Nota da 3. a edição).
} 
在他领导下的葡萄牙人委员会与美国官方机构合作, 组织了接待我们的活动。 毫无疑问, 我们在经过这个葡萄牙侨民重要聚居点时, 这一切让我们激动万分 (并 将永远留在我们的心中)。

在某些地方, 就像在加利福尼亚一样, 人们怀着巨大的热情与慷慨接待了我 们。

在那些日子里, 我们可以从近处密切观察生活在繁荣的美国的葡萄牙人, 能够 再次确认 “祖国号” 的这次飞行给他们心理上带来的影响。

人们在市政厅向我们致敬。在那儿, 我们向一位美国海军军官承认理解美国 英语很困难, 结果从他口中我们听到了这句令人惊奇的话:

“这也难怪, 您是跟英国人学的英语。英国人不会说英语。”

我们举两个事实, 只是来定义一下善良的葡萄牙人是多么感性。从他们的嘴 唇中吐出的呼喊, 让我们依稀听见了离开千泉新城时人们的欢呼声。

他们组织了一次在萨克拉门托的巡游。八辆汽车组成了车队, 葡萄牙旗帜和 美国旗帜迎风飘扬。车队快速行进在水泥路面的公路上, 喇叭发出刺耳的轰鸣声 167 , 通过了一个个有葡萄牙人居住的小镇和村庄。

在一个公路的拐弯处, 车队停了下来。

一个男人举着一面小小的葡萄牙旗帜, 问飞行员在哪儿。

他一言不发地打开车 ${ }^{168}$ 门, 伸出双臂紧紧地拥抱着我们, 激动地久久抱着我们 不放, 沉默中涌动着他对遥远祖国的思念。那一刻, 对他来说, 我们就代表着遥远 的祖国。

那是很短的一瞬间, 只有几秒钟。之后, 车队继续前进。这位默默无闻的人那 令人难忘的形象消失在公路扬起的尘埃中, 但却永远地刻在了我们的心间。

我们动身去波士顿的那天, 快车下午 16 点停在了奥克兰。在大道上, 葡萄牙领 事和他的家人一直陪我们到那里。此时, 一个小伙子进到车厢里, 给我们每个人一 张小收藏卡, 上面写着幼稚但真诚的四行诗, 他狂热地拥抱了我们, 当火车渐行渐 远往东开去, 他哭了。

167 原文为kláxons, 英语单词Klaxon的派生词, 指高音汽笛的声音, Klaxon曾是制造商的商标。(编者注) 168 指的是非常豪华的超长轿车, 一般为白色或黑色, 通常是很有钱的人或是在特别的聚会场合才使用。 (编者注) 
se afirma, pelo valor moral e intelectual, como a simpatia que rapidamente se transforma em amizade. A Comissão de portugueses que, sob a sua presidência, organizou a recepção em que colaboraram as entidades oficiais americanas não duvida, por certo, da emoção que nos causou (e em nós perdurará) a nossa passagem naquele núcleo importantíssimo de colonos portugueses.

Em parte alguma, como na Califórnia, a recepção atingiu culminâncias tamanhas de entusiasmo e de generosidade.

São alguns dias em que, observando de perto os portugueses do florescente Estado Norte-Americano, podemos constatar novamente o alcance psicológico da viagem do Pátria.

Somos homenageados no City Hall, e ali ouvimos, da boca de um oficial da Marinha de Guerra Norte-Americana, a quem confessávamos o nosso embaraço para compreender o inglês da América, esta frase estupenda:

- Não admira. O senhor aprendeu inglês com os ingleses. E os ingleses não sabem falar inglês.

Citaremos dois factos que, por si só, definem a sensibilidade dessa boa gente portuguesa, de cujos lábios parece desprender-se anda o mesmo grito que ouvíramos na hora incerta da largada de Milfontes.

Organizara-se um passeio a Sacramento. Os oito automóveis que formavam o cortejo, bandeiras portuguesas e americanas flutuando ao vento, deslizavam, velozes, na estrada cimentada, fazendo bramir os klaxons ${ }^{167}$ estridentes ao passar pelas vilas e aldeias onde residiam portugueses.

Num cotovelo da estrada, a marcha suspende-se.

Um homem, segurando uma pequenita bandeira portuguesa, pergunta pelos aviadores.

Sem uma palavra, abre a portinhola da limousine ${ }^{168}$, e são dois braços que nos apertam, longamente, comovidamente, num silêncio enorme latejante de toda a sua saudade da Pátria longínqua, que, naquele momento, para ele representamos.

É um instante breve, de alguns segundos. O cortejo prossegue, e a figura inesquecível daquele homem obscuro desaparece na poeira da estrada e fica gravada em nós.

No dia da nossa partida para Boston, quando o expresso parou em Oakland, na 16th Avenue, até onde nos acompanhou, com sua família, o cônsul de Portugal, um rapaz sobe à carruagem e, depois de entregar a cada um de nós um pequenino cromo em que escrevera três quadras ingénuas mas sinceras, abraça-nos com frenesi, e fica chorando quando o trem se afasta, na sua longa caminhada para Leste.

\footnotetext{
${ }^{167}$ Buzina estridente dos automóveis. Palavra inglesa, derivada de Klaxon, que era a sua marca comercial. (Nota do editor).

${ }^{168}$ Carro muito longo e luxuoso, normalmente de cor branca ou preta, geralmente usado por pessoas muito ricas ou em ocasiões de festa muito especiais. (Nota do editor).
} 
在这些场合 (布里托 - 帕艾斯在他一次精彩的演说中说的), 我们觉得自己很 伟大。

那些臂膀, 是拥抱我们的葡萄牙臂膀, 代表着万里之外的同样的葡萄牙人民, 是他们帮助我们取得了胜利!

我们通过险峻的落基山脉时, 灾难性的森林大火让山梁在整晚都散发着悲剧 性的红色; 通过盐湖时, 盐湖城的海鸥仿佛在述说着摩门教的传说; 终于, 通过普拉 特河到了新英格兰这片散落着湖泊和灌木从的地区，我们到了波士顿。在波士顿， 奥特子爵, 葡萄牙驻华盛顿部长, 葡萄牙领事和葡萄牙侨民热情地接待了我们。尽 管人们挣扎在令人遗憾的危机之中, 但是他们确认了罗德里格 - 罗德里格斯的话, 告诉我们应该做出牺牲, 从北美动身回国, 尽管这样做会推迟我们到达里斯本的日 期。

我经过马萨诸塞州的时候，一场让人痛苦的健康烦恼把我关在酒店的房间中， 无法去参观新贝德福德、普罗维登斯、秋河和其他葡萄牙侨民聚居区。在这些地 方, 布里托・帕艾斯和戈维亚受到了极为亲切的接待。

在我们动身前往纽约的前夜, 为了致敬, 一群工人给我们带来了纪念品。他们 能够体会到飞机的机翼真是泯灭边界的伟大武器, 这些人做着手势, 含蓄地承认了 跨洲和跨洋飞行为人类皆兄弟这一大同思想贡献良多。

纽约, 纽瓦克和泽西市是我们在美国最后参观的几个地方。

每到一处, 同样的热情, 同样的友爱, 这卢西塔尼亚式的敏感一一或许在都市 中变弱了, 在海外, 却大大增强了, 加上强大的种族适应性, 让葡萄牙侨民在与生活 的奋斗中得到了更多的制胜法宝, 在美国的土地上到达胜利的顶峰。

美国东部的葡萄牙侨民中, 纽瓦克侨民聚居点对我们的接待极为殷切, 令人印 象深刻。

我们终于在8月28日登上 “阿基塔尼亚” 号, 动身前往欧洲。

晨雾中, 逆光祄出了纽约那些高大建筑物的长方形形状。阳光照耀着自由女 神像, 女神高举着火炬。

“阿基塔尼亚” 号沉浸在大西洋的孤独之中...... 
Nessas ocasiões (disse-o Brito Paes, num dos seus discursos mais brilhantes), sentimo-nos grandes.

Aqueles braços são braços de Portugal que nos estreitam e simbolizam, a milhares de léguas, o mesmo Povo Português que nos ajudara a vencer. Na mudez eloquente do seu gesto, parecia que Portugal nos bendizia pelo triunfo das asas portuguesas.

Através da paisagem ríspida e alcantilada das Rocky Mountains, em cujos contrafortes o incêndio sinistro das florestas punha, durante a noite, trágicas vermelhidões; através do Lago Salgado onde a gaivota de Salt Lake City conta a lenda dos mórmons; através do vale do rio Platte, da região dos lagos e dos bosques da Nova Inglaterra, chegávamos a Boston, onde o Visconde de Alte, ministro de Portugal em Washington, nos recebia, com o cônsul de Portugal e a Colónia Portuguesa, que, apesar da lamentável crise em que se debatia, confirmava, com o calor da sua recepção, as palavras do Dr. Rodrigo Rodrigues, ao dizer-nos que devíamos sacrificar-nos, regressando pela América do Norte, muito embora, por esse facto, tivéssemos de retardar um pouco a nossa chegada a Lisboa.

A minha passagem pelo Estado de Massachusetts foi assinalada por um doloroso incómodo de saúde que, imobilizando-me no quarto de hotel, me inibiu de visitar New Bedford, Providence, Fall River e outros núcleos de colonos portugueses, onde Brito Paes e Gouveia foram recebidos com grandes demonstrações de simpatia.

$\mathrm{Na}$ véspera da nossa partida para Nova-Iorque, um grupo de operários vinha trazer-nos a homenagem de uma recordação. Pressentindo nas asas a grande arma demolidora das fronteiras, esses homens, com o seu gesto, reconheciam implicitamente nas viagens aéreas transcontinentais e transatlânticas o pacífico factor da idade luminosa da Grande Fraternidade Humana.

New-York, Newark e Jersey-City são as nossas últimas visitas, nos Estados Unidos.

Por toda a parte, o mesmo entusiasmo, o mesmo carinho e essa sensitividade lusitana que na Metrópole amolenta, mas que além-mar centuplica energias, combinando-se com a formidável adaptabilidade da raça, para lhe dar elementos de triunfo na luta pela vida, elevada ao expoente máximo em terras da América.

A destacar-se entre as colónias portuguesas de Leste, pela maneira como nos recebe, o núcleo de Newark requinta de solicitude.

Finalmente, no dia vinte e oito de Agosto, a bordo do Aquitânia, partíamos para a Europa.

Na neblina da manhã, os rectângulos esguios dos altos edifícios nova-iorquinos recortavam-se em contraluz. A Estátua da Liberdade, iluminada em cheio pelo sol, levantava bem alto o seu facho ardente.

E o Aquitânia mergulhou na solidão do Atlântico... 
我们在海天之间航行了六天。

9 月 2 号夜里, 船到了伦敦。在此, 我们耽搁了三天, 接受了葡萄牙商业厅的致 敬, 还出席了一个宴会。宴会是由葡萄牙大使诺尔顿・德马托斯将军主导的。

7日, “阿尔兰扎号” 离开了南安普顿, 开往里斯本。

船上一些葡萄牙人说: 在我们到达时, 应该有庆祝活动。这消息在乘客中传 播。

9 日中午, 在雨中, 我们进入特茹河防波堤内。在那遥远的 4 月 2 日下午, 当我们 离开时, 这个城市阳光明媚, 而此时在雨天悲伤的光线下, 城市仿佛在打着哈欠。

我们穿着制服倚在船舷上, 盘算着坏天气或许会阻碍水上庆典活动, 但河流和 城市一派正常的面貌让我们有些吃惊。

许多乘客一一那些冷漠的乘客一一似乎是故意的, 用讽刺的目光看着我们, 这 让我们一小会儿之后就下到客舱, 换上了我们的西服便装。

船下了锚。

来接我们的是布斯莱恩船运公司的若泽・瓦雷里奥先生。

“里斯本没人知道。”他明确道: “我自己也是偶然得知的.......”

“可是没人收到一份从伦敦拍来的电报吗?”

“没有! 我是从“阿尔兰扎号”被拦截的一次无线电中得知的。”

烦人的雨水让我们记起在中国的降落。

我们的离开几乎是秘密的, 似乎我们是阴谋家。

若泽 - 瓦雷里奥先生的及时帮助让我们办理复杂的海关手续时不那么辛苦 劳碌。全程中, 我们的行李第一次在海关只是由于被关照而没被搜查一一尽管我 们持外交护照。

布里托・帕艾斯笑着说:

“好极了! 好极了! 这样我们就可以说, 我们是怎么出去的就是怎么回来的。”

我们跟所有人一样, 得到的解释是: 在这个混乱的电报故事中, 电报在一位部 长的写字台上睡了两天, 从一位部长秘书的文件夹中消失了。

9月 14 日, 这令人激动的旅程结束于宫殿广场。在此, 共和国总统特谢拉 - 戈 麦斯阁下亲手向我们授予金塔佩剑勋章, 里斯本人民高声欢呼。 
Seis dias, entre céu e mar.

No dia dois de Setembro à noite chegávamos a Londres, onde nos demorávamos três dias, recebendo a homenagem da Câmara Portuguesa de Comércio, num banquete a que presidia o general Norton de Matos, Embaixador de Portugal.

No dia sete, o Arlanza deixa Southampton, a caminho de Lisboa.

A bordo, alguns portugueses comunicam-nos e fazem correr entre os passageiros o programa dos festejos que deviam ter lugar, à nossa chegada.

Pelo meio-dia de nove, entramos a barra do Tejo sob um aguaceiro, e a cidade que deixáramos, risonha de sol, nessa tarde distante de dois de Abril, aparece-nos, bocejando, sob a luz triste de um dia de chuva.

Debruçados na amurada, fardados, e calculando que o mau tempo tivesse impedido o cortejo fluvial anunciado, o aspecto normal do rio e da cidade surpreende-nos.

Muitos passageiros, a quem aquela indiferença parece intencional, olham-nos quase com ironia e impelem-nos, dentro em pouco, a descer aos beliches para envergar os nossos discretos fatos à paisana.

O navio lança ferro.

A receber-nos, aparece o sr. José Valério, da Booth Line.

- Em Lisboa ninguém sabe! - esclarece. - Eu próprio, só tive conhecimento por acaso...

- Mas então não se recebeu nenhum telegrama de Londres?

- Não!! Eu soube por um rádio do Arlanza, que foi interceptado.

A chuva impertinente recorda-nos a aterragem na China.

O nosso desembarque é quase clandestino. Parecemos conspiradores.

O auxílio providencial de José Valério facilitava-nos extraordinariamente a faina difícil das formalidades da Alfândega, onde, pela primeira vez em toda a viagem, só por favor as nossas bagagens não eram vasculhadas, apesar dos passaportes diplomáticos.

Brito Paes comentava sorrindo:

- Óptimo! Óptimo! Assim podemos dizer que entramos como saímos!

A explicação, tivemo-la como toda a gente, nessa confusa história do telegrama, dormitando dois dias sobre a secretária de um ministro, desaparecido da pasta de um secretário de ministro.

Essas jornadas comoventes de catorze de Setembro, quando, terminada a parada no Terreiro do Paço, durante a qual S. Ex. a o Dr. Teixeira Gomes, Presidente da República, por suas próprias mãos nos condecorou com a Torre e Espada - o Povo de Lisboa delirantemente nos ovacionou; - da visita impressionante ao Porto, onde, no Teatro Sá da Bandeira, Leonardo Coimbra nos saudava em nome da cidade, num daqueles rasgos de oratória que dele fizeram 
在令人印象深刻的波尔图之旅中, 在萨 - 达班德拉剧院, 在一次让他成为伟大 演说家的讲演中, 里奥纳多 - 科因布拉以城市的名义向我们致以欢迎。在千泉新 城的迷人聚会中, 人们感叹着我们到达时的沉寂一一这很大程度上是由于疏忽或 是某些人的故意, 他们想要阻止人民表达自己的情感, 跟对待我们的方式相比较, 他们更为严重地欺骗了人民。

千百人的眼中都含着热泪, 他们把鲜花掷向我们, 所有人都在热情地高喊着最 美的词汇, 表达着 “祖国号”飞机的胜利给葡萄牙带来的欢乐, 表达着葡萄牙空军的 胜利。这胜利是回响, 是我们在精神上曾经度过, 曾忍受过的痛苦和快乐的回声。

觉得幸福——坦率地说我们觉得幸福——那不是因为因为人们试图加在我 们身上的光环, 也不是因为在这些致敬仪式中含有满足我们骄傲的阿诅奉承, 甚至 也不是因为我们觉得自己配得上这些欢呼。

而是因为它们是葡萄牙人民的胜利欢歌, 这些庄严的仪式是为了向这些举行 仪式的人民自己致敬。这些人民, 葡萄牙人民, 他们高贵, 慷慨, 勇敢, 在本土, 在海 外各省, 在外国, 他们是 “祖国号” 飞行之旅的灵魂; 这些翻开这本小书的葡萄牙人 民, 请接受我的全部感激之情。

1924年8月

1925年1月 
um tão grande tribuno; - da festa encantadora de Milfontes - supriram, porém, largamente, o silêncio feito em volta da nossa chegada, por desleixo ou intenção de alguém, que, impedindo o Povo de se manifestar, o ludibriou mais do que a nós.

As lágrimas que brilhavam em milhares de olhos, as flores que sobre nós foram lançadas, os gritos de entusiasmo soltados por tantas bocas traduziam, melhor que todas as palavras, a alegria de Portugal pelo triunfo das asas do Pátria, pela vitória da Aeronáutica Portuguesa, e eram a repercussão dessas horas em que, de mãos dadas com o Brasil, tinha vivido e sofrido espiritualmente a beleza e as angústias que nós vivêramos e sofrêramos.

E se nos sentimos felizes - sinceramente o afirmo -, não foi pela glória de que pretenderam aureolar-nos, nem pelo que nessas homenagens havia de lisonjeiro para o nosso orgulho, nem tão-pouco porque julgássemos ter merecido essas hossanas.

Mas porque elas eram o cântico da Vitória do Povo, porque essas solenidades eram em honra do próprio Povo que as celebrava - esse Povo português, nobre, generoso, admirável, que, na Metrópole, no Ultramar e no estrangeiro, fora a alma da viagem do Pátria - esse Povo de Portugal em cujas mãos desponho hoje estas páginas, com toda a minha gratidão.

Agosto, 1924

Janeiro, 1925 



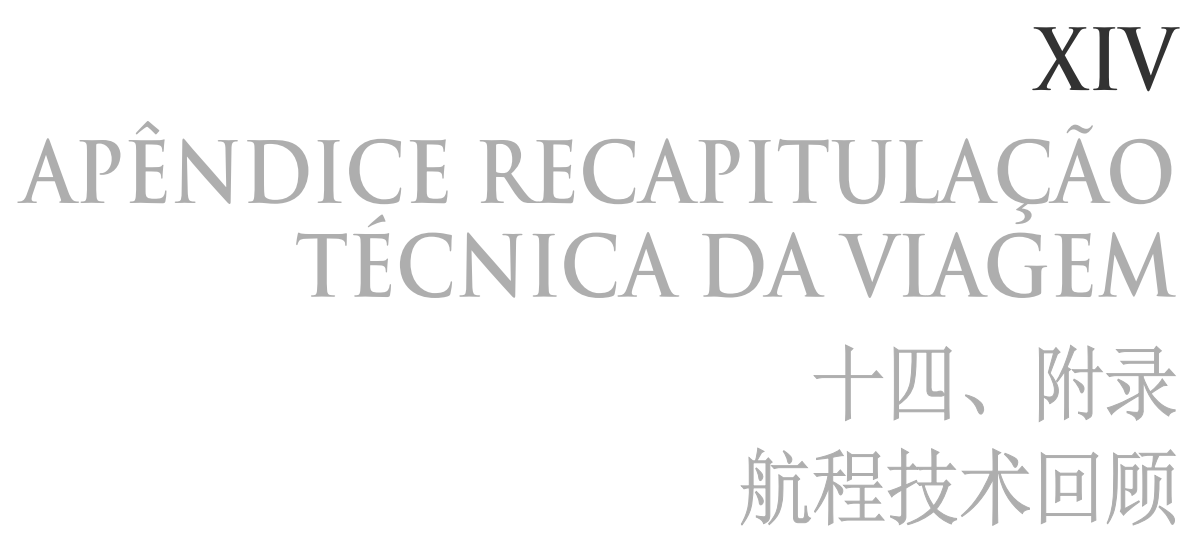



Voos do avião Pátria (Breguet 16 - BN 2)

“祖国号”飞机航程 (布雷盖16飞机一-BN2型)

\begin{tabular}{|c|c|c|c|c|c|c|c|}
\hline \multirow[t]{3}{*}{$\begin{array}{l}\text { Data } \\
\text { 日期 }\end{array}$} & \multirow{3}{*}{$\begin{array}{l}\text { Emprego } \\
\text { do Tempo } \\
\text { 工作时间 }\end{array}$} & \multirow{3}{*}{ 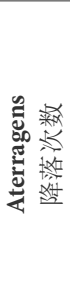 } & 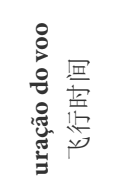 & \multirow{3}{*}{ 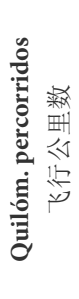 } & \multirow{3}{*}{ 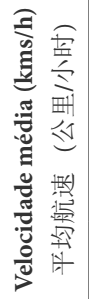 } & \multirow{3}{*}{ 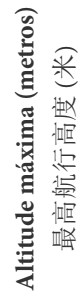 } & \multirow{3}{*}{$\begin{array}{c}\text { Estado } \\
\text { Atmosférico } \\
\text { 天气状况 }\end{array}$} \\
\hline & & & & & & & \\
\hline & & & $\begin{array}{c}\text { Hora } \mid \text { Min. } \\
\text { 小时 | 分 }\end{array}$ & & & & \\
\hline
\end{tabular}

ANTES DA PARTIDA

出发前

\begin{tabular}{|c|c|c|c|c|c|c|c|}
\hline 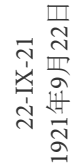 & $\begin{array}{l}\text { Manhã - primeiro ensaio do avião. Passageiro } \\
\text { Brito Paes } \\
\text { 早晨一一第一次试航。 } \\
\text { 乘客: 布里托・帕艾斯 }\end{array}$ & 1 & 030 & 50 & - & 600 & $\begin{array}{c}\text { Bom tempo } \\
\text { 天气晴好 }\end{array}$ \\
\hline 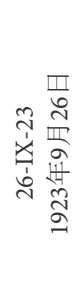 & $\begin{array}{l}\text { Manhã - Voo de ensaio depois de sofrer várias } \\
\text { reparações. Comportamento satisfatório. } \\
\text { Percurso: Amadora-Sesimbra-Setúbal-Vila Nova } \\
\text { de Milfontes. Passageiro: Mecânico Luís Rodrigo } \\
\text { Pilo } \\
\text { 早——经过多次修理后试飞。 } \\
\text { 路线: 阿玛多拉一一色辛布拉一一千泉新城。 } \\
\text { 乘客: 机械师路易斯・罗德里格・皮路 }\end{array}$ & 1 & 105 & 160 & 160 & 1.000 & $\begin{array}{c}\text { Bom tempo } \\
\text { 天气晴好 }\end{array}$ \\
\hline 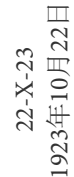 & $\begin{array}{l}\text { Manhã - Regresso à Amadora, via Setúbal. } \\
\text { Passageiro: Mecânico Manuel Gouveia } \\
\text { 早——经塞图巴尔回到阿马多拉。 } \\
\text { 乘客: 机械师曼努埃尔・戈维亚 }\end{array}$ & 1 & 102 & 140 & 155 & 900 & $\begin{array}{l}\text { Nuvens baixas } \\
\text { Vento S. fresco } \\
\text { 云层较低, 南 } \\
\text { 风, 凉爽 }\end{array}$ \\
\hline \multirow[t]{2}{*}{ 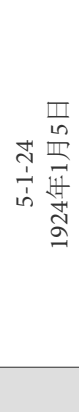 } & $\begin{array}{l}\text { Manhã - Amadora- Lisboa-Setúbal-Vila Nova de } \\
\text { Milfontes. Passageiro: Mecânico Manuel Gouveia } \\
\text { 早——阿马多啦一一里斯本一一千泉新城 } \\
\text { 乘客: 机械师曼努埃尔・戈维亚 } \\
\text { Tarde - Regresso à Amadora, seguindo o mesmo } \\
\text { itinerário e com o mesmo passageiro } \\
\text { 下午一经同一路线回到阿马多拉, 乘客为同 } \\
\text { 一人 }\end{array}$ & 1 & 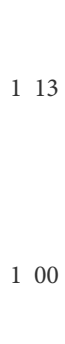 & 140 & 127 & 1.000 & $\begin{array}{c}\text { Bom tempo } \\
\text { 天气晴好 }\end{array}$ \\
\hline & A transportar | 载重 & 5 & 450 & 630 & & & \\
\hline
\end{tabular}




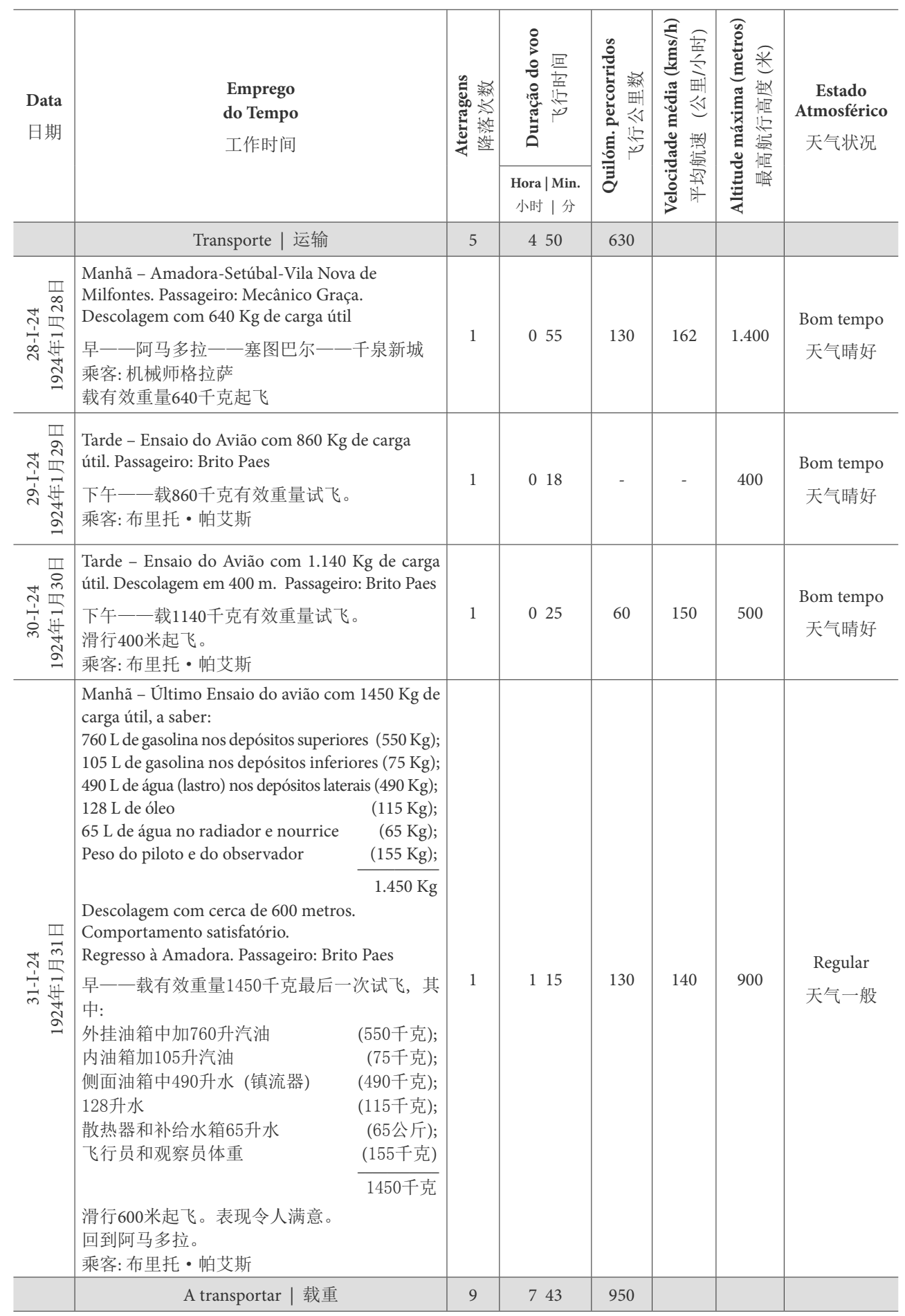




\begin{tabular}{|c|c|c|c|c|c|c|c|}
\hline \multirow[t]{2}{*}{$\begin{array}{l}\text { Data } \\
\text { 日期 }\end{array}$} & \multirow{2}{*}{$\begin{array}{l}\text { Emprego } \\
\text { do Tempo } \\
\text { 工作时间 }\end{array}$} & \multirow{2}{*}{ 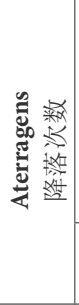 } & 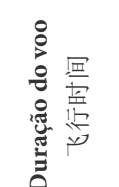 & \multirow{2}{*}{ 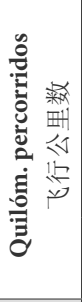 } & \multirow{2}{*}{ 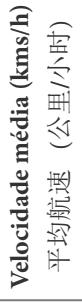 } & \multirow{2}{*}{ 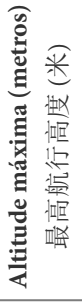 } & \multirow{2}{*}{$\begin{array}{c}\text { Estado } \\
\text { Atmosférico } \\
\text { 天气状况 }\end{array}$} \\
\hline & & & $\begin{array}{l}\text { Hora | Min. } \\
\text { 小时 | 分 }\end{array}$ & & & & \\
\hline & Transporte | 运输 & 9 & 743 & 950 & & & \\
\hline \multirow[t]{2}{*}{ 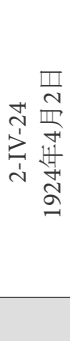 } & $\begin{array}{l}\text { Tarde - Condução do } \\
\text { Avião para Vila Nova de Milfontes. } \\
\text { (Ante-primeira } \\
\text { etapa da viagem) } \\
\text { Passageiro: Brito Paes } \\
\text { 下午——驾驶飞机前往千泉新城。(第一段 } \\
\text { 航程前) } \\
\text { 乘客: 布里托・帕艾斯 }\end{array}$ & 1 & 050 & 130 & 185 & 1.100 & $\begin{array}{l}\text { Nortada rija. } \\
\text { Atmosfera } \\
\text { Agitada } \\
\text { 强硬的北 } \\
\text { 风。 } \\
\text { 大气层活 } \\
\text { 跃。 }\end{array}$ \\
\hline & Totais | 共计 & 10 & 833 & 1.080 & & & \\
\hline
\end{tabular}

\begin{tabular}{|c|c|c|c|c|c|c|c|}
\hline \multirow{3}{*}{$\begin{array}{l}\text { Data } \\
\text { 日期 }\end{array}$} & \multirow{3}{*}{$\begin{array}{l}\text { Emprego } \\
\text { do Tempo } \\
\text { 工作时间 }\end{array}$} & \multirow{3}{*}{ 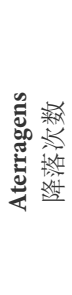 } & 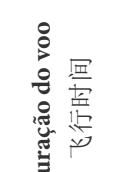 & \multirow{3}{*}{ 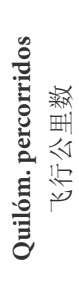 } & \multirow{3}{*}{ 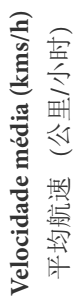 } & \multirow{3}{*}{ 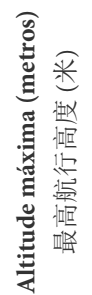 } & \multirow{3}{*}{$\begin{array}{c}\text { Estado } \\
\text { Atmosférico } \\
\text { 天气状况 }\end{array}$} \\
\hline & & & $\tilde{0}$ & & & & \\
\hline & & & $\begin{array}{l}\text { Hora | Min. } \\
\text { 小时 | 分 }\end{array}$ & & & & \\
\hline
\end{tabular}

\section{ROTEIRO DA VIAGEM}

飞行日志

Tripulação. Comandante e observador: Cap. Brito Paes.

Piloto: Cap. Sarmento de Beires

机组

指挥官及观察员: 布里托・帕艾斯上校

飞行员: 萨尔门托・德贝雷斯上校

\begin{tabular}{|c|c|c|c|c|c|c|c|}
\hline 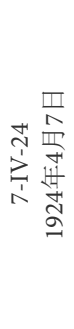 & $\begin{array}{l}\text { Manhã - Partida de Vila Nova de Milfontes às } \\
\text { 6h.02m. Percurso: Odemira-Vila Real de Santo } \\
\text { António-Sevilha-Tarifa-Algeciras-Málaga. } \\
\text { Aterragem às 10h.22m (TMG) } \\
\text { 早一一6:02从千泉新城出发。 } \\
\text { 路线: 奥德米拉——维拉里奥 - 德圣安东 } \\
\text { 尼奥一一塞维利亚——塔里发一一奥热希 } \\
\text { 拉——马拉加 } \\
10 \text { 点22分降落 }\end{array}$ & 1 & 430 & 630 & 146 & 1.200 & $\begin{array}{c}\text { Temporal, } \\
\text { aguaceiros, } \\
\text { vento SO } \\
\text { fortíssimo } \\
\text { 暴风雨, 极强 } \\
\text { 的西南风 }\end{array}$ \\
\hline & A transportar | 载重 & 1 & 430 & 630 & & & \\
\hline
\end{tabular}




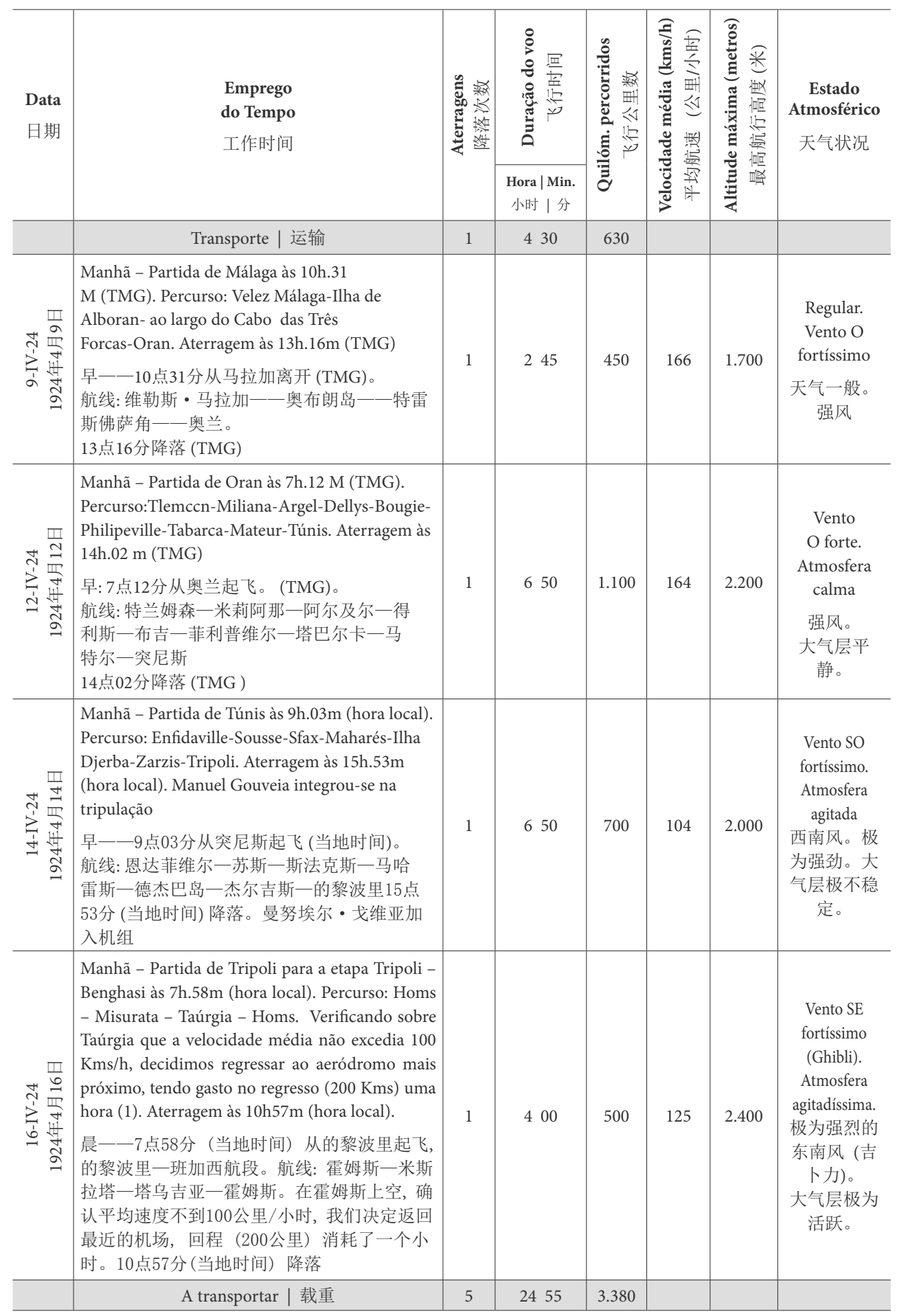




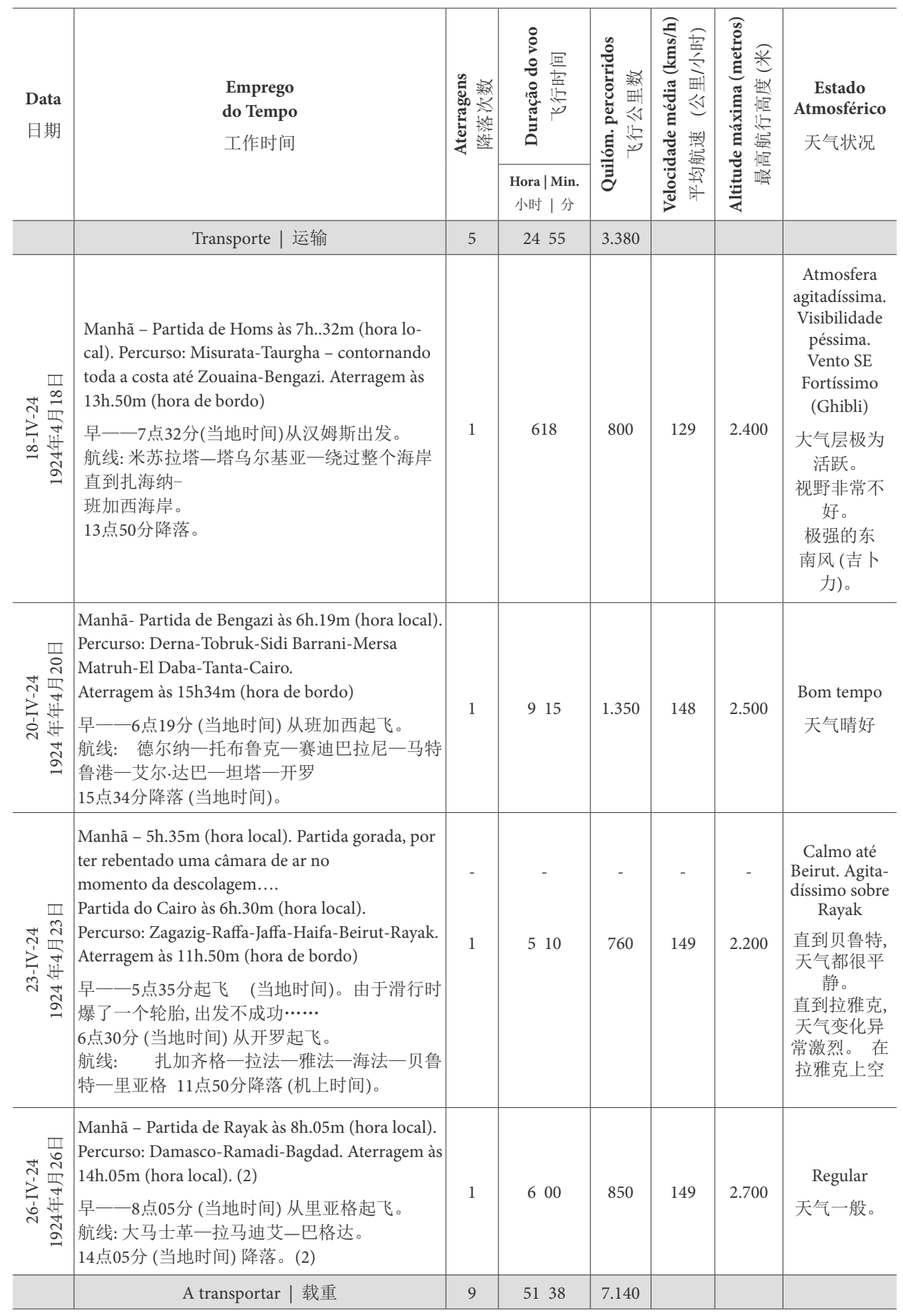




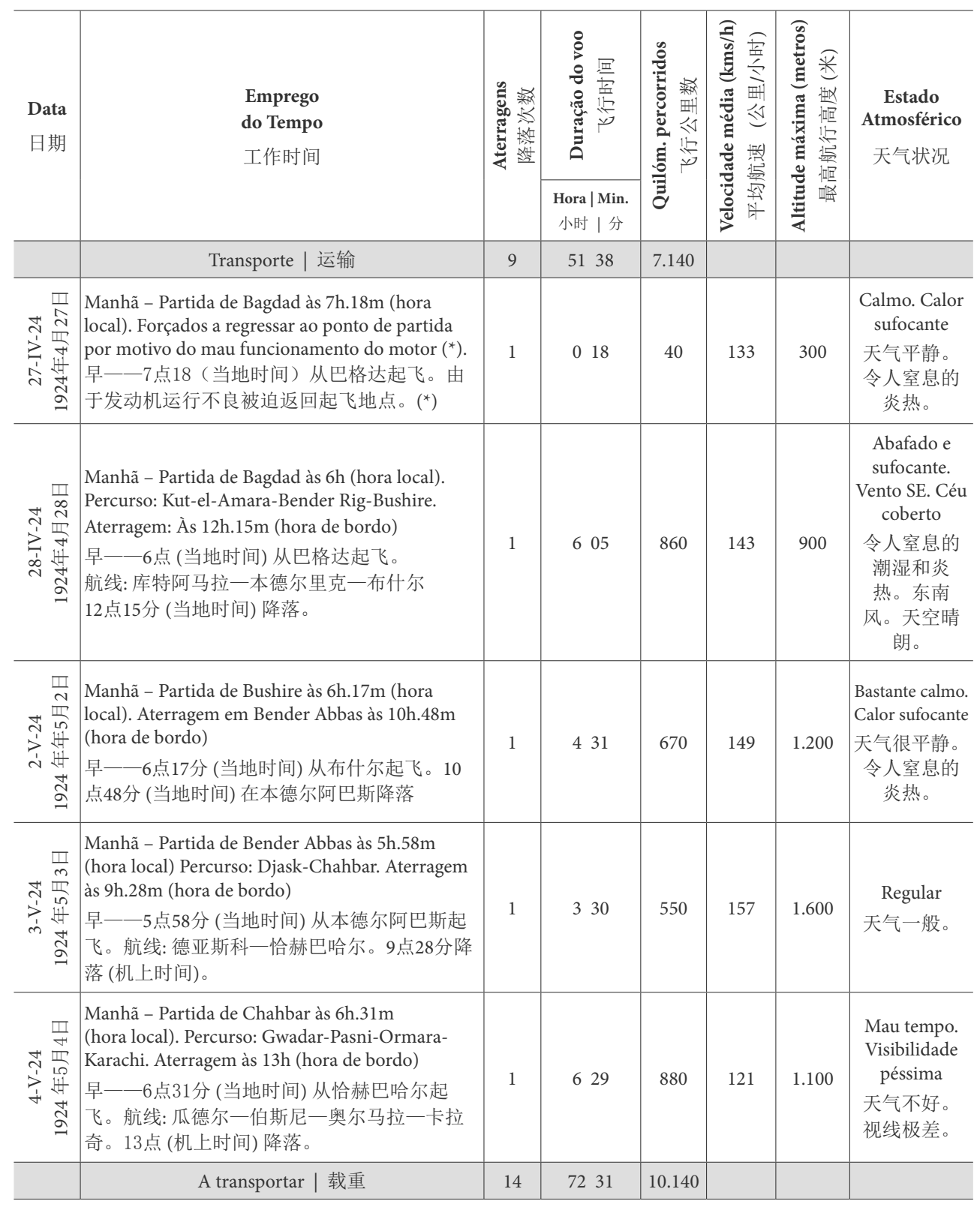




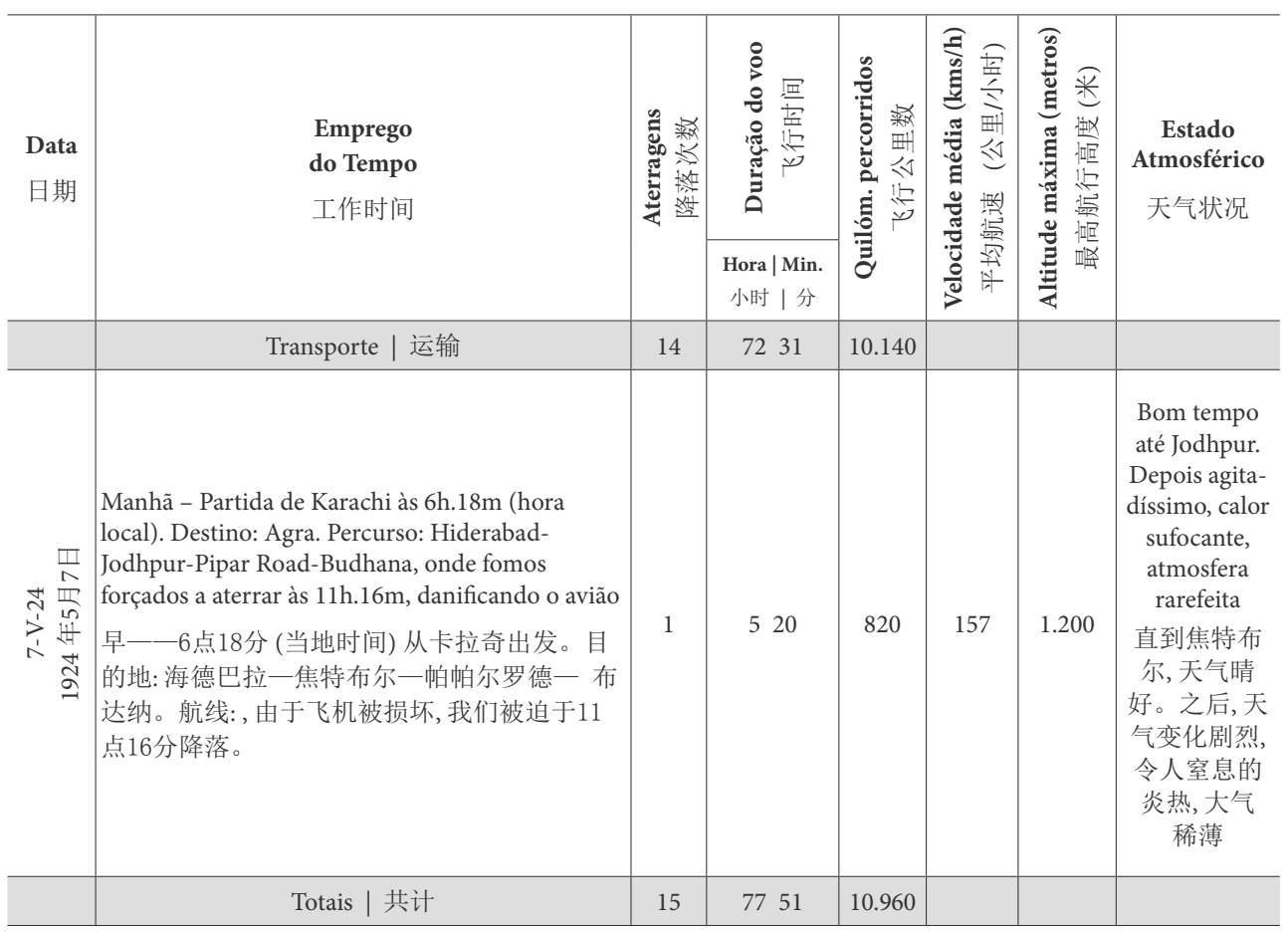




\section{VOOS DO AVIÃO PÁTRIA II (De Haviland DH 9) “祖国二号”飞机航程(德哈维兰 DH9)}

\begin{tabular}{|c|c|c|c|c|c|c|c|}
\hline \multirow[t]{2}{*}{$\begin{array}{l}\text { Data } \\
\text { 日期 }\end{array}$} & \multirow[t]{2}{*}{$\begin{array}{c}\text { Emprego } \\
\text { do Tempo } \\
\text { 工作时间 }\end{array}$} & \multirow[t]{2}{*}{ 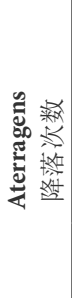 } & 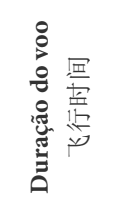 & \multirow{2}{*}{ 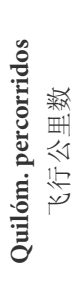 } & \multirow{2}{*}{ 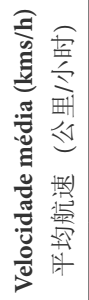 } & \multirow{2}{*}{ 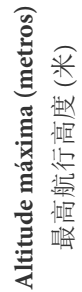 } & \multirow[t]{2}{*}{$\begin{array}{c}\text { Estado } \\
\text { Atmosférico } \\
\text { 天气状况 }\end{array}$} \\
\hline & & & $\begin{array}{l}\text { Hora } \mid \text { Min. } \\
\text { 小时 | 分 }\end{array}$ & & & & \\
\hline
\end{tabular}

TREINOS EM LAHORE $(*)$

在拉合尔训练 $(*)$

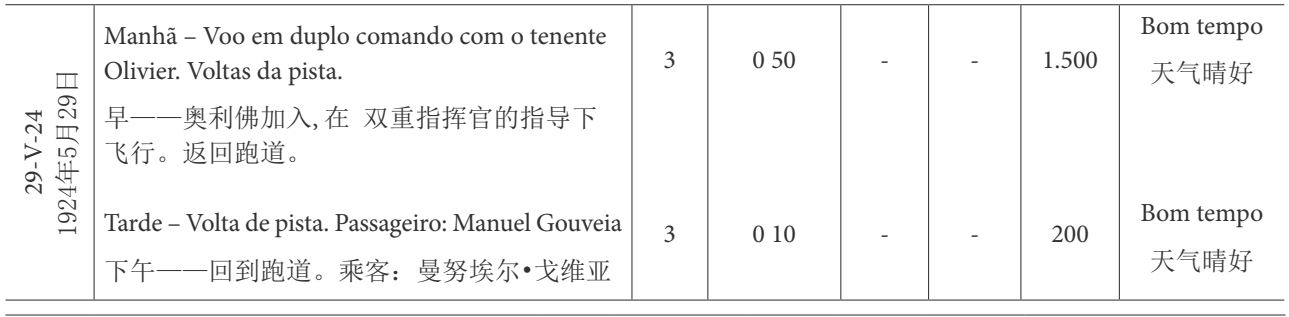

ROTEIRO DA VIAGEM (CONTINUAÇÃO) (1)

\begin{tabular}{|c|c|c|c|c|c|c|c|}
\hline \multicolumn{8}{|c|}{ 飞行日志 (续) (1) } \\
\hline 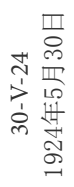 & $\begin{array}{l}\text { Manhã: Percurso Lahore-Amballa } \\
\text { 早——路线: 拉合尔——安巴拉 }\end{array}$ & 1 & 205 & 290 & 145 & 1.900 & $\begin{array}{l}\text { Calmo } \\
\text { 天气平静。 }\end{array}$ \\
\hline 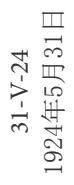 & $\begin{array}{l}\text { Manhã: Percurso Amballa-Allahabad } \\
\text { 早——航线: 安巴拉一阿拉哈巴德 }\end{array}$ & 1 & 430 & 800 & 177 & 2.200 & $\begin{array}{l}\text { Vento O forte } \\
\text { 强风。 }\end{array}$ \\
\hline 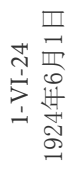 & $\begin{array}{l}\text { Manhã: Percurso Allahabad-Calcutá } \\
\text { 早——航线: 阿拉哈巴德一加尔各答 }\end{array}$ & 1 & 415 & 800 & 195 & 2.200 & $\begin{array}{l}\text { Agitado } \\
\text { 天气变动剧烈 }\end{array}$ \\
\hline 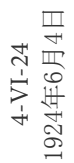 & $\begin{array}{l}\text { Manhã: Percurso Calcutá-Chitaggong- } \\
\text { Akyab } \\
\text { 早一一航线: 加尔各答一吉大港一阿 } \\
\text { 恰布 }\end{array}$ & 1 & 355 & 650 & 162 & 2.200 & $\begin{array}{l}\text { Regular } \\
\text { 天气一般 }\end{array}$ \\
\hline & A transportar | 载重 & 4 & 1445 & 2.540 & & & \\
\hline
\end{tabular}




\begin{tabular}{|c|c|c|c|c|c|c|c|}
\hline $\begin{array}{r}\text { Data } \\
\text { 日期 }\end{array}$ & $\begin{array}{c}\text { Emprego } \\
\text { do Tempo } \\
\text { 工作时间 }\end{array}$ & 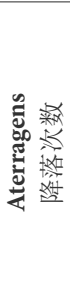 & 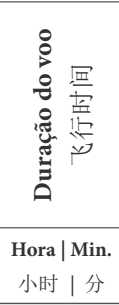 & 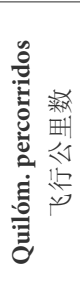 & 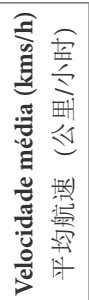 & 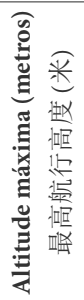 & $\begin{array}{c}\text { Estado Atmosférico } \\
\text { 天气状况 }\end{array}$ \\
\hline & Transporte | 运输 & 4 & 1445 & 2.540 & & & \\
\hline 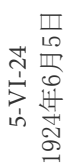 & $\begin{array}{l}\text { Manhã: Partida para Rangoon. Forçados } \\
\text { a retroceder pelo mau tempo }\left(^{*}\right) \\
\text { 早一一出发前往仰光。由于天气不好 } \\
\text { 被迫后退。 }\end{array}$ & 1 & 155 & 260 & 144 & 1.200 & $\begin{array}{c}\text { Temporais. } \\
\text { Vento SO forte } \\
\text { 风暴。 } \\
\text { 强烈的西南风。 }\end{array}$ \\
\hline 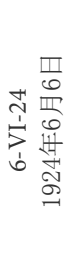 & $\begin{array}{l}\text { Manhã: Partida de Akyab às } 9 \mathrm{~h} .10 \mathrm{~m} \\
\text { (hora local). } \\
\text { Aterragem em Rangoon às } 13 \mathrm{~h} .15 \mathrm{~m} \\
\text { (hora de bordo) } \\
\text { 早——9点10分 (当地时间) 从阿恰布 } \\
\text { 出发。 } \\
13 \text { 点15分 (机上时间) 在仰光降落。 }\end{array}$ & 1 & 405 & 650 & 158 & 4.000 & $\begin{array}{l}\text { Regular. Céu } \\
\text { coberto. } \\
\text { Aguaceiros } \\
\text { 天气一般。多云。 } \\
\text { 阵雨 }\end{array}$ \\
\hline 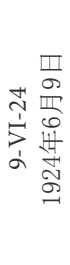 & $\begin{array}{l}\text { Manhã: Partida de Rangoon às } 8 \mathrm{~h} .40 \mathrm{~m} \\
\text { (hora local). Aterragem em Bangkok às } \\
13 \mathrm{~h} .55 \mathrm{~m} \text { (hora de bordo) } \\
\text { 早—— } 8 \text { 点 } 40 \text { 分 (当地时间) 从仰光 } \\
\text { 起飞。13点55分 (机上时间) 在曼谷 } \\
\text { 降落。 }\end{array}$ & 1 & 515 & 680 & 129 & 4.500 & $\begin{array}{l}\text { Mau tempo até à } \\
\text { cordilheira. } \\
\text { Regular até } \\
\text { Bangkok } \\
\text { 一直到山脊, 天气糟 } \\
\text { 糕。到曼谷为止, 天气 } \\
\text { 晴好。 }\end{array}$ \\
\hline 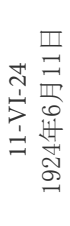 & $\begin{array}{l}\text { Manhã: Partida de Bangkok às } 7 \mathrm{~h} .05 \mathrm{~m} \\
\text { (hora local), rumo a Korat e Oubon. } \\
\text { Aterragem às } 10 \mathrm{~h} .10 \mathrm{~m} \text { (hora bordo) } \\
\text { 早——7点 } 05 \text { 分 (当地时间) 从曼谷起 } \\
\text { 飞, 飞往呵叻和乌汶。10点 } 10 \text { 分 (机上 } \\
\text { 时间) 降落 }\end{array}$ & 1 & 305 & 550 & 177 & 600 & $\begin{array}{l}\text { Nuvens e chuviscos } \\
\text { 云块和细雨。 }\end{array}$ \\
\hline 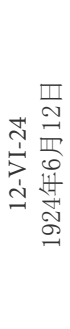 & $\begin{array}{l}\text { Manhã - Partida de Oubon às 6h.55m } \\
\text { (hora local). Percurso: Tahkek-Ha Tinh- } \\
\text { Vinh-Nam Dinh-Haifongue-Hanói. } \\
\text { Aterragem às } 12 \mathrm{~h} .45 \mathrm{~m} \text { (hora de bordo) } \\
\text { (Pista completamente encharcada } \\
\text { 早——6点55分 (当地时间) 从乌汶 } \\
\text { 起飞。航线: 他曲一河静一荣市一南 } \\
\text { 定一海防一河内。12点45分 (机上时 } \\
\text { 间) 降落 (跑道完全湿透)。 }\end{array}$ & 1 & 550 & 780 & 136 & 2.600 & $\begin{array}{c}\text { Chuva no Sião. Cortina } \\
\text { de nuvens sobre as } \\
\text { montanhas. Nevoeiro } \\
\text { sobre o delta do Rio } \\
\text { Vermelho } \\
\text { 在暹罗有将于。云雾 } \\
\text { 遮山。红河三角洲上 } \\
\text { 空有浓雾。 }\end{array}$ \\
\hline & A transportar | 载重 & 9 & 3455 & 5.460 & & & \\
\hline
\end{tabular}




\begin{tabular}{|c|c|c|c|c|c|c|c|}
\hline $\begin{array}{l}\text { Data } \\
\text { 日期 }\end{array}$ & $\begin{array}{c}\text { Emprego } \\
\text { do Tempo } \\
\text { 工作时间 }\end{array}$ & 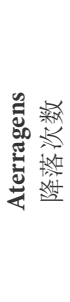 & 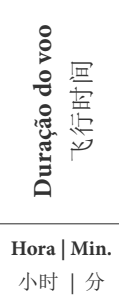 & 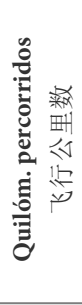 & 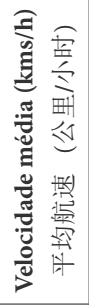 & 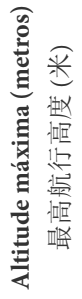 & $\begin{array}{c}\text { Estado Atmosférico } \\
\text { 天气状况 }\end{array}$ \\
\hline & Transporte | 运输 & 9 & 3455 & 5.460 & & & \\
\hline 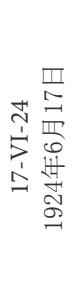 & $\begin{array}{l}\text { Tarde - Transferência do avião de } \\
\text { Bac-Mai para Tong, por motivo do mau } \\
\text { estado da pista. Passageiro: Mecânico } \\
\text { francês Maison. Voltas sobre Hanói e } \\
\text { Tong }\left(^{\star}\right) \\
\text { 下午一一由于跑道状况不佳, 将飞机 } \\
\text { 从白梅机场转到宗机场。乘客: 法国 } \\
\text { 机械师梅森。在河内和宗上空打转。 }\end{array}$ & 1 & 045 & 100 & 166 & 1.600 & $\begin{array}{l}\text { Regular } \\
\text { 天气一般。 }\end{array}$ \\
\hline 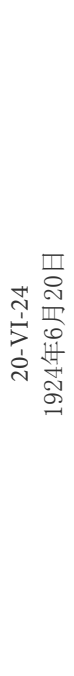 & $\begin{array}{l}\text { Manhã - Partida de Tong às 9h.58m } \\
\text { (hora local). Percurso: Hanói-Haifongue- } \\
\text {-Kwang Tcheou-Wang-Yang Kiang- } \\
\text {-Macau-Kowloon-Shum Chun (China), } \\
\text { onde fomos forçados a aterrar por avaria } \\
\text { no Delca System (ignição). } \\
\text { Impossibilitados de aterrar em Macau, } \\
\text { devido ao temporal. A aterragem } \\
\text { efectuou-se às14h.48m (hora de bordo), } \\
\text { num cemitério chinês. Avião ligeiramente } \\
\text { danificado } \\
\text { 早一一9点58分 (当地时间) 从宗机 } \\
\text { 场起飞。航线: 河内一海防一广州 } \\
\text { 湾一阳江一澳门一九龙一岑覃 (Shum } \\
\text { Chun) (中国), 在此地由于带戴尔加系 } \\
\text { 统 (点火) 故障我们被迫降落。由于 } \\
\text { 风暴, 无法在澳门降落。1点48分 (机 } \\
\text { 上时间) 在一片中国墓地上实施了降 } \\
\text { 落。飞机有轻微的损毁。 }\end{array}$ & 1 & 450 & 1.050 & 223 & 3.000 & $\begin{array}{c}\text { Tempo excelente até } \\
\text { Yang Kyang. } \\
\text { Trovoadas, chuva, } \\
\text { vento, temporal desfeito } \\
\text { até Shum Chun. } \\
\text { Aterragem debaixo de } \\
\text { chuva torrencial. } \\
\text { 直到阳江, 天气状况都 } \\
\text { 极好。到岑覃 (Shum } \\
\text { Chun)为止, 雷鸣, 雨, } \\
\text { 强风暴。高飞机在大 } \\
\text { 暴雨中降落。 }\end{array}$ \\
\hline & Totais | 共计 & 11 & 4030 & 6.610 & & & \\
\hline
\end{tabular}




\section{NOTAS}

\section{注释}

- No cálculo das velocidades médias, descontaram-se sempre no tempo de voo cerca de $5 \mathrm{~m}$, correspondentes às voltas de pista à partida e à chegada.

- As distâncias foram calculadas em função do percurso efectuado.

${ }^{*}$ ) Todos os voos assinalados com o asterisco não são contados na Recapitulação Final, por não terem representado qualquer avanço na direcção de Macau.

(1) No cálculo do tempo de voo gasto no percurso total foram descontadas $2 \mathrm{~h} .30 \mathrm{~m}$ correspondentes ao percurso Homs - Taurgha - Homs e na distância percorrida descontaram-se igualmente 400 kms correspondentes ao referido trajecto, por não terem representado qualquer avanço na direcção de Macau.

(2) No cálculo da velocidade média relativa a esta etapa, descontaram-se $12 \mathrm{~m}$ gastos sobre Rayak, na subida a $2.700 \mathrm{~m}$.

(3) Os apontamentos incompletos tomados durante a segunda parte da viagem não permitem a descrição detalhada das etapas.

\section{RECAPITULAÇÃO FINAL 最终回顾}

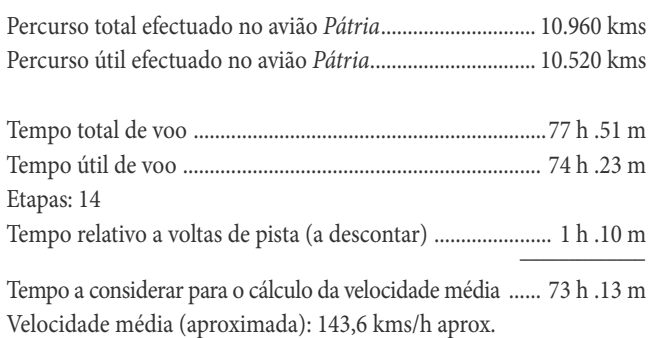

Percurso total efectuado no avião Pátria II.

Percurso útil efectuado no avião Pátria II.. $6.610 \mathrm{kms}$ . $.6 .250 \mathrm{kms}$

Tempo total de voo 40 h. $30 \mathrm{~m}$

Tempo útil de voo $37 \mathrm{~h} .50 \mathrm{~m}$

Etapas: 10

Tempo relativo a voltas de pista (a descontar) $50 \mathrm{~m}$

Tempo a considerar para o cálculo da velocidade média.....37 h. $00 \mathrm{~m}$ Velocidade média (aproximada): 169,1 kms/h aprox.

Percurso total nos dois aviões $17.570 \mathrm{kms}$

Percurso útil nos dois aviões. $16.760 \mathrm{kms}$

Tempo total de voo $118 \mathrm{~h} .21 \mathrm{~m}$ Tempo a considerar para o cálculo da velocidade média $110 \mathrm{~h} .13 \mathrm{~m}$ Velocidade média (aproximada): $152 \mathrm{kms} / \mathrm{h}$ aprox.
- 计算平均速度时, 要减去飞机离开、到达时在跑道上盘旋 的时间, 约为 5 分钟。

- 距离的计算以实际飞过的路程计算。

${ }^{*}$ ) 所有带有星号的航程都未计入最终的技术回顾中, 因为 它们对于澳门方向的行进无任何意义。

(1) 在计算所有飞行时间时, 减去了 2 个小时 30 分钟, 对应的 是汉姆斯 - 塔乌尔基亚- 汉姆斯路线, 这段路线的飞行 距离 400 公里也将同样减去。因为这段飞行对于向澳门 行进无任何代意义。

(2) 计算这一段的平均速度时, 减去在里亚格上空的12分钟, 飞行高度2700米。

(3) 因为第二段航程的笔记不全, 所以无法详尽描述这几段 航程。

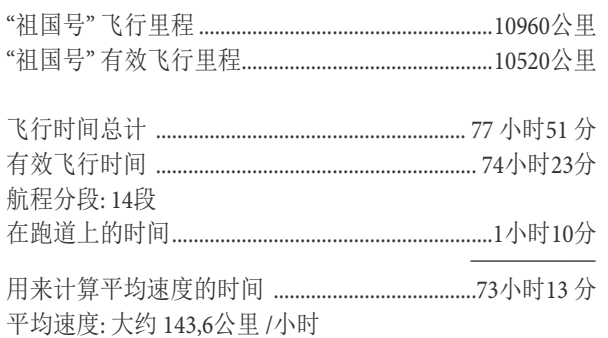

“祖国号”飞行里程 .6610公里 “祖国号”有效飞行里程 6250 公里

总飞行时间 40 小时 30 分

有效飞行时间 37 小时 50 分

航程分段: 10段

在跑道上盘旋时间: (需减去) 50 分

用来计算平均速度的时间。 37 小时 00 分 平均速度 (大约) : 169,1 公里/小时

两架飞机总飞行距离 17.570 公里 两架飞机有效飞行距离。 16.760 公里

总飞行时间 118 小时 21 分

用来计算平均速度的飞行时间. 平均速度: 约 152 公里/小时 



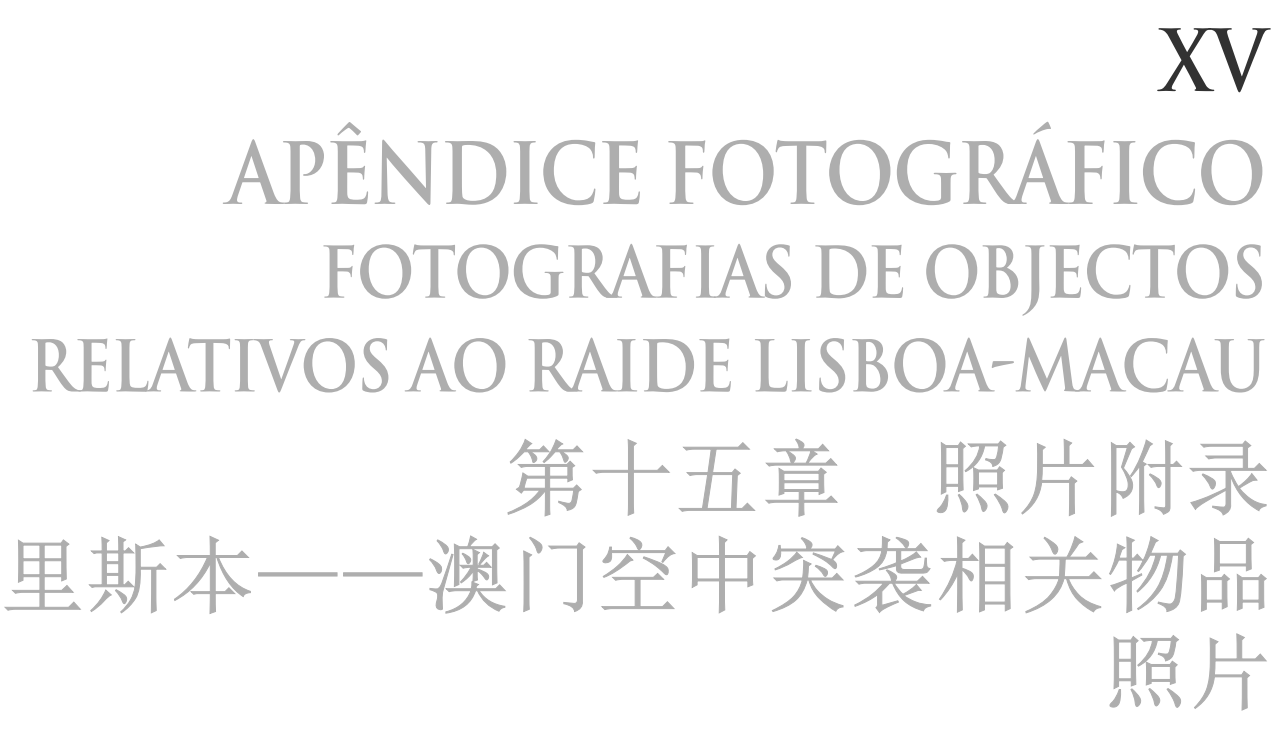




\section{AGRADECIMENTOS}

\section{感谢}

Agradece-se a Leonor Brito Paes a solicitude com que nos atendeu e a autorização para publicar a fotografia do anel do aviador Brito Paes, referido no capítulo III desta narrativa.

感谢莱奥诺尔 - 布里托 - 帕伊斯对我们关怀备至的接待并允许我们出版在书中第三章提到的 布里托・帕伊斯的戒指照片。

Agradece-se ao Museu do Ar a autorização para fotografar estes objectos do seu acervo, relativos à viagem do Pátria.

感谢航空博物馆允许我们拍摄这些与 “祖国号” 航空之旅有关的馆藏物品。 


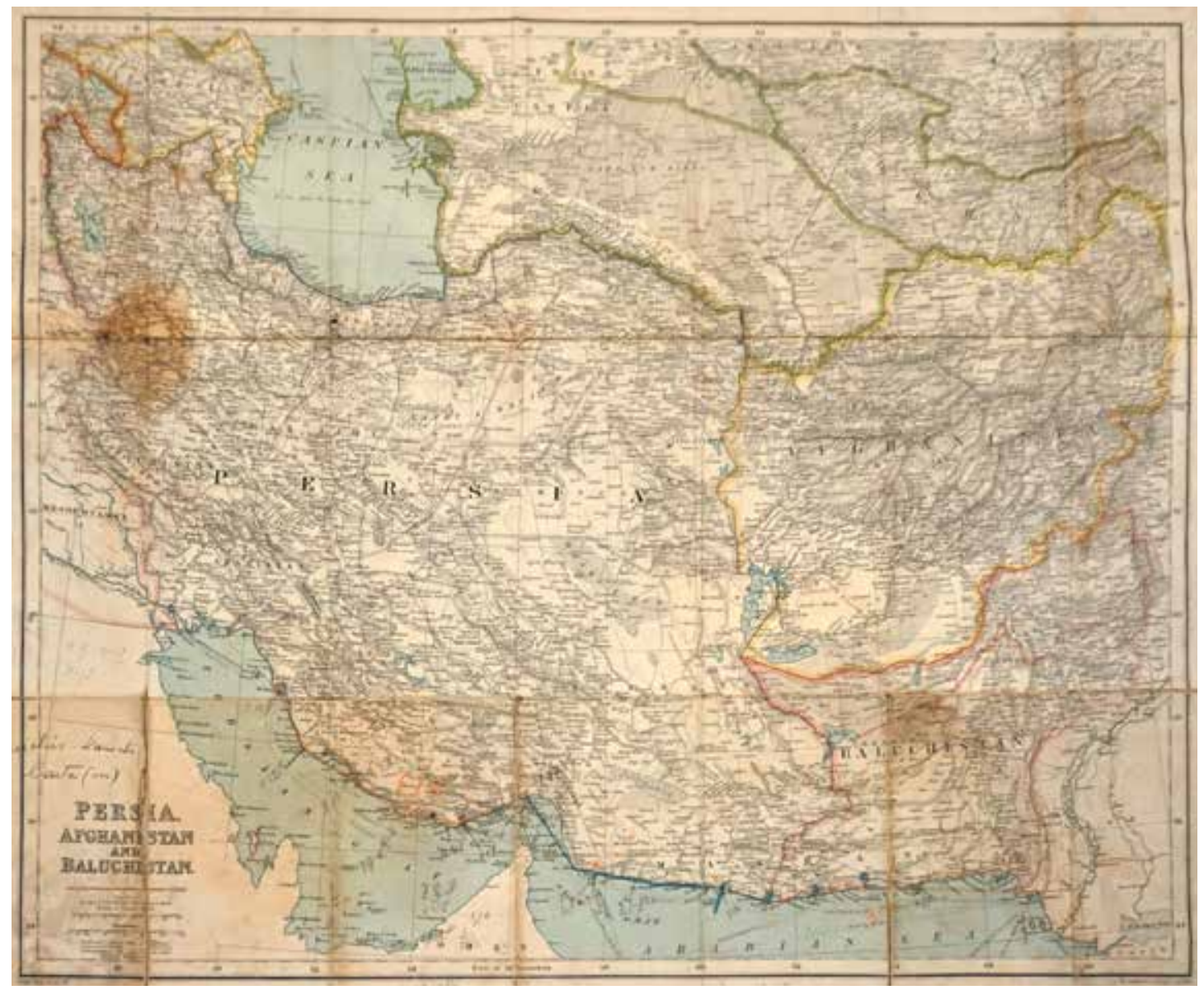

Mapa utilizado pelos aviadores durante a viagem, anotado pelos próprios (vista total e parcial)

飞行员们在飞行期间使用的地图, 由他们自己标注 (部分及完整视图)

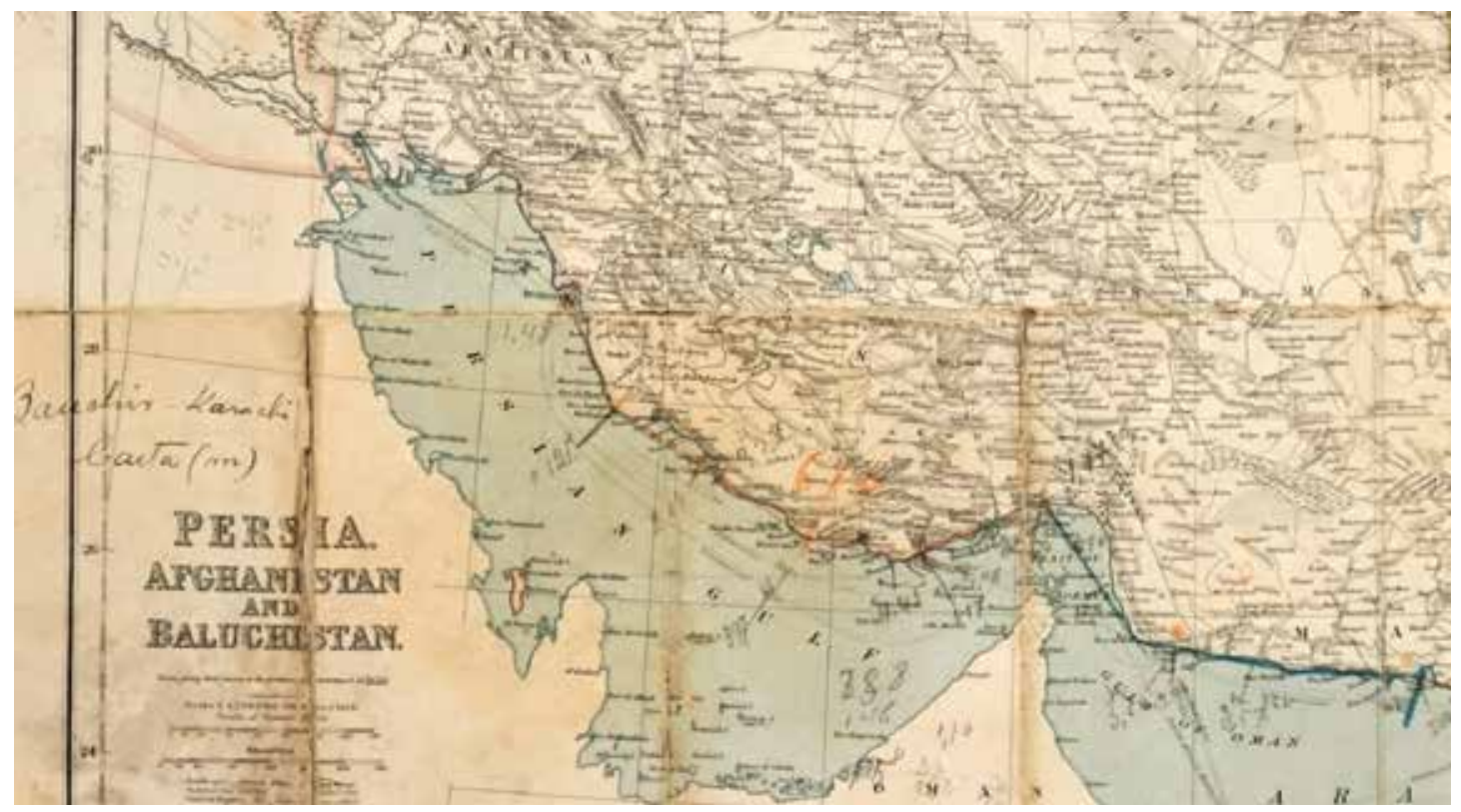




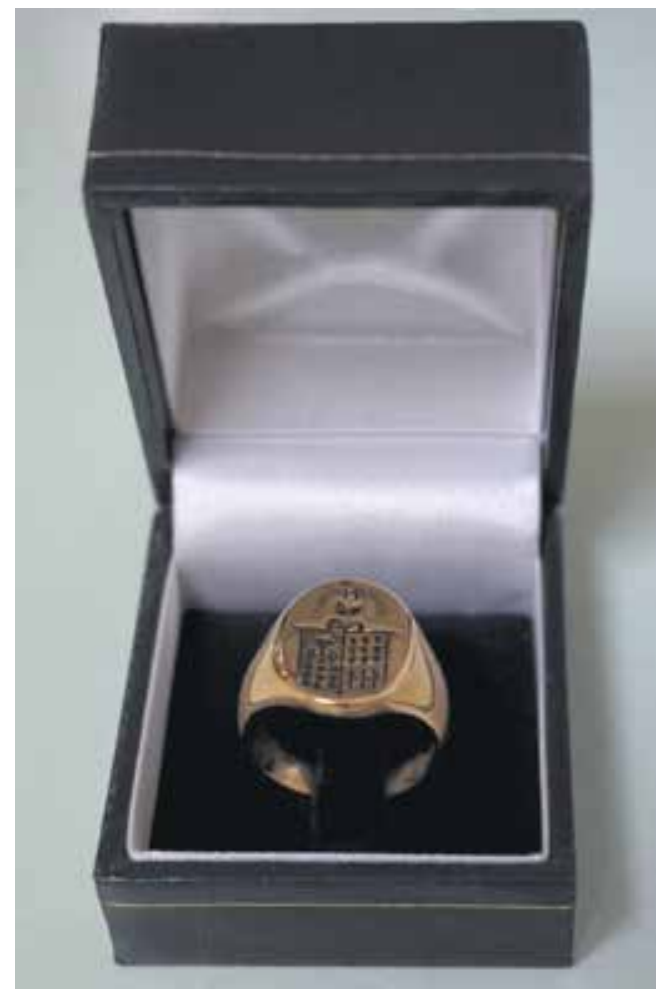

Anel com o brasão da família Brito Paes, oferecido ao aviador pelo seu pai, momentos antes de levantarem voo em Vila Nova de Milfontes

从千泉新镇起飞前, 刻着布里托 - 帕伊斯家族徽章的戒指, 它是这位飞行员的父亲赠给他的。

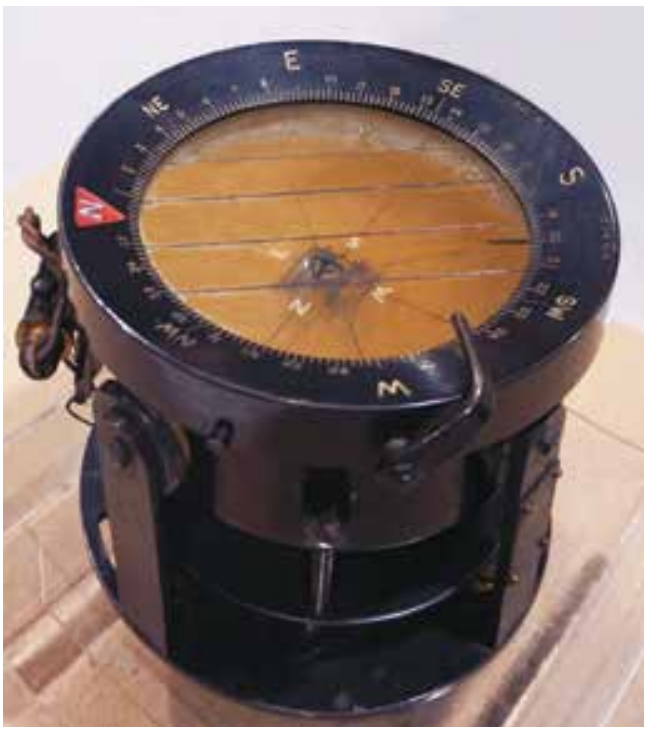

A bússola do Pátria |“祖国号” 的罗盘 


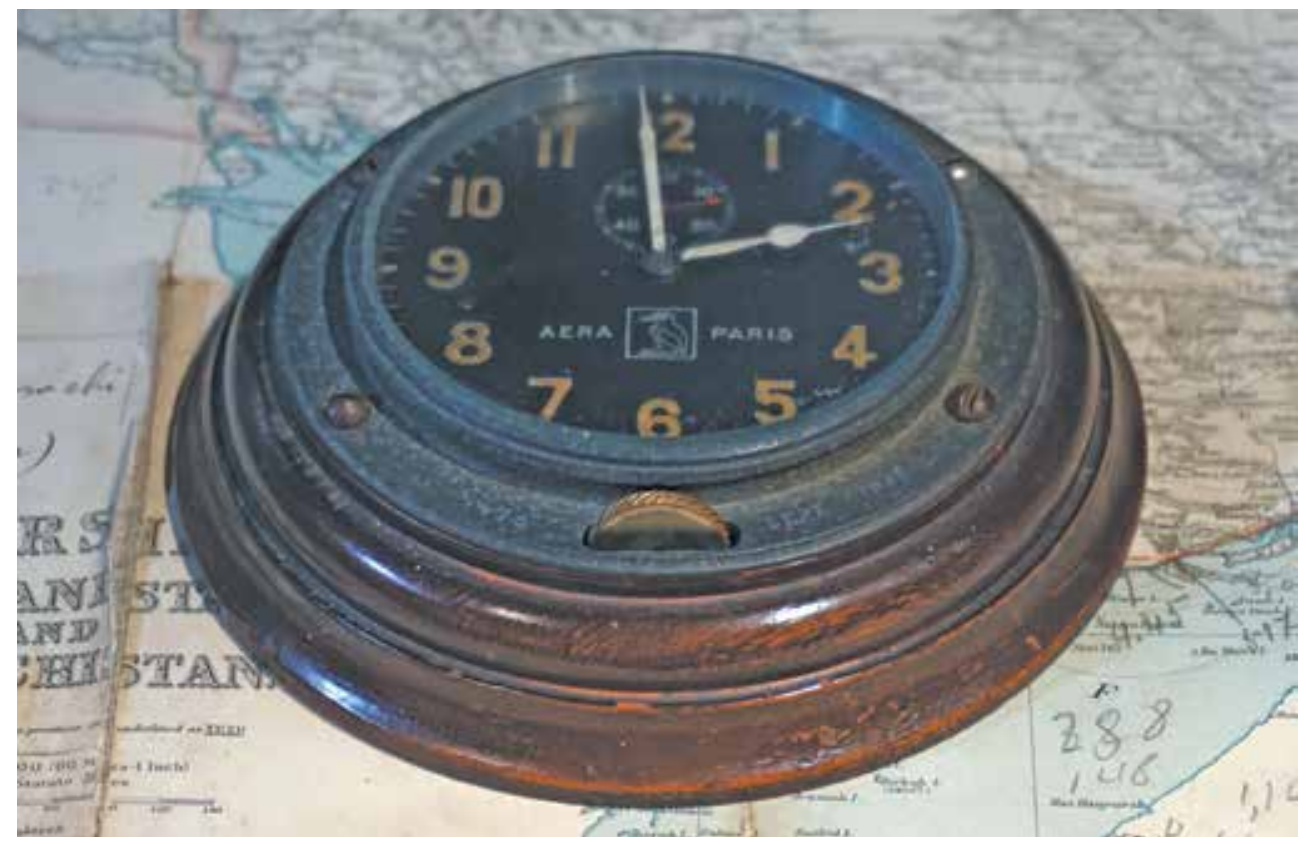

Relógio de bordo do Pátria | “祖国号” 上的时钟

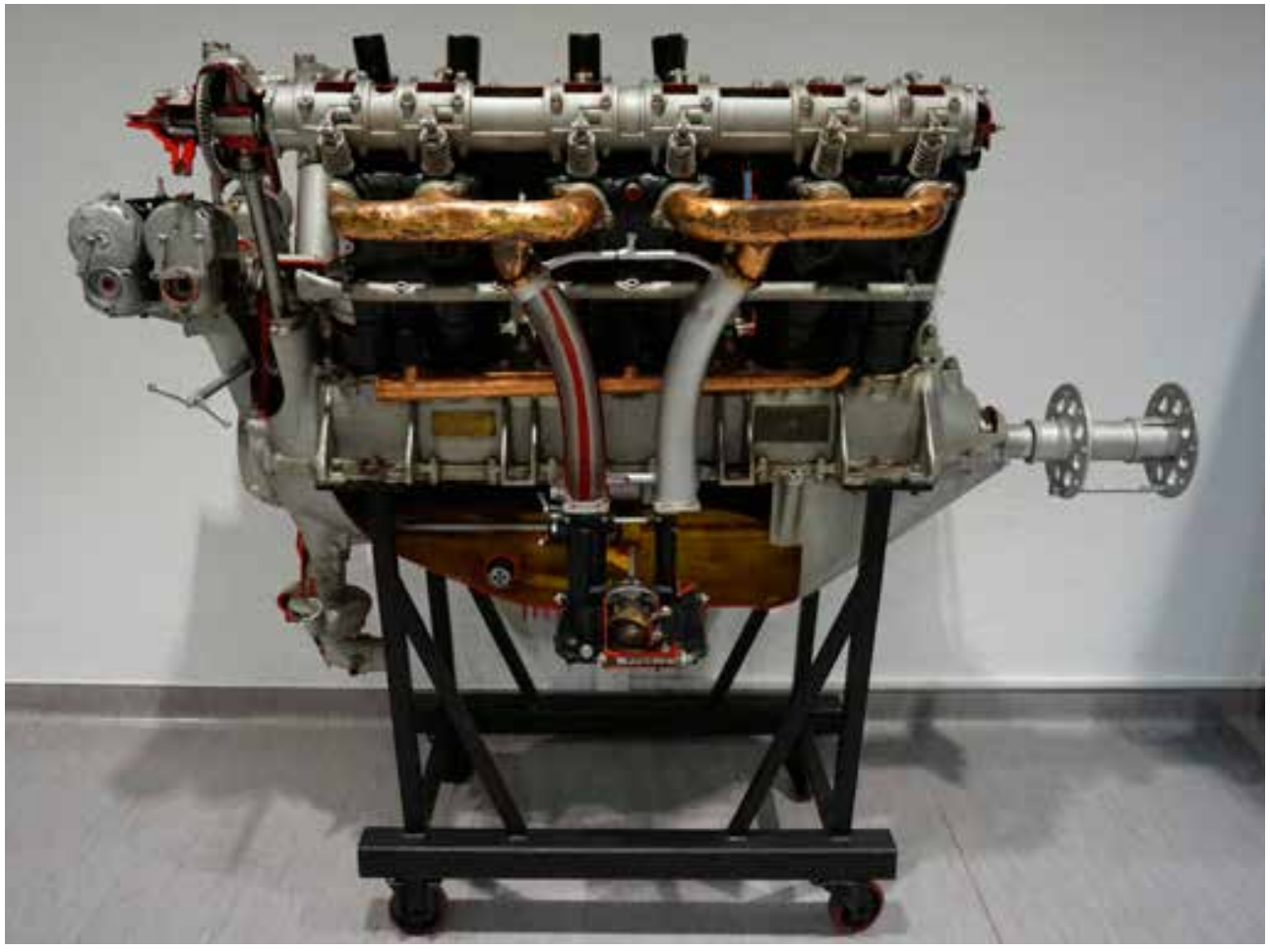

Motor do Pátria (Renault 300 CV)| “祖国号” 的发动机 (雷诺300CV) 

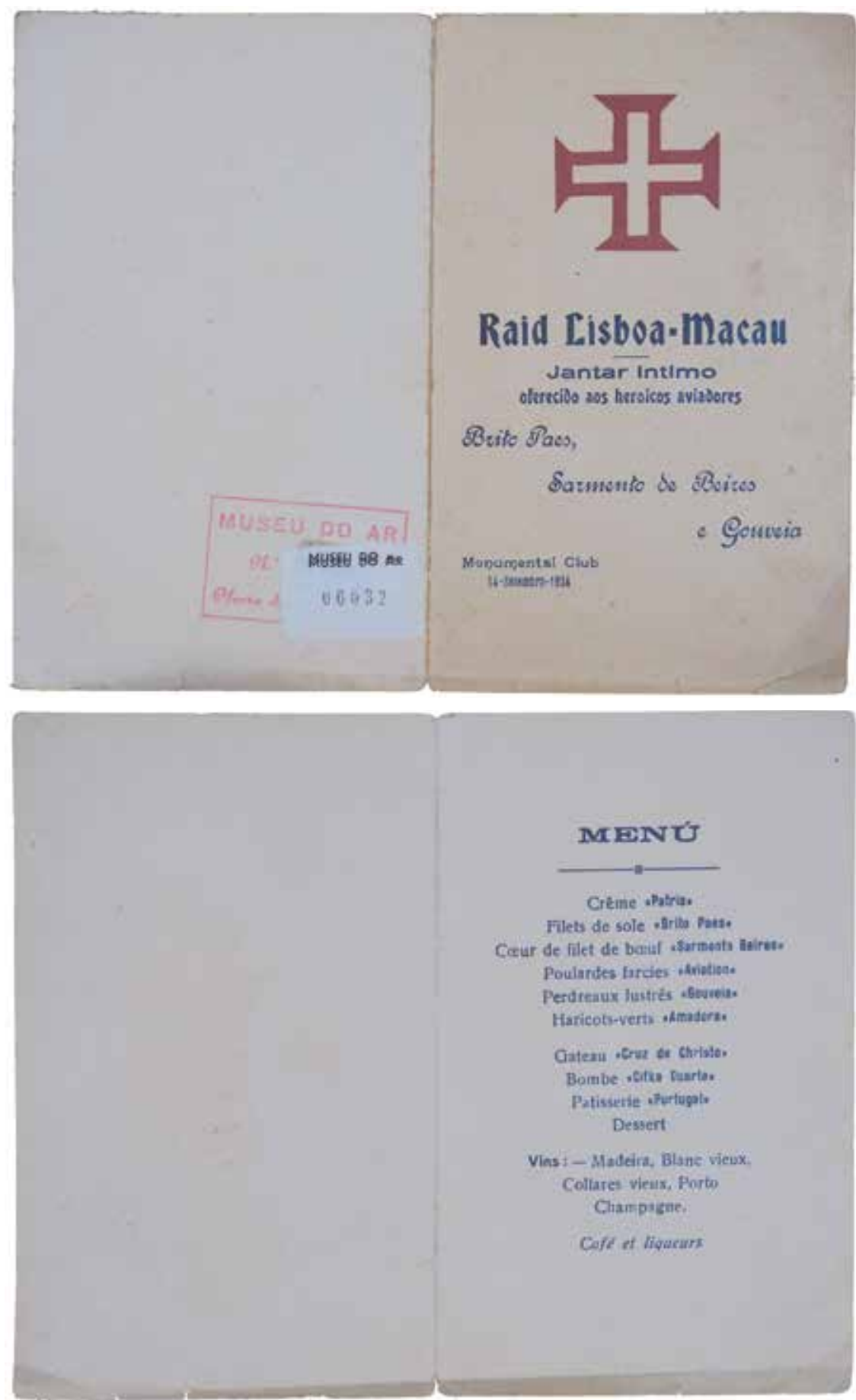

Menu de um jantar de homenagem aos aviadores no Monumental Club, em Lisboa, em Setembro de 1924. 1924年9月, 在里斯本纪念俱乐部举行的向飞行员们致敬的晚宴菜单 


\section{NOTAS BIOGRÁFICAS DAS EDITORAS}

\section{编者简历}

ISABEL MORUJÃO é Professora na Faculdade de Letras da Universidade do Porto, onde se doutorou em Literatura Portuguesa, em 2005. Integra o Centro de Investigação Transdisciplinar Cultura Espaço \& Memória (CITCEM), sediado na Faculdade de Letras do Porto, e é colaboradora do Centro de Estudos Camonianos da Universidade de Coimbra. Tem produzido numerosos estudos, dispersos por revistas da especialidade, actas e livros, no país e no estrangeiro.

A sua área preferencial de investigação é a Literatura Feminina dos séculos XVI-XVIII, mas interessase também por epistolografia, história do teatro português, história do livro e da leitura, edição de manuscritos e literatura de viagens. Neste último campo, destaca-se a atenção que lhe têm merecido as narrativas de viagens do aviador Sarmento de Beires, em torno das quais publicou diversos artigos e de que editou, em 2011, em colaboração com Jorge Bastos da Silva, a obra A Cidade do Sol.

伊莎贝尔 - 莫茹让是波尔图大学文学院教师, 她于 2005 年在该校获得葡萄牙文学博士学位。她是总部位于 波尔图大学文学院的 “文化、空间与记忆跨学科研究中心”一员, 也是科因布拉大学卡蒙斯学研究中心合作 者。她在国内外多种专业杂志、纪要和书籍上发布了自己的多种研究成果。

她偏爱的研究领域是十六至十八世纪女性文学, 但也对书志学葡萄牙戏剧史、书籍和阅读史、手稿编辑和 旅行文学感兴趣。在最后这个领域, 她特别注意到了飞行员萨尔门托 - 德贝雷斯的飞行叙事。围绕这个主 题, 她撰写发表了多篇文章, 并于2011年与若尔热・巴斯托斯・席尔瓦合作编辑出版了著作 “太阳之城”。

RITA PINA BRITO é licenciada em Jornalismo, pela Escola Superior de Comunicação Social, e mestre em Culture Studies, com especialização em Performance e Criatividade, coordenado pelo The Lisbon Consortium, da Universidade Católica Portuguesa.

Com a paixão pela comunicação desde cedo, investiu na formação em screenwriting para cinema e desenvolveu o argumento para o documentário sobre a vida e obra do escritor Rui de Brito, seu avô.

Começou a sua carreira profissional numa agência de publicidade e consultadoria, onde coordenou projectos de publishing que a levaram até ao Oriente, passando por Guangzhou, Hong Kong, Macau, Taipé e Tóquio, estando particularmente envolvida na edição e divulgação do Portugal Wine Guide e do primeiro livro em mandarim sobre o Vinho do Porto, do crítico de vinhos português, João Paulo Martins.

Actualmente, é consultora de comunicação para a internacionalização, sobretudo para mercados asiáticos, e de planeamento estratégico em marketing digital internacional de várias marcas portuguesas.

丽达・皮纳·布里托本科毕业于里斯本理工学院社会传媒高等学校新闻学专业, 后在葡萄牙天主教大学人文 科学院里斯本合作集团 (The Lisbon Consortium) 指导下, 专业研究表现力与创造力而获得文化研究硕士学 位。

她从小就对交流沟通充满热情, 长大后投资了电影编剧培训, 并为一部讲述她祖父一一作家路易. 布里托 生活和作品的纪录片撰写了剧本。

在一家广告和咨询公司她开始了自己的职业生涯。在该公司, 她指导协调了一些出版项目, 这些项目把她带 到东方世界, 到了广州、香港、澳门、台北和东京等城市, 尤其是她参与了《葡萄牙葡萄酒指南》的编辑与 推广, 并第一次以中文出版了葡萄牙葡萄酒品论家若昂・保罗・马丁斯撰写的波特酒书籍。

目前, 她是多个葡萄牙品牌国际化 (特别是在亚洲市场) 的传播顾问, 并为这些品牌做出国际数字营销战略 规划。 

A poucos anos do centenário do raide aéreo Lisboa-Macau, realizado entre 7 de Abril e 20 de Junho de 1924, a reedição da obra De Portugal a Macau, de José Manuel Sarmento de Beires, adquire antecipadamente um sentido celebrativo.

A viagem [...] foi, de facto, um extraordinário feito de engenharia aeronáutica e de aviação pioneira, reconhecido internacionalmente. Em Portugal, durante os quase três meses que durou a travessia aérea, o país inteiro viveu suspenso das notícias que chegavam sobre o sucesso dos seus aviadores.

Enquanto narrativa da viagem do avião Pátria, no contexto do risco de uma travessia pioneira e sem apoios do Estado, este livro de Sarmento de Beires tem um interesse inegável para os entusiastas da aviação e para os que se interessam pelos acontecimentos portugueses nesta época nevrálgica da Primeira República. Mas a relevância da obra, escrita num registo testemunhal e com um recorte literário que não escapa ao leitor, alarga-se, naturalmente, a um público diversificado, pois narra uma aventura real, em que os heróis são de carne e osso e vivem inúmeras situações de alto risco.

值此距1924年4月7日到6月20日第一次实现里斯本一一澳门 之间的飞行近 100 年之际, 再版若泽・曼努埃尔・萨尔门托・ 德贝雷斯的《从葡萄牙到澳门》颇具提前庆祝之意。

实际上, 这次空中之旅 $(\cdots . .$.$) 是国际公认的、航空工程$ 和航空先驱的非凡壮举。在这次空中航行持续的近三个月 中，整个匍萄牙翅首以待，等待着飞行员们成功的消息。

作为 “祖国号” 飞机的飞行叙事，作为一次面临开创性飞 行的风险且没有国家支持背景下的航空之旅, 对于那些对 飞行、对葡萄牙第一共和国这个关键时期发生的历史事件 感兴趣的人，萨尔门托・德贝雷斯的这本书有着令人无法否 认的兴趣。然而, 这是部写在见证记录基础上并经过文学 剪裁的作品, 自然而然地使读者群扩展到了不同的公众之 中, 因为它讲述了一次真正的冒险, 其中的英雄有血有 肉, 他们曾无数次面对极为危险的情况。

Envolvem-nos lufadas de poeira em brasa, açoita-nos o vento, sacodem-nos vácuos inesperados, correntes descendentes, succões bruscas, redemoinhos ciclónicos, - um inferno de que a gente não compreende como conseguiu escapar. Brito Paes realiza esforcos sobre-humanos para me ajudar. Há o que quer que seja de demência nesse voo quase apavorante. São cinco minutos de tragédia muda que nunca mais acabam, com interrogações pávidas a eriçar-se de segundo em segundo. E tudo em nós é ânsia de salvar o avião.

我们被火热的沙尘包围了, 被狂风抽打着; 出人意料的真空, 下行 的气流, 猛烈的吸附, 气流漩涡……这一切将我们吞没。我们不知 如何才能摆脱这地狱般的境地。布里托 - 帕艾斯做出了超人的努力 来帮助我。在这次几乎是令人胆战心惊的飞行中，有一些东西让人 发狂。这寂静的、悲剧性的五分钟仿佛永远不会结束, 惊恐每秒钟 都浮现出来。希望挽救飞机的强烈情绪弥漫在我们的当中。

COLECÇÃO «FONTES», N. ${ }^{\circ} 12$

J. SARMENTO DE BEIRES

J. 萨尔门托・德贝雷斯

DE PORTUGAL A MACAU

(A VIAGEM DO PÁTRIA)

从葡萄牙到澳门

(“祖国号”之旅)

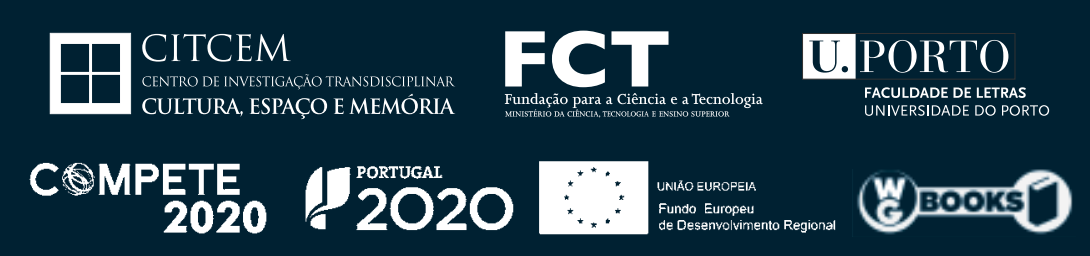

